DEPARTMENT OF THE INTERIOR

UNITED STATES GEOLOGICAL SURVEY

GEORGE OTIS SMITH, DIRECTOR

Wather-SUPPIy Paper 319

\title{
GEOLOGY AND GROUND WATERS OF FLORIDA
}

BY

GEORGE CHARLTON MATSON

AND

SAMUEL SANFORD

Prepared in cooperation between the United States Geological Survey and the Florida Geological Survey, under the direction of Thomas Wayland Vaughan

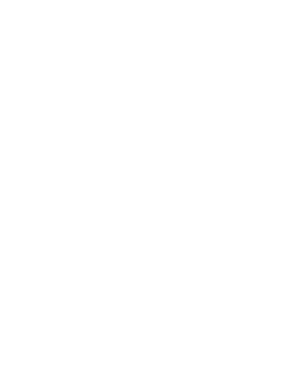

WASHINGTON

GOVERNMENT PRINTING OFFIOA 1913 



\section{CONTENTS.}

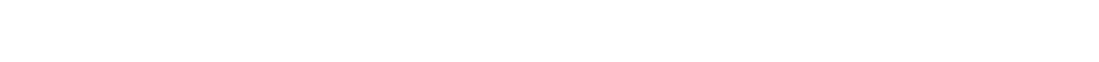

Part I.-Geography....................................... 21

Northern and central Florida, by G. C. Matson ................. 21

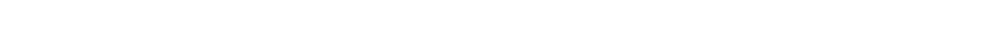

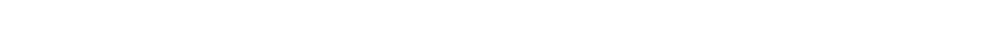

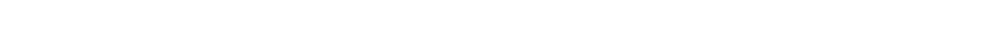

Rivers........................................ 23

Lakes and swamps................................... 24

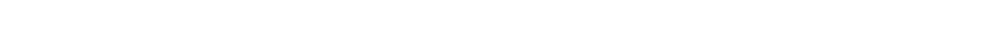

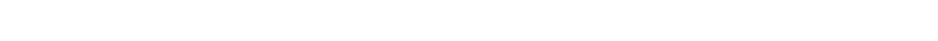

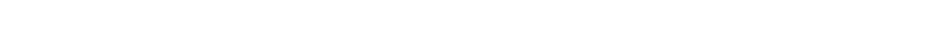

Underground drainage.................... 25

Caverns....................................... 26

Sink holes................................... 26

Natural bridges............................... 28

Springs................................. $\quad 29$

Erosional features............................. $\quad 30$

Lakes. . . . . . . . . . . . . . .

Sand dunes...................... $\quad \mathbf{3 0}$

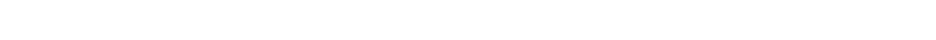

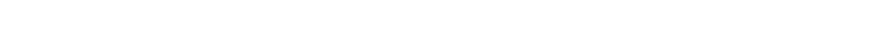

Ridges................................. $\mathbf{3 1}$

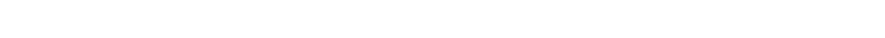

Terraces........................................ 31

General features............................... 31

Newberry terrace........................... 32

Tkala Apopka terrace............................ 33

Pensacola terrace .............................. 34

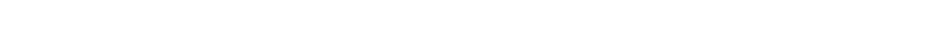

Coral reefs........................................ 35

Submerged continental border..................... $\mathbf{3 5}$

Bars........................................... 37

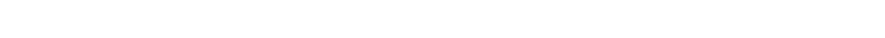

Inlets. . . . . . . . . . . . . . . .

Tidal runways................................ 38

Capes................................... $\quad 38$

Soịls.............................................. 39

Origin and character................................. 39

Soil types................................... 40

Southern Florida, by Samuel Sanford $\ldots \ldots \ldots \ldots \ldots \ldots \ldots \ldots \ldots \ldots ., 42$

Location and area.................................. 42

General features...................................... 42 
Part I.-Geography-Continued.

Southern Florida, by Samuel Sanford-Continued.

The mainland.

Page.

Subdivisions.................................... 45

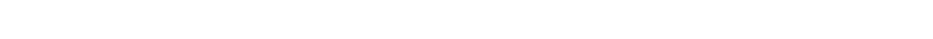

Area and distribution.............................. 45

Dunes......................................... ${ }_{46}$

Character.............................. 46

Distribution............................. 47

Rolling sand plains............................... 49

Flatlands............................ 50

Rock ridges. . . . . . . . . 51

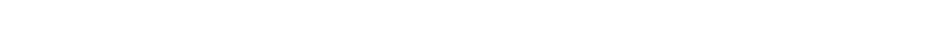

Controlling conditions........................... 52

Everglades..................................... 53

Extent........................................ 53

Elevation and drainage........................ 54

Bedrock................................. 5

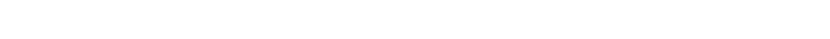

Cypress swamps................................. 58

Coastal swamps..................................... 58

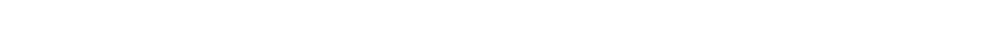

General character.................................. 59

The Florida reef $\ldots \ldots \ldots \ldots \ldots \ldots \ldots \ldots \ldots \ldots \ldots \ldots \ldots, \quad 61$

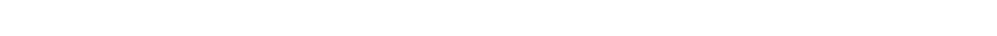

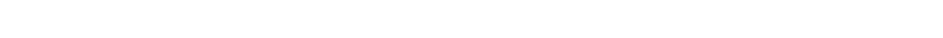

Ocean currents...................................... 63

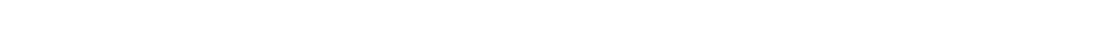

Northern and central Florida, by G. C. Matson ................. 65

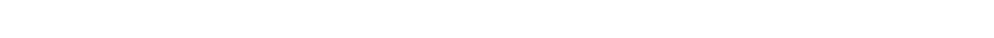

General succession of formations . . . . . . . . . . .

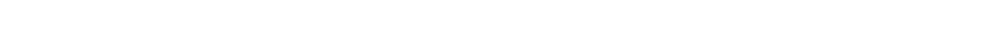

Oligocene series.................................... 71

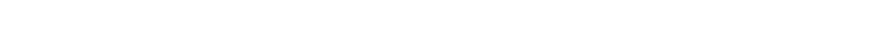

Vicksburg group................................ 71

Nomenclature................................ 71

Marianna and "Peninsular" limestones............. $\quad 73$

Stratigraphic position...................... 73

Lithologic character ........................ 73

Thickness................................. 73

Physiographic expression...................... 74

Paleontologic character.................... 74

Structure.................................. 74

Areal distribution........................... $\quad 75$

Ocala limestone................................ $\quad 79$

Nomenclature........................... $\quad 79$

Stratigraphic position...................... $\quad 80$

Lithologic character........................ $\quad 81$

Thickness................................... 81

Physiographic expression...................... 81

Paleontologic character.................... 82

Structure............................... 82

Areal distribution........................ 82

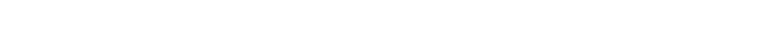


Part II.-Geology-Continued.

Northern and central Florida, by G. C. Matson-Continued.

Tertiary system-Continued.

Oligocene series-Continued. Page.

Apalachicola group........................... $\quad 85$

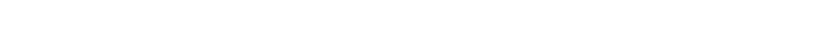

Hawthorn formation......................... 87

General character......................... 87

Stratigraphic position..................... 88

Lithologic character.................... 89

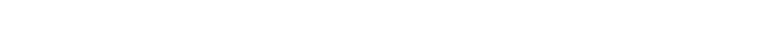

Physiographic expression................... 89

Paleontologic character................... $\quad 89$

Structure.............................. 90

Areal distribution......................... 90

Chattahoochee formation...................... 93

Nomenclature............................ 93

Stratigraphic position...................... $\quad 93$

Lithologic character....................... 94

Thickness............................... 95

Physiographic expression..................... 95

Paleontologic character..................... 95

Structure.................................. 96

Areal distribution.......................... $\quad 96$

Tampa formation............................. 102

Character and nomenclature.................. 102

Stratigraphic position....................... 103

Lithologic character.................... 103

Thickness................................ 104

Physiographic expression.................... 104

Paleontologic character.................... 104

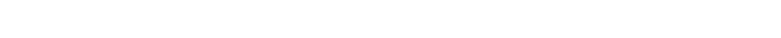

Areal distribution....................... 105

Alum Bluff formation........................ 108

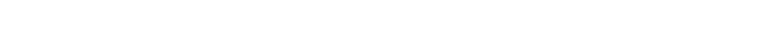

Stratigraphic position....................... 108

Lithologic character..................... 109

Thickness................................ 110

Physiographic expression.................... 111

Paleontologic character................... 111

Structure.............................. 111

Areal distribution....................... 111

Chipola marl member.................... 117

Oak Grove sand member................... $\quad 119$

Shoal River marl member................. 120

Miocene series................................... 121

Nomenclature and subdivisions..................... 121

Jacksonville formation............................ 123

Stratigraphic position....................... 123

Lithologic character....................... 123

Thickness................................... 125

Physiographic expression...................... 125

Paleontologic character...................... 125

Structure................................. 126

Areal distribution....................... 126 
Part II.-Geology-Continued.

Northern and central Florida, by G. C. Matson-Continued.

Tertiary system-Continued.

Miocene series-Continued. Page.

Choctawhatchee marl . . . . . . . . . . . . . . . . . . . . . . $\quad 127$

Stratigraphic position...................... 127

Lithologic character...................... 128

Thickness............................. 129

Physiographic expression...................... 129

Paleontologic character...................... 129

Structure.............................. 130

Areal distribution........................ 130

Pliocene series................................ 133

Caloosahatchee marl............................ 134

Nomenclature.............................. 134

Stratigraphic position....................... 134

Lithologic character...................... 135

Thickness............................... 135

Physiographic expression...................... 135

Paleontologic character...................... 135

Structure................................. 135

Areal distribution............................ 136

Nashua marl.................................... 138

Discrimination............................... 138

Stratigraphic position....................... 139

Lithologic character....................... 139

Thickness................................. 139

Physiographic expression...................... 139

Paleontologic character.................... 139

Structure................................... 140

Areal distribution........................... 140

Alachua clay....................................... 141

Deposition................................ 141

Stratigraphic position....................... 142

Lithologic character...................... 142

Thickness............................... 142

Physiographic expression....................... 142

Paleontologic character...................... 142

Structure................................ 143

Areal distribution........................... 143

Bone Valley gravel.............................. 144

Nomenclature............................. 144

Stratigraphic position........................ 145

Lithologic character......................... 145

Thickness................................. 145

Physiographic expression....................... 146

Paleontologic character....................... 146

Structure.................................. 146

Areal distribution............................ 146

Pliocene (?) series............................... 146

Lafayette (?) formation........................ 146

Correlation............................. 146

Stratigraphic position $\ldots \ldots \ldots \ldots \ldots \ldots \ldots \ldots \ldots \ldots \ldots, \quad 147$ 
PART II.-Geology-Continued.

Northern and central Florida, by G. C. Matson-Continued.

Tertiary system-Continued.

Pliocene (?) series-Continued.

Lafayette (?) formation-Continued. . Page.

Lithologic character........................ 147

Thickness................................... 148

Physiographic expression..................... 148

Paleontologic character..................... 148

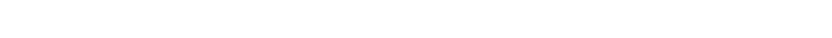

Areal distribution........................... 148

Quaternary system................................ 150

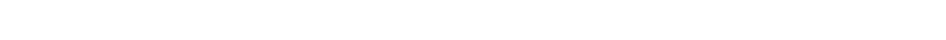

Pleistocene series. . . . . . . . . . . . . . . . . . . . . . . . . 151

Subdivisions.................................. 151

Fossiliferous marls............................ 151

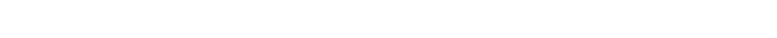

"Planorbis marl" ....................... 155

Coquina............................... 155

"Vermetus rock".......................... 156

Yellow clay............................ 156

Stratigraphic position............................. 156

Thickness...................................... $\quad 157$

Physiographic expression. . . . . . . . . . . . . . . . 158

Paleontologic character......................... $\quad 158$

Structure................................. 158

Recent series....................................... 158

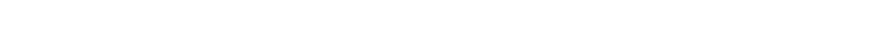

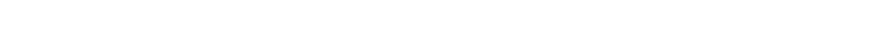

"Vermetus rock"

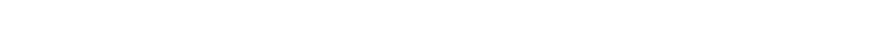

Coral reefs.................................. 160

Beach deposits.............................. 160

Eolian deposits............................... 160

Chemical deposits. . . . . . . . . . . . . . . . . . . . . . . 161

Human remains................................. 162

Structure. . . . . . . . . 163

Early investigations............................. 163

General character.................................. $\quad 165$

Southern Florida, by Samuel Sanford . . . . . . . . . . . . . . . 167

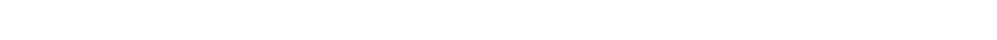

Pre-Pleistocene formations. . . . . . . . . . . $\ldots \ldots \ldots \ldots \ldots, \quad 167$

Character and distribution.................... 167

Well records.................................. 167

Distribution of wells....................... 167

Palm Beach.................................. 168

Indian Key Channel......................... 168

Key Vaca................................. 169

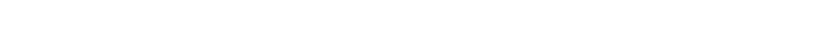

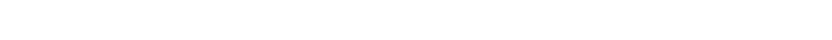

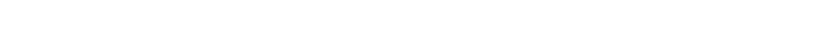

Buck Key.............................. 172

Oligocene series............................... 173

Miocene and Pliocene series..................... 173 
Part II.-Geology-Continued.

Southern Florida, by Samuel Sanford-Continued.

Stratigraphy-Continued. Page.

Pleistocene series. . . . . . . . . . . . . . . . . . . . . . . . . . . 174

Unexposed formations.......................... 174

Exposed formations............................... 175

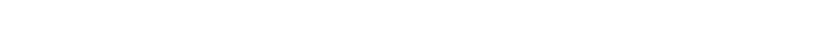

Palm Beach limestone.......................... $\quad 175$

Synonymy.................................. 175

Stratigraphic position...................... 176

Lithologic character...................... 176

Thickness................................. 176

Physiographic expression.................... 176

Paleontologic character.................... 177

Areal distribution......................... 177

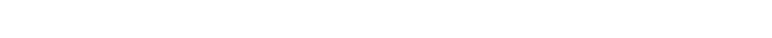

Miami oolite................................ 177

Synonymy............................. 177

Stratigraphic position..................... 178

Lithologic character....................... 178

Thickness................................ 179

Physiographic expression................... 179

Paleontologic character.................... $\quad 179$

Areal distribution........................ 180

Structure.......................... 180

Correlation........................... 180

Origin................................... 180

Key West oolite........................... 180

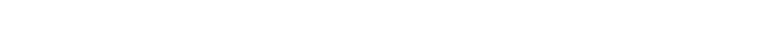

Stratigraphic position..................... 180

Lithologic character...................... 181

Thickness.................................. 181

Physiographic expression.................... 182

Paleontologic character...................... 182

Origin................................... 182

Chemical character........................... 184

Key Largo limestone........................... $\quad 184$

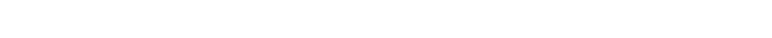

Stratigraphic position........................ 186

Lithologic character........................ 186

Thickness............................. 187

Physiographic expression..................... 187

Paleontologic character..................... 188

Areal distribution.......................... 188

Lostmans River limestone..................... $\quad 189$

Synonymy.................................. 189

Stratigraphic position........................ 189

Lithologic character...................... 190

Thickness............................... 190

Areal distribution.......................... 190

Origin ................................... 191

Correlation of Pleistocene formations................ 191

Lithology of Pleistocene beds..................... 192

Coquina.................................. 192

Sands................................... 193 
Part II.-GeologY-Continued.

Southern Florida, by Samuel Sanford-Continued.

Stratigraphy-Continued.

Pleistocene series-Continued.

Lithology of Pleistocene beds-Continued. Page.

Marls.................................... 194

Summary................................. 194

Thickness of the Pleistocene rock................. 194

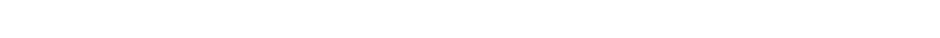

General character............................ 195

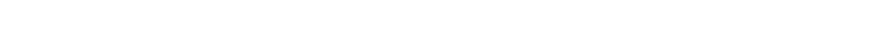

Marl....................................... 196

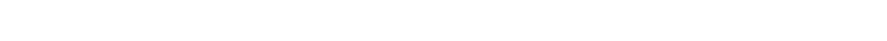

Coral...................................... 197

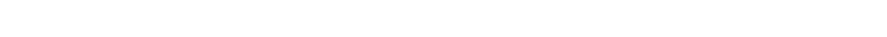

Oyster banks. . . . . . . . . . . . . . . . . . . . .

Soils........................................... 198

Structure.......................................... 199

Geologic history, by G. C. Matson and Samuel Sanford.............. 199

Data ............................................. 199

Oligocene epoch....................................... 199

Vicksburg epoch.................................. 199

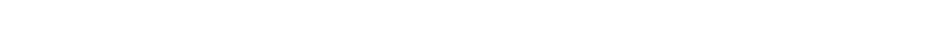

A.palachicola epoch................................ 202

Miocene epoch....................................... 203

Physiographic changes............................... 203

Deposition........................................... 204

Pliocene epoch................................... 205

Physiographic changes............................... 205

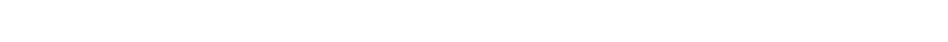

Pleistocene epoch.................................. 207

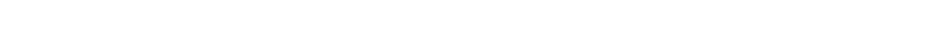

Submergence................................. 209

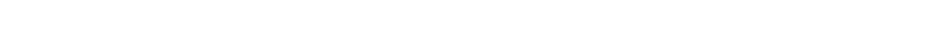

Southern Florida.................................... 211

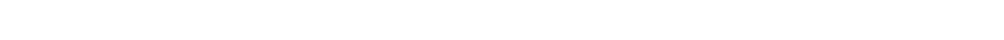

Northern and central Florida......................... 212

Southern Florida................................. 214

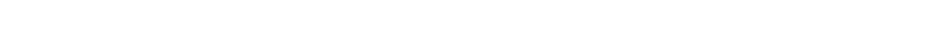

Part III.-Underground water............................. 219

General features, by G. C. Matson.......................... 219

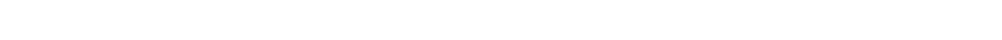

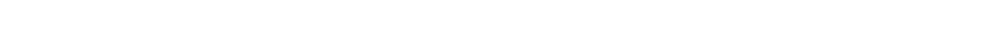

In the earth as a whole.............................. 221

In Florida.......................................... 221

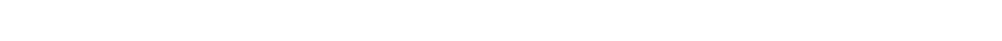

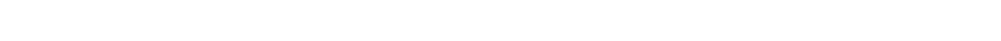

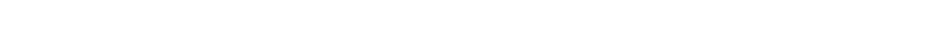

Depth of potable supplies............................ 225

Circulation........................................... 227

Recovery............................................ 228

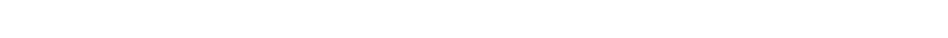

Seepage............................................ 228

Springs....................................... 228 
Part III.-Underground water-Continued.

General features, by G. C. Matson-Continued.

Recovery-Continued.

Artificial recovery ............................... 229

Wells......................................... $\quad 229$

Types................................... 229

Position...................................... 230

Methods of well making........................ 231

Dug wells................................ 231

Bored wells............................. 231

Driven wells............................. 232

Drilled wells.............................. 232

Methods of raising water....................... 233

Central and northern Florida, by G. C. Matson.................... 234

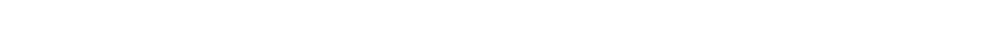

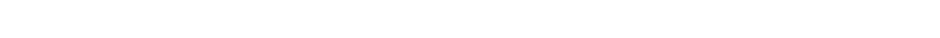

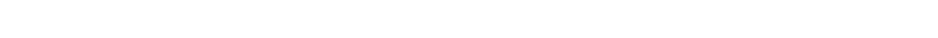

Controlling factors............................... 235

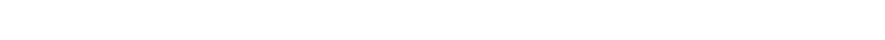

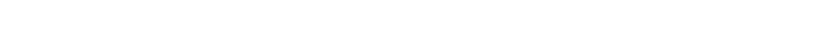

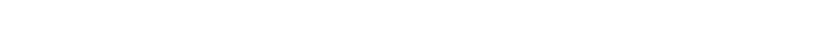

Southern Florida......................... 237

West coast................................. 237

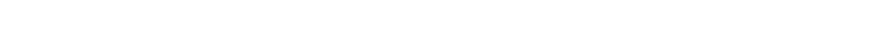

Natural causes............................. 237

Artificial causes........................... $\quad 239$

Artesian fallacies............................... 241

Occurrence........................................ 242

Water-bearing materials................................ 242

Character.................................... ${ }_{242}$

Sand and gravel................................ 242

Clay.............................................. 242

Shell marl...................................... 243

Limestone.................................. 243

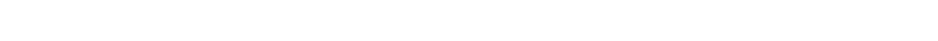

Governing conditions............................ $\quad 243$

Oligocene series................................. 248

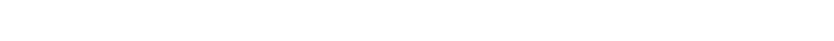

Limestones of the Vicksburg group............... 248

Chattahoochee formation........................ 249

Hawthorn formation.......................... 249

Tampa formation........................... 250

Alum Bluff formation.......................... 250

Miocene series................................. 251

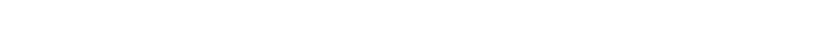

facksonville formation........................ 251

Choctawhatchee marl......................... 251

Pliocene series................................. 252

General conditions....................... 252

Nashua and Caloosahatchee marls................ 252

Alachua clay................................ 252

Bone Valley gravel........................ 253

Pliocene (?) series............................. 253

Lafayette (?) formation...................... 253

Pleistocene and Recent series.................... 253 
Part III.-Underground water-Continued.

Central and northern Florida-Continued. Page.

Public water supplies.................................... 254

Surface and underground waters of southern Florida, by Samuel Sanford.. $\quad 255$

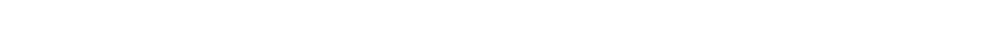

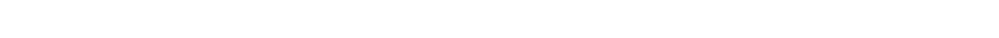

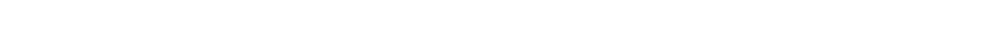

Water-bearing formations............................... 258

Oligocene....................................... 258

Miocene and Pliocene............................... 258

Pleistocene........................................... 258

Artesian water....................................... 259

Quality................................................... 259

Relations of fresh and salt water underground................... 261

Part IV.-County descriptions............................... 263

Alachua County, by G. C. Matson........................... 263

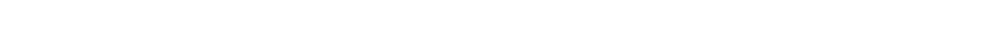

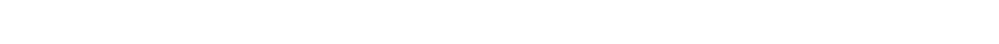

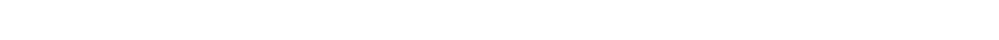

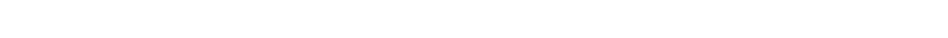

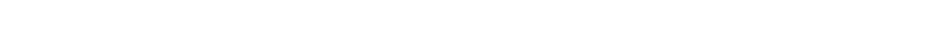

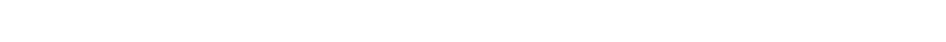

Baker County, by G. C. Matson........................... 267

General features................................... 267

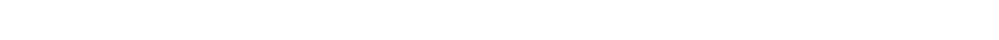

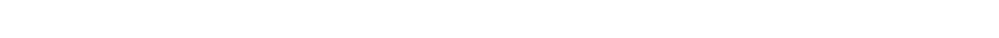

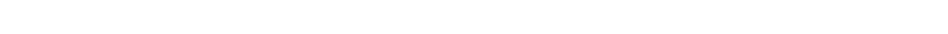

Quality....................................... 268

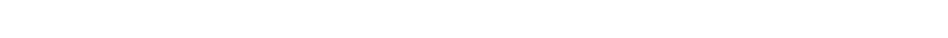

Bradford County, by G. C. Matson........................ 269

General features.................................... $\quad 269$

Geologic formations. .................................. 269

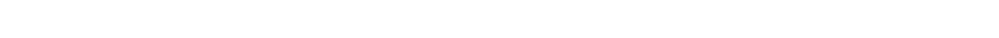

Source...................................... $\quad 270$

Quality.......................................... 270

Development...................................... $\quad 270$

Brevard County, by G. C. Matson.......................... 273

General features....................................... 273

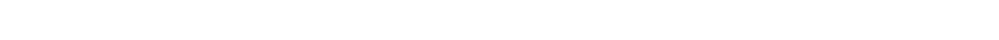

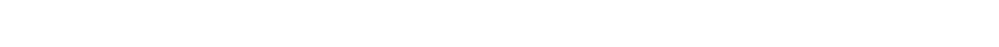

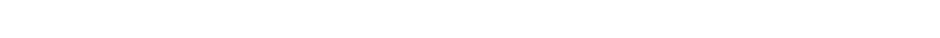

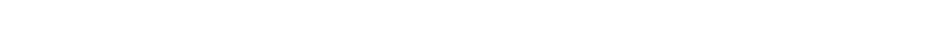

Development..................................... $\quad 275$

Calhoun County, by G. C. Matson....................... 277

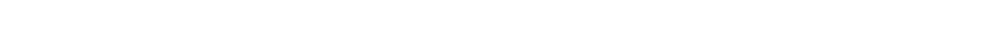

Geology ............................................. 278

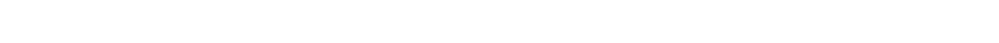

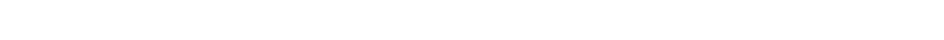

Quality......................................... 278

Development................................... 279

Citrus County, by G. C. Matson............................ 280

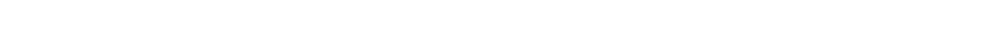

Geology ......................................... 280 
Part IV.-County descrtptons-Continued.

Citrus County, by G. C. Matson-Continued. Pago.

Water supply.................................. 281

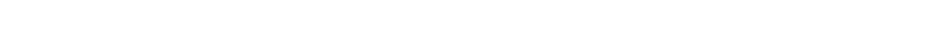

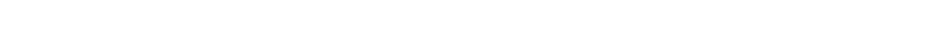

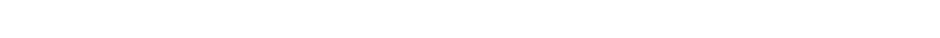

Clay County, by G. C. Matson ......................... 283

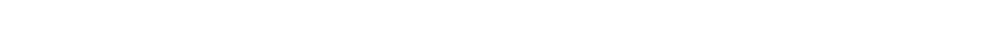

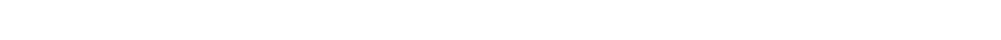

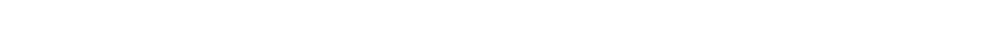

Source........................................ 284

Quality...................................... 284

Development.................................. 284

Columbia County, by G. C. Matson......................... 286

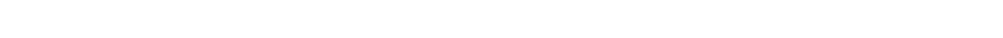

Geology............................................. 286

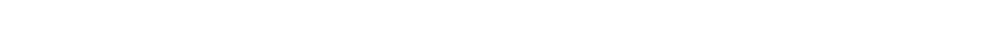

Source........................................ 287

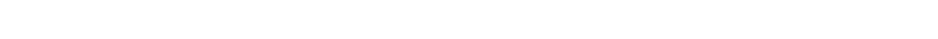

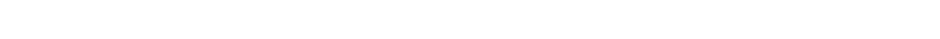

Dade County, by Samuel Sanford.............................. 288

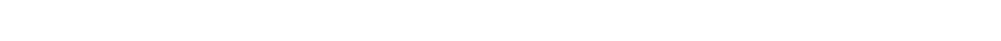

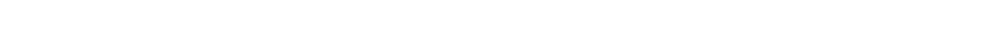

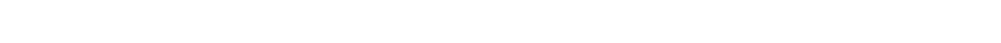

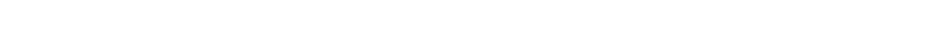

Springs............................................. 289

Wells......................................... 289

Artesian prospects................................... 292

De Soto County, by G. C. Matson.......................... 294

General features..................................... 294

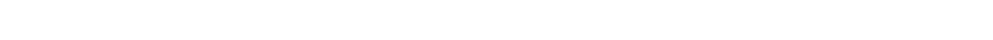

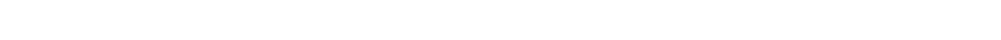

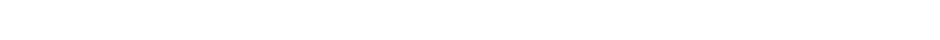

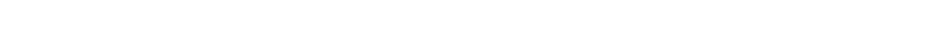

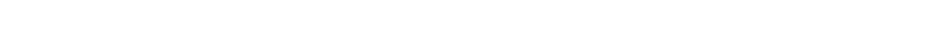

Duval County, by G. C. Matson........................... 296

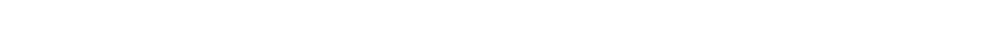

Geology...................................... 297

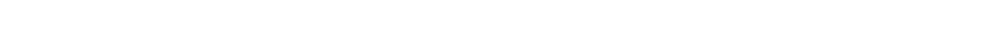

Source...................................... 299

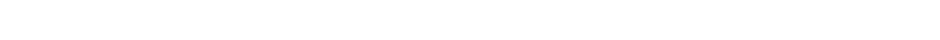

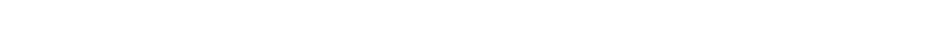

Escambia County, by G. C. Matson........................ 301

General features......................................... 301

Geology............................................ 302

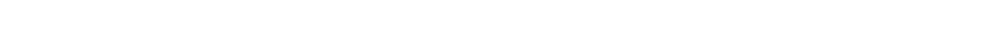

Source........................................ 304

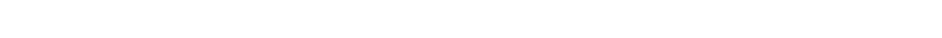

Development..................................... 304

Franklin County, by G. C. Matson ......................... 305

General features....................................... 305

Geology ............................................. 305 
Part IV.-County descriptions-Continued.

Franklin County, by G. C. Matson-Continued. Page.

Water supply.................................... 306

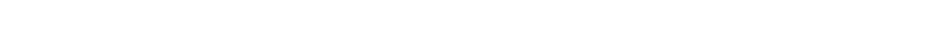

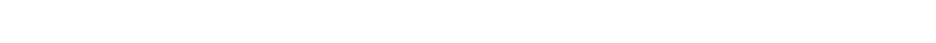

Development....................................... 306

Gadsden County, by G. C. Matson........................ 308

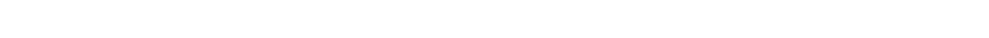

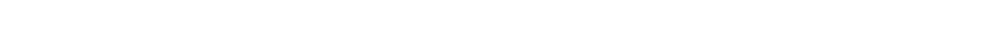

Water supply.................................... 310

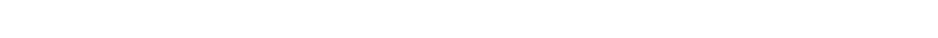

Quality.................................. 310

Development................................. 310

Hamilton County, by G. C. Matwon........................ $31 \dot{2}$

General features..................................... 312

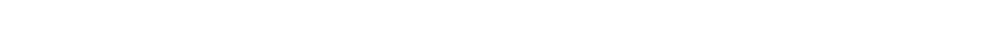

Water supply....................................... 313

Source......................................... 313

Quality.......................................... 313

Development................................... 313

Hernando County, by G. C. Matson..................... 316

General features...................................... 316

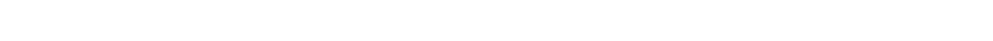

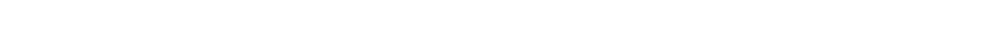

Source......................................... 317

Quality......................................... 317

Development....................................... 317

Hillsborough County, by G. C. Matson....................... 319

General features....................................... 319

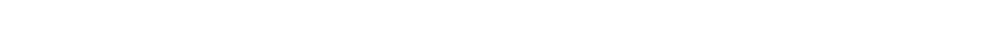

Water supply......................................... 322

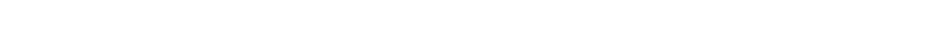

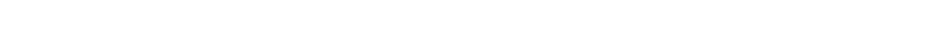

Development.................................... 322

Holmes County, by G. C. Matson........................... 325

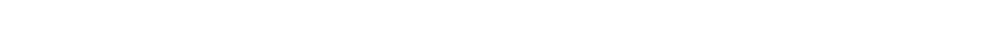

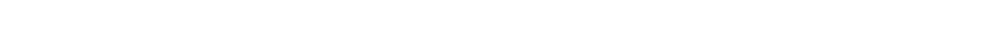

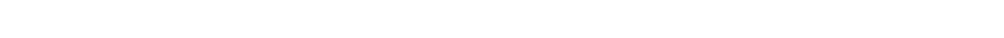

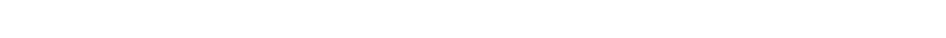

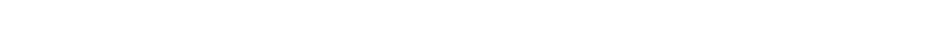

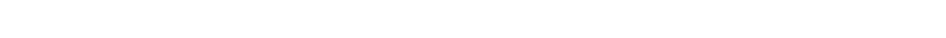

Jackson County, by G. C. Matson ......................... 327

General features...................................... 327

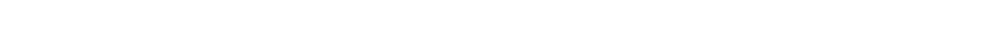

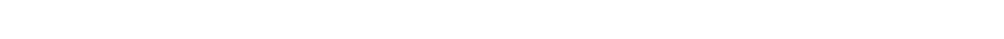

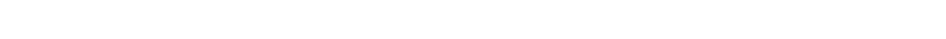

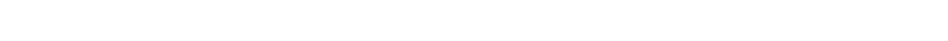

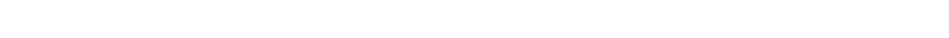

Jefferson County, by G. C. Matson........................ 330

General features........................................ 330

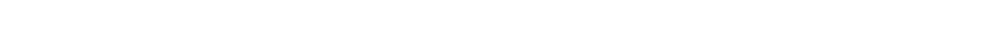

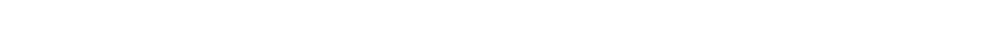

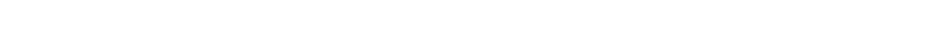

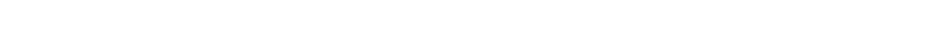

Development................................... 331 
Part IV.-County descriptions-Continued. Page.

Lafayette County, by G. C. Matson........................... 335

General features...................................... 335

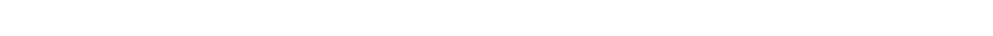

Water supply......................................... 335

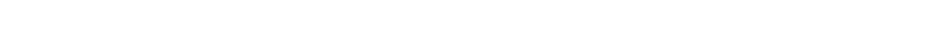

Quality.......................................... 335

Development................................... 335

Lake County, by G. C. Matson............................ 338

General features........................................... 338

Geology ............................................. 338

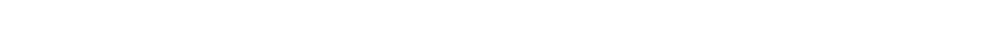

Source.......................................... 341

Quality........................................ 341

Development................................... 341

Lee County, by Samuel Sanford....................... 344

General features..................................... 344

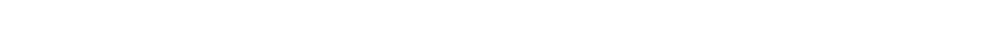

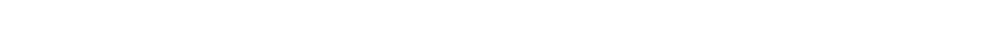

Source and quality................................. 344

- Development........................................ 345

Artesian prospects.............................. $\mathbf{3 5 0}$

Leon County, by G. C. Matson......................... $\quad 350$

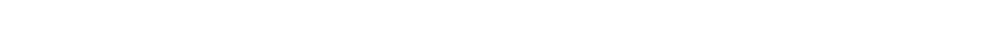

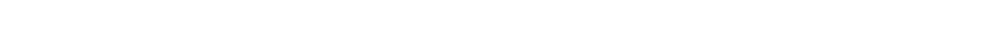

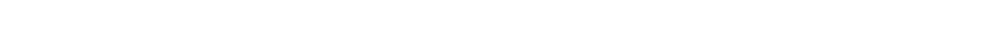

Source........................................ 351

Quality........................................ 352

Development................................... 352

Levy County, by G. C. Matson.............................. 354

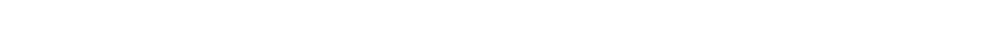

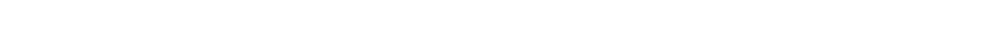

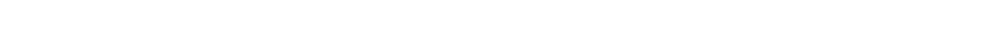

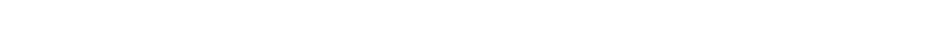

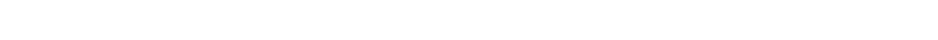

Development..................................... 355

Liberty County, by G. C. Matson........................... 357

General features....................................... 357

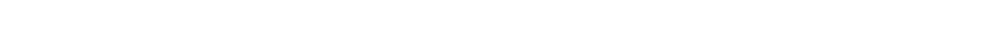

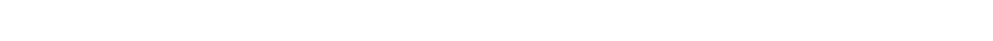

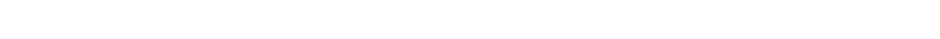

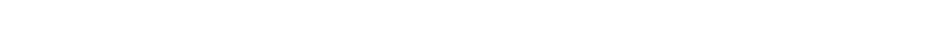

Development.................................. 358

Madison County, by G. C. Matson........................ 359

General features................................... 359

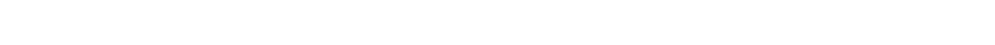

Water supply......................................... 359

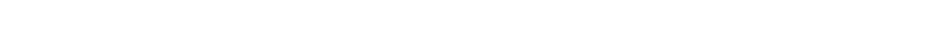

Quality.................................. $\quad \mathbf{3 6 0}$

Development........................................ 360

Manatee County, by G. C. Matson.......................... 362

General features.......................................... 362

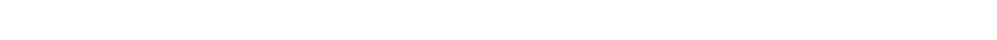


Part IV.-County Descriptions-Continued.

Manatee County, by G. C. Matson-Continued. Page.

Water supply....................................... 363

Source............................................ 363

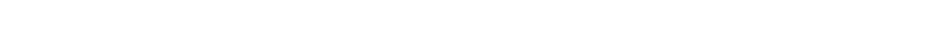

Development. . . . . . . . . . . . . 363

Marion County, by G. C. Matson......................... 365

General features.................................... 365

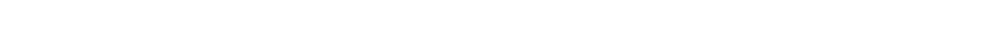

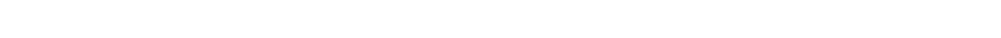

Source......................................... 366

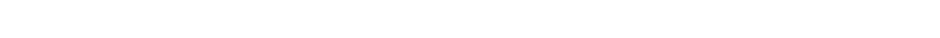

Development................................... 366

Monroe County, by Samuel Sanford .......................... 370

General features........................................... 370

Geology............................................. 370

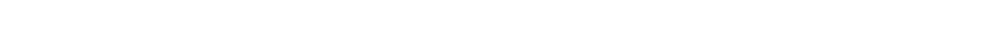

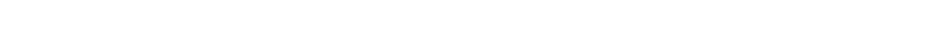

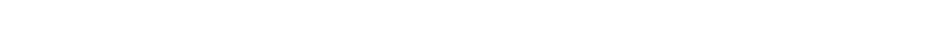

Nassau County, by G. C. Matson.......................... 373

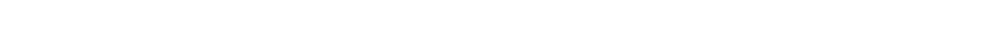

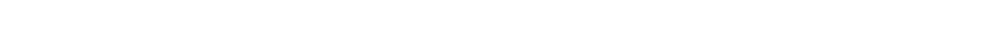

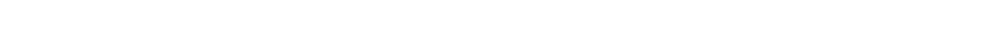

Source.............................................. 374

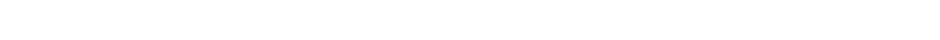

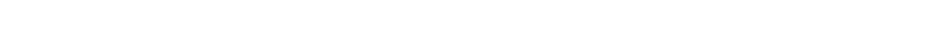

Orange County, by G. C. Matson............................. 376

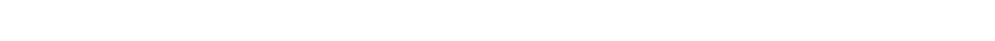

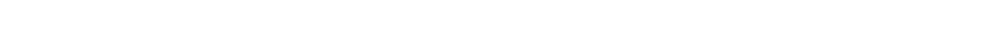

Water supply.......................................... 377

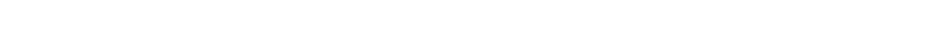

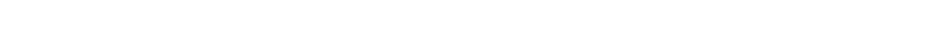

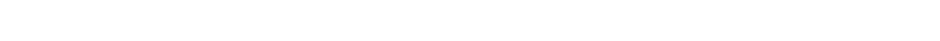

Osceola County, by G. C. Matson.......................... 379

General features..................................... 379

Geology ............................................ 379

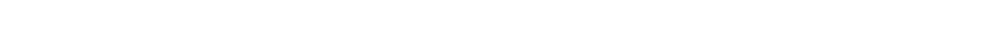

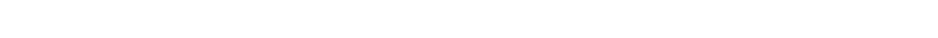

Quality........................................ 380

Development.................................... $\quad 380$

Palm Beach County, by Samuel Sanford ...................... 381

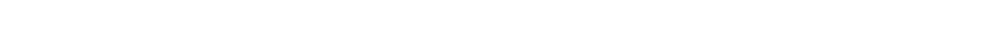

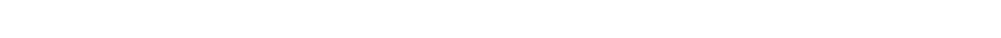

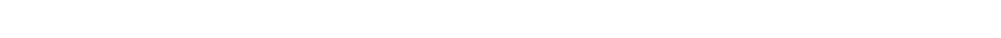

Source............................................ 382

Artesian prospects.................................. 384

Pasco County, by G. C. Matson................................ 385

General features..................................... 385

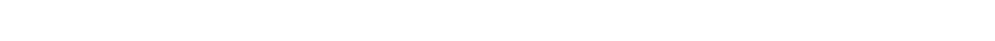

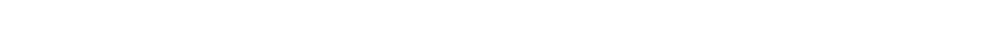

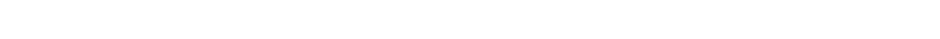

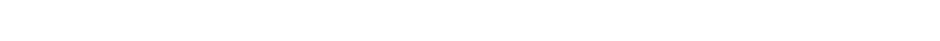

Development................................... 386

Pinellas County........................................ 387 
Part IV.-County descriptions-Continued. Page.

Polk County, by G. C. Matson ............................... 388

General features.......................................... 388

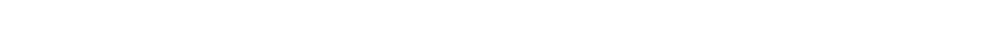

Water supply............................................ 389

Source........................................... 389

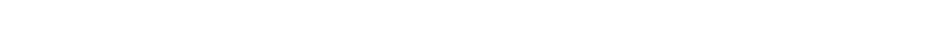

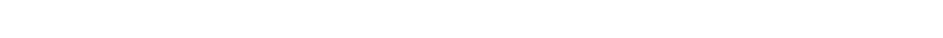

Putnam County, by G. C. Matson........................ 391

General features..................................... 391

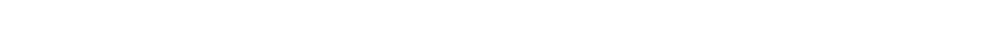

Water supply...................................... 392

Source.......................................... 392

Quality...................................... 392

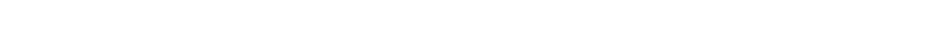

St. John County, by G. C. Matson.............................. 394

General features..................................... 394

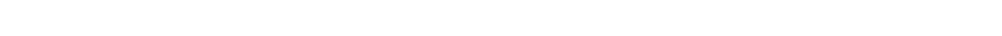

Water supply......................................... 397

Source................................................. 397

Quality.......................................... 397

Development......................................... 397

St. Lucie County, by G. C. Matson........................... 398

General features....................................... 398

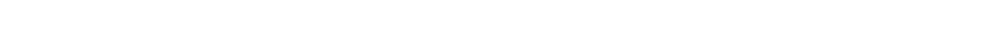

Water supply.......................................... 399

Source................................................ 399

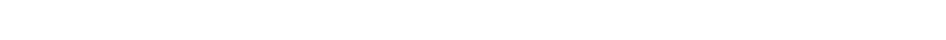

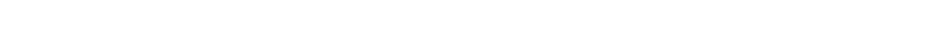

Santa Rosa County, by G. C. Matson ......................... 401

General features...................................... 401

Geology ............................................. 401

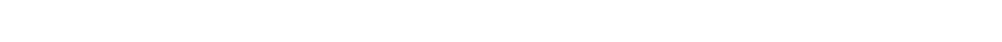

Source............................................ 401

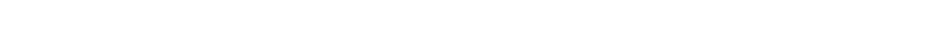

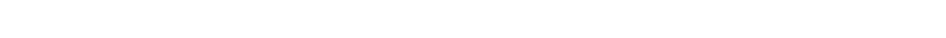

Sumter County, by G. C. Matson......................... 404

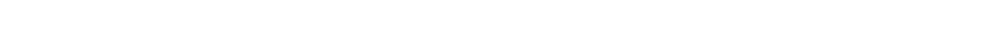

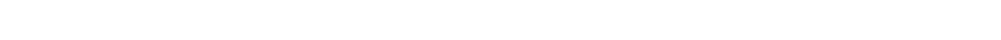

Water supply....................................... 406

Source......................................... 406

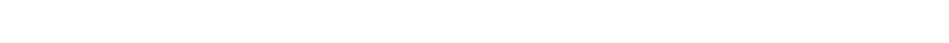

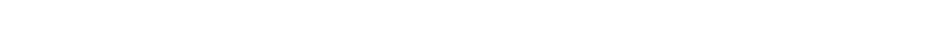

Suwannee County, by G. C. Matson ......................... 408

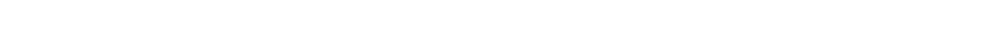

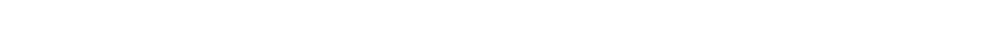

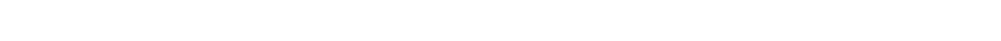

Source............................... " 408

Quality.......................................... 408

Development....................................... 409

Taylor County, by G. C. Matson .......................... 413

General features.......................................... 413

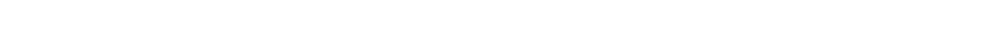


Part IV.-County descriptions-Continued.

Taylor County, by G. C. Matson-Continued.

Page.

Water supply

Source............................................ 413

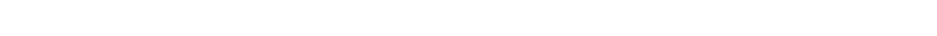

Development........................................ 414

Volusia County, by G. C. Matson $\ldots \ldots \ldots \ldots \ldots \ldots \ldots \ldots \ldots \ldots \ldots \ldots \ldots \ldots \ldots \ldots$

General features................................. 416

Geology ..................................... 416

Water supply...................................... 418

Source.................................... 418

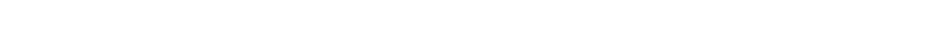

Development................................... 418

Wakulla County, by G. C. Matson.......................... 420

General features................................. 420

Geology..................................... 420

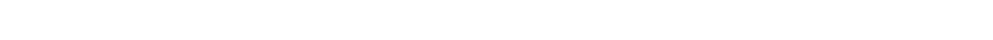

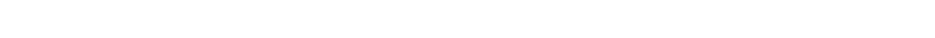

Quality........................................ 421

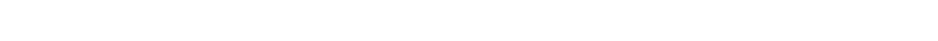

Walton County, by G. C. Matson......................... 422

General features................................ 422

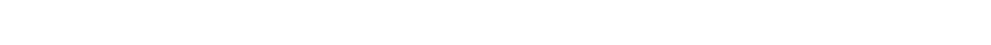

Water supply....................................... 424

Source....................................... 424

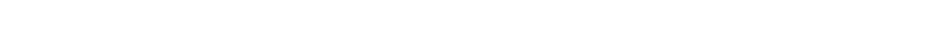

Development................................ 424

Washington County, by G. C. Matson ....................... 426

General features.................................. 426

Geology ...................................... 426

Water supply.................................... 428

Source..................................... 428

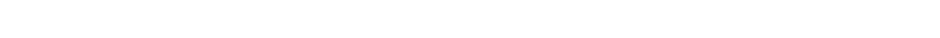

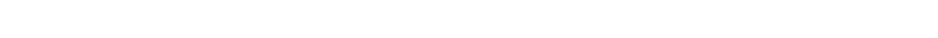

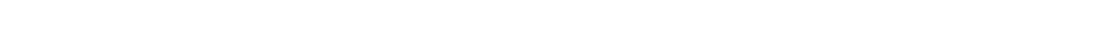

INserts (tables) facing pages $254,266,276,282,284,286,294,300,304,322,328,342$, $348,356,360,364,366,378,380,390,392,396,406,418$. 


\section{ILLUSTRATIONS.}

PuATE I. General topographic and geologic map of Florida Page.

II. Map of part of Williston quadrangle, showing sink holes .......... 26

III. $A$, Sink hole, Alachua County; $B$, Sink hole containing pond, 10 miles southeast of Vernon, Washington County ...............

IV. $A$, Sink of Santa Fe River; $B$, Drainage sink of Oclahatchee Lake, 7 or 8 miles south of Lake Park, Ga..................... 27

V. Generalized map of Pleistocene terraces of Florida........... In pocket.

VI. $A$, Pleistocene terrace and escarpment bordering St. Marys River on Florida side, opposite Traders Hill, Ga.; B, Old well of Spanish

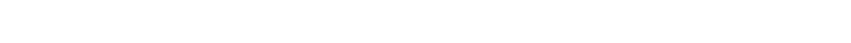

VII. $A$, Beach ridge of coral and shell sand, Knights Key; $B$, Calcareous sand on reef rock........................................

VIII. $A$, Mangrove key, water's edge; $B$, Root growth of mangroves south end of Key Vaca......................................

IX. $A$, Section in quarry of Ocala Lime Co. at Ocala; $B$, Quarry of Ocala Lime Co. (old Phillips quarry), 1 mile southeast of Ocala........

X. $A$, Limestone of Tampa formation exposed along Sixmile Creek, a quarter of a mile below Atlantic Coast Line Railway bridge, Hillsborough County; $B$, Limestone of Chattahoochee formation on Withlacoochee River at New Bridge (or Horn Bridge), 3 miles below Georgia \& Florida Railway bridge, Lowndes County, Ga..

XI. $A$, Contact of Nashua marl and Pleistocene sand, a quarter of a mile below Nashua, on St. Johns River; $B$, Clay unconformably overlying Nashua marl in pit about half a mile south of De Leon

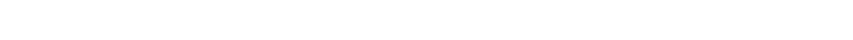

XII. $A$, Conglomerate of Lafayette (?) formation, resting on sandstone of uncertain age, top of Rock Hill, Washington County; $B$, Rock face in coquina quarry, Anastasia Island.................

XIII. $A$, Coquina rock on Gulf side of Sarasota Key; $B$, Turtle Mound, an ancient shell mound on North Indian River...............

XIV. $A$, Reef rock, Key Largo limestone, showing erosion; $B$, Quarry in Miami oolite.

XV. $A$, Reef rock, Key Largo limestone, coral head; $B$, Mud cracks in crustal layers of Key West oolite........................

XVI. $A$, Well at Quincy, illustrating type of bored well and bucket in use in Gadsden County; $B$, Flowing well at New Smyrna, with provision for shutting off water when not in use.................

XVII. $A$, Waterwheel for pumping water, Caloosahatchee River; $B$, Wekiva Spring, showing spring and bathhouse......................

Frgure 1. Section near edge of Everglades west of Fort Lauderdale..........

2. Relation of underground-water level to Silver and Blue springs....

3. Relation of underground-water level to surface contour in Suwannee

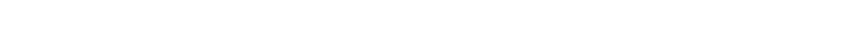

4. Profile across peninsula of Florida in latitude $29^{\circ} \mathrm{N} \ldots \ldots \ldots \ldots$

5. Diagram showing importance of choosing proper locations for wells.

6. Conditions governing the occurrence of artesian water in some parts

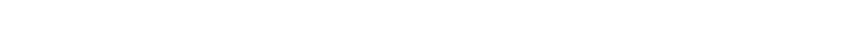

7. Variation of water level in Johnson well near San Bernardino, Cal.. 


\title{
GEOLOGY AND GROUND WATERS OF FLORIDA.
}

\author{
By George Charlton Matson and Samuel Sanford.
}

\section{INTRODUCTION.}

The geology of Florida has been a subject of investigation for many years, for the delightful winter climate of the State early attracted to it many scientists who attempted, with varying degrees of success, to solve some of the geologic problems. The investigations, however, have thus far resulted in only one comprehensive stratigraphic report, although many papers have appeared in scientific journals, notably in the transactions of the Wagner Free Institute of Science and the American Journal of Science.

The present report, like all similar reports covering large areas, contains data derived from many sources. The authors have carefully studied the earlier literature and have compared the different views presented, which are here summarized, credit being given to the several investigators. The work of W. H. Dall, of the United States Geological Survey, has been especially helpful. Mr. Dall made extensive investigations of the paleontology of the State and, in 1892, published a treatise ${ }^{1}$ covering nearly a hundred pages, in which he outlined the conditions as they were then known. A later report by $\mathrm{Mr}$. Dall ${ }^{2}$ is primarily paleontologic, but contains also a summary of the geology and the stratigraphy of the State.

The paleontologic studies of T. Wayland Vaughan, of the United States Geological Survey, under whose immediate supervision this report has been prepared, in connection with the work of Mr. Dall, have also been of great value, because they have formed a basis for all subsequent work. Mr. Vaughan examined and identified the fossils collected during the progress of the work, and he has very generously placed at the disposal of the writers his own extensive notes, accumulated during many years. The work of other geologists, prominent among whom are Dr. Eugene A. Smith, Prof. Angelo Hellprin, and Prof. Alexander Agassiz, has added much to the writers' knowledge of the geology of Florida.

1 Correlation papers-Neocene: Bull. U. S. Geol. Survey No. 84, 1892, pp. 85்-159.

2 Contributions to the Tertiary fauna of Florida: Trans. Wagner Free Inst. Sci., vol. 3, pts. 1-6, 1890-1903. 
After the discovery of phosphate in Florida George H. Eldridge was sent by the United States Geological Survey to make detailed investigations of the deposits. He obtained much valuable data but unfortunately did not live to prepare his final report. His notebooks have been available, however, and have occasionally been drawn upon by the writers.

Aside from incidental references to underground waters in Florida, brief summaries of the water resources have been published by the United States Geological Survey and by the Florida Agricultural Experiment Station. Most of the scattered references to Florida waters are of historic interest only, but some of the records of deep-well borings are important. Four lists of these are worthy of special mention. The first two were compiled by Darton, ${ }^{1}$ the third by Fuller, Lines, and Veatch, ${ }^{2}$ and the fourth by Fuller and Sanford. ${ }^{3}$

Summaries of the underground-water resources of Florida have been published by Fuller ${ }^{4}$ and Sellards. ${ }^{5}$ A report on the ground waters of central Florida has recently been published by the State Geological Survey. ${ }^{6}$

The investigations leading to the present report were made possible primarily by the passage of the act incorporating the new State survey. The United States Geological Survey was then engaged in making a systematic investigation of the geology of the Atlantic Coastal Plain of the United States and with the financial cooperation of the new survey was enabled to make a more comprehensive study than could have been carried out in a single season by either bureau alone.

In October, 1907, F. G. Clapp, then employed by the Federal survey, began a field study of the stratigraphy and underground water resources of northern and central Florida. In November of the same year he was joined by G. C. Matson, and the two remained in the State continuously until May 1, 1908, visiting nearly every town in the northern and central sections and gathering as much data as time would permit. At the same time Prof. E. H. Sellards, State geologist, and his assistant, Herman Gunter, visited 16 counties in central Florida and gathered data on the water supplies.

The funds available for field expenses having been exhausted, Messrs. Clapp and Matson returned to the office about May 1, 1908.

1 Darton, N. H., Preliminary list of deep borings in the United States: Water-Supply Paper U. S. Geol. Survey No. 57, pt. 1, 1902, pp. 21-22; and Water-Supply Paper No. 149, 1905, pp. 25-26.

${ }^{2}$ Fuller, M. L., Lines, E. F., and Veatch, A. C., Record of deep-well drilling for 1904: Bull. U. S. Geol. Survey No. 264, 1905, pp. 44-45.

3 Fuller, M. L., and Sanford, Samuel, Record of deep well drilling for 1905: Bull. U. S. Geol. Survey No. 298, 1906, pp. 47-50, 195-199.

4 Fuller, M. L., Contributions to the hydrology of eastern United States, 1903: Water-Supply Paper U. S. Geol. Survey No. 102, 1904, pp. 18, 27, 238-275; and Underground waters of eastern United States: Water-Supply Paper U. S. Geol. Survey No. 114, 1905, pp. 159-163.

6 Sellards, E. H., Occurrence and use of artesian water: Bull. Florida Agr. Ex. Station No. 89, 1907, pp. $1-113$.

- Sellards, E. Ḧ., A preliminary report on the underground water supply of central Florida: Bull. Flotida Geol. Survey No. 1, 1908, pp. 1-103. 
On July 1, 1908, Mr. Clapp resigned from the United States Geological Survey, and the work of preparing the manuscript for the report on the northern and central parts of the State was intrusted to Mr. Matson. Before tendering his resignation Mr. Clapp prepared the topographic map of the State and drew up a tentative outline of the paper published in the Second Annual Report of the Florida Geological Survey. ${ }^{1}$

Shortly after the appearance of the State report Thomas Wayland Vaughan published a paper entitled "A contribution to the geologic history of the Floridian plateau,"'2 containing a résumé of the geologic history and valuable information concerning the influence of depth and temperature of ocean waters, and the action of ocean currents in the development and history of the peninsula of Florida.

The geologic information contained in the earlier papers has been incorporated in the present report, with such revisions as were deemed essential to make it suitable for a Water-Supply Paper. The results of field work by Mr. Matson while in the employ of the General Land Office during the winters of 1909-10 and 1910-11 have been utilized in the preparation of additional discussions of the Pleistocene geology. Some important changes in both the text and map of the earlier report have also been made possible by Mr. Matson's recent field work. The base map accompanying both reports was prepared by the United States Geological Survey.

At the time when the field work for this report was begun Samuel Sanford was engaged in geologic work for the Florida East Coast Railway, and the task of investigating the geology of the keys and of the southern end of the State was intrusted to him.

The interest and cooperation of the people of Florida have rendered this work a pleasure, and the authors wish here to make public acknowledgment of the numerous favors and courtesies extended them in the field and office. Several persons deserve particular mention, among them being Dr. J. N. MacGonigle, of Miami; Mr. Goff and several other officials of the Florida East Coast Railway, for affording opportunities to visit the extension of the railroad during the process of its construction. Mr. Frank Clark, of Gainesville, furnished introductions which greatly facilitated the investigations; Dr. DeWitt Webb, of St. Augustine, and Dr. Crill, of Palatka, have interested themselves in the work. Many well drillers have furnished logs and records, adding valuable data to the knowledge of the stratigraphy. Capt. Alexander Near, of Eau Gallie; Mr. H. C. Haven, of De Land; Mr. W. D. Holcomb and Mr. Edward Pettigrew, of Manatee; Mr. H. W. Pearce, of Arcadia; Mr. H. Walker, of St.

\footnotetext{
1 Matson, G. C., and Clapp, F. G., A preliminary report on the geology of Florida, with special reference to the stratigraphy: Second Ann. Rept. Florida Geol. Survey, 1909, pp. 28-173.

2 Pub. Carnegie Institution of Washington No. 133, 1910, pp. 99-185.
} 
Augustine; Mr. Wm. E. Hughes, of Charleston, S. C.; J. E. Ingraham, of the Florida East Coast Railway; J. C. Meredith, formerly constructing engineer, and W. J. Krome, constructing engineer, of the Key West extension, rendered special assistance.

Many others, who can not be mentioned on account of lack of space, have given substantial assistance. A number of citizens have interested themselves in acting as guides and in furnishing specimens and samples from wells. The officials of the Atlantic Coast Line Railroad, the Seaboard Air Line Railway, the Florida East Coast Railway, and the Louisville \& Nashville Railroad, in Jacksonville, Wilmington, Norfolk, and Louisville, have allowed access to their profiles and other records, which gave valuable information for use in the construction of the topographic map of the State. (See Pl. I.) 


\section{PART I.-GEOGRAPHY.}

\section{NORTHERN AND CENTRAL FLORIDA.}

By G. C. Matsen.

\section{NATURE OF COUNTRY.}

The area described in this report comprises all the State of Florida. (See Pl. I, in pocket.) It forms a part of the provinee commonly known as the Coastal Plain-a broad tract of relatively low land which extends from New York to Mexico, rising gradually from the coast to a height of a fow hundred feet and for the most part apparently flat or gently rolling. In Florida the shores are low and swampy, variations in the altitude amounting to only a few feet in several miles. Farther inland the surface is more rolling, and is in some places hilly, but the relief is nowhere great. Most of the surface is sandy, though in a few localities the soil contains considerable clay. The sandstones, clays, shales, and limestones of the older formations are nearly everywhere only a few feet beneath the surface.

\section{RELIEF.}

Although Florida is a region of comparatively slight relief, its surface presents considerable diversity, ranging from a nearly level plain in the coastal region and the Everglades to a deeply dissected upland in the northern part of the State, where it is trenched by steep-walled valleys, and to a highland in the peninsula, where it shows many more or less rounded depressions separated by narrow divides. Altitudes within the State range from sea level to more than 200 feet above at places on the ridge that forms the center of the peninsula and to about 300 feet above, at the western end of the State near the northern boundaries of Gadsden, Walton, Santa Rosa, and Escambia counties.

The topographic map (Pl. I) is intended to show the approximate areas of land which lie above and below certain altitudes. The datum plane is mean sea level, and the contour lines connect points of equal altitude at intervals of 50 feet. The map embodies the results of the earlier topographic surveys, the river surveys of the United States Army Engineers, and the several railnoad surveys, together with a large number of barometric determinations made during the field work. Although the exact location of the contours is in places more or less uncertain, it is believed that they are sufficiently acce- 
rate to give a good idea of the relative areas of different altitudes and to present a general plan of the broader topographic features of the State. The small scale of the map made it necessary to omit such minor details as sink holes, valleys of small streams, narrow ridges, and small more or less isolated elevations. The United States Geological Survey has already published detailed maps of seven contiguous quadrangles (Arredondo, Citra, Dunnellon, Ocala, Panasoffkee, Tsala Apopka, and Williston), comprising an area of about 1,800 square miles, situated in the central part of the peninsula, and to these the reader is referred for local information.

The southern part of the peninsula, comprising an area about 150 miles long and over 100 miles in average width, lies in general less than 50 feet above sea level. Narrow strips of lowland also border the Atlantic and Gulf coasts. The valleys of the streams do not rise above the 50-foot contour for a considerable distance from the coast, and one of them (St. Johns River) is nowhere more than 30 feet above tide.

The uplands of the peninsula and the adjacent part of north Florida are separated into two more or less distinct parts by Ocklawaha River. Beginning southeast of Arcadia, a belt of high land, very irregular in shape, extends northward to Summit on the Atlantic Coast Line Railroad, and separates the Kissimmee River drainage basin from that of the streams to the west. At Lakeland, Brooksville, and several other points this upland rises more than 200 feet above sea level.

Another broad, irregular upland, stretching northward from Ocklawaha River to the Georgia line, includes a considerable tract more than 150 feet above sea level and forms the divide between the Atlantic and Gulf drainage basins. Its narrowest part is along the western boundaries of Clay and Duval counties, where it forms the long north-south divide known as Trail Ridge. This upland includes Lake City, at an altitude 201 feet above sea level, and Highland on Trail Ridge at an altitude of 210 feet. Near the Georgia line the upland broadens into the Okefenokee swamp, which occupies a large area in Georgia and extends a short distance into Florida. The western slope of the highland is cut by Santa Fe River and its tributaries, and its eastern slope is deeply dissected by the tributaries of St. Johns and St. Marys rivers.

Near the State line in the northern and western parts of Florida lies a narrow upland which has been deeply dissected by several streams. On its seaward side this highland in many places descends rather abruptly to the low coastal region. Its highest points are near the northern line of the State, where considerable areas rise above the 250 -foot contour. Notable examples of this upland are seen in Gadsden County and in the counties west of Choctawhatchee River. 
Tallahassee, the capital of the State, stands about 205 feet above sea level, on a remnant of the upland which has been isolated by erosion. East of Apalachicola River the railroad stations at Monticello, Midway, and Quincy are all reported to be over 200 feet above sea level, and west of this river are some of the highest points in Florida. Between Argyle and Deerland, and at several points north of Crestview, all on the Louisville \& Nashville Railroad, the profiles show that considerable tracts rise above the 200-foot contour, Argyle, De Funiak Springs, and Mossyhead are also above 250 feet. It appears probable that at some localities near the Alabama line the surface may be somewhat higher. According to the list of altitudes furnished by the Seaboard Air Line Railway, Mount Pleasant is 301 feet above sea level. This is the highest accurately determined point recorded in Florida.

\section{DRAINAGE.}

RIVERS.

The changes in relative positions of land and sea which have affected the drainage of Florida are so closely interwoven with the general geologic and physiographic history that their full discussion is left till later. (See pp. 199-218.) Here it is only necessary to note the general character of the streams and to state briefly the factors which have produced existing conditions.

Some of the rivers are confined to the coastal lowlands, where they assumed their courses in consequence of the initial slope of the land as it emerged from the sea; they are therefore known as consequent streams. The channels of many of them are winding. Wherever there were depressions in the sands lakes were formed, and some of the consequent streams consist of a chain of such lakes joined by more or less well-defined channels. To this class belongs the KissimmeeCaloosahatchee system with its numerous lakes.

Consequent streams that have removed the thin mantle of surficial sand and cut into the older formations belong to the class known as superimposed streams. Thus Caloosahatchee River, which in parts of its course has eroded a channel through the surface formations into the underlying Pliocene marls, is superimposed upon these older formations. In like manner St. Johns River north of Sanford has been superimposed upon the Pliocene and probably the Miocene rocks. Manatee and Aucilla rivers have in parts of their courses been superimposed upon the Oligocene formations. In Florida there are many other examples of consequent and superimposed streams and many rivers which, like the St. Johns, are in part consequent and in part superimposed.

The rivers that cross both the older and younger geologic formations existed before the sands that form the surface of the lowlands were 
deposited, and originally they entered the sea at the edge of the present highland belt. Where they crossed the highland these streams now have broad, deep valleys floored with a deposit of alluvium and bordered by many prominent bluffs. In their courses across the upland they take directions determined by the slope of the surface, but in most places they have removed the surficial formations and cut deeply into the older rocks upon which they are superimpased. As the coastal belt emerged from the sea by successive additions to its landward margin, these streams gradually extended their channels across this new land and hence became in part what is commonly known as extended streams. On the Coastal Plain they flow in broad shallow trenches bordered by low banks of sand, and in some places they have removed the Pleistocene sand and eroded channels in the underlying limestones and marls. The most important extended streams of the State are Escambia, Blackwater, Yellow, Choctawhatchee, Apalachicola, Ochlockonee, Aucilla, Withlacoochee, Hillsboro, Peace, and St. Marys rivers. With the possible exception of Escambia River, all these streams are in part superimposed upon the Pliocene or older geologic formations.

After the deposition of the younger geologic formations and the extension of the streams across the newly emerged land, a slight submergence caused a shortening of the streams and permitted the sea water to ascend the river channels for several miles from the coast. In this way the lower parts of the stream valleys were transformed into estuaries which contain brackish water and are affected by the tides. The exact length of these estuaries or tidal portions of the rivers differs in different streams, and even in a single river it may change with the strength and direction of the wind, strong onshore winds raising the height of the water and forcing the sea water farther upstream and offshore winds having an opposite effect.

\section{LAKES AND SWAMPS.}

Although the State of Florida is srossed by many large rivers, it contains numerous tracts of land which are very imperfectly drained and are occupied by lakes or swamps, some of them being of considerable size. The most noteworthy undrained area is in the southern part of the peninsula where the Everglades and adjacent lowlands form a nearly impenetrable wilderness. In this lowland tract lies Lake Okechobee, one of the largest and most interesting lakes in the south Atlantic States. According to Sanford the Everglades nowhere rise more than 25 feet above sea level, and the slope of the surface is so gentle that much of the water which falls during the rainy season is held for a time in broad, shallow ponds and marshes that carry excellent growths of saw grass and other aquatic plants. These plants, 
by their partial decay under water, have formed extensive peat and muck deposits several feet in thickness.

Smaller swamps and marshes are found in all parts of the State but are especially numerous in the belt of lowland that borders the coast. In the highlands occupying the northern portion of the State they are smaller and less numerous. In the coastal belt there are also many small lakes and ponds, some of them permanent but mast of them lasting only during the rainy season. Few exceed 2 or 3 feet in depth.

In the central part of the peninsula and in some localities near the northern boundary of the State are lakes and swamps which appear to be the result either of unequal depression of the surface sands or of solution of the subjacent limestone and consequent lowering of the surface. (See p. 74.) Some of the lakes are shallow and resemble those of the coastal belt, but others are deep basins partly or wholly inclosed by a rim of rock. Many of the smaller swamps contain peat or muck, but few of the deposits attain any great thickness and many of them form only a thin coating of partly decomposed vegetable matter mingled with more or less sand.

\section{TOPOGRAPHIC PROVINCES.}

\section{CHARACTERISTIC FEATURES.}

Florida may be divided into three topographic provinces-the upland region of the peninsula (commonly known as the "lake" region), the lowland, and the coast. Lakes, of course, are not confined to the upland or "lake" region. Generally speaking, however, they are grouped in two more or less distinct areas, those lying in rock basins occupying the upland and those lying in shallow depressions in the sand in the coastal and southern lowlands, though many in the highlands lie in depressions in the sand and some small ones in the lowlands are known to occupy rock basins. The highland area of the peninsula, however, where rock basins predominate, has commonly been known as the lake region, and for convenience this designation is retained.

\section{UPLAND OR LAKE REGION.}

\section{UMDERGROUND DRATVAGE.}

The lake region comprises a type of topography common to all limestone areas that have been sufficiently elevated to permit the formation of large underground streams. The character of the surface is well shown by Plate II, which is a part of the Williston sheet of the topographic atlas of the United States. The numerous depressions shown in the plate are known as sink holes, and in order 
to understand their origin it is necessary to consider the development of the underground drainage.

Caverns.-This region is underlain at no great depth by several hundred feet of porous limestone of Vicksburg age. Where surface water bearing carbonic acid derived from decaying organic matter enters this rock, it gradually dissolves the limestone and forms underground channels. A large part of the mineral matter thus removed by the underground water is carried to the surface and, entering the rivers, is transported to the sea. Sellards ${ }^{1}$ estimates the amount of solid matter removed in this manner, basing his calculations on the amount of mineral matter contained in solution in the waters of eight of the large springs of the State. These springs emerge from caverns in the underlying limestone and are fed by the rain falling on the surrounding areas. The percentage of mineral matter in solution was determined by analysis and the volume of flow was estimated. By this method Sellards estimated that Silver Spring brought to the surface 340 pounds of mineral matter per minute. The figures for the other springs were different, but all were large. With a conservative estimate of the average mineral content of the spring water (219 parts per million) and the assumption that about one-half ${ }^{2}$ the rainfall of Florida entered the earth and removed this amount of material, Sellards reached the conclusion that the amount of solution was sufficient to remove about 400 tons per square mile each year. If evenly distributed this would lower the surface of the limestone about a foot in 5,000 or 6,000 years. The concentration of this solution along certain beds or channels of active circulation would permit the formation of large underground passages in comparatively brief geologic time, and it has dissolved out many channels, known as caverns, which are already hundreds of feet in diameter and several miles in length. A level surface and a porous soil, such as that of the lake region, favor the development of caverns because most of the rainfall sinks into the earth instead of flowing off over the surface.

Sink holes.-As solution progressed the cavern roofs became weakened at numerous points and collapsed, forming the depressions known as sink holes. (See Pl. II.) In some areas these depressions are so numerous that they occupy a large part of the surface and give the region its characteristic topography. Splendid examples of ancient sinks, such as the Devils Mill Hopper, are to be found in different parts of the State, and the formation of sinks in different parts of the lake region by the collapse of cavern roofs is within the memory of persons now living. A good example of a recently formed

1 Sellards, E. H., A preliminary report on the underground water supply of central Florida: Bull. Florida Geol. Survey No. 1, 1908, pp. 47-48.

2 Idem, p. 16. 


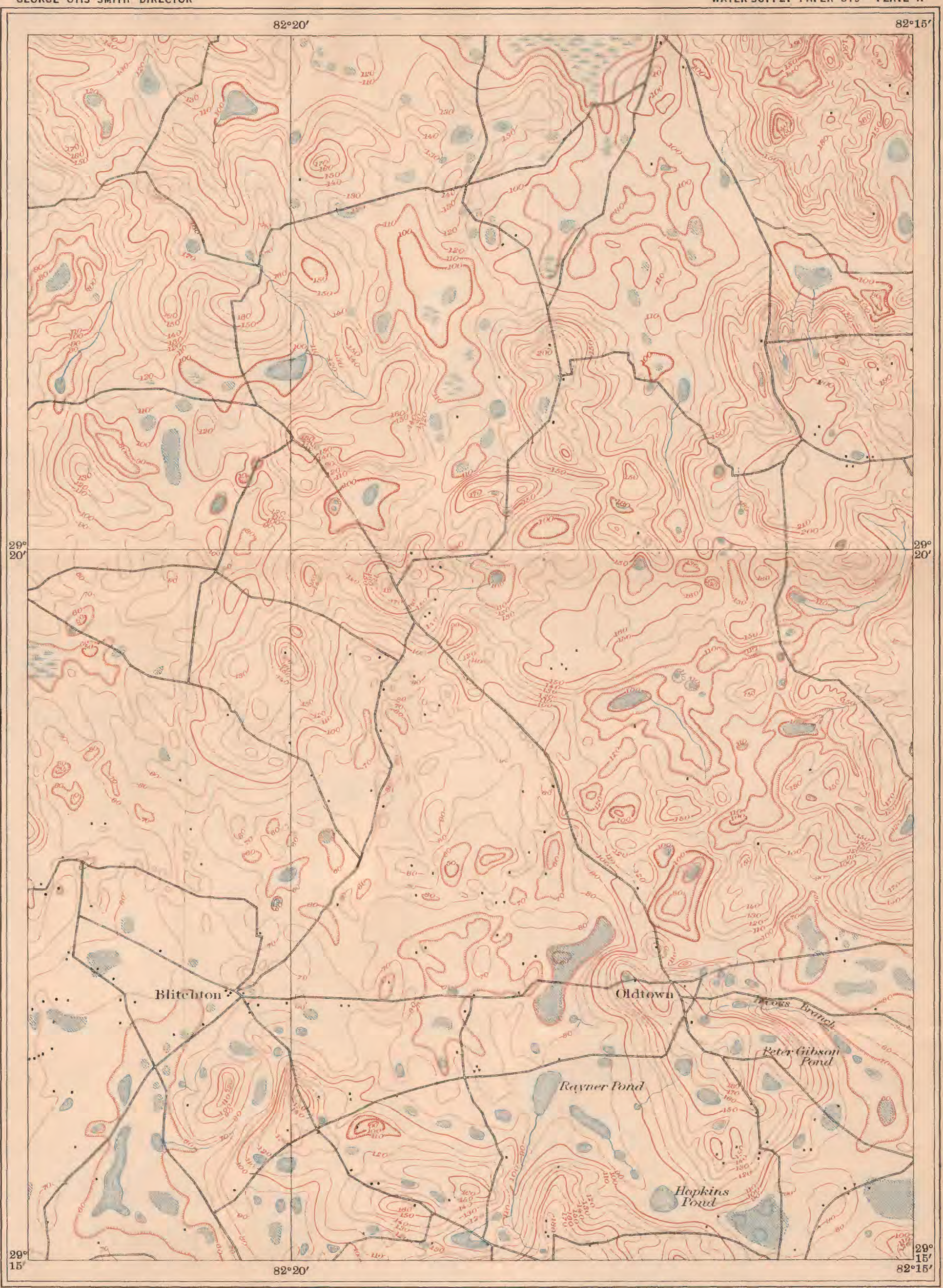

MAP OF A PART OF THE WILLISTON QUADRANGLE, FLORIDA

Henry Gannett, Chief Topographer Gilbert Thompson, Chief Geographer

Control by H. L. Baldwin, Jr.

under direction of $\mathrm{H}$. L. Baldwin, Jr.

SHOWING SINK-HOLE TOPOGRAPHY

$$
\begin{aligned}
& \text { direction of } H \text {. L. Barveyed in } 1893 \\
& \text { Sul }
\end{aligned}
$$





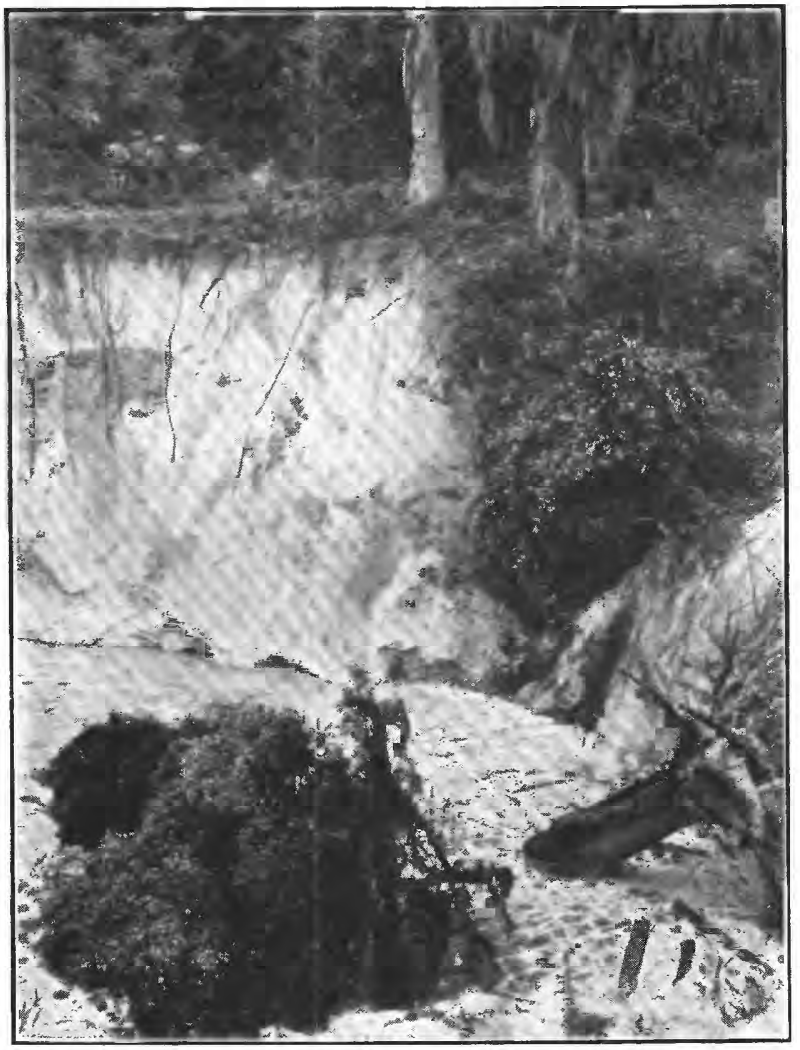

A. SINK HOLE, ALACHUA COUNTY.

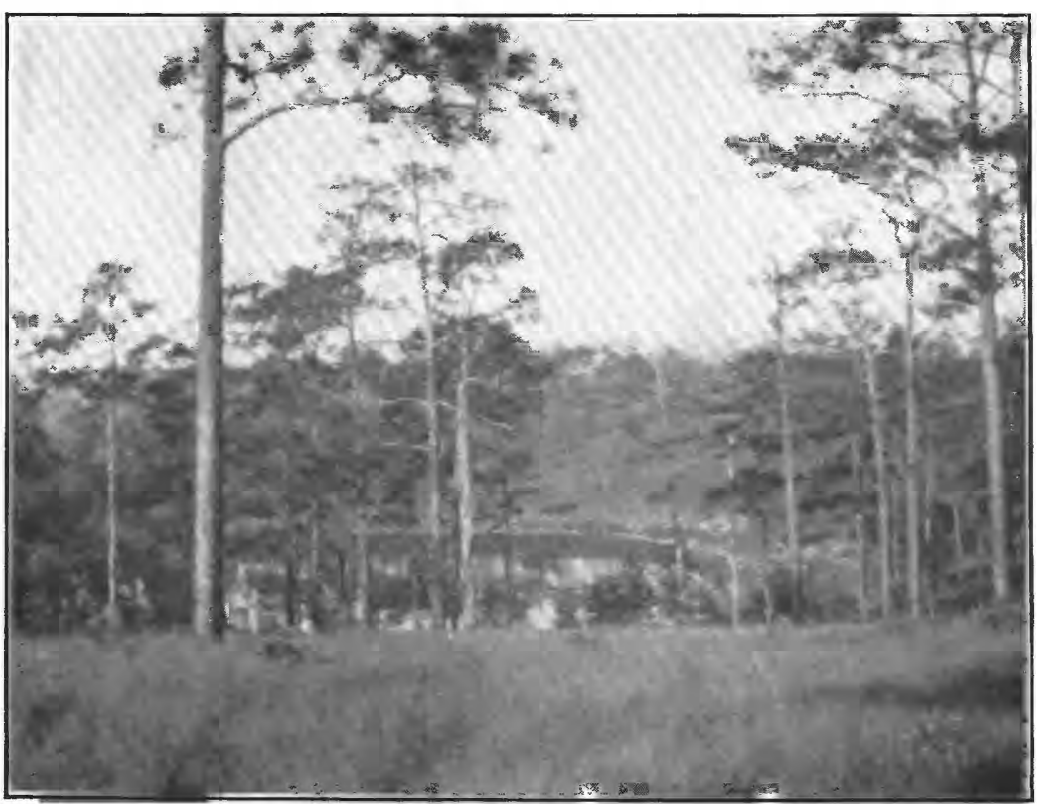

B. SINK HOLE CONTAINING POND, 10 MILES SOUTHEAST OF VERNON, WASHINGTON COUNTY. 


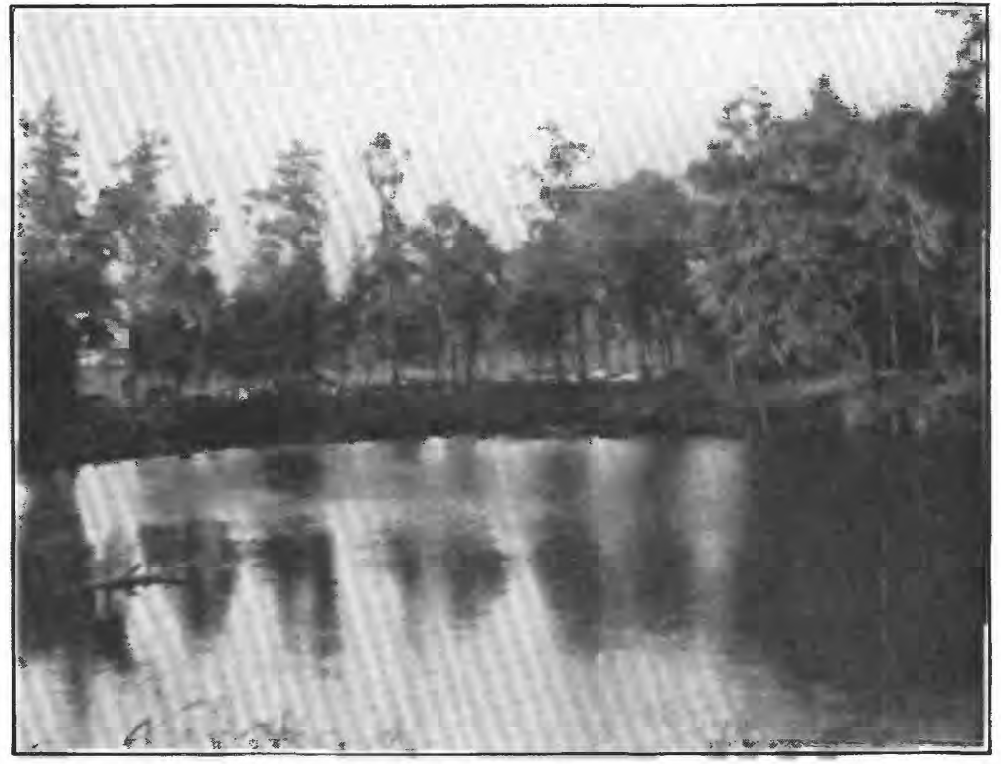

$A$. SINK OF SANTA FE RIVER.

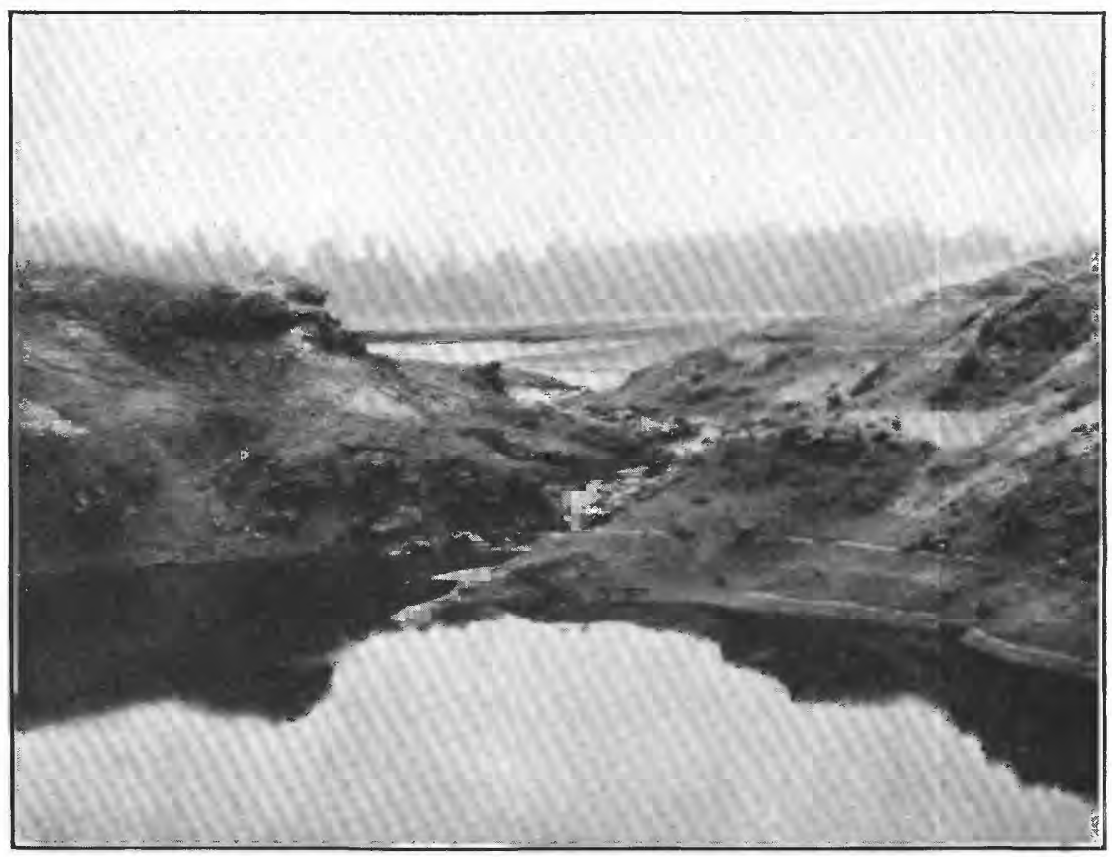

B. DRAINAGE SINK OF OCLAHATCHEE LAKE, 7 OR 8 MILES SOUTH OF LAKE PARK, GA. 
sink is to be seen on the road between High Springs and the "sink" of Santa Fe River. A second example is a new sink near Alachua sink, Alachua County, where a section of the surface 100 feet in diameter has recently dropped over 30 feet, leaving an open hole filled with water. (See Pl. III, A.) In the phosphate region, a large quantity of water, which has been used in mining operations, is allowed to enter the ground. That this water may have a noticeable effect in weakening the roofs of the underground-drainage channels is shown by the following quotation from the unpublished notes of George H. Eldridge:

Since the mining of phosphate has been undertaken many sinks have been formed near the settling ponds or along the line of drainage from the mine washers. The writer has in the morning passed over a stretch of apparently firm road which on his return at night had given way to a chasm. 40 feet across, in which earth, shrubs, and trees had been engulfed and into which water was pouring down to an underground passage in the weirdest conceivable way. At one of the Southampton mines the floor of the old pit and an adjoining area of overlying sand has sunk several feet, leaving a rift in the earth 4 or 5 feet across.

If the bottom of the sink does not contain an opening the water that accumulates after rainfall will in most places escape to the underground stream by seepage, but if the amount of rainfall is too great to be carried away in this manner it accumulates in lakes or ponds. The level of the standing water in such ponds fluctuates, rising after each rainfall and gradually sinking during dry weather. Hundreds of lakes in Florida belong to this class. Some sinks have openings in the bottom which connect directly with underground streams, and into these openings the surface streams plunge, carrying loads of sediment and other débris. This sediment probably aids the underground stream in enlarging its channel by mechanical wear, but sometimes it accumulates in such quantities as partly or even wholly to close the passage, causing the surface water to form a lake or pond. (See Pl. III, B.) Examples of open sinks receiving the discharge of surface streams are common, conspicuous among them being the sink of Santa Fe River (Pl. IV, $A$ ), the sink of Chipola River, the Lake sink in Jefferson County, the sink of Oclahatchee Lake (Pl. IV, $B$ ), and the Alachua sink near Gainesville.

The Alachua sink is important because it illustrates some of the changes which sink holes undergo. In the early days of the State, this sink," which receives the drainage of a large stream crossing Paynes Prairie, appears to have been in about the same condition as it is to-day; ${ }^{1}$ later, owing to the closing of the outlet, ${ }^{2}$ perhaps by logs and other rubbish, a large lake was formed. About 1891 the sink reopened and the basin was drained, effectually ending the steamboat traffic that had developed on the lake.

2 Dall, W. H., Correlation papers-Necene: Bull. U. S. Geol. Survey No. 84, 1892, pp. 94-96. 
In some parts of the caverns the water enters through the openings in the limestone and evaporates, leaving a deposit of calcium carbonate. By gradual accretion these deposits may form large pendants (stalactites) hanging from the roof or walls. When the water falls to the floor of the cavern and evaporates, its remaining carbonate builds up projections known as stalagmites. The deposits in caverns are frequently highly ornamental and form the chief attraction for visitors.

Sometimes the underground streams form new passages and abandon portions of their old channels, and it is the abandoned channels that are commonly visited by travelers. In Florida, only a few caverns have been explored and none are reported to be highly ornamented. The most important caverns noted during the field work are located near Marianna, Ocala, and Alachua. The one near Alachua is known as Warren Cave and is said to be well worth visiting.

Natural bridges.-Where the underground stream emerges, it forms a spring, and as the roof of the cavern falls it leaves an open channel through which the spring drains to some surface stream. By a continuation of this process, the underground stream is transformed into a surface stream. Where a segment of the roof of the underground channel remains after the parts above and below have fallen, a natural bridge results. Natural bridges may also be formed in another manner where the river water gradually works its way into an underground passage, establishing an underground stream beneath the floor of the surface channel. As such a channel is gradually enlarged by solution and mechanical wear, more river water passes through it. Finally, the surface channel may be unoccupied except during high water, or if the underground passage is large enough the surface channel may be entirely abandoned. A surface channel may also be produced across a natural bridge whenever the underground passage is partly obstructed.

There are many natural bridges in Florida, small ones being reported near Homosassa, north of Clarksville, in northern Walton County, and in many other localities. Large natural bridges occur on Chipola River above Marianna, on Santa Fe River northeast of High Springs, and on several other rivers. The natural bridge on Chipola River is submerged during high water, and a broad shallow surface channel crossing the natural bridge near High Springs is said to carry a portion of the flood waters of Santa Fe River (Pl. IV, $A$ ). The breadth of the surface channel near High Springs suggests that the natural bridge of Santa Fe River may have been formed by the second method outlined above. The natural bridge of Chipola River was submerged at the time the field work was done in that vicinity, so that no observations could be made. However, 
the broad valley of the river above the bridge indicates that the upper part of the river has been a surface stream for a long period. As natural bridges in such rocks are not apt to endure for long periods, it appears probable that this one may also have been formed by the second method.

\section{SPRITGS.}

The great development of underground drainage in many parts of the State has given rise to many springs at places where streams emerge from subterranean channels. The number of such springs is very great. In size they vary from mere seeps to discharges which give rise to creeks and rivers large enough to float good-sized passenger and freight steamers. The best known and largest is the Silver Spring in Marion County, which gives rise to a large stream of remarkable clearness and beauty. The water emerges from a basin over 35 feet deep in a stream (Silver Spring Run) that is about 50 feet in average width and more than 9 feet in minimum depth in the center of the channel. The water is so clear that objects lying on the bottom are distinctly visible.

Among the other large springs of the region are Wekiva Spring, the source of the river of the same name; Sulphur Spring, near Tampa; Suwannee Sulphur Spring, near Suwannee; Blue Spring, near Juliet Station; Blue Spring, near Orange Junction; Green Cove Spring, on St. Johns River; Itchatucknee Spring, near Fort White; Poe Spring, near High Springs; Crystal River Springs, the source of Crystal River; Weekewachee Spring, near Bayport; and Newland Spring, near Falmouth. All these springs are well known and many of them are very large. They are supplied with water by the limestones of the Vicksburg group, which are everywhere porous and in many places cavernous.

A spring at Tarpon Springs is worthy of special mention because it appears to be in part supplied with water from a small lake. The water emerges at the bottom of the bay a few feet below mean tide level. On the opposite side of the town is a small lake which is without surface outlet and apparently occupies a sink hole. Usually the flow of this spring is comparatively insignificant, but at times the discharge is enormous. Observations made upon the lake just before and after one of these outbursts of the spring appear to show that the lake discharges water into the spring through some underground channel, for the surface of the lake is said to have been lowered several inches while the spring was flowing rapidly.

Aside from the large springs mentioned many others yield large quantities of water, and springs of moderate size exist in nearly all parts of the State. Some of the smaller springs are supplied with water from the superficial sands, but many of them derive their supplies from the limestones. 


\section{EROSIONAL IEATURES}

In west Florida and in parts of peninsular and north Florida the surface configuration has been largely determined by the erosion of surface streams. However, sink-hole topography is common as far west as Walton County, and many of the depressions are occupied by small lakes.

From Leon County westward the major streams cross the upland in wide, level-floored valleys bordered by well-defined bluffs. The depth of these valleys is due to the erosive action and the width to the meandering of the streams. Most of them contain a deposit of sand and mud, which rises but little above the level of the streams and is partly overflowed when the latter are high.

The small streams of the uplands flow in narrow valleys with steep walls and high gradients. In most of these valleys erosion has not extended far from the main streams and many of the divides between the principal rivers are comparatively level. Near the rivers the areas of level land become smaller and the number and depth of the valleys increase until the surface is largely reduced to steep slopes. It is also worthy of note that the amount of dissection increases toward the south. Thus most of the largest level tracts of upland are found near the northern line of the State. At its southern edge the upland in places descends quite abruptly to the coastal belt bordering the Gulf of Mexico. In some places, however, the transition to the coastal lowlands is by a gradual slope.

\section{LAKES.}

The uplands are for the most part covered by a few feet of gray sand, which masks the minor inequalities of the erosion topography. Moreover, it is in many places difficult to determine whether shallow depressions are sink holes or are merely irregularities in the surface of the sand. However, the sink-hole origin of deep depressions such as the lake at De Funiak Springs appears to be unquestionable.

\section{SAND DUNES.}

Sand dunes and ridges are common, especially along the southern edge of the uplands, but few of them are more than a few feet in height. Wind-blown sands are probably much more widespread than is indicated by the surface topography, the heavy precipitation, together with the abundant vegetation, preventing the development of extensive dunes.

LOWLAND.

The coastal region of Florida comprises a belt of lowland little of which rises above the 100-foot contour and much of which is only a few feet above high tide. Its emergence from the sea took place 
after the drainage of the uplands had been well developed and the rivers gradually extended their channels across it as new areas were added to the land.

STREAMS AND PONDS.

The Pleistocene sands, which form a large part of the surface in the coastal region, slope gently toward the sea and are in places crossed by small streams flowing in shallow valleys. Minor irregularities in the suiface of the sand have resulted in the shallow lakes and ponds that cover large areas during the rainy season. The difference in elevation between the bottoms of many of these ponds and the surface of the surrounding areas is less than 2 feet.

\section{RIDGES.}

Scattered throughout the coastal region are small areas of higher land which in some places resemble sand ridges and in other places are very irregular in form. Some of them contain a core of rock covered by a thin mantle of sand, but many appear to be composed entirely of sand. These areas represent the higher parts of the original sea floor and their positions were determined by the inequalities in the surface of the underlying rock or by unequal deposition of the sands.

\section{SAND DUNES.}

A large part of the surface of Florida is covered by a few feet of gray sand. Along the coast this sand has in some places reduced the original inequalities of the surface and in others has increased them by forming sand dunes and ridges. However, few of the dunes and ridges are more than a few feet in height and hence they have little effect on the topography.

TERRACES.

General features.-Bordering the coast and extending into the valleys of all the large streams are a series of terraces presenting generally level surfaces bordered by low, seaward-facing scarps. These plains have been grouped into three divisions and as they represent successive stages in the Pleistocene physiographic history of Florida they will be discussed at some length. They form broad plains but little dissected by stream valleys and are so poorly drained that marshes and lakes are common. The surface of the lowermost terrace ranges in altitude from sea level to about 40 feet above it, and includes both Recent and Pleistocene deposits; the second terrace ranges from 40 to 60 feet above sea level; and the third from 60 to 100 feet above the same datum plane. They are known, respectively, as the Pensacola, the Tsala Apopka, and the Newberry terrace, the first-named being the youngest. (See Pl. V, in pocket.)

These terraces are for the most part constructed of lithologically similar materials, and this fact together with the absence of char- 
acteristic fossils makes it necessary to rely on the topography for their discrimination. The general distribution of the terraces is shown on Plate V. This map does not show their occurrence in detail, for, in the absence of suitable topographic maps, it is in many places difficult to decide on the correlation of more or less isolated plains. The failure to delineate narrow terraces along some of the streams is necessary because of the small scale of the map.

The Pleistocene terraces were formed during submergence of portions of the land beneath the sea. The maximum amount of submergence was sufficient to permit the sea to encroach on all the land less than 100 feet above the present level of the sea. The relations of the land and water remained nearly uniform at some stages long enough to permit the waves to erode and redeposit the materials from the underlying formations. The erosive action of the waves of the Pleistocene sea produced low seaward-facing scarps (see Pl. VI, $A$ ) and at the same time the materials eroded from the older formations were redeposited in the form of plains that are locally several miles wide. The surfaces of these plains are not everywhere level, but few inequalities exceed 2 or 3 feet, except where subsequent erosion has changed the toppography.

The Pleistocene terraces were originally slightly irregular and the result of unequal deposition on an eroded surface. The most striking topographic features are the sink holes in the limestones that lie near the surface in the west-central part of the peninsula. Some of the minor variations are the low sand ridges, lying nearly parallel to the coast, which were built by the waves of the Pleistocene sea. Their recognition is exceedingly difficult because in most places they rise less than 5 feet above the adjacent surface. Depressions of varying size and shape are numerous, but they are seldom noticed except during the rainy season, when they are transformed into ponds and marshes.

The Pleistocene terraces extend up the river valleys, where they are composed in part of estuarine and in part of fluviatile materials; the two types merge into each other and are not everywhere distinguishable. Inasmuch as the deposition of fluviatile sediments shifted seaward during freshets and landward when the rivers were low and sluggish, the fluviatile deposits should dovetail with the estuarine.

Newberry terrace.-The Newberry terrace, which is composed of light-gray or yellow sand with local deposits of clay, forms a plain rising from about 70 feet to more than 100 feet above sea level. Its formation was brought about by an encroachment of the sea upon the land and its size depends upon the amount of erosion and deposition accomplished during that submergence, less whatever portion has been subsequently removed by erosion. Before the time of 


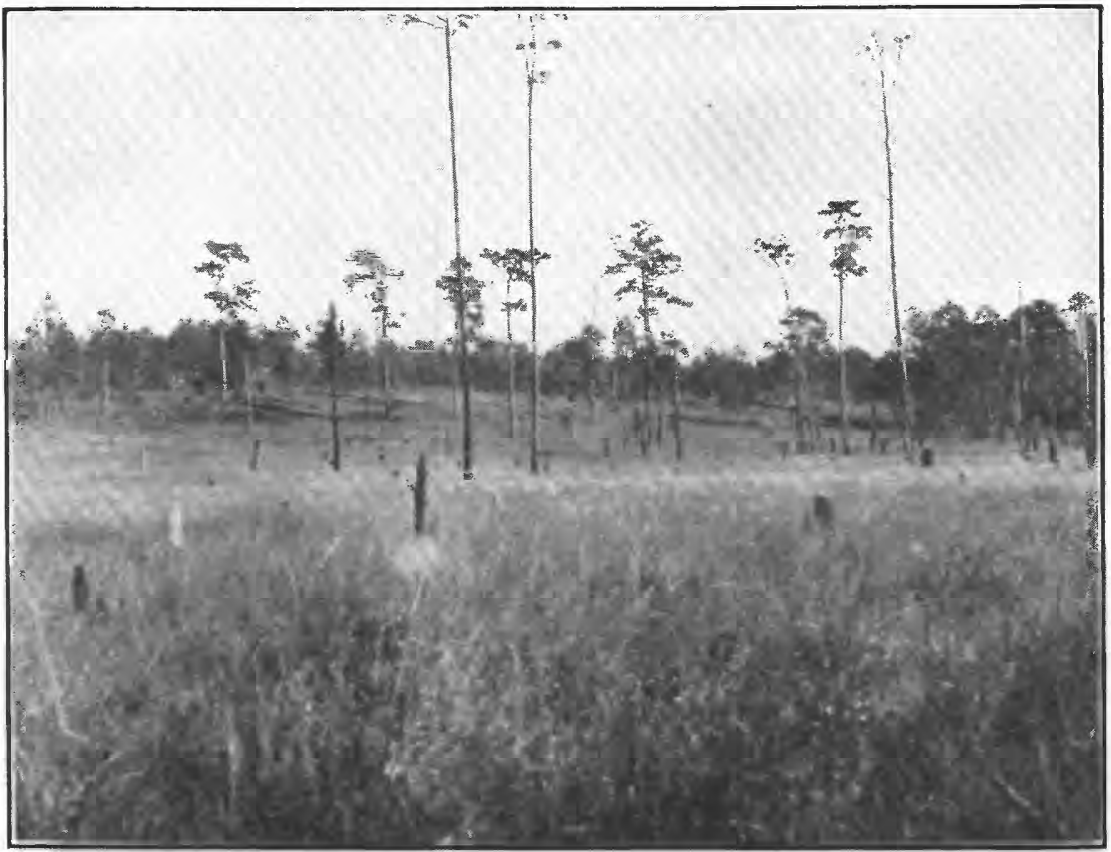

A. PLEISTOCENE TERRACE AND ESCARPMENT BORDERING ST. MARYS RIVER ON FLORIDA SIDE, OPPOSITE TRADERS HILL, GA.

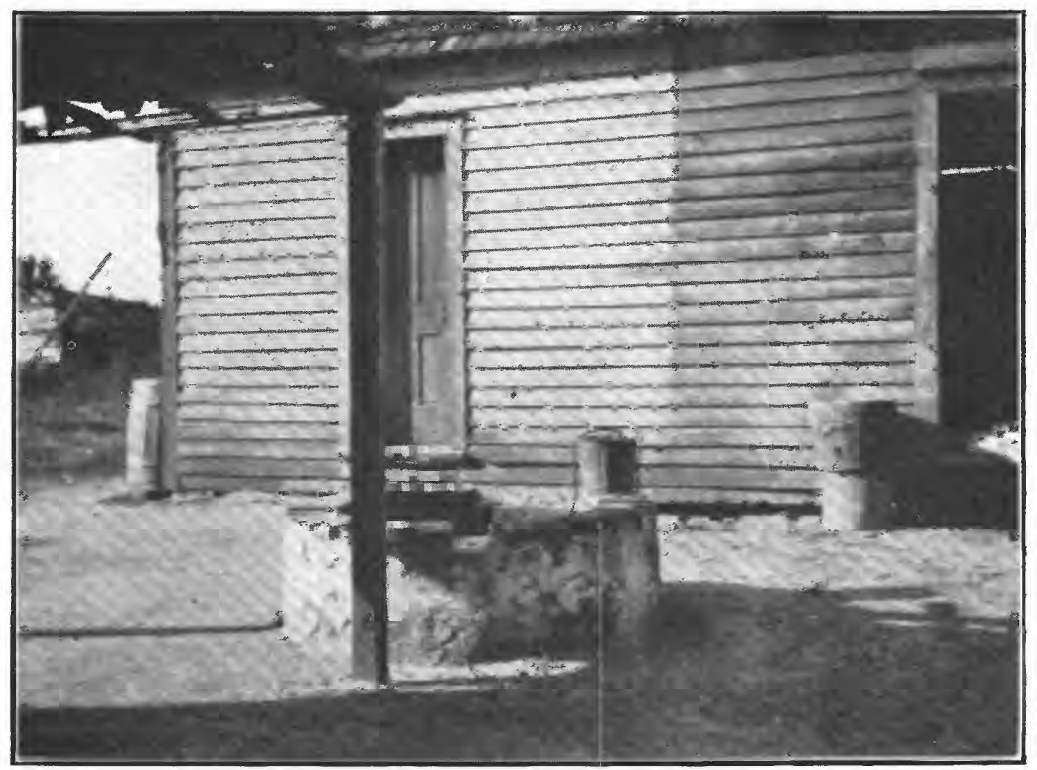

B. OLD WELL OF SPANISH TYPE, ST. AUGUSTINE. 

this encroachment Florida had suffered considerable erosion and the Tertiary formations had been subjected to some tilting and folding, so that the materials composing the terrace rest on the eroded surfaces of formations ranging in age from the Vicksburg to the Pliocene, and their relation to the Tertiary formations is everywhere unconformable.

Weathering had been active before the invasion of the Pleistocene sea, and the terrace consists largely of the weathered portions of the subjacent rocks. Limestone is generally absent, the prevailing materials being sand with some clay and a little chert, especially where the underlying rocks belong to the Vicksburg group. No fossils have been found in the exposed portions of the Newberry terrace, and it is doubtful if it contains many. Some of the Pleistocene shells obtained from well borings at Kissimmee probably came from the layers near the base of this terrace, but they are not unlike those found in the younger Pleistocene terraces. The fluviatile portions of the terrace are somewhat coarser than the marine portions and contain a much larger proportion of colored sands and clays, especially in the northern part of the State.

The Newberry terrace encircles the Tertiary formations, forming an almost unbroken band about them. Its presence at several points in northern Marion and southern Alachua counties has led to the belief that a Pleistocene strait separated the higher portion of the peninsula from the upland to the north, thus transforming the central portion of the peninsula into an island. Other smaller areas to the west were probably separated from the central area by narrow straits. However, these conclusions need to be confirmed by more detailed observations than have as yet been possible. At the Georgia boundary the materials of the Newberry terrace, and probably those of the Tsala Apopka terrace, merge into the deposits of the Okefenokee formation. ${ }^{1}$

Few exposures give adequate sections of the Newberry terrace and well records rarely shed much light on its thickness. A few exposures in the phosphate rock region show that the sands range from 1 to 20 feet in thickness. However, the maximum thickness of the sands and clays forming this terrace may exceed 100 feet in some of the valleys where considerable erosion preceded the Pleistocene submergence.

Tsala Apopka terrace.-The Tsala Apopka terrace is composed chiefly of sand, with clay at some localities. These deposits, resting unconformably upon Tertiary formations, form a plain rising 40 to 60 feet above sea level. The encroachment of the sea at the time of

1 Veatch, Otto, and Stephenson, L. W., Geology of the Coastal Plain of Georgia: Bull. Georgia Geol. Survey No. 26, 1911, p. 45. 
the formation of the Tsala Apopka terrace was not so extensive as during the development of the Newberry terrace. The stratigraphic relations of the materials comprised in the two terraces have not been observed, though the materials composing the Tsala Apopka terrace may rest upon the eroded edges of the Newberry terrace. The Tsala Apopka terrace materials have been observed resting upon eroded surfaces of the beds of Tertiary age at the type locality, in the Tsala Apopka lake region, and at many other places. As in the case of the Newberry terrace, the underlying beds include the different formations from the Oligocene to the Pliocene.

Sand is the principal constituent of the Tsala Apopka terrace, although some clay is found in places and fragments of chert occur where the underlying beds are of Oligocene age. In general, the sands are gray, but in northern Florida red and yellow sands are found in many of the stream valleys. The deposits composing the Tsala Apopka terrace probably average 25 to 30 feet in thickness, but this estimate is uncertain because good exposures are rare.

The Tsala Apopka terrace is well developed in the vicinity of the lake of that name, and it extends southward nearly to Punta Gorda, thence east and north along the west side of St. Johns River valley. An area of the terrace lies east of St. Johns River, but its outlines are very imperfectly known. The Paynes Prairie plain, as well as the plain partly occupied by Orange Lake, are regarded as portions of this terrace, and a broad branch extends up Ocklawaha River. The upland portion of the State is surrounded by this terrace, and it probably extends beyond the State line in the valleys of the principal streams.

Pensacola terrace.-The Pensacola terrace is a broad plain, rising less than 40 feet above sea level, and apparently including two divisions, one being less than 20 feet above, and the other from 20 to 40 feet above sea level. There has been no attempt to differentiate these two subdivisions, and on the map (Pl. V) they are not separated from the Recent deposits. This terrace merges with the plain that forms the surface of the Satilla formation in Georgia. ${ }^{1}$ The Pensacola terrace presents topographic conditions similar to those of the Satilla plain, but the composition of the materials entering into the construction of the two plains are unlike.

The Pensacola terrace is largely constructed of sand with local beds of clay but in the southern portion of the State includes important limestone beds, several of which are described by Sanford. A large amount of coquina underlies the sand that forms the surface of the terrace from St. Augustine southward. Aside from the limestones the terrace materials are sand, except at a few localities

I Veatch, Otto, and Stephenson, L. W., Geology of the Coastal Plain of Georgia: Bull. Georgia Geol. Survey No. 26, 1911, p. 434. 
where they include marls containing shells of land and marine animals. The thickness of the sands and limestones is variable, ranging from less than a foot to more than 100 feet, the average being probably greater than in any other Pleistocene terrace. Where the base of the terrace materials is exposed, it is found resting unconformably upon the older beds, but good exposures are rare.

The Pensacola terrace occupies a wide belt surrounding all the older formations. It extends the entire length of St. Johns River valley and occupies an area nearly 150 miles long in the southern end of the peninsula. The Everglades and adjacent marshy lowlands, together with the depressions occupied by numerous lakes, lie within the area included in the Pensacola terrace. The area occupied by this terrace on the west side of the peninsula is smaller than on the east because the winds and currents of the west coast are less favorable for adding to the land area than those on the east coast. On the southern edge of western Florida the terrace broadens near some of the large streams and in areas where the direction of the winds is favorable to the extension of the land seaward. The estuarine and fluviatile portions of the Pensacola terrace are so narrow that it is not practicable to show it along the river valleys except near the coast. Along some of the larger streams this terrace may extend beyond the northern boundary of the State.

THE COAST.

The extensive coast line of Florida presents a great variety of topographic forms, for the most part shaped by waves, tides, shore currents, and living organisms, chiefly corals. The configuration of the shore is dependent on the relative importance of these agencies.

CORAL REEFS.

Coral reefs are restricted to an area near the southern end of the peninsula, and it was to this area that much of the earlier geologic work was devoted. Sanford discusses the formation of the Florida keys and the adjacent portion of the mainland in the light of his recent studies in that region. Here it is only necessary to call attention to the fact that coral reefs have been of minor importance in the development of the peninsula; in fact there appears to be no reason to suppose that reefs have been important on the west coast or north of the north line of Dade County on the east coast.

SUBMERGED CONTINENTAL BORDER.

Reference to the charts of the United States Coast and Geodetic Survey shows that the depth of the water along the Florida coast is in few places more than 10 fathoms. Submarine contours (Pl. V, in pocket) which have been compiled from the charts previously mentioned, 
show the general relations of the submarine portions of the Floridian plateau to the land surface. In 1910 these relations were fully discussed by Vaughan, ${ }^{1}$ and consequently only a few facts will be considered in this report. From the present shore line the sea bottom slopes gently to a depth of 100 fathoms, and at that depth the descent becomes abrupt. The submarine area less than 100 fathoms in depth is regarded as a portion of the continental mass, and is more closely related to the land than to the deep-sea bottom beyond the 100-fathom line. An uplift of 600 feet would add to the land surface all the area inclosed by the 100-fathom curve. Reference to Plate V will show what a large increase in the land area would result from such an uplift.

Within the area circumscribed by the 10-fathom contour are large areas where the water is shoal. It would take an uplift of only 60 feet to bring the land inclosed by this curve above sea level. From soundings this submerged area is known to have a gentle slope seaward, and its outer margin is comparatively regular. This would give to the land surface a much more regular outline than it now has, and, according to Vaughan, ${ }^{2}$ would increase the area of the land about one-third.

A study of Plate V shows that the position of the present land surface is excentric on the Floridian plateau as outlined by the 100fathom curve. The 100-fathom curve is farther offshore on the west side of the peninsula than on the east side. Not only does the land lie near the east edge of the plateau but in the vicinity of Jupiter and thence southward the land actually extends nearly to the 100-fathom contour. Two factors are thought to be responsible for the excentric position of the peninsula upon the continental shelf. First, there has been differential movement resulting in a depression of the west coast, carrying some of the land beneath the sea. This is shown by the narrowing of the belts of outcrop of the younger formations and the apparent absence of other formations on the west side of the peninsula. Second, the east coast is being rapidly extended by the large amount of sediment supplied to it by waves acting under the influence of the strong northeasterly winds. The effect of this is well shown by Cape Canaveral, as well as by the numerous bars that are transforming the coastwise straits into lagoons. Evidence is not wanting to show that such processes have been active in the past, for ancient bars and lagoons that have been filled with sediments may be recognized at numerous places.

1 Vaughan, T. W., A contribution to the geologic history of the Floridian plateau: Pub. Carnegie Inst. Washington No. 133, 1910, pp. 107-114.

2 Idem, p. 109. 
BARS.

In the shallow water at some distance from the shore the waves gradually build bars which rise nearly to the surface. As the material is derived from the sea bottom the bars vary with the character of the latter. At present the prevailing material on both the east and west coasts is sand, often considerably admixed with shells, and the bars now being formed consist largely of sand with a small proportion of shell fragments. In comparatively recent geologic time, the beach materials on some parts of the coast appear to have been largely shells, which were built into bars and afterwards cemented to form coquina. Some layers of sand and a considerable percentage of silica in the coquina show that terrigenous material was never entirely absent, though it was often of minor importance. In the shallow water along the exposed shores, both of the mainland and the islands, currents are formed which transport the beach materials and build them into numerous forms. Among these are the bars which are found across the entrance of all the bays, constituting one of the important obstacles which confronts the Army engineers in their endeavor to make the rivers and harbors accessible to steamers.

On the east coast, where the prevailing currents move southward, the bars are commonly extended by additions to their southern ends. On the Gulf coast, the dominant currents appear to be in the opposite direction and the bars are usually building by successive additions to their northern ends, though an eastward current of some importance may be inferred from the position of the bar at the entrance to St. Andrews Bay.

\section{SOUNDS.}

Behind the shore bars are narrow bodies of shallow water which, on the east coast, are commonly known as rivers, though they might more appropriately be termed sounds. To this class belong such bodies of water as Halifax and Indian rivers. As the sounds become more nearly surrounded by the growing bars they change into lagoons which are in turn gradually filled with silt and thus transformed into marshes. Mosquito Lagoon and Lake Worth on the east coast are excellent examples of lagoons, and marshes are numerous along both the east and west coasts.

About 20 years ago an attempt was made to open a passage for steamship navigation by deepening the sounds and lagoons. This plan was successful, but in recent years the channels have been allowed to become obstructed by sand bars and oyster reefs. In the last few years interest in this "inside" channel has been revived, and it is now proposed to extend the passages northward to New Jersey. 
INLETS.

Where drainage from the land enters a sound or partly inclosed bay, the water escapes through a narrow passage in the bar known as an inlet. As the bars are built under the influence of a prevailing current, the inlet is gradually shifted in the direction of growth, and after a time the opening becomes so obstructed that a new inlet is formed during high water. Usually the inlets are formed near the head of the bar and their direction of movement on the Atlantic coast is southward and on the Gulf coast northward or westward. At Jupiter, on the east coast, an opening is sometimes dredged near the north end of the bar and this opening gradually shifts toward the south. It has been found that the inlet remains open much longer when the opening is made toward the northern end of the bar than when it is made farther south.

TIDAL RUNWAYS.

At ordinary high tide the level of the water in the bays and sounds is raised from 1 to 2 feet above the normal low-water level. If at the same time a strong wind is blowing toward the land the water rises much higher. When the tide recedes, a seaward current is formed which scours the bottom and sides of the channels. Frequently the water pours through some low gap in a shore bar, thus helping to form a passage. Many of the inlets across the Florida bars are formed in this way. To the erosive action described above the name "tidal scour" is applied." Gulliver thinks that the channels near Cedar Keys present an example of tidal runways produced by tidal scour, and he designates them the "western Florida type." At the mouth of St. Johns River and elsewhere along the South Atlantic and Gulf coasts, the Army engineers have constructed dams to narrow the runway so that the effect of the tidal scour will keep open a channel deep enough to permit the entrance of large vessels.

CAPES.

Many of the important capes of Florida appear to have been built of sand deposited by currents moving along the shore, Cape Canaveral on the east coast was formed where the easterly trend of the current caused the southward-moving current to move outward from the coast into the deeper water where the velocity of the water was checked, causing it to deposit some of its load of sand. From the outward end of the cape there projects a long narrow spit of sand, which rises nearly to the surface. The seaward end of this spit is often bent into a hook by the action of the current.

On the west coast the northward-moving current encounters the islands near the west end of St. Vincent Sound, and turning westward

${ }^{1}$ Gulliver, F. P., Shore-line topography: Proc. Am. Acad. Arts and Sci., vol. 24, 1899, pp. 180-181. 
forms Cape San Blas. Cape St. George at the western end of the island of the same name, and Southwest Cape, west of Apalachee Bay, appear to have been formed in a similar manner. All of these capes are gradually being extended seaward by the continual addition of material transported along shore by the currents. Many minor projections usually known as points have originated in practically the same manner as the larger capes. In 1898 Gulliver ${ }^{1}$ studied the origin of Capes Canaveral and San Blas, and designated them "current cuspate forelands."

\section{soIrs.}

\section{ORIGIN AND CHARACTER.}

The soils of Florida are almost all derived from the sandy Tertiary and Pleistocene formations; and, since the gray Pleistocene sand is the most widespread of the surface deposits, it naturally gives rise to the soils over the greater portion of the State. The soils of the Lafayette (?) formation occupy considerable areas in northern and western Florida, and they form the subsoil in many localities where thePleistocene sands are thin. Both the Alachua clay and the Pliocene marls are so thinly covered in some parts of peninsular and west Florida that they form part of the subsoil. In some areas, where erosion has been especially active, Pliocene and Pleistocene have both been removed, leaving the older geologic formations exposed to form the soils; but such areas are confined to the uplands of the peninsula and west Florida. On the uplands residual materials formed by the weathering of the Oligocene formations lie so near the surface that they become a more or less important part of the soil or subsoil or both.

Peat and muck soils occupy a large area in the southern part of the peninsula and smaller areas in several parts of the State. Their greatest development is in the Everglades, but they are found in many other localities where swamps exist. They consist of organic matter mixed with more or less inorganic material, such as sand and clay. These soils are of recent origin and are still being formed, especially over a large area south of Lake Okechobee, where the surface is very low and flat and the drainage imperfect.

Pleistocene sands form the soil below the 100-foot contour in nearly all of peninsular Florida and extend to the margin of the uplands in northern and western Florida. The soils of the Lafayette (?) formation are largely confined to the upland areas near the northern boundary of the State. They do not form large unbroken tracts but occur in more or less isolated areas where the post-Pliocene sands are absent. In many localities the overlying sands are so thin that 
the Lafayette (?) deposits form an essential part of either the soil or the subsoil, even where the surface materials are younger.

Pleistocene marls and coquina, in a more or less decomposed state, form the subsoil at numerous places along the east coast and along the west coast south of Bradentown. Areas where these Pleistocene marls lie near enough to the surface to be considered part of the soil are much more restricted than is their geologic distribution.

In the central part of the peninsula, especially northwest of Gainesville, the Alachua clay lies so near the surface that it forms a part of the subsoil, but so far as is now known it does not enter into the formation of the surface soil. Over much of the area where this formation occurs it is too deeply buried to be considered a part of the soil.

On the north bank of Manatee River, in the vicinity of Ellenton, there are some areas of land, valuable for truck gardening, where the residual clays left by the solution of the limestone of the Tampa formation form very good soils. In some places these clays contain more or less Pleistocene sand and numerous fragments of angular or subangular chert. Doubtless other localities exist where the residual products of this limestone lie near enough to the surface to form part of the soils, but the areal distribution of these soils is not yet known.

Decomposition products of the limestones of the Chattahoochee formation and the Vicksburg group form parts of the soils in localities where younger deposits are absent, but over large areas they are too deeply buried beneath the younger geologic formations to be important in soil formation. It is the proximity to the surface of marls or residual products of the rocks of the Vicksburg group which is regarded as the source of the fertility of many of the "hammock" lands near the west coast, and it is doubtless the presence of such materials near the surface which accounts for the excellent growth of timber in places on the peninsula where the surface soil is very poor.

SOIL TYPES.

In 1897 Whitney $^{1}$ made a general examination of the Florida soils. He säys:

The principal types of soils examined were the first, second, and third quality of high pine land; the pine flats or so-called "flat woods"; the light hammock, the gray or heavy hammock, the mixed land, the heavy marl hammock; the pineapple land; the Etonia scrub, the spruce-pine scrub; and the Lafayette formation.

Since the publication of Whitney's report, detailed soil surveys have been made in the vicinity of Gainesville and in Escambia County.

1 Whitney, Milton, A preliminary report on the soils of Florida: Bull. Bur. Soils No. 13, U. S. Dept. Agr., 1898, p. 7. 
In this detailed work the soils were classified by their physical properties, origin, and topography, texture being considered the most important characteristic. The principal types recognized were sands, fine sands, sandy loams, and fine sandy loams. Subordinate types were loams, silt loams, clays, mucks, and meadow. These types have, with some exceptions, been grouped into three series and correlated with similar soils elsewhere in the Coastal Plain. Aside from these general types are the Gainesville and Gadsden sands, so named by the Bureau of Soils of the Department of Agriculture, and some other types which have not yet been correlated.

The clay and loam soils of Florida cover a very small area and are not of great importance. The clay soils are chiefly small tracts in the neighborhood of streams and are not tilled; in this connection it should be borne in mind that much of what is commonly called clay in northern and western Florida is to be classified as a sandy loam, because, though more or less plastic, it contains sand as its most important constituent. The sand or sandy loam soils, which cover the greater part of Florida, may be subdivided into a large number of types, all of which have certain general characteristics. When brought under cultivation their natural productivity is commonly low, but they respond quickly to proper treatment and can be made to produce large crops, which grow rapidly and mature early. These characteristics, when linked with a subtropical climate, make the production of early fruits and vegetables very profitable. In order to procure the best results it is necessary to exercise skill and judgment in the treatment of the soils, and in some places to expend considerable money for fertilizers. There is apt to be a deficiency of moisture on some of the sands and sandy loams, and hence irrigation is sometimes practiced.

Fertilizers are used in nearly all parts of the State, the amount and kind used in the different localities being governed by the nature of the crops grown and the experience of the most successful farmers. A striking example of the productivity of a sandy soil properly tilled is furnished by the yield of pineapples from a ridge of sand near Fort Pierce. The value of barnyard refuse and legumes as fertilizers is recognized in some localities, but their use should be much more extensive. Some recent experiments of the Department of Agriculture $^{1}$ are of interest, as they show that lime, which is not generally used on Florida soils, may add greatly to the productivity of certain types of the sand and sandy loam soils.

The peat and muck soils of Florida have not been extensively used because they are in swampy areas, which require drainage. Extensive drainage operations are in progress in the Everglades, and if these are continued large areas of peat soil will be available for cultivation.

1 Soil survey of Escambia County, Florida: Field Operations Bur. Soils, U. S. Dept. Agr., 1906, p. 348. 
The natural productivity of the peat and muck soils of Florida has seldom been determined, but, judging from the experience of farmers in other States, it is safe to predict that the everglade soils are destined to take rank among the best lands of the State for the production of certain crops. Moreover, experience in several other States has shown that such soils seldom require the addition of complete fertilizers, such as are used on sandy soils. In fact, the addition of small quantities of salts of potassium should usually be sufficient to cause a peat or muck soil to produce good crops, though possibly in some areas the addition of phosphates would be necessary. These facts are important, because it will cost much less to fertilize the peat and muck soils than is now being expended on the sandy soils.

\section{GEOGRAPHY OF SOUTHERN FLORIDA.}

By Samuel Sanford.

\section{LOCATION AND AREA.}

The term southern Florida is here made to include, for convenience of description, the portion of the peninsula with its bordering islands or keys lying south of a roughly northeast-southwest line extending from the north line of Palm Beach County on the east coast past the south end of Lake Okechobee to the mouth of San Carlos Bay on the west coast. The piece of mainland thus arbitrarily cut off is 140 miles in extreme length, north and south, and 120 miles in maximum width, east and west. Its area is about 7,300 square miles, of which 6,000 square miles are swamp or land so low as to be covered with water during the rainy season, from June to October, or, near the coast, by unusually high spring tides. The total number of the keys is unknown, but their area is here estimated at 300 square miles. (See Pl. I, in pocket.)

\section{GENERAL FEATURES.}

Growing coral reefs extend along the Florida coast for over 200 miles and are found nowhere else in the continental limits of the United States. Because of the reefs and the teeming marine life of the surrounding waters, southern Florida has attracted attention for over 50 years and has been visited by a number of eminent scientists who have described and discussed the main features of the keys and the southeast shore of the mainland. Owing to the difficulties of travel in this region and its comparative remoteness and inaccessibility before the building of the Florida East Coast Railway, these visitors confined their observations largely to the reefs, the shore line of the keys, and the edge of the mainland in the vicinity of Biscayne Bay.

In 1907 and 1908 the writer had an opportunity to study in detail some features of the topography and geology and their relation to 
underground waters that were not so evident in former years as they are to-day. Between 1896, the year of two important contributions to the geology of the region-the papers by Alexander Agassiz ${ }^{1}$ on the elevated reef and by Griswold ${ }^{2}$ on the southern Everglades-and 1909 , when the geology was described in detail in the second annual report of the State geologist, the railroad had been completed from Palm Beach to Miami and from Miami to Knights Key. At the mouth of Miami River, where only a few houses stood at the time of Griswold's visit, there is now a city of over 5,000 inhabitants, from which radiate miles of excellent macadam roads. What was then a barren wilderness now includes thousands of acres of truck farms and orange and grapefruit plantations. The result to the geologist from this transformation is a great increase in the easily obtainable rock evidence. Wells, quarries for road metal, and railroad borrow pits make the compiling of geologic data along the east coast vastly easier than it was in 1895 . Even on the relatively remote west coast, from Cape Sable north, there are more settlements to-day than there were then, and with the coming of the motor boat the exploration of the shallow and tortuous passages characterizing that coast has been much facilitated.

The larger portion of the interior is included in the great saw-grass swamp of the Everglades. Though repeatedly crossed by troops in the Seminole War and well known to many white men, hunters of alligators and plume birds, living on its borders, this expanse of water and sedge-covered muck had until 1907 been visited by few geologists and traversed by none. Griswold's account of what he saw toward the south end of the Everglades remained for years the best description of the more noteworthy features of the topography and geology of the region. Now, however, the drainage and reclamation work carried on by the State is yielding evidence that the individual explorer, from the physical difficulties to be overcome, could not possibly hope to obtain.

In a general review of the salient features of the topography of southern Florida it is convenient to consider the mainland, the keys, and the shore line separately.

Taken as a whole the topography of the Florida mainland has all the aspects of infancy. Drainage is defective; sloughs, shallow ponds, and lakes abound. Most of the interior is a swamp; no well-defined river systems nor stream valleys exist; and some of the short rivers that flow from the Everglades into the Atlantic are, where bedrock comes a few feet above sea level, characterized by rapids in their upper courses.

t Agassiz, Alexander, The elevated reef of Florida: Bull. Mus. Comp. Zool. Harvard Coll., vol. 28, No. 2, 1896, pp. 29-51.

2 Griswold, L. S., Notes on the geology of southern Florida: Bull. Mus. Comp. Zool. Harvard Coll., vol. 28 , No. 2, 1896, pp. 52-59. 
This infantile aspect is due to two causes, one the actual recency of deposition of the beds, consolidated and unconsolidated, that constitute the land surface, and the other the slight elevation of the beds above sea level since deposition. The rocks have had relatively little time to decay, and there has been no elevation of the land high enough or long enough to give streams an opportunity to erode valleys and establish well-marked drainage systems.

The shore-line topography is more varied; in places its forms are those of infancy and in places those of youth or adolescence, these differences in aspect being determined by the influence of opposing factors-those that tend to extend the land's edge irregularly and those that smooth shore lines into long sweeps and easy curves.

The relations between land and water on any coast are inconstant and ever varying. Not only is the shore a line of battle between the forces that destroy and those that build up the land but geologic history shows that changes of level are the rule, that the lands or the oceans slowly rise or fall during long periods of time, parts of the sea bottom becoming dry land and parts of the land being invaded by the ocean. In places these movements are rapid enough to be proved by human records. Where highlands border the ocean invasion is slow; where coasts are low it is relatively swift. The transitions of coast lines and the changes resulting from slight elevations or depressions of coast are factors of high importance in contemplating the present shape of the land mass of southern Florida.

As has been pointed out by Agassiz, Dall, and others, the present Florida mainland is but the top of a vastly greater submarine plateau, the southeastern and southern edges of which are near the present shore line, and the western edge many miles to the west. Hence, we may regard the present outline of the Florida mainland as a mere accident. Though stable enough when measured in terms of human life, it is ephemeral when compared with the duration of a geologic period. A depression of $\mathbf{5 0}$ feet would cover all the area considered in this report, except the tops of a very few sand hills and ridges; an elevation of 50 feet would extend the shore line but little on the east, though making dry land of Biscayne Bay; on the south it would dry the Bay of Florida; and on the west it would extend the land for 30 miles west of the entrance to Shark River and 20 miles west of Cape Romano.

The keys or islands that fringe the coast of southern Florida, or form the great arc that ends in the Tortugas, are of several types, but for the larger part are alike in being lower than most of the mainland. Except for some beach ridges and dunes, the general elevation of the keys is less than 10 feet, and hundreds of keys are merely mud flats hidden by mangroves. 
THE MAINLAND.

\section{SUBDIVISIONS.}

Although the surface of the south Florida mainland has slight relief, it yet shows considerable variety of type. A detailed study of its forms is beyond the province of this paper, but certain surface features will be discussed at some length because of their intrinsic importance, because of the attention given them by previous writers, and because a general understanding of the topographic types is essential in the study of the recently deposited formations and is necessary to a consideration of underground-water supplies.

Southern Florida lies low. The average elevation of the surface is below 20 feet and over long stretches the ground is almost a dead level. The general slope of the surface is south, though elevations along the east coast may average 10 feet higher than along the west coast. This is shown by the drainage of Lake Okechobee, the greater length of the west coast rivers, and the trend of the river courses, features that are considered individually on succeeding pages.

In consequence of the slight relief, the imperfect drainage, and the resulting accumulation of surface water during the rainy season, small differences in elevation have a marked effect on vegetation and make it possible roughly to divide the mainland into pineland and swamp. The pineland includes the hammocks, isolated patches whereon grow hardwood trees of several genera, and many of the prairies or grassy tracts; the swamp land includes the coastal swamps with their characteristic growths of sedges or black and red mangroves.

Owing to the low relief the line of demarcation between swamp and pineland is extremely irregular. In many places it is not a line but a variable width of prairie, which may be 2 feet under water at the end of a rainy season, but which in most years gets so dry during the winter months that tomatoes and other garden truck can be grown on it at a profit without artificial drainage.

As Matson has stated (p. 35), practically all of southern Florida lies within the boundaries of the lowest of the three terraces or terrace plains that may be differentiated within the State. This lowest terrace, which has a maximum altitude of 40 feet, Matson has designated the Pensacola terrace.

\section{PINELANDS.}

AREA AND DISTRIBUTION.

The pinelands of southern Florida are not remarkable by reason of the size of the trees, the thickness of growth, nor the yield of good timber per acre, but as they include the larger portion of the surface lying above what may be termed normal water level they are impres- 
sive from their extent. Their total area is a matter of conjecture, for though the pinelands have been surveyed by the United States Land Office, the township maps give an imperfect idea of the actual extent of the timber. In round figures perhaps 1,300 square miles are to be regarded as pineclad.

The pinelands of the eastern coast extend for the most part as a narrow belt between the Everglades and the coastal swamp from the north line of Palm Beach County to 12 miles southwest of Homestead. This belt is widest at the north, where it may be 20 miles across, and is much narrower south of Jupiter Inlet, where it is about 6 miles wide, varying in width from 2 to 8 miles and tapering to its southwestern extremity. West of the Everglades the pines are more irregularly distributed; at Naples they grow to the shore of the Gulf; along the north line of Monroe County they grow in more or less disconnected areas separated by narrow and broad strips of cypress; between Cape Romano and the mouth of Lostmans River they lie from 5 to 15 miles back of the outer face of the network of keys that constitutes the apparent shore line. South of Lostmans River there is no pineland.

As the trees grow on areas of very different topographic aspect, the pineland of southern Florida may be divided according to the character of its relief into dunes, rolling sand plains, rock ridges, and flat lands.

DUNES.

Character.-Dunes as here considered are purely eolian accumulations and do not include deposits of sand that owe their relief wholly or in part to the action of water, whether that of currents or of waves. Dunes are sharply differentiated from beach ridges, those coastal accumulations of sand and other loose material in the shaping of which waves and wind-driven spray took part. Thus some of the ridges facing the ocean at Palm Beach are not considered to be true dunes. Moreover, in this discussion the term dune is applied to ridges that are at least 4 or 5 feet higher than the general level of the sand near by.

The dunes are composed of medium fine quartz sand, varying in tint from pale yellow to orange or to light reddish brown. This sand is rather angular and some of it can be broken down to finer grains by rubbing between the fingers. Fossil shells are rare, if present.at all; none were seen by the writer in a rather careful inspection of sections through several dunes. The different tints of the sand are not, according to the writer's observations, arranged in distinct bands, nor is the sand everywhere plainly stratified. However, the color tends to increase with depth below surface, thus causing the gradation seen in a section through a dune to follow the surface contours. In many places the shades of yellow and brown are mottled 
or blotched. Streaks of gray sand, possibly caused by the decay of pine tree roots, extend from the surface to varying depths into the yellow and reddish sands below. In some dunes the sands toward the center have been so cemented by iron oxide as to form irregularly rounded masses of hard rock.

Perhaps the most noteworthy feature of the dunes of southern Florida is their quiescence. If cleared of pine timber and palmetto scrub they grow good pineapples, but even when bare their sands are little moved by the prevailing winds. The blasts of a hurricane may affect them somewhat, but certainly nowhere in southern Florida is there any such movement as is characteristic of dunes in active growth; no leeward march overwhelms trees and threatens dwellings, and no such drift is in progress as can be seen at Cape Henry, Va., and at other points on the Atlantic coast. Instead of burying forests the dunes of southern Florida, where not cleared, are covered with scrub or large pine trees. In short, they are quiescent.

Evidently, therefore, the dunes were formed during a time when conditions were different from those now prevailing - a time when the topographic and the climatic conditions favored sand drift. Though near the coast the dunes are not directly related to the present shore line, but, as shown by the fringes of swamp and the off-lying keys, to another shore line now below sea level. The significance of these facts as bearing on the post-Tertiary history of southern Florida will be discussed later.

Distribution.-In southern Florida the larger dunes lie near the coast. East of the Everglades and Lake Okechobee they reach south to New River as a discontinuous series of irregularly distributed mounds and ridges, in places separated by considerable intervals of flat or gently rolling country or by stretches of shallow water; but in few places do they extend more than a few miles inland and in few do they face the open ocean. South of New River there are, so far as the writer knows, no true dunes; certainly there are none on the 150-mile chain of keys that extends from Biscayne Bay to the Marquesas, the nearest approach to them being many low indistinct ridges and mounds, nowhere 8 feet above mean sea level. These are most pronounced along stretches of beach facing breaks in the living coral reef, particularly where the water near the shore has more than average depth, or rather where the seaward slope of the bottom is greatest. These low heaps of sand, from their position, may be the work of the waves quite as much as of the wind, and in fact most, if not all, of them are true beach ridges. Their outlines may probably have been modified slightly by wind-borne sand, but their main features are clearly due to wave action, particularly to the waves that break on the exposed beaches during a hurricane, when tides 4 feet or more

$76854^{\circ}$-wsP $319-13-4$ 
above mean high-water mark inundate the keys and facilitate the formation of unusually high inshore waves.

Along the east coast the position of the more prominent dunes near the shore is indicated on the Coast Survey charts. A noteworthy succession of ridges extends in an approximately north-northwest direction from 2 miles north of the dune on which stands Jupiter lighthouse, at the north side of Jupiter Inlet, to and past Hobe Sound station on the Florida East Coast Railway; just back of the station the summit of one has a height of 63 feet above sea level. Back of the lighthouse at Jupiter the top of one dune is perhaps 45 feet high. North of Hobe Sound station the dune belt veers to the westward and dies away within 3 miles. There are no large dunes along the railroad from Hobe Sound to the north line of Palm Beach County, and, according to report, no large ones north of the northern end of the Hobe Sound belt and no high ground between it and Kissimmee.

South of Jupiter Inlet dunes are numerous but occur as disconnected mounds or ridges and not as continuous or contiguous ridges. A typical dune, 47 feet high, at West Palm Beach, according to report, contained masses of rock. There are dunes 20 feet high near Palm Beach. Isolated dunes and ridges near the shore between West Palm Beach and Jupiter are shown by the Coast Survey charts. South of West Palm Beach the dune belt lies farther inland, though generally parallel to the seashore, and the more prominent dunes have not been mapped. There is a fine dune ridge near the east side of Lake Osborne, sbout a mile west of Lantana station. Isolated dunes of diminishing height occur to the south, the southernmost one of any prominence known to the writer being Pine Island, in the Everglades back of Fort Lauderdale, 6 miles from their eastern margin. The belt of country containing the prominent dunes south of West Palm Beach probably in no place exceeds 5 miles in width.

On the west coast of southern Florida, dunes are not nearly so numerous as on the east coast and are more irregularly distributed; like the east-coast dunes they are found near the shore rather than inland.

The best-developed dune system seen by the writer on the west coast is the one that covers parts or the whole of several islands near Caximbas Pass. It extends east from the south end of Caximbas Island in a disconnected line having somewhat the shape of the Greek letter $\Omega$, the total length being about 8 miles. Just back of Caximbas post office, at the west end of the system, there is a dune about 35 feet high. A mile to the northeast another ridge, having a maximum height of 60 feet, is said to be the highest in the system.

There are no dunes on the islands near the mouth of Caloosahatchee River, where from the configuration of the present coast line they 
might be expected, although a high beach ridge forms the backbone of Captiva Island. Between the mouth of the Caloosahatchee and Caximbas there are said to be two dunes, one on a small inner key near Estero, the other, much larger, on the mainland about halfway between Marco and Naples.

South of Caximbas there are no dunes, not even back of the 10-mile stretch of sandy beach at Cape Sable, and there are none along the southern edge of the mainland from Cape Sable eastward.

From this review it appears that though the distribution of the south Florida dunes is in some way related to the present coast line, the relation is not a definite one. The high ridges lie back from the ocean and from the Gulf, yet extend only a few miles inland. Those lying on keys rise out of mangrove swamps where dune building is now impossible; those near open water, like the dune back of Jupiter Light, generally lie back of a protecting key and back of a fringe of mangroves.

ROLLING SAND PLAINS.

By rolling sand plains is here meant sandy stretches of the mainland undulating in broad swales and low ridges. In the swales are shallow lakes or lagoons, wet prairies, or cypress swamps. On the east coast these sand plains form a belt that extends, with a maximum width of 6 miles, from the north side of Palm Beach County nearly to Miami River. Out of this belt rise most of the dune mounds and ridges. Inland the rolling sand plains merge imperceptibly into the monotonous level of the flatlands and the prairies bordering the Everglades; seaward they are bounded by swamps or by open water.

On the west coast south of Caloosahatchee River the rolling sand plains are of relatively slight importance, though in them may be included the arable land, a succession of beach ridges back of the present shore line at Cape Sable, and the sandy keys, many of them not pine clad, that fringe the coast from Cape Romano northward.

Near the shore on the east coast the higher ground and the ridges of the sand plains are in many places covered with a straggling growth of spruce pine. In the hollows are many fresh-water lakes, some several miles long. Most of these are less than 10 feet deep, and some are so shallow that they disappear entirely for months during a period of deficient rainfall such as prevailed from November, 1906, to May, 1908. A few of the lakes may be over 10 feet deep, and the writer was told that Lake Osborne had a maximum depth at the end of a normal rainy season of 30 feet, extending some feet below sea level. However, the lakes, as a rule, are so shallow and the slopes of their banks so gentle that a survey of the rolling sand-plain country made in or shortly after a summer of normal rainfall would show vastly different relations of land and water from 
one made in early spring following a year of deficient precipitation. This accounts in part for lakes appearing on maps of southern Florida at many places where the visitor may find none.

The sand grains, like those of the dunes, are angular rather than rounded. They are gray at and near the surface, but become yellowish a short distance below, except in places where water stands during most of the year. The decoloration of the sands near the surface is to be explained by the decay of plant roots, the action of soil bacteria, and the leaching effect of rain.

The character of the sands and the elevation and prevailing trend, parallel to the coast, of the ridges indicates that the rolling sand plains are in part beach deposits and in part the work of the wind and that they are related to the dunes.

FLATLANDS.

The term "flatlands" is applied to the imperfectly drained pinelands lying between the rolling sand plains and the Everglades or their bordering prairies and forming a discontinuous strip of country which on the east coast extends from the north side of Palm Beach County to the vicinity of New River, in Dade County. Its greatest width back of Hobe Sound is about 10 miles.

The flatlands have a soil of light-gray sand, resembling that of the rolling sand plains, and bear a thin growth of pine trees separated in places by expanses of prairie a mile or more wide, a difference of a foot in elevation determining the character of the vegetation. In the rainy season these prairies are shallow lakes. In the flatlands lie also exceptional sloughs or pond holes, some of which are a fourth of a mile or more across, and which, being 3 to 5 feet below the general level of the country, are never entirely dry. In places these deeper hollows support good growths of cypress, and as the region of relatively permanent standing water, the Everglades, is approached the pine and the cypress growths intermingle in most irregular fashion. In some places pines grow up to the edge of the prairie bordering the Everglades; in others a fringe of dwarf cypress separates pineland and swamp; and in still others considerable areas support good growths of cypress.

On the west coast the surface of the country between the Everglades and the Gulf is even more monotonously level than that of the east coast and the relations of swamp and dry land are more irregular. Much of the pine grows in patches and strips, in places miles in extent, separated by cypress swamps. In consequence, the timberclad flatlands of the west coast are described as pine islands and cypress strands. Prairies are scattered through or fringe the pinelands, and toward the Everglades and north of the Big Cypress great stretches of prairie make excellent cattle ranges. 
ROCK RIDGES.

The absence of rock outcrops over the greater part of that portion of the mainland included under the term southern Florida is striking, and indeed remarkable when one finds that in many places solid rock lies only a few feet below surface. To outcrops of any extent the term rock ridges is here applied, though it should be understood that these rock ridges may not rise more than 2 feet above the level of the surrounding country and probably nowhere have an elevation exceeding 25 feet above sea level.

The rock ridges of the east coast comprise the prominent outcrops of oolitic limestone that extend from 5 miles north of Miami to Homestead and separate the great saw-grass swamp of the Everglades from the fringe of mangrove swamps and salt prairie along the western shore of Biscayne Bay. This rocky country forms part of the Biscayne pineland. The area of these outcrops is estimated at 200 square miles, but is really a matter of conjecture. The relations of rock ridge and prairie along the western edge of the pineland are extremely intricate, the elevation of the outcrops falling gradually to the level of the Everglades and the pineland tapering off in a series of rocky keys or islands (of which Long $\mathrm{Key}$ is the largest) that extend fully 15 miles beyond the southwest corner of the main body of the pineland. Over many square miles between Miami and Long Key and about Long Key the limestone forms the surface. North of Miami the outcrops are mantled by sand before the elevation of the rock surface has become as low as 6 feet above mean sea level.

North of New River, between the sea and the Everglades, except for the coquina near the beaches, outcrops of rock are few and scattered. In the Everglades some of the keys have a rocky foundation, such being reported nearly to Lake Okechobee, but so far as known the only ones that form bare rock ridges are Long Key and the keys related to it, none of which reach as far north as the latitude of Miami.

On the west coast of southern Florida hard rock outcrops are more scattered than on the east but cover a much wider area. Throughout the pine island and cypress strands, limestone projects here and there through the sands and is found along the roads from Fort Myers to Fort Shackelford and from Fort Myers past Immokalee to the head of Allens River. Moreover, narrow interrupted strips of bare rock, some of them several miles in width, run through the pinelands.

A peculiar feature of the rock outcrops of southern Florida is the erosion of the surface. On the west coast, where the limestones are denser and finer than on the east coast, the rocks weather irregularly into rounded knobs and lumps a few inches to a foot above the general level of the surrounding sands, making it difficult to drive a wagon 
across bare expanses. In the rocky area of the east coast the softer oolitic limestone weathers into angular shapes, producing extremely rough surfaces and making walking a task that requires constant watchfulness. The ground is strewn with loose, sharply angular fragments (products of weathering and of the disruptive power of tree roots), and fixed angular masses a foot or so high, with irregularly pointed summits and jagged outlines, vaguely suggest miniature pagodas.

Hand in hand with this surficial erosion has gone underground solution. Next to the bristling rock surface, the most striking feature of the Biscayne pineland south of Miami is the presence of innumerable holes and hollows. The holes, which communicate with underground solution channels, are of all sizes, varying from not over an inch across to 20 feet or more in diameter. Besides the sharply outlined holes, there are throughout the pineland countless shallow hollows 1 to 3 feet deep and 10 to 100 feet across. A few of these hollows owe their origin to original conditions of deposition, some may be due to the overturning of trees and consequent upheaval of the rocks by roots, and others have been caused by the falling in of the roofs of subterranean watercourses.

Few of these holes and hollows are large enough to be termed sinks. The large vertical-walled holes running down to permanent water level form natural wells; the shallow hollows are best denominated potholes. Deep, or Devils, Lake, near the west coast, 12 miles north of Everglade post office, is, so far as the author knows, the only rockrimmed opening in southern Florida that resembles the great sinks in the country to the north. It is about 500 feet across, is nearly circular in outline, and its reported greatest depth is 90 feet.

Although there is danger of exaggerating the activity of underground and surface water in eating away the soft limestone of the east coast, yet there are plentiful evidences of solution. The potholes and the hollow-sounding areas of rock, perhaps 25 feet across, with as many as six or seven holes a foot or so in diameter showing the water beneath, that are found along the edges of the southern Everglades; the springs below tide level at Cocoanut Grove and other points on the shore of Biscayne Bay; the Punch Bowl, a spring basin; the deep holes in New River; and the shallow gorge of Arch Creek, with its low rock bridge-all bear witness to the work that is being done.

\section{SWAMPS.}

CONTROLLING CONDITIONS.

As before stated, the swamp land of southern Florida includes the great saw-grass morass of the Everglades, the cypress swamps and strands around its edges or intermingled with the pineland, and the salt meadows and mangrove swamps of the coast. The very slight 
differences in elevation over long stretches of the mainland, the gradual slope of the rock surface below sea level, the rock ridges on the southeast, the configuration of the upper surface of the bedrock, and the rapid growth of grasses and sedges are all factors in the distribution of land that is permanently wet and of that which is, for a part of every year, dry.

\section{EVERGLADES.}

Extent.-It is difficult for a person who has not seen the Everglades to form even an approximate idea of that far-extending expanse of sedge, with its stretches of shallow water, its narrow winding channels of deeper water, its scattered clumps of bushes, and its many islands. Photographs fail to convey the impressions of distance, of remoteness, and of virgin wildness which strike the visitor who for the first time looks out across that vast expanse.

The Everglades occupy the greater portion of southern Florida. They reach from Lake Okechobee on the north to the vicinity of Whitewater Bay on the south and may have a maximum width of 60 miles. They have not been surveyed and their exact area is undetermined, but it is estimated at 5,000 square miles. The relief of the drier land is slight and the actual dividing line between sawgrass morass and cypress swamp, prairie, pineland, and coastal swamp is extremely intricate. A difference of 2 feet in water level means the difference between shallow lake and dry land over hundreds of square miles. Hence, the relation between land and water shown on a particular map is not necessarily to be taken as absolute or even general; it may only show the relation as determined in the month or months and year of the survey.

On the north the main body of the Everglades reaches to the southern and southwestern sides of Lake Okechobee. Arms extend farther north, but much of the eastern and most of the northern shore of the lake is bordered by cypress swamps, some of these containing the tallest and cleanest cypress to be found in Florida.

East of the lake the Everglades fade away irregularly in the Allapattah Flats, a region largely under water at the end of each rainy season, where interwinding strips of saw-grass swamp and grassy prairie, set with patches of cypress and, more rarely, with hammocks of hardwood, stretch away in an almost dead level. Farther south the Everglades are bordered by prairie and cypress swamp or at a few places reach nearly to the coast. The rocky pine-clad islands that extend southwestward from the main body of the Biscayne pineland nearly to Whitewater Bay have a fringe of prairie, but east of them lies a saw-grass strait and to the south lie wide expanses of saw grass dotted with keys that disappear seaward among thickets of dwarf cypress or mangrove. On the west the Everglades from 
Whitewater Bay to Lostmans River reach the mangrove swamps that fringe the coast. North of Lostmans River an arm of the Everglades runs up between the mangrove swamp and the prairie bordering the pine islands and gradually disappears before reaching Allens River. Cypress swamp and prairie form the western boundary of the main body of the Everglades from Lostmans River to Caloosahatchee River. A narrow strip of small cypress is said to extend along the western edge of the Everglades for 60 miles south of Sam Jones town.

Elevation and drainage.-Differences in elevation are slight; few of the islands are more than 2 feet above high-water level, and the slopes are so gentle as to be detected only by the movement of the water or by leveling. The general slope is south but, in spite of the water seen everywhere in the rainy season, is not uniform. Low, irregular rises, measured by inches only, serve to diversify the water and sedge-covered peat in the dry months of the year. There are also sloughs-narrow winding strips of open water through the sedgesome of which extend for miles. Often it is not possible to detect a persistent current in these passages, which, for the most part, seem to lie north and south along the west side of the Everglades and north-northwest and south-southeast along the east side.

The water brought down by Kissimmee River escapes from Lake Okechobee through a canal connecting with the Caloosahatchee and through the saw grass. The short streams around the southern edge of the lake, shown on most maps of Florida, do not flow into the lake but from it. They close up within a few miles and the thick growth of saw grass makes the movement of water in any given direction very slow. Some of the water entering the lake reaches the Gulf and some the Atlantic, the water moving as a mass slowly southward. When the lake rises to about 22 feet above mean sea level it is said to overflow into the Everglades along its whole southern border.

As evidence of the flatness of the Fverglades, residents of the east coast state that when the canal leading from the lake was dammed at Lake Hicpochee in the year 1904, raising the level of the water above the dam 3 feet, more water came down the east coast rivers as far south as New River, and the marginal prairies were under water so late in the fall as to hinder seriously the growing of vegetables, but whether the dam caused all the trouble complained of is doubtful.

Since Lake Okechobee overflows to the south and the waters escaping from it may reach either the Atlantic or the Gulf, the elevation of its surface is in a way a measure of the elevation of the Everglades. Several determinations of its level have been made by Government engineers and surveyors. An elevation of 20.4 feet was found by a party of engineers in April, 1901, but an even lower level-19.8 feet- 
is reported to have been found in March, 1908. High-water levels published by the United States Chief of Engineers are 22.4 feet in 1886 and 23.4 feet in 1878. Comparatively few determinations along the edges have been reported. Some determinations along the eastern margin are: West of Lantana, 18 feet; west of Hillsboro Inlet, 14 feet; west of Fort Lauderdale, 3 to 9 feet; at the pool at the head of Miami River, 6.2 feet. South of the Biscayne pineland and Long Key the height of the Everglades is less than 6 feet. Wright ${ }^{1}$ says that the mean water level of the lake is 20.5 feet, that the lowwater level is about 19 feet, and the greatest depth at low water is 22 feet, making the bottom at that point 3 feet below sea level.

Willoughby in his trip across the Everglades from Harney River to Miami River found that the water on the west side had a slow movement southwest, and on the east side a similar movement southeast. Ingraham, who crossed the Everglades from Fort Shackelford to Miami, found a southerly movement in a creek connecting Okaloakoochee Slough and the Big Cypress but little current in the sloughs.

W. J. Krome, who made a careful survey of the southern Everglades for the Florida East Coast Railway, found a slight southerly current in the slough that forms the headwaters of Taylor River between the mainland and Long Key. The writer, however, found no perceptible current in this slough near Paradise Key in June, 1908.

Evidently at times of high water there is a perceptible movement of the water of the Everglades down the slight slopes toward the nearest outlets. At times of extremely low water the sloughs may be so separated that except in the immediate vicinity of a river no current is perceptible.

The normal difference between high and low water in the Everglades is about 2 feet; the maximum difference may be twice as great. In the spring of 1908 it was possible to travel by wagon from the Biscayne pineland to and about Long $\mathrm{Key}$, whereas in the early winter of 1906-7 one could cross the southern Everglades in a power boat. During the Seminole War successful pursuit of the Indians depended on a depth of water sufficient to permit the use of ship's boats.

Bedrock.-The Everglades have been variously called a lake in a rock-rimmed basin and a vast sink. In the light of the facts accumulated by surveys of the War Department, the Disston Co., the Florida East Coast Railway, and the State of Florida, and by the explorations of Ingraham, Willoughby, and others, both these designations appear inexact.

Bedrock apparently lies at or near the surface around the edges of the Everglades. Along the east side from Jupiter River to Hillsboro

\footnotetext{
1 Wright, J. O., Report of the special joint committee of the legislature of Florida on the Everglades of Florida, p. 5, 1909.
} 
River outcrops are few. South of New River they are more numerous, and from just north of Miami to Homestead the rock forms bare ridges with a maximum elevation of 15 feet above mean water level in the Everglades. This line of ridges bends at its southern end to the west and gradually disappears as a series of rocky keys running west and southwest and reaching nearly to Whitewater Bay. South of this rock ridge, from Cutler on Biscayne Bay around the southern end of the mainland, past Cape Sable, Whitewater Bay, Ponce de Leon Bay, and the Ten Thousand Islands, there are no outcrops of bedrock above the sea level; nor are there any along the shore south of Sanibel Island. On the southwestern side of the Everglades rock comes within a foot of low-water level in Rock Creek, an arm of one of the series of bays that together make up much of the lower 12 miles of Lostmans River. Three miles northeast of this point rock outcrops in a pine island. Thence northward many rock exposures are scattered through the flatlands. They can be seen at the head of Allens River and 11 miles to the east on the property of the Deep Lake Fruit Co. The belt of country in which rock is exposed widens northward and at Naples is fully 40 miles wide from east to west. This region is monotonously level and the rise of the rock surface inland is slight. In short, bedrock outcrops around the main body of the Everglades from Jupiter River to Fort Shackelford with no important interruption except between Lostmans River and the westernmost of the rocky keys beyond Long Key. In this break rock does not on the average lie more than 5 feet below the level of low water.

If allowance be made for the general slope of the water level toward the drainage channels on the east and west coasts, the hydraulic gradient amounts to 0.3 foot per mile for 30 miles northwest of Miami. It is evident that the actual depth to bedrock in the middle of the Everglades is only 3 to 4 feet below a level line extending from rock rim to rock rim. As these points might be 40 miles apart, and as the depth below the line at the latitude of Miami averages less than 5 feet, the inappropriateness of the term basin for the southern portion of the Everglades is evident.

Nor is the term sink more accurate. The area is too large; the rock floor too flat. Potholes and small sinks are common in the rocky prairie south and southeast of the main body of the Everglades, and large sinks filled with mud may exist in the main expanse, but their existence is not proved. Possibly, also, sinks of some size may exist between the line of rocky keys and the north shore of the Bay of Florida. Certain features of Bear and other lakes back of Flamingo suggest that they are sinks.

Although the rock floor of the southern Everglades is known to be almost flat, yet it is altogether possible that farther north there are true basins of considerable extent. The preliminary surveys for the 
drainage work undertaken by the State at New River showed that bedrock sloped off more steeply at that place than to the south or the north, and a depth of 20 feet to bedrock is probable in a strip a few miles wide. Reports are current of an east-west rock ridge 8 or 10 miles south of Lake Okechobee within 6 feet of the surface but are probably without substantial basis. A rock ridge rises north from Long Key, reaching as far north as Miami, but according to report, sounding with a 10-foot pole on a line from Fort Shackelford to Miami, found no rock till within 15 miles of Miami. Hence there is a probability that the Everglades cover a series of shallow rock hollows. Whether these hollows were as deep when first occupied by the Everglades as they are now, whether they represent original inequalities of deposition of the lime rock, or whether they are buried shallow valleys can not be determined from the evidence at hand. It is probable, however, that the deepening and enlarging effect of underground solution has been exaggerated.

Bedrock lies 10 feet below low-tide level at Jewfish Creek, 18 feet below at Flamingo, 5 to 10 feet below in Whitewater Bay, 13 feet below at the mouth of Shark River, 13 feet below at the mouth of Lostmans River, 12 feet below on Chokoloskee Island, and 5 to 10 feet below at Everglade.

Dredging in the canals west of Fort Lauderdale show rock (not oolite) near the surface 7 to 10 miles west of the town. Regarding the rock ridge reported in the Everglades south of Lake Okechobee, R. E. Rose, State chemist, who is familiar with the results of the Disston surveys, in a letter to the writer says that no rock was found at 12 feet, the length of the sounding rod, between a point 20 miles south of the lake and the lake, and that he has never found rock with a 10-foot rod near the south side of the lake. According to his recollection, rock was found at 8 feet 20 miles south of the lake. The South Canal survey approaches the rock reef on the west (in T. 48 S., R. 35 E.); farther east the muck is deeper.

The slight westward slope of the larger part of southern Flcrida, to which reference has been made, is due to a recent tilting and to deeper accumulation of sand along the ocean than along the Gulf shore rather than to variations in bedrock level. The latter is effective only along the southeast side of the Everglades.

Origin of the Everglades.-The Everglades owe their existence primarily to an abundant rainfall and to the slight elevation of southern Florida. Even were there no basin-like structure whatever, and were the bedrock surface absolutely flat along an east-west line, the present rainfall, the sluggish drainage, and the luxuriant growth of vegetation would result in a swamp forming across the center of the peninsula from Lake Okechobee. In short, the Everglades resemble in origin the Dismal Swamp of North Carolina and Virginia. 
The peat found throughout a large part of the Everglades rests on rock, sand, or marl. In places soundings indicate more than one peat bed, with sand between. The relations of peat and sand to bedrock west of Fort Lauderdale are shown by a section along the drainage canal there. (See fig. 1.)

\section{CYPRESS SWAMPS.}

Most of the many tracts of cypress scattered over southern Florida call for no especial notice. Probably the finest cypress grows northeast of Lake Okechobee, but the largest tracts of good timber are west of the Everglades; Okaloacoochee Slough and the Big Cypress are the two most important. Both have extremely irregular outlines with numerous arms forming strands among adjacent pine islands or prairies. The southern boundary of the Big Cypress is not indicated on most maps of southern Florida and on many its extent is greatly exaggerated, the name being printed across a region where cypress swamps, prairies, hammocks, and pineland are intermingled. During

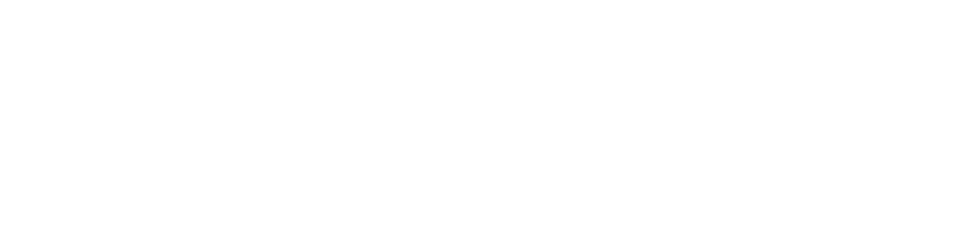

Figure 1.-Section near edge of Everglades west of Fort Lauderdale. $A-B$, sea level. Vertical scale, 1 inch $=30$ feet; horizontal scale, 1 inch $=1 \frac{3}{r}$ miles.

periods of high water boats can pass through the Big Cypress from the Everglades to the Gulf north of Cape Romano. The maximum east-west width of the swamp may be 40 miles. Ten miles east of the head of Henderson Creek is a cypress swamp 6 miles wide, and east of Everglade is another swamp 6 to 12 miles wide, these swamps being connected with other swamps that form arms of the Big Cypress.

\section{COASTAL SWAMPS.}

As a consequence of the low relief and the gradual slope of the land below sea level, southern Florida has wide areas of coastal swamp. These areas include (1) wet lands along lagoons or rivers lying back of the barrier beaches of the east coast, covered partly by open marsh and partly by scrubby growths of mangrove, and (2) the more extensive swamps of the south and southwest coast, which die away in a network of channels and islands. On the west coast these mangrove-covered islands and the mangrove swamps behind them extend from Whitewater Bay, the southernmost arm of which is separated from the Bay of Florida by less than 5 miles of wet prairie and swamp, to Cape Romano. North of Marco the coastal 
islands and the swamp land include pine islands, and in places north of Naples pines grow to the Gulf shore.

The red mangrove most frequently grows as a bushy tree, under 20 feet high. The swamp that forms the southern fringe of the mainland from Chis Cut to 6 miles east of Flamingo has such low trees, as have many islands in Whitewater Bay and most of the patches of swamp along the main line of the Florida Keys from Biscayne Bay to the Marquesas. But in the Shark River archipelago and the southern portion of that unmapped maze of land and water, the Ten Thousand Islands, the mangrove forms a noble forest, the trees growing to a height of 60 feet or over with clean smooth trunks 2 feet or more in diameter at the butt and without a limb for 30 feet from the ground. They rise from the Gulf like a green wall and are one of the most striking features of the shore line of southern Florida. The majestic appearance of these trees compared with the look of those in Whitewater Bay can not be explained by any local peculiarity of climate. Rather does it result from the aeration of the thick bed of soft gray marl on which they grow by the swing of the tides, which here have greater amplitude than anywhere else on the whole coast of the peninsula, fully 5 feet. Northward, toward Cape Romano, the trees become smaller and along the inlets back of Caximbas they are as bushy as in Whitewater Bay.

The maximum width of coastal swamp in southern Florida is unknown, since the boundary between coastal swamp and Everglades is a matter of conjecture. After a season of heavy rainfall the channels leading from the latter carry fresh water and after a dry season salt water. Thus in May, 1908, the writer found salt water in Lostmans River within the Everglades, 17 miles from the mouth of the river, while in October of the same year, after the heavy rainfall of the summer and early fall, the water was fresh to a point within 5 miles of the Gulf.

\section{THE KEYS.}

\section{GENERAL CHARACTER.}

The keys or islands that fringe the south Florida mainland differ greatly in size, shape, and surface features. Some are typical barrier beaches, long, narrow, low-lying banks of sand, crowned with coconut palms and buried in mangrove swamps to landward. Many are true mangrove islands, shoals formed by the efforts of tidal and windinduced currents where mangroves were able to take root and arrest material thrown up by the waves. Others are sand banks so lowlying or so exposed as to support only a scanty growth of beach grasses and weeds; and still others, notably those in the main chain that extends from Virginia Key opposite Miami to Key West, are of rock or have a rock foundation reaching to or above mean sea level 
and covered with various scrubby hardwood trees, palms, and even pines.

Within this chain, fringing the mainland or dotted over the Bay of Florida are many keys in. all stages of growth, from banks below sea level to banks just bare at low tide on which mangroves have got a foothold and by their entangling roots are catching seaweed and driftwood, arresting the movement of calcareous sand and mud, and actively pushing out the shore line. Whitewater Bay, which lies behind Cape Sable and has an extreme northwest-southeast length of perhaps 20 miles, is full of these mangrove islands.

North of Whitewater Bay the Ten Thousand Islands form a network of channels and of marl banks supporting a heavy growth of red and black mangrove. From Big Marco Pass to Sanibel Island an almost continuous beach of siliceous sand, broken only by narrow inlets, such as Johns Pass, Gordon Pass, Big Hickory Pass, and Big Carlos Pass, faces the Gulf. These passes lead to inner "bays" dotted with islands of many sizes, but with few features of especial interest.

Though the islands along the coast of southern Florida may be readily divided into definite types, as barrier beaches, rocky islands, and mangrove islands, it is not possible to state from present information the relative importance of these types.

The decided differences of surface of the keys-bare rock or rock with a very thin veneer of leaf mold, sand, and marl-and the slight differences of elevation above high tide, have resulted in great differences of vegetation.

Near the water's edge and on flats or on rock beaches below hightide level grow mangroves; on the beach ridges coconut palms, not indigenous, flourish. Inland the low marl flats support grasses, sedges, and salt meadow weeds. The higher ground, called hammock, supports a dense growth of scrubby hardwood trees, buttonwood, ironwood, and madeira, little of which attains a height of more than 20 feet. Three of the keys, No Name, Little Pine, and Big Pine, notably the latter, carry patches of pine.

The rock outcrops along the keys differ from those of most of the bare rock in the Biscayne pineland or in the flat lands of the west coast between the Everglades and Cape Romano. They are less weathered, hence more even, and not jagged looking, except on sprayworn beach slopes. Angular blocks, disrupted by tree roots or by temperature changes, are scattered over them, but in places the surface is comparatively smooth over areas of 20 to 100 square yards. Holes and hollows resembling those found in the Biscayne pineland and formed in the same way abound, but the rock itself has a look of newness; its major inequalities are not the result of subaerial decay. It is like that of some of the low keys in the Everglades west of Long Key. 
Since the keys were elevated to their present height they have been subjected to forces that tend to advance the shore line and to those that tend to push it back. The easterly winds have played an important part in giving the eastern and southern faces of the keys their present forms. Differences in time and height of tides in Florida Strait and the Bay of Florida, together with the area of the bay, result in strong currents sweeping through the passages between the keys, particularly the openings west of Long Key. When northers blow the shallow waters of the bay are milk-white over large areas from the limy stuff in suspension. This is deposited, to be picked up with a change of wind or tide, or is carried to sea in such quantities as to show in the blue waters of the Gulf Stream 10 miles outside the keys. The bars and banks about the keys and in the Bay of Florida, the areas of marl and calcareous sand above sea level, show the activity of waves and currents and indicate how much material they have recently handled.

THE FLORIDA REEF.

The shores of the main line of keys, extending from opposite Biscayne Bay to Key West and Boca Grande, are in places rocky and in other places are bordered by flats of soft marl or calcareous sand. On some keys the surface is bare rock; on others it is sand or marl; on very few do wide strips of land stand as much as 6 feet above the highest spring tides. (See PI. VII, $A, B$.)

The longest key-Key Largo-is 30 miles in extreme length, but is nowhere over 3 miles wide, and its maximum width above the high spring tides is considerably less. Big Pine Key is 10 miles long and its high ground is nearly 2 miles wide with a greatest elevation of 10 feet. Key West is 4 miles long by 1 mile wide and its highest ground, which is near the center of the city of Key West, has an elevation of 13 feet. The highest measured points in the whole chain of keys are two small knolls 18 feet high, one on Windleys Island and the other on Plantation Key, just to the north. The knoll on Windleys Island was quarried for fills and ballast along the railway line to Knights Key.

The Florida Keys are separated by Bahia Honda Channel into two distinctly differentiated divisions. East of the channel the iskands are narrow and lie along a sweeping arc curved toward the southeast. Outside this are is the Florida Strait; inside it are the Bay of Florida, Barnes Sound, Blackwater Bay, Card Sound, and Biscayne Bay. The western end at Bahia Honda is 35 miles from East Cape on Cape Sable, the nearest point of the Florida mainland. The rock ridge of Key Largo is not 2 miles from the edge of the mangrove swamp that fringes the end of the peninsula and from there northward the keys are within 8 miles of the mainland. 
West of Bahia Honda the keys form an archipelago roughly triangular in outline. In this group, the westward prolongation of the arc in which lie Bahia Honda and the keys to the east and northeast is found in the southern shore line of the keys; but the keys themselves, instead of lying parallel to this are, have a prevailing north-northwest, south-southeast arrangement, perpendicular to the arc. The causes of this striking dissimilarity in position are twofold, a difference in rock structure and a difference in the direction of the forces which have shaped the islands.

Bahia Honda and the keys east of it represent an uplifted coral reef more or less covered with sand and marl; hence their basement rock ridges have the trend of the coral patches of the old reef. The keys west of Bahia Honda consist of an oolitic limestone formed from deposits in a broad expanse of shallow water; hence there was no original ridgelike upbuilding, no pronounced trend to the rock structure. Differences in resistance to erosion have resulted in irregularities of the rock surface, which, as along the old reef to the east, have been more or less covered with marl and calcareous sand. The prevailing northsouth trend of the passages separating the keys, hence the trend of the keys themselves, is due to tidal currents, which owe their power to differences in time and height of the tides of the Gulf and the Strait of Florida.

The shaping of the great arc of the keys is the joint production of several factors. The old coral reef that forms its greater part was built up from the bottom in water of a certain depth along a line that had the general direction of the southeastern and southern edge of the submarine plateau of the Florida peninsula. The curve of its western end was controlled more or less by the eastward flow of the Gulf Stream against the westerly movement of the prevailing winds.

The writer did not visit the Tortugas, which have been described by Agassiz and by Vaughan, nor the Marquesas, an atoll-like group of beach ridges and mangrove islands that is presumably underlain by the Key West oolite not more than 10 to 15 feet below sea level. The Marquesas are of Recent age, and according to Vaughan the Tortugas are also.

\section{THE SHORE LINE.}

TOPOGRAPHY.

The shaping of the shore lines of any region is the joint work of tidal and wind-made currents, waves, and winds. The share of each of these agencies is determined by the efficiency permitted through antecedent conditions of coastal topography, the character of the shore-line materials, and the circumstances controlling the general circulation of ocean currents and winds, and the work being done at any given time is in a measure controlled by the rise or fall of the land with reference to sea level. Thus shore-line features have the aspects of infancy, adolescence, or maturity, according to the length 


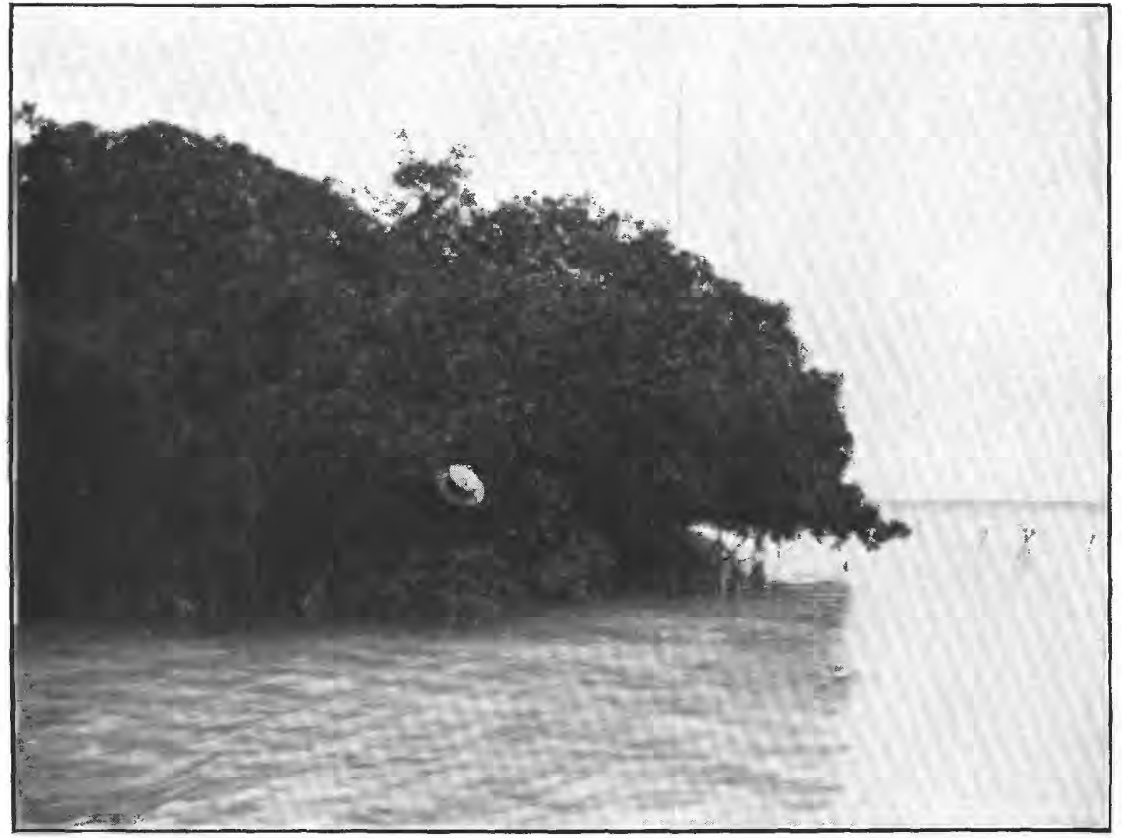

A. MANGROVE KEY, WATER'S EDGE.

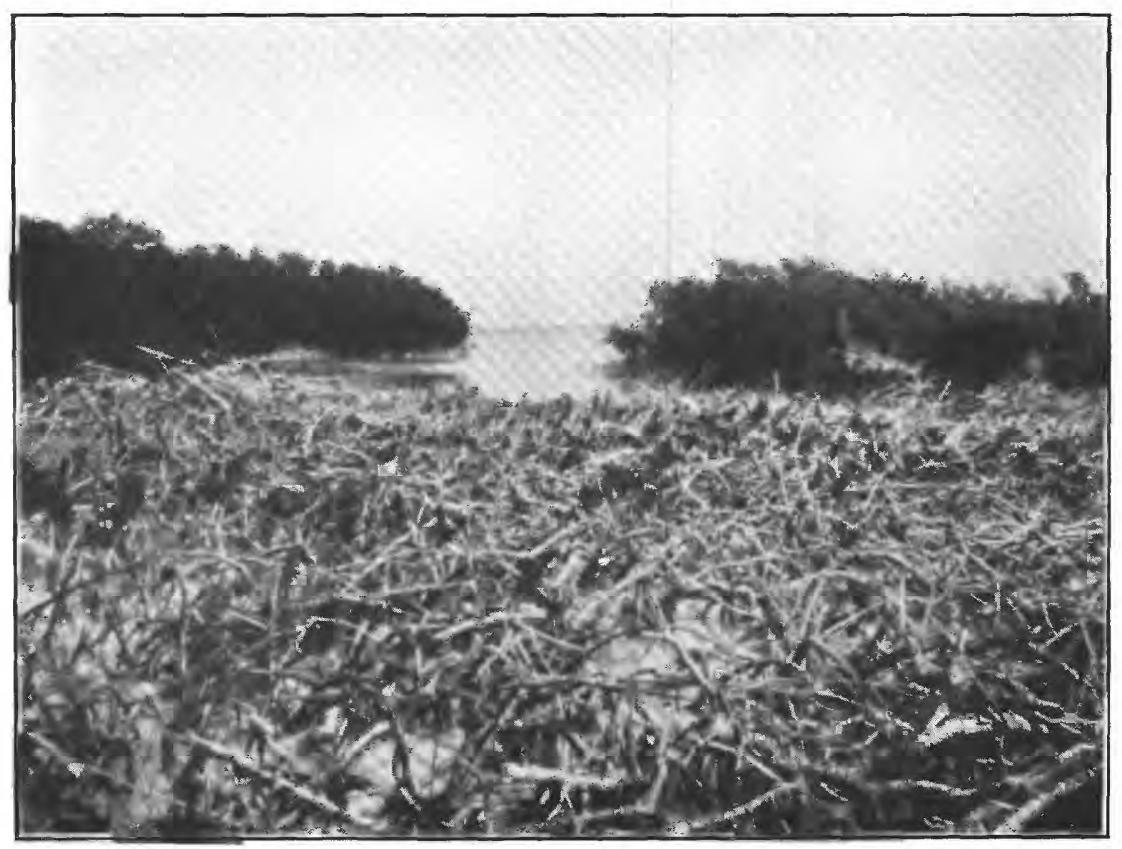

b. ROOT GROWTH OF MANGROVES, SOUTH END OF KEY VACA. 


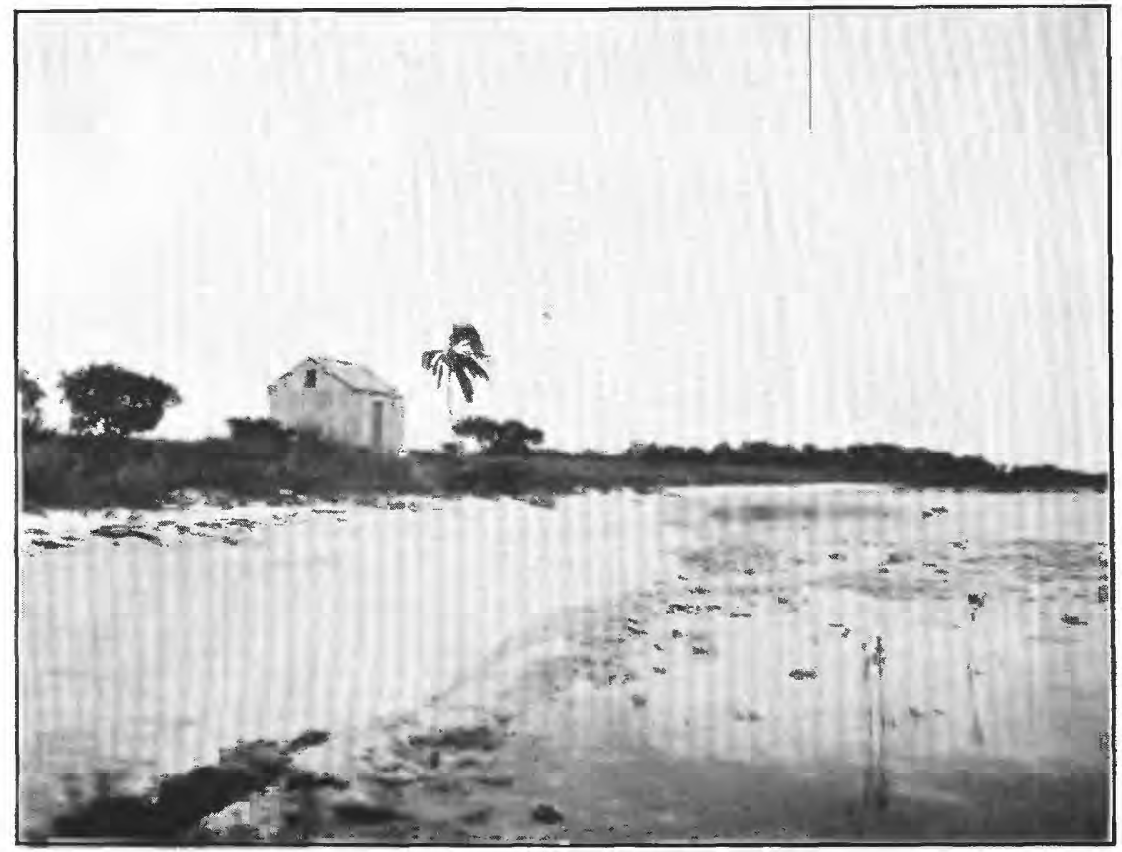

A. BEACH RIDGE OF CORAL AND SHELL SAND, KNIGHTS KEY.

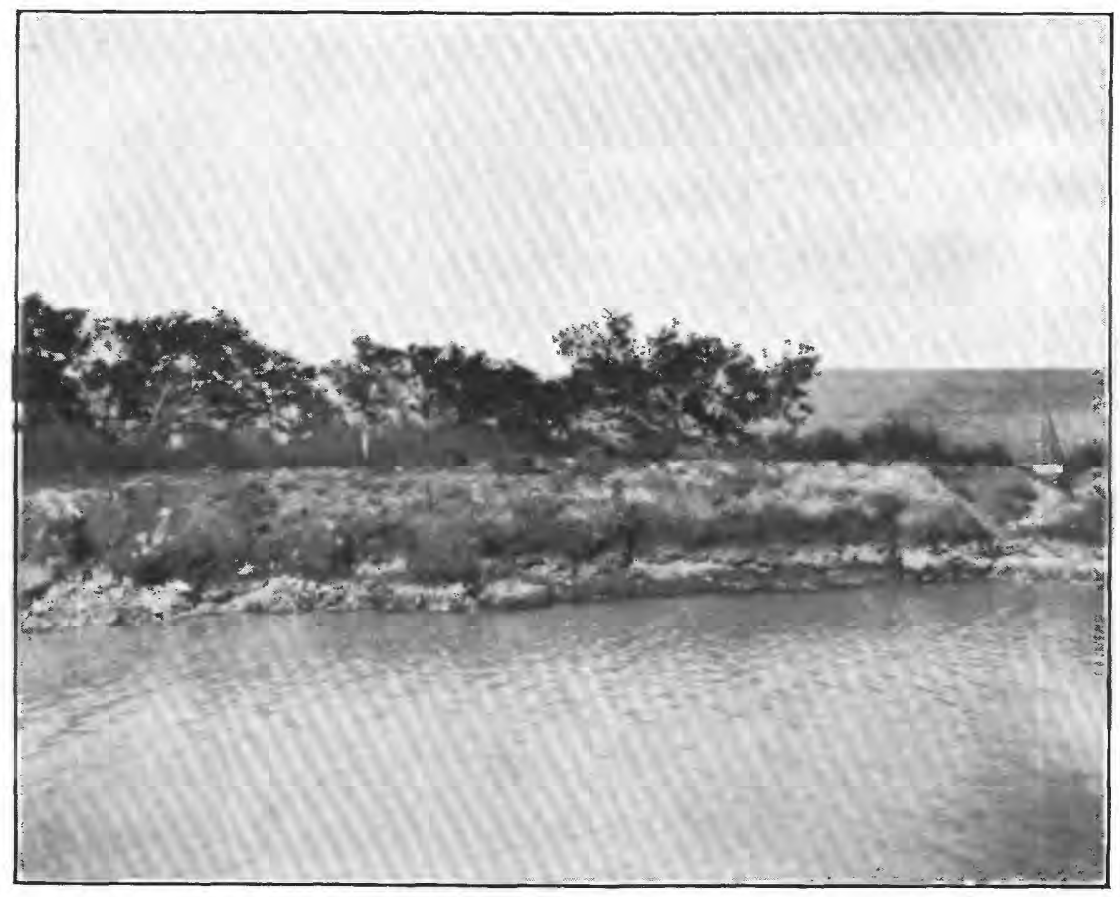

B. Calcareous SAND on REeF Rock. 
of time the waves and currents have been working at a certain level and the effectiveness of their attack on the land. In the same region, as in southern Florida, adolescent features may be found where the attack is strong, and infantile where the attack is weak or ineffective.

The south Florida mainland is low, its coasts dip gently beneath the water, and the shore-line materials are nearly everywhere unconsolidated. Under these conditions slight changes of level can swing shore lines over long distances, and the effectiveness of wave attack is easily modified by agencies, such as corals, which tend to build up land, or agencies, such as mangroves, which tend to push out the shore. (See Pl. VIII, $A, B$.)

The region has no well-marked valleys and no large rivers; hence antecedent drainage has been of minor importance in determining the work of waves and currents. The streams are clear, they bring down little matter in suspension, their waters are not heavily mineralized, and they contribute comparatively little to the sea bottom; hence delta building is insignificant. At the same time an immense amount of limy material is supplied by the remains of marine organisms, the agitation of the shallow near-shore water facilitates the deposition of calcium carbonate, and the effluent swamp waters contain organic compounds that may act as precipitants; hence banks of marl form near river entrances or outside of passages leading from lagoons, and where the banks are protected mangroves gain a foothold and interrupt the sequence of forms that would result from the unopposed action of waves and currents.

Maps of the east coast show a shore line with adolescent features, such as cuspate forelands, well-developed bay bars, and long beaches with gentle curves. The offsets and overlaps of the bars and beaches show that the movement of sand is toward the south. This movement is very marked at Jupiter Inlet. When the bay bar at the mouth of the inlet is cut through at its north end to make a navigable channel, the drift of the sands makes the channel travel southward, till as it approaches the south side of the inlet it shoals up and the water flows over the bar in a shallow sheet.

\section{OCEAN CURRENTS.}

Vaughan has summarized the action of the forces that produced the Floridian Plateau and has called special attention to the importance of ocean currents, as follows: ${ }^{1}$

The importance of currents in shaping the land area of Florida has been emphasized in several sections of the preceding discussion. Before the history of the currents of the region can be thoroughly understood it is necessary to know the history of the Hatteras axis of North Carolina. The present Florida countercurrent seems due partly to the impingement of the Gulf Stream. against the Hatteras projection, resulting in a

1 A contribution to the history of the Floridian Plateau: Pub. Carnegie Inst. Washington No. 133, 1910, p. 185 .

$76854^{\circ}-$ WSP $319-13-5$ 
portion of the waters being deflected southward along the coast instead of continuing their northward journey. The Hatteras axis has existed as a dividing line between depositional areas apparently since Middle Cretaceous time, and it has been either a region of shoal water, or occasionally a land area, since later Eocene time. The Vicksburgian and Apalachicolan seas were both warm, tropical or subtropical in temperature. It is not definitely determinable at present whether the warmth of these waters was due to currents directly from the Tropics or to warm return currents produced by the northward-flowing Gulf Stream having a portion of its waters diverted southward by impinging against a salient from the more northerly land area.

In Miocene time it is definitely known that a cold inshore current found its way southward to Florida and westward to Pensacola. This current may be due to the Miocene submergence of the Hatteras area sufficiently lowering the sea bottom off Hatteras to permit the Gulf Stream to continue its course unobstructedly northward. Should this hypothesis be correct a reexamination of the faunas of the Miocene deposits of northern North Carolina and Virginia, and those of southern North Carolina (the Duplin marl), South Carolina, Georgia, and Florida, with reference to synchrony may be necessitated. The Miocene southward current transported quantities of terrigenous material and deposited it on the eastern border of the Floridian Plateau.

Since Miocene time there have been constantly return currents of warm water (however, not so warm as the Gulf Stream), and they, aided by winds and tides, have deposited terrigenous material on the eastward side of the existing land areas, sweeping a portion of it to the southern end of the Plateau. These currents were active during Pliocene and Pleistocene times, and are still active to-day.

The shape of the upper surface of the Floridian Plateau, the land area of its eastern side, the arrangement of the geologic formations of successive ages, the directions of the stream courses, and the contour of the present coast line owe their peculiarities and characteristics to the concomitant operation of the forces producing deformation and to oceanic currents.

The writer does not share Vaughan's view as to the existence of great return eddies of the Gulf Stream and their effectiveness in modifying coast lines, either to-day or in time long past. The sand grains along the east coast of Florida have traveled southward not at great depths but in shallow water, along beaches and bars. Such being the case, their travel was determined by the inshore waves and currents, which are mostly tidal or wind induced. The angle of incidence of the waves along a stretch of beach is chiefly a matter of wind direction. Were the near-shore currents and waves to move material northward rather than southward, a return eddy of the Gulf Stream, a mile or more offshore, would have very little to do with the shaping of the shore line. Moreover, the writer doubts the existence of a great eddy of the form that Vaughan's words imply. Of course, the movement of such a body of water as sweeps through Florida Strait must be accompanied by eddying, but the writer in his observations along the keys saw no sign of any general, persistent return eddy. The drift of sand and mud, as indicated by beaches, banks, and bars along the great arc of the main line of the keys, is the work of local inshore currents that change continually in direction and strength but are chiefly controlled by the tides and the more effective winds. A balance of effect is shown in the Marquesas, where waves from the east and waves from the west seem to be of nearly equal strength in piling up sand and mud. 


\title{
PART II.-GEOLOGY.
}

\section{NORTHERN AND CENTRAL FLORIDA.}

\author{
By G. C. Matson.
}

\section{GEOLOGIC RECORD.}

The processes which formed the rocks comprising the State of Florida have changed from time to time, but they have always been similar to those now operating along the coast. That the rocks are largely of marine origin is shown by the presence in many of them of shells of marine animals sinilar to those that live along the coast to-day. When the sea was clear animal life abounded and the shells accumulated to form limestones, but when the water was muddy sand and clay predominated in the deposits. Thus the rocks of Florida record the conditions which existed during their deposition. In some places accumulations of clay, sand, and gravel appear to have taken place on land or in rivers and lakes, giving rise to nonmarine formations, but these deposits are only a minor portion of the whole.

Although the rocks of Florida may appear to indicate continuous sedimentation there is good evidence that deposition has at times been interrupted by periods when the land emerged from beneath the sea and was subjected to erosion. During these periods the action of air and water removed part of the materials already deposited and left an uneven surface. When the land was again submerged beneath the sea other materials were deposited upon the eroded surface. Such breaks are known as unconformities.

The same forces which caused the land to rise above sea level sometimes operated to produce a slight compression of the strata. In this manner the peninsula was raised in the form of a broad arch several hundred feet above the floor of the deep sea. This fact is not readily apparent, because the land surface represents only the higher portion of the arch. Minor folds of the strata are also known in Florida, but they are mostly inconspicuous and are recognized with difficulty.

\section{GENERAL SUCCESSION OF FORMATIONS.}

The time that has elapsed since the oldest known rocks were formed in the New World is so long that any attempt to estimate its duration in years would be futile. The rocks deposited during that time have been divided into several systems, of which only 
the last two are represented in Florida. Of these two the most recent is known as the Quaternary and the one immediately preceding as the Tertiary. The rocks belonging to the Quaternary system are subdivided into two series, known as the Recent and the Pleistocene.

In Florida the Pleistocene began with an uplift that carried the surface higher above sea level than it is at the present day. This uplift was followed by an interval of extensive erosion, which was terminated by a sinking of sufficient extent to carry the lowlands beneath the sea. The degree of submergence varied. Later another emergence raised the surface of the State somewhat above its present altitude. This change in level is regarded as the closing event of the Pleistocene epoch. During the Recent epoch slight changes have occurred, none of them being of sufficient magnitude to be compared with the movements during the Pleistocene. During both the Pleistocene and the Recent epochs sand, peat, marl, and coquina accumulated over nearly the entire State.

The rocks belonging to the Tertiary system are commonly grouped into four series, of which the youngest is the Pliocene. The Pliocene of Florida has been subdivided into five formations which differ more or less from each other. They are known as the Lafayette (?) formation (Pliocene?), the Nashua and Caloosahatchee marls, the Alachua clay, and the Bone Valley gravel. The Lafayette (?) formation is commonly composed of red and yellow sands and sandy clays, which cap the hills and uplands of north Florida. The Nashua and Caloosahatchee marls consist of sands and marls which contain shells of marine organisms. The Alachua clay is commonly sandy and locally contains many bones of large land animals. The Bone Valley gravel is a phosphatic gravel, which is known as land-pebble phosphate. Subsequent to the preparation of this manuscript some evidence was obtained that seems to warrant the tentative inclusion of the Bone Valley gravel in the Miocene. Though these formations are described separately and are represented by three different colors on the geologic map (Pl. I in pocket), it is probable that all of them except the Bone Valley gravel are largely contemporaneous.

Next older than the Pliocene are rocks belonging to the Miocene series. These are divided into two formations, known as the Choctawhatchee marl and the Jacksonville formation, though probably deposited at about the same time. The former, which is a shell marl, is well exposed in north and west Florida; and the latter consists of limestone, clay, and sand, known chiefly from well records at Jacksonville and farther south along the east coast.

The oldest rocks known in Florida belong to the Oligocene series. They comprise several formations arranged in two groups, known as the Apalachicola group and the Vicksburg group. Of these groups, 
the younger (Apalachicola) contains four formations-Alum Bluff, Chattahoochee, Hawthorn, ${ }^{1}$ and Tampa. The Alum Bluff formation is the youngest, but the other three are believed to be largely contemporaneous. The Alum Bluff formation comprises the typical sands and clays which characterize the formation along Apalachicola River and elsewhere, together with the Chipola marl, Oak Grove sand, and Shoal River marl members. The Vicksburg group includes three formations, known as the Ocala limestone, "Peninsular" limestone, and Marianna limestone. The limestones of the Vicksburg group are especially important because they underlie the entire State, and furnish the artesian water in all the large areas where flowing wells are obtained. They are exposed in many of the building-stone quarries and phosphate mines. The rocks belonging to the oldest epoch of the Tertiary (Eocene) are not exposed in Florida, but they occur at the surface in the adjoining States and they doubtless underlie the limestones of the Vicksburg group.

The following table shows the general succession and character of the geologic formations of Florida.

1 The name of this formation is printed on the map (P1. I) as Hawthorne, the spelling used in some previously published reports, but as the geographic name from which it is derived is spelled Hawthorn, the final e has been dropped in the text. 


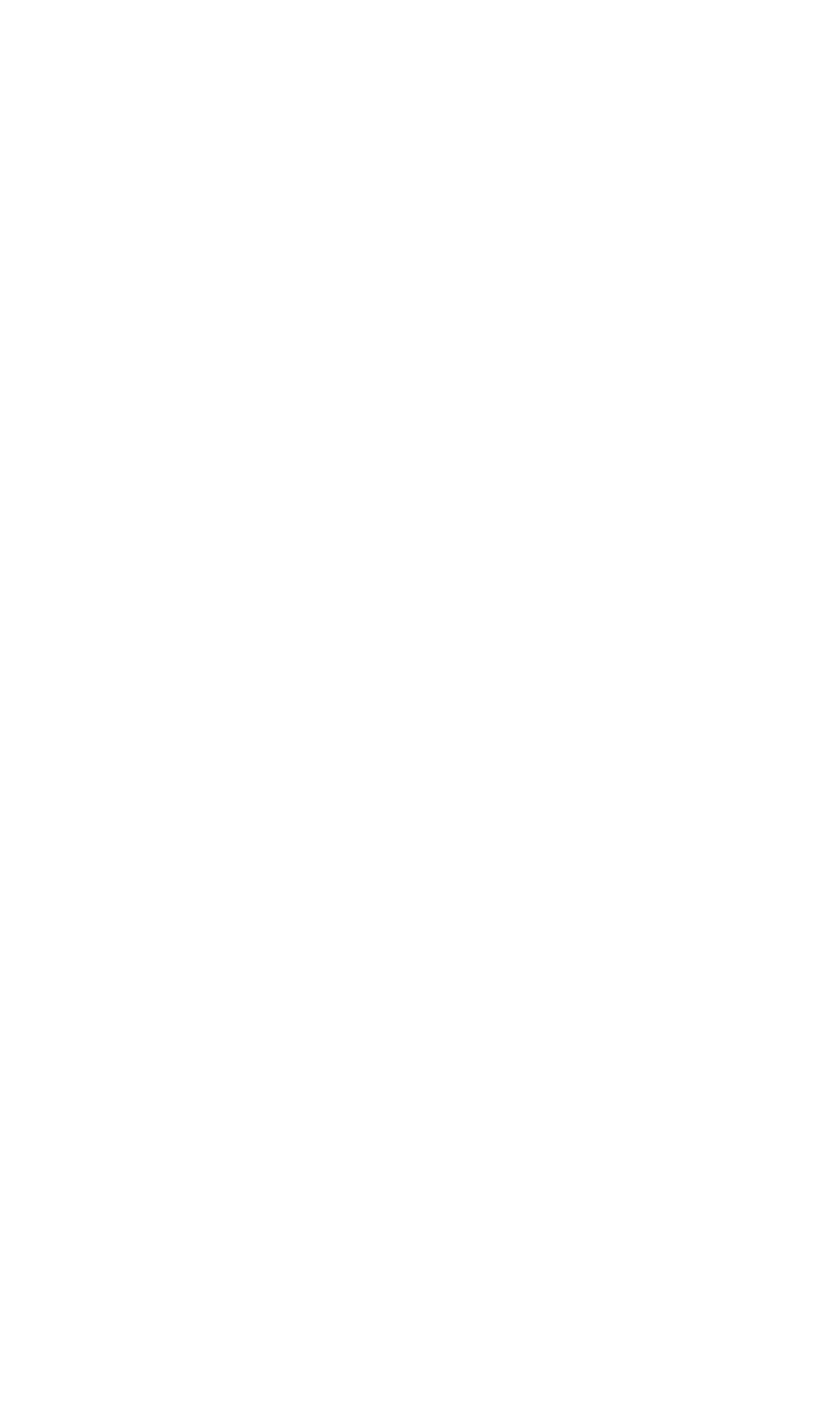


GEOLOGY OF NORTHERN AND CENTRAL FLORTDA.

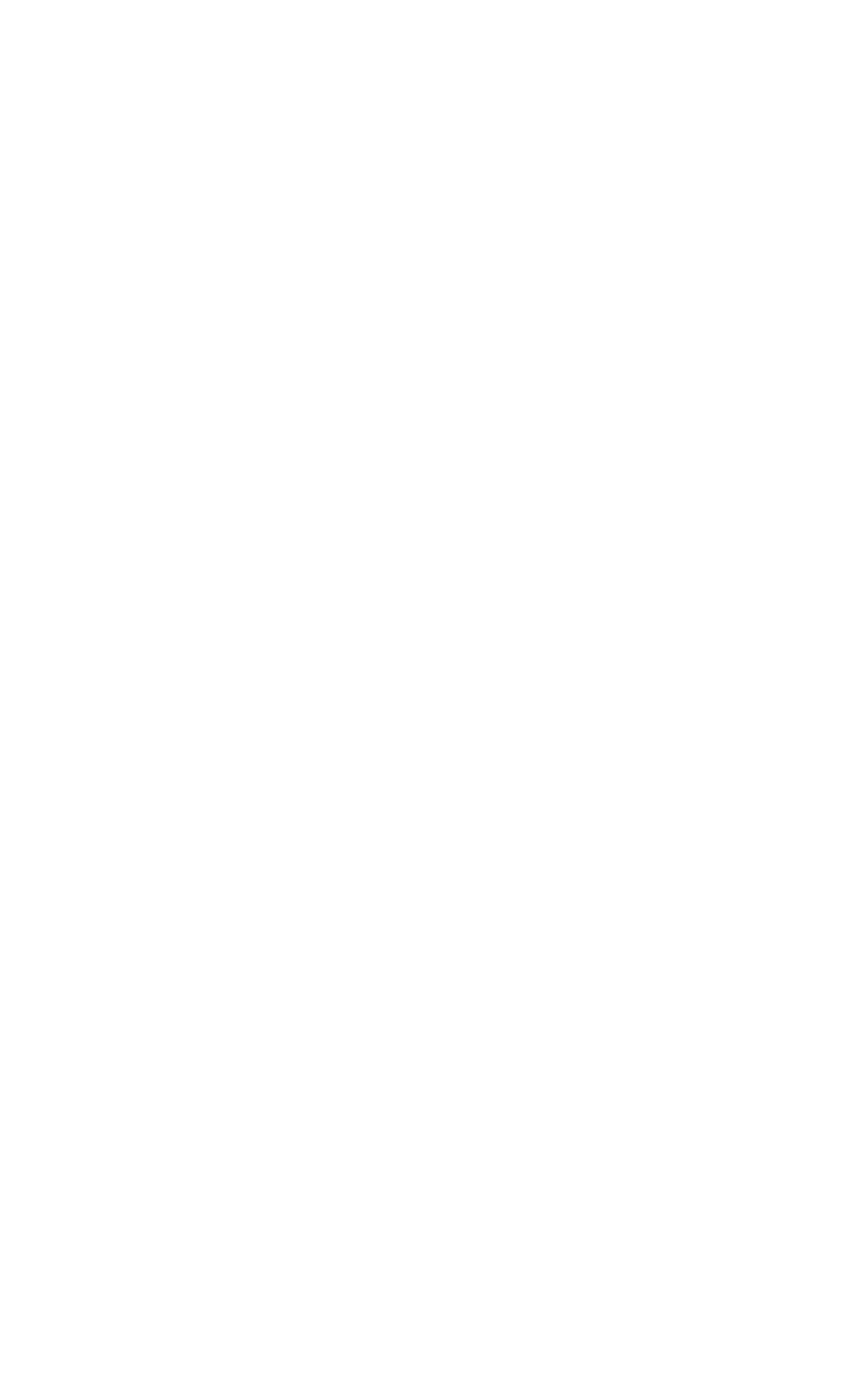




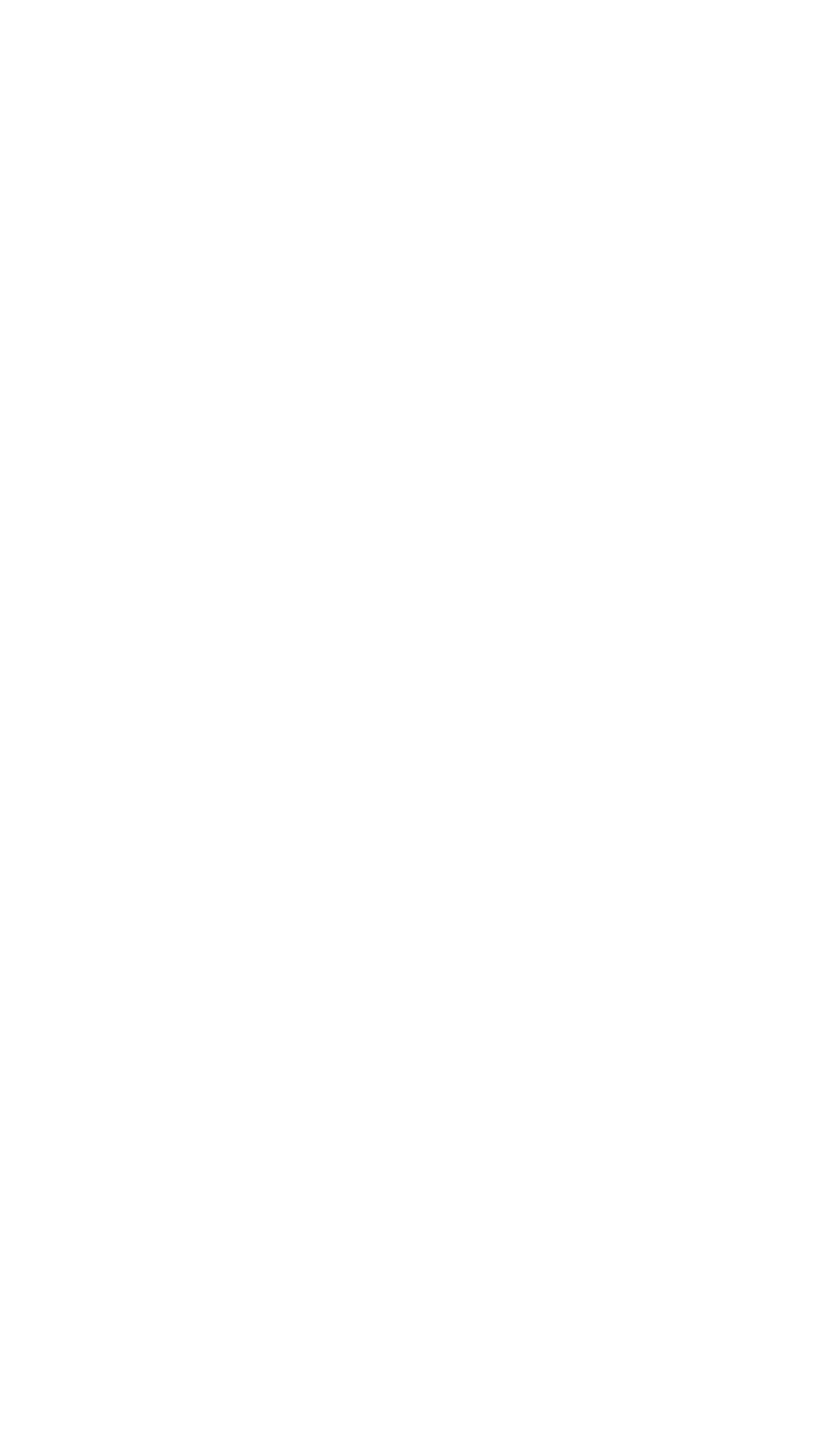


TERTIARY SYSTEM.

OLIGOCENE SERIES.

SUBDIVISIONS.

The Oligocene rocks may be separated into two groups, called here the Vicksburg group and the Apalachicola group. These two groups were formerly regarded as Eocene and Miocene, respectively. As early as 1846 Conrad $^{1}$ referred the rocks exposed at Ballast Point near Tampa, together with the prevalent rock of the peninsula, to the upper division of the Eocene; and for many years the rocks here included in the Vicksburg group continued to be called Eocene by numerous writers, including Bailey, ${ }^{2}$ Tuomey, ${ }^{3}$ Smith, ${ }^{4}$ and Dall. ${ }^{5}$ The deposits here called Apalachicola group were first differentiated from the Vicksburg in 1887, when Langdon ${ }^{6}$ examined the Oligocene beds of Apalachicola River and reported that they were Miocene. This name was retained for some time but it was modified by the use of "old Miocene" or "subtropical Miocene" to distinguish it from the later Miocene. In 1896 Dall ${ }^{7}$ published a brief statement of the reason for regarding the so-called Eocene and the so-called "old Miocene" of Florida as Oligocene; and this designation has since been followed in many but not in all publications dealing with southern Coastal Plain geology.

\section{VICKSBURG GROUP.}

NOMENCLATURE.

After the setting apart of the "old Miocene," there remained a considerable thickness of rock which was still regarded as Eocene and was known as the Vicksburg limestone. ${ }^{8}$ This name ${ }^{9}$ had been used to include all the older Tertiary rocks of the peninsula, comprising both the Vicksburgian limestones and the deposits here called Apalachicola group, but with the increase of knowledge of the geology of the State it was gradually restricted to the older limestones. Subsequent study indicated that this group of older limestones, though presenting but slight lithologic variation, was divisible on paleontologic grounds into two parts, the lower division (here

1 Conrad, T. A., Observations on the geology of a part of east Florida, with a catalogue of recent shells of the coast: Am. Jour. Sci., 2 d ser., vol. 2, 1846, pp. 36-48.

2 Bailey, J. W., Am. Jour. Sci., 2d ser., vol. 10, 1849, p. 282.

3 Tuomey, M., A notice of the geology of the Florida keys: Am. Jour. Sci., 2d ser., vol. 11, 1850, pp. 390 et seq.

1 Smith, E. A., On the geology of Florida: Am. Jour. Sci., 3d ser., vol. 21, 1881, pp. 292-309.

5 Dall, W. H., and Harris, G. D., Correlation papers-Neocene: Bull. U. S. Geol. Survey No. 84, 1892, pp. 101-105.

- Langdon, Daniel, jr., Some Florida Miocene: Am. Jour. Sci., 3d ser., vol. 38, 1889, pp. 322-324.

7 Dall, W. H., Descriptions of Tertiary fossils from the Antillean region: Proc. U. S. Nat. Mus., vol. 19, No. 1110,1896 , pp. 303-305.

8 Bull. U. S. Geol. Survey No. 84, 1893, pp. 101-104.

9 Srcith, E. A., On the geology of Florida: Am. Jour. Sci., 3d ser., vol. 21, 1881, pp. 292-309. 
called "Peninsular" limestone) being designated the "Vicksburg" limestone and the upper the Ocala limestone. Still later, Dall ${ }^{1}$ proposed the abandonment of the name Vicksburg as applied to limestones of the peninsula of Florida and the substitution of the term "Peninsular" for the lower division above described. He states:

From the observations on the typical Vicksburgian by Col. Casey it seems probable that the Orbitoidal limestone which forms the mass of the Floridian Plateau, and which has been, in this work and in the literature generally, called the Vicksburg limestone, may really form a different horizon altogether from the typical Vicksburgian and be intermediate between the latter and the nummulitic Ocala limestone. In order to promote clearness and avoid confusion, it is probably advisable to adopt a distinct name for the Orbitoidal phase or formation, for which I would suggest the term Peninsular limestone. This is intended not as a permanent formation name but as a general term for the fundamental plateau limestone of Florida, in which a close and thorough study may result in the discrimination of more than one horizon or zone.

The reason for the change suggested by Dall is the fact that the fossils which have been regarded as characteristic of the Vicksburg have been found to occur at other horizons, and hence their occurrence in the limestones which underlie the nummulitic rock of the peninsula can not be regarded as proof of equivalence of that limestone with the limestone at the type locality at Vicksburg, Miss. The question of the correlation of the Florida formations is further complicated by the fact that two horizons are represented in the bluff at Vicksburg. To avoid further confusion, however, the lower Oligocene rocks in Florida, originally known as the Vicksburg limestone, are here designated the Vicksburg group. The group is thought to comprise three formations, here called the Ocala limestone, the "Peninsular" limestone, and the Marianna limestone.

The "Peninsular" and Ocala limestones were recognized by Dall; and the name Marianna limestone was later given ${ }^{2}$ to the soft, porous, light-gray to white limestones of western Florida, which are characterized by an abundance of Orbitoides mantelli and other Foraminifera and many other fossils, prominent among which are Pecten poulsoni and $P$. perplanus. At the type locality (Marianna, Jackson County) this limestone is so soft that it can be cut into blocks with a saw. It contains some beds of chert and many of the fossils are silicified. Lithologically the rock at Marianna resembles the Ocala limestone at Ocala and the "Peninsular" limestone; but it differs from the former in the character of its fauna, especially in the absence of nummulites, and it is believed that it may represent a horizon below the "Peninsular" limestone of Dall. The close litho-

1 Trans. Wagner Free Inst. Sci., vol. 3, pt. 6, 1903, p. 1554.

2 Matson, G. C., and Clapp, F. G., Second Ann. Rept. Florida Geol. Survey, 1909, p. 52. 
logic resemblance between the Marianna limestone and the "Peninsular" limestone, however, makes it possible to combine much of the discussion concerning these two formations.

MARIANNA AND "PENINSULAR" LIMESTONES.

Stratigraphic position.-The base of the "Peninsular" limestone is not exposed in Florida and there is no satisfactory evidence that it has been reached in drilling wells; hence the character of the subjacent formation is not known. Reference has already been made to the uncertainty concerning the exact correlation of the "Peninsular" limestone of Florida. It will thus be seen that no satisfactory conclusions can be drawn concerning the relation which the "Peninsular" limestone bears to the underlying beds. Its relation to the overlying formations will be discussed in connection with those formations.

The Marianna limestone is thought to be the stratigraphic equivalent of the upper part of the bluff at Vicksburg, Miss. Some wells in west Florida enter beds of sand and clay that probably represent older formations, but the stratigraphic relation of the Marianna to these older beds can not be determined. In west Florida, where this formation is recognized, it is unconformably overlain by beds belonging to the Apalachicola group or by post-Pliocene formations.

Lithologic character.-The Marianna and the "Peninsular" formations consist of soft, porous, white or light-gray limestones, in some places resembling marl, especially when partly decomposed. Some bands of darker-colored dense limestone are reported in wells, and nodules and layers of chert are common; chert beds are especially prominent at certain horizons. For the most part the cherty beds are darker in color than the limestone and range in thickness from a fraction of an inch to 15 feet. In some localities as many as six or seven successive beds of chert have been encountered in a single well, the heavier layers being, in general, the more persistent. It is usually chert which forms a nearly. water-tight cap to the artesian water beds in these formations. Certain beds are abundantly fossiliferous, containing innumerable specimens of Orbitoides and shells of mollusks, such as Pecten poulsoni. At several localities the rock is so soft that it can be cut into blocks with a saw. On exposure to the weather these blocks harden rapidly, making a building stone of very fair quality. Beds of sand, some of them 10 feet or more in thickness, are reported in some of the wells that penetrate this formation. In general these sand beds appear to be most numerous in the northwestern part of the State, but even there they are a minor part of the formation.

Thickness.-The thickness of the "Peninsular" limestone and the Marianna limestone appears to be exceedingly variable. The 
thickness given by Foerste, ${ }^{1}$ from his investigations in southwestern Georgia and the adjacent part of Florida, is 220 feet, and probably this should be regarded as the approximate measure of the Marianna. The thickness of the Vicksburg group is reported by Dall ${ }^{2}$ to be 140 feet at Salt Mountain, Ala., and, on the basis of well borings, is estimated by the same writer to be over 350 feet at Gainesville, 212 feet at Lake Worth, and 1,068 feet at St. Augustine. From recent examinations of well borings by Vaughan and Bassler limestone of Vicksburg age is known to have a thickness of over 225 feet at Quincy, 250 feet at Alachua, and 325 feet at Bartow; apparently it thickens markedly southward from its exposures in Georgia and Alabama. It is hard to estimate just how much reliance can be placed on well records, because the drill may penetrate some distance into a formation before characteristic fossils are obtained, and it is possible for fossils to drop from the side of the bore and thus continue to appear in the drillings far below the base of the formation to which they belong. Of all the estimates given above the one at Gainesville is probably the most reliable, because the well is said to be cased to the bottom.

Physiographic expression.-The "Peninsular" limestone and the Marianna limestone are characterized by a topography due to solution and marked by numerous underground streams, natural bridges, sink holes, and large irregular depressions. That the underground streams in these formations attain considerable size is shown by a number of large springs which emerge apparently from definite channels. The most noted natural bridge of the Marianna limestone is on Chipola River near Marianna; but there are many others of smaller size, both in this formation and in the "Peninsular" limestone. Wherever the limestone lies near the surface, rounded hills and sink holes characterize the topography; the sinks form many lake basins in the central part of the peninsula.

Paleontologic character.-Both the "Peninsular" limestone and the Marianna limestone are characterized by an abundant fauna, the most prominent fossil being Orbitoides mantelli, with which is associated Pecten poulsoni and $P$. perplanus. Dall ${ }^{3}$ says that the fauna of the "Peninsular" limestone includes about 222 species, of which 102 are restricted to it. With the imperfectly known fauna of the Ocala limestone it has 15 species in common; 9 species continue into the "silex bed" and limestone of the Tampa formation, and 2 continue into the Miocene and down to the Recent fauna.

Structure.-The "Peninsular" limestone and the Marianna limestone have been affected by the earth movements which have pro-

\footnotetext{
1 Foerste, A. F., Am. Jour. Sci., 3d ser., vol. 48, 1890, p. 46.

2 Bull. U. S. Geol. Survey No. 84, 1892, p. 103.

a Trans. Wagner Free Inst. Sci., vol. 3, pt. 6, 1903, pp. 1553.
} 
duced the present structure of the State. Their major structural feature consists of a broad anticline. The dips are low and are generally seaward. Local variations in altitude of the surface of these limestones are so pronounced as to suggest that there has been considerable local warping as well as a general arching. Toward the southern end of the State the "Peninsular" limestone dips southward beneath the Everglades, where it is probably buried under some hundreds of feet of younger sediments. Along the east coast this formation shows marked variations in depth; nowhere, however, does it rise to withm less than $\mathbf{1 7 5}$ feet of the surface, and at Jacksonville it lies at least 525 feet below the surface.

At Tampa, on the west coast, the "Peninsular" limestone probably lies somewhat more than 100 feet below the surface, but farther north along the coast it may be exposed. Apparently the dip of the Marianna limestone toward the southwest in the long western extension of the State is very rapid, for at Pensacola this limestone is buried more than 1,100 feet beneath younger sediments.

Areal distribution.-As early as 1849 limestone of Vicksburg age was noted by J. W. Bailey, who obtained some "Orbitulites" from a chert at Pyles plantation, about 40 miles west of Palatka. The locality where these specimens were obtained is only a few miles south of Ocala. The same writer mentions the occurrence of similar rock at several points between Palatka and Tampa, but in no case does he give the exact localities.

While collecting statistics for the Tenth Census, Smith ${ }^{2}$ gathered much valuable information relating to the geology of Florida. $\mathrm{He}$ presented evidence to show that limestone of Vicksburg age underlies nearly the entire peninsula of Florida, giving in part its areal outcrop and noting the occurrence of Orbitoides mantelli, Pecten poulsoni, and other characteristic fossils in exposures of the limestone here called Marianna a few miles southeast of Campbellton, at the Big Spring, east of Marianna, and at other localities which he does not name. From a limestone collected by him 6 miles from St. Marks, in Wakulla County, Heilprin identified Orbitoides mantelli, and pronounced the rock to be Vicksburg; but the rock at St. Marks belongs to the Apalachicola group instead of to the Vicksburg group. Smith examined a marl which occurs at various points along the Gulf coast and decided that it also was of Vicksburg age. He states that it forms the basis of the "gulf hammock" land in the coastal counties from Wakulla County nearly to Tampa Bay in Hillsborough County. In describing the areal extent of the Vicksburg, Smith included in it large areas of rock which are now known to belong to the upper Oligocene or Apalachicola group; for example, the lime-

1 Bailey, J. W., Am. Jour. Sci., 2d ser., vol. 2, 1851, p. 86.

'Smith, E. A., On the geology of Florida: Am. Jour. Sci., 3d ser., vol. 21, 1881, pp. 292-309. 
stone extending along Suwannee River for many miles and the limestone at Tampa. He called attention to the fact that the limestones of the Vicksburg group prevail in the vicinity of Gainesville and that in many places they are composed largely of Orbitoides mantelli. Other localities included in the Vicksburg were Paynes Prairie and Ocala.

In addition to the localities mentioned above, Smith reports limestone of Vicksburg age at Live Oak and Lake City, in the northern part of the peninsula. At these localities, as in many other parts of the peninsula, the formation is overlain by a few feet of younger rock. Dall ${ }^{1}$ gives the following summary of localities where the Vicksburg has been observed:

It is impracticable with the data yet printed to determine exactly at how many of Smith's localities the country rock belongs to the Orbitoides horizon. Some of them, doubtless, will eventually be shown to be of later age, as will be indicated later in this summary. Only those where no doubt seems to exist will be specified here. In Alachua County it is widespread, having been observed by Smith and Dall at Gainesville and westward to and about Archer, though in many places overlain by solutionary residuum, remnants, or even beds of later age but moderate thickness. It had been identified at Silver Spring, 6 miles east from Ocala, by Le Conte, as early as 1861, ${ }^{2}$ and subsequently the observation has been confirmed by Smith. Specimens of this rock have been collected by Willcox at Martin station, Marion County, about 8 miles north of Ocala, where the rock is very cherty; and at Jarves's spring, on the southern border of Pasco County; at Fort Foster, on the North Fork of the Hillsboro River, where, as in many other places, relics of the old Miocene beds overlie it. Several of the localities referred to by Heilprin must remain for the present on the doubtful list, but among them should hardly be counted the islet at the mouth of Homosassa River, from which Mr. Willcox obtained the Pygorhynchus (Ravenelia) gouldii Bouvé, a small echinoderm originally described from the buhrstone (ante-Claibornian) of Georgia.

It will be seen from this quotation that later investigations indicate that the limestone at some of the localities mentioned by Smith is not of Vicksburg age. However, this should not be regarded as detracting from the value of the earlier work, for with the increase of knowledge it is inevitable that formation lines should be shifted and that new formations should be discriminated.

Miss Maury's ${ }^{3}$ summary of the Vicksburg indicates that it forms a large part of the country rock in north-central Florida, and she cites many of the localities mentioned by Dall and Bailey. She mentions especially the exposures seen in the vicinity of Gainesville, which are surrounded by rocks belonging to the division here called Apalachicola group. Attention is also called to the occurrence of gypsum, which is regarded as the result of the action of sulphur on calcium carbonate, and the occurrence of phosphate rock, resulting from an analogous chemical action.

1 Bull. U. S. Geol. Survey No. 84, 1892, pp. 102-103.

2 Am. Jour. Sci., 2d ser., vol. 21, 1861, pp. 1-12.

8 Maury, C. J., The Oligocene of western Europe and southern United States: Bull. No. 15 Am. Paleontology, vol. 3, 1902, pp. 45-46. 
During the progress of recent field work the occurrence of the Marianna limestone was noted at Natural Bridge, in north-central Walton County, but there is no indication that it reaches the surface west of this county; indeed, from well records and exposures of other formations, there is every reason to believe that in Escambia and Santa Rosa counties this formation lies some hundreds of feet below the surface of the upland.

East of Marianna the formation is exposed at several localities where it presents considerable variation in its lithologic characteristics. At some of these localities it is a soft porous white limestone, and at others it is a tough dense gray limestone. However, some of this difference in texture may be accounted for by the fact that the rock hardens on exposure to the air, and it is perhaps significant that the hard gray limestone is usually seen at natural exposures and the soft porous rock at quarries.

Near the east edge of the town of Marianna a small exposure affords the following section:

Section No. 1, near east edge of Marianna.

Lafayette (?) formation: $\quad$ Feet.

Clay, red, sandy; some beds of sand and gravel............... 25

Marianna limestone:

Clay, white, marly............................... 5

Limestone, hard, earthy, gray $\ldots \ldots \ldots \ldots \ldots \ldots \ldots \ldots \ldots \ldots .2$

Marl, blue, with many Pectens........................... 8

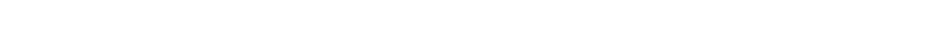

Section No. 2 (approximately 20 feet below section No. 1).

Limestone, hard, gray, very fossiliferous; contains Orbitoides man- Feet. telli, Pecten poulsoni, etc........................... $\quad 5$

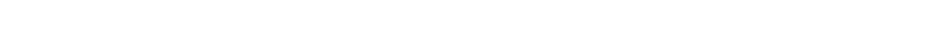

Limestone, soft, porous, white; a few Orbitoides and other fossils... $\quad 30$

The white limestone of this section is exposed in a quarry, where it is obtained by sawing. It is used locally for building, especially in the construction of chimneys. Upon exposure to the weather the rock hardens until it resembles the hard member at the top of the section.

A well drilled at Marianna penetrated limestone, marl, and clay to the depth of 265 feet, where a bed of quicksand was encountered. An incomplete log of this well is given below.

Log of well at Marianna.

\begin{tabular}{|c|c|c|}
\hline & Thickness. & Depth. \\
\hline $\begin{array}{l}\text { Sand and sandy loom (Pleistocene) } \\
\text { Clay, red and yellow, sandy, and sand (Lafayette(?) } \ldots \ldots \ldots \ldots \ldots \ldots \ldots \ldots \ldots \ldots \ldots \ldots \ldots \ldots \ldots \\
\text { Limestone, hard, and marl, alternating beds; doubtless includes section No. } 1 \text { at the }\end{array}$ & $\begin{array}{l}\text { Feet. } \\
{ }_{20}^{1 \frac{1}{2}}\end{array}$ & $\begin{aligned} \text { Feet. } & \text {. } \\
21 \frac{1}{2} & \end{aligned}$ \\
\hline 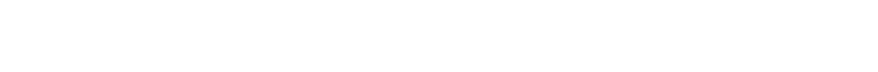 & $\begin{array}{r}45 \\
200\end{array}$ & \\
\hline
\end{tabular}


The log of this well does not afford any means of judging at what depth the base of the Marianna limestone was reached, but it is possible that an underlying formation was entered some distance above the bottom of the well.

At a locality $2 \frac{1}{2}$ miles southeast of Chipley, the Marianna limestone outcrops in the edge of a sink, and about 6 miles southwest of Chipley and 1 mile north of Duncan it is exposed in some small quarries where it had been obtained for building stone. At one of these quarries, belonging to F. G. Owens, the rock has also been burned for lime, which was reported to be of good quality. This quarry shows about 20 feet of porous white limestone, resembling the rock in section No. 2 at Marianna. Near the surface it is very hard and durable, but at greater depths it is much softer.

Fossils occur throughout the section, but they are especially numerous in the upper 5 feet, where the rock appears to be largely composed of Orbitoides mantelli. A well-defined ridge at the quarry appears to consist of the Marianna limestone covered by a few feet of white Pleistocene sand and sandy loam, the presence of the Marianna being indicated by numerous bowlders containing characteristic organic remains.

A few miles northeast of Duncan, at Falling Water, a large sink exposes several feet of light-gray limestone, probably belonging to the Marianna. At this locality there appears to be a well-defined system of underground drainage, which is indicated at the surface by numerous sink holes. The best exposure is seen where a small stream plunges into one of these sink holes with a reported fall of over 70 feet. The rock, however, forms a nearly perpendicular cliff and is not easily accessible.

At Natural Bridge, near the north line of Walton County, a lightgray to yellowish-gray marl forms the arch which spans a small stream. The width of the channel is probably 20 feet and the length of the bridge about one-fifth mile. The height of the exposure above the level of the water in the creek was estimated by Vaughan ${ }^{1}$ to be 35 to 40 feet. When fresh the rock is soft and crumbles readily in the fingers, but when exposed to the weather it hardens rapidly and assumes the yellowish color mentioned above. It is quarried by sawing, and is locally known as "chimney rock," because it is used in the construction of chimneys. A considerable percentage of clay, which occurs in fine particles distributed through the rock, indicates that the material is a marl rather than a limestone. Pecten poulsoni is the most abundant fossil. From the lithologic character of the rock, together with the occurrence of numerous specimens of the species mentioned above, the rock is considered to belong to the Marianna limestone. 
A quarter of a mile south of Natural Bridge, near a turpentine still, a similar marl outcrops in the bed of a small stream with a thickness of about 20 feet. This rock is slightly more compact than that described above and has a distinctly grayish or bluish color. These differences, however, are probably due to the fact that it has not suffered so much weathering as the rock at the Natural Bridge, and its substantial equivalence with the latter can hardly be questioned. Numerous concretions of nearly pure carbonate of lime are scattered throughout this marl, but they do not appear to have any relation to the occurrence of the fossils.

About 7 miles southwest of Marianna and nearly 1 mile from Kynesville, a number of fragments of limestone were obtained from a field, where they were said to have been turned up by the plow. They represent a very cherty phase of the Marianna limestone and are probably residual products of weathering. They consist of bowlders up to 2 or 3 feet in diameter, which contain innumerable specimens of Orbitoides mantelli and Pecten poulsoni.

At the phosphate mines in the vicinity of Croom, where a number of specimens of Orbitoides mantelli were collected, the rock has the lithologic characteristics of the "Peninsular" limestone. The collection was made from bowlders dredged from a mine, and it is difficult to decide whether it is "Peninsular" or Ocala limestone. The presence of a number of specimens of Cassidulus suggests that limestone belonging to the Apalachicola group is also represented. In the absence of characteristic Nummulites in the collections, it appears not unlikely that the limestones of the Apalachicola group may here rest upon the "Peninsular" limestone. However, this conclusion is made subject to revision in case future collections from this locality should reveal the presence of fossils belonging to the Ocala limestone.

The "Peninsular" limestone is known to outcrop throughout the central part of the peninsula, where it may be observed in numerous natural and artificial exposures. It has been encountered in many of the hard rock phosphate mines from Croom northward nearly to the north line of the State. It is also known to underlie a large part of the central lake basin of the peninsula, and it is encountered in wells along the east coast from Fernandina southward to beyond Palm Beach and along the west coast south of Tampa.

OCALA LIMESTONE.

Nomenclature.-The Ocala limestone was formerly regarded as part of the "Orbitoides limestone," but in 1882 Nummulites derived from waste products of the limestone were described by Heilprin." The specimens were obtained by Willcox from Chassahowitzka River,

1 Heilprin, Angelo, On the occurrence of nummulitic deposits in Florida and the association of Nummulites with a fresh-water fauna: Proc. Philadelphia Acad. Nat. Sci., 1882, pp. 189-193. 
and their association with fresh-water forms of recent shells was rightly interpreted to mean that the Nummulites had been transported from some other locality and redeposited with the younger shells. In 1884, Willcox ${ }^{1}$ announced the occurrence of the nummulitic rock in place some distance above the original locality on Chassahowitzka River, and Heilprin, in commenting on the announcement, stated that the beds belonged to the Oligocene.

The rock occurs at the old Confederate iron works in Levy County where it was given the name "Levyville formation" by Johnson," who described it as consisting of about 20 feet of soft porous building stone. He believed that it had been partly removed by erosion in the western part of the peninsula, where it is much thinner than farther east, but expressed doubt as to its having been deposited over the entire surface of the underlying "Peninsular" limestone.

Johnson mentioned several other localities where this formation was recognized, among them being Paynes Prairie. He reported that at a quarry on the Noonanville road near Santa Fe River the Neocene formations rested directly upon the "Peninsular" limestone, the nummulitic rock (Ocala limestone) being absent. Johnson's Levyville formation has usually been regarded as the substantial equivalent of the Ocala limestone; but it is not possible at present to verify the determination of the nummulites, and the rocks at Levyville may really belong to some other formation.

In subsequent publications by Heilprin this rock was called "Nummulitic" limestone, but in 1892 Dall $^{3}$ proposed the name Ocala limestone. He states:

Among the rocks which until recently were not discriminated from the Orbitoides limestone, and which appear in central Florida directly and conformably to overlie the latter, though no one has described their contact, is a yellowish friable rock containing many Foraminifera, conspicuous among which are two species of Nummulites, $N$. willcoxii and $N$. floridana $\mathrm{Hp}$. This rock was first brought to notice by Mr. Joseph Willcox, and to Prof. Heilprin we owe a description of it which discriminates between it and the Vicksburg or Orbitoides rock. The rock was early recognized as Eocene, though not discriminated from the earlier beds. It is best displayed at Ocala, Fla., where it forms the country rock, and has been quarried to a depth of 20 feet without coming to the bottom of the beds.

Stratigraphic position.-The Ocala limestone lies stratigraphically between the "Peninsular" limestone and the beds here designated the Apalachicola group. Lithologically, it bears a strong resemblance to the underlying "Peninsular" limestone, with which it also has close faunal relation. These facts have led to the conclusion that the two formations are conformable, and it has also been suggested that the Ocala limestone is a local phase of the "Peninsular" lime-

1 Science, new ser., vol. 3, 1884, p. 607 .

2 Johnson, L. C., Am. Jour. Sci., 3d ser., vol. 26, 1883, pp. 230-236.

Bull. U. S. Geol. Survey No. 84, 1892, pp. 103-104. 


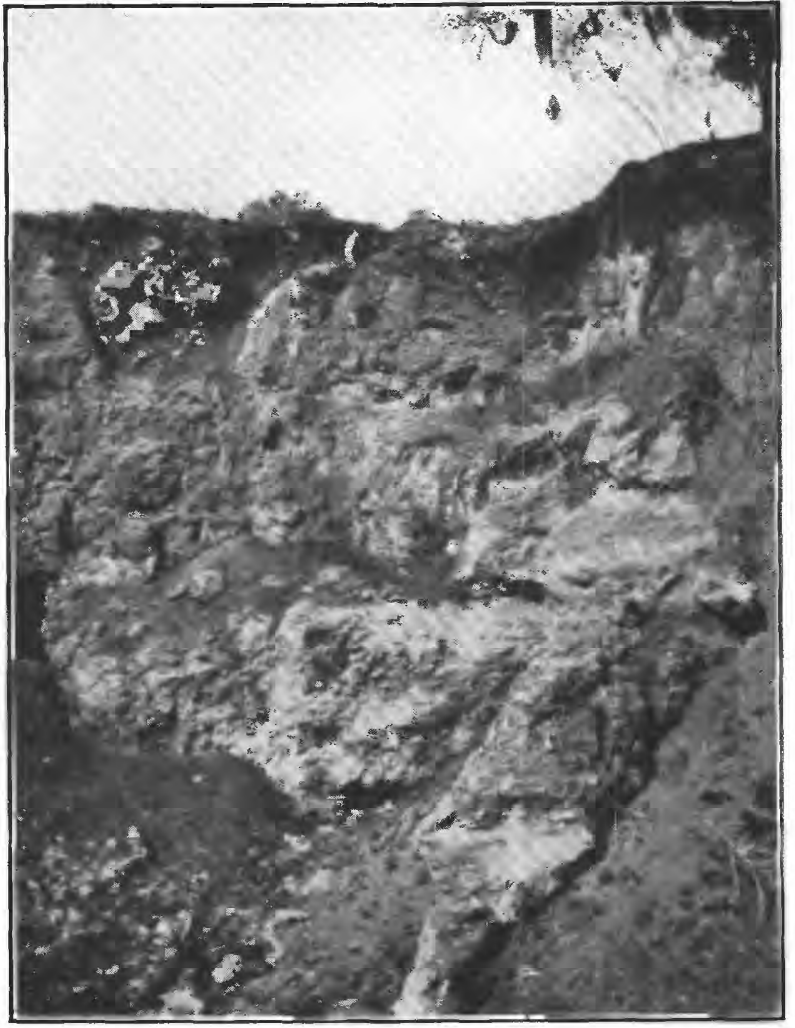

A. SECTION IN QUARRY OF OCALA LIME CO. AT OCALA.

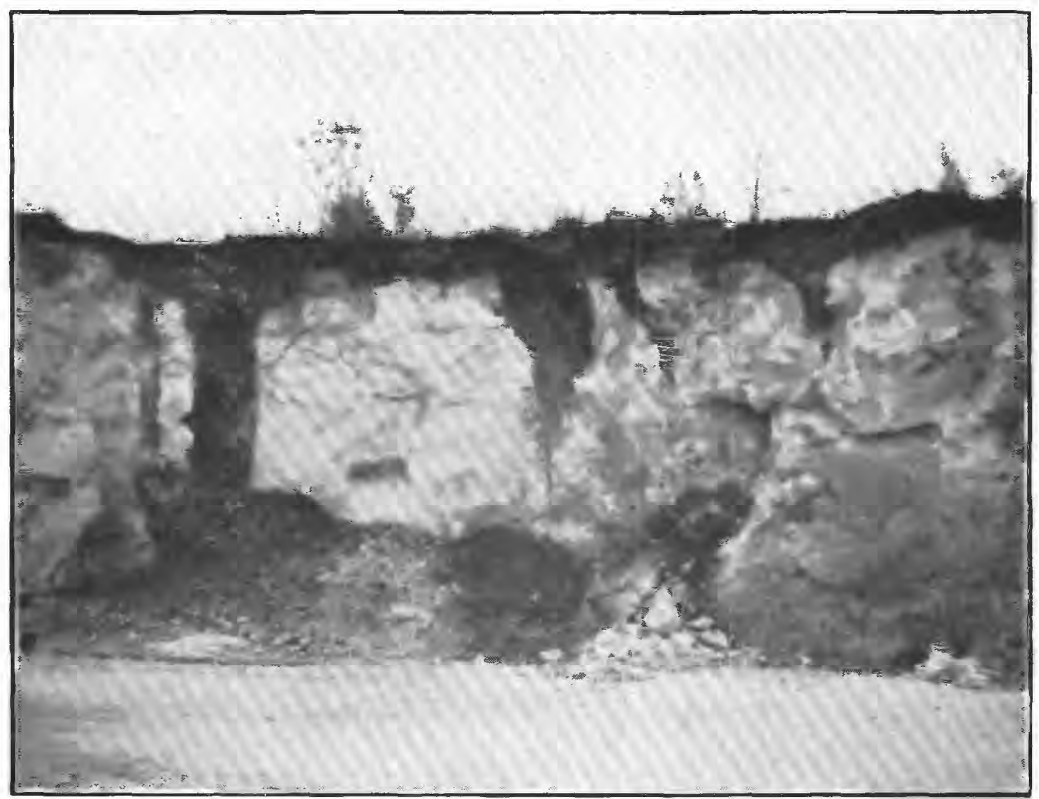

B. QUARRY OF OCALA LIME CO, (OLD PHILLIPS QUARRY) 1 MILE SOUTHEAST OF OCALA. 

stone. Although the two formations are probably conformable, the extensive distribution of the nummulites of the Ocala limestone shows that it represents a widespread change in conditions and is not to be classed as a mere local phase of the underlying beds.

The Ocala limestone, as already noted by Johnson, is in places wanting, so that the overlying formations rest directly upon the "Peninsular" limestone.

Lithologic character.-The Ocala limestone consists of a soft, porous, light-gray to white limestone which bears a strong lithologic resemblance to the underlying "Peninsular" limestone but is distinguished from it by the included fossils. When slightly weathered, the rock becomes light yellow, and owing to its granular appearance is often regarded as a sandstone. The removal of the calcareous material by the leaching action of underground water leaves a pale yellow, more or less incoherent sand, containing a small percentage of calcium carbonate. When fresh, the Ocala limestone is so soft that it is easily broken, but many exposed surfaces become hardened by the deposition of calcium carbonate by waters emerging along the outcrop. For this reason the rock locally appears to be hard and firm. Its porosity and ready solubility permit the formation of numerous underground channels which appear in some of the outcrops and are elsewhere inferred from the numerous sink holes. (See Pl. IX, B.) The rock contains an abundance of organic remains which are commonly preserved as casts. Nodules and large masses of chert are also common and in some localities a large part of the rock has been silicified. (See Pl. IX, A.)

Thickness.-No definite determination of the maximum thickness of the Ocala limestone has been made, and as yet no exposures have been observed which show the contact with the underlying "Peninsular" limestone. All the information now available indicates that the thickness is variable and that the variation is probably in considerable measure due to subsequent erosion rather than to the inequalities of deposition. Dall ${ }^{1}$ states that at the type locality the Ocala limestone has been quarried to a depth of 20 feet without reaching its contact with the underlying "Peninsular" limestone. The greatest thickness noted during the recent field investigation was in a sink hole near Ocala, in which the formation is exposed to a depth of about 40 feet without reaching its base.

Physiographic expression.-As in the case of the "Peninsular" limestone, the Ocala limestone is soft and porous and hence gives rise to a topography characterized by low hills, gentle slopes, sink holes, sinking streams, and natural bridges. This limestone has had an important influence in the development of many of the lake 
basins, and it forms the natural bridge over Santa Fe River near High Springs. In the central portion of the peninsula underground streams are common and many large springs emerge from the Ocala limestone.

Paleontologic character.-The Ocala limestone, like the underlying "Peninsular" limestone, is characterized by a great number of Foraminifera, but it differs from the latter in the presence of Nummulites. A few mollusks are said to be restricted to this formation, but as yet the fauna is very imperfectly known, and future study may add to the number of fossils known to be peculiar to it.

Structure.-The Ocala limestone shows the same stiuctural features as the underlying "Peninsular" limestone, both formations having doubtless been subjected to the same deformation since their deposition.

Areal distribution.-It was in 1882 that Joseph Willcox discovered a rock in the vicinity of Chassahowitzka River which he submitted to Heilprin ${ }^{1}$ for identification. The presence of Nummulites was regarded as an indication that a new formation had been discovered. In 1886 Heilprin ${ }^{2}$ added to the published list of localities where the nummulitic fauna was known to occur a spot near Arredonda, about 6 miles southwest of Gainesville, where Nummulites floridanus had been collected by G. A. Wetherby and Joseph Willcox.

In 1902, after summarizing the results of previous investigations, Dall ${ }^{3}$ mentions certain new localities of the Ocala limestone, as follows:

Since then Mr. Willcox has obtained the rock in place 15 miles northeast of the original locality, from the shore of Waccassassa Bay, near Cedar Keys, and also from the banks of Waccassassa River, Levy County; from a "sink hole" at Pemberton's ferry on Withlacoochee River, about 10 miles eastward from Brookville, and also at Bayport, Hernando County, and at various places about Ocala. Prof. Wetherby has also sent specimens from a well 5 miles southwest of Gainesville, Alachua County, and Mr. L. C. Johnson reports it from an old Confederate iron furnace, 3 miles north of Levyville, Levy County, where it is only 20 feet thick and is covered with a bed of bog iron ore, formerly worked. Pemberton's ferry is the most southern point at which it has been recognized at the surface, but at Bartow, Polk County, it occurs covered by about 6 feet of later strata.

From the character of its included organic remains the exposure at Martin station is regarded by Dall ${ }^{4}$ as equivalent to the Ocala limestone. At this locality the rock is more or less silicified and has been found useful for railroad ballast, road metal, and other purposes where durable material is needed.

The Ocala limestone is extensively exposed at the type locality, where it has been quarried for the construction of roads and the

\footnotetext{
1 Heilprin, Angelo, Proc. Philadelphia Acad. Nat. Sci., 1882, pp. 189-193. Abstract in Am. Jour. Sci, 3 d ser., vol. 24, 1882, p. 294 .

2 Heilprin, Angelo, Notes on the Tertiary geology and paleontology of the southern United States: Am. Jour. Sci., 3d ser., vol. 29,1885 , p. 69.

3 Bull. U. S. Geol. Survey No. 84, 1902, p. 104.

4 Trans. Wagner Free Inst. Sci., vol. 3, pt. 6, 1903, pp. 1156-1157.
} 
manufacture of lime. Some exposures are seen in the walls of sinks, and its presence may be inferred by the appearance of numerous bowlders containing Nummulites. These scattered fragments are frequently found resting upon surface sands and are mostly rather firmly cemented, probably by an accumulation of silica and iron. A thin deposit of sand, commonly found resting upon the uneven surface of the limestone, appears to be largely the result of disintegration of the country rock, and is therefore residual. The residual sands constitute the impurities of the original rock and may have formed only a small percentage of the whole.

Since the publication of Dall's report quarrying at Ocala has been carried to a somewhat greater depth. The quarry or the Ocala Lime Co., situated near the southwest corner of the city, now shows the following section:

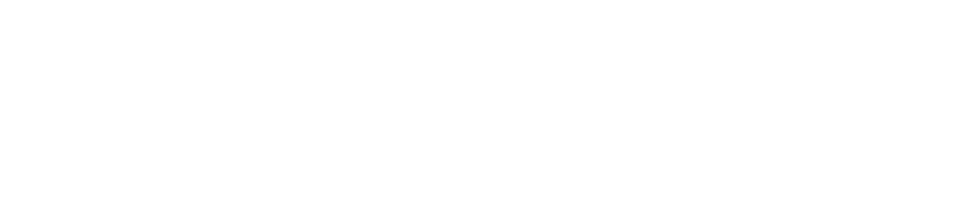

In this quarry the fossils occur throughout the greater portion of the limestone but are especially numerous near the top, where the removal of the calcium carbonate has loosened the casts of the organic remains. Chert nodules occur in various parts of the section, and in places two sets of vertical silicified bands were noted. These cherty bands are locally approximately at right angles to each other and probably represent planes of silicification along vertical joints.

A good section of this limestone is exposed in another quarry situated on the north side of the road to Silver Spring, about one-half mile east of the town. At this locality the rock, which is considerably decomposed, has been quarried to a depth of 40 feet and contains an abundance of Nummulites.

About 20 feet of Ocala limestone is exposed in a third quarry situated one-fourth mile north of Ocala, and about 15 feet of the same rock was seen in a quarry $2 \frac{1}{2}$ miles southwest of the city. One of the most important sections may be seen about 3 miles southwest of Ocala in a sink hole approximately 40 feet deep, which affords entrance to a small cavern which may be penetrated for a short distance. Clapp reports that Nummulites occur down to the base of this exposure but are not so numerous as at some of the other localities. Lithologically this rock is essentially the same as that exposed at the quarry of the Ocala Lime Co., and the section shows the maximum observed thickness of the formation.

$a$ Since this manuscript was prepared it has been learned that the vertebrate fossils from the Ocala mentioned on p. 143 were obtained from this sandy loam. 
A section at the old "Phillips" quarry, a mile southeast of Ocala, shows about 25 feet of soft, porous, light-gray limestone, which contains an abundance of chert disseminated throughout the section. As this rock contains many Nummulites, its identification as the Ocala limestone can scarcely be questioned. Solution cavities are common, and along certain vertical crevices the rock has been removed, forming passages 2 to 3 feet in width, which have been filled by the settling of the overlying sandy clay.

On Anclote River, about a mile from Tarpon Springs, an exposure extending some distance up the stream shows from 2 to 3 feet of Ocala limestone. The rock here lies near the surface over a considerable area, and bowlders containing Nummulites are common. A similar exposure of Ocala limestone was noted near Port Richey on Pithlachascotee River, where the rock is said to outcrop over a considerable area. At the mine of the Fort White Rock Phosphate Co., one-half mile southwest of the railroad station, the Ocala limestone is well exposed. In the north pit belonging to this company the following section was observed:

Section in quarry of Fort White Rock Phosphate Co., near Fort White.

Loam, light gray, sandy (Pleistocene) $\ldots \ldots \ldots \ldots \ldots \ldots \ldots \ldots \ldots \ldots$
Sand, fine, even grained, yellow (residual) $\ldots \ldots \ldots \ldots \ldots \ldots \ldots \ldots$
Limestone and phosphate rock (Ocala) $\ldots \ldots \ldots \ldots \ldots \ldots \ldots \ldots \ldots \ldots$

In this pit the Ocala limestone occurs in irregular ledges separating the phosphate rock, which appears to be in part the result of replacement of the Ocala. The limestone ledges commonly form two discontinuous series at approximately right angles to each other, the intervening space being occupied by the irregular bodies of phosphate rock. In general, the limestone bands thicken toward the base of the pit and the phosphate deposits become smaller. Both the limestone and phosphate are more or less cherty, but the silicification appears to be in the form of nodules and small bowlders rather than to constitute an extensive replacement. Fossils are very abundant in the limestone, prominent among them being the characteristic Nummulites of this formation. At the mine of the Cummer Lumber Co., 4 miles west of High Springs, the Ocala lies much nearer the surface, the total thickness of overlying sand being in few places greater than 10 feet. There is the same characteristic arrangement of the limestone and phosphate rock as at Fort White.

Similar relations between the Ocala limestone and the phosphate were observed at the mine of the Union Phosphate Co., 7 miles east of Newberry. The Alachua sink was visited by Clapp, who reports an exposure of about 10 feet of soft white limestone containing many flint nodules. From the collections made at this locality it is evident that the Ocala limestone forms part of the walls of the sink, 
and it also appears probable that the overlying Hawthorn formation is present. On the island opposite Melbourne, Sellards reports the occurrence of the Ocala limestone at a depth of 222 feet, basing this determination on a large fragment containing Nummulites, which was obtained in drilling a well; although the specimens were not specifically determined, the occurrence of the genus appears to warrant the correlation of the rock with the Ocala limestone. This is a point of special interest, because it shows the Ocala limestone to be nearer the surface in that part of the State than would have been inferred from previous publications.

The Ocala limestone is known to be well exposed at various points in the region where rock phosphate is being mined. Nummulites have been collected from various mines in the vicinity of Hernando, Citrus County. In a pit in sec. 10, T. 18 S., R. 19 E., a section was observed consisting of 2 to 3 feet of yellow sand, with phosphatic gravel and brown and yellow clays, and phosphatic white and gray sand, in places greenish, the whole underlain by phosphatic bluishgray clays, containing some hard sandstone with bowlders of hard rock phosphate containing Nummulites. The entire section probably represents altered and weathered phosphatic Ocala limestone.

Nummulites were also obtained by Eldridge from a stone quarry on the Burns place, $1 \frac{1}{2}$ miles southwest of Owensboro, Citrus County, and from Mr. Clement's mine No. 8, on the east side of Blue Springs, T. 16 S., R. 19 E.

"Miliolite limestone."-In 1887 Heilprin ${ }^{1}$ noted at Wheelers, on Homosassa River, the occurrence of a porous and cavernous limestone which he called "Miliolite limestone" because of the presence of many Foraminifera belonging to the Miliolidæ. Dall ${ }^{2}$ reports similar rock 6 miles southwest of Lake City; he thinks the "Miliolite limestone" belongs with the other foraminiferal limestones but does not express an opinion as to whether it belongs with the "Peninsular" or the Ocala limestone. The "Miliolite limestone" is here placed with the Vicksburg group and is tentatively referred to the Ocala limestone, to which it probably belongs.

APALACHICOLA GROUP.

NOMENCLATURE.

Prior to 1887 the rocks belonging to the subdivision of the Oligocene, here designated the Apalachicola group, from its exposures along Apalachicola River in western Florida, were included with the Eocene and were regarded as part of the Vicksburg. In 1887, however,

\footnotetext{
1 Heilprin, Angelo, Explorations on the west coast of Florida: Trans. Wagner Free Inst. Sci., vol. 1, 1887 , p. 57.

2 Dall, W. H., Bull. U. S. Geol. Survey No. 84, 1892, pp. 104-105.
} 
Langdon ${ }^{1}$ described beds occurring on Apalachicola River, referring them tentatively to the lower Miocene and designating them the Chattahoochee group. With the Miocene beds, Dall, ${ }^{2}$ in 1892 , included not only the Chattahoochee group of Langdon but the Hawthorn formation, the "Waldo formation," the "Tampa limestone," the "Tampa silex bed," the Chipola marl, the Alum Bluff formation, and certain sands, gravels, and clays which he did not specifically name.

The use of the name Miocene to designate the group here called Apalachicola continued for a number of years, the Oligocene beds being often called "old Miocene" or "subtropical Miocene," to distinguish them from the "new Miocene" or "cold-water Miocene." In 1896 Dall ${ }^{3}$ discussed the faunal reasons for regarding the "old Miocene" as Oligocene, and in his publications since that date he has restricted the term Miocene to later beds (here called Jacksonville formation and Choctawhatchee marl). However, the Chattahoochee formation is still included in the Miocene by both Smith ${ }^{4}$ and McCallie ${ }^{5}$ in their latest publications.

The Apalachicola group was formerly designated "upper Oligocene or Chipolan stage" "and "Chipola group," 7 but these names are abandoned because the name Chipola has been used to designate a marl belonging to the upper formation of the group.

The Apalachicola group includes a number of beds which differ widely in lithologic character but which are recognized by their fossils as integral parts of a single group. Limestones and marls predominate, but the group also includes beds of nearly pure sand and clay. The entire period of deposition appears to have been characterized by the accumulation of more or less terrigenous materials, rendering most of the limestones impure by admixture of clay and sand. At certain times the conditions appear to have been especially favorable for the development of organic life, and some members, such as the Chipola marl member of the Alum Bluff formation and the "silex bed" of the Tampa formation, contain very large faunas.

Owing to the lithologic variations and widely separated exposures, the exact correlation of the formations of the group is dependent on the organic remains they contain; and, although the paleontologic studies, especially those of Dall, have shed much light on the strati-

1 Langdon, D. W., jr., Some Florida Miocene: Am. Jour. Sci., 3d ser., vol. 38, 1889, pp. 322-324.

2 Bull. U. S. Geol. Survey No. 84, 1892, pp. 105-123.

. 3 Description of Tertiary fossils from the Antillean region: Proc. U. S. Nat. Mus., vol. 19, No. 1110, 1896, pp. 303-305.

4 Smith, E. A., The underground water resources of Alabama: Geol. Survey Alabama, 1907, p. 81.

- McCallie, S. W., Prelıminary report on the underground waters of Georgia: Geol. Survey Georgia, 1908, pp. 31 and 32.

6 Dall, W.H., A table of North American Tertiary horizons: Eighteenth Ann. Rept. U. S. Geol. Survey, pt. 2,1898, p. 334 .

${ }^{7}$ Foerste, A. H., Studies on the Chipola Miocene of Bainbridge, Ga., and of Alum Bluff, Fla.: Am. Jour. Sci., 3d ser., vol. 46, 1893, p. 244. 
graphic relations of the different beds, many points are as yet undecided. For this reason it seems best to retain the old names of certain formations and to indicate as far as possible their relationships. The Apalachicola group, therefore, is described as consisting of four formations, the Chattahoochee, the Hawthorn, the Tampa, and the Alum Bluff. There is some reason for believing that the first three are, in part at least, synchronous, but exact equivalence is difficult to determine where outcrops are widely scattered and faunal studies are incomplete. The Alum Bluff formation is clearly younger than the Chattahoochee formation, upon which it rests.

The name Chattahoochee group was first applied by Laingdon " to the beds occurring at a series of outcrops along Chattahoochee and Apalachicola rivers. The localities examined by Langdon extend from the final outcrops of the Vicksburgian, 9 miles by water above River Junction (Chattahoochee), to where the Oligocene outcrops give place to the overlying sands and marls of younger formations. The outcrops examined are at Alum Bluff, Rock Bluff, Ocheesee, and River Junction.

In 1893 the section along Apalachicola River was examined by Foerste, ${ }^{2}$ who recognized the presence of three dissimilar groups, to which he gave the names Chattahoochee, Chipola, and Chesapeake. His paper gives considerable attention to the character of the materials comprising his Chipola and Chesapeake groups, with a view to correlating them with the nonmarine deposits grouped under the name of "Grand Gulf and Lafayette formation." The major portion of the discussion, however, deals with the conditions of sedimentation during the deposition of the rocks belonging to the various groups.

In $1892 \mathrm{Dall}^{3}$ divided the formations here included in the Apalachicola group into two groups, retaining the name Chattahoochee group for the limestones and marls, which are extensively developed in the northern part of the State, and applying the name Tampa group to the beds which he called Chipola marl, Alum Bluff sands, Sopchoppy limestone, Tampa limestone, and Tampa silex bed. In his later paper on the Tertiary faunas of Florida, Dall places the "silex bed" at Tampa in his Chattahoochee group. The discovery of the characteristic species of the genus Orthaulax in the basal portion of the Chattahoochee formation led to this change in the correlation.

HAWTHORN FORMATION.

General character.-In 1892 Dall $^{\text {* }}$ described, under the name Hawthorne beds, some limestones, sands, and clays extensively exposed in the interior of Florida. These beds are here designated

1 Langdon, D. W., jr., Some Florida Miocene: Am. Jour. Sci., 3d ser., vol. 38, 1889, p. 322.

2 Foerste, A. H., op. cit., pp. 241-254.

3 Bull. U. S. Geol. Survey No. 84, 1892, pp. 105-123.

\& Bull. U. S. Geol. Survey No. 84, 1892, pp. 107 et seq. 
the Hawthorn formation. At the time of the publication of Dall's report, the Hawthorn formation was being quarried and had aroused considerable interest because of the presence of phosphoric acid in the rock. The formation consists of clays, sands, and phosphatic limestones and lies stratigraphically between the limestones of the Vicksburg group and the Alum Bluff formation. It is apparently the stratigraphic equivalent of the Chattahoochee formation but differs from it lithologically and is therefore given a separate name.

Stratigraphic position.-The stratigraphic relation of the Hawthorn formation to the underlying Vicksburg group has been observed at several localities in the interior of the peninsula. It is believed that the deposition of the Vicksburg group was followed by widespread emergence, which permitted extensive erosion and the formation of hills and valleys. There is no doubt that such emergence and consequent erosion affected the central part of the peninsula, where the Hawthorn formation is well exposed, for this formation rests unconformably upon either the Ocala or the "Peninsular" limestone. This relation is emphasized by the lithologic character of the beds, there being an abrupt change from the soft fine-grained limestones of the Vicksburg group to the clays, sands, and phosphatic limestones of the Hawthorn formation.

At numerous points in the peninsula of Florida the Hawthorn formation is found resting unconformably upon limestone of Vicksburg age, and in the vicinity of Hawthorn thin beds of conglomerate occur in the base of the group. At many of the phosphate mines in central Florida the limestones of the Hawthorn formation are found overlying either the Ocala limestone or the "Peninsular" limestone with an apparent unconformity which has permitted the deposition of sands and some limestone beds along channels developed in the upper surface of the Vicksburg formations. It should be said, however, that in many of these places the materials belonging to the Hawthorn formation appear to have been more or less disturbed since their deposition, and it is possible that at some localities the apparent unconformity may be due to the falling of the roof of caverns developed near the contact of the two formations.

The relation of the Hawthorn formation to the Alum Bluff formation has not yet been accurately determined, though, at $\mathrm{De}$ Leon Springs, Chipola fossils have been found in a marl overlying phosphate rock which belongs to this formation.

The relation of the Hawthorn to the other formations of the Apalachicola group is somewhat uncertain, but there is no doubt that its deposition was in part contemporaneous with the Tampa and Chattahoochee formations. In fact, although the absence of 
paleontologic information makes it impossible to correlate these formations on biologic grounds, there is no doubt that they were all deposited during an extensive submergence which succeeded the emergence of the rocks belonging to the Vicksburg group. On physical grounds, therefore, there is good reason for regarding these formations as synchronous.

Lithologic character.-At the request of Mr. Vaughan the type locality of the Hawthorn formation was recently visited by Sellards, who reports that the rock is no longer quarried. According to Sellards, the rock is a light-colored, soft, porous limestone. The original building-stone quarry near Grove Park station, about 3 miles west of Hawthorn, is badly overgrown, so that the thickness of the limestone can not be determined. At the old phosphate mine, which is at least a mile southwest of the stone quarry, the rock is a phosphatic conglomerate.

At many localities the limestones of the Hawthorn formation are silicified, forming bowlders and beds of chert. (See Pl. IX, p. 80.) This is a very common condition in the rock-phosphate region, where these limestones rest directly on those belonging to the Vicksburg group. (See Pl. X, p. 94.) Beneath the phosphatic limestones of the Hawthorn formation at some localities are beds of sand, sandstone, or gravel, which are underlain by several feet of clay. The sand beds contain iron oxide, which forms a coating on the grains of silica. The clays are greenish and locally are sufficiently calcareous to be called marls.

Thickness.-The thickness of the Hawthorn formation varies greatly, in places aggregating approximately 95 feet. The three members of this formation with their maximum observed thicknesses, according to Dall, ${ }^{1}$ consist of greenish clay 70 feet, ferruginous yellow sandstone 4 feet, and phosphate rock 20 feet. The maximum thickness of the Hawthorn formation, as given by the same author, is 125 feet. $^{2}$ However, over a large part of the peninsula, where the sole representative of the Hawthorn formation is the phosphatic or siliceous rock, the thickness is but a few feet.

Physiographic expression. - The Hawthorn formation in few places has much influence on the surface configuration of the region which it underlies. Locally, however, the cherty beds protect the underlying rock from erosion and thus give rise to ridges, and where the clays lie near the surface they are characterized by an erosion surface of moderate relief. Most of the chert-capped ridges are inconspicuous, but in some parts of the phosphate region they form distinct topographic features.

Paleontologic character. - The fauna of the Hawthorn formation has received but little attention and is practically unknown. The 
green clay and sands are reported to contain many thoroughly silicified oyster shells, and the phosphatic limestones and the chert beds are characterized by numerous specimens of an echinoid belonging to the genus Cassidulus. Molluscan remains are associated with this echinoid, but they have not yet been studied.

Structure.-The Hawthorn formation has been affected by the broad earth movements which produced the peninsula of Florida. It has a gentle seaward dip, noticeable in few single exposures but determinable by means of well records, which show that it sinks below sea level on the east coast. The strata probably incline both northward and southward from the central part of the peninsula, but the determination of the degree of dip requires more detailed study than has yet been made. The general easterly dips are known to be irregular in amount but probably do not average as much as 75 feet to the mile, and the dips in other directions may be less steep.

Areal distribution.-Although the Hawthorn formation is well known, detailed sections are comparatively few. The most complete sections which have been recognized as belonging to this formation are those described by Dall. ${ }^{1}$ At the type locality near Hawthorn the rock is phosphatic and has been mined and crushed for use as a fertilizer, and at many other places it contains more or less phosphate. One of these localities is at the Devils Mill Hopper, northwest of Gainesville, where the rock is exposed in the walls of the sink, which has a depth of about 115 feet. Here the greater portion of the section belongs to the Vicksburg group, but a phosphatic rock near the top probably represents the Hawthorn formation. Another sink which exposes this formation (sec. 18, T. 7 S., R. $18 \mathrm{E}$.) is described by $\mathrm{Dall}^{2}$ as follows:

This place is locally known as "Nigger Sink," and the Vicksburg limestone has been reached by a well hole in the center of it. Above the well the lower 10 feet of the wall of the sink is hidden by talus, but is believed to be clay of a greenish-yellow color, 30 feet of which rises above the talus, covered by a 4-foot layer of firm, hard sand, almost a sandstone, and this by a sandy ferruginous layer of clay and gravel containing an oyster, like $O$. virginica, reproduced in chalcedony. This ferruginous layer, which will be referred to here under the term ferruginous gravel, seems to appear in many different sections, with its oyster and silicified corals. It also occurs in Georgia. Above it is a layer 2 feet thick of soft sandstone resembling the phosphatic rock in appearance. Covering this is a bed of sand and clay 8 feet thick, containing fragments of all sizes from a few pounds to a ton in weight, of the phosphatic rock and its large silicified coral heads. These last, when they appear on the surface as around Archer, from the solution of the phosphatic matrix are popularly known as "fossil stumps" or "nigger heads." They are large masses of chert or chalcedony, often hollow, retaining on the surface more or less obscure indications of the original coral structure. Above this stratum come the surface sand and loam, here about 20 feet thick. 
In this sink a well was drilled to limestone of the Vicksburg group, but the depth and character of the material penetrated is not given. The same writer gives more or less complete descriptions of several other sections. One of these is at Newnansville, where the clay which immediately overlies limestone of the Vicksburg group has a thickness of 70 feet and is overlain by 2 feet of ferruginous sand, 3 feet of undescribed material, and 8 to 20 feet of phosphatic rock. About 5 miles east of Mixons the ferruginous sand rests on the Vicksburg group and is overlain by the phosphatic bed, and nearer Archer the remnants of the phosphatic rock are found resting directly upon the Vicksburg. Occurrences of similar phosphatic rock are reported where the railroad crosses Hillsboro River and at Jarves Springs, and at De Leon Springs a phosphatic rock is said to be overlain by beds containing Chipola fossils. The same phosphatic rock is also reported from Live Oak and Lake City, and the ferruginous bed with its silicified oysters is known to occur at Levyville and at Magnesia Springs. The following sections are given and described by Dall: ${ }^{1}$

\section{Section at White Springs on Suwannee River.}

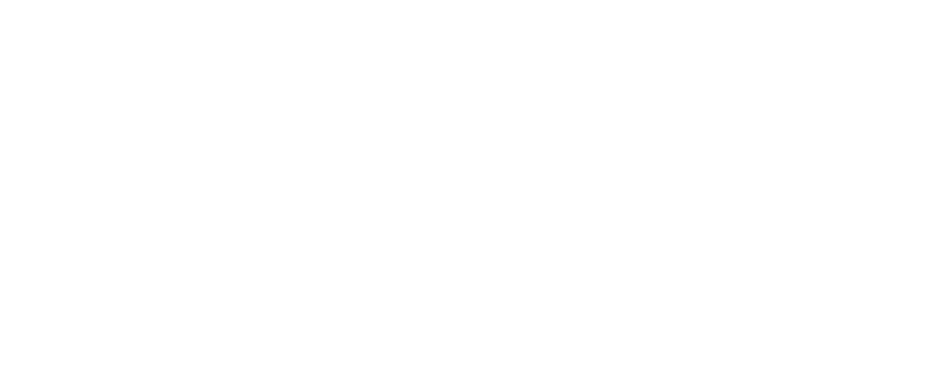

The silicified corals of bed III are sometimes $20-60$ pounds in weight, and along the river when dislodged from the clay often wear immense potholes in the softer limerocks. Miocene sharks' teeth and fragments of bone also occur in the clay. Under bed VIII, when it is tilted up, as occurs in various places along the river, is found the older Orbitoides limestone of the Vicksburg group.

Section in sink 4 miles north of Lake City.

I, II. Sand and sandy soil.......................... Feet.

IV. Indurated clayey rock $\ldots \ldots \ldots \ldots \ldots \ldots \ldots \ldots \ldots \ldots, \quad 2$

VII. Lime-cemented sandrock.......................... 8

VIII. Foraminiferal Eocene (indefinitely down).

At White Springs numerous specimens of Cassidulus were obtained from a cherty rock which had been used in constructing a foundation for the spring house. According to reports obtained from wellinformed residents of the town this rock was quarried from the river channel. At the time of the field investigations for this report the 
river was too high to permit examination of the outcrop, but subsequent examination by Stephenson ${ }^{1}$ resulted in finding the cherty beds of the Hawthorn formation in close proximity to exposures of the Alum Bluff formation. This strengthens the conclusion that was formed at the time of the earlier field work-that the Cassidulusbearing zone lies near the top of the Hawthorn formation.

Dall ${ }^{2}$ gives this section:

Section 2 miles south of Lake City.

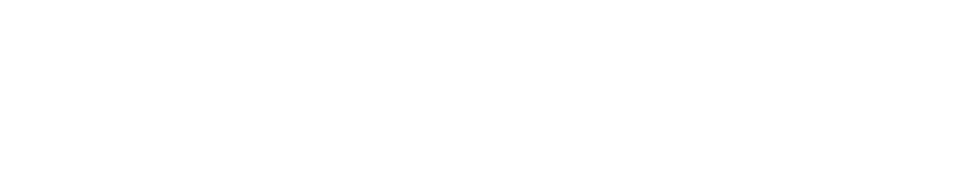

Near the southern boundary of Columbia County, at Fort White, the rocks are gently folded and the surface has been more or less worn into basins containing phosphatic breccia of the older limerocks, which are themselves under these basins of phosphate slightly phosphatized in their upper portions. Here, owing to the fact that the Miocene and Foraminiferal Eocene (Miliolite) beds have been more or less broken up by the action of water dissolving or wearing away the softer parts, the Orbitoides limestone sometimes immediately underlies the breccia in the basins, and in other places the basins are composed of the Miliolite limestone. Beds VI, VII, and VIII of the above series are more or less silicified, or when broken up the resulting breccia contains numerous angular fragments of chert.

In the north-central part of the peninsula and extending as far south as Croom many exposures of chert and cherty limestone rest on the limestone of the Vicksburg group. Most of this rock contains many casts and molds of an echinoid, which Vaughan has identified as a Cassidulus. The rock appears to be very persistent but in few places attains any great thickness. At Bass station, about 6 miles southwest of Lake City, it was quarried to a depth of 12 or 15 feet without reaching the underlying Vicksburg group. About 6 miles west of Gainesville, on the Newberry road, it appears to have a thickness of more than 15 feet and to rest directly on the Ocala limestone, which forms the country rock of that region. The same echinoid is found in cherty beds in many localities between Bass station and High Springs and at Alachua sink, White Springs, Ellaville, and Croom, and at numerous localities in the hard rock phosphate region.

At the railroad trestle just west of White Springs sands, marls, and clay, probably the local equivalent of the limestones of the Hawthorn formation, are exposed passing under the Chipola marl member of the Alum Bluff formation. A section at the railroad trestle shows the following materials: 
Section at railroad trestle just west of White Springs.

Loam, sandy

Feet.

Marl, soft, friable, containing some bands of chert and numerous

echinoids

Marl, soft, containing oyster shells

Clay, light green, thinly laminated, siliceous................. 4

Sand, light green; to water.......................... 4

CHATTAHOOCHEE FORMATION.

Nomenclature.-The limestones and marls exposed along Apalachicola River have been differently grouped by different writers. In this paper the name Chattahoochee formation is restricted to those limestones and marls of north and west Florida which lie stratigraphically between the limestones of the Vicksburg group and the Chipola marl member of the Alum Bluff formation. Beds of chert occur in this formation and thin layers of sand and clay are not uncommon. The type locality is at new Chattahoochee Landing, where there is a small exposure of light-gray marl and impure limestone. This formation is a part of Langdon's ${ }^{1}$ Chattahoochee group, and it is apparently the Chattahoochee group of Foerste. ${ }^{2}$ In 1892 Dall $^{3}$ called it the Ocheesee beds, but in a subsequent paper he notes the absence of exposures at Ocheesee ${ }^{4}$ and uses the names Chattahoochee formation ${ }^{5}$ and Chattahoochee limestone. ${ }^{6}$ As the formation contains considerable marl, the use of Chattahoochee limestone is not entirely satisfactory, and hence the name Chattahoochee formation is retained.

Stratigraphic position.-The Chattahoochee formation is known to rest unconformably on the underlying limestone of the Vicksburg group in southern Georgia. The evidence of the unconformity was summarized in 1893 by Pumpelly, ${ }^{7}$ who states that there is usually a limestone conglomerate at the base of the Chattahoochee formation in southwestern Georgia and that the altitude of the contact between the two limestones varies considerably in short distances. The variations in altitude given by Pumpelly might, if considered alone, be regarded as due to deformation rather than to erosional unconformity, but the evidence of erosion is strongly supported by

\footnotetext{
1 Some Florida Miocene: Am. Jour. Sci., 3d ser., vol. 38, 1889, pp. 322-324.

Am. Jour. Sci., 3d ser., vol. 48, 1894, pp. 41-54.

8 Bull. U. S. Geol. Survey No. 84, 1892, p. 87.

4 Dall, W. H., and Stanley-Brown, Joseph, Cenozoic geology along Apalachicola River: Bull. Geol. Soc. America, vol. 5, 1894, p. 154.

5 Idem, p. 152.

Idem, p. 155.

7 Pumpelly, Raphael, An apparent time break between the Eocene and Chattahoochee Miocene in southwestern Georgia: Am. Jour. Sci., 3d ser., vol. 46, 1893, pp. 445-448. Also Vaughan, T. W., A Tertiary coral reef near Bainbridge, Ga.: Ścience, new ser., vol. 12, 1900, pp. 873-875.
} 
the conglomerate, which in some places resembles breccia but in others contains rounded pebbles of the underlying rock. The difference in lithologic character between the limestones of the Vicksburg group and the limestones of the Chattahoochee formation is so marked that it would hardly be possible to mistake the source of these pebbles. The probability that the inequalities of the surface of the limestones of the Vicksburg group are due to erosion is strengthened by the paleontologic evidence. On evidence furnished by Foerste, Pumpelly states that the Chattahoochee at Griffins Creek contains a fauna characteristic of the upper part of the formation and in other localities examined contains faunas belonging to the lower part. It thus appears that at Griffins Creek deposition did not begin until after the formation of the beds exposed in the immediate neighborhood; or, in other words, that an island consisting of the underlying limestone of the Vicksburg group was not submerged until after the deposition of the lower part of the Chattahoochee formation.

Tuomey also collected corals at the contact between the Chattahoochee and the underlying limestones, and Dall identified these as belonging to the base of the Miocene, to which the members of the Apalachicola group were formerly assigned.

In Florida the base of the Chattahoochee formation was not seen, but there is little doubt that its relation to the limestones of the Vicksburg group is similar to that in Georgia. This view is strengthened by what is already known of the physical history of the State and by the fact that both the Hawthorn and Tampa formations, which appear to have been deposited at about the same time as the Chattahoochee, rest upon the eroded surface of the limestones of the Vicksburg group.

Lithologic character.-The Chattahoochee formation consists of light-colored limestones and marls, containing some thin beds of chert, clay, and sand. The colors vary from creamy white to light gray or green on recently exposed surfaces to light yellow-brown or more rarely pink on weathered outcrops. Lithologically, there is a gradation from nearly pure limestone to sands and clays, but in general the argillaceous and siliceous limestones predominate, forming marls. The formation is in part composed of semicrystalline limestone (Pl. X, $B$ ), but soft, loosely coherent rock resembling an impure chalk is more common. Chert beds occur at various horizons, but they are much thinner and less persistent than in the underlying Vicksburg group. At times organic life appears to have been abundant, some layers being very fossiliferous; the fossils are usually preserved in the form of imperfect casts and molds which have been left by the solution of the shells. 


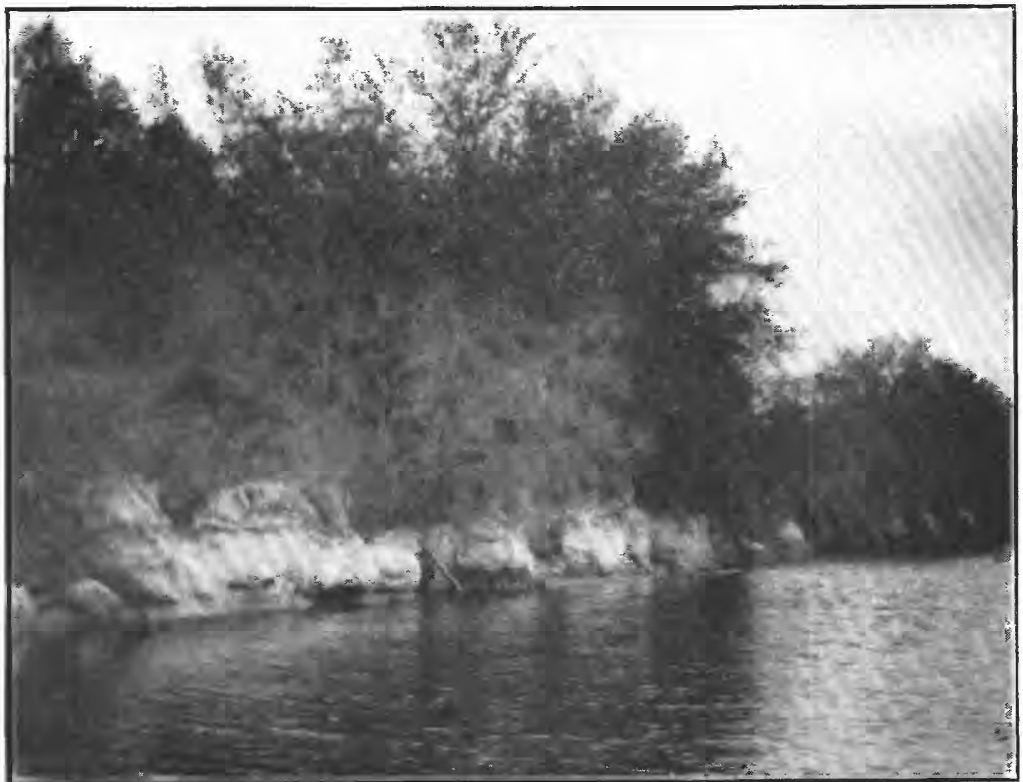

A. LIMESTONE OF TAMPA FORMATION EXPOSED ALONG SIXMILE CREEK A QUARTER OF A MILE BELOW ATLANTIC COAST LINE RAILWAY BRIDGE, HILLSBOROUGH COUNTY.

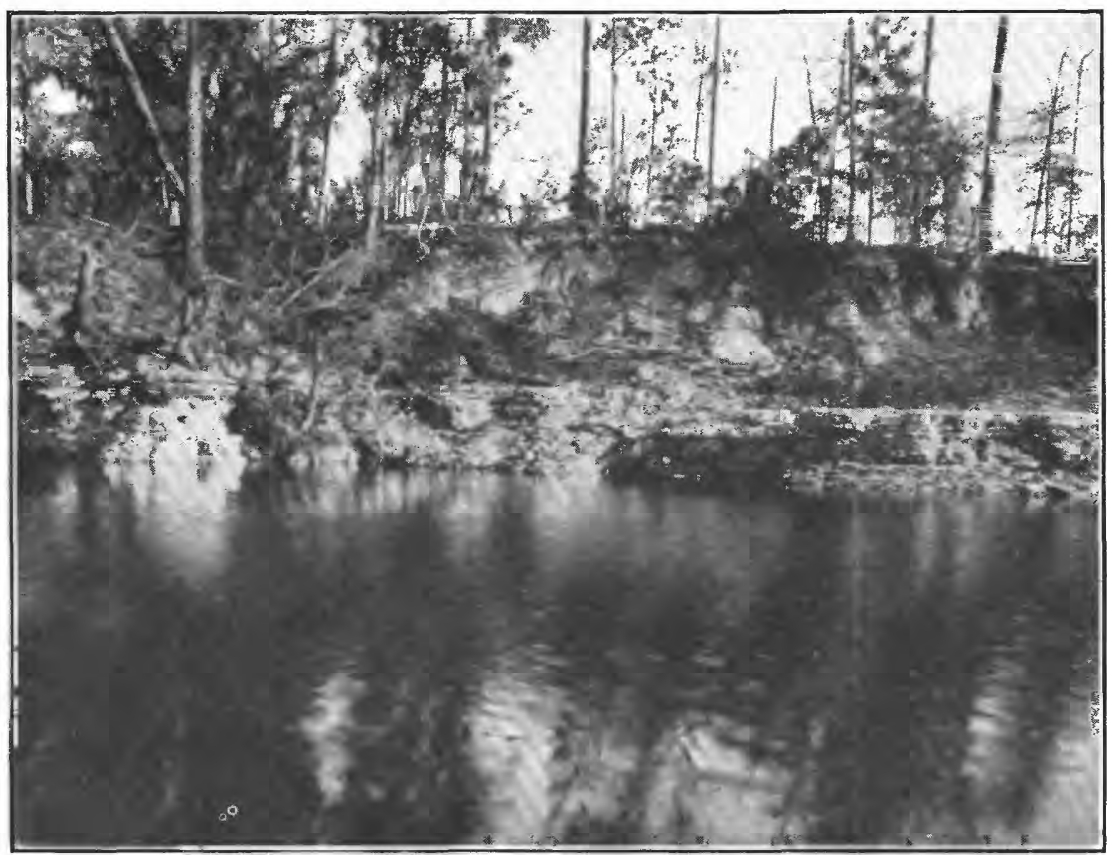

B. LIMESTONE OF CHATTAHOOCHEE FORMATION ON WITHLACOOCHEE RIVER AT NEW BRIDGE (OR HORN BRIDGE), 3 MILES BELOW GEORGIA \& FLORIDA RAILWAY BRIDGE, LOWNDES COUNTY, GA. 
. 
Thickness.-Vaughan's ${ }^{1}$ observations along Apalachicola River show that the Chattahoochee formation attains considerable thickness near the type locality. He says:

The Chattahoochee limestone at the Old Landing has a thickness of at least 85 feet and probably more, for the basal 20 feet of the two sections measured on the roads to the water's edge at the river is not exposed. However, in all probability the alluvium bottom accompanying the river is underlain by this formation, giving it a total thickness of slightly more than 100 feet.

Well borings from Quincy indicate that the thickness of the Chattahoochee formation at that locality is slightly greater than 100 feet; but here, as elsewhere, it is difficult to determine the exact thickness of formations from well samples. The maximum thickness is probably 200 feet and may even be as great as 250 feet.

Physiographic expression.-In general the region underlain by the Chattahoochee formation is one of high relief and well-developed surface drainage. However, this is not always due to the character of the formation, for in the northern part of the State the surface configuration is in many places determined in part by the character of superficial sands and clays of late Oligocene and post-Oligocene age. The limestones of the Chattahoochee formation are less soluble than those of the underlying Vicksburg group, and hence contain fewer underground streams and a less characteristic sink-hole topography. However, underground streams, sink holes, and natural ridges are by no means rare. Where the limestones belonging to the Chattahoochee formation are thin, the topography is often the combined result of solution of the lower Oligocene limestones and the protection of the ridges and hills by the more durable upper Oligocene limestones.

Paleontologic character.-At some localities in southern Georgia the basal layers of the Chattahoochee formation are rich in corals. ${ }^{2}$ The lower part of the formation contains Orthaulax pugnax, a gastropod characteristic of the "silex bed" at Tampa. This locality has been studied by Vaughan, ${ }^{3}$ whose description emphasizes the existence of an erosion interval between the deposition of the Vicksburg and the Apalachicola groups, and shows the existence of fossil coral reefs. Of this coral reef, Vaughan says:

My estimate is that there are between 25 and 30 species.

This is the richest fossil coral fauna known from any one locality of the continental North American Tertiaries. However, the state of preservation of the specimens is not always satisfactory, and it may not be possible specifically to describe all of them.

The particular interest of this fauna does not lie in its richness but in its geologic import. The Tertiary coral faunas of the United States below the Chipola horizon were very isolated, no species from the continent, excepting the Orbicella mentioned, being found in any other area. This fauna is distinctly Antiguan in types. Besides

\footnotetext{
1 Vaughan, T. W., unpublished notes.

2 Pumpelly, Raphael, An apparent time break between the Eocene and Chattahoochee Miocene in southwestern Georgia: Am. Jour. Sci., 3d ser., vol. 46, 1893, pp. 445-447.

${ }^{3}$ Vaughan, T. W., A Tertiary coral reef near Bainbridge, Ga.: Science, new ser., vol. 12, 1900, pp. 873-875,
} $76854^{\circ}-$ wsP $319-13-7$ 
the Orbicella referred to, there is a very large celled Orbicella, very close to 0 . crassilamellata (Duncan), if not identical with that species, found abundantly at Russell Spring. An Astrocœnia is extremely close to A. ornata of Duncan from Antigua. The same remark will apply to the Stylophora and Alveopora.

From this field examination it appears that the reef corals of the Antiguan marls and cherts can be correlated with the base of the Chattahoochee limestone, the base of Dall's Upper Oligocene. It is also quite probable that the Oligocene reefs in the vicinity of Lares, Porto Rico, and of Serro Colorado, Curacao, represent the same horizon. The Bowden, Jamaica, fauna would be slightly higher, to be correlated with the Chipola fauna.

It is evident that this coral fauna from Russell Spring, besides filling a gap in the faunal succession on the continent, furnishes a basis for correlating many of the West Indian fossil reefs with the continental Tertiary section, and we may confidently expect more light upon the correlation of American and European horizons.

One interesting feature of these corals, not already mentioned, is that they apparently bring the fauna of Vicksburg, Miss., into closer relations with the succeeding faunas. A great deal is shown regarding the succession and interrelations of the faunas of the continent itself.

A bed in the lower part of the Chattahoochee formation in most places contains an abundance of echinoids, and several different genera belonging to this group are known to occur at other horizons. About 20 feet above the echinoid bed there is a layer containing an abundance of gastropods belonging to the genus Helix; a slightly higher layer is characterized by numerous specimens of Cerithium.

Structure.-In northwestern Florida the limestones of the Chattahoochee formation dip toward the south. The exact amount of this dip is difficult to determine, but careful estimates by Miss Maury ${ }^{1}$ place the average descent at 23 feet per mile. The same writer has noted a variation in the rate of dip; she says:

That this dip is steeper toward the north is shown by the following rate of slope: Aspalaga to the ravine, one-eighth mile, 10 feet, or 80 feet per mile; Aspalaga to Camp Scott, 2 miles, 70 feet, or 35 feet per mile: Camp Scott to Rock Bluff, 3 miles, 48 feet, or 16 feet per mile.

Areal distribution.-The Chattahoochee formation, which is best exposed along Apalachicola River, has been described by a number of writers. According to Dall the major portion of the rock exposed at Chattahoochee belongs to the Alum Bluff formation. His most complete sections are given below: ${ }^{2}$

Section on road running northeast from old Chattahoochee Landing.

1. Reddish sand and gravel, with streaks of clay ............ Feet.

2. Grayish yellow friable marl, with harder layers.......... 20

3. Greenish clayey marl, very adhesive ............... $2 \frac{1}{2}$

4. Chattahoochee limestone, with fossil casts............ 4

5. Talus to water's edge, about $\ldots \ldots \ldots \ldots \ldots \ldots \ldots \ldots \ldots \ldots, \quad 3$

$49 \frac{1}{2}-69 \frac{1}{2}$

1 Maury, C. J., Bull. Am. Paleontology, vol. 3, No. 15, 1899-1902, p. 58.

2 Dall, W. H., and Stanley-Brown, Joseph, Cenozoic geology along the Apalachicola River: Bull. Geol. Soc. America, vol. 5, 1894, p. 152. 
Section on road running southeast from old Chattahoochee Landing.

1. Reddish sands, gravel, and clays................. $15-20$

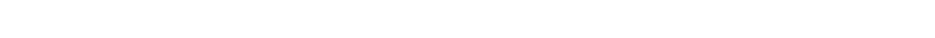

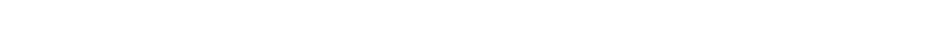

4. Talus to water's edge, about $\ldots \ldots \ldots \ldots \ldots \ldots \ldots \ldots \ldots \ldots . . . \ldots$

$30 \frac{1}{2}-45 \frac{1}{2}$

\section{Dall says:}

Section. No. 2 was taken on the road which runs about southeast from the landing. The exposures are mostly in the gullies. The fossil-bearing bed is No. 4 and contains, among other fossils, echinoids, Pecten (Chipola sp.), Arca (like transversa), large solitary coral, Venus penita, Lima (like scabra), Hemicardium, Ostrea, Loripes, Scala, Plicatula, Divaricella, Pyrazisinus, Phorus, all as poor casts; fish bones and ribs of some mammal resembling those of the manatee. No orbitolites were seen.

From the correlations made by Dall it is apparent that he regarded No. 1 of the above section as Lafayette and Nos. 2 and 3 as Alum Bluff. A generalized section made by Vaughan from old Chattahoochee Landing to Chattahoochee post office is given below:

\section{Generalized section from old Chattahoochee Landing to Chattahoochee post office.}

3. Red sands with some gravel, toward base becoming more argillaceous; in places composed of mottled red sands and bluish or purplish clays. The basal portion forms a mantle following rather closely the contact with the Alum Bluff formation. The mottled basal portion extends through a vertical distance of about 40 feet...

2. White chalk and clays, in places greenish or bluish. The greater portion of these clays is calcareous and a considerable portion is argillaceous limestone in harder and softer ledges. A calcareous specimen (chalky) was taken 70 feet above the water's edge of the river. The clays are jointed and show conchoidal exfoliation. The lower portion of this exposure does not appear to be calcareous. Some fine sands at the bottom. (Rocks of the same character, either clay or limestone, occur 100 feet above the river. The total thickness of the Chattahoochee formation here exposed is 80 feet.).

1. Alluvium of river bottom composed of reddish sands along the river. No exposure of beds beneath the river alluvium was seen ..

\section{Feet.}

In commenting on this section, Vaughan says:

It is evident that I did not examine the specific locality described by Dall, for I did not see his Chattahoochee limestone. The upper part of his No. 2 is the lower part of my No. 2. From Dall's description, the whole of my No. 2 would be referable to the Alum Bluff. The combination of his section and mine give a thickness of over 80 feet. His maximum thickness is 67 feet. 
The following more detailed section by Vaughan shows the character of the rocks exposed in the lower part of the section given above:

Detailed character of lower part of section given above.

Feet.

White argillaceous chalk in harder and softer layers. . . . . . . . 46

Very calcareous blue clay . . ....................... 2

Indurated calcareous clay, stained yellow in places. . . . . . . . . $15 \frac{1}{4}$

Six feet six inches above the base are fine-grained, very calcareous

marls, white or slightly tinged with yellow in spots. This stratum

contains casts of many shells, etc.

$63 \frac{1}{4}$

At Wileys Landing on Chattahoochee River, about 7 miles above River Junction, Vaughan obtained a section given below, but it has not been correlated with the other sections farther down the river:

Section of bluff at Wileys Landing.

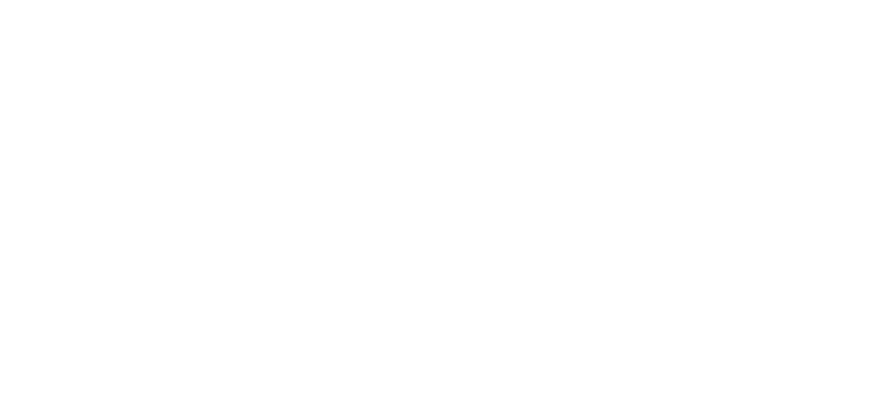

Feet.

$5-6$

25

The surface of this bluff is so covered by red clay and talus from above (limestone pebbles and bowlders) that it is not possible to discover the details of the section. The basal 11 feet are argillaceous, while the succeeding 47 feet are for the most part limestone. But the rock is so indurated that the fossils can scarcely be freed from the matrix. In one portion of the limestone horizon, the lower 25 feet, very large oyster shells are abundant. These weather out in good condition, probably because their matrix is argillaceous or because the limestone is softer. The greater portion of the limestone is hard and rings under blows of the hammer.

No fossils were found in the basal argillaceous layers. These lower layers would, according to the literature, probably be referred to the Vicksburg. The limestone belongs to the Chattahoochee. The lithologic specimen of it was taken from the top of the exposure and a fair number of fossils were collected. The exposure was also photographed. This section was measured by a hand level.

The following descriptions were also furnished by Vaughan:

Section at Aspalaga Landing.

5. Sand

4. White limerock. The surface appearance and color are those of chalk. This rock is indurated in thick, massive ledges, and fragments show concentric exfoliation. Its color is originally bluish and becomes white upon drying.................

3. Chalky limestone, more calcareous in the basal portion. 
2. Friable limestone, containing patches of blue clay and very poor remains of fossil mollusks.......................

1. Whitish chalk, tinged yellowish, which when kneaded in the

Feet. water forms a whitish sticky paste. The stratum is sufficiently indurated to form a ledge and extends at least 1 foot below the surface of the water.........................

The argillaceous basal portion of stratum No. 3 is about 2 feet, then follows a chalky stratum and bluish clays at the base of No. 4 .

At the extreme upper end of the bluff the exposure is more satisfactory. The bluff face (Nos. 1, 2, and 3, and the lower 10 feet 8 inches of No. 4, total thickness 30 feet 5 inches) is white chalk with layers of more or less friable and argillaceous marl. Fossils are very numerous in several layers of the chalk, especially in stratum No. 2 and at the top of the bluff face, but all are miserably preserved, there being no shell substance left, only casts. Nucula, Pecten, Venericardia, Lucina, Isocardia, Meretrix, Turritella, Stylophora, solitary corals, etc., were observed.

A résumé of the exposure at Aspalaga, excluding the surface sands, is as follows:

\section{Résumé of section at Aspalaga landing.}

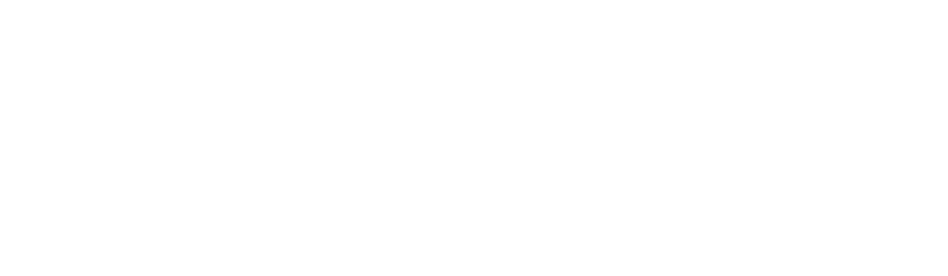

The whole of these $59 \frac{1}{2}$ feet (perhaps excepting some marl beds near the top) is chalky limestone. This section was measured with a hand level.

I could not find the marl bed described by Dall and think it must have been a disintegrated chalky stratum or weathered chalk, as the weathered chalk is frequently a clay marl. The limestone was sectioned at two places, one near the lower end of the bluff; the measurements were by hand level and steel tape; the uppermost exposure was a ledge and the thickness, as has already been stated, was 59 feet 6 inches, or roughly, 60 feet.

Near the upper end of the bluff an aneraid section was made and 55 feet was the thickness by that measurement, practically the same as the preceding.

Coming down the road to Aspalaga landing is an exposure just before passing to the river bottom. To the right of the road is a small branch that empties into the Apalachicola at Aspalaga landing. The Chattahoochee formation forms an escarpment a few feet high along the northern side of the branch. An aneroid measurement from the water's edge to the highest exposure on the road gave a thickness of 35 feet; that is, only a portion of the limestone is there exposed.

At the crossing of the River Junction-Bristol road (over Flat Creek) is an exposure of limestone of small extent, probably the Chattahoochee.

Tests with acid of specimens from Aspalaga Bluff.

Stratum 4. Specimen from highest exposure effervesces.

Specimen from chalk ledge in face of bluff, effervesces.

Stratum 3. Clay, just beneath base of No. 4, considerable effervescence.

Very calcareous, stiff blue clay, effervesces strongly.

Stratum 2. A friable limestone, containing considerable clay.

Stratum 1. Is an argillaceous limestone, chalk. 
Section at western end of trestle east of River Junction, milepost 206.

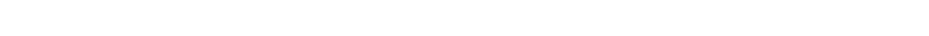

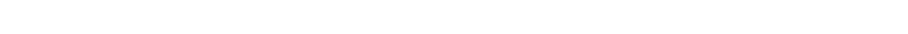

(5) 2. Stiff mottled sandy clay ............................

(4) 1. Stiff noncalcareous blue clay ....................... 3.2

Section measured with steel tape.

Section immediately below (4) 1 of the preceding section and nearer the creek.

3. Sandy ferruginous clays, containing black, apparently carbonaceous particles. Stratum mottled yellowish or brown, and Feet. bluish white with black spots........................ 3

2. Stiff blue clay with lumps or seams of white clay............. 1

1. White sandy noncalcareous clay, oxidizing yellowish or brown on surface.

The barometer readings correlate these clays in altitude with those immediately back of the station house at River Junction, and as they are similar in character this correlation is apparently trus worthy.

One telegraph pole west of milepost 205 is an exposure of the argillaceous chalk of the Chattahoochee 2.7 feet in thickness. It is overlain .by the dump from the railroad excavation. The material was tested with acid and found to be calcareous. It has the appearance of the usual limestone of the Chattahoochee. The surface shows irregular joints and conchoidal or concentric exfoliation. One imperfect fossil was found, a surface cast, probably a Lucina.

This locality is about $2 \frac{1}{2}$ miles east of River Junction railroad station on the Seaboard Air Line Railway. River Junction is at milepost 208, 208 miles from Jacksonville. •

From looking along the railroad this exposure seems to be topographically lower than the two preceding exposures.

Excepting the two exposures described, there are none between this locality and River Junction excepting surficial sands and maybe some red sands or clays and sands. There are no deep cuttings along the railroad track.

\section{Section at station house, River Junction.}

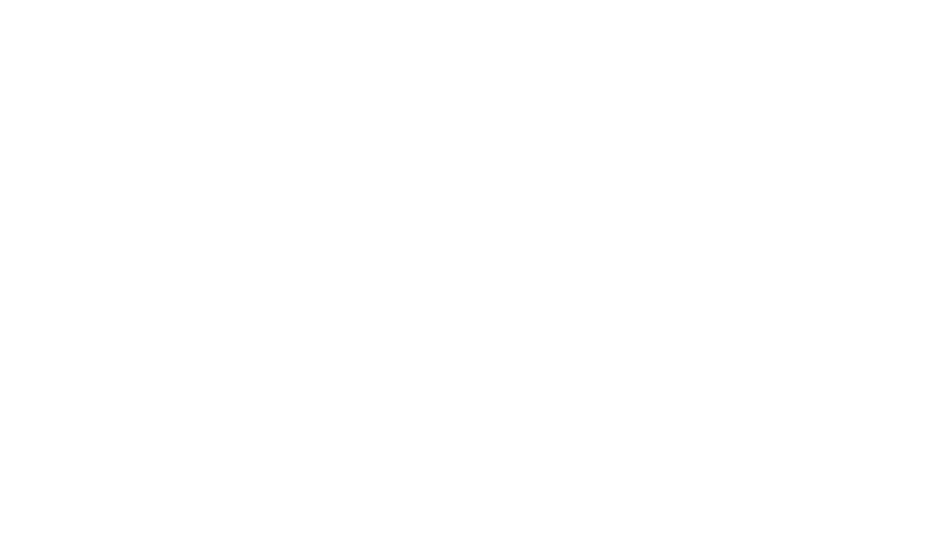

No. 1 at edge of sand flat of small branch. This last bed is the one from which Dall mentioned fossils. I found as poor casts Isocardia, Hemicardium, Venericardia, Tagelus, Turritella (very large species), cast of inside of large gastropod (Orthaulax?), smaller gastropods, etc. There were many specimens and many species, all poorly preserved.

Between River Junction and the railroad bridge over Apalachicola River there are no rock exposures except the one already mentioned. 
A number of fossils were obtained by Vaughan at a small fall in a ditch running east from the back of the station house at River Junction. A list follows:

Mammalian ribs, fragments. (These ribs are probably of the manatee.)

Large cheliped crustacean claws, the animal apparently the size of a large lobster.

Cardium, several species.

Hemicardium.

Venericardia.

\author{
Pecten. \\ Venus. \\ Lucina. \\ Astarte. \\ Natica (very large species). \\ Orthaulax?. \\ Fusus. \\ Cerithium or Turritella.
}

The shells are all casts, internal or external, but the fauna is evidently typical Chattahoochee. One fine regular echinoid was collected.

Cement quarry one-half mile south of River Junction.

Superficial coating of black humus and some gray sand.

Feet.

Friable chalky limestone, forming slope of hill.............. 13

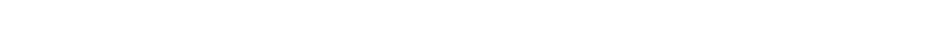

Softer chalky layer.................................. 1.5

Harder, somewhat saccharoidal limestone................. .9

Softer fossiliferous chalk............................. 1.7

Harder limestone with numerous fossils, the commonest being Hemicardium and an orbitoid foraminifer. This material when weathered turns reddish and forms a residual red clay. No original molluscan tests were observed, but they are sometimes replaced by crystalline calcite..........................

Soft white chalk, indurating upon exposure, used in making cement brick. (Base, by barometer, 50 feet above the railroad at River Junction) ....................................

Some 12 to 15 feet of limestone belonging to the Chattahoochee formation is exposed at Rock Bluff and it doubtless underlies the Chipola marl member at Alum Bluff. On Chipola River the same limestone is exposed at intervals from near the mouth of Tenmile Creek northward to beyond Peacock Bridge. Few of these exposures exceed 4 or 5 feet in thickness and the rock is a chalky limestone similar to that exposed on Apalachicola River. The outcrops at Peacock and Willis bridges on Chipola River were visited, but they proved to be nearly destitute of organic remains. This limestone doubtless forms the natural bridges over Tenmile and Sinking creeks, tributaries of Chipola River, but high water prevented a close examination of the localities. Similar limestone occurs in the form of loose bowlders in the vicinity of Knoxhill, Walton County, and outcrops of it are reported on Choctawhatchee River, south of the Louisville \& Nashville Railroad bridge. At Caryville the well of the Wood Lumber Co. penetrated 8 feet of pinkish limestone, which doubtless belongs to the Chattahoochee formation. The limestone at St. Marks and at some localities farther north and east is also tentatively referred to this formation. 
TAMPA FORMATION.

Character and nomenclature.-The Tampa formation consists of greenish clays, light gray to yellow limestones, and a very fossiliferous bed of "silex." Hitherto, the "silex" and a portion of the limestone has been all that was known of the formation. The "silex bed" and limestone of the Tampa formation were first examined by Conrad $^{1}$ more than 60 years ago. In the same year Prof. Allen ${ }^{2}$ described both the limestone and "silex bed" at Tampa, and his account of these beds has been generally accepted as correct. The same locality was subsequently visited by Tuomey. ${ }^{3}$ In 1884 Kerr and Mitchell ${ }^{4}$ visited Tampa and noted the replacement of fossiliferous limestone by chalcedony in what has since been called the "silex bed." Ballast Point, near Tampa, where the "silex bed" is best exposed, is the locality where Bailey ${ }^{5}$ found what he regarded as infusorial earth resting on the "silex bed." Later investigations have shown this bed to be merely residual material produced by the action of the weather on the silicified limestone.

In 1887 Heilprin ${ }^{\circ}$ published an account of explorations near Tampa and called attention to the fact that the fossil which Conrad regarded as a nummulite was really an orbitolite. Heilprin gave a brief description of Ballast Point and other exposures near Tampa but does not appear to have recognized the relations between the limestone and the "silex bed." Later publications by Dall give more complete descriptions of the Tampa exposures and show clearly that there are two beds represented, which he called the Tampa silex bed (the lowermost) and the Tampa limestone (the uppermost). Because the "silex bed" is characterized by the presence of Orthaulax pugnax, Dall has called it the Orthaulax bed and the limestone has been designated "Cerithium " rock" on account of the presence of many specimens belonging to that genus.

In his report on the Neocene of North America, Dall ${ }^{8}$ described the "Tampa group," including what he designated the Tampa, Chipola, and Alum Bluff beds. But the subsequent discovery of Orthaulax pugnax in the Chattahoochee led him to place the "silex beds" in his Chattahoochee group. ${ }^{9}$

\footnotetext{
1 Conrad, T. A., Observations on Eocene formations and descriptions of 105 new fossils of that period from the vicinity of Vicksburg, Miss.: Proc. Philadelphia Acad. Sci., vol. 3, 1848, pp. 19-27; Am. Jour. Sei., $2 d$ ser., vol. 2, 1846, pp. 36-48.

2 Allen, J. H., Am. Jour. Sci., 2d ser., vol. 2, 1846, pp. 36-48.

3 Tuomey, $\dot{M}$., Notice on the geology of the Florida Keys and the southern coast of Florida: Am. Jour. Sei., 2d ser., vol. 11, 1851, pp. 390-394.

- Mitchell, Elisha, and Kerr, W. C., Scientific Soc., 1884-85, p. 87.

- Bailey, J. W., Microsconic observatiors: Smithsonian Contr. to Knowledge, vol. 2, No. 8, 1850, p. 19.

- Heilprin, Angelo, Explorations on west coast of Florida: Trans. Wagner Free Inst. Sci., vol. 1, 1887. pp. 10 and 11.

7 Bull. U. S. Geol. Survey No. 84, 1892, pp. 112-113.

8 Op. cit.

9 Dall, W. H., Tertiary fauna of Florida: Trans. Wagner Free Inst. Sci., vol. 3, pt. 6, 1893, pp. 1564-1565,
} 
While engaged in the field work for this report, the writer obtained additional information concerning the rocks at Tampa. Stated briefly, the observations revealed the presence of a limestone below the "silex bed" and the existence of clay beds at both the base and top of the formation. The limestone below the "silex bed" is similar to what Dall ${ }^{1}$ has called Cerithium rock, and in this connection it is interesting to note what he has said concerning its existence:

From these observations it appears that, while the existence of a Cerithium rock under the Orthaulax bed is a priori probable, sufficient evidence of its existence is still to be collected, and the rock identified as such by Heilprin may very possibly have been a portion of the Tampa limestone.

Since the publication of the report from which the above quotation is taken, a series of wells have been drilled, and the samples which were preserved show the presence of the limestone below the silex.

Stratigraphic position.-Evidence of an unconformity at the base of the Tampa formation was obtained in drilling wells for the city of Tampa. The log of one of these wells (see p. 106) shows that after passing through 30 feet of limestone and chert the drill entered a blue clay 41 feet thick. The limestone and chert represent the limestones and "silex bed" of the Tampa formation, and the clay appears to belong at the base of that formation. At 200 feet from this well, the clay was encountered at about the same depth and was said to have a thickness of 64 feet. This variation shows that the underlying limestones of the Vicksburg group have an irregular surface which was doubtless produced by erosion.

The relation of the Tampa formation to the Hawthorn and Chat- tahoochee formations has not been observed, but the presence of the gastropod Orthaulax pugnax in both the Tampa and Chattahoochee formations makes it possible to correlate them, and its stratigraphic relation to the Alum Bluff formation is probably similar to that of the other two formations mentioned. The post-Oligocene formations, which occur in the area where the Tampa formation is known, rest unconformably upon it.

Lithologic character.- The upper member of the section at Tampa comprises a well-stratified greenish clay containing some calcareous nodules and thin beds of limestone near the base. Scattered throughout the clay are many silicified corals, some of them having a diameter of 2 to 3 feet. Although the collection of corals has not been examined, there is little doubt that this clay belongs to the Alum Bluff formation. The clay is very plastic and hence is valuable for the manufacture of brick. Beneath this clay is the light-gray to yellow limestone, which was formerly called the "Tampa limestone." (See Pl. X, $A$, p. 94.) The "silex bed" represents a silicified zone in this limestone; and is therefore a zone of replacement. This is well 
shown by some of the fossils, which have been only partly silicified; and by the presence of more or less unaltered carbonate of lime in the original rock. Small nodules of chert occur at other horizons in the limestone, and outcrops of the rock are commonly denser and harder than exposures in quarries. Locally, the limestone is hard enough to make a durable building stone which might be useful in the construction of foundations for buildings. Fossils are abundant in some parts of the limestone, but they are largely represented by casts and molds, which have been left by the solution of the original shells. The "silex bed" contains numerous fossils which have been wholly or partly replaced by chalcedony. Here and elsewhere the action of the percolating water has removed the matrix, leaving many beautifully preserved pseudomorphs and casts of shells. These fossils are commonly composed of chalcedony, which in many specimens exhibit the characteristic markings of the original shells.

Beneath the limestone beds is a greenish clay which commonly contains a considerable admixture of sand. This clay is very plastic and resembles the clay which overlies the limestone. Judging from well records, the deposit is homogeneous, but it is possible that the sand contained in the well samples may be derived from thin sand partings in the clay bed.

Thickness.-The information concerning the thickness of the Tampa formation is meager, but it is sufficient to fix the maximum thickness at more than 130 feet. The clay bed at the top of the formation has a known thickness of 15 feet. The limestone between the "silex bed" and the upper clay measures about 40 feet. The thickness of the "silex bed" varies considerably, ranging from about 4 feet to more than 10 feet. Beneath the "silex bed" is a limestone which has a known thickness of 6 feet. The clay bed at the base of the formation has been penetrated by two wells within 200 feet of each other; its thickness was 41 feet in the one and 64 feet in the other.

Physiographic expression. - The area underlain by the Tampa formation is so near sea level that no marked physiographic features can be discerned. The influence of the limestone of the formation is seen in the rapids of Hillsboro River; and its solution may have produced some of the depressions northeast of Tampa. Aside from these minor features, the surface of the formation is not very diversified.

Paleontologic character.-In addition to the characteristic Orthaulax pugnax, the "silex bed" of the Tampa formation has furnished a very large number of species, including some corals, many species of gastropods and pelecypods and a few specimens of Orbitolites floridanus, which becomes abundant in the overlying limestone. At Ballast Point the fauna of the "silex bed," though largely marine, contains many fresh-water shells which were probably supplied from 
some lakes or lagoons situated near the shore. The complete list of the fossils from the "silex bed" is given by Dall, who says:"

About 49 per cent of the species in the Orthaulax bed are peculiar to it, and very few of the more minute forms which should be present in such a fauna are known. The relations of the fauna are most intimate with that of the Oligocene beds above it, the Orbitolite or Tampa limestone, the Chipola, and the Oak Grove sands. With either of these the percentage of species common to both is more than twice as great as with any of the beds below, such as the nummulitic, the Peninsular limestone, or the Vicksburg. But it must be admitted that the faunas of all these, except the last, are very imperfectly known. With the faunas of the horizons above the Oak Grove sands there is little in common, though in the tropical waters of the Antilles about 8 per cent of the species are believed to survive to the present day. Only about 2.6 per cent survive except in tropical waters.

One of the most interesting features of the fauna is the assembly of land shells, which are southern immigrants and have left no survivors on the American continent at the present day, though representative species occur to the southward.

The fauna of the limestone in the Tampa formation contains fewer species than that of the "silex bed," but the two faunas are closely related, as will be seen by the following quotation, which contains Dall's comments on the list of fossils from these two beds:"

Total, 95 species, of which 36 are uncertain specifically, leaving 59 identified, of which 37 are common to the silex beds, 10 are peculiar to the Tampa limestone horizon, 4 are known from the Ocala nummulitic limestone, and 2 appear in the Vicksburgian, the Jacksonian, and the Claibornian. One species (and probably more not yet discriminated) survives into the Chipola and two are believed to persist to the recent fauna.

Structure.-The Tampa formation lies near sea level, and hence it is difficult to get sections which show the structure of the beds. Apparently the formation is nearly horizontal with a slight seaward dip; gentle flexures may exist, but the evidence is still too meager to show their existence.

Areal distribution.-The "silex bed" of the Tampa formation is best exposed at Ballast Point, where it rises only a few feet above tide. At this locality, the maximum thickness of the bed is not shown. Dall's ${ }^{3}$ section at Tampa is:

Section of "silex bed" at Tampa.

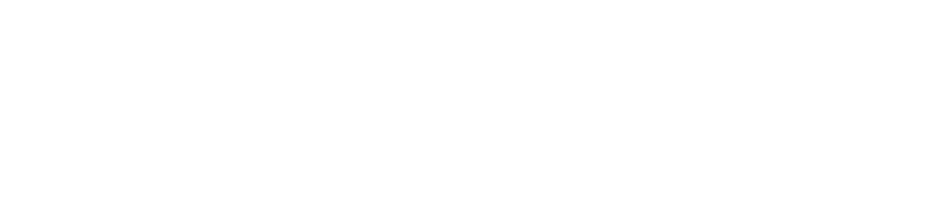

In drilling wells at the Tampa waterworks, between Sixth and Seventh avenues, the "silex bed" was found to have a thickness of only 4 feet. Beneath it was a thin bed of limestone, underlain by

3 Bull. U. S. Geol. Survey No. 84, 1892, p. 113. 
greenish clay, that varied in thickness from 41 to 64 feet. The log of one of these wélls follows:

Log of well at Tampa waterworks.

\begin{tabular}{|c|c|c|}
\hline & Thickness. & Depth. \\
\hline & Feet. & Feet. \\
\hline 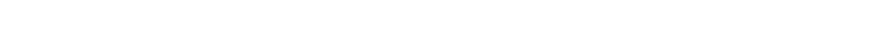 & 20 & 2 \\
\hline 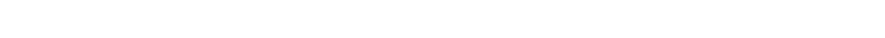 & 10 & $\begin{array}{l}12 \\
26\end{array}$ \\
\hline Chert ("Tampa silex bed") & 4 & 30 \\
\hline Limestone, soft; closely resembles No. $3 . n^{\prime}$ & 6 & 36 \\
\hline Clay, tough, plastic, greenish, sandy (base of the Tampa formation)........... & 41 & 77 \\
\hline 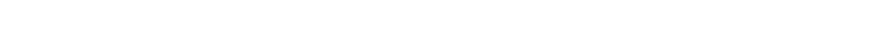 & 2 & 79 \\
\hline . & 6 & 85 \\
\hline Limestone, soft . . . . . . . . . . . . & 6 & 91 \\
\hline 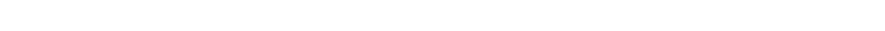 & 15 & 106 \\
\hline 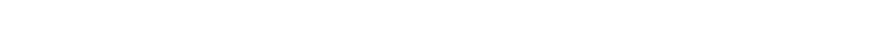 & 6 & 112 \\
\hline 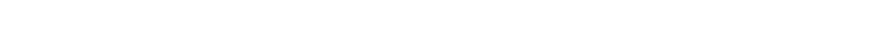 & 15 & 127 \\
\hline 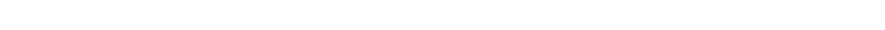 & 14 & 141 \\
\hline 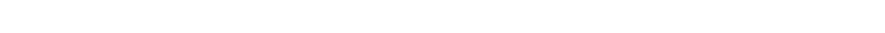 & 14 & 155 \\
\hline 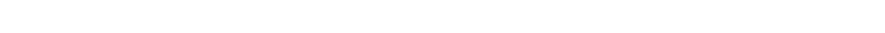 & 10 & 165 \\
\hline 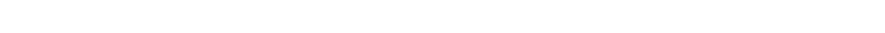 & 3 & 168 \\
\hline 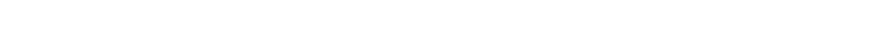 & 10 & 178 \\
\hline 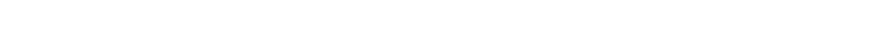 & 23 & 203 \\
\hline
\end{tabular}

The section from 12 to 77 feet represents the Tampa formation, but at this locality the upper clay and a portion of the limestone have been removed by erosion. The rest of the section represents the Vicksburgian limestones.

Another well 200 feet away encountered 64 feet of the clay, which suggests an unconformity at base of this bed, and this hypothesis is strengthened by the fact that the rock immediately below the clay differed in the two wells.

The upper clay bed of the Tampa formation is best exposed at the pit of the Tampa Brick Co., on the bank of Hillsboro River 5 miles northeast of the city, where an exposure of 10 to 14 feet of lightgreen siliceous clay is unconformably, overlain by 2 to 4 feet of lightgray Pleistocene sand. The clay is very plastic and is said to make excellent brick. Scattered throughout the deposit are numerous cobbles and bowlders of chert which represent silicified corals. The major portion of the exposure is of a light-greenish color, but toward the bottom the clay becomes gray and is interbedded with thin nodular layers of limestone.

A light-green siliceous clay similar to that described above was seen on the west side of Old Tampa Bay, near Safety Harbor (Espiritu Santo Springs), where the section shows 4 to 6 feet of white Pleistocene sand resting unconformably on 6 feet of greenish clay. On the beach near this exposure are several large chert bowlders, which were probably derived from beds beneath the clay. About a mile north of the post office the following section was observed:

Section 1 mile north of Safety Harbor post office.

Sand, white (Pleistocene) . . . . . . . . . . . . . . . . . . . 2-4

Sand, dark brown, partly indurated $\ldots \ldots \ldots \ldots \ldots \ldots \ldots \ldots \ldots \ldots \ldots$

Clay, light greenish, thinly laminated $\ldots \ldots \ldots \ldots \ldots \ldots \ldots \ldots \ldots \ldots$ 
Numerous exposures of cherty limestone on the Gulf coast, near Clearwater, are probably to be correlated with the rocks at Tampa, but in the absence of paleontologic evidence this correlation must be regarded as merely tentative. A generalized section at this locality was obtained from well records and observations along the beach.

\section{Generalized section near Clearwater.}

Feet.

Sand, white (Pleistocene) . . . . . . . . . . . . . . . . . . . . . 12

Clay, light colored.................................... 14

Limestone, light colored; with chert concretions. . . . . . . . . . . $\frac{1}{2}-1$

Clay, bluish, laminated, marly; with chert concretions.......... 2-4

Limestone, light gray; with chert concretions.............. 2-3

A generalized section near Lapenotieres Spring is given by Dall: ${ }^{1}$

Generalized section near Lapenotieres Spring.

Humus, yellow sand, etc...................6-36 inches.

Tampa limestone........................

Orthaulax bed............................ 7 inches to 10 feet.

The limestone of the Tampa formation is exposed near the pumping station, where it has been quarried to a depth of over 15 feet, and at intervals along Hillsboro River for more than 15 miles inland. Probably the best exposures are in the excavations near the Sulphur Spring, northeast of Tampa, and at the rapids about a mile above the spring. The same limestone was observed resting on the "silex bed" at the railroad crossing over Sixmile Creek, where the limestone is immediately overlain by fossiliferous Pleistocene shell marl which grades upward into coarse white sand.

Section one-eighth mile below railroad bridge at Orient (Tampa).

Feet.

Marl, soft, white.............................. 6

Quartz sand, light gray to buff, fine grained.................. 3

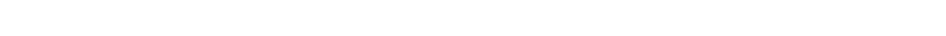

Limestone, white, soft, with some gastropods and other fossils...... 5

The shell marl is thin but persistent; it rests unconformably upon the limestone.

Section at railroad bridge at Orient (Tampa).

Feet.

Sand, fossiliferous, white......................... 2

Marl, white...................................... 6

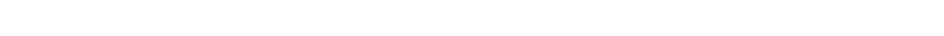

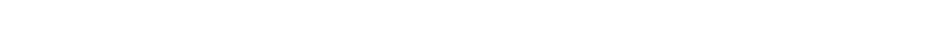

Limestone, gray to yellow; very fossiliferous in places......... 6

The shell marl rests unconformably upon the limestone and is evidently the bed shown in the preceding section. The limestone in both of these sections is what has commonly been called "Tampa limestone." In the section at the railroad bridge some "silex" near the base evidently represents the "silex bed" at Ballast Point. 
ALUM BLUFF FORMATION.

Members. - The name Alum Bluff formation as here used includes beds that belong stratigraphically above either the Chattahoochee or the Hawthorn formations and below the marls and limestones of Miocene age. This usage differs from that of Dall, ${ }^{1}$ who appears to have regarded the Chipola marl as distinct from the Alum Bluff formation. The Alum Bluff formation includes two different though closely related members, the Chipola marl and the Oak Grove sand. To these is added a third member, recently discovered by Vaughan ${ }^{2}$ in West Florida and called the Shoal River marl member, from the stream along which it is best exposed. The Chipola marl member and the sands of the type locality at Alum Bluff were first described by Langdon, who referred them to the Miocene. ${ }^{3}$

The type locality of the Chipola ${ }^{4}$ marl member is at McClelland's farm near Baileys Ferry on Chipola River, and the Alum Bluff formation is named from the bluff on Apalachicola River where it was first examined. The fuller's earth deposits which represent the Alum Bluff formation east of Apalachicola River have been mentioned by a number of writers, but the first comprehensive description of them was given by Vaughan ${ }^{5}$ in 1901. The Oak Grove sand member was described by Dall ${ }^{6}$ in 1893.

Exposures of limestone on Sopchoppy and Ochlockonee rivers, some 5 or 6 miles from the town of Sopchoppy, have been called "Sopchoppy limestone." This rock was first described by Dall," who assigned it to about the horizon of the Chipola marl member. In this report it is tentatively included with the Alum Bluff formation, but further investigation is needed to determine its exact stratigraphic relations.

The limestones and marls on Manatee River near Ellenton were thought by Heilprin ${ }^{8}$ to belong to the Miocene, but are probably somewhat older. They are here referred tentatively to the Oak Grove sand member of the Alum Bluff formation, but this correlation is subject to revision if subsequent investigations should show that the fauna is characteristic of some other horižon.

Stratigraphic position.-The Alum Bluff formation is conformable upon both the Chattahoochee and the Hawthorn formations. No distinct evidence of a stratigraphic break between these formations

1 Dall, W. H., Cenozoic geology along the Apalachicola River: Bull. Geol. Soc. America, vol. 5, 1894, p. 167.

2 Vaughan, T. W., unpublished notes.

3 Langdon, D. W., jr., Some Florida Miocene: Am. Jour. Sci., $2 d$ ser., vol. 38, 1889, p. 32.

4 Bul. U. S. Geol. Survey No. 84, 1892, p. 122.

5 Vaughan, T. W., Fuller's earth: Mineral Resources U. S. for 1901, U. S. Geol. Survey, 1902, pp. 921-948.

6 Bull. Geol. Soc. America, vol. 5, 1893, pp. 166-167.

7 Bull. U. S. Geol. Survey No. 84, 1892, pp. 119-120.

8 Heilprin, Angelo, Explorations on the west coast of Florida: Trans. Wagner Free Inst. Sci., vol. 1, 1887, p. 13. 
has been noted, and their faunas are closely related. At Alum Bluff on Apalachicola Biver and at Jacksons Bluff on Ochlockonee River marls of Miocene age rest upon an eroded surface of the Alum Bluff formation, but farther west, in Walton County, it is possible that they may be conformable.

Lithologic character.-The Alum Bluff formation consists of marl, sand, and clay, which are in places fairly distinct but are more commonly interbedded. Limestones also occur in the formation, but they are not extensively developed and commonly contain enough earthy material to form marls. Shell marls with a calcareous or sandy matrix are common, occurring in many places interbedded with nearly pure sand. In general the beds belonging to this formation are light gray, but sporadically shades of green or yellow prevail.

At Alum Bluff on Apalachicola River, Dall ${ }^{1}$ gives the following section:

Section at Alum Bluff on Apalachicola River.

Feet.

1. Superficial sands.............................. $8 \frac{1}{2}$

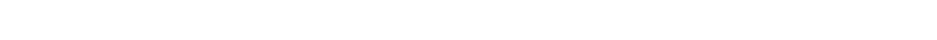

3. Reddish and yellowish streaked sands................ 66

4. Aluminous clay ................................. 24

5. Chesapeake gray marl. . . . . . . . . . . . . . . . . 35

6. Alum Bluff sands with streaks of clay . . . . . . . . . . . $21 \frac{1}{2}$

7. Hard Chipola marl to water (variable) $\ldots \ldots \ldots \ldots \ldots \ldots \ldots \ldots .3 \frac{1}{4}$

Total thickness above water. . . . . . . . . . . . . . . $160 \frac{3}{4}$

The composition in detail of these several beds is as follows:

No. 1.-Pale yellowish-gray incoherent sand.

No. 2.-Hard reddish clay, weathering with vertical face.

No. 3.-Streaky yellowish and reddish sands, with small little-worn gravel of siliceous character mixed with it. Near the lower third a few obscure impressions, possibly representing fossils, were observed by Mr. Stanley-Brown. The lower 3 feet of the sands is more or less loamy from admixture with underlying clay. They are distinctly stratified in conformity with the other beds of the bluff.

No. 4.- - Tough gray aluminous clay weathering nearly vertical, with a few fragments of vegetable matter in it and some obscure indications of gastropod and bivalve fossils, the shells entirely dissolved and represented chiefly by color marks in the clay. The appellation of "lignitic," heretofore applied to this clay on the authority of Mr. Johnson, can not be regarded as justified, as the amount of phytogene material is trifling. The fossils may have been marine or fresh water. No satisfactory evidence is afforded by their faint traces, as observed by us.

No. 5.-Bluish-gray tough clayey marl, replete with characteristic Chesapeake fossils, especially Mactra congesta. The upper 6 inches is discolored by iron oxide, derived from the water oozing from the bed above, which has also dissolved the shells, leaving only cavities. Toward the north, at a point near the camp, the Chesapeake is thinned to 5 or 6 feet in thickness.

Nos. 6 and 7.-The Chipola marl is compact and of a dark-reddish color from hydrated peroxide of iron contained in it. The fossils, which are abundant, are rather soft. Orthaulax is the most common shell; there are no traces of Orbitolites. The 
matrix is chiefly sand mixed with clay. At least 6 or 8 feet of the Chipola is below the water; it rises at the lowest stage of the river from 3 to 11 feet above the water's edge, weathering almost like a rock. There is no well-defined line of separation between the marl and the Alum Bluff sands (No. 6) above it, but the change takes place in a space of 5 feet, the lower portion of the sands containing more or less of the Chipola fauna. Above this they are mottled bright ferruginous and yellow and exhibit distinct marks of cross bedding. They contain sheets-laminæ or lenticular streaks of clay-which show abundant leaf remains resembling willows and other water-loving plants, while the sands in the lower part of the bed contain large leaves and stalks of palmetto or other palm-like vegetation, the thicker parts of which are reduced to the condition of lignite. These are too friable to remove without previous hardening applied in situ. The upper part of these sands did not show any fossil remains at the points where we examined them.

Toward the north, where the bluff is much lower and the "Chesapeake" thins out to 5 or 6 feet in thickness, the sands below it are unfossiliferous and modified. The upper part is more exclusively sandy, and lower down the bed has the clayey character and greenish color of the oyster marl at Rock Bluff, a few miles above; at the latter place, however, the green marl contained no fossils.

The typical Alum Bluff formation is composed of coarse, light greenish-gray to white argillaceous sands, which in many places show cross bedding and generally contain more or less interbedded clay and fuller's earth. One of the most characteristic features of the sands is the presence of innumerable flakes of white micathe "isinglass" of the well diggers. The change from the shell marls of the Chipola marl member is by a transition zone which contains some of the same species of shells which characterize the marls. This zone also contains nodules of calcium carbonate, many of which inclose fossils. The upper part of the sands is usually free from shells but here and there contains impressions of leaves and fragments of plants. Locally, the Alum Bluff formation contains some clay, and near Chattahoochee it consists of greenish sticky marl.

The fuller's earth has the appearance of a dense, hard, fine-grained, siliceous clay. It is thinly laminated, and is generally light gray to greenish in color. Sand partings occur in places, but they are comparatively scarce, the material usually being homogeneous. Beds of sand and clay are commonly associated with the fuller's earth, and the sections generally consist of interbedded sand and clay.

Thickness.-The aggregate thickness of the Alum Bluff formation is at least 135 feet, but the maximum thickness observed at any locality is scarcely one-half that amount. The thickness of the sands of the Alum Bluff formation at the type locality is about 20 to 25 feet, but farther north, at Rock Bluff, Dall ${ }^{1}$ reports a maximum of 63 feet. The fuller's earth generally occurs in beds 2 to 10 feet in thickness associated with several feet of clay and sand or sandstone. In

1 Dall, W. H., and Stanley-Brown, Joseph, Cenozoic geology along the Apalachicola River: Bull. Geol. Soc. America, vol. 5, 1894, p. 166. 
some sections two or more beds of fuller's earth occur, separated by beds of sand and clay. The maximum observed thickness of fuller's earth in a single section is about 15 feet, and the aggregate thickness of the associated clays and sand which appear to belong to the same beds is not less than 20 feet.

Physiographic expression.-The members of the Alum Bluff formation, with the exception of the Chipola marl member, are soft and easily eroded into deep valleys but are sufficiently resistant to form steep slopes. Thus the region where the Alum Bluff formation lies near the surface is characterized by a topography that has been formed by surface erosion and that is in marked contrast to the sinkhole topography of the central part of the peninsula. However, wherever the formation is thin, solution has given rise to many sink holes and the topography is a composite of valleys and poorly drained depressions.

Paleontologic character.-As already noted, the typical sands and clays of the Alum Bluff formation are sparingly fossiliferous, the lower part containing a fauna allied to the Chipola marl member and the upper part being characterized by plant remains. The fuller'searth beds contain a very poorly preserved fauna, from which Vaughan ${ }^{1}$ secured enough material to show that they belonged to the Alum Bluff formation. He also notes the fact that these beds contain Carolia floridana Dall, which is characteristic of the Apalachicola group. Both the Oak Grove sand member and the Shoal River marl member are very fossiliferous.

Structure.-The Alum Bluff formation shows no marked peculiarities of structure. Though it has undoubtedly been affected by some of the movements which resulted in the general arching of the strata of the State, the disturbance has not produced any effect, except to give a general seaward dip to the beds. If any local deformation has produced folding of the beds belonging to the Alum Bluff formation, the existence of the folds has not yet been detected. However, this may be due to the imperfect exposures.

Areal distribution.-Micaceous white sands belonging to this formation are well exposed on Tenmile Creek at Carrs Mill, Calhoun County, and at intervals for about a mile farther upstream, where they consist of coarse light-gray sands containing many flakes of silvery-white mica. Upon weathering, the sand changes to a pale-yellow color from the presence of hydrated iron oxide. The sands show some evidence of cross bedding and appear to be destitute of organic remains. Similar sands are reported in wells farther west in Walton County, and exposures were noted beneath the Shoal River marl member near Knoxhill, Walton County.

Vaughan, T. W., Fuller's earth: Mineral Resources U. S. for 1901, U. S. Geol. Survey, 1902, pp. 926-932. $76854^{\circ}$ - WSP $319-13-8$ 
Vaughan's investigations ${ }^{1}$ have shown that the fuller's-earth beds are the stratigraphic equivalent of the sands at Alum Bluff. About 4 miles southeast of River Junction at an abandoned fuller's earth mine belonging to Mr. Hymeson, Vaughan reports the following section:

\section{Section 4 miles southeast of River Junction.}

Feet.

4. Surface sands, beneath which are reddish sands containing some quartz gravel................................... 60

3. Clay, stiff, blue; the top of the fuller's earth deposit........ 4

2. Fuller's earth. A considerable amount of the overburden had been thrown off, but due to weathering and wash there is really no good exposure. Judging from what can now be seen, according to a roughly leveled section, it seems that the deposit is at least 8 feet thick, and it may be thicker. There is no means of determining its horizontal extent. A box of the earth was collected from the best exposure....................

1. Immediately beneath the fuller's earth there appears to be a deposit of sandy, very stiff blue clay. Thickness unknown.

The following is the generalized section, according to aneroid readings made in the vicinity of River Junction:

\section{Generalized section near River Junction.}

Feet.

Surface sands..................................... 60

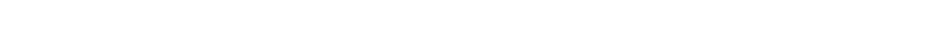

Not exposed; probably argillaceous sands................. 17

Chalk or limestone; some layers of marl (Chattahoochee)........ 88

The rocks beneath the Chattahoochee formation are not exposed near River Junction.

The inference from this section apparently would be that the Chattahoochee formation is $88+$ feet in thickness and is separated by 17 feet of unexposed strata from the deposit of fuller's earth above. This would stratigraphically correlate the fuller's earth with the Alum Bluff formation.

The following detailed description and section of Rock Bluff on Apalachicola River was published by Dall and Stanley-Brown. ${ }^{2}$ The writer is of the opinion that the fuller's earth stratum corresponds to No. 3 of their section:

The lower part of the bluff formed by the Chattahoochee is vertical, rising 12 feet above the water, and presumably nearly as much below it at low stages of the river. Above this is a mass of marl varying from bluish green to gray in color, weathering white, more arenaceous below and more marly above, replete with oyster shells, a fine, large Anomia, a Pecten, like young madisonius (but, as observed by Foerste, only four-sevenths the size of that species; it is really a Chipola species), a Turritella, and many Balani. This assemblage of species indicates a shallow-water oyster-reef fauna unquestionably belonging to the "old Miocene" (Apalachicola group) and forming

I Fuller's earth: Mineral Resources U. S. for 1901, U. S. Geol. Survey, 1902, pp. 926-927.

2 Bull. Geol. Soc. America. vol. 5, 1894, pp. 155-156. 
the shoal-water equivalent of the Chipola and Alum Bluff beds, especially the latter. Above this marl lie the red Lafayette clays and gravels-in this case worked-over materials-variable in thickness, owing to denudation, but apparently averaging about 15 feet, and covered with a thin layer of superficial soil and sand. This section was carefully measured with a steel tapeline, due allowance being made for the inclination of the tape from the vertical. It shows the finest and thickest section of the greenish marl exposed anywhere on the river. The contact of the marl with the Chattahoochee limestone is distinct and without apparent unconformity or transition beds of any kind.

This section was measured on the highest part of the bluff, which is the first approached as the turn of the river is made in descending:

\section{Section at Rock Bluff, Apalachicola River.}

- Feet.

1. Superficial sands, thin and variable, say............... 3

2. Reddish clayey sand and gravel, about ................ 15

3. Greenish-white compact marl, with fossils................ 67

4. Chattahoochee limestone, to water................... 12

Total thickness above water.................... $\overline{97}$

The list of fossils given under the head of paleontologic characters indicates the correctness of the conclusions reached on the bases of purely stratigraphic work, for they show that the fuller's earth beds are to be correlated with the Alum Bluff formation.

In 1900 the fuller's earth deposits of northern Florida were investigated by Vaughan, ${ }^{1}$ and the results of his studies were published in Mineral Resources of the United States for 1901. He says:

There is an exposure of fuller's earth on the south bank of Mosquito Creek, near the foot of a bluff, on land belonging to Mr. John D. McPhaul. The overburden is here too great for working. The deposit is along a small stream running north into Mosquito Creek in the NW. $\frac{1}{4}$ sec. 16, T. 3 N., R. 4 W. A sample was taken at this locality where a pit had been sunk.

A section in the pit shows overburden (sand), 4 feet; fuller's earth, 6 feet. . The bed was not completely penetrated.

The material was also exposed in the bed of a creek near by. The slope down to the creek valley is gradual. A strip several hundred yards wide and probably half a mile long could be worked. Fuller's earth occurs also on the land of Mr. A. J. Key, in sec. 15, T. 3 N., R. 4 W.; and on the land of Mr. Elias Howell, in sec. 10, T. 3 N., R. 4 W., and extends also along the creek about one-half mile below Mr. McPhaul's.

The following is a section through the fuller's earth at the Chesebrough Manufacturing Co's. mine, 1 mile south of Quincy. The section was given by T. L. Ward.

\section{Section of Chesebrough Manufacturing Co's. mine.}

Feet.

5. Overburden of clay and sands...................... 7

4. Fuller's earth (average) $\ldots \ldots \ldots \ldots \ldots \ldots \ldots \ldots \ldots \ldots \ldots \ldots$

3. White argillaceous sandstone containing fossils............ 5

2. Fuller's earth............................... 9

1. Soft sandstone, sand, and fuller's earth . . . . . . . . . . 15

1 Vaughan, T. W., Fuller's earth: Mineral Resources U. S. for 1901, U. S. Geol. Survey, 1902, pp. $926-932$. 
It is estimated that there are about 10,000 tons to the acre. The mine was visited in company with Mr. Ward. About 2 acres have been mined, and 20,000 tons were taken out. Mr. Ward states that operations were begun in 1895 and closed down in December, 1899, because the Standard Oil Co. had sufficient earth on hand for the present. Bed No. 3 contains numerous poor fossils. Several species were collected, of which the following is a list:

Cypræa, agreeing in form and size with $C$. pinguis Conrad from the Chipola horizon; Murex mississippiensis Conrad? var.; Fulgur spiniger Conrad?; Modulus sp.; Crucibulum auricula Gmelin; Arca staminata Dall; Pecten (Nodipecten?) sp.; Cardita serricosta Heilprin, and Chione sp.

These fossils indicate an upper Oligocene horizon, corresponding stratigraphically with No. 3 of Dall and Stanley-Brown's Rock Bluff section, which was given on a preceding page.

A specimèn of Carolia floridana Dall, from the fuller's earth horizon at Quincy, is in the United States National Museum. This is considered an index fossil of our upper Oligocene.

An examination of the section at the Owl Commercial Co's. mine disclosed the following exposure:

Section of the Owl Commercial Co's. mine.

Feet.

Overburden. . . . . . . . . . . . . . . . . . . . . . .

Fuller's earth............................... 6-10

Sandstone containing crystals and lumps of calcite or aragonite... 3-4

Fuller's earth............................... 6

The mining is done by stripping.

Fuller's earth occurs along Quincy Creek above the Owl Commercial Co's. works, about $1 \frac{1}{2}$ miles west of Quincy, on land belonging to Mr. William Bruce, in sec. 12, T. 2 N., R. $4 \mathrm{~W}$. A specimen taken from an auger bore was donated by $\mathrm{Mr}$. Bruce. The overburden along the creek flat is 4 or 5 feet thick. Mr. Bruce also donated some pieces of the material which came from a pit that is at present filled with water. A pit has also been dug in sec. 2, T. 2 N., R. 4 W., on land belonging to Messrs. Taussig and Wedeles. Some pieces were picked up out of the dump around this hole. The overburden is from 4 to 5 feet thick, the same as on Mr. Bruce's land.

The fuller's earth in these localities has not been thoroughly explored. It seems to be of good quality, the overburden is not great, and the land is flat. Transportation by railroad is within one-half to three-fourths of a mile. From what Mr. Bruce says, the deposit is thick enough for profitable working-about 8 feet.

[In Leon County] 12 miles west of Tallahassee, on property belonging to Messrs. W. H. Allen \& Sons, are occurrences of fuller's earth. Several pits have been sunk by Mr. Rosendale. The overburden is about 6 feet, and there are about 8 feet of fuller's earth. The writer was not able to get fresh specimens, hence pieces from the dump were selected. The land lies rather flat, along a small creek running into Ochlockonee River.

A section on the Seaboard Air Line Railway, about 1 mile east of Tallahassee, at milepost 163, shows the following exposures:

\section{Section on Seaboard Air Line Railway.}

The upper 25 or 30 feet at the ends of the cut are reddish, yellowish sands.

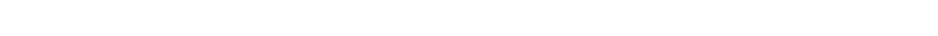

Whitish or bluish clay resembling fuller's earth in thin laminæ with sand partings. . . . . . . . . . . . . . . . . 
In a curve in the railroad track between mileposts 163 and 164 is another cut between 15 and 20 feet deep, and the same section as above described was again seen. The clay at the base resembles more closely fuller's earth than in the firstdescribed section. It contains less sand.

A fuller's earth horizon is also mentioned in the Jacksons Bluff section, which is included under the discussion of the Miocene.

On the bank of Ochlockonee River, a mile north of Holland post office, there is an exposure of hard light-gray limestone, which was formerly quarried. The surface is now almost obscured by débris, but it is still possible to find small exposures which indicate that the beds are at least 12 feet thick. The upper 4 feet contain many specimens of Carolia floridana Dall, but the remainder of the outcrop is conglomeratic and appears to be almost destitute of fossils.

A record of a well sunk by J. A. Henderson near the western limits of Tallahassee was furnished by Vaughan. It shows 25 feet of sands and clays, underlain by 75 feet of limestone containing clay layers.

The limestone furnished Ostrea rugifera Dall, Pecten chipolanus Dall, Anomia sp.

On Rouses Mill Creek, near West Sopchoppy, about 10 feet of soft light-gray sandstone is exposed. The rock is friable and resembles the Alum Bluff formation in texture. A few fossils occur in the sandstone, but they are too friable to obtain good specimens, only one identifiable specimen of Pecten madisonius var. sayanus Dall having been obtained.

At West-Sopchoppy there is a bed of very fossiliferous marl which probably lies stratigraphically above the soft sandstone at the mill. The marl contains some material like that at the mill, but is much more calcareous and contains many shells. The thickness of the outcrop is about 10 feet, but the base of the marl is not exposed, and hence its maximum thickness may be considerably greater. The marl furnished specimens of Carolia floridana Dall and Scutella sp.

In addition to the localities given above, the Alum Bluff formation is exposed at numerous localities.

An exposure at White Springs, on Suwannee River, is referred to the Alum Bluff formation. The section given below was measured with a hand level at the point where the wagon bridge spans the river.

Section at White Springs, on Suwannee River.

1. Loam, dark colored, sandy

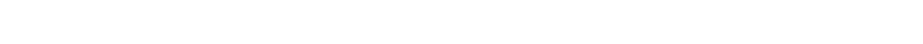

3. Unconformity.

4. Clay, greenish, thinly laminated, siliceous.............. 8

5. Sand, light yellow, containing many casts of shells......... 17

6. Sand, fine grained, light gray ...................... 11

7. Marl, ljght gray, arenaceous and calcareous, sandy.......... 51 
Feet.

8. Marl, light gray, arenaceous, with nodules of chert ..........

9. Sand, bluish, and light-green sticky marl containing thin layers of limestone in alternating beds, nodules of chert, and some imperfect oyster shells.............................

10. Sand, gray, with thin nodular and brecciated layers of limestone.

11. Sand and light-gray shell marl in alternating beds; many wellpreserved fossils near base of section...................

River level reported 4 feet above low-water stage.

Nos. 1 and 2 of the foregoing section are the ordinary surface sand which covers a large part of the State.

Nos. 4 to 11 , inclusive, probably belong to the Alum Bluff formation.

From the material collected near the base of No. 11 Vaughan identified Ostrea rugifera Dall, Pododesma scopelus Dall, and Pecten madisonius var. sayanus Dall.

On Ochlockonee River, about one-fourth mile above Stuarts Bridge, thinly laminated, light-gray to white marl outcrops with a thickness of about 6 feet. The material is so brittle that it was difficult to secure fossils.

Rocky Bluff, on Manatee River, about a mile from Ellenton, was visited by Heilprin, ${ }^{1}$ who says:

The "Bluff" we found to be a ledge of rock, rising 2 or 3 feet above water level at the time of our visit, and consisting of at least two well-defined layers-a basal white "marl" and yellowish sandstone and an overlying siliceous conglomerate. The latter is almost entirely deficient in organic remains, whereas the marl is densely charged with them. Among the recognizable forms occurring here I determined a number of well-known and distinctive Miocene species of mollusks, such as Pecten jeffersonius, $P$. madisonius, Perna maxillata, Venus alveata, Arca incongrua, etc., which left no doubt as to the age of the deposits in which they were embedded.

The exposures in the vicinity of Ellenton are of considerable interest because they contain valuable deposits of fuller's earth. Three-fourths mile southeast of Ellenton a section was measured which showed the following beds:

Section three-fourths mile southeast of Ellenton.

Feet.

Loam, dark gray to black, sandy ................... $4-6$

Sand, dark colored, clayey, containing chert pebbles, worn and rounded fragments of bones, and shark teeth. "Clam" shells are said to occur in this bed, but none could be found .......... 0 - 2

Unconformity.

Fuller's earth, dense, thinly laminated, light gray, weathering pale yellow................................. 5

9-16

About one-fourth mile farther east another exposure shows thinner beds of fuller's earth and underlying limestone. 
Section at Rocky Bluff, about a mile southeast of Ellenton.

Loam, light and dark gray, sandy, about................ Feet. 1

Loam, black, clayey, with bone fragments................. I

Unconformity.

Fuller's earth, light gray.......................... $2-3$

Limestone, dense, light gray to pale yellow, impure, fossiliferous $\ldots .\left\{\begin{array}{l}{ }^{1} 4 \\ 29\end{array}\right.$

$14+$

The material which Heilprin ${ }^{3}$ called sandstone appears to be a coarse-grained sandy limestone. Shells and fragments of bone are numerous in certain stratums, but the rock is so brittle that it is difficult to get good collections. The presence of Turritella alcida Dall and Pecten madisonius var. sayanus Dall have led to this limestone being referred to the Alum Bluff formation, but larger collections may show that it belongs to some other subdivision of the Apalachicola group. The exact relation of the fuller's earth bed to the limestone was difficult to determine, though it is apparently conformable; and if so, it belongs to the Oligocene. Heilprin's reference of the exposures at Rocky Bluff to the Miocene appears to have been an error, unless he intended to use the term Miocene, in the sense in which it was formerly employed, to include the Apalachicola group of the Oligocene.

Chipola marl member.-The Chipola marl member forms the basal portion of the Alum Bluff formation and rests conformably on the Chattahoochee and the Hawthorn formations. At the type locality of the Alum Bluff formation it constitutes the basal division of that formation, but farther north it thins out, permitting the sandy beds of the Alum Bluff to lap over on the Chattahoochee formation. This overlap is probably explained by the gradual shoaling of the water, which prevented the development of abundant organic life toward the north. As the sands were deposited farther south they gradually encroached upon the area where marl had previously been forming. According to this hypothesis, there would be no necessity for an erosion interval between the Chattahoochee and the Alum Bluff formations, as a gradual emergence of the land or a filling of the shallow water along the margin of the sea would permit the deposition of sands upon the limestones and marls.

When fresh the Chipola marl member consists of a light-gray to yellow marl, containing many shells and shell fragments. The matrix is composed of calcareous clay containing a small proportion of fine sand. When weathered the marl becomes dark-yellow or reddish-yellow from the presence of hydrated iron oxide. The character of the deposit indicates comparatively quiet water with 
conditions especially favorable for the development of organic life. In some localities, as at White Springs on the Suwannee, the Chipola is represented by a very sandy marl. The "Sopchoppy limestone," which Dall has assigned to the Chipola marl, varies from a soft white or light-gray to a dense gray limestone, some of which is cherty. Some beds of soft sandstone are doubtfully referred to this stratum. The beds contain layers which appear to have been broken and recemented, thus forming a brecciated limestone which is said to be somewhat phosphatic. Locally the rock is abundantly fossiliferous, containing imprints of shells and fragments of bones.

The Chipola marl member of the Alum Bluff formation is not known to have a thickness of more than 15 feet and the average is probably only a few feet. The limestone belonging to this member is so imperfectly known that it is difficult to make a satisfactory estimate of its thickness. The maximum reported exposure is about 10 feet.

The fossils of this member have been studied by Dall,, who says:

The fauna comprises 333 species, to which we may expect additions on further exploration. A species of Orthaulax different from that found in St. Domingo or the Tampa Orthaulax bed, a rich development of the genus Marginella, a species of the group of Oliva called by von Martens Omogymna, a species of Spheniopsis, heretofore only known from the European Oligocene; these are among the interesting features of the fauna.

The group of species is distinctly subtropical but less indicative of warm seas than the Bowden marl of Jamaica, with which the Chipola beds have 16 species in common. Only one species is known to be found both in the Chipola beds and the Oligocene of St. Domingo. About half the species in the Chipola marl are peculiar to it, and of the others the largest percentage is found in the Tampa silex beds, while in the subsequent Oak Grove sands 24 per cent of the Chipola species occur. Thirty-five species survive to the existing fauna.

According to Dall ${ }^{2}$ the "Sopchoppy limestone" contains orbitolites and "about 30 species of shells, most of which are common to the Chipola marl or the Orthaulax beds." Judging from the presence of fragments of bones occurring in this limestone at some localities, a vertebrate fauna of considerable size is doubtless represented, but no attempt has been made to secure collections and hence its characteristics are unknown.

The type locality of the Chipola marl member is the McClelland farm, which is situated on the west side of Chipola River just south of Tenmile Creek. Here the marl was formerly mined, but at the present time the pit is covered with sand and débris, so that the deposit can only be reached by digging. The section given by Dall ${ }^{3}$ is as follows:

\footnotetext{
I Dall, W. H., Trans. Wagner Free Inst. Sci., vol. 3, pt. 6, 1903, pp. 1574-1575.

2 Bull. U. S. Geol. Survey No. 84, 1892, p. 120.

3 Dall, W. H., Bull. Geol. Soc. America, vol. 5, 1894, p. 159.
} 
Section on the McClelland farm, on Chipola River.

Superficial sands, 1 to 3 feet, say...................... $\begin{array}{r}\text { Feet. } \\ 2\end{array}$

Chipola marl, varying from........................ $7-12$

Chattahoochee limestone at water's edge, extending below not less than ...................................... 6

The marl is exposed on the north bank of Tenmile Creek, where it attains a thickness of 6 to 12 feet, and is underlain by the Chattahoochee formation, which is exposed at a natural bridge 200 or 300 yards farther downstream. At this locality the marl has the same general characteristics as in McClelland's marl pit. Other small exposures are reported on Chipola River, near the McClelland farm, and at the base of Alum Bluff.

Oak Grove sand member.-On paleontologic grounds Dall ${ }^{1}$ has correlated the Oak Grove sand member with the typical sands of the Alum Bluff formation. The correlation ${ }^{2}$ has been made because of the presence in both of Ostrea trigonalis, Pecten sayanus, a Pododesmus, and Turritella alcida Dall.

The Oak Grove member consists of fine-grained, light-gray to greenish sands containing many excellently preserved shells. It is a sandy shell marl, which in many places has a considerable admixture of calcareous material. Some soft marly limestones on Manatee River are tentatively referred to this member. The Oak Grove member is not fully exposed at the type locality and may attain a thickness of several feet, but its observed thickness is only a few feet.

The fauna of the Oak Grove member is closely related to that of the Chipola marl member, but it contains large species of both Cardium and Lyropecten, which appear to foreshadow the large species of those genera occurring in the Miocene marls.

Owing to the heavy rains, the Oak Grove sand member was submerged at the time that locality was visited. The exposure is said to be less than 4 feet in thickness and to consist of light-gray extremely fossiliferous sand. The type locality was subsequently examined by Vaughan, who reports the following section:

Section of bluff, Yellow River, about 100 yards below road bridge.

Sands, fine, yellow........... Feet.

Marl, very fossiliferous, gray, sandy, extending at least 1 foot below

level of water in the river............................. 2

1 Bull. Geol. Soc. America, vol. 5, 1894, pp. 166-167, 170.

2 Trans. Wagner Free Inst. Sci., vol. 3, pt. 6, 1903, X. 1588. 
The fossiliferous marl forms a platform 20 to 30 feet wide along the base of the bluff, sloping (at the present stage of the water) from 2 feet next the bluff to 1 foot along the river edge above the water. The surface in places is practically covered with shells freed from the matrix. The weathered marl is an ashy gray but when fresh is dark bluish.

Vaughan also examined the exposure at Senterfitt Creek, which he describes as follows:

After studying this exposure [Oak Grove, Yellow River], and collecting from it, I drove to the Senterfitt gristmill and revisited the exposure from which I collected in May, 1903. The latter locality is by aneroid 30 feet above the fossil bed at the Oak Grove Bridge and is 2 miles northeast of that locality. The marl bed on Senterfitt Creek is therefore stratigraphically slightly above the Oak Grove horizon.

The Senterfitt horizon seems very persistent, extending at least from the Ýllow River to Argyle.

Vaughan also examined an exposure of marl on the south side of the river at Crowders Crossing in sec. 5, T. 3 N., R. 21 W. At this locality a blue or bluish-green marl rises about 2 feet above the river at a very low stage of water. This exposure is probably the stratigraphic equivalent of the Oak Grove sand member.

Shoal River marl member.-The Shoal River marl member lies stratigraphically about 30 feet above the Oak Grove sand member. It thus forms the upper part of the Alum Bluff formation. In the following section at Shell Bluff, the lower sand represents the Oak Grove sand member and the upper fossiliferous marl the Shoal River marl member.

\section{Section at Shell Bluff.}

Gravel, mostly quartz, in rather coarse red sands, on slope; gravel ellipsoidal, one-half inch probably usual length, rarely 1 inch.. 30

Sand, gray, finẹ, blotched yellow, decidedly argillaceous...... 10 1 Shell marl, greenish; matrix arenaceous, fine, fossiliferous (Shoal

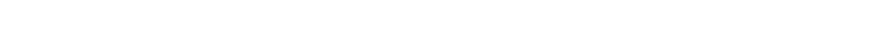

Sand, nonfossiliferous, coarser, greenish; becoming argillaceous at base....................................... 3

Clay, green.......................................

Sands, coarser, gray, greenish; last $2 \frac{1}{2}$ feet loose, purple and white. 6

Unexposed....................................... 15

Sands, nonfossiliferous, green, oxidized yellowish on surface (Oak

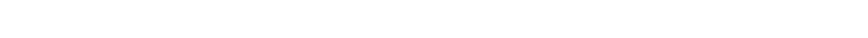

$80 \pm$

Lithologically the Shoal River marl member consists of interbedded sands, clays, and marls. In most places the color is greenish, oxidizing yellow; in a few it is whitish or purplish. The material varies from fine clay to sand.

The Shoal River marl member of the Alum Bluff formation is about 50 feet thick. It is very fossiliferous; extensive collections from it have been made by Vaughan but have not yet been studied 
in sufficient detail to permit comprehensive statement concerning the fauna.

In addition to the type locality, the Shoal River marl member is exposed at numerous localities in Walton County. It outcrops in the valleys on the west side of Choctawhetchee River in the vicinity of Knoxhill and westward in the vicinity of Eucheeanna. It is also reported southwest of De Funiak Springs. A well on the farm of Niel Campbell near Knoxhill penetrated the following beds:

Record of well on Campbell farm near Kn:shill.

Feet.

Clay, yellow, sandy ................................. 16

Shell marl, blue (Shoal River member) .................. 12

Sand, white, micaceous; with many shells and some sharks' teeth

(Oak Grove member?)........................ 8

36

Fossils obtained at a depth of 33 feet from Divid George's well, 9 miles southeast of De Funiak Springs, seem to show the presence of the marls belonging to the Shoal River member; and what is probably the same marl is exposed on Folks Creek $1 \frac{1}{2}$ miles southwest of David George's house. The Shoal River member was discovered in digging a mill race, about a mile east of Argyle. At this locality the following section was measured by Vaughan:

Section a mile east of Argyle.

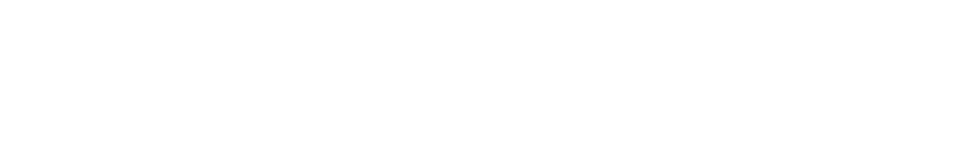

Other localities mentioned by Vaughan are (1) north side of the river, at the head of the first draw below Sh.ll Bluff; about 400 yards northwest of the bluff and 200 yards from the river; (2) along the south side of Adams Mill Creek, near the top of a low bluff; and (3) on Hulion Mill Creek (sec. 7, T. 3 N., R. 21 W.).

\section{MIOCENE SERIES.}

NOMENCLATURE AND SUBDIVISIONE.

The first account of Miocene rocks in Florida was published in 1881, when Smith ${ }^{1}$ made known the results of investigations carried on in connection with the statistical work for the Tenth Census of the United States. Smith's original Miocene locality is in Orange County at Rock Springs, where he collected a series of fossils, identified by Heilprin as Miocene, from an exposure of soft limestone. Dr. Smith did not make any attempt to correlate the Miocene at Rock Springs with that at any other locality nor did he give the beds a local name. 
As already noted in the discussion of the Oligocene, the term Miocene was used for some time to designate all the rocks in this region belonging stratigraphically between the Vicksburg group (then called Eocene) and the known Pliocene and Quaternary. During that period the Apalachicola group (upper Oligocene) was known as the "old Miocene" or "subtropical Miocene" and the true Miocene was discriminated by the use of such terms as "newer Miocene," "cold-water Miocene," or "Chesapeake Miocene." As early as 1897 paleontologic studies ${ }^{1}$ determined the proper correlation for the rocks of Oligocene age and thus left in the Miocene that portion formerly known as "new Miocene" or "Chesapeake Miocene." This usage is in accordance with the later papers of Dall."

To the beds of true Miocene age $\mathrm{Dall}^{3}$ gave the name Chesapeake group. This name was originally proposed by Darton ${ }^{4}$ for Miocene beds of Maryland and Virginia bordering on Chesapeake Bay and belonging to Dana's Yorktown epoch. Chesapeake, as used- by Darton, is the name of a formation, but it was subsequently used by Dall to include a number of beds which he designated the Chesapeake group.

The term Chesapeake group, as independently suggested, here includes as typical Darton's Chesapeake formation and also all other beds belonging to the same horizon and containing the same general fauna on the Atlantic and Gulf coasts of the United States. ${ }^{5}$

In accordance with the usage proposed by Dall, the name Chesapeake is a general term to include all the Miocene of the Coastal Plain.

In 1894 Dall ${ }^{6}$ divided the "Chesapeake" of Florida into two formations, which he called Jacksonville limestone and Ecphora bed. In a subsequent paper by the same author these two divisions are placed together. ${ }^{7}$

After the elimination of the Oligocene series from the so-called Miocene of Florida, we have remaining practically only one series of beds which have been identified over a considerable area of northern Florida. The Miocene appears as a soft limestone rock in the vicinity of Jacksonville and has been traced by material from artesian wells on the east side of the peninsula as far south as Lake Worth. The layers of fossiliferous marl in the vicinity of Chipola River, at Alum Bluff, and other localities in western Florida are usually less than 30 feet in thickness, but counting unfossiliferous clays, etc., it has been estimated that the rocks of this age in Florida may have attained to a thickness of some 500 feet or less.

1 Dall, W. H., Descriptions of Tertiary fossils from the Antillean region: Proc. U. S. Nat. Mus., vol. 19, No. 1110,1896 , p. 303.

2 Eighteenth Ann. Rept. U. S. Geol. Survey, pt. 2, 1898, p. 329; The Floridian Miocene: Trans. Wagner Free Inst. Sci., vol. 3, pt. 6, 1903, p. 1594.

${ }^{3}$ Bull. U. S. Geol. Survey No. 84, 1892, p. 122.

4 Darton, N. H., Mesozoic and Cenozoic formations of eastern Maryland and Virginia: Bull. Geol. Soc. America, vol. 2, 1891, pp. 443-445.

5 Dall, W. H., Bull. U. S. Geol. Survey No. 84, 1892, p. 123.

Tdem, p. 124.

7 Trans. Wagner Free Inst. Sci., vol. 3, pt. 6, 1893, p. 1594. 
In Florida the limestones, clays, and sandstones of the Miocene are lithologically so unlike the shell marls that in the absence of satisfactory paleontologic evidence for their exact correlation it seems best to describe them separately. The two divisions are therefore retained, but a new name is given to the marl. The Ecphora bed of Dall is here called the Choctawhatchee marl from the river in western Florida, where it is well exposed. At Dall's type locality the Jacksonville formation is known only from well records and excavations; hence the name is not entirely satisfactory. However, the United States Geological Survey has decided to retain Jacksonville as the name of the formation, because (1) it is reasonably well fixed in the literature and (2) the type faunas were collected at Jacksonville. The existence of exposures on Black Creek, however, would have led to the adoption of another name if Jacksonville had not already been used. The samples of rock from wells on the east coast indicate that the limestone beds are thin and form only a minor part of the Miocene in that portion of the State; hence the word formation is here substituted for limestone.

JACKSONVILLE FORMATION.

The Jacksonville formation was first recognized by Dall, who . obtained samples of the rock, together with fossils showing its age, from an excavation at the Jacksonville waterworks. ${ }^{1}$

Stratigraphic position.-The Miocene beds lie stratigraphically between the underlying Oligocene and the overlying Pliocene and Pleistocene formations. From well records and samples obtained along the east coast of Florida, the Jacksonville formation appears to rest unconformably on the eroded surface of the limestones of the Vicksburg group at Jacksonville, St. Augustine, and other localities. Farther west it probably rests on the beds belonging to the Apalachicola group, but no contacts were observed.

Lithologic character.-When fresh the limestone of the Jacksonville formation varies in color from light gray to nearly white; but on weathering it changes to pale yellow or yellowish gray. It generally has a porous texture but in some places is hard and dense. Much clear quartz sand may be easily distinguished by the use of an ordinary hand lens, and microscopic examination shows a large amount of clayey material that varies in color from light gray to pale yellow. At certain horizons fossils are very abundant, but most of the shells have been dissolved, leaving nothing but casts or molds; and this fact, together with the friable character of the rock, makes it very difficult to obtain satisfactory collections. However, enough material has been obtained to indicate the Miocene age of the rock. Unlike the 
Choctawhatchee marl, the Jacksonville formation appears to contain practically no mica. It also differs from the marl in its relatively higher percentage of lime and a correspondingly lower percentage of sand.

Although the Jacksonville formation is fossiliferous the organic remains are less numerous and in a much poorer state of preservation than in the Choctawhatchee marl. An examination of well samples shows that limestone forms only a minor part of the formation, a fact well illustrated by a well at Jacksonville, in which the formation attains a thickness of about 500 feet and is composed largely of arenaceous and siliceous beds. From samples obtained in drilling a well at Jacksonville the clays are known to be siliceous and the hard materials described as gravel found to be chert nodules. Some of the beds consist of a hard gray siliceous rock which appears to have been formed by the replacement of the calcareous portion of a sandy limestone by silica probably derived from organic remains such as sponge spicules and diatoms. A detailed log of the Jacksonville well is given below:

Log of well at Jacksonville waterworks.

\begin{tabular}{|c|c|c|}
\hline & Thickness. & Depth. \\
\hline & Feet. & Feet. \\
\hline Filled ground and sand....... & 15 & 15 \\
\hline Sand, varicolored, gray to red... & 19 & 34 \\
\hline 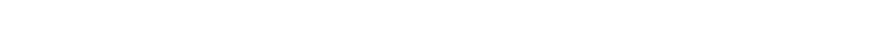 & $\frac{1}{2}$ & $34 \frac{1}{2}$ \\
\hline Rock, yellowish, fossiliferous . & $5^{2}$ & $40^{2}$ \\
\hline Gravel; with water & 4 & 44 \\
\hline Rock, gray, fossiliferous & 9 & 53 \\
\hline Clay; with thin layers of white rock ${ }$ & 5 & 58 \\
\hline Clay, blue; with black gravel at $58-70$ and $82-89$ feet. . & 31 & 89 \\
\hline 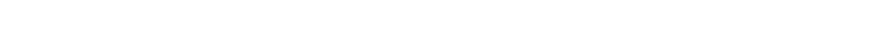 & 5 & 94 \\
\hline Clay, blue; with black gravel. & 6 & 100 \\
\hline Rock (2 inches thick) & & 100 \\
\hline 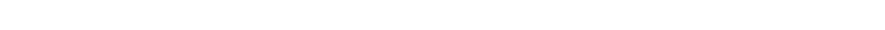 & 30 & 130 \\
\hline 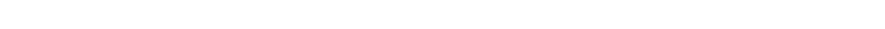 & 12 & 142 \\
\hline 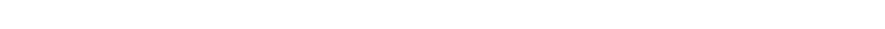 & 58 & 204 \\
\hline Clay, greenish, sandy; with more or less black gravel and some streaks of pure clay. & 46 & 250 \\
\hline 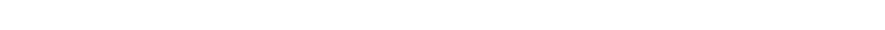 & 13 & 263 \\
\hline 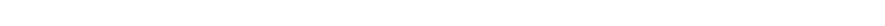 & & $263 \frac{1}{2}$ \\
\hline Clay, greenish, sandy; with heavy gravel bed $\ldots \ldots \ldots \ldots \ldots \ldots \ldots \ldots \ldots \ldots \ldots \ldots$ & & 272 \\
\hline 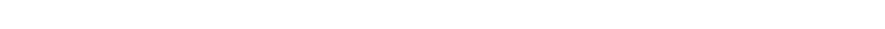 & $15^{2}$ & 287 \\
\hline 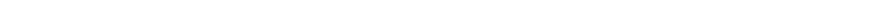 & 2 & 289 \\
\hline Shells, oysters, etc., living types.......... & 1 & 290 \\
\hline 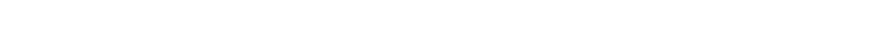 & 4 & 294 \\
\hline 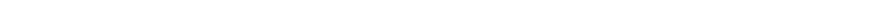 & 4 & 298 \\
\hline Clay, compact, greenish, sandy; with streaks of nearly pure clay $\ldots . . . \ldots . . . . .$. & 16 & 314 \\
\hline Sand, containing shells; with just enough clay to hold them $\ldots \ldots \ldots \ldots \ldots \ldots \ldots$ & 6 & 320 \\
\hline 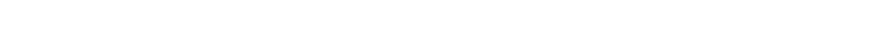 & 10 & 330 \\
\hline 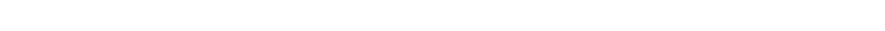 & 1 & 331 \\
\hline 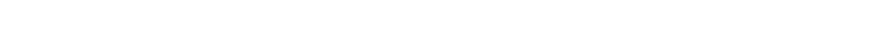 & & 340 \\
\hline 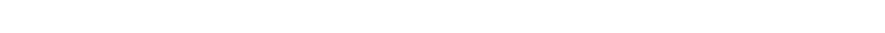 & 10 & 350 \\
\hline Clay, sticky, blue; very little sand. . & & 358 \\
\hline Clay, with black gravel ................... & & 365 \\
\hline $\begin{array}{l}\text { Clay, blue; with gravel and shell casts... } \\
\text { Clay, white; with gravel..... }\end{array}$ & & 368 \\
\hline $\begin{array}{l}\text { Clay, white; with gravel } \ldots . . . \\
\text { Marl, white; with very little sand }\end{array}$ & & 375 \\
\hline Marl, white; with very little sand. & 10 & 385 \\
\hline Clay, light-colored $\ldots \ldots \ldots$ & & 390 \\
\hline (1) & 10 & 400 \\
\hline Clay, greenish, sar & 10 & 410 \\
\hline (1) & 18 & $\begin{array}{l}428 \\
434\end{array}$ \\
\hline $\begin{array}{l}\text { Clay; with very little sand } . . . . . . . . \\
\text { Clay, nearly pure; very light when dry }\end{array}$ & $\begin{array}{l}0 \\
9\end{array}$ & \\
\hline Clay, bluish, sandy; gravel and streaks of sticky clay with some nodules of rock.... & 27 & 470 \\
\hline Rock. . & $\frac{1}{2}$ & $470 \frac{1}{2}$ \\
\hline Clay, greenish; fine sand above and coarse sand below; small flow of water at 487 feet. & $16 \frac{1}{2}$ & 487 \\
\hline Rock bowlder (siliceous concretion) in blue, sandy clay $\ldots \ldots \ldots \ldots \ldots \ldots \ldots \ldots \ldots$ & & 492 \\
\hline
\end{tabular}


Log of well at Jacksonville waterworks-Continued.

\begin{tabular}{|c|c|c|}
\hline & Thickness. & Depth. \\
\hline Clay, compact, blue. & Feet. ${ }_{4}$ & $\begin{array}{l}\text { Feet. } \\
496\end{array}$ \\
\hline Clay, white........... & 1 & 497 \\
\hline 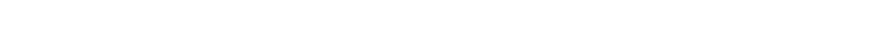 & 2 & 499 \\
\hline 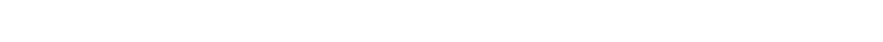 & $\begin{array}{l}5 \\
6\end{array}$ & $\begin{array}{l}504 \\
510\end{array}$ \\
\hline $\begin{array}{l}\text { Rock, very hard, compact (siliceous limestone)........ } \\
\text { Rock, soft, white; some water....................... }\end{array}$ & ${ }_{9}^{6}$ & $\begin{array}{l}519 \\
519\end{array}$ \\
\hline 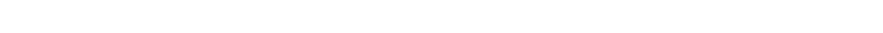 & 5 & 524 \\
\hline $\begin{array}{l}\text { Rock, very soft, white; in layers } 1 \text { to } 5 \text { feet thick with strata of more compact rock } 3 \text { to } \\
12 \text { inches thick; increase in the flow of water on breaking each hard stratum. Gaged }\end{array}$ & & \\
\hline 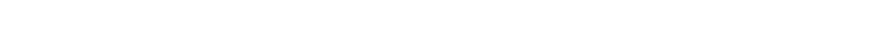 & 203 & 727 \\
\hline 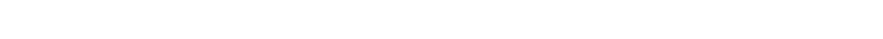 & $\begin{array}{r}31 \\
7\end{array}$ & $\begin{array}{l}758 \\
865\end{array}$ \\
\hline $\begin{array}{l}\text { Rock, soft, white; hard brown layers } 1 \text { to } 3 \text { feet thick every few feet; a slight increase } \\
\text { Rof flow from each soft layer }\end{array}$ & & \\
\hline 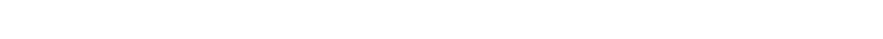 & $\begin{array}{r}65 \\
5\end{array}$ & 935 \\
\hline Roek, soft, brownish; with hard layers, flow increasing as each hard layer is broken.. & 15 & 950 \\
\hline Rock, hard and soft, in alternate layers; small increase in flow ........... & 20 & 970 \\
\hline , more compact; no water.............. & & \\
\hline
\end{tabular}

The sands and gravels for the first $34 \frac{1}{2}$ feet are probably Pleistocene, though they may include some Pliocene beds.

- The fossiliferous limestone at 35 feet is the Jacksonville. This formation may continue to a depth of at least 496 feet.

Thickness.-Few exposures of the limestone of the Jacksonville formation exceed 5 or 6 feet in thickness, though one attains a maximum of about 15 feet 2 miles above Middleburg on Black Creek.

Concerning the thickness of the Miocene in Florida, Dall ${ }^{1}$ says:

The Chesapeake group is represented over a very wide area in Florida, if the scattered observations already made can be regarded as indicative of its extension. Borings on the eastern coast of Florida and in the St. Johns Valley indicate that there the beds of this group in some places attain a thickness of at least 500 feet.

Some uncertainty arises when thickness is estimated from samples of rock obtained from borings, and the difficulty is increased several fold when it is necessary to rely upon descriptions prepared by drillers.

Information relating to the thickness of the Jacksonville formation on the east coast will be given in connection with the detailed sections (pp. 298-299); and it is only necessary here to note that Dall's estimate is probably essentially correct. Samples obtained from a well at Jacksonville indicate that at that locality the formation may have a thickness of over 460 feet; its limestone phase begins at 35 feet; and at 495 feet there was obtained a shark's tooth, which is not known to occur in rocks older than the Miocene.

Physiographic expression.-Where the Jacksonville formation lies near the surface characteristic sink-hole topography may exist, as at the original Miocene locality near Rock Spring; but here, as in some other places, it is impossible to say how much of the topography is due to solution of the underlying porous limestone of Oligocene age.

Paleontologic character.-Owing to the difficulty of obtaining good collections the fauna of the Jacksonville formation is imperfectly 
known. Dall ${ }^{1}$ reports fossils from several localities, among them being Pecten jeffersonius, Carditamera arata, etc., from Preston sink 3 miles north of Waldo; and Venus rileyi, V. permagna, and Arca limularin a well at St. Augustine at a depth of 208 feet.

Heilprin ${ }^{2}$ identified Pecten madisonius, Venus alveata, Venericardia granulata, Carditamera arata, Mytiloconcha incurva, Cardium sublineatum, and Oliva literata from Rock Springs, Orange County.

During the progress of the recent field work a few fossils were obtained from exposures on Black Creek. Though the collections were small, it was possible for Vaughan to determine a few species, which indicate the Miocene age of the rock.

Structure.-The Jacksonville formation presents no peculiarities of structure and appears to have undergone no considerable disturbance since its deposition. Its exposures border those of the rocks belonging to the Apalachicola group and from these it dips gently seaward. The Miocene beds were probably affected by the general arching of the strata of the State, though the initial movement doubtless occurred before their deposition.

Areal distribution.-On Black Creek the Jacksonville formation is exposed at intervals for several miles, but few exposures are more than 6 feet thick. On the north bank of Black Creek, about 5 miles above the Atlantic Coast Line Railroad, a section shows 5 feet of massive typical light-gray porous limestone containing a considerable admixture of sand and clay, overlain by 6 to 8 feet of light-gray sand and sandy loam. The weathered surface of the limestone varies in color from pale yellow to buff, and, owing to the solution and removal of the lime, much of the weathered rock appears to be a calcareous sandstone. The limestone is exposed at intervals for about 2 miles above this locality and then gives place to Pleistocene and alluvial sands. Fossils are abundant in the form of casts and molds, which are often very beautifully preserved but are difficult to secure because of the friable character of the matrix. A few- fossils collected at this locality were identified by Vaughan as Miocene.

About 2 miles above Middleburg, on the north bank of the creek, the Jacksonville formation again appears in a bluff about 25 feet high.

Section about 2 miles above Middleburg on north bank of Black Creek.

Feet.

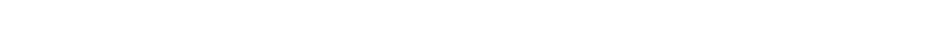

Sand, white (Pleistocene).............................. 2

Erosion unconformity.

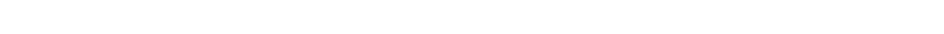

Erosion unconformity. 
Clay, dark blue to brown, sandy; plastic when wet, granular when

dry ........................................... 4

Unconformity.

Limestone, soft, porous, light gray; siliceous and arenaceous limestone very fossiliferous, with casts chiefly of bivalve shells......... 10

Limestone, soft, dense, light gray; similar to above (to water)...... 4

The Miocene age of the limestone is shown by the fossils identified by Vaughan from the upper part of the beds.

The Jackson ville formation is exposed at several points along the creek above this locality, but few outcrops exceed 3 or 4 feet in thickness.

Excavations ${ }^{1}$ at the city waterworks at Jacksonville revealed the presence of a yellowish siliceous limestone containing casts and molds of fossils, among which are Pecten jeffersonius and Carditamera.

According to Dall ${ }^{2}$ some of the rock at Live Oak and Lake City may also belong to the Miocene; but as yet this opinion lacks confirmation.

In the well at the Ponce de Leon Hotel, St. Augustine, about 65 miles southeast of Jacksonville, the Miocene appears to have been encountered at a depth of 110 feet. According to Dall ${ }^{2}$ the Miocene fossils Venus rileyi, V. permagna, and Arca limula were found at a depth of 208 feet, while fossils characteristic of the Vicksburg group were obtained at 224 feet. This would indicate that the Miocene, which here has a thickness of 114 feet, may rest directly upon the Vicksburg group.

At Rock Springs, the original Miocene exposure, the rock consists of a light-gray to white marly linuestone, from which $\mathrm{Smith}^{3}$ collected Pecten madisonius, Venus alveata, Venericardia granulata, Carditamera arata, Mytiloconcha incurva, Cardium sublineatum, and Oliva literata. According to Dall, Miocene fossils were also obtained in a boring at Lake Worth on the east coast.

CHOCTAWHATCHEE MARL.

The Choctawhatchee marl includes the Ecphora bed ${ }^{1}$ and the aluminous clay ${ }^{4}$ of Dall. The formation comprises a grayish sandy shell marl and gray plastic sandy clay of Miocene age. It lies stratigraphically between the Oligocene and Pliocene beds and contains characteristic species of Miocene fossils.

Stratigraphic position.-According to Vaughan the Choctawhatchee marl rests unconformably upon the Alum Bluff formation at Alum

1 Bull. U. S. Geol. Survey No. 84, 1892, p. 124.

2Idem, p. 125.

Smith, E. A., Am. Jour. Sci., 3d ser., vol. 21, 1881, p. 302.

1 Dall, W. H., and Stanley-Brown, Joseph, Cenozoic geology along the Apalachicola River: Bull. Geol, Soc. America, vol. 5, 1894, pp. 168-169.

$76854^{\circ}-$ W\$P $319-13-9$ 
Bluff, where the contact shows a wavy surface marked by shallow channels due to erosion and where the coarse light-gray sands of the Alum Bluff formation, which contain few fossils, change abruptly to the bluish-gray shell marl of the Choctawhatchee with its abundant fauna. Several years ago Vaughan noted similar evidence of an unconformity between the Oligocene and Miocene at Jacksons Bluff on Ochlockonee River; his section at that locality well discloses the relations:

\section{Section at Jacksons Bluff, Ochlockonee River.}

Feet.

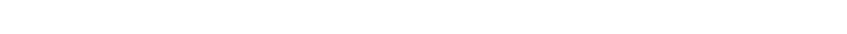

Unexposed in slope to top of bluff face................... $16 \pm$

Sands, yellow, unconformably overlying the Choctawhatchee marl 5

Marl, yellow, sandy, fossiliferous (Choctawhatchee); greenish

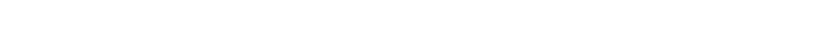

(About 3 feet additional underlie the yellow sands. This bed is extremely fossiliferous and from it I obtained the species listed by Dr. Dall in his discussion of the Florida Miocene.)

Yellow calcareous clay, the same horizon as the fuller's earth on land of W. W. Williams (sec. 21, T. 1 S., R. 4 W.). The upper surface of this stratum is extremely irregular. There are small channels in it; one is about 5 feet wide and more than a foot deep. The basal 6 to 10 inches is very largely composed of small pebbles and in it are embedded pieces and fragments of the calcareous clay. There were apparently cracks in the calcareous clay and small pebbles went down into them. The contact is distinctly one of erosion unconformity .............

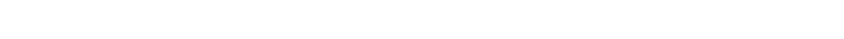

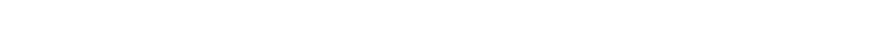

Limestone ledge..................................

Sands, greenish, passing beneath level of water in river....... 7

This section is located in the SW. $\frac{1}{4}$ sec. 16, T. 1 S., R. 4 W., in a southwesterly bend of Ochlockonee River.

The paleontologic evidence indicates a stratigraphic break between the Oligocene and Miocene.

As I have on various occasions insisted, the faunal gap between the uppermost Oligocene [Oak Grove member] and the Chesapeake [Choctawhatchee marl] or Miocene is the most sudden, emphatic, and distinct in the whole post-Cretaceous history of our southeastern Tertiary, and indicates physical changes in the surrounding region, if not in Florida itself, sufficient to alter the course of ocean currents and wholly change the temperature of the waters on our southern coast. ${ }^{1}$

The relation between the Miocene and Pliocene beds of Florida will be discussed later.

Lithologic character.-Lithologically the two members of the Miocene in Florida are very unlike, both in character of material and state of aggregation. The Choctawhatchee marl varies in color 
from greenish gray to light gray and consists of quartz sand containing very large admixtures of shells and shell fragments and a smaller proportion of calcareous sand. In some parts of the formation the shells comprise a large percentage of the whole, many of them being in an excellent state of preservation. Elsewhere the organic remains form a very subordinate part of the whole or they may be entirely wanting. One phase of this formation is distinctly plastic and was called aluminous clay by Dall and Stanley-Brown. ${ }^{1}$

When examined with a microscope, the marl is found to consist of clear quartz sand of medium fineness, coated and partly cemented with calcium carbonate mixed with more or less dark-colored clay. Calcium carbonate may be detected by the effervescence when treated with dilute hydrochloric acid. A certain amount of lightgray to nearly black material which appears in the form of a flocculent sediment in water is without doubt organic matter. In addition, hydrous iron oxide may be detected, generally in the form of a coating about the sand grains or as a stain along the cracks and on the exposed surfaces of the beds. It is this iron which gives some of the exposed surfaces a rusty color.

Thickness.-The Choctawhatchee marl attains a thickness of over 50 feet in the vicinity of Redbay, Walton County, where it is exposed in some small ravines, and exceeds 30 feet on the banks of Mill Creek near Holland, in Leon County. However, from observations elsewhere it appears probable that the average thickness is not more than 25 feet to 30 feet.

Physiographic expression.-The Choctawhatchee marl rises to the surface in a belt from 6 to over 12 miles in width, extending from southern Walton County eastward to Leon County. Though the topography of this area is in part determined by the younger formations, the influence of the soft marls is seen in the deep narrow valleys. The slopes are everywhere steep and many of the small streams head in springs which emerge near the upper surface of the Choctawhatchee marl. North and west of Crestview the surface is characterized by similar narrow valleys, but the marls are so effectually concealed by younger sands and clays that if present they probably have very little influence on the configuration of the surface.

Paleontologic character.-The Choctawhatchee marl contains an abundant faun a consisting of nearly 200 species. The most numerous fossil is a small bivalve, Mactra congesta, which is associated with other mollusks, one of the most characteristic being the gastropod Ecphora quadricostata. Other prominent fossils are: Conus adversarius, Fusus equalis, Crucibulum constrictum, Pecten eboreus, Venus

1 Cenozoic geology along the Apalachicola River: Bull. Geol. Soc. America, vol. 5, 1894, p. 157. 
rileyi, Arca incile, A. idonea, Cardium acute-laqueatum, C. robustum, Carditamera arata, and several species of Turritella, Dentalium, etc.

Structure.-The Choctawhatchee marl presents no marked peculiarities of structure. It rises over 50 feet above sea level along its inner margin and dips gently seaward beneath the younger formations which border the coast. Probably the formation shared in the slight deformation which occurred during the late Tertiary or early Quaternary, but the exposures are so limited that no satisfactory evidence of folding was observed.

Areal distribution.- On the west bank of Choctawhatchee River, about a mile southeast of Redbay, numerous exposures of bluishgray Miocene marl have an aggregate thickness of probably more than 30 feet. The slope above the outcrops of marl is covered by sandy loam and shows scattered bowlders of ferruginous sandstone resembling the sandstones of the Lafayette (?) formation, observed elsewhere in Walton County and in some of the counties to the east. The marl at this locality is rather clayey and contains many fossils, which have been identified by Vaughan as Miocene.

Miocene shell marl was encountered in a well drilled for the Southern States Lumber Co. near Cantonment. A complete log of this well was furnished by Frank Sutter, driller, but unfortunately the samples of material penetrated are incomplete. In a "greenish clay," at a depth of 500 feet, fossils were obtained, which, according to Vaughan's identifications, indicate the presence of beds belonging to at least two geologic horizons, one being Miocene.

Bluish-green shell marl was reported on the east bank of Holmes Creek, 4 miles south of Vernon, and similar material was encountered in a well at Millers Ferry beneath 20 feet of sand and clay.

The Choctawhatchee marl was observed by Dall, Foerste, Vaughan, and others at several places on Chipola, Apalachicola, and Ochlockonee rivers. The sections recorded by Dall $^{1}$ on Chipola River are as follows:

The section here was measured with a steel tapeline on the left bank of Chipola River, Calhoun County, Fla., at the bluff about 200 feet north of the spring, which here flows from a wooden pipe.

Section at Abes Spring.

1. Superficial sands, about....................... 4

2. Reddish and yellowish streaked sands................. 30-32

3. Gray aluminous clay ............................ 19

4. Chesapeake gray marl to water (variable)............. 7

Total thickness above water...................... 62

1 Dall, W. H., and Stanley-Brown, Joseph, Cenozoic geology along the A palachicola River: Bull. Geol. Soc. America, vol. 5,1894 , pp. 160-161. 
In detail these strata have the following composition:

No. 1.-Pale yellowish-gray incoherent sand, such as might be deposited by a river during seasons of high water; less like beach sand than the analogous material at Alum Bluff.

No. 2.-Of the same character as No. 3 of Alum Bluff. The material is generally a little coarser and the gravels a little larger, and there is also greater heterogeneity in structure.

No. 3.-Same as No. 4 (aluminous clay) of Alum Bluff.

No. 4.-Chesapeake, just as at Alum Bluff.

On Chipola River a mile or more north of Abes Spring, is a "slide" where timber is cast into the river for the construction of rafts, which are floated down the river to the mills at Apalachicola, on the Gulf. This place is locally known as Darlings slide, and is a very steep natural bank, affording an excellent section, though somewhat obscured by weathering and the friction of the enormous logs which are rolled over it. It is on the left bank, and the bank opposite is low and apparently of alluvium.

\section{Section at Darlings Slide.}

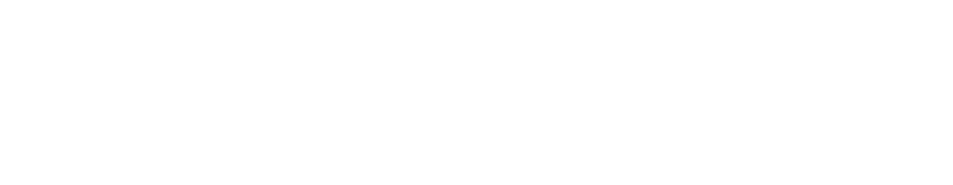

Total thickness above water.................... $\quad 50$

The composition of the several beds is as follows:

No. 1.-Pale yellowish-gray incoherent sand, such as might be deposited by a river during floods; less like beach sand than the analogous material at Alum Bluff.

No. 2.-Of the same character as No. 3 of Alum Bluff. The material is generally coarser and the gravels a little larger. There is also greater heterogeneity in structure.

No. 3.-The conditions were unfavorable for determining the presence or thickness of the gray aluminous clay, but from the fact that it is well exposed with sharp contacts at Abes Spring but a short distance south, and, together with the Chesapeake, makes up 27 feet of thickness, it is reasonable to suppose that it forms part of the 27 feet assigned to Nos. 3 and 4.

No. 4.-Chesapeake marl, in every respect the same as that formation found at Alum Bluff.

It is notable that nothing below the Chesapeake is visible, although it has been stated that the Chipola beds exist under the gray marl. This can only be an assumption, since, with the water, as we were informed, within a foot of its lowest stage, nothing of the sort was visible, nor does the stream show any material such as would be washed out of the older Miocene beds, if present. The principal fossil here, as at Alum Bluff, is Mactra congesta Conrad, with which are associated Venus mercenaria L., and Turritella variabilis Conrad. The beds above the Chesapeake appear to be destitute of fossils.

From Dall's discussion in an earlier part of this paper he appears to have regarded No. 1 of each section as Pleistocene and No. 2 as Pliocene ${ }^{1}$ and he correlates the "aluminous clay" with the Pascagoula formation and the so-called "Chesapeake" (Choctawhatchee marl) with the Chesapeake of Virginia and Maryland, respectively. 
On the south bank of Fourmile Creek, about three-fourths mile north of Clarksville, the following section was observed:

Section on Fourmile Creek, north of Clarksville.

Feet.

Covered by sandy loam.............................. 30

Clay, bluish gray, marly (plastic)....................... 14

Shell marl, very fossiliferous, bluish gray (to water) $\ldots \ldots \ldots \ldots \ldots .4$

The fossils observed here were the same as those which characterize the Choctawhatchee marl at Alum Bluff and elsewhere. Associated with the shells were a number of dark-colored fragments of bones which are locally regarded as an indication that the deposit might prove valuable as a fertilizer. Even though these fragments may be phosphatic they are not sufficiently abundant to be of economic value.

At Alum Bluff, on Apalachicola River, the Choctawhatchee marl was observed by Dall. At this locality the "aluminous clay" is 24 feet thick and is immediately underlain by 35 feet of sandy shell marl which contains an abundant Miocene fauna. There does not appear to have been any abrupt physical break between the fossiliferous shell marl and the nonfossiliferous "aluminous clay," though the latter appears to have a larger percentage of clay than the former. Both have the same color and both are arenaceous; but the one is highly fossiliferous and the other barren of animal remains, except for a few obscure traces of gastropods and bivalves.

Toward the north the shell marls thin to scarcely more than 5 feet. On the east side of Apalachicola River, Mr. Burns ${ }^{1}$ traced the Miocene marl from about 5 miles above Bristol southward for about 13 miles to the place where it finally disappears.

The Choctawhatchee marl is exposed at numerous points on Ochlockonee River. About 16 miles west of Tallahassee (sec. 9, T. 1 S., R. 2 W.) Vaughan found an exposure of Miocene marl. The outcrop is on Duggar Creek near the house of W. C. Allen; the material contains the same fauna and is lithologically similar to the Choctawhatchee marl at Alum Bluff.

On the farm of J. R. Harvey, a mile west of Holland, a bed of very fossiliferous marl was encountered in a well at a depth of 28 feet. The section is:

Well section 1 mile west of Holland.

Feet.

Sand, red, ferruginous................................. 10

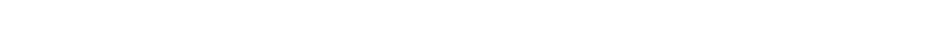

Marl, yellow, becoming bluish gray below the surface (Choctaw-

hatchee); water bearing.............................. 7

A few fossils from the material obtained from this well, identified by Vaughan, show the age of the marl to be Miocene. 
Near Block's sawmill, on the banks of Mill Creek, the Choctawhatchee marl is more than 30 feet thick, but the exposures are poor. The material in the bed of the creek ranges from blue to yellowish gray in color and is not fossiliferous, but an exposure of about 5 feet of bluish-gray shell marl about 25 feet above the stream contains fossils. A small collection obtained from this bed shows the Miocene age of the marl.

About a mile southwest of Holland similar shell marl was encountered in digging a mill race at Hugh Black's sawmill. According to statements made by James R. Harvey, this shell marl extends southward along Ochlockonee River nearly 12 miles. At Jacksons Bluff, about a mile southwest of Bloxham, the Choctawhatchee marl is 8 to 10 feet thick. This locality was described in 1894 by Dall, ${ }^{1}$ and the locality was visited in 1900 by Vaughan, who collected the fossils listed by Dall ${ }^{2}$ in his discussion of the Florida Miocene.

Vaughan also collected from a yellowish sand representing a slightly higher stratum of the same bluff (NE. $\frac{1}{4}$ sec. 20, T. 1 S., R. 4 W.); he reports the occurrence of similar fossils in sections 21 and 30 .

The presence of Pecten madisonius in a collection of Pliocene fossils from the banks of St. Johns River one-fourth mile below Nashua, Putnam County, suggests that Miocene may occur at that locality. The collection was made from a shell marl forming a bluff which rises about 3 feet above the river.

Samples of marl from a well at De Land were found by Vaughan to contain Pecten (type of madisonius) and Chione (type of cancellata). From the presence of the madisonius type of Pecten the marl is believed to be Miocene.

Species of Pecten eboreus and Pecten gibbus, together with Ostrea haitiensis Sowerby, are also found about a mile above Caloosa on Caloosahatchee River. The presence of these fossils may indicate that the beds are Miocene; but this conclusion is held subject to revision in case subsequent investigations should result in the finding of larger collections belonging to some other period. This locality, should it be Miocene, is of special interest because heretofore no Miocene has been reported so far south on the Gulf coast of the State.

\section{PLIOCENE SERIES.}

The Pliocene of Florida comprises the Caloosahatchee marl, the Nashua marl, the Alachua clay, and the Bone Valley gravel. Only the Alachua clay is considered to be a land deposit, the others being supposedly of marine origin.

\footnotetext{
1 Dall, W. H., and Stanley-Brown, Joseph, Cenozoic geology along the A palachicola River: Bull. Geol. Soc. America, vol. 5, 1894, p. 158.

2 Trans. Wagner Free Inst. Sci., vol. 3, pt. 6, 1903, pp. 1596-98.
} 
Nomenclature.-Pliocene beds were recognized in Florida as early as 1885, but the first published account of them is found in Heilprin's report, issued in 1887. ${ }^{1}$ This writer gives a description of the shell marls exposed along Caloosahatchee River and states that they are of Pliocene age. He says:

It will thus be seen that the relation of recent to extinct species is as 48 to 41 , giving a very much higher percentage for living forms than obtains in any of the divisions of our recognized Miocene deposits, even the "Carolinian," which holds a position nearly equivalent to the so-called Mio-Pliocene of Europe. It becomes manifest that this most extensive Floridian exposure represents the Pliocene age--a circumstance interesting, apart from the general bearing which its presence has upon the geology of the State in particular, from the fact that it gives us the first unequivocal indication of the existence of marine Pliocene deposits in the United States east of the Pacific slope.

To the beds described Heilprin ${ }^{2}$ gave the name Floridian. The name Caloosahatchee marl was applied by Dall to the Pliocene beds along Caloosahatchee River and the streams entering Charlotte Harbor. ${ }^{3}$ In 1887 the shell marls on Caloosahatchee River were described by Dall, ${ }^{4}$ who agreed with Heilprin in referring them to the Pliocene. In subsequent papers ${ }^{5}$ by the same author these marls were called the Caloosahatchee beds, from the type locality on the river of that name. Thus Dall's Caloosahatchee beds include the Floridian beds of Heilprin. The name proposed by Dall is retained for the Pliocene beds of Caloosahatchee River and neighboring streams, but as these beds are largely marl the formation is here called Caloosahatchee marl.

The type locality of the so-called "Arcadia marl" is on Mare Branch, a tributary of Peace River, about 6 miles north of the town of Arcadia, and with this marl is included an oyster marl which Dall described from a locality about 3 miles north of the wagon bridge at Arcadia. ${ }^{7}$ The close resemblance of this marl to the Caloosahatchee marl seems to warrant regarding it as a phase of that formation, thus making the term "Arcadia marl" superfluous.

Stratigraphic position.-The contact of the Caloosahatchee marl with the underlying Miocene has not been observed, but the faunas show a considerable difference, probably due to physiographic changes which permitted the erosion of the Miocene beds before the beginning of the Pliocene deposition. The contact of the Caloosahatchee marl with the overlying Pleistocene is commonly marked

I Trans. Wagner Free Inst. Sci., vol. 1, 1887, pp. 26-33.

2 Idem, p. 32.

3 Dall, W. H., Notes on the geology of Florida: Am. Jour. Sci., 3d ser., vol. 34, 1887, p. 169.

1 Tdem, pp. 161-170.

G Bull. U. S. Geol. Survey No. 84, 1892, pp. 140-149; Trans. Wagner Free Inst. Sci., vol. 3, pt. 6, 1893, pp. 1603-1605.

B Bull. U. S. Geol. Survey No. 84, 1892, pp. 131-132.

7 Idem, pp. 132-133. 
by an erosional unconformity. Where this unconformity is not noticeable it may have been obscured by the reworking of the Pliocene marl by the waves of the Pleistocene sea.

Lithologic character. - The Caloosahatchee marl consists of a lightgray shell marl, in many places interbedded with nearly pure sand. The matrix is generally very calcareous but locally it consists of sand, and even in the most calcareous portion sand is abundant. The shells are remarkable for their excellent state of preservation and their abundance in certain layers makes it possible to secure large collections.

Thickness.-It is difficult to correctly estimate the thickness of the Caloosahatchee marl, but its maximum is probably at least 25 feet. Few single exposures exceed 5 to 10 feet, and the average thickness is probably less than 8 feet. On the whole the Caloosahatchee marl is a thin deposit, though it may thicken considerably toward the central portion of the peninsula and toward the southern end of the State.

Physiographic expression.-The Caloosahatchee marl occupies a region of such low altitude that it has been only slightly dissected. In fact with the exception of the valleys of the streams entering Charlotte Harbor the surface of the region underlain by this formation is an almost unbroken plain. Though this is in part due to the later deposit of Pleistocene sand, it is doubtful if the surface of the Caloosahatchee marl has ever suffered extensive erosion.

Paleontologic character.-Dall's list of Pliocene fossils obtained from the Caloosahatchee marl in Florida includes 639 species, of which 256 species are not known from other States. The marine formations of this period are very fossiliferous, and the fauna as a whole is such as might be expected in shallow water. Dall ${ }^{1}$ notes that the upper beds of the Caloosahatchee Pliocene contain a fauna more closely related to living forms than the lowermost layers, and that the shoaling of the water permitted the formation of oyster reefs and the final influx of fresh-water species of Planorbis, etc.

Structure.-The dip of the Pliocene beds in Florida is usually very difficult to determine. Caloosahatchee River crosses the Caloosahatchee marl at the type locality and thus affords a good opportunity for observing the attitude of the marl beds. Dall ${ }^{2}$ says:

The uppermost strata of the Pliocene beds begin to appear above the level of the river at low water (during the dry season) about 24 miles due east from the shore of Charlotte Harbor, and they dip to the eastward out of reach about 30 miles farther east. Their total measured breadth here is thus at least 30 miles and includes the whole of the elevated land between Lake Hicpochee and the point on the river above mentioned. In this distance there are not less than 20 visible but very gentle folds of the strata in the direction of the trend of the peninsula. 


\section{In a later paper Dall says: ${ }^{1}$}

The Pliocene beds dip gently to the westward so that those portions near the sea are newer than those outcropping near the headwaters of the streams.

In the discussion of the Miocene rocks the marls near Caloosa were doubtfully referred to that epoch. The Caloosahatchee marl is exposed at intervals from near Caloosa to the vicinity of Labelle, several miles farther upstream, where the Pleistocene appears. The relation of the Pliocene and the Pleistocene here may be interpreted by supposing an easterly dip of the beds. The alternative hypothesis of a westerly dip could only be true if the increase in altitude of the water surface were somewhat greater than the thickness of the Caloosahatchee marl. The actual rise in water level between Caloosa and Labelle as determined instrumentally varies with the stage of the river, but at mean low water is probably less than 5 feet. The actual dip of the beds is probably easterly instead of westerly.

Aside from a slight tilting the marls of Caloosahatchee River have been gently folded so that they exhibit a series of low undulations with axes parallel to the general trend of the peninsula. These arches are usually less than one-fourth mile wide, and they probably do not exceed 15 feet in height. Elsewhere no folding has been observed; but it is probable that the disturbance which produced the low arches on the Caloosahatchee was general and that the other Pliocene beds may exhibit the same structural features.

Areal distribution.-Exposures of the Caloosahatchee marl are numerous on Caloosahatchee River between Labelle and Caloosa. Of this Pliocene rock Dall ${ }^{2}$ says:

On the Caloosahatchee the strata may be divided into oyster-reef marl beds, conchiferous or Turritella marl, and layers of sand, which intergrade without distinction and have no invariable succession but always grade into the shallow-water fauna at the top, which is overlain by the Planorbis rock, and this in turn by post-Pliocene deposits which are seldom of great thickness.

At Labelle the Caloosahatchee marl, consisting of 4 feet of calcareous sand containing a large number of Pliocene shells, lies beneath 3 feet of fossiliferous Pleistocene marl, which in turn underlies 3 feet of sandy loam. A mile below Labelle the following section was observed:

Recent:

Section on Caloosahatchee River 1 mile below Labelle.

Surficial soil and muck................................ 3

Pleistocene or recent:

Marl, banded, varying from nearly black to yellow........... 1

Caloosahatchee marl:

Marl, gray, clayey, containing some nodules; very fossiliferous... 4

Marl well stratified, greenish gray, clayey, containing some fossils. 2

1 Trans. Wagner Free Inst. Sci., vol. 3, pt. 6, 1903, p. 1604.

2 Bull. U. S. Geol. Survey No. 84, 1892, p. 147. 
One-half mile below the last locality the Caloosahatchee marl is about 7 feet thick and is abundantly fossiliferous, containing many large pectens, ostreas, and gastropods. About a mile farther downstream a conspicuous oyster bed about a foot thick rises above the level of the river. Five miles below Labelle the following section was examined:

Section on Caloosahatchee River 5 miles below Labelle:

Feet.

Marl, concretionary calcareous; very fossiliferous............... 3

Oyster bed characterized by large Ostrea sculpturata and Pecten ebor-

eus.......................................... 2

Marl, soft, white, clayey.......................... 4

9

The oyster bed is exposed at intervals for several miles.

In addition to the exposures of Caloosahatchee marl already described Dall mentions several localities on other streams entering Charlotte Harbor: ${ }^{1}$

Near the north end of Charlotte Harbor a small creek comes in from the east called Alligator Creek. Here Mr. Willcox found an extension of the Caloosahatchee beds. The banks are about 12 feet high, the upper half being pure sand; the lower half contains fossils of Pliocene age, mollusks, barnacles, and flat Echinidæ. They differ from the Caloosahatchee deposits in being in pure sand instead of marl as a matrix. The upper half of the fossiliferous stratum shows the shallow-water fauna, with its usual partial admixture of strictly Pliocene extinct species. Some parts of the bed are united by siliceous cementation into a hard rock. * * * The banks are higher here than on the Caloosahatchee, being 25 feet at the highest point, but the difference is chiefly of unfossiliferous marine sand 12 feet deep. Then comes about 2 feet of shallow-water fauna with some Pliocene species, below which is a hard limestone stratum 2 or 3 feet thick, beneath which is a bed of conchiferous marl like that of the Caloosahatchee. There are slight differences in the fauna, such as might be expected at points 20 miles apart.

Here [on Miakka River] Mr. Willcox found a bed of limerock at the sea level with uncharacteristic species poorly preserved. Above the limerock are beds of shell marl considerably mixed with sand. In this deposit was collected about 40 species of shells, of which about 10 per cent were extinct Pliocene species. This bed seems to have fewer extinct species than the Caloosahatchee marls and may be regarded as a little younger, perhaps corresponding to the Planorbis rock, which seems to be absent on the Miakka.

Along Rocky Creek, which falls into Lemon Bay near Stump Pass, in about latitude $26^{\circ} 55^{\prime}$ west from the Miakka, a bed of Venus cancellata rises to about a foot above the water, or in many places forms the bed of the stream. It is probably the upper shallow-water layer of the Pliocene, as Cerithidea scalata Heilprin, a Pliocene species, has been found near by on the beach of the bay.

On Peace Creek there are no banks high enough to afford a section, and no trace of Pliocene yet observed up to 3 miles above Fort Ogden.

Farther north, on Peace Creek, the Caloosahatchee beds appear at Shell Point, 3 miles above Arcadia, as previously described; and I was informed that the same bed occurs on Joshua Creek, near Nocatee, and at a point on Peace Creek 6 miles below the works at Arcadia, between that place and Fort Ogden. The same oyster bed is con- 
spicuous in the banks of a small stream just north of the railroad station at Zolfo Springs. This stream, a feeder of Peace Creek from the east, has cut quite a deep gully, and the oyster bed occurs in the vertical sides about 2 feet, or possibly less, above the water when the latter is low, as in January, when I observed it. Above the oyster bed the elevation cut by the stream is composed of some 20 or 25 feet of yellow sand, with a foot or two of the white sand covering it. Some portions of the yellow sand here, as at Shell Point, are quite indurated and stand vertically like rock. The section can be well observed from the railway culvert.

Considerably east of Peace Creek beds of marl containing "large clams" have been reported to Mr. Willcox as occurring on the banks of Arbuckle Creek. Something of the same sort on the Kissimmee River, near Fort Kissimmee, was mentioned to me by prospectors at Bartow who had visited that locality. Both these marl beds are likely to prove to be Pliocene.

The oyster marl which occurs on Peace Creek about 3 miles above Arcadia has been correlated with the Caloosahatchee marl. ${ }^{1}$ Dall's section is:

\section{Section on Peace Creek 3 miles above Arcadia.}

Feet.

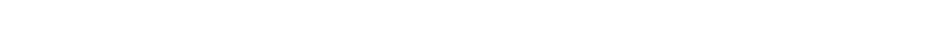

2. Yellow sand (indurated) ................................ 3

3. Oyster marl (in part subaqueous) ...................... $2-4$

- Nos. 1 and 2 of this section are doubtless Pleistocene.

Dall ${ }^{2}$ gives the following section of the "Arcadia marl," which he considers to be slightly older than the Caloosahatchee:

Section of "Arcadia marl" at edge of Peace Creek.

Feet.

Humus and white sand......................... $1 \frac{1}{2}-6$

Yellow sand ..................................... $6-10$

"Peace Creek bone bed" phosphatized rock with bones (about).. 1

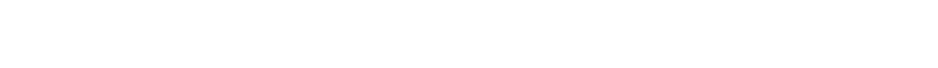

The "Peace Creek bone bed" is probably to be correlated with the Alachua clay, and the first and second members of the section are doubtless Pleistocene.

\section{NASHUA MARL.}

Discrimination.-During the progress of the field work for this report, fossils were collected which indicate that Pliocene marls are extensively developed along the valley of St. Johns River. These beds possess certain faunal elements which distinguish them from the other Pliocene beds of Florida and are given a distinct name-the Nashua marl-from a locality on St. Johns River where they are best exposed. Further study may result in uniting all of the marine Pliocene of Florida under a single name; but for the present it appears desirable to avoid hasty correlation by the use of local names for the beds of different localities, especially where conditions governing deposition appear to have been unlike. 
Stratigraphic position.-The Nashua marl is thqught to rest unconformably on the Miocene at De Land, but this opinion lacks confirmation, as the fossils from that locality have not been studied in sufficient detail to determine the exact age of the beds. At several localities the contact between this formation and the overlying Pleistocene sand has been observed and it is everywhere marked by distinct unconformity. The Pleistocene beds rest upon an undulating surface, clearly due to erosion, of Nashua marl, and the contrast between the fossiliferous marl and the overlying barren sands helps to emphasize the break between the two. (See Pl. XI, $A, B$.)

Lithologic character.- The Nashua marl bears a strong lithologic resemblance to the Caloosahatchee marl, showing the same alternation of sand beds with shell marl. The matrix of the Nashua marl, though calcareous, is everywhere more or less sandy and in places consists of nearly pure sand. The shells are generally well preserved, though locally marls consisting of broken and eroded fragments of shells are not uncommon, and it is easy to obtain good collections of fossils.

Thickness.-The Nashua marl, the only Pliocene formation in the area of its occurrence, is much thinner than the underlying Miocene strata. This fact, together with its distribution beneath the lowlands near the coast, indicates that the Pliocene submergence in northeastern Florida was less prolonged than the Miocene; and the presence of shallow-water fossils shows that the Pliocene sea did not attain any great depth over that part of the State where the marine beds are now exposed. The Nashua marl is in few places more than 6 or 8 feet thick, but locally it attains a greater thickness. Samples from a well at De Land indicate that there the Nashua marl is about 32 feet thick.

Physiographic expression.-The Nashua marl occupies the St. Johns Valley, where it underlies a broad terrace bordering the stream. It probably occurs beneath the plain east of St. Johns River, but the overlying Pleistocene forms a mantle so thick that the Nashua marl has no effect on the topography and appears not to outcrop.

Paleontologic character. - The fauna of the Nashua marl is imperfectly known, but it has been sufficiently studied to show that it resembles that of the Caloosahatchee marl. The most striking difference between the faunas of the two formations is the existence of certain species in the Nashua marl which occur in the Waccamaw fauna of the Carolinas but are not known to be present in the Caloosahatchee marl. This affinity with the fauna to the north suggests the existence of a cold current along the Atlantic coast which permitted a southward migration of the Waccamaw fauna. Thelack of exposures in the central portion of the peninsula prevents the tracing of the 
connection between the two formations and the determination of the limits of the southward movement of this current of cold water.

Structure.-The Nashua marl is exposed at only a few localities in the St. Johns Valley and it is difficult to form any definite idea concerning its structure. It has probably been subjected to the same deformation as the Caloosahatchee marl, but its isolated exposures afford no evidences of folding. The dip is doubtless seaward and is probably very slight.

Areal distribution.-In the St. Johns Valley the Nashua marl is exposed in many places. At the type locality, one-fourth mile south of Nashua, Putnam County, 5 feet of white sand is exposed, resting unconformably upon about 15 feet of white shell marl. From this locality fossils were obtained which Vaughan identified as Pliocene, though the presence of Pecten madisonius suggests that there are also Miocene beds in the exposure.

One-half mile above the Atlantic Coast Line Railroad bridge over St. Johns River in Putnam County, in a bluff which rises 3 to 8 feet above high water, the Pliocene (Nashua marl) is well exposed and abundantly fossiliferous. The age determination of the fossils is by Vaughan.

About one-half mile south of De Leon Springs in Volusia County the following section was examined:

Section one-half mile south of De Leon Springs.

Sand, white (Pleistocene or Recent) Feet.

Unconformity.

Sand, yellowish brown, and clay; unassorted near the top, but

grading downward to well-stratified clay (Pleistocene)......... 7

Unconformity.

Shell marl, yellow to white (Nashua marl) $\ldots \ldots \ldots \ldots \ldots \ldots \ldots .6$

17

At one place the clay extends downward into the Pliocene marl in a channel 2 feet across and 4 feet deep.

The names of a few fossils obtained from this locality are given by Dall. ${ }^{1}$ His list contains Crepidula aculeata Gmelin, Ostrea sculpturata Conrad, Carditamera arata Conrad, and Mulinia congesta Conrad.

This list includes only four species, of which the first (Crepidula aculeata Gmelin) is marked by an asterisk in Dall's table to indicate that it is believed to survive to the Recent fauna. Of the other three, one, Ostrea sculpturata ${ }^{2}$ is known from the Florida Pliocene of Caloosahatchee River, Alligator Creek, and Shell Creek, and

1 Trans. Wagner Free Inst. Sci., vol. 3, pt. 6, 1903, pp. 1596-1598.

2 Idem, pp. 1605-1614. 


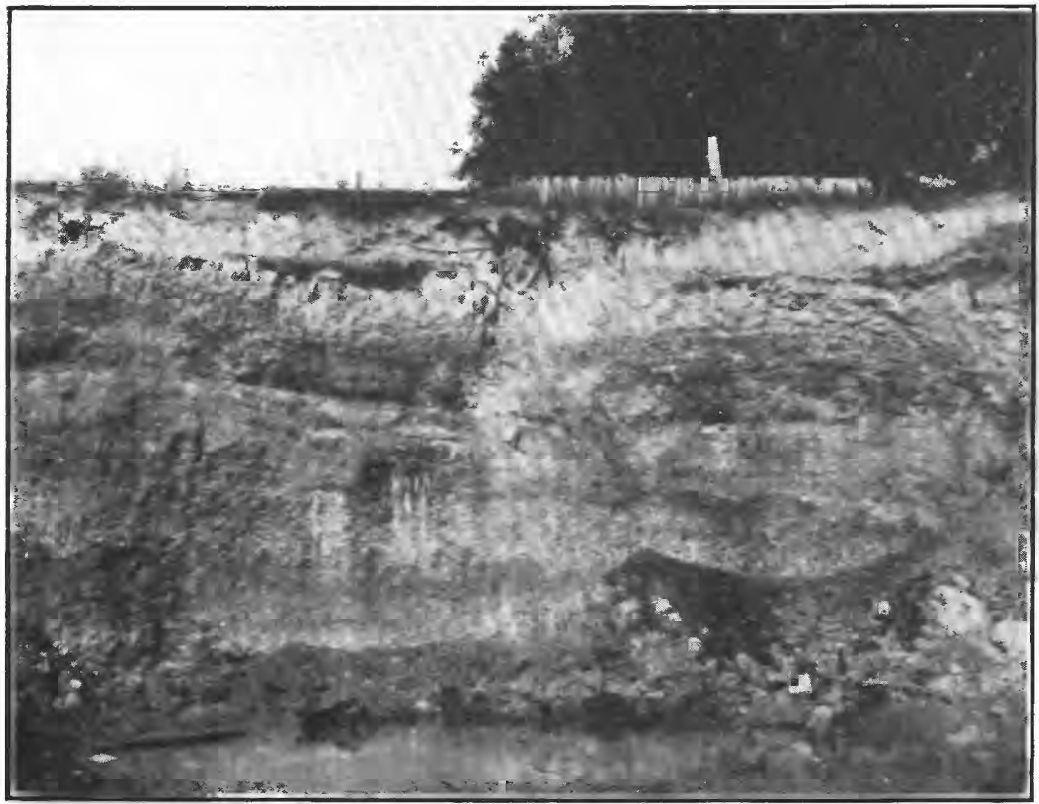

A. CONTACT OF NASHUA MARL AND PLEISTOCENE SAND A QUARTER OF A MILE BELOW NASHUA, ON ST. JOHNS RIVER.

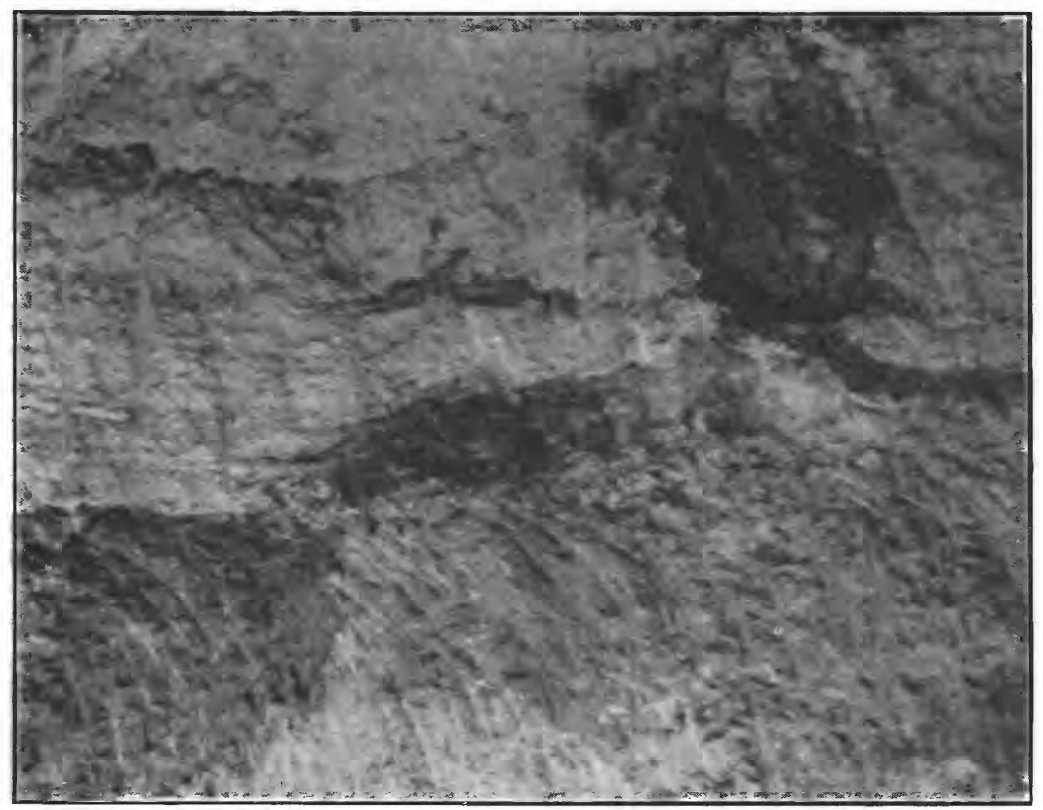

B. CLAY UNCONFORMABLY OVERLYING NASHUA MARL IN PIT ABOUT HALF A MILE SOUTH OF DE LEON SPRINGS STATION. 

another, Carditamera arata, is known from the same beds and from the Pliocene fauna of the Waccamaw formation of the Carolinas. This leaves' but one species, Mulinia congesta, of Dall's list which is not known from the Florida Pliocene. This species is not known to occur in beds younger than the Miocene, and hence the exposure was called Miocene by Dall. A much larger collection was made during the progress of the field work and according to Vaughan's identification there are Pliocene beds in the exposure.

On the east side of St. Johns River, about 5 miles north of the Atlantic Coast Line Railroad bridge in Volusia County, there is a low exposure of sandy loam, sand, and marl. The upper member consists of about 2 feet of light-colored sandy loam which passes by gradual transition into a coarse-grained gray sand. Beneath this sand and probably separated from it by an unconformity is a bed of light-green clayey marl containing many well-preserved shells. A collection of fossils was obtained. The presence of Cardium æedalium has led to the inference that the marl is of Pliocene age.

About 300 yards farther north and on the same side of the river the marl is in some places unconformably overlain by a thin bed of gray limestone and in other places by partly indurated sand. The limestone is probably of Pleistocene age. About 2 miles north of the first locality an exposure of shell marl one-half foot thick is capped by a deposit of clay and sand which is probably alluvial. From this locality a few species were obtained, and Vaughan regarded the beds as "probably Pliocene."

From a well near Kissimmee, Vaughan obtained fossils that not only serve to indicate the presence of Pliocene beds but also show that they are buried beneath at least 96 feet of Pleistocene sand and marl.

ALACHUA CLAY.

Deposition.-The nonmarine Alachua clay has usually been regarded as Pliocene, and it appears to be a terrestrial or fresh-water deposit.

This formation was described by Dall ${ }^{1}$ in 1892:

Later in this essay I shall endeavor to indicate all that is known to date of writing of the marine Pliocene beds of Florida, but there is another formation to be spoken of which has been referred by some authorities to the upper Miocene, though regarded by others as late Pliocene or even Pleistocene. This comprises the deposits of clay containing bones of extinct Mammalia which, in my report to the Director of the United States Geological Survey in 1885, I termed the Alachua clays.

The report mentioned above does not appear to have been published, and hence the quotation probably contains the first published reference to these clays. With these beds is included the Peace Creek 
bone bed of Dall, ${ }^{1}$ which appears to consist of eroded and redeposited material derived from an older deposit.

Stratigraphic position.-The Alachua clay is known to occupy sinks and gullies in the Oligocene and probably also in the Miocene beds. Observations made by Dall along the banks of Peace Creek show that a bone bed ("Peace Creek bone bed"), which he correlates with the Alachua clay, rests upon older Pliocene beds." The Alachua clay and the "Peace Creek bone bed" have not been observed in contact, but they are believed to be lacustrine or fluviatile deposits formed at different times. The Alachua clay is also thought to be contemporaneous with a part of the Caloosahatchee and Nashua marls.

Lithologic character.-The Alachua clay consists of blue to gray sandy clay which weathers to light yellow or red from the presence of iron oxide. It generally contains sufficient clay to give it distinct plasticity but also commonly contains sand in considerable quantities. The weathered material is frequently more or less concretionary as a result of the aggregation of the iron oxide. The formation is nearly destitute of fossils except in a few localities where it is filled with vertebrate remains.

Thickness.-The Alachua clay represents accumulations in depressions of the surface of the Oligocene beds, and hence its thickness is variable, being known to reach 15 feet and possibly much more; its average is probably not less than 10 feet.

Physiographic expression.-The Alachua clay has no marked effect on the topography, but by its accumulation in depressions in the underlying rocks it probably helps to diminish the relief. Locally it is represented by low ridges which rise above the general level.

Paleontologic character.-The Alachua clay contains a few obscure remains of what appear to be fresh-water shells, in a state of preservation that does not permit their identification. Locally, vertebrate remains are abundant, and it was this fauna which first called attention to the formation.

At the request of the senior author of this report, Dr. J. W. Gidley, assistant curator of the United States National Museum, made a study of the lists of fossils from the Alachua clay and the "Peace Creek bone bed." His report is given below:

Notes on the relative ages of the beds at Archer, at Mixon's, and at Ocala, Fla., and their correlation with deposits of the western-plains region.

The faunas of the beds at Archer and Ocala indicate two distinct horizons, the latter being much the newer. With the possible exception of Elephas columbi from the beds at Ocala and the "Peace Creek beds," none of the Florida horizons contain any species in common with beds of the western-plains region, hence an accurate estimate regarding the relative age of these beds with those of the west is not possible at the present time. 
The presence of Elephas and true Equus, as well as specimens referred to Bison, Cervus, and Megalonyx, in the beds at Ocala and in the "Peace Creek beds," suggest Pleistocene for these horizons, although they may just as well be late Pliocene. Judging from the less-advanced stage of development of these species, these beds seem to be older than the beds at Hay Springs, Nebr., which have been considered to be deposited near the beginning of the Pleistocene, and may be about the equivalent of the deposits of Loup River, Nebr., which are held to be either late Pliocene or early Pleistocene.

The beds at Archer and at Mixon's contain a fauna which in point of development seems to correspond closely with that of the "Republican River formation" of Kansas and Nebraska, thus bringing them near the dividing line between the Miocene and Pliocene, and they may be, with good reason, placed in either the upper Miocene or lower Pliocene.

The horses are represented by Miocene genera, but the species seem in general to be more highly specialized. This does not necessarily mean a later phase or horizon but suggests it.

From the evidence furnished by vertebrate fossils, therefore, it may be concluded that the beds at Archer and those at Mixon's, 10 miles east of Archer, are in age near the transition from the Miocene to the Pliocene and that the newer beds at Ocala and Peace Creek, Fla., may be placed in time very near the beginning of the Pleistocene.

Gidley's report was made since the preparation of the manuscript for this paper, and it is incorporated here without attempting to place the discussion of these beds in separate sections of the report. The topographic position of the Alachua clay suggests that it may be Miocene. The fossils identified from Ocala came from the depressions in the surface of the limestone at the quarry of the Ocala Lime Co. The topographic position of the "Peace Creek bone bed" is such that it might be either Pliocene or Pleistocene, for it lies near the present water level of the stream and may be either an older formation exposed by erosion or a Pleistocene deposit made in the valley.

Structure.-The Alachua clay appears to have undergone no marked disturbance since its deposition and hence presents no structural features of interest. Its accumulation in local depressions prevents its having any general attitude; the dips observed are slight and variable.

Areal distribution.-Sections of the Alachua clay are to be seen in the vicinity of Gainesville and Archer, in Alachua County. In an exposure in an old mill race, a mile northwest of Gainesville, the outcrop probably does not exceed 4 feet; but farther up the hill to the east 15 feet of similar material, which is overlain unconformably by about 4 feet of white sand, is exposed in a ditch. The basal portion of the section, which evidently represents one of the localities mentioned by Dall, ${ }^{1}$ is a greenish-blue clay containing a large admixture of coarse sand. It changes to a very light yellow when exposed to the weather, and in this respect agrees with the material on the hillside above.

1 Bull. U. S. Geol. Survey No. 84, 1892, p. 128.

$76854^{\circ}-$ wSP $319-13-10$ 
The complete section at this locality is:

Section a mile northwest of Gainesville.

Feet.

Sand, light gray.$\ldots \ldots \ldots \ldots \ldots \ldots \ldots \ldots \ldots \ldots \ldots \ldots \ldots \ldots \ldots$

Erosion unconformity.

Clay, greenish blue, sandy; weathering light yellow .......... 15

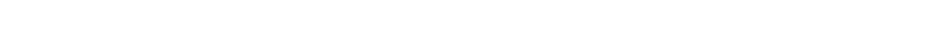

Clay, greenish blue, sandy $\ldots \ldots \ldots \ldots \ldots \ldots \ldots \ldots \ldots \ldots \ldots .4$

About $2 \frac{1}{2}$ miles west of Gainesville another exposure of Alachua clay consists of a light-yellow clayey sand which is very plastic when wet but hardens into a moderately firm rock on drying. The outcrop is not less than $\mathbf{1 5}$ feet thick and is covered by a deposit of sandy loam of Pleistocene age, which rests unconformably on the clays. Thin partings of sand are common; the upper 4 feet of the section contains many small calcareous nodules, and near the middle some casts of what appeared to be fresh-water bivalves.

Dall ${ }^{1}$ mentions the occurrence of vertebrate remains on Peace Creek, Caloosahatchee River, and in Wakulla County. $\mathrm{He}$ also gives the following list of localities for the Alachua clay:

Among the localities to be noted are: In Alachua County, Mixon's farm, 10 miles south and $1 \frac{1}{2}$ miles east of the railway station at Archer; Hallowell's place, 10 miles north and 2 miles west of the station; a pond about one-fourth of a mile from the station; another in the vicinity of Mixon's, 2 miles northwest of the first; a ditch about $2 \frac{1}{2}$ miles west of Gainesville; a spot where the railway crosses Santa Fe River, near Gainesville; 1 mile north of Gainesville, on the Newnansville road, in a ditch dug for a mill race; and Owen's, nearer the town. Other localities are: Clay Landing, on the Suwannee River, near Fort Griffin, Levy County; Rocky Creek (old Tampa Bay), Hillsborough County (Bison latifrons); Phillips quarry, Ocala, Marion County.

BONE VALLEY GRAVEL.

Nomenclature.-The deposits here called Bone Valley gravel have been described by both Eldridge ${ }^{2}$ and Dall. ${ }^{3}$ They comprise nearly all of the pebble phosphates now being mined in Florida, the name being derived from a locality west of Bartow, where the beds were worked on a large scale. Different names were formerly used for this formation by different writers, Eldridge designating the deposits land-pebble phosphates and Dall calling them simply pebble phosphates. Both writers distinguish between the Tertiary deposits of Pliocene age and the younger pebble phosphates, which range in age from Pleistocene to Recent.

The general character of this formation, with its rounded pebbles and good stratification, shows that it is of subaqueous origin, and the

1 Bull. U. S. Geol. Survey No. 84, 1892, p. 128.

2 Eldridge, G. H., Preliminary sketch of the phosphates of Florida: Trans. Am. Inst. Min. Eng., vol. 21, 1893, pp. 196-231.

${ }^{3}$ Dall, W. H., and Harris, G. D., Ccrrelation papers-Neocene: Bull. U. S. Geol. Survey No, 84, 1892, pp. 137-138. 
presence of marine and land vertebrate remains indicates that it was deposited in a shallow sea. The shallow-water origin of these beds is also shown by the many alternations of coarse and fine material and by the lenticular character of many of the beds.

Stratigraphic position.-The Bone Valley gravel rests on an eroded surface of the Alum Bluff formation. The overlying Pleistocene sands, where present, rest on an uneven surface of the Bone Valley gravel, and though the surface of the gravel and associated sands does not appear to be very irregular, the widespread character of the unconformity indicates that the interval between the deposition of the Pliocene and Pleistocene was marked by erosion. The exact correlation is somewhat uncertain, but the Bone Valley gravel is believed to be older than the upper beds of the Caloosahatchee marl. It is probably in part contemporaneous with the Alachua clay and may therefore be upper Miocene. This is inferred from the fact that the two formations were deposited under similar physiographic conditions.

Lithologic character.-The Bone Valley gravel consists of a finegrained matrix containing pebbles of phosphate or chert, fragments of bone, and other organic remains. The teeth and dermal plates of sharks and fish are so common in this formation that they may be gathered by the score from the washed material at the phosphate mines. The matrix is commonly sand, though a marly clay is not uncommon, especially in the lower part of the formation. The finer-grained material is soft and plastic when wet but hardens on exposure to the air.

Partial sections of the Bone Valley gravel may be observed in most of the land-pebble phosphate mines; these sections have certain general characteristics which are worth noting. In some places a deposit of a few inches to several feet of light-gray to white sand or coarse sandy loam rests unconformably upon Pliocene beds, which may be roughly divided into the nonproductive marls, gravels, and sand, and those which are commercially valuable on account of the high percentage of phosphatic pebbles they contain. The miners group the Pleistocene and the nonproductive Bone Valley gravel under the term "overburden," because they must be removed in order to reach the productive beds. As the percentage of phosphate diminishes toward the top of the gravels, the organic remains become less numerous. This probably means that the deposition of the upper part of the gravels took place when the land was rising rapidly enough to rejuvenate the streams and thus permit them to carry materials from some distance inland.

Thickness.-The Bone Valley gravel is exposed in the land-pebble phosphate mines, the excavations usually extending to the base of the formation and frequently reaching a depth of more than 30 feet before entering the underlying beds of the Alum Bluff formation; 
hence the thickness may be safely fixed at more than 30 feet. The average thickness, however, is probably lower and may not exceed 15 to 20 feet.

Physiographic expression.-The Bone Valley gravel occupies a region ranging from less than 100 to more than 150 feet above sea level, but the surface presents gentle slopes. The formation has been trenched by some of the larger streams which have eroded shallow valleys, and in places it forms low hills and ridges. Like some of

- the other Pliocene formations, the minor inequalities of the surface are locally masked by the younger Pleistocene beds.

Paleontologic character.-The Bone Valley gravel contains abundant organic remains, such as fish and shark teeth and worn shells. However, it is probable that some of these fossils were derived from the older geologic formations by erosion and by weathering. These are, therefore, to be regarded as contemporaneous with the phosphatic pebbles and older than the gravel in which they are found. The Bone Valley gravel, however, contains many fossils which are contemporaneous with the deposition of the beds, among them being teeth of horses, rhinoceroses, mammoths, sharks, and manatees.

Structure.-Though the Bone Valley gravel shows no marked structural features it appears to have a gentle seaward inclination. From its mode of origin it is thought that this dip may be original and not the result of tilting subsequent to deposition. If the formation has been folded the deformation is so slight that it does not show in the small exposures observable in the pebble-phosphate mines. However, it is not improbable that gentle arching, such as may be seen on Caloosahatchee River, also exists in the pebble-phosphate region.

Areal distribution.-The Bone Valley gravel is widely distributed in the valleys of Peace and Alafia rivers, along which it is exposed in numerous phosphate mines. The exact extent of the formation is somewhat uncertain because natural exposures are rare and it is difficult to determine whether the beds are continuous beneath the covering of surface sand. Large areas of the Bone Valley gravel are known in De Soto, Polk, and Hillsborough counties, and smaller patches occur in some other counties. The largest areas are south and west of Bartow, where the formation is now being extensively exploited.

\section{Pliocene (?) SERIEs.}

LAFAYETTE (?) FORMATION.

Correlation.-Deposits referred to the Lafayette formation occupy large areas of the Coastal Plain and have been discussed by a number of authors, the most comprehensive report being that of McGee. ${ }^{1}$ The name is derived from Lafayette County, Miss., ${ }^{2}$ and is synony-

\footnotetext{
1 MeGee, W J, The Lafayette formation: Twelfth Ann. Rept. U. S. Geol. Sarvey, pt. 1, 1891, pp. 347521.

2 Hilgard, E. W., Orange sand, Lagrange, and Appomattox: Am. Geologist, vol. 8, 1891 „pp. 129-131.
} 
mous with "Orange sand" and "Appomattox" formation. However, it is apparent that each of these names has, at times, been used to include beds of different geologic ages, and hence the exact significance of the terms have varied with localities and even in a single locality, being used by different writers with different meanings. Berry ${ }^{1}$ has recently shown that at the type locality near Oxford, Miss., the beds referred to the Lafayette formation belong to the Wilcox formation and are therefore of Eocene age. He states that at other places weathered deposits of Cretaceous age have been included in the Lafayette formation.

Investigations made since the preparation of the manuscript for this report have shown that the beds referred herein to the Lafayette formation in Florida include sands and sandy clays belonging to the Alum Bluff and Choctawhatchee formations, together with similar materials of Pliocene age. The beds of Pliocene age are well developed in Florida, Alabama, and Mississippi but have not yet been given a specific name. As it is not possible at the present time to determine the correct ages of all the different exposures in Florida here referred to the Lafayette formation it was decided to retain the name in this report but with a query.

Stratigraphic position.-The deposits included in the Lafayette (?) formation have been observed to rest unconformably upon the Alum Bluff formation at Tallahassee. The amount of time represented by the unconformity is difficult to determine and it is probable that the erosion of the sands and clays and their redeposition on the slopes is recent. The surface on which the Lafayette (?) formation was deposited appears to have been comparatively even; but this may mean either that the Alum Bluff had not been extensively eroded, or that it had been worn down to a nearly uniform altitude. In some places, the Lafayette (?) formation is unconformably overlain by the white sand of Pleistocene age, and in this case the extensive erosion of the Lafayette (?) indicates the lapse of considerable time, during which there were marked changes in the altitude and surface configuration of the land before the Pleistocene sands were deposited.

Lithologic character.-The materials composing the Lafayette (?) formation vary from clay and fine sand to coarse sand containing small pebbles, the whole being commonly stained with enough oxide of iron to give the deposit a deep-orange color. (See Pl. XII, A.) The variation in physical character, together with the lenticular shape of many of the beds and numerous instances of cross bedding, show the changing conditions under which the beds were deposited. Under such conditions numerous unconformities are to be expected, but it is seldom possible to determine their extent because the exposures are poor.

1 Berry, E. W., The age of the type exposures of the Lafayette formation: Jour. Geology, vol. 19, No. 3 , April, May, 1911, pp. 249-256. 
Thickness.-Though widely distributed, the Lafayette (?) formation is comparatively thin, seldom exceeding 30 to 60 feet, and having perhaps an average thickness of less than 50 feet.

Physiographic expression.-The Lafayette (?) formation has undergone extensive erosion since its deposition, and so much of the original material has been reworked and redeposited under different conditions and in different physiographic positions that it is now difficult to determine which deposits were original and which are to be classed as the secondary products from the erosion of the original. However, considerations of physiography suggest that the more or less flat-topped hills and dissected table-lands in the northern part of the State can best be explained as remnants of a more extensive plain formed when the region was one of low relief. It is difficult to make any close correlation between the separate remnants of this upland because the amount of erosion has varied greatly. The general range in altitude is approximately 50 feet, and there is a gradual increase from about 250 feet above sea level at the southern margin of the upland to nearly 300 feet along the northern boundary of the State.

Paleontologic character.- The deposits referred to the Lafayette (?) formation are not known to contain fossils of marine organisms except such as have been derived from the erosion of older strata. Remains of land and fresh-water fossils have been found outside the State; but no fossils of any sort have been reported from the beds tentatively assigned to this formation in Florida, and since the beds are well exposed it appears safe to say that they do not contain many fossils.

Structure.-The Lafayette (?) formation shows no structural features of interest, though it may have been subjected to the same deformation which produced the gentle arching of the marine Pliocene beds.

Areal distribution.-The deposits referred to the Lafayette (?) formation occupy a belt about 40 miles wide, extending from near Suwannee River westward to Escambia County. Large tracts are found in Gadsden, Leon, and Jefferson counties on the east side of Apalachicola River; and in Holmes, Walton, Santa Rosa and Escambia counties in west Florida. They are best developed in the uplands of the counties along the north line of the State, but show few good exposures. The red sands of the counties mentioned are largely assigned to the Lafayette (?) formation, but their age is doubtful because of the absence of fossils. The selection of typical sections of the Lafayette (?) formation is a difficult task because of the uncertainty which frequently attends the identification and correlation of exposures. The sections given below are few, but they are fairly representative of the materials included in the Lafayette (?) formation in Florida. Sands belonging to this formation have already been mentioned in connection with the sections of other formations. 


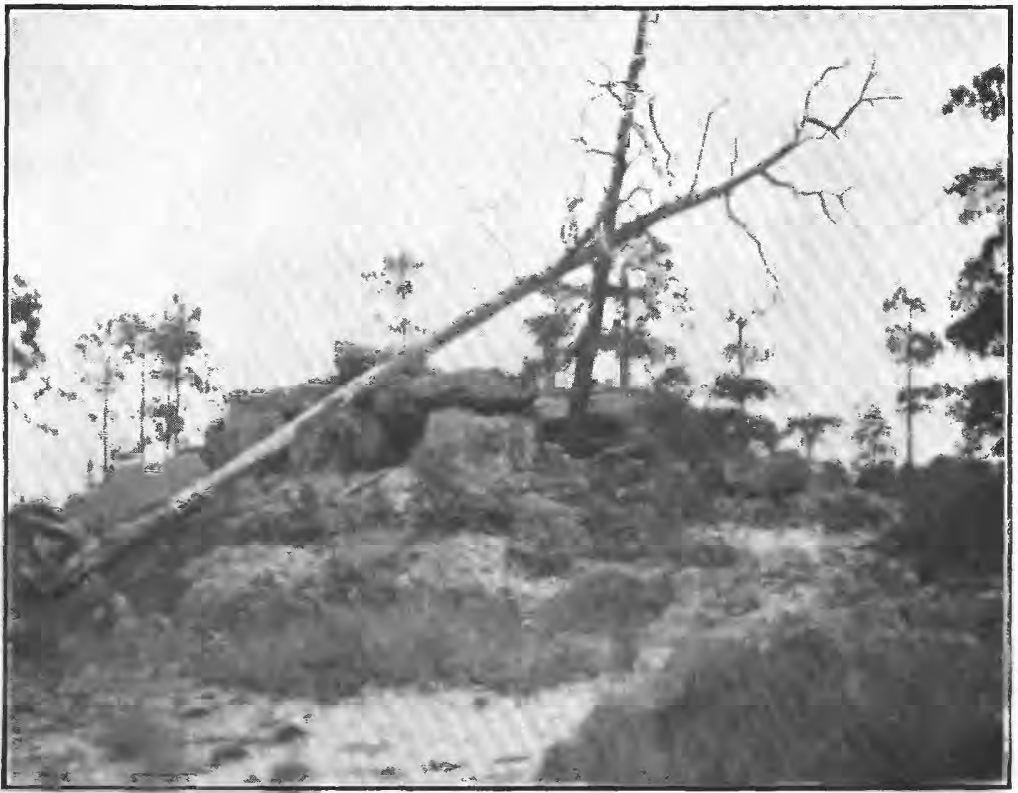

A. CONGLOMERATE OF LAFAYETTE (?) FORMATION, RESTING ON SANDSTONE OF UNCERTAIN AGE, TOP OF ROCK HILL, WASHINGTON COUNTY.

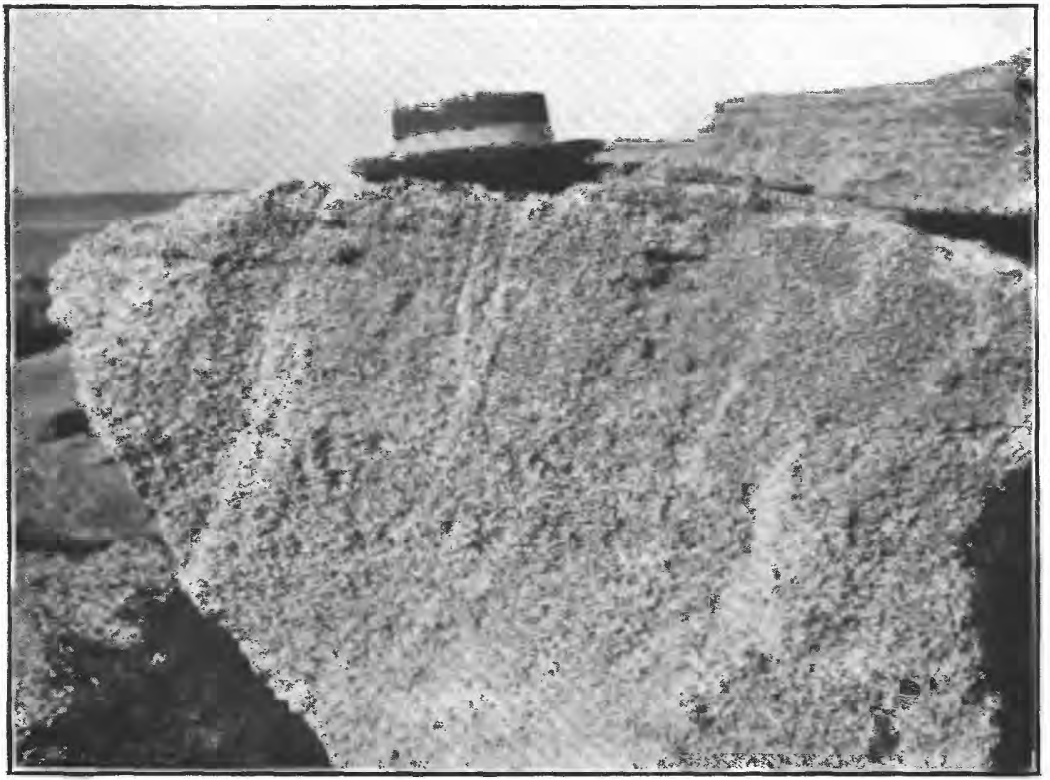

B. ROCK FACE IN COQUINA QUARRY, ANASTASIA ISLAND. 

In the descriptions of sections, made by Vaughan in the vicinity of Tallahassee, the red sands are assigned to the Lafayette (?) formation, though they are probably weathered portions of Oligocene beds.

Section on St.Augustine road from Hancock's place to the Seaboard Air Line Railway, south side of railway.

Lafayette (?):

Feet.

Clay, red, sandy (from plateau summit)................ 55

Alum Bluff:

Clay, gray, interlaminated with sands; and gray clays (level

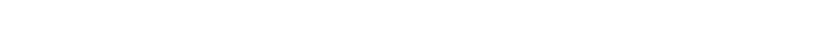

In this section the contact of the sands and clays shelves downward toward the north, descending through 16 feet. The contact dips at a less angle than the clay for a stretch of 20 feet.

In ravines near the southern edge of Tallahassee several small exposures show the red sands of the Lafayette (?) formation resting on older sands and clays. The red sands mantle the slope and the total thickness of the section is about 55 feet. At the base of the hill there is an exposure of gritty sand; 5 feet above the base of the section there is a bed of gray clay; and 15 feet higher there is an exposure of gray grit. The clay at the base of this bluff is probably 20 feet above the clay in the section above.

Section on Bellair road, south from Tallahassee, south side Seaboard Air Line Railway.

Pleistocene: Feet.

Soil, sand, etc

Alum Bluff:

Clay, massive, plastic, gray blue; cuboidal fracture.......... 10

Sands, and siliceous clay (of the appearance of Alum Bluff)... $3+$

By aneroid the base of this section is 60 feet below the capital terrace and 30 feet above the railroad crossing.

Vaughan's comment is that "the clays at this locality are lower than in Tallahassee and higher than on the St. Augustine road; that is, the contact between the red sands and the underlying clays is an uneven surface. The actual relations between the sands and clays were difficult to observe, but the indications from aneroid observations are that the sand rests on an uneven, probably eroded surface."

Section at McCulloughs Bridge, $10 \frac{1}{2}$ miles northwest of De Funiak Springs, ${ }^{1}$ just below mill pond.

Sands, light yellowish gray....

Feet.

Sands, red, gritty and small pebbles, somewhat argillaceous, with clay seam, $\frac{1}{2}$ to 2 inches thick, cross-bedded on a large scale near the base..................................... $10_{ \pm}$

Unconformity.

Sands, yellow, argillaceous, interlaminated with gray clay........ $6 \frac{1}{2}$

Lafayette (?) formation. 
A local resident says that this outcrop is on sec. 2 , T. 4 N., R. 20 W. In an exposure on Rock Hill south of Chipley the upper member probably represents the Lafayette (?) formation. The age of the lower part could not be determined. The section follows:

Section on Rock Hill south of Chipley.

Sand, red, and gravel, containing pebbles up to 1 inch. In places cemented into hard conglomeratic bowlders several feet through... 20

Sandstone, hard, yellowish gray to green, with pebbles of soft green clay............................................ 10

Sections of the Lafayette (?) were observed on the tops of hills about 250 feet above tide on the road between River Junction and Aspalaga Bluff. A short distance from River Junction the following section was leveled:

Section near River Junction.

Feet.

Sand, red, containing numerous pebbles.................. 8-10

Sand, red, argillaceous................................. $\quad 45$

Clay, gray, marly, stained with iron oxide................. $1+$

About 5 miles from River Junction a similar exposure was observed.

Section 5 miles from River Junction.

Sandstone, friable, orange; containing some lenses of clay and some Feet.

pebbles...................................... 15

Sandstone, gray; streaked with yellow iron stains; well cemented.. 5

QUATERNARY SYSTEM.

\section{SUBDIVISIONS.}

The Quaternary is commonly divided into Pleistocene and Recent, but a difficulty often arises in attempting to discriminate these subdivisions, for the reason that the name Pleistocene is associated with the glacial epoch and Recent with the time since the final melting of the great sheets of ice which covered large areas in the north of Europe and North America. In regions like Florida, remote from the direct influence of glaciation, it is everywhere difficult and in many places impossible to draw satisfactory lines between the deposits of the two epochs. In the following discussion Quaternary will be applied to deposits which may belong to either Pleistocene or Recent or both, and Pleistocene will, so far as possible, be restricted to such beds as may safely be placed in the early part of the Quaternary and are probably to be correlated chronologically with the glacial deposits farther north. Recent will be restricted to deposits such as sand dunes and alluvial sands which are clearly of late geologic age. In general it is considered safe to draw the line between 
the two epochs at the final emergence of the lowlands from beneath the sea; and, as this movement appears to be the most marked physical change since the early Quaternary, it probably forms the best line of demarcation between Pleistocene and Recent. Theoretically the line may be drawn with considerable exactness, but practically the discrimination of Pleistocene and Recent deposits often presents many difficulties because the changes in conditions governing deposition were gradual and the materials for the Recent deposits were often derived directly from the beds of late Pleistocene age.

\section{PLEISTOCENE SERIES.}

\section{SUBDIVISIONS.}

In Florida beds of Pleistocene age include both marine and nonmarine deposits, and the nonmarine beds may be separated, on the basis of origin, into residual, lacustrine, fluviatile, and eolian. On a basis of character the Pleistocene deposits may be described as fossiliferous marls, gray sand, "Planorbis rock," coquina, "Vermetus rock," and yellow clay.

Fossiliferous marls.-The fossiliferous marine Pleistocene is one of the most interesting of the Quaternary formations. It comprises sands and shell marls in a sandy matrix. On North Creek, a tributary of Little Sarasota Bay, Dall ${ }^{1}$ obtained a large number of fossils from a shell bed consisting of sand darkened by organic matter and having a total thickness of less than 2 feet.

During the field work for this report collections were obtained which indicate that the fossiliferous Pleistocene is much more extensively developed than was formerly believed. The beds containing fossils of this age present great uniformity in character, being composed of white or light-gray sands, commonly coarse grained and in some places containing layers of marine or fresh-water shells. A few beds of clay occur interstratified with the sand, and in a few localities the sand contains scattered argillaceous material. Most of the fossils are found near the base of the beds and the fauna in some places changes from marine near the bottom of the exposure to nonmarine above, indicating a freshening of the water during deposition. In many localities the fossils are confined to the lower layers of sand; and, in such places, the absence of fossils in the upper part of the sand may have been caused by the partial emergence of the beds during deposition. Sharks' teeth, pieces of bone, and other organic remains are found in the basal portion of these sands at some places, probably eroded from the underlying formations. An uncommon but interesting example of such a conglomerate, found by 
Stephenson at Stokes Ferry on St. Marys River, comprises a shark's tooth, a fragment of a mammoth's tooth, the ear bone of a whale, a fragment of a plate from the shell of a turtle, three horse's teeth, and indeterminate bone fragments. Pebble phosphates occur in the lower layers of the sands of Pleistocene age. Some unsuccessful attempts have been made to mine them, but the deposits have usually been found too thin to be of economic value. Phosphates of this character are to be found at many localities in the peninsula. They represent the hard materials separated from the residual clays and sands by the action of the waves and currents in the Pleistocene sea. The absence of extensive clay beds in the sands of Pleistocene age is due to its scarcity in the older geologic formations from which the sands were derived. This characteristic of the rocks of Florida is so pronounced that good clays are comparatively rare, except in certain localities of limited area.

Fossiliferous marine beds of Pleistocene age are probably more widely distributed in Florida than in any other State east of the Appalachian Mountains. Pleistocene fossils were collected from the marls at Labelle, Sarasota Bay, Manatee River, and Sixmile Creek (near Tampa), on the west coast, and at Fort Lauderdale, Eau Gallie, Titusville, Daytona, and Mims on the east coast. In the center of the peninsula no exposures of marls were noted, but samples obtained at a depth of 100 feet in the well of $\mathrm{H}$. Clay Johnson, at Kissimmee, show that the marine marls of Pleistocene age occur at that locality beneath nearly 100 feet of sand. This suggests that they probably extend some distance north of Kissimmee in the east-central portion of the peninsula. The distribution of the exposures of the marls over so wide an area in a region where the beds are practically horizontal and undisturbed, as is the case in the southern part of the peninsula, indicates that the marls probably underlie a very large area. Thus they doubtless extend along the western coast from Tampa southward to near Fort Myers. From a point near Labelle the inner margin swings northward, passing east of Arcadia and Bartow to some distance north of Kissimmee, and then turns eastward. On the east side of the peninsula the marls of Pleistocene age extend north to Orange City and Mims, and they probably extend through the low valley occupied by St. Johns River. Throughout the area where these beds are known, they maintain striking similarity of texture indicating widespread uniformity in the conditions governing their deposition.

In general the Quaternary formations in the northern part of the State and as far south as Lake Okechobee present small differences; hence the discussion of local details is omitted except in the case of the shell marls. A section of the Pleistocene shell marl at Orient 
station, where it rests unconformably on the Tampa formation, follows:

Section at Orient station.

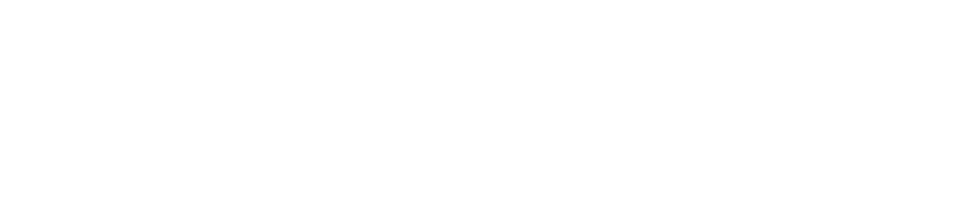

The lower member of the above section furnished many species of fossils identified by Vaughan as Pleistocene.

In a ditch about one-eighth mile south of Manatee station, an exposure of sandy marl contains an abundance of Pleistocene fossils. One-fourth mile south of the railroad station at Orange City an exposure of marl is doubtfully referred to the Pleistocene, though further fossil collections may show it to be Pliocene. - The section at this last locality has a thickness of about 18 feet, but only the lower part is fossiliferous:

Section one-fourth mile south of Orange City station.

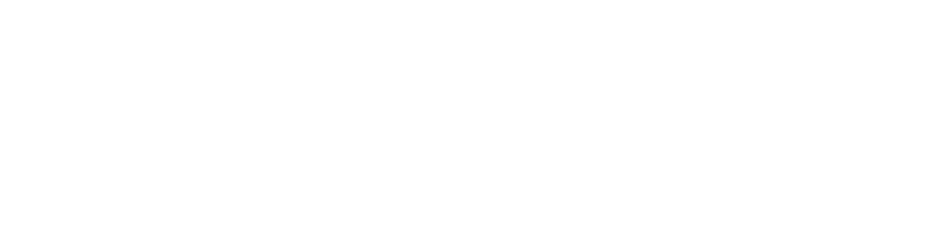

From a well at Kissimmee Vaughan obtained fossils which he regarded as Pleistocene. It is interesting to note that the sample came from about the same depth as those mentioned in discussing the Pliocene (p. 141).

A loosely cemented sandy shell marl a mile west of Titusville furnished several shells identified as Pleistocene, and many worn fragments. In a ditch 4 miles west of Eau Gallie a good exposure of sandy shell marl covered by from 1 to 3 feet of white Pleistocene sand yields Pleistocene fossils. Two miles southeast of Eau Gallie, on Merritts Island, a section shows about 8 feet of coquina covered by 2 to 4 feet of white Pleistocene sand; the lower part of the sand supplied several species of Pleistocene fossils, and there is no doubt that the coquina, though slightly older, belongs to the same epoch as the overlying sand.

Well records in many parts of the State show Pleistocene beds, but only where samples have been preserved has it been possible to recognize with certainty the shell marls of that age. In the well at Ormond Hotel, Ormond, in a sample of hard sandy marl from a depth of 50 to 56 feet Vaughan identified Donax variabilis Say, etc. A gray sandy marl, lying between 66 and 68 feet, furnished Littorina 
irrorata Say, Arca pexata Say, and Mulinia lateralis Say. Vaughan regarded these samples as Pleistocene. At a depth of 66 to 90 feet the material was still a marl, but unfortunately the organic remains were too meager to show whether the material was Pleistocene or Pliocene.

The well of the Model Land \& Railroad Co., at West Palm Beach, may be entirely in the Pleistocene, but fossils were identified (by Vaughan) only from samples 4 and 5. Sample 4, from 55 to 70 feet, furnished Crepidula fornicata Say, Pecten gibbus Linn., Cardium robustum Sol., and Venus mortoni Conrad, which were thought to be Pleistocene; and this conclusion was strengthened by the occurrence of Donax variabilis Say in sample No. 5, which was obtained at 70. to 74 feet. In another well at the same locality the Pleistocene marls were identified in samples extending from 8 to 57 feet.

Gray sand.-One of the most widespread deposits of the Atlantic and Gulf Coastal Plain is a white or light-gray coarse-grained sand. Locally some of the subsurface layers of this sand have been stained light yellow or even red by a deposit of iron oxide, but the colors when present are usually less prominent than those of the Lafayette formation. This material, which has commonly been called white sand, covers nearly all of Florida below the 100 -foot contour, and rests unconformably upon the older geologic formations. (See Pl. V.) It forms the surface over all the lowlands and extends upon the seaward margin of the elevated region toward the north end of the State. In the valleys, the white sand forms a mantle over a large part of the slopes, where it is arranged in more or less well-defined terraces. Locally this sand has been removed from hillsides by erosion.

Lithologically this sand presents no marked peculiarities. It is everywhere coarse and is on the whole remarkably free from silt or clay. The sand grains are not materially different in form from those of the present beach and belong to the type commonly known as "sharp" sand, being subangular to subrotund. In this they differ from sands which have undergone extensive wind transportation and have been well rounded by violent impact with other sand grains when not buoyed up by liquid. Clay beds are generally absent, and the sands are apparently nonfossiliferous except near the base of the sections, which extend down nearly to or below sea level.

The gray sands are usually uncemented, but locally the presence of iron oxide has transformed them to a concretionary sandstone. A driller reported a pine log embedded in incoherent sands, probably of Pleistocene age, at a depth of 60 feet in a well at Carrabelle. Other examples of vegetable matter as well as logs, noted at numerous localities in Florida, suggest that swamps may have existed during the deposition of the sands, but the absence of any considerable bodies of peat. interbedded with the sand shows that such marsh 


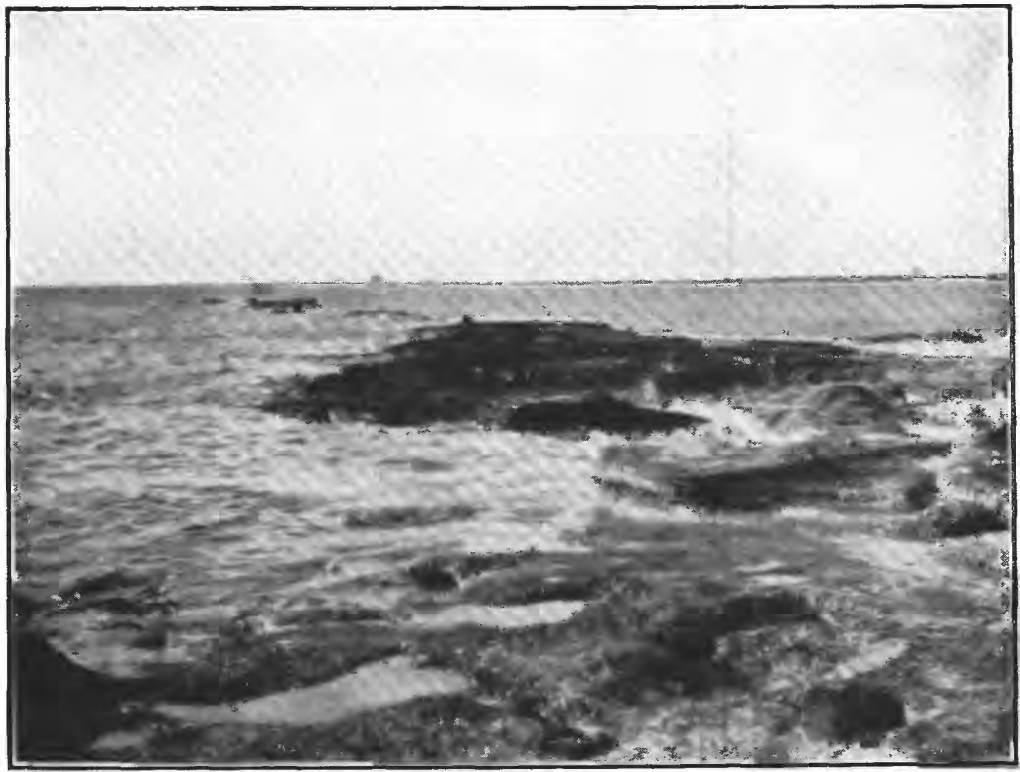

A. COQUINA ROCK ON GULF SIDE OF SARASOTA KEY.

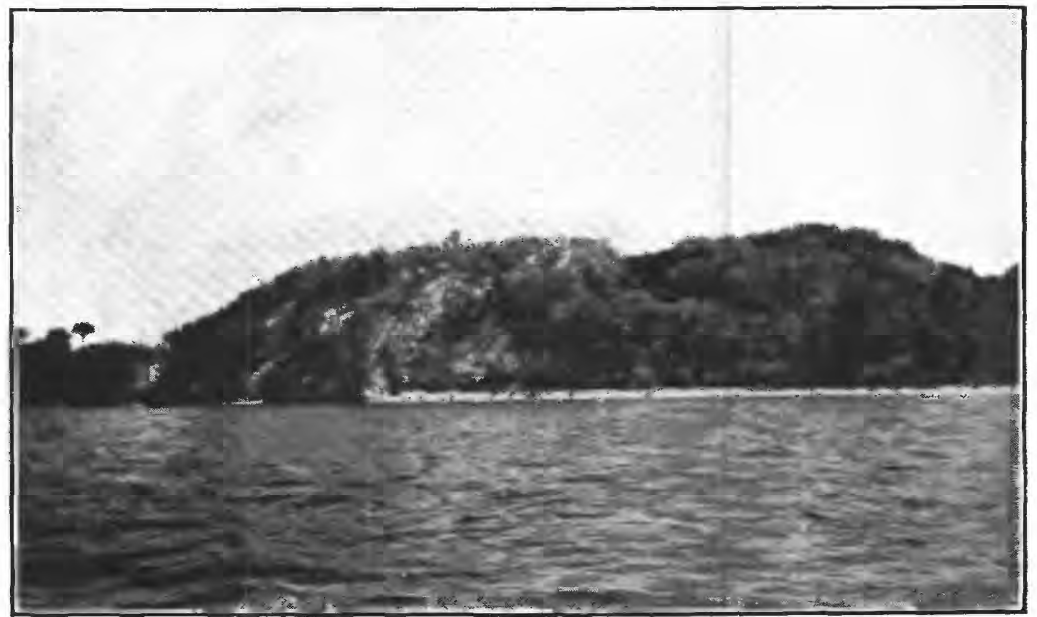

$B$. TURTLE MOUND, AN ANCIENT SHELL MOUND ON NORTH INDIAN RIVER. 

conditions must have been of short duration or that the supply of sediment was sufficient to prevent the accumulation of thick layers of pure organic matter.

The thickness of the gray sands is seldom sufficiently great to mask the major features of the topography of the underlying formations except where there are well-defined terraces.

"Planorbis marl."-After the deposition of the main body of the gray sands, a number of shallow bodies of fresh water appear to have occupied depressions in the surface of the newly emerged land. In these bodies of fresh water there accumulated thin deposits of marl which differ from the earlier marls of the epoch in being composed of calcareous matter nearly free from sand. In this marl the most conspicuous fossils are gastropods, especially those belonging to the genus Planorbis. This rock may be in part post-Pleistocene but can not be satisfactorily subdivided at the present time. It should not be confounded with the "Planorbis rock" of Caloosahatchee River, which has been regarded as Pliocene. "Planorbis marl" of Quaternary age has been observed at Daytona, Sanford, and on Santa Fe River southwest of Fort White; and, according to Eldridge, ${ }^{1}$ it occurs in most of the "hammocks" between Kissimmee and Lake Okechobee.

The Quaternary deposits of the southern end of the peninsula and the keys will be discussed by Mr. Sanford. (See pp. 174-199.)

Coquina.-One of the most common of the marine Quaternary deposits is coquina, a mass of more or less waterworn shells loosely cemented by calcium carbonate, which occurs in numerous places along the coast. The amount of cement is seldom great enough to close the openings between the individual shells, though in some localities the process of cementation has proceeded far enough to produce a rather compact fossiliferous limestone. More or less sand is commonly included in the form of thin laminæ separating the shell beds, and gradations from sandrock to shell rock may be noted. (See Pls. XII, $B$ (p. 148), and XIII, $A$.)

This rock was described by several of the earlier writers on the geology of the State. The following account is from a paper published by Pierce in 1825. ${ }^{2}$

Extensive beds of shell rock, of a peculiar character, occupy the borders of the ocean in various places from the river St. Johns to Cape Florida. They are composed of unmineralized marine shells of species common to our coast, mostly small bivalves, whole and in minute division, connected by calcareous cement. I examined this rock on the isle of Anastasia opposite St. Augustine, where it extends for miles, rising 20 feet above the sea and of unknown depth. It has been penetrated about 30 feet. In these quarries horizontal strata of shell rock of sufficient thickness and solidity for good building stone alternate with narrcw parallel beds of larger and mostly unbroken 
shells, but slightly connected. Hatchets are used in squaring the stone. Lime is made from this material, of a quality inferior to ordinary stone lime.

The large Spanish fort [Fort Marion] and most of the public and private buildings of St. Augustine are constructed of this stone. The rock extends in places into the sea, with superincumbent beds of new shells of the same character.

Similar shell rock is found on the continent in several places.

"Vermetus rock."-Another organic rock, which has been described by Dall, ${ }^{1}$ is now being formed by colonies of a small gastropod, Vermetus (Petaloconchus) nigricans. This organism secretes a skeleton in the form of a winding calcareous tube, and when the tubes of a colony are seen united together they are thought to resemble coral, hence the local name "worm coral." This rock is now being formed on the coast, and it doubtless extends back to the Pleistocene and possibly even to the Pliocene, for Dall ${ }^{1}$ reports the same species of gastropod from the Caloosahatchee marl.

Of the organic Quaternary rocks Dall says: ${ }^{2}$

There is a general opinion among the inhabitants, which was frequently expressed to me in conversation, to the effect that between Tampa and the Keys coquina rock is only to be found at one place, the mouth of Little Sarasota Pass. But this idea is certainly erroneous, as at every projecting point of the keys along the Gulf shore which we visited I found traces of this rcck, though often not visible above water and frequently composed more of sand grains than of shell, so that it looks much like wet loaf sugar.

Yellow clay.-With the Pleistocene is included a silty or sandy yellow clay which is found in some places on the highlands in the central part of the peninsula. This material, which is evidently the residual product left by the decomposition of the underlying rock, is found on all the Oligocene formations and it doubtless began accumulating immediately after the final emergence of these beds from beneath the sea. However, much of it has doubtless been removed, and what remains represents in the main the results of weathering since the depression which resulted in the deposition of the marine Pliocene beds, though probably part was formed during preceding epochs. For convenience it is all included under Pleistocene. It was this material which Dall ${ }^{3}$ described as yellow sand; from the analysis which he gives, it appears to be about 80 per cent silica. Lime, locally an important constituent of the original rock, has dwindled to less than 2 per cent, but this condition is to be expected, as the residuum of the weathering of limestone is the insoluble silica and silicates which existed as impurities in the original rock.

STRATIGRAPHIC POSITION OF THE PLEISTOCENE.

Where observed, the contact between the gray sands of Pleistocene age and the older formations is characterized by marked unconform-

1 Bull. U. S. Geol. Survey No. 84, 1892, p. 153.

2 Geology of Florida: Am. Jour. Sci., 3d ser., vol. 34, 1887, pp. 162-163.

a Bull. U. S. Geol. Survey No. 84, 1892, pp. 154-156. 
ity due to erosion. The contact between the gray and yellow sands has been observed at many localities and is one of unconformity. The yellow sand appears to pass by gradation into the underlying Tertiary from which it was derived by weathering. The stratigraphic relations between the coquina, the "Vermetus rock," and the underlying beds have not been observed but they doubtless show unconformity.

With the exception of the yellow residual sand the several members of the Pleistocene and the overlying Recent deposits exhibit conformable relations. In fact the gradation between Pleistocene and Recent beds often makes it impossible to differentiate them. This is the case with the sands of Recent age, which are usually derived from the erosion and redeposition of the sands from the beds of Pleistocene age. Much of the material has not been transported far, and in many deposits the lack of definite arrangement of the layers renders the recognition of unconformity very uncertain. The interpretation of the observations is also subject to considerable unreliability because it is difficult to say whether such unconformities as are seen are general or merely local.

THICKNESS OF THE PLEISTOCENE.

In Florida the beds of Quaternary age vary greatly in thickness, and in some localities they are wholly wanting. The differences in thickness are due to uneven deposition on a surface which had been more or less dissected by erosion. The gray sands are commonly not more than 20 or 25 feet thick, but in places they rise in sand dunes 40 to 50 feet high, and hence their maximum thickness is over 50 feet.

The thickness of the coquina is difficult to determine, because sections showing the base are wanting and many well records are unreliable, the driller often reporting as "coquina" any soft rock that contains abundant shell fragments. However, at St. Augustine it is known to attain a thickness of over 30 feet, and at many points along the east coast it outcrops with a thickness of 10 or 12 feet.

Few exposures of the shell marls are more than 3 to 4 feet thick, unless the unfossiliferous gray sand immediately overlying them is included, when these figures will usually be increased three to four fold. The data supplied by well samples show that the Quaternary along the east coast varies in thickness from about 40 feet at Jacksonville to over 70 feet at West Palm Beach and more than 100 feet at Miami.

Concerning the deposits along the west coast the information is much less satisfactory, and it is probable that from Manatee River northward nearly to Carrabelle the thickness of the Quaternary deposits averages less than 30 feet, though in places it exceeds 50 feet. 'In a well at Carrabel'e the "Sopchoppy-limestone" was en- 
countered at about 50 feet, but some of the overlying sands and clays may be older than the Quaternary. Westward, in the vicinity of Pensacola, there is a great thickness of sands with some thin clay beds. Satisfactory collections of fossils from these sands have not been obtained, but it appears probable that the Quaternary may attain a thickness of several hundred feet near the coast. At Kissimmee, in the south-central part of the peninsula, the presence of Pleistocene fossils in a well at a depth of 100 feet indicates that the beds thicken toward the south.

On the uplands of the peninsula the yellow sandy clay has been penetrated for over 50 feet in the vicinity of Lakeland, and at other localities in the south-central part of the peninsula it is known to have a thickness of 20 to 30 feet.

PHYSIOGRAPHIC EXPRESSION OF THE PLEISTOCENE.

In the coastal belt the Quaternary is characterized by low relief, forming a region of low sandy plains crossed by shallow valleys and containing many broad marshes and ponds which are seldom more than 2 to 3 feet in depth. The Quaternary of the interior for the most part exhibits the same topography as the underlying rocks, except where it is sufficiently thick to form well-defined terraces. In some localities, especially along the east coast, wind action has built the sand into dunes and ridges, which in some places rise to 30 to 50 or more feet and form conspicuous topographic features.

PALEONTOLOGIC CHARACTER OF THE PLEISTOCENE.

That the Pleistocene fauna bears a close resemblance to that now living along the coast is illustrated by the collection of fossils from North Creek which, according to Dall, ${ }^{1}$ comprised 71 species, of which 5 are believed to be extinct. ${ }^{2}$

STRUCTURE OF THE PLEISTOCENE.

The beds of Pleistocene age show no indications of having been subjected to marked deformation, and their general attitude has probably not been materially changed since their deposition. They seem to have a gentle dip toward the sea and they were apparently raised to their present altitude by a broad movement which was not of such a character as to produce notable flexures.

\section{RECENT SERIES.}

The Recent formations of Florida include alluvial and lacustrine deposits, Recent beach sand and sandrock, coquina, oyster reefs, coral reefs, and eolian sand.

\footnotetext{
1 Trans. Wagner Free Inst. Sci., vol. 3, pt. 6, 1903, p. 1616.

2 For lists of fosslls, see Matson, G. C., and Clapp, F. G., A preliminary report of the geology of Florida with special reference to the stratigraphy: Second Ann. Rept. Florida Geol. Survey, 1909.
} 
ALLUVIAL DEPOSITS.

The alluvial deposits occur along all large streams in belts from a few yards to a mile or more in width. They are divisible into Recent flood-plain deposits and terrace deposits of Pleistocene age. During high water the flood plains are partly overflowed; and in some localities the inundated tracts take the form of nearly impenetrable cypress swamps which are partly flooded during a large part of the year.

The Recent silts and sands in few places rise more than a few feet above the high-water levels of the streams, and the transition to the terraces above is generally poorly defined. The terraces were formed during a submergence in the Pleistocene epoch. Both flood plains and terraces are composed of coarse white sand, or, locally, of yellow and red sands derived from the erosion of the Lafayette (?) formation. Silt and clay are comparatively rare, though a few of the smaller swamps are underlain by these materials. Shells of land and freshwater mollusks occur in the flood-plain deposits, but few of them are of importance. The fluviatile deposits of this age often contain more or less gravel, with phosphatic pebbles derived from the erosion of the Bone Valley gravel and other phosphate-bearing formations. This material was formerly dredged from the beds of the streams and was known as river-pebble phosphate.

LACUSTRINE DEPOSITS.

The deposits here classed as lacustrine include those now being formed in the numerous lakes and swamps. They consist of gray sand derived from beds of Pleistocene age, and animal and vegetable remains supplied by the growth and decay of aquatic organisms. The sand does not differ greatly from the white sand of Pleistocene age which covers such a large part of the surface of the State. Where the organic deposits consist of molluskan remains mixed with sand they form shell marls and where animal remains predominate they form beds of soft marly limestone. On the bank of St. Johns River, at the mouth of Blue Spring Outlet in Volusia County; a semicrystalline limestone more than 4 feet thick, overlain by 3 feet of sand, contains many shells of a fresh-water mollusk (Unio); and the overlying sands contain shells of the common land snail (Helix albolabris). From the position of these beds the sand is evidently of Recent age and the limestone may belong to the Pleistocene.

The vegetable remains form beds of peat or muck, few of which, outside of the Everglades, attain a thickness of more than a few feet and many of which are to be measured in inches. Locally they contain thin beds of sand which were evidently washed into the swamp and in many places considerable organic silica in the form of tests of diatoms. These deposits, which are known as diatomaceous or infusorial earth, are sometimes mined and sold for silver polish. Such a mine was formerly operated near Eustis.

$76854^{\circ}$-wSP $319-13-11$ 
"VERMETUS ROCK."

Under the head of Pleistocene mention was made of the "Vermetus rock" formed of the tube-shaped calcareous skeletons of a gastropod. Although the formation of this rock probably began in the Pleistocene or even earlier, its accumulation has continued down to the present time and it forms one of the most interesting of the Recent deposits.

OYSTER REEFS.

At the mouths of many of the rivers and at many points in the sounds that border the Florida coast oyster beds are numerous. The shells accumulate in large numbers and become cemented into hard jagged rock that is locally a menace to small boats. Oyster beds and the rock formed by their cementation may be found in most of the so-called rivers along the east coast, where they clog what is known as the Inside passage; they may also be found obstructing the mouths of rivers behind the offshore bars. Such reefs are not confined to the east coast, for they may also be found along the west side of the peninsula and along portions of the coast of west Florida. Their growth is so rapid that frequent local dredging is necessary in order to keep shallow channels open for navigation.

CORAL REEFS.

The coral reefs are restricted to southern Florida, and as they have been fully discussed by Mr. Sanford (see pp. 197-198) no description of them need be given here.

BEACH DEPOSITS.

The Recent beach deposits consist largely of sand, though a friable sandrock is not uncommon: and the formation of coquina, which began as early as the Pleistocene, has continued down to the present time. The gray sand derived from the Pleistocene deposits is by far the most common material, though locally fragments of rock derived from some of the older geologic formations predominate. Such rock has been noted by Heilprin ${ }^{1}$ on Chassahowitzka River, and by Dall ${ }^{2}$ at several points along the west coast south of Tampa. An admixture of recent and extinct fossils may result from the erosion and redeposition of the older formations.

EOLIAN DEPOSITS.

The eolian deposits consist of sand in the form of dunes, ridges, or more or less irregular hillocks, which occur in many localities from the northern line of the State southward to the vicinity of Lake Okechobee, but which are best developed along the east coast. In the

1 Explorations on the west coast of Florida: Trans. Wagner Free Inst. Sci., vol. 1, 1887, pp. 57-58,

2 Bull. U. S. Geol. Survey No. 84, 1892, p. 153. 
interior few ridges or dunes are conspicuous, this probably being ascribable to the vegetation and climatic conditions. During a large part of the year the ground water stands very near the surface, especially where the relief is slight, and serves to keep the sand moist and prevent its being blown about by the wind.

Another factor which hinders the formation of dunes in the interior is the general absence of strong winds blowing from a single direction. This is well shown by contrast with the islands along the east coast, where the prevailing winds from the northeast have resulted in the formation of dunes, some of which attain a height of over 50 feet as far south as Dade County. And, finally, the presence of luxuriant subtropical vegetation not only protects the sand from the direct. force of the wind but also tends to hold it in place by a matting of roots and stems.

\section{CHEMICAL DEPOSITS.}

In a region where solution is so extensive chemical deposits would naturally be expected, but except at the extreme southern end of the State such deposits do not appear to be important. The chemical deposits are of two classes, one being dropped from underground water, where it emerges in the form of springs, and the other being deposited in crevices and caverns beneath the surface. The spring deposits vary with the character of the material in solution. The waters containing hydrogen sulphide deposit sulphur, which appears as a white flocculent material coating the plants and earth at the point of emergence. Other waters deposit carbonate of lime or hydrated iron oxide (limonite). Examples of the deposition of sulphur may be found at any sulphur spring or well, but lime and iron deposits are much less common. The subject of deposition in crevices and caverns has already been considered in the discussion of cavern formation (p. 26). In the first annual report ${ }^{1}$ of the Geological Survey of Florida mention was made of the occurrence of sulphur near Floral City, and it was suggested that the deposit may have been the result of the decomposition of hydrogen sulphide gas escaping from underground waters.

Recent investigations by Drew ${ }^{2}$ have shown that the chemical formation of limestones is much more rapid than has generally been supposed, and Vaughan ${ }^{3}$ has discussed the formation of calcareous sediments in Florida in considerable detail. The most important chemical deposits now being made are the layers of calcium carbonate precipitated by the action of denitrifying bacteria in shallow seas. This precipitation accounts for the large amount of calcareous ooze

1 Sellards, E. H., First Ann. Rept. Florida Geol. Survey, 1908, pp. 44-45.

2 Year Book Carnegie Inst. Washington No. 11, 1912, pp. 136-144.

${ }^{3}$ A contribution to the geologic history of the Floridian Plateau, Pub. Carnegie Inst. Washington No. 133, 1910, pp. 135-138. 
found in the Bay of Florida and adjacent to the living coral reef. Vaughan ${ }^{1}$ has recently shown that oolites are now being formed from the ooze in the neighborhood of the keys and in shoal water near the Bahamas.

The investigations of Drew and Vaughan, cited above, have determined how chemical deposits are made and have shown how important a rôle some hitherto unknown agencies may play in the formation of limestones and oolites.

A detailed discussion of the limestones and oolites of southern Florida, where chemical deposition is most active, has already been given by Mr. Sanford (pp. 175-191), and it is therefore unnecessary to describe them here.

\section{HUMAN REMAINS.}

For many years Florida has been a very important collecting ground for human relics. Both sand and shell mounds are common along the coast, and sand mounds occur at many localities on the banks of the principal streams farther inland. Some of the sand mounds appear to have been used for dwelling places and others to have served as burial grounds. Several accounts have been published, ${ }^{2}$ describing the skeletons, implements, and pottery obtained by excavating in these mounds. Apparently all the mounds are built of Pleistocene sands or shells of living mollusks, and they are doubtless of Recent geologic age. (See Pl. XIII, $B$, p. 154.)

In 1871 attention was drawn to a skeleton found by J. G. Webb near Osprey, Manatee County. Subsequently, other human remains were discovered in the same county, ${ }^{3}$ on the farms of $\mathbf{J}$. G. Webb and of J. W. Webb, both near Osprey; at Hanson Landing, 8 miles north of Osprey, and $1 \frac{1}{2}$ miles south of Osprey.

Chemical analysis showed that the bones had undergone considerable change, especially in the diminution in the phosphates and other compounds of lime, and a corresponding increase in silica and iron. The increase in iron was notably large, and there were other changes which seemed to show a marked antiquity of the remains. ${ }^{4}$ However, the close resemblance of these remains to recent Indian bones appears to contradict the chemical evidence.

In consequence of the importance of the find the locality was visited by Vaughan. His report, which is summarized below, was published in full in the paper cited above. ${ }^{5}$

Osprey is situated on a narrow tongue of land rising some 15 to 20 feet above sea level, about one-third of a mile long and from 100 to 150 feet wide. The ridge of the

1 Unpublished manuscript, Carnegie Inst. Washington, 1913.

2 For a partial list of these papers, see Moore, C. B., Jour. Acad. Nat. Sci., vol. 13, 1908.

3 Hrdlička, Aleš, Skeletal remains in North America: Bull. Smithsonian Institution, Bureaư of American Ethnology, No. 33, 1907, pp. 53-64.

4 Idem, p. 57.

${ }^{6}$ Idem, pp. 64-66. 
tongue is formed by an Indian shell mound. There is an Indian burial mound at its base, on its northeast side, and about one-fourth of a mile east of Osprey. Portions of a skeleton enveloped and partly replaced by limonite were found at this locality. Dr. Hrdlicka had a pit about $3 \frac{1}{2}$ feet deep dug at this place and exposed the following section:

Section one-fourth mile east of Osprey.

4. Black soil, about

Inches.

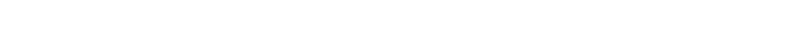

2. Irregular bed of yellowish sand, continuous with the

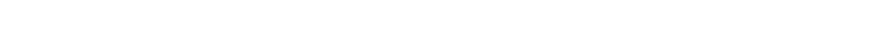

1. Greenish, argillaceous, and sandy layer............. Unknown.

The yellowish sand is the layer in which the skeleton was found.

A study of the lower end of the shell mound on its side next to the bay gave the following section:

Section of Indian shell mound near Osprey.

4. Black soil ..............................

3. Shells, numerous species, all of which are Recent,

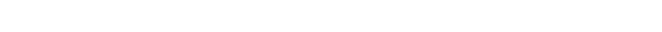

few.

The base of the mound contains shells, many of which are cemented together and filled with ferruginous sandstone; others are filled with greenish sand. All stages from the green sand to the ferruginous sandstone are represented. The layer is not uniformly developed, occurring only in places........

Inches.

Several.

6

1. Green sand to the water level in the bay.......... Undetermined.

A collection of shells was made from Nos. 2 and 3 of the section and were determined by Dr. Wm. H. Dall. All the species found in No. 2 were also found in No. 3, and all of them are Recent. The geologic age of 2 and 3 is post-Pleistocene. Both from the contained fossils and stratigraphic relations they are younger than the Pleistocene of North Creek. The material in which the fossil human remains were found in the old burial mound seems to correspond to the ferruginous layer at the base of the shell mound and can scarcely be older-that is, the human remains are postPleistocene in age.

No importance can be attached to the fossilized condition of the human remains found at any one of the three localities studied. At Osprey, where paleontologic and stratigraphic evidence is available, the evidence is in favor of the human remains being geologically recent. Positive paleontologic and stratigraphic evidence is absent at the locality between 1 and 2 miles south of Osprey and at Hanson's landing. In each locality there is no evidence to favor the remains being geologically as old even as Pleistocene. All of the positive evidence and the conditions under which these fossilized human bones were found in Florida favor the opinion that man geologically is a recent immigrant into that area.

\section{STRUCTURE.}

\section{EARLY INVESTIGATIONS.}

One of the earliest discussions of the structure of Florida was written by Johnson ${ }^{1}$ in 1888. Though hampered by lack of detailed knowledge of the stratigraphy, he presented much evidence to show that 
the peninsula is a broad anticline. The conclusion reached by him was, in a general way, the same as that of several subsequent writers. His paper is accompanied by a section of the strata across the northern end of the peninsula showing a broad arch with the apex in the vicinity of Gainesville. The location of the crest of the arch was recognized by the sink-hole topography, which was thought to indicate the presence of "Eocene" (Oligocene) limestone (of the Vicksburg group) within less than 100 feet of the surface, and the dips away from the central part of the peninsula were determined by noting the presence of younger formations at the surface and by the altitude of the Oligocene beds in wells at different points.

About two years after the appearance of Johnson's paper Shaler ${ }^{1}$ published a brief discussion of the topography of Florida, and in the same article stated his ideas of the structure of the State. Shaler appears to have regarded the peninsula as a broad arch, which he likened to the Cincinnati anticline:

The first question before us concerns the origin of the Florida uplift. It will be observed that we have on the peninsula of Florida a very remarkable ridge, which has grown up from the sea floor to the altitude of about 5,000 feet, and a somewhat similar elevation in the archipelago of the Bahama Islands. Neither of these ridges has a mountainous character. Indeed it is at first sight difficult to find the analogues of these great anticlinal-like folds in the existing structures of the land. They can hardly be classed with any of our known table-lands, for the reason that such elevations are in all cases more or less associated with definite mountain folding. The only similar structure which is known to me is that exhibited in the "Cincinnati anticlinal," that well-known ridge extending from near Columbus, Ohio, to northern Alabama. This elevation in length and breadth may be compared to that of Florida, though it never had more than one-half the height of the Floridian peninsula.

It 'should be remembered that there is to be included with the peninsula the submerged plateau which borders it on either side and extends to the edge of the abyssmal depths of the ocean, and when Shaler speaks of a broad earth arch he includes in it not only the land but this submarine plateau, which in places extends more than 150 miles beyond the coast and descends steeply to profound depths. In a later paper Shaler ${ }^{2}$ reiterates the same view and states that he regards Florida as a broad submarine fold, approximately 600 miles in length, which has risen from a depth of about 5,000 feet.

In commenting on Shaler's hypothesis Dall ${ }^{3}$ says:

In considering the topography of Florida it has been customary among geologists and others to speak of the "central ridge," "elevated axis," and in the latest contribution to the subject Prof. Shaler regards Florida as "formed of lowlands rising as a broad fold from the deep water on either side to a vast ridge, the top of which is relatively very flat, there being no indication of true mountain folding in any part

1 Shaler, N. S., Topography of Florida: Bull. Mus. Comp. Zool. Harvard Coll., vol. 16, No. 7, 1890, pp. 139-156.

2 Shaler, N. S., Relation of mountain growth to formation of continents: Bull. Geol. Soc. America, vol. 5, 1894, p. 206.

3 Bull. U. S. Geol. Survey No. 84, 1892, p. 87. 
of the area." In an extremely wide and general sense it is of course true that the peninsula forms a great fold, but in the ordinary and literal meaning of the words this description conveys an inaccurate idea of the structure of the region.

Dall regards the structure of Florida as characterized by low folds approximately parallel to the general trend of the peninsula. By means of railroad profiles he finds indications of two well-defined ridges, one near the Atlantic coast and another near the Gulf coast, and notes a third in the vicinity of Brooksville and Plant City. The eastern ridge, which forms the eastern boundary of the central "lake basin," includes the well-known "Trail" ridge and was, he thought, composed of "Miocene" rocks (probably intended to include the Oligocene rocks belonging to the Apalachicola group, which were then known as Miocene). The western ridge forms the western boundary of the central "lake basin" and passes through Lakeland. The theories advanced by Dall and Johnson differ in one important point. Dall believes that the central lake basin is a synclinal valley; Johnson held that this region, which he designates "high hammocks" or "lake region," represents the eroded apex of a broad arch.

\section{GENERAL CHARACTER OF THE STRUCTURE.}

The State as a whole is merely the southern extension of the Coastal Plain, and its history has in general been the same. Broadly, it includes two distinct axes of uplift which appear to extend in a general north-south direction. The outline of the Vicksburgian limestone west of Apalachicola River indicates a gentle uplift, and field observations show that this limestone has there an altitude of about 75 to 100 feet over a considerable area. From this uplift the rock dips steeply to the south and west and more gently, but still perceptibly, to the southeast. Toward the north and northeast it rises to form the basis of the highlands of southern Georgia and Alabama and then gives place to the underlying Jackson, which outcrops farther north. The exact trend of the uplift which brought the limestone of the Vicksburg group to its present altitude in west Florida is not known, but it is probably east of north. The peninsular portion of Florida represents a broad uplift, such as was postulated by Johnson and Shaler, and the comparison with the Cincinnati arch appears to be appropriate. The objection to the use of the term "anticline" in connection with these broad uplifts is due to the fact that most geologists are inclined to associate the word with narrower archings of the strata, such as are common in the Appalachian or other closely folded regions. By the use of the term "arch" it is hoped that this objection will be removed. In the peninsula of Florida the arching of the beds has raised the lower Oligocene to an altitude of more than 100 feet above sea level over considerable areas from the 
vicinity of Brooksville and Croom northward to and beyond Gainesville, Live Oak, and Lake City. Around the outcrops of the rocks belonging to the Vicksburg group, which have been exposed on account of the erosion of this arch, are the exposures of the formations which comprise the Apalachicola group and younger beds. The rocks belonging to the Apalachicola group occupy a broad belt from Sarasota northward to the Georgia-Florida line and extend westward to where it is overlapped by beds of Miocene age. On the eastern side of the central uplift the Apalachicola group occupies a much narrower area and within a short distance is buried beneath younger beds. Since there is little difference in the thickness of the beds belonging to this group on the east and west sides of the arch, it may be readily inferred that the easterly dips are more steep than the westerly.

The northern end of the arch which forms the peninsula pitches gently downward, so that the limestones of the Vicksburg group dip below the surface north of Live Oak and Lake City and the formations comprising the Apalachicola group appear in the valley of Suwannee River. The southern end of the arch sinks gently beneath the younger formations so that the limestones of the Vicksburg group lie several hundred feet below the surface in Lee County and at Key West, where they were encountered in drilling wells.

The variation in the depth to rocks of Oligocene age along the east coast of Florida is probably due in part to local variations in the rate of dip and to minor folds. There appears to be little doubt that any upheaval which produced the broad arch forming the peninsula of Florida would also produce minor arches or folds parallel to the direction of the main uplift, as well as minor folds transverse to the main arch. The satisfactory discrimination of these minor folds calls for a large amount of detailed stratigraphic work based on a knowledge of the fossils representing different horizons. It is possible that the ridges mentioned by Dall are really minor folds, but he does not appear to have eliminated the possibility of their being due to circumdenudation. That there are many minor folds in Florida can not be denied. Good examples of such folds are those which Dall ${ }^{1}$ noted on Caloosahatchee River. These small folds are not more than 10 to 12 feet high and are mostly not more than onefourth mile wide. They are of more than usual interest because they involve marls of Pliocene age and hence were probably formed during Pleistocene or even Recent time.

${ }^{1}$ Notes on the geology of Florida: Am. Jour. Sci., 3d ser., vol. 34, 1887, p. 168; Tertiary fauna of Florida: Trans. Wagner Free Inst. Sci., vol. 3, pt. 6, 1903, p. 1604; Correlation papers-Neocene: Bull. U. S. Geol. Survey No. 84, 1892, p. 143. 


\section{GEOLOGY OF SOUTHERN FLORIDA.}

By Samuel Sanford.

The general geologic structure of the Florida peninsula, the character of the materials that underlie the surface, and the areal distribution, relative position, and age of these materials have already been discussed (pp. 65-166) and will not be reviewed here, but as the topography of southern Florida, as a whole, is different from that of the central and northern parts of the State, so the geology has features which differentiate the region from the greater portion of the peninsula.

\section{STRATIGRAPHY.}

Except for a possible extension of Pliocene beds south of the exposures on Caloosahatchee River (p. 136), all the surficial formations: of southern Florida, unconsolidated and consolidated, are of Quaternary age and include those laid down in Recent and in Pleistocene time.

\section{PRE-PLEISTOCENE FORMATIONS.}

CHARACTER AND DISTRIBUTION.

The outcrops of Oligocene, Miocene, and Pliocene beds in central and northern Florida and the relations of the beds have been discussed (pp. 71-150). Neither Oligocene nor Miocene strata come to the surface in southern Florida and outcrops of Pliocene deposits are not known. ${ }^{1}$ Hence the character, thickness, and relations of any beds older than Pleistocene must be inferred from what has been determined to the north or proved by samples collected from a number of scattered wells. But the nearest outcrops of Miocene and Oligocene beds are so far from the greater part of the area under discussion that inferences as to the character, thickness, and depth of Miocene or older beds are little better than guesses, and, unfortunately, reliable records of deep wells are few. Still, enough is known of the deeper-lying beds to permit the drawing of general conclusions as to the character and origin of the Miocene and Pliocene deposits.

\section{WELL RECORDS.}

DISTRIBUTION OF WELLS.

On the east coast wells over 100 feet deep have been sunk at Gomez, 1,200 feet; Hobe Sound, 1,100 feet; West Jupiter, 101 feet; Palm Beach, 1,215 feet; Fort Lauderdale, 108 and 387 feet; and Delray, 119 feet. Along the line of the keys deep wells have been sunk at Indian Key, 135 feet; Indian Key Channel, 687 feet; Key Vaca, 700 feet; Knights Key, over 620 feet; Big Pine Key, 711 feet;

1 That isolated patches of Pliocene beds, thinly hidden by Pleistocene sand, occur some distance south of Caloosahatchee River is regarded by the writer as highly probable. 
Key West, 500, over 900, and 2,398 feet. On the west coast there are wells at Marco, 376 feet; Estero, 285 feet; Punta Rasa, 140 and 280 feet; St. James City, 148 and 335 feet; Sanibel Island, 420 and over 600 feet; and Buck Key, 605 feet. In addition, wells have been sunk in the prairies south of Caloosahatchee River and west of Lake Okechobee as follows: T. 47 S., R. 31 E., 647 and 691 feet; T. 48 S., R. 31 E., 720 feet; T. 46 S., R. 33 E., 921 feet.

The logs of most of the wells mentioned were not recorded carefully and the logs of several are not available. More or less continuous series of samples were saved at Palm Beach, Indian Key Channel, Key Vaca, Key West, and Buck Key.

PALM BEACH.

Darton ${ }^{1}$ gives the following record for the Palm Beach well:

Record of well of C. I. Craigin, Palm Beach.

\begin{tabular}{|c|c|c|}
\hline & Thickness. & Depth. \\
\hline Sands, with thin layers of semivitrified sand at 50 and 60 feet. $\ldots \ldots \ldots \ldots \ldots \ldots \ldots$ & \multirow[t]{2}{*}{ Feet. 400} & Feet. \\
\hline 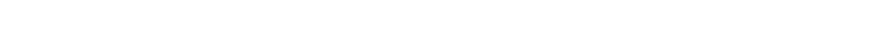 & & \multirow{3}{*}{$\begin{array}{l}800 \\
850 \\
860 \\
904\end{array}$} \\
\hline 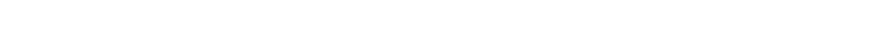 & \multirow{2}{*}{$\begin{array}{r}400 \\
50 \\
10 \\
44\end{array}$} & \\
\hline $\begin{array}{l}\text { White sand, with abundant Foraminifera of four or five species } . . . \ldots \ldots \ldots \ldots \ldots \ldots \\
\text { No sample. }\end{array}$ & & \\
\hline 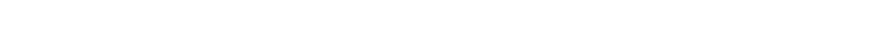 & \multirow{2}{*}{85} & \multirow{2}{*}{$\begin{array}{r}915 \\
1,000\end{array}$} \\
\hline 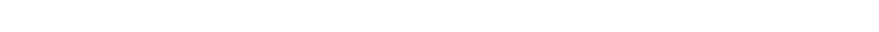 & & \\
\hline 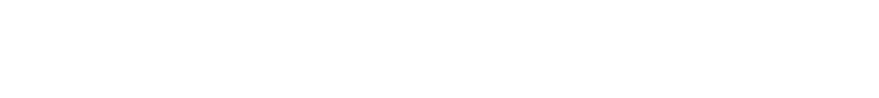 & 212 & 1,212 \\
\hline
\end{tabular}

Darton was unable to determine definitely the age of the series overlying the limestones, but the organic remains from 800 to 915 feet suggest Miocene age, and the Foraminifera between 400 and 800 feet indicate that the beds whence they came are also probably of Miocene age.

This record shows that the top of the Vicksburg group (lower Oligocene) lies between 915 and 1,000 feet below the surface at Palm Beach. The great thickness of quartz sand is the most noteworthy feature of the record.

INDIAN KEY CHANNEL.

The following log of the well at Indian Key Channel, on the grade of the Florida East Coast Railway (sec. 12, T. 64 S., R. 36 E.), is of more than average value, as the driller kept notes and saved a good series of samples. The latter were examined by Vaughan and some of his comments are given in parentheses after the driller's notes. The tentative correlation of the strata is also by Vaughan, who based his determinations on a few recognizable and distinctive fossils. 
Record of well at Indian Key Channel.

\begin{tabular}{|c|c|c|}
\hline & Thickness. & Depth. \\
\hline 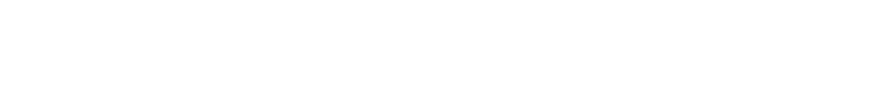 & Feet. $\begin{array}{r}19 \\
29 \\
40\end{array}$ & $\begin{array}{r}\text { Feet. } \\
19 \\
48 \\
88\end{array}$ \\
\hline 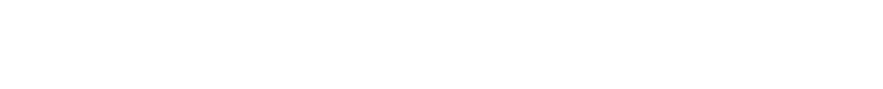 & $\begin{array}{r}40 \\
9 \\
6\end{array}$ & $\begin{array}{l}128 \\
137 \\
143\end{array}$ \\
\hline 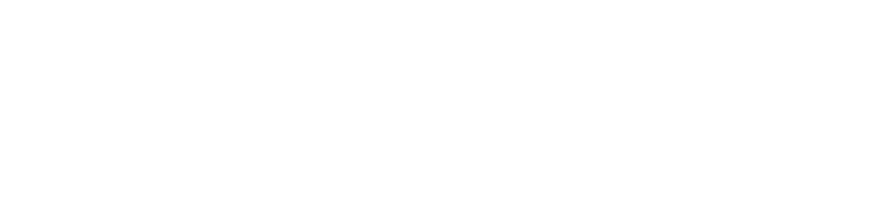 & $\begin{array}{r}112 \\
20 \\
20\end{array}$ & $\begin{array}{l}255 \\
275 \\
295\end{array}$ \\
\hline 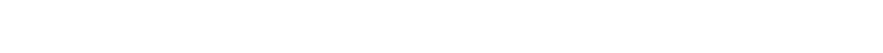 & $\begin{array}{r}180 \\
20\end{array}$ & $\begin{array}{l}475 \\
495\end{array}$ \\
\hline 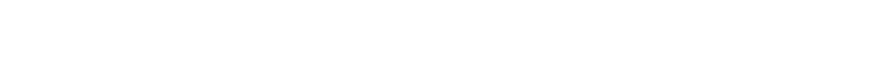 & 20 & 515 \\
\hline 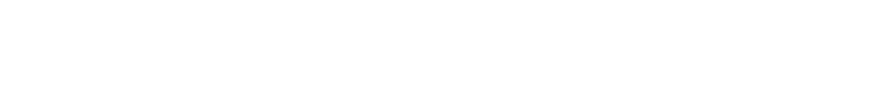 & 60 & $\mathbf{5 7 5}$ \\
\hline $\begin{array}{l}\text { Rock, soft, white, clay, and sand (cream-colored limestone, with shell fragments } \\
\text { at } 604 \text { feet) }\end{array}$ & & \\
\hline $\begin{array}{l}\text { Lime formation, soft, clay and sand (siliceous limestone) } \\
\text { Lime formation, soft rock (cream-colored marl, with a few grains of silica)....... } \\
\text { Lime formation, with sand (gray siliceous sand with numerous calcareous par- }\end{array}$ & $\begin{array}{r}27 \\
3\end{array}$ & 635 \\
\hline & 7 & 645 \\
\hline $\begin{array}{l}\text { Rock (yellowish limestone and coarse siliceous sand) } \ldots \ldots \ldots \ldots \ldots \\
\text { Soft rock (yellowish limestone) } \ldots \ldots \ldots \ldots \ldots \ldots \ldots \ldots \ldots\end{array}$ & $\begin{array}{r}2 \\
40\end{array}$ & $\begin{array}{l}647 \\
687\end{array}$ \\
\hline
\end{tabular}

The predominance of sandy beds is a noteworthy feature of this section.

KEY VACA.

Two wells were drilled at Marathon, near the west end of Key Vaca, one to a depth of 534 feet and the other to about 700 feet. The combined records of the two wells gives the following section:

Record of wells at Marathon.

\begin{tabular}{|c|c|c|}
\hline - & Thickness. & Depth. \\
\hline 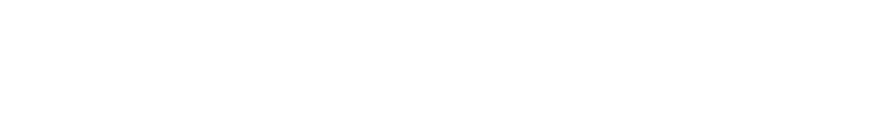 & Feet. & $\begin{array}{l}\text { Feet. } \\
105\end{array}$ \\
\hline $\begin{array}{l}\text { Marl, white, and hard, white and yellowish limestone; branches of Porites, } 105-107 \\
\text { feet; hard white limestone, 125-138 feet; grains of silica at } 140 \text { feet } \ldots \ldots \ldots \ldots \ldots \ldots \ldots\end{array}$ & & \\
\hline 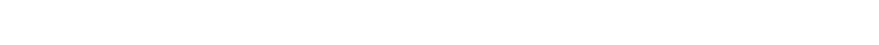 & $\begin{array}{r}2 \\
5\end{array}$ & $\begin{array}{l}150 \\
155\end{array}$ \\
\hline 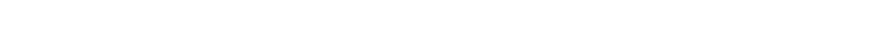 & 21 & 176 \\
\hline 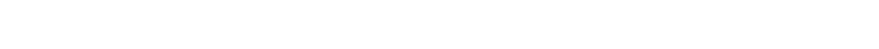 & 54 & \\
\hline 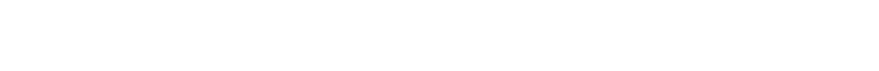 & 70 & 300 \\
\hline 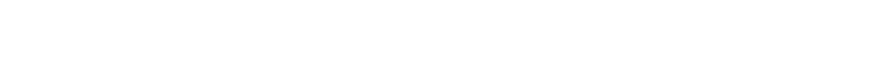 & 100 & 400 \\
\hline 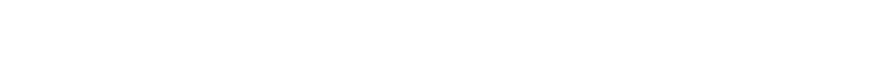 & 20 & 420 \\
\hline 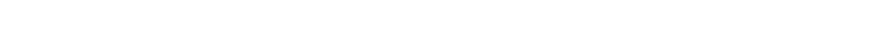 & $280 \pm$ & $700 \pm$ \\
\hline
\end{tabular}


Although the many samples of drillings from this well show the lithology of the formations penetrated, they give unsatisfactory evidence as to geologic age. The sands below 176 feet yielded but a small variety of determinable fossils. A few claws or carapaces of a small crab or a few barnacle plates were the only organic remains noted in going through many feet of sand. The friable sandstones contained many casts, internal and external, of pelecypod shells, the external casts being of sandstone, the internal of more clayey material. These casts, though numerous, were not sharp enough to be of diagnostic value.

The shell beds yielded a small variety of species; from collections between 375 and 420 feet Vaughan identified 5 species, including pectens and an oyster, which were probably Miocene.

Thus the Key Vaca section, though it shows Pleistocene limestone and Miocene sands, gives no data for separating Pliocene from Miocene. The top of the Pliocene may be at 155 feet. The coarseness of the sands, their barrenness, and the character of the few determinable fossils between 176 and 400 feet indicate shoal water and strong currents. No break in deposition is determinable.

\section{KNIGHTS KEY.}

Little information is available regarding the well on Knights Key, about a mile west of Marathon. It went through the bed of Key Largo limestone, the limy beds, and the great thickness of sands below, and struck solid limy sandstone underlain by limestone at 620 feet. A few fossils brought up between 620 and 720 feet were examined by Vaughan, who reported that they were probably of Miocene age.

BIG PINE KEY.

The well on Big Pine Key is reported to have gone through the surficial limestones and struck fine sands with a considerable proportion of clay (or calcareous mud), much like the sands under Key Vaca, at a depth of 125 feet. Work stopped at 711 feet because the driller was unable to go deeper with his rig.

KEY WEST.

Samples collected at 25 -feet intervals from the deep well at Key West were examined by E. O. Hovey. ${ }^{1}$ The following generalized log is from his detailed description of the samples down to 2,000 feet:

\footnotetext{
1 Hovey, E. O., Notes on the artesian well sunk at Key West, Florida, in 1895: Bull. Mus. Comp. Zool. Harvard Coll., vol. 38 , No. 2, 1896, pp. 65-91.
} 
Record of well at Key West.

\begin{tabular}{|c|c|c|}
\hline & Thickness. & Depth. \\
\hline Oolite, yellowish. & Feet. $_{25}$ & Feet. \\
\hline Limestone, white, yellowish, or light gray; with oolitic lun & 150 & 175 \\
\hline 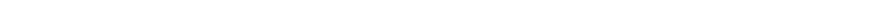 & 25 & 200 \\
\hline Limestone, white, porous, oolitic, and sandy... & 75 & 275 \\
\hline Limestone, white, more or less solid........... & 100 & 375 \\
\hline 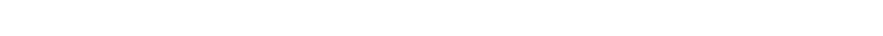 & 300 & 675 \\
\hline Lime sandrock, yellowish to brownish; Orbitoides $800-850$ feet & 400 & 1,075 \\
\hline Limestone, light gray; partly dense and partly porous........... & 100 & 1,175 \\
\hline 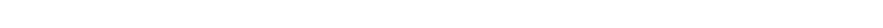 & 175 & 1,350 \\
\hline Lime sandrock, yellowish gray; some porous limestone. & 100 & 1,450 \\
\hline Lime sandrock, varying in color and compactness; strata of dense limestone ... & 525 & 1,975 \\
\hline Limestone, yellowish to light-brownish gray; rather solid, with porous portions & & 2,000 \\
\hline
\end{tabular}

Aside from the depth, this log is notable for absence of beds of quartz sand, though such beds have a total thickness of over 400 feet at Key Vaca, and over 200 feet at Big Pine Key, which are respectively 40 miles and 25 miles to the east. Certain peculiarities of the samples described by Hovey, taken with the reported incomplete casing of the well, throw doubt on the value of the record, but probably no considerable bed of quartz sand was penetrated.

The general aspect of the organic remains, bits of molluskan shells, corals, Foraminifera, echinoids, and-coralline Algæ, led Hovey to believe that the rocks originally were shoal-water deposits. The samples show that during Miocene and Pliocene time, as during Pleistocene and Recent time, quartz sands did not get as far south and west as Key West. Hovey thought the Pleistocene beds' at Key West might be less than 50 feet thick but was unable to separate the Pliocene and the Miocene. The top of the Vicksburg group he placed at 700 feet, thus making the total thickness of the Pliocene and Miocene less than 650 feet.

Other samples from this deep well, probably portions of a duplicate series, were examined by Eldridge, whose determinations, contained in his unpublished notes, agree in general with those of Hovey except with regard to the presence of Orbitoides. Eldridge noted in samples below 700 feet abundant remains of Foraminifera of several species, but apparently did not recognize Orbitoides in a single sample. Evidently the samples examined by Eldridge, like those examined by Hovey, contained no quartz sands. A summary of Eldridge's notes on the samples is:

Summary of record of deep well at Key West (by Eldridge).

\begin{tabular}{|c|c|c|c|}
\hline & & Thickness. & Depth. \\
\hline 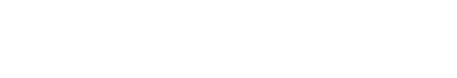 & ds, streaks or masses of secondary calcite, & $\begin{array}{r}\text { Feet. } \\
375 \\
325\end{array}$ & $\begin{array}{r}\text { Feet. } \\
375 \\
700\end{array}$ \\
\hline $\begin{array}{l}\text { Limestones, soft to hard, white to gray or b } \\
\text { beds of shells and calcareous sand......... }\end{array}$ & fown, abounding in Foraminifera; a few & 1,300 & 2,000 \\
\hline
\end{tabular}


Another deep well was sunk at Key West in 1908-9. Samples were saved from it at irregular intervals, from the surface to a depth of 960 feet. They were not taken closely enough for the compiling of a good record, and most of the material saved was finely divided and contained very few determinable organic remains. The samples are of interest, however, for the additional information they give regarding the substructure of the western end of the chain of keys. In general the agreement at specific depths with Hovey's description of samples from the well sunk in 1895 is not close. The materials brought up comprise oolitic and nonoolitic limestone, marls, calcareous sands, and sands containing a larger proportion of siliceous material than those described by Hovey. Samples from different depths were examined by Vaughan, Sellards, and the writer. Taken as a whole the samples from the surface to 350 feet are oolitic and nonoolitic limestone showing no decided nor persistent change. From 350 to 500 feet the samples contain some soft, yellowish, greenish, or gray calcareous material. Fragments of oolitic limestone appear in the samples from 350 to 475 feet, and fine siliceous sand grains at 530 and 540 feet. From 540 to 710 feet no samples were saved. At 710 feet the material was much the same as at 540 feet. A dark, firm, nonoolitic limestone, apparently struck at 786 and continuing to 950 feet, contained many comminuted fragments of shells and some siliceous grains. At 960 feet the limestone was softer and white, with shell fragments but very few siliceous grains. The notable characteristic of the samples below 710 feet is the absence of determinable remains of Orbitoides. Though some of the samples contained fine siliceous sand grains, there is no evidence that the well penetrated any thick arenaceous beds.

Summary of record of 1908-9 Key West well.

\begin{tabular}{|c|c|c|}
\hline - & Thickness. & Depth. \\
\hline $\begin{array}{l}\text { Limestone, oolitic and nonoolitic layers, and layers composed largely of shell frag- } \\
\text { ments. }\end{array}$ & Feet. ${ }_{350}$ & $\begin{array}{l}\text { Feet. } \\
350\end{array}$ \\
\hline $\begin{array}{l}\text { Marls and calcareous sands, with a very little siliceous sand and some layers of lime- } \\
\text { stone. }\end{array}$ & 436 & 786 \\
\hline 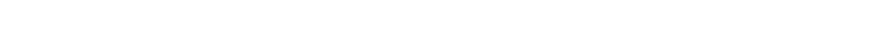 & 174 & 960 \\
\hline
\end{tabular}

BUCK KEY.

A record of the Buck Key well, given from memory by the driller, W. Sykes, of Fort Myers, supplemented by samples saved at different depths, furnishes the following section: 
Record of well of W. H. Knowles at Buck Key.

\begin{tabular}{|c|c|c|}
\hline & Thickness. & Depth. \\
\hline 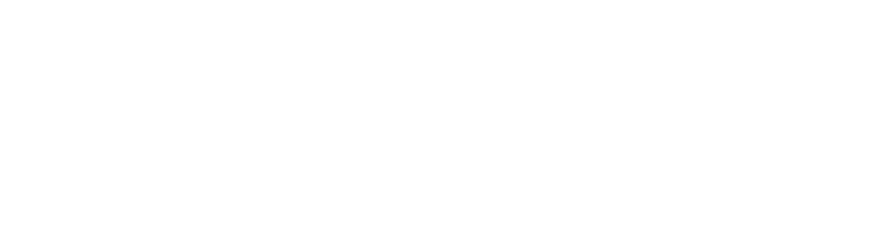 & $\begin{array}{r}\text { Feet. } \\
50 \\
10 \\
3 \\
2 \\
80 \\
130 \\
215 \\
115\end{array}$ & $\begin{array}{r}\text { Feet. } \\
50 \\
60 \\
63 \\
65 \\
145 \\
275 \\
490 \\
605\end{array}$ \\
\hline
\end{tabular}

The thickness of the sands and marls and the small proportion of hard rock above 490 feet are the striking features of the section.

\section{OLIGOCENE SERIES.}

Foraminifera of the genus Orbitoides, which characterizes the Vicksburg group, were found in drillings from the wells at Palm Beach and Key West. The top of the limestone may lie about 950 feet below the surface at Palm Beach and 700 feet below at Key West. An eastward dip of the limestone is indicated by the records of wells east of Fort Myers, but evidence to show the amount of dip is meager. A southern prolongation of the anticlinal fold of west central Florida is probable, but can not be established from the known data.

Samples from the Palm Beach well showed Orbitoides for 312 feet; samples from the Key West well, according to Hovey, showed the same fossils at 750 feet and below. It is fairly certain that the latter well was not cased below 1,000 feet; hence little reliance can be placed on the samples from 1,000 to 2,000 feet. Thus no evidence to establish the thickness of the Vicksburg group is available, though Hovey noted changes in the character of the limestones at 1,475 and 2,000 feet. Evidence to establish the thickness of Oligocene beds above the Vicksburg group is also lacking.

\section{MIOCENE AND PLIOCENE SERIES.}

A comparison of records from points so widely separated as Palm Beach, Key Vaca, and Buck Key shows a surprising thickness of beds composed largely of quartz sand, and contradicts the old belief that the southern end of the peninsula rests on a solid limy foundation. Between the surficial limestones and the limestones of upper Oligocene age are 200 to 900 feet of unconsolidated material that is more predominantly siliceous than calcareous. The succession of limy beds at Key West is explainable by remoteness from the mainland and consequently from the source of the quartz sands.

No deep well in southern Florida has proved definitely the thickness of Miocene and Pliocene sediments at a given point, and it is 
doubtful if any well that may be drilled will show Miocene deposits sharply separated from Pliocene or if wells in most of the region will afford a basis for separating the Miocene from the upper beds of the Oligocene. Hence the total combined thickness of the Pliocene and Miocene beds is likely to remain conjectural. It may amount to over 800 feet at Miami.

Some of the Miocene and Pliocene sands probably represent siliceous grains derived by weathering and erosion from the upper Oligocene and lower Oligocene limestones. Much more of it may have worked south along the east and west coast of the peninsula or around the shores of the islands that foreshadowed the peninsula. The quartz grains no doubt were halted many times in the form of beds of sand, sandy marl, and even sandy limestones in their journey from their parent ledges to the south end of the peninsula. They were worked over again and again and even roughly concentrated in their southward drift, so that the mass of siliceous material at the south end of the peninsula represents the removal and assortment of many times its bulk of quartz-bearing rock. The process of concentration apparently continued through the Miocene and Pliocene epochs a sufficient length of time for the accumulation of hundreds of feet of sandy material. Only a depression of the coast and the substitution of offshore for near-shore deposits or a change that would greatly increase the deposition of calcareous material would interrupt the process. There is no evidence of the interruption of the sands under Key Vaca.

\section{PLEISTOCENE SERIES.}

\section{UNEXPOSED FORMATIONS.}

Of Pleistocene formations earlier than the limestones and sands to be described the only positive evidence at hand is that of well samples. A few records show a considerable thickness of Pleistocene material. Thus a bed of coquina at a depth of 118 feet in a well at Delray yielded 24 species of mollusks and 2 of corals (nonreef-builders), of which 90 per cent were identified as Recent by Vaughan, indicating that the age of the coquina was early Pleistocene, earlier than the Miami oolite. Few samples have been taken from other east coast wells between depths of 100 and 200 feet. Samples from the well on Key Vaca indicated reef rock to 105 feet. At Key West limestones, evidently of shoal-water origin, are indicated by the samples from the deep well, but the thickness of Pleistocene beds earlier than the surface oolite is uncertain. On the west coast rather fine quartz sand underlies the Lostmans River limestone at Everglade. This sand is at least 40 feet thick. No samples were saved from the deep well at Marco and but few from the wells at the mouth of 
Caloosahatchee River. The latter show sands and marls to a depth of over 100 feet.

The notable feature of the well records is the reported finding of sands and unconsolidated material below hard rock at widely separated localities. Samples from West Palm Beach, 55 to 75 feet, show much-worn shell fragments, cemented and replaced by crystalline calcite, with pockets or beds of quartz sand but no hard rock close to surface. Samples from Miami show much the same variety of material below the surficial oolite.

\section{EXPOSED PLEISTOCENE FORMATIONS.}

GENERAL CHARACTER.

The Pleistocene surficial deposits comprise limestones, coquina, shell marls, and sands. The limestones form bare ridges and occur as inconspicuous scattered outcrops. The coquina lies along or back of many miles of ocean beach on the east coast, and the sands mantle the surface of the greater part of the pine land.

The limestones described on the following pages are alike in being of marine origin, but nonmarine limestones probably occur. Dall has mentioned the finding of hard ringing eolian limestone on Corkscrew Creek southeast of the mouth of Caloosahatchee River, and scattered deposits corresponding to the Planorbis rock of Dall will probably be found toward Lake Okechobee or between Caloosahatchee River and the Big Cypress. In the localities visited by the writer, however, but one occurrence of a possibly nonmarine limestone was noted-a soft, loosely compacted rock lying in lumps in the flatlands over an area but a few rods across, 3 miles west of West Palm Beach.

The marine limestones seen are classified on the basis of lithology and areal extent as the Palm Beach limestone, Miami oolite, Key West oolite; Key Largo limestone, and Lostmans River limestone. ${ }^{1}$

PALM BEACH LIMESTONE.

Synonymy.-References to the limestone on the east side of the Everglades and to limestone forming the eastern rim appear in various early accounts of travelers and of Army officers who traversed the Everglades, but no distinctive term has been applied by anyone, so far as is known, to the inconspicuous outcrops of limestone sparsely scattered through the pineland, cypress swamp, and prairie along the eastern side of the Everglades, from Delray northward. The term

\footnotetext{
1 Evidence not available at the time this classification was made indicates that the boundary between areas underlain by the Lostmans River limestone and the Palm Beach limestone can not be determined with precision in the Everglades, and there is good reason for believing that the oolites grade into limestones that are not oolitic. But the writer adheres to the classification here stated for the reason that he has not had opportunity to revise it in the light of the evidence to be gained by a careful examination of the material excavated along the miles of drainage canals dug during the past five years.
}

$76854^{\circ}-$ WSP $319-13-12$ 
Palm Beach limestone is here used to distinguish these nonoolitic marine limestones because the outcrops are found throughout a considerable extent of country in the northeastern part of Palm Beach County. No similar rock outcrops near the town of Palm Beach. Though the outcrops are few and separated, it is possible that the limestone extends northward into St. Lucie County and is the equivalent of limestones elsewhere described.

Stratigraphic position.-As the exposures are all low, consisting of mere heads of rock projecting a few inches to a foot above the surrounding sands, and as none of the rivers, so far as reported, show good sections, little is known of the stratigraphic relations of the Palm Beach limestone. It is overlain by the sands of the pinelands and by the sands and peat of the Everglades. It is underlain, so far as can be told from the records of the few wells that have penetrated it, by marl and.sand.

Seaward it grades into coarser and less solid rock or sand, overlain by the coquina deposits forming the backbone of some of the barrier beaches of the east coast. The limestone has not been seen in contact with the coquina and the exact relations remain to be ascertained. Some of the coquina may represent beach and bar deposits formed at the same time as the limestone. To the south, the limestone seems to grade into the Miami oolite, but the two have not been seen in contact.

Lithologic character.-At the type locality in T. 45 S., R. 42 E., 8 miles west of Hypoluxo, the rock is a white to yellowish limestone, containing a variable proportion of fine to medium quartz sand. The lime cement is not coarsely crystalline, nor does the rock contain, like other limestones of southern Florida, many patches and streaks of coarsely crystalline calcite, replacing amorphous material or filling cavities left by the solution of shell fragments. Its hardness varies greatly. In some places it is compact and dense, ringing under the hammer; in other places it contains so much sand that it is really a friable calcareous sandstone.

Thickness.-Owing to the low elevation of the belt of country where the outcrops are found and the horizontal position of the limestone, the only evidence available to determine its thickness is that of well records. The testimony of these is contradictory, as is to be expected from the fact that most of them are given from memory. Such evidence as can be had, howerer, indicates that the limestone may be 5 to 50 feet thick.

Physiographic expression.-From the low relief of the pinelands and the monotonous flatness of the ground, it can not be said of the Palm Beach limestone that it contributes to the physiography of the country. It helps, howcver, to define the eastern boundary of the Everglades for possibly 30 miles. 
Paleontologic character.-The Palm Beach limestone is, as a whole, abundantly fossiliferous. The fossils comprise gastropod and pelecypod shells, all of marine type and probably of living species. Corals, as is to be expected from the sandy character of the limestone, are few or altogether lacking. In places, the rock is full of shells of Chione cancellata, well bedded, with the valves closed, indicating that the shells had not been disturbed since the mollusks died. The limestone thus has the facies of a shallow-water deposit formed in bays or lagoons with bottoms of sand or sandy marl.

Areal distribution. - The northernmost exposure of the Miami oolite seen by the writer was in T. 47 S., R. 42 E., 5 miles south and 7 miles west of Delray. The southernmost exposure of nonoolitic limestone seen is about 5 miles north of Delray. There are outcrops between, but they are scattered and were not visited, as it was thought doubtful that any direct transition from oolitic to nonoolitic beds could be found or any line of demarcation established. The northern limits of the formation are undefined. As before stated, it probably extends into St. Lucie County. Little is known of its western extent under the Everglades, but similar rock is found 7 to 11 miles west of Fort Lauderdale, along the drainage canal. To seaward it is buried by or grades into sand and coquina.

Structure.-The rock is not as distinctly cross-bedded as are many exposures of the Miami oolite and the beds are more massive. The sandy layers at the type locality west of Lantana are 2 to 3 inches thick, and the limy beds may be a foot or more thick.

MIAMI OOLITE.

Synonymy.-The outcrops of oolite at New River, Miami River, Long Key in the Everglades, and at other points in southeastern Florida were noted by Army officers at the time of the Seminole War. The first writer to recognize the age of the deposits appears to have been Buckingham Smith, who in 1847 noted the many shells of mollusks in the oolite at Miami River and determined the age as post-Pliocene. ${ }^{1}$

In 1851 Tuomey described outcrops of the rock, on Miami River, ${ }^{2}$ and in the same year L. Agassiz mentioned them in his account of the Florida reefs. ${ }^{3}$

Shaler ${ }^{4}$ in 1890, following the views of L. Agassiz, regarded the oolitic limestones at New River and Cocoanut Grove as forming a

1 Smith, Buckingham, Report on reconnaissance of the Everglades, made to the Secretary of the Treasury, June, 1848.

2 Tuomey, Michael, Notice of the geology of the Florida keys and of the southern coast of Florida: Am. Jour. Sci., 2d ser., vol. 11, 1851, pp. 390-394.

${ }^{3}$ Agassiz, Louis, Florida reefs, keys, and coast: U. S. Coast Survey Rept. for 1851; appendix 10, 1852, pp. $145-160$.

4 Shaler, N. S., The topography of Florida: Bull. Mus. Comp. Zool. Harvard Coll., vol. 16, No. 7, 1890, p. 143. 
coral reef and included it and other rock, possibly coquina, in his Miami reef.

A. Agassiz in 1895 stated that he believed the limestones at Miami and Cocoanut Grove to be of eolian origin, ${ }^{1}$ and in a paper published the following year gave his reasons in detail. ${ }^{2}$ His views were not accepted by Griswold, who saw the rock not only along the water front but possibly 20 miles inland. ${ }^{3}$ All the exposures of oolitic limestone on the mainland of southeastern Florida are in this paper included under the designation of Miami oolite.

Stratigraphic position.- The relation of the Miami oolite to the other limestones described in this paper is not definitely established. The extent of the oolite north, south, and southwest is obscured by sand or swamp deposits. The rock is perhaps younger than the Palm Beach limestone and is younger than the lower part of the Key Largo limestone. It lies almost flat. Griswold saw an interstratification of oolitic and nonoolitic rock, the latter probably the same as that designated coquina in this paper, at Linton, 20 miles south of Palm Beach.

Although the Miami oolite is so overlain by unconsolidated deposits that its field relations can not be determined with exactness, well records and samples from a few wells show what is below it at several places. At Miami samples from the wells of the water company show that the oolite loses its typical appearance a few feet below sea level and rests on an irregularly cemented aggregate of shell fragments and quartz sand much like coquina. At Dania the oolite rests on "blue mud with gravel"; at Fort Lauderdale it rests on "sand."

Lithologic character.-Typically the rock is a soft white oolitic limestone, containing streaks or thin irregular layers of calcite separating less crystalline streaks. The rock breaks with an irregular fracture, dresses nicely, hardens on exposure, and makes good road metal and building stone. The aspects of quarry and rock-cut faces are shown in Plate XIV, $B$.

Hand specimens show that the oolite carries a varying proportion of quartz sand. The quartz grains are mostly small and angular to subangular in outline, but a few are large and rounded. On the average the grains are considerably smaller than the ovules of the oolite, which have a mean longest diameter of one-fourth to one-half millimeter.

The proportion of quartz sand is greatest to the north. Along the drainage canal west of Fort Lauderdale streaks of sand in the oolite

1 Agassiz, Alexander, Note on the Florida reef: Am. Jour. Sci., 3d ser., vol. 49, 1895, pp. 154-155.

2 Agassiz, Alexander, The elevated reef of Florida: Bull. Mus. Comp. Zool. Harvard Coll., vol. 28, No. 2, 1896, pp. 29-62.

3 Griswold, L. S., Notes on the geology of southern Florida: Bull. Mus. Comp. Zool. Harvard Coll., vol 28 , No. 2, 1896, pp. 52-59. 


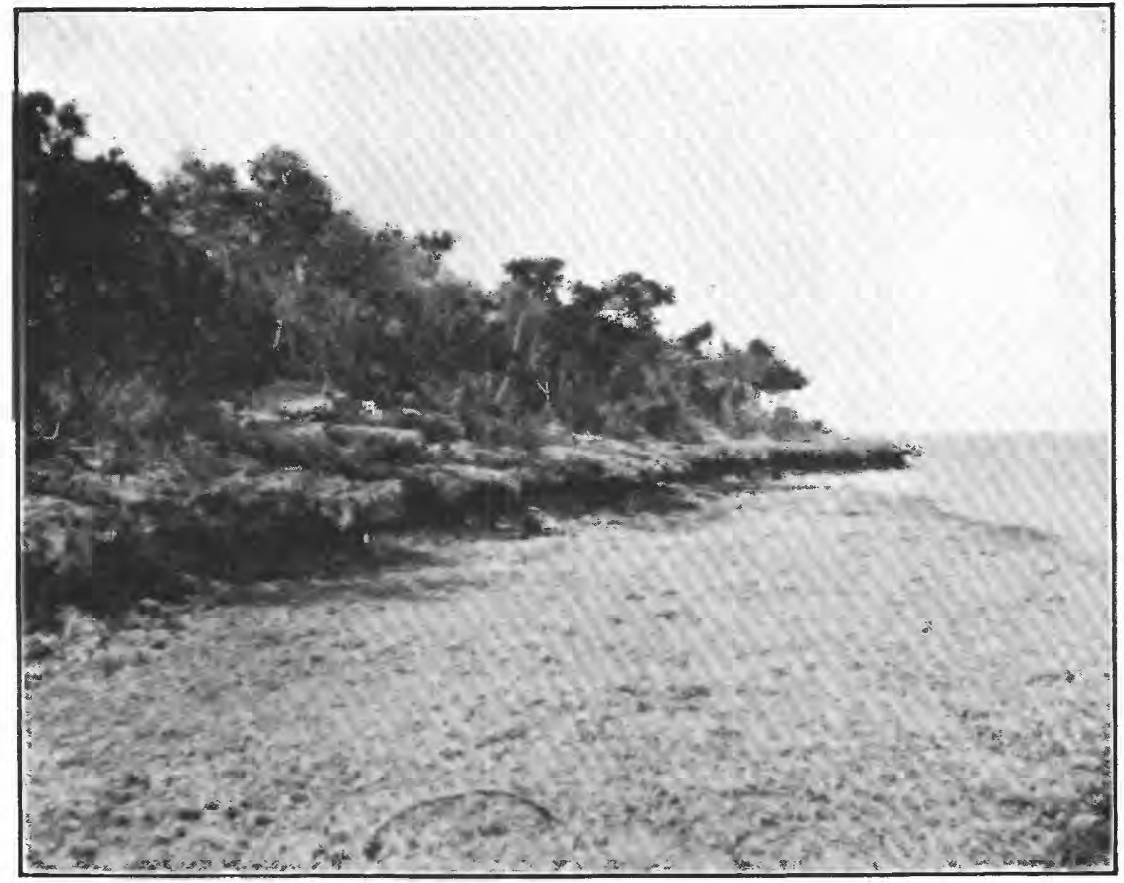

A. REEF ROCK, KEY LARGO LIMESTONE, SHOWING EROSION.

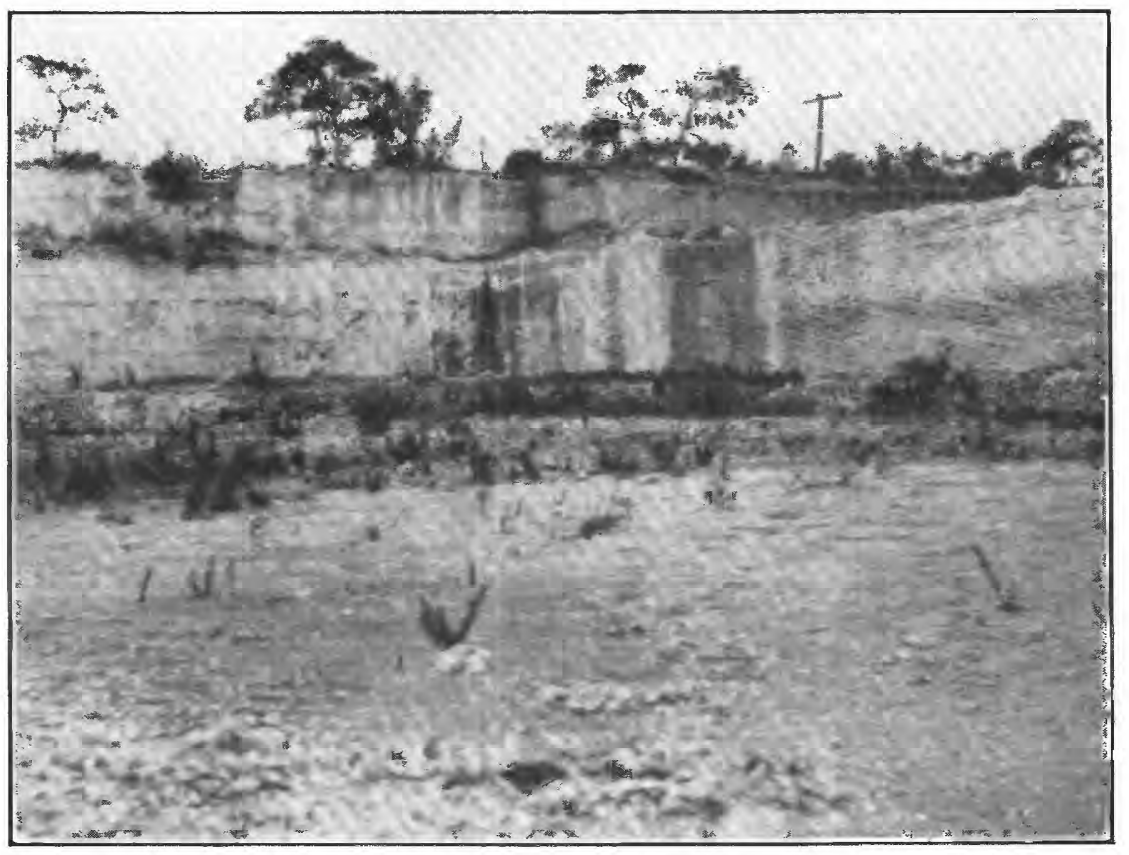

B. QUARRY IN MIAMI OOLITE. 

are so loosely cemented that perfectly preserved shells of Chione cancellata can be picked out with the fingers, whereas at Long Siding quartz grains in the oolite are relatively rare. Besides being more plentiful to the north, the sand grains seem to form a larger proportion of the rock near Biscayne Bay than farther west, as on Long Key.

Examination with the microscope shows that the ovules have a well-marked concentric structure; some have as nucleus a rounded aggregate of minute calcite crystals; others have as nucleus a rounded aggregate less evidently crystalline; some are built around shell fragments and many around grains of quartz. The concentric layers vary in number from 1 to 5 and in appearance from clear and rather coarsely crystalline to opaque, the shade varying with the amount of organic matter and amorphous material.

Thickness.-A well at Fort Lauderdale, according to the driller, went through 12 feet of oolitic limestone, one at Dania 40 feet of oolite, and the wells of the Miami Water Co. about 15 feet. These figures, making due allowance for the scantiness of the data and the unreliability of well records unless accompanied by samples, show that the maximum thickness may be 50 feet along the coastal outcrops and perhaps less inland.

Physiographic expression.-L. Agassiz and subsequent observers noted that the oolite ledges near Miami and Cocoanut Grove have a steep seaward face, forming a low cliff, and slope off in a succession of low ridges toward the Everglades. Shaler also noted along the bluff back of the present shore evidences of wave erosion that indicated an uplift of the coast. The ridges back from the bluff appear to have a general trend to west of north. The absence of soil, and the quality of the rock surface, indicate that these ridges are to be accounted for by original manner of deposition, or by erosion during uplift, and not by erosion since; yet, that there has been some removal of rock is proved by the potholes, large springs, and such water work as the Punch Bowl and the shallow gorge of Arch Creek.

The maximum elevation of the ledges south of Miami may be 25 feet above sea level. The maximum elevation on Long Key in the Everglades is about 8 feet and at New River about 8 feet.

Paleontologic character.-The Miami oolite varies in content of wellpreserved fossils but is a distinctly fossiliferous rock. The animal remains comprise molluscan shells, echinoids, and corals. The corals are not reef builders, and one at least is plentiful in the Bay of Florida to-day. Collections by Vaughan near Miami in the winter of 1907-8 yielded 2 species of corals and 14 of mollusks, all 16 species being Recent. Of 26 species collected along the drainage ditch west of Fort Lauderdale by Matson in the same winter Vaughan specifically deter- 
mined 20 as Recent and 1 as Pliocene. Many small heads of coral (Siderastrea) were thrown up by the dredge.

Areal distribution.--The most northern exposure of oolite known to the writer is west of Delray. The rock outcrops on Long Key and the neighboring keys in the Everglades for 15 miles west of the southwestern corner of the Biscayne Pineland, and was found by Griswold at an estimated distance of 20 miles west of Miami. Its extent under the Everglades farther north, at Fort Lauderdale, is apparently slight. Samples dug up along the drainage canals show that the rock rim of the Everglades is oolite; but the rock found west of the narrow, and presumably shallow, sand-filled hollow inside the rim is not oolitic, judging from samples collected by the engineer in charge of the dredges.

Structure.-At the type locality, Miami, the rock is plainly stratified and cross-bedded. (See Pl. XIV, B.) The bedding is that of waterborne sediments. No regional tilt can be distinguished from the outcrops, though it is probable that the formation dips slightly west.

Correlation.-The contemporaneous deposition of coquina and oolite suggested by Shaler and accepted by Griswold can not be proved from any outcrops seen by the writer, but the contemporaneous deposition of the two seems probable.

Origin.-The origin of the Miami oolite is discussed in connection with that of the Key West oolite. (See pp. 182-184.)

KEY WEST OOLITE.

Synonymy.-The first distinctive reference to the rock here designated Key West oolite appears to be that of G. W. Featherstonhaugh, who at a meeting of the New York Lyceum of Natural History in September, 1828, exhibited samples of oolite from Key West. ${ }^{1}$

Conrad on his visit to the keys in $1847^{2}$ suggested the post-Pliocene age of the rock. Tuomey, in $1850,{ }^{3}$ noted the oolite and compared it to recent deposits along the keys, and L. Agassiz, ${ }^{4}$ in 1852, described the rock in some detail. Hunt believed that the oolite had formed from the consolidation of limy material similar to that accumulating about the keys, and A. Agassiz thought that the Key West oolite, like the Miami oolite, had an eolian origin. All the oolite outcropping on the keys south of Florida Bay is here designated the Key West oolite.

Stratigraphic position.-On the south side of Big Pine Key and on one of the Newfound Harbor keys the Key West oolite apparently overlies the Key Largo limestone. Its relation to the nonoolitic rock

1 Am. Jour. Sci., 1st ser., vol. 16, 1829, p. 206.

2 Conrad, T. A., Observations on the geology of a part of the coast of east Florida: Am. Jour. Sci., 2d ser., vol. 2, 1841, pp. 36-48.

3 Tuomey, Michael, On the geology of the Florida keys: Am. Jour. Sei, 2d ser., vol. 11, 1851, p. 390.

4 Agassiz, Louis, Florida reefs, keys, and coast: Rept. U. S. Coast Survey for 1851, Appendix 10, 1852, pp. $145-160$. 
called in this paper the Lostmans River limestone can not at present be determined, since the contact, or possibly the line of gradation, between the two lies under the Bay of Florida. The oolite is overlain by recent marls and calcareous sands and in places along the shores of the keys may have a thin veneer of beach rock.

Lithologic character.-Typically the Key West oolite is a soft white or light-colored fossiliferous oolitic limestone, the ovules being scattered through amorphous carbonate of lime or surrounded by a crystalline cement that develops most freely along bedding planes. The ovules on the average have a longer diameter of about one-half millimeter. The rock is less sandy than the Miami oolite but resembles the latter in general appearance and physical qualities, there being little difference between hand specimens of the two.

Like the Key Largo limestone, the Key West oolite shows on many unweathered exposures a thin dark crust, finely banded, of more or less amorphous carbonate of lime. In this crust all traces of oolitic structure disappear. That this crust is due to deposition of limy ooze is shown by a slab of crust containing unmistakable mud cracks which was photographed by Vaughan (Pl. XV, B, p. 184). Much of the rock shows cross bedding, but not so conspicuously as does the. Miami oolite. It is easily quarried and dressed and makes fair building stone and good road material.

Under the microscope the ovules of the Key West rock resemble those of the Miami rock. The nuclei of the ovules are mostly rounded calcareous grains, though in some ovules a grain of quartz forms the nucleus. The general appearance of the ovules indicates a formation in unconsolidated material in the presence of water.

Thickness.-The maximum thickness of the Key West oolite is unknown. Several wells over 50 feet deep have been sunk at Key West, but from only one of these were many samples preserved. According to the driller a well sunk near the plant of the Consumers Ice Co. penetrated 65 feet of rock of the same general character as that at the surface. Samples from the deep well in Jackson Square have been described in much detail by E. O. Hovey. ${ }^{1}$ From them Hovey concluded that the Pleistocene rock at Key West was but 25 to 50 feet thick. There can be no question as to the accuracy of Hovey's description, but it seems doubtful whether the samples were taken and labeled with equal accuracy. Hence the evidence of the samples is not conclusive. East of Key West no section of greater depth can be had than those of the excavations along the line of the Florida East Coast Railway, and from none of these was material taken at a greater depth than 10 feet belów sea level except in some of the crossings between the keys where the maximum depth may

1 Hovey, E. O., Notes on the artesian well sunk at Key West, Fla., in 1895: Bull. Mus. Comp. Zool. Harvard Coll., vol. 38, No. 2, 1896, pp. 65-91. 
have been more. So far as the writer knows, all the material extracted between Big Pine Key and Key West was oolitic. A well at Big Pine Key went through the oolite; the exact thickness there is uncertain but is probably less than 50 feet.

Physiographic expression.-As the Key West oolite covers the islands west of Bahia Honda to Key West the distribution of the outcrops is quite different from that of the Key Largo limestone, the islands west of Bahia Honda lying in an irregularly triangular archipelago instead of in a long, thin line. The relief of these islands is nowhere 15 feet. The highest land on the largest of the islands, Big Pine, is but 13 feet above tide, as is the highest ground on Key West. On many of the keys between Big Pine Key and Key West bedrock barely reaches to sea level, the islands being low-lying flats of marl with many patches of mangrove swamp that are inundated to a depth of 5 feet during hurricanes.

Like the Miami oolite the Key West oolite weathers easily, but its surface nowhere has the rough and jagged appearance of the rock in the Biscayne pineland. Roots have disrupted angular blocks, but the surface in general is smooth and areas as extensive as 100 square yards show no sign of roughening by decay.

Small vertical holes of varying size and shallow hollows characterize the outcrops. Many of the holes communicate with undergroundwater channels, many of which are larger than those found in the Key Largo limestone. In places these passages contain salt water a quarter of a mile or more from the shore line and therefore must be comparatively free openings of considerable extent.

Paleontologic character.- The abundant marine fossils in the Key West oolite comprise remains of corals, echinoderms, and mollusks, with foraminifera and other less evident fossils. Collections made by Vaughan on Torch Key and by the writer on Big Pine Key give, according to Vaughan, a total of 26 species, of which 2 are corals, 1 an echinoid, and 23 mollusks. The corals were not of reef-building species, and Vaughan found several delicate pelecypod shells with both valves closed, indicating that the shells had not been rolled about much. A study of the exposures on Big Pine Key shows that the shells as a rule are but slightly worn. All the specimens are of living species.

Origin.-The Miami and Key West oolites differ so slightly, the chief differences being the greater percentage of quartz grains and stronger cross bedding near Miami, that they may be assumed to have had a common origin. Whether this was eolian or whether it was marine is a point of interest. The evidence comprises the field relations of the rocks, their appearance in outcrops, and their lithologic and paleontologic characteristics. 
The oolites are thin. - At Dania the Miami oolite overlie "blue mud and gravel," and at Miami it overlies quartz sand and worn shell fragments cemented by clear crystalline calcite separated by layers of sand containing nodules made of quartz grains. At Key West the oolite apparently overlie shallow water lime-sand rock. Nowhere has the Miami oolite been proved to rest on an old coral reef.

Outcrops of oolite are not known north of Delray, on the east coast, or anywhere on the west coast. Though exposures form conspicuous bluffs near Miami and low ridges for a few miles west, yet much of the Miami oolite is flat topped, outcrops showing differences of less than 5 feet in elevation for miles toward Long Key. Long Key itself is nowhere 10 feet above sea level. Nowhere on the mainland are ridges comparable with the dune ridges of siliceous sand at Hobe Sound. The flat smooth tops of the oolite exposures in the keys west of Bahia Honda are one of their most striking features.

The cross bedding of the oolites is more marked in some outcrops than in others; in some the cross bedding is not at all conspicuous, the best being near the ocean or the Florida Strait rather than inland. The writer believes the cross bedding is that of water-laid material; he can not see that it is like that of the wind-borne sands in such dunes as those at Cape Henry, Va.

The oolite is abundantly fossiliferous, in places containing delicate shells with valves adherent, in places shells of some size and heavy heads of nonreef-building corals. Buckhorn corals (Porites) so plentiful in present beach ridges of coral sand are uncommon in the oolite exposures seen by the writer.

An oolite from China examined by Blackwelder, ${ }^{1}$ exhibited peculiarities which indicate that the concentric structure of the ovules developed when the material composing the rock was loose and somewhat mobile - that is, was a calcareous mud. The microscopic structure of the Key West and Miami oolites suggests an underwater origin for the ovules. The rounded aggregates of amorphous carbonate of lime that serve as nuclei of many ovules are like aggregates now lying on the bottom of the Bay of Florida. Hunt thought he saw one case of incipient oolitization in marl at Key West. Vaughan has detected oolitic grains in muds and sands from about the keys.

The characteristics of the calcareous sands and marls accumulating about the keys and in the Bay of Florida and the distribution, topographic relief, bedding, contained fossils, and structure of the Key West and Miami oolites indicate that the latter were originally limy muds, with a varying proportion of lime sand and a little quartz sand, which accumulated on the bottom of shallow bays or lagoons, where the water was in places relatively still and in places agitated

1 Willis, Bailey, and Blackwelder, Eliot, Research in China, Pub. Carnegie Inst. Washington No. 54, vol. 1, pt. 2, 1907, p. 380 . 
by waves and currents strong enough to build up and level off banks and bars, conditions approaching those that exist in many places about the koys. That oolites may be forming now in the Bay of Florida is possible. That they will be found in process of formation is not certain. Examination of material from the surface of banks will probably give negative results, examination of material buried for some time may give positive results.

The exact method in which oolitic structure develops is not yet evident. Colloidal $\mathrm{CaCO}_{3}$, precipitated by organisms or by the action of an electrolyte, as salt water, tends to form such minute aggregates as occur on the bottom of the Bay of Florida and to adhere about grains of sand in a concentric layer. Consequently it is easy to see how a single-ring ovule can develop; but alternate crystalline and noncrystalline rings, 3 or 4 in all, of typical oolites imply secondary replacement of carbonate of lime and special conditions favoring replacement.

Chemical character.-Chemically, except for silica included as grains or spicules and scattered cherty streaks, the oolites are almost pure carbonate of lime. The following analysis, published by Hovey, was of rock taken from the surface near the deep well in Jackson Square, Key West.

Analysis of Key West oolite.

[George Steiger, analyst.]

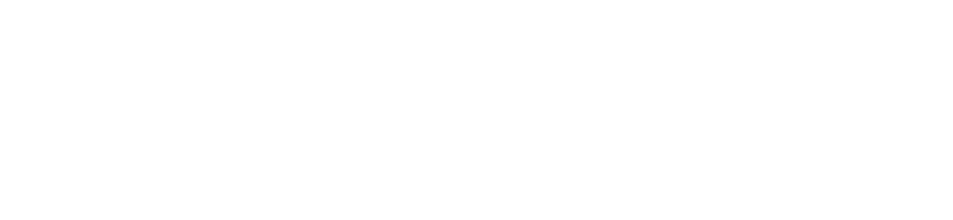

KEY LARGO LIMESTONE.

Synonymy.-The elevated reef that forms the backbone of the main chain of the Florida keys from Soldier Key to Bahia Honda has been recognized as made up of coralline material by practically all the writers who have described the keys in any detail. One of the first references is that of Henry Whiting, who called it a coralline limestone. ${ }^{1}$

The first reference to the keys representing an uplift is that of T. A. Conrad. He visited the islands in the winter of 1842 , and besides correlating the evidences of elevation there with other evidences in northern Florida determined the age of the reef rock as post-Pliocene. ${ }^{2}$

\footnotetext{
1 Whiting, Henry, Cursory remarks on east Florida in 1838: Am. Jour. Sci., 1st ser., vol. 35, 1838, pp. 47-64.

2 Conrad, T. A., Observations on the geology of a part of east Florida: Am. Jour. Sci., 2d ser., vol. 2, 1846, pp. 36-48.
} 


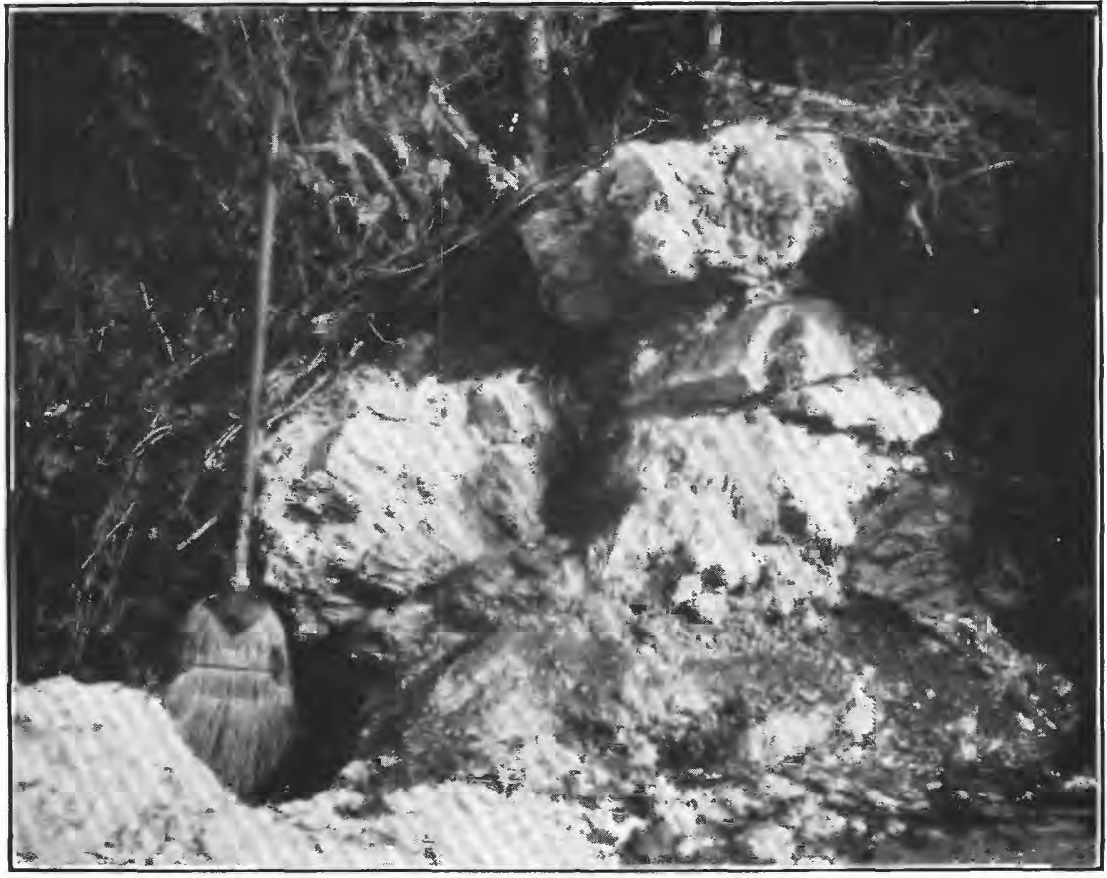

A. REEF ROCK, KEY LARGO LIMESTONE, CORAL HEAD.

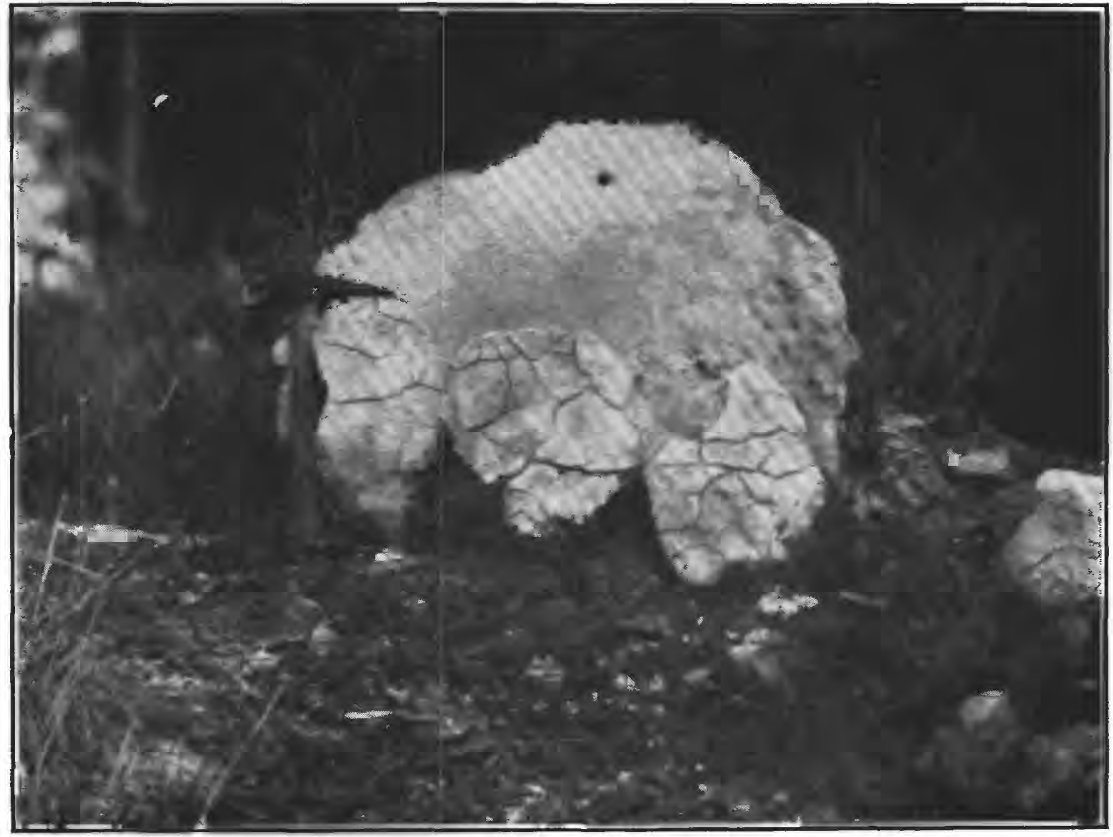

B. MUD CRACKS IN CRUSTAL LAYERS OF KEY WEST OOLITE, 

Tuomey visited the keys in 1850 and noticed the large heads of coral in the reef rock at Key Vaca, Indian Key, and elsewhere. (Seè Pl. $\mathrm{XV}, A$.) He stated very clearly: "There can be no doubt that this great chain of keys is due to the elevation of a vast uneven coral reef whose prominent points rising above the water form the foundation of the keys, the sands driven up by the waves having done the rest." 1

L. Agassiz and Le Conte visited the keys in 1851. Agassiz gave an accurate description of the coral rocks, but positively denied the evidences of elevation seen by Conrad and Tuomey, believing that the coral bowlders had been thrown up by hurricanes and cemented by calcareous sands and.mud-the keys having been built up to their present elevation above sea level purely by the action of the waves and winds-making the rock "subaerial, not a marine accumulation." 2

This view of the rock above sea level having resulted from the cementation of material thrown up by the waves was shared byHunt ${ }^{3}$ and Le Conte. ${ }^{4}$

In $1883 \mathrm{~A}$. Agassiz published a paper on the keys in which he attributed their western growth to a return eddy of the Gulf Stream, previously postulated by Hunt, and said: ${ }^{5}$ "The line of keys seems to be formed by the waste of the exterior present reef rather than by the remains of an older reef." He recognized that the Tortugas were younger than the keys to the east, saying that the deposits composing them "have not as yet been transformed into the normal coral rock."

On a subsequent visit to the keys Agassiz saw the evidences of elevation and confirmed the conclusions of Tuomey. ${ }^{6}$ He elaborated his views of the growth of the keys in a comprehensive account of their geology and topography. ${ }^{7}$

The recent construction work of the Florida East Coast Railway has shown the character of the rock from the place where the railroad bends southwest on Key Largo to the west end of Knights Key. Borrow pits expose the limestone, not only where it was lightly covered by leaf mold but where it was buried under several feet of marl and sand, and dredging has revealed its character where it lies, as in channels between the keys, 10 feet or more below sea level. Hence, the opportunities for observing the various phases of the

1 Tuomey, Michael, Notice of the geology of the Florida keys and of the southern coast of Florida: Am. Jour. Sci., 2d ser., vol. 11, 1851, pp. 390-394.

2 Agassiz, Louis, Florida reefs, keys, and coast: U. S. Coast Survey Rept. for 1851, appendix 10, 1852, pp. 145-160.

3 Hunt, E. B., On the origin, growth, substructure, and chronology of the Florida reef: U. S. Coast Survey Rept. for 1862, appendix 25, pp. 241-248.

- Le Conte, Joseph, On the agency of the Gulf Stream in the formation of the Peninsula of Florida: Proc. Am. Assoc. Adv. Sci., 1857, pt. 2, pp. 103-119.

5 Agassiz, Alexander, The Tortugas and Florida reefs: Mem. Am. Acad., vol. 2, 1883, pp. 108-109.

6 Agassiz, Alexander, Note on the Florida reef: Am. Jour. Sci., 3d ser., vol. 49, 1895, pp. 154-155.

7 Agassiz, Alexander, The elevated reef of Florida: Bull. Mus. Comp. Zool. Harvard Coll., vol. 28, No. 2 , 1896 , pp. 26-62. 
rock and for determining its origin are incomparably better than when A. Agassiz visited the keys in 1894.

On Key Largo cuts and borrow pits expose the limestone at short intervals from the south shore of Lake Surprise to the west end of the Island at Tavernier Creek, a distance of 15 miles. As this is the longest series of exposures on any of the keys, the reef rock is here designated the Key Largo limestone.

Stratigraphic position.-As the Key Largo limestone represents the only known fossil coral reef in southern Florida, it forms a lithologic unit and is sharply differentiated from any of the other limestones of the mainland and keys. Having been built up from the bottom from a depth of perhaps more than 100 feet during a considerable interval of time, it may in part be contemporaneous with the other limestones, and in part may be older, as these limestones are believed to represent shallow-water deposits, some of which accumulated behind the reef while the latter was growing and finally extended over it. In places the Key West oolite apparently rests on the Key Largo limestone; the relations to the Miami oolite and Lostmans River limestone are less certain.

Lithologic character.- The Key Largo limestone is extremely variable in appearance and structure. Considered as a whole it greatly resembles the reef rock of the southern Pacific, described by Dana. ${ }^{1}$ In some parts it is a coral conglomerate or breccia, made up of fragments firmly cemented. Over much larger areas it is a fine white limestone, as compact as any secondary marble and as homogeneous in texture. It is often free from any traces of organic life or proofs of an organic origin. It breaks with conchoidal fracture, splintery surface, and rings under the hammer. Other portions of the rock, of less extent, are made of standing corals with the intervals filled in by reef débris, and the whole cemented solid.

Though the Key Largo limestone represents an elevated coral reef, as is shown by the countless heads of reef-building corals, yet it is doubtful if more than a fourth of the total mass of the formation is derived from corals. Coralline algæ undoubtedly contributed much calcareous material, but a great though undeterminable bulk of such calcareous material was derived from sea water by other organisms.

Since the solidification of the rock much solution and redeposition of calcareous matter has taken place. In places the rock contains heads of coral replaced by clear, rather coarsely crystalline calcite that shows quite plainly the structure of the original head. In places the rock is a typical breccia composed of angular and cherty fragments in a limy cement, this cement and many of the fragments being of a bright red. These breccias evidently represent loose

\footnotetext{
1 Dana, J. D., On coral reefs and islands: Am. Jour. Sci., 2d ser., vol. 14, 1852, p. 76.
} 
material that has fallen into solution cavities and been recemented, the red color being due to iron oxide.

The rock is harder within a few feet of its surface than below. This is true not only of the ledges which are bare but of those below sea level. Besides this general surficial hardening, the rock shows in many places on unweathered surfaces a thin layer, generally less than 2 inches thick and nowhere, so far as seen, as much as a foot thick, that is darker than the rock below and is finely banded. In this layer all traces of the corals and shells visible in the mass of the rock disappear. The crust follows slight inequalities of surface and may represent a deposition of limy ooze in pools or hollows which began after the elevation of the reef and in places may be still in progress.

Some other features of the rock were brought out by the railway work along the keys. Measured in terms of a day's work with a hand drill, the rock is twice as hard as the Key West oolite. Yet, though hard, it is so honeycombed with solution passages that many borrow pits instead of yielding more loose rock than the cubic contents of the pit actually yield less.

Thickness.-The only information available regarding possible variations in thickness of the Key Largo limestone is that of well records. The presence of reef rock below Jackson Square in the city of Key West was not shown by the samples of borings described by E. O. Hovey, ${ }^{1}$ but at Key Vaca a well has shown reef rock fully 100 feet thick. At Indian Key over 130 feet of reef rock is indicated by a record published by Hunt, but at Indian Key Channel a well went through hard rock into marl at about 40 feet below sea level.

Physiographic expression.-The causes determining the outline of the great arc of the reef have already been discussed. The islands form a discontinuous low wall separating the waters of the Atlantic from those of Biscayne Bay, the Bay of Florida, and Blackwater and Card sounds. Mention has already been made of the average and maximum elevation of the rock surface, the depths of the surrounding water, the outlines of the keys, and the weathering of the rocks.

The work of water is shown by the numerous vertical holes forming natural wells, or, as they are called, springs, and the many shallow hollows or potholes. These potholes seldom reach much below sea level. A few holes may run down 20 feet, and free openings or cavities filled with soft material that extended 30 feet below sea level have been noted. Yet, though the rock is full of holes, it is not cavernous. Most wells and potholes end in crevices or passages filled with loose material, without free openings of any considerable

\footnotetext{
1 Hovey, E. O., Notes on the artesian well sunk at Key West, Fla., in 1895: Bull. Mus. Comp. Zool. Harvard Coll., vol. 38, No. 2, 1896, pp. 65-91.
} 
size. Cavities a foot in diameter extending more than a few feet from the bottom of a surface opening are scarce.

Along beaches the reef rock above mean high-tide mark presents a curiously rough and jagged look and is honeycombed with holes from the solvent effect of spray. Between tide levels the faces of the low ledges are undercut by the waves. In many places a loose slab 6 to 12 inches thick and 3 to 6 feet wide looks as though it had been thrown up by the sea, or an apparent heavy bedding slopes toward the water, giving the appearance of beach rock. Examination shows that the loose slab and the apparent bedding are erosion effects, due to solution and cementation. The appearance of a sprayworn beach is shown in Plate XIV, $A$ (p. 178).

Paleontologic character.-The Key Largo limestone shows a rather small variety of fossils recognizable by the naked eye, though heads of corals standing as they grew are numerous, and here and there an overturned head like those of the present reef is visible. All the corals are of living species. Determinable shells are not especially common, though aggregates of shell fragments are found from place to place. Among the most common molluscan remains are the holes made by various lithodomes in the coral. In addition to mollusks, foraminiferas, coralline algæ, and echinoids have contributed to the formation of the rock. The fossils indicate the post-Pliocene age of the reef.

Areal distribution.-The total length of this Pleistocene coral reef is still undetermined. Its essential continuity from Soldier Key to Bahia Honda, 90 miles, is undisputed. Virginia Key, north of Soldier $\mathrm{Key}$, is covered with sand but is probably underlain by the reef rock. The farthest northward growth of Pleistocene reef-building corals known is to Hillsboro Inlet, 10 miles north of New River. On the east side of the Florida Coast Line canal, south of the inlet, can be seen fragments of large heads of reef-building corals (Orbicella, Mæandra) that were blasted out in dredging the canal. According to Capt. Gleason, who had charge of the dredge, no coral rock was found in the work south of this point along the canal. It is possible that these heads formed an isolated patch and that the main reef never extended so far north.

Reef rock is exposed here and there at about low-water mark on the south shore of Bahia Honda. To the west it shows on the south face of Big Pine Key and on one of the Newfound Harbor keys, though obscured in places by angular compactly cemented fragments of recent beach rock. It does not show on any of the larger keys farther west, though bowlders of coral rock were found, according to L. Agassiz, 12 feet below surface at Fort Taylor, Key West. The rock is reported on Sand Key south of Key West and probably extends under water a considerable distance westward. Thus the 
possible length of the Pleistocene coral reef of southern Florida was close to 200 miles. There is no evidence to prove its maximum width. The maximum width shown by exposures above sea level may be 3 miles.

The best exposures of the Key Largo limestone are probably those in the quarry at Windleys Island, where vertical faces 14 feet high were seen. Other good exposures appear in the railroad cuts on Plantation Key, just east of Snake Creek, and near the south shore of Lake Surprise. The cuts and the many borrow pits show the varying structure of the rock and its mode of origin. The bedding that characterizes most detrital rocks is nowhere visible. The peculiar features of the shore-line erosion of the rock can be seen at many promontories and detached islets along the north side of Key Vaca.

LOSTMANS RIVER LIMESTONE.

Synonymy.-This term is applied to the nonoolitic fossiliferous limestones which apparently underlie the western coast of southern Florida and outcrop inland. Though doubtless noted by Army officers at the time of the Seminole War, and by other observers since, the first published description of these limestones which the writer has been able to find is that of Dall, ${ }^{1}$ who described samples collected by Willcox in the winter of 1887-88 at the head of Allens River and in Lostmans River.

Willis, ${ }^{2}$ who subsequently examined the samples, considered that certain peculiarities of those from Lostmans River and certain points in Dall's description of the location from whence they came, showed that the rocks might be in process of formation.

In this paper all the west-coast nonoolitic Pleistocene limestones showing marine fossils are grouped as a single formation although they vary considerably in appearance.

Stratigraphic position.-The Lostmans River limestone underlies the gray sands of the mainland, the marls of the coastal swamps, and the keys of the southern portion of the Ten Thousand Islands. It also extends along the southwestern border of the Everglades. Its relations to the nonoolitic marine Palm Beach limestone could not be determined in 1908, because the great saw-grass swamp of the Everglades separates the nearest natural exposures, the minimum interval between outcrops being about 35 miles. The relation to the Miami oolite has not been determined with exactness, though from samples collected along the Florida East Coast Railway between Long Siding and Jewfish Creek the writer believes that the oolite is younger than the nonoolitic limestone which lies south of it. Beyond the

1 Dall, W. H., and Harris, G. D., Correlation papers-Neocene of North America: Bull. U. S. Geol. Survey No. 84, 1892, p. 100.

2 Willis, Bailey, Jour. Geology, vol. 1, 1892, pp. 512, 513. 
shore line of the mainland the rock lies below sea level, and its relation to the Key West oolite across the Bay of Florida has not been determined.

A well drilled through the rock at Everglade shows that the limestone there rests on a fine gray sand. It is uncertain whether or not the limestone was struck at Marco; possibly it may be represented there by unconsolidated quartz sand and shell fragments.

Lithologic character.-The Lostmans River limestone varies so greatly that it is impossible to give a description that contains features common to all localities. At the type locality on Lostmans River, the limestone is described by Dall as very hard rock, consisting of large masses of Polyzoa more or less completely changed into crystalline limestone. The cavities are filled with crystals of calc spar, hand specimens showing individual crystals an inch long. All the samples collected by the writer from Lostmans River and from below water level in Allens and Turners rivers had common features. Near Deep Lake the rock is softer and more friable. Rock from the head of Hendersons Creek contained much more sand than specimens collected to the south; specimens collected at several localities in Whitewater Bay from its mouth to its eastern extremity, a distance of nearly 20 miles show very small proportions of quartz sand; and few microscopic sections show sand at all. Along the line of the Florida East Coast Railway between Jewfish Creek and Manatee the rock is much less crystalline than on the west coast or toward the entrance to Whitewater Bay.

Thickness.-The formation is probably thin. The well at Everglade went through only 30 feet of it, but a well at the plant of the Minetto Lumber Co., near the mouth of Shark River, penetrated over 40 feet of hard rock.

No wells have been drilled inland through rocks that can as yet be correlated with the Lostmans River limestone. The deep wells nearest Marco on the east are those on cattle ranges in Ts. 47 and 48 S., R. 31 E. According to the driller, H. Seniff, of Fort Myers, no hard rock was found in these wells near the surface.

Areal distribution.- Marine limestones have been found to underlie the shore of the mainland wherever samples have been collected, from Jewfish Creek westward and northwestward to near Marco. They outcrop in the southernmost patch of the west-coast pineland 3 miles northeast of the head of Rock Creek and at the heads of Turners and Allens rivers and Hendersons Creek.

At Everglade the writer was told that limestones are found nearly to the border of the Everglades, 12 miles to the east, and at Hendersons Creek he was informed that outcrops making bare ridges occur in the pineland. Limestone is also reported along the road from Fort Myers to Fort Shackelford, but the marine origin of exposures 
more than 20 miles from the coast of southern Florida has not been established.

Origin.-Willis ${ }^{1}$ has suggested that the rock at Lostmans River was perhaps formed by the deposition of crystallizing calcium carbonate from the presumably limy waters of the Everglades. There can be no doubt that deposits of marl are now accumulating along the coast, but the present hardening of ' marl to crystalline limestone or the direct deposition of such limestone is not established. As the writer has stated, the bedrock of the western coast, wherever soundings have been made, whether in the Everglades, on swamp islands along the coast, or in the numerous creek channels, seems to slope gently toward the Gulf. The rock is no farther below water level in the swamp than in adjacent channels; moreover, the rock surface in channels where the current runs strongly is full of crevices, is extremely rough, and is evidently being eroded. Loose fragments that have been detached by solution are found not only near the mouths of rivers but at their heads, on the bare rock, under marl, and under vegetable muck. Another fact that impairs the deposition and crystallization theory of Willis is the quality of the Everglades water, which, though it contains lime, is far from being as hard as the water of most springs and wells in limestone regions. Most of the marl in the Ten Thousand Islands has come from the ever-dirty shallows of the Gulf and not from the land surface to the east. The dark limestones below water in the creeks are the same as those that outcrop above water a short distance away, and a recent crystallization from solution of those is hard to understand.

The limestone on Lostmans River, though containing calcite crystals an inch long, is not greatly different from other limestones of southern Florida. Removal, deposition, and crystallization of carbonate of lime are characteristic of the region.

The limestone, from its petrographic and paleontologic characteristics, is a shoal-water deposit of limy sand and marl, containing shells of living species of marine mollusks that have been solidly cemented and subjected to conditions favoring crystalline growth. In places, no doubt, this growth is still in progress.

\section{CORRELATION OF PLEISTOCENE FORMATIONS.}

The limestones and the related marls and sands of Pleistocene age can not as yet be separated into contemporaneous stages. The best that can be done is to group them roughly on the basis of areal extent and lithologic resemblance. A careful study of the rocks and associated fossils along the miles of canals now constructed in the Everglades might enable a more exact differentiation. So far as the known facts go, however, the several limestones differentiated by the 
author can not be correlated according to an exact time scale. The important fact to be borne in mind is that though they are of Pleistocene age they are not necessarily contemporaneous, and that though the peninsula has grown southward the northernmost exposures of the Lostmans River limestone are not necessarily older than the southern nor older than the Key Largo limestone.

\section{LITHOLOGY OF PLEISTOCENE BEDS.}

COQUINA.

The word coquina is here used, as it is used on the east coast, to designate those deposits of cemented-shell fragments and quartz sand that can be seen at many localities near the present ocean shore of southern Florida. In some exposures noted by the writer the rock bore slight resemblance to the long-known occurrences on Anastasia Island (Pl. IX, $B$, p. 80), being a rather fine grained dense gray sandstone that rang under the hammer. This is probably the rock Griswold saw interstratified with coquina (shell rock) near Linton.

All phases between shell rock and material made up mostly of quartz sand can be found near Hillsboro Inlet, Delray, and Palm Beach. At the Spouting Rocks, 4 miles south of Hobe Sound Station, the rock contains quartz grains, coarse and fine, and much-worn fragments of shells (including axial pillars of conchs over a foot long), the whole so solidly cemented that the seaward face of the ledge, worn into shallow grottoes, resists the breakers well enough to make a feature of unusual interest, the only spouting horn on the Atlantic coast on the United States south of Newport, R. I.

Coquina outcrops at Jupiter Inlet, along the east and west shores of Lake Worth, at Boca Ratone, at Hillsboro Inlet, and on Sarasota Key (Pl. X, $A$, p. 94). It was found in the Florida Coast Line Canal at the cut to Indian River, the cut below Hillsboro Inlet, and near Boca Ratone. In few places do the ledges make rock knolls, though on the island east of Hobe Sound are several knolls, the highest, according to Mr. Grant, local representative of the Indian River Association, who has surveyed much of the island, having a maximum elevation of 30 feet above sea level. Its greatest extent inland is undetermined; as exposures seem to be confined to localities within a few miles of the beaches, it may be represented inland by unconsolidated material. In the canal south of Hillsboro Inlet the coquina apparently extended over fossil coral heads. No ledges of rock resembling the east coast coquina have been reported from the west coast.

The predominance of well-worn material in the coquina indicates an origin from sands that accumulated on barrier beaches or on bars where the surf had full swing. Certain features of the outcrops 
east of Hobe Sound suggest that the coquina there has acquired at least part of its hardness above sea level. One of the facts testifying to such consolidation is the presence at the Spouting Rocks of numerous vertical tubelike streaks of crystalline calcite which end in minute stalactites, indicating a downward movement of limecharged water through passages between sand grains.

Coquina has been quarried for road metal at several localities along the east coast. For this purpose it is not as satisfactory as the Miami oolite, for it is not so calcareous, is loosely cemented where quarried, and breaks up instead of packing solidly.

\section{SANDS.}

The widespread mantle of sand that is so striking a feature of the central part of the peninsula extends as far south as Miami on the east coast and south of Everglade on the west coast. The sand is composed of angular grains of quartz, varying considerably in size. At the surface it is white or gray; below the surface its hue is yellow, orange, and red. The color is caused by iron oxide and represents the result of subaerial decay, the oxide coming from small grains of iron-bearing minerals scattered through the sand. There seems to be no sharp dividing line between the gray and the colored sands, the intensity of color increasing with depth. The decoloration of the surface sands is due to the action of plant roots and of soil bacteria, the decay of vegetable matter, and the leaching effect of rains.

In places there is yellow sand finer and apparently more decayed than the bulk of the gray sand; and the sand of the dunes seems to be finer and more highly colored than that of the sand plains and flatlands, but there are so many gradations of size and hue that to separate the sands into gray and yellow seems a useless undertaking.

Whence came the sand is an interesting problem. Undoubtedly much of it represents the southward invasion of the peninsula by material worked down the Atlantic and Gulf coasts by waves and currents, the remnant of the material worn by streams from land far to the north. Some of it no doubt is all that is left of sandy limestones or marls that had accumulated below water level and after partial or complete consolidation were elevated and worked over or leached, the limy material going away in suspension or solution. Possibly some of the sand now lying on the ground in southern Florida has been cemented to rock and reduced to separate particles many times since the grains were worn from some quartzbearing rock in the hills of Alabama, Georgia, or the Carolinas.

In journeying down the shores the sands have been moved by the wind, blown inland, and the contours of the dunes represent wind action, as do to a large extent those of the rolling sand plains. 
MARLS.

Shell marls having the same general characteristics as those seen and described by Mr. Matson at points farther north undoubtedly underlie the surface sands at many points in southern Florida. The Palm Beach limestone and the Lostmans River limestone undoubtedly here and there grade into such marls, and the Miami oolite contains lenses of sandy marl. Outcrops of distinctly Pleistocene marls, that is, those underlying sands or marls now being worked over on flats and beaches, are not common, though found here and there. Marls under the sandy foreland at Cape Sable are practically continuous with those of the prairie at Flamingo. Along the west-coast rivers soft marls rise above sea level in the river banks for varying distances; they contain fresh-water shells but are probably contemporaneous with the marls of the Gulf shore, here classed as Recent. Near the mouth of Shark River these marls are fully 20 feet thick, and at the mouth of Lostmans River the strip of marl land is 3 miles wide. On many of the keys marls and shell sands form level areas having a maximum elevation of possibly 3 feet above mean high tide.

SUMMARY.

The summation of the evidence indicates, except along the keys, a larger proportion of siliceous material in the early Pleistocene beds than in the surficial limestones and less consolidation of sediments. Considering the total bulk of the Pleistocene deposits and the relative proportion of limy and sandy materials, the facts indicate that on the mainland the Pleistocene beds as a whole are not to be grouped as limestones. There are limy beds and limestones which can be mapped as lithologic units, but the proportion of siliceous and unconsolidated material is much greater than has been supposed.

THICKNESS OF THE PLEISTOCENE ROCK.

The maximum thickness of the Pleistocene formations of southern Florida can not be determined from the available evidence. There was no distinguishable break in deposition, no pronounced change in marine life, at the beginning of Pleistocene time. The sequence of events shown by the sands, marls, and limestones and the organic remains they contain is practically continuous. Pliocene time passed and Pleistocene time began with no record of the fact.

For this reason the total thickness of the Pleistocene formations can not be determined from the available evidence. It could be approximated with considerable exactness from a study of the fossils and a determination of the relative percentages of living and Pliocene species found in a given bed, but the drillers of the more important wells on the east coast saved few fossils. The evidence, such as it 
is, shows that the Pleistocene beds measure over 75 feet at West Palm Beach, over 118 feet thick at Delray, over 50 feet at Dania, about 90 feet at Indian Key Channel, fully 100 feet at Key Vaca, and over 50 feet at Buck Key. Of the above measurements the only ones that are at all definite are those at Indian Key Channel and at Key Vaca. Fragments of reef-building coral were found at Key Vaca at 100 feet. Below was a soft white limestone with shell casts that graded downward into a sandy limestone (quartz sands) at 152 feet; this limestone continued to 176 feet and then gave way to a clean white quartz sand, the first upper 10 feet of which contained many irregular nodules of quartz sand held by a limy cement. The changes from quartz sand to sandy limestone at 176 feet, and from limestone to undoubted reef rock at about 100 feet, are suggestive but insufficient for drawing a sharp line between Pleistocene and Pliocene material. It is probably safe to say that below 176 feet is Pliocene sand and above 100 feet is Pleistocene reef rock. Though the thickness of the reef rock at Key Vaca does not necessarily indicate the thickness of the Pleistocene beds at Palm Beach or the mouth of Caloosahatchee River, yet taking all the data into consideration, the maximum thickness of the Pleistocene of southern Florida, disregarding sand hills, is probably about 125 feet.

RECENT SERIES.

GENERAL CHARACTER.

The establishing of sharply marked limits for geologic time intervals is difficult, particularly in regions where there are no well-marked breaks in the stratigraphic succession nor sudden changes in the character of the fossil evidence. Hence differences of opinion may exist as to where the line between Recent and Pleistocene time, as applied to the geology of southern Florida, should be drawn. The writer, however, here includes as Recent all deposits now being laid down or that have been laid down since the last well-marked elevation of the land surface.

Most of the Recent deposits are unconsolidated peats, marls, and sands. The consolidated rocks embrace coquina, a few deposits of beach rock of no special importance, some of the calcareous masses of corals, coralline algæ, shells, and other organic remains now hardening on the Tortugas; the growing coral reef outside the keys; the worm rock; and the oyster banks.

PEAT.

Surficial dèposits of peat are found throughout the Everglades where saw grass grows tall and in places outside the main body of the saw grass. They have resulted from the subaqueous incom- 
plete decay of roots and blades of saw grass and of other vegetation. Their thickness varies greatly. In places they rest on rock; in places, especially toward the southern edge of the Everglades, on fine marl; over considerable areas, as at New River, they rest on sand. Dredging along New River shows one or more peat beds in places, with sand beds between.

The average rapidity with which peat is now accumulating in the Everglades is unknown, as is the rate of increase under the most favorable or most unfavorable circumstances. Hence the thickness of a peat bed at a particular place can not be used as a measure of the time that has elapsed since peat formation began there. It is the writer's opinion that, because of water level in dry seasons lying several feet below surface, and the consequent opportunity for rapid decay of vegetable remains, little peat is now accumulating except about Lake Okechobee and other lakes and in sloughs.

MARL.

Recent marls include beach, swamp, lagoon, and sea-bottom deposits of finely divided calcareous material, differing in appearance, origin, and manner of deposition. Some represent rock, shell, or coral flour, ground up by the mill of the surf; some, as those accumulating in places in the Everglades and in pools along the coast of the mainland or the keys, represent lime that had been dissolved and later precipitated through the evaporation of the water that held it in solution, whereas others, such as the marls accumulating on the bottom of Whitewater Bay, ${ }^{1}$ have been precipitated from solution. Organic agencies are undoubtedly active in the work. ${ }^{2}$ From the first and third of these classes of marls have been formed the limy oozes that cover wide expanses of the bottom of the Bay of Florida, the inlets of the mainland, and the passages about the keys; tidal and windmade currents have heaped them up into flats and banks, and through the growth of vegetation they have become islands. Such is the history of the gray marls on which flourish the mangrove forests of the Shark River archipelago and the Ten Thousand Islands.

The boundary between limy mud and quartz sand in the southern part of the Everglades is said to be along the south line of T. 55, Rs. 32 and 33. North of this lime the white marl disappears. On the west coast, at Lostmans River, where the Everglades approach the Gulf, is a fringe of marl 3 miles wide.

SAND.

The sands classified as Recent are those of the shores and those that winds and waves move or bury in the work of destruction or construction. At Jupiter Inlet and Palm Beach, Hillsboro Inlet, 
and even as far south as Cape Florida, the beacht material is quartz sand with a varying proportion of ground-up sea shells and other calcareous material. From Soldier Key around nearly to Cape Romano the beaches as a rule are of calcareous sand. Some quartz grains, however, appear as far south as the keys; of a series of 47 samples from the bottom of the inside passages collected between Biscayne Bay and Bahia Honda by Vaughan and examined by Matson, nearly all show quartz grains, though the grains are fine and not particularly abundant west of Card Sound.

Along the shores of the keys from Soldier Key to Key West the beach sand is of corals, coralline algæ, Foraminifera, and molluscan. shells (single valves of pelecypods and whole shells of gastropods) and in many places, as at the sand pits on Lower Metacumbe and Long Key, numerous branches of buckhorn coral (Porites). The thicker deposits of this sand, 5 to 8 feet at Lower Metacumbe, show the material to be roughly stratified, with inconspicuous cross-bedding; the material includes some fragments of rock a foot long and has neither the texture nor the arrangement of a purely eolian deposit. The beach ridges near the west end of Long. Key, 5 feet above mean tide, show that they have reached their present height during hurricanes. The work of relatively high waves is particularly evident in the outlines of the beach ridges on one of the inner keysSand Key, off East Cape-which is exposed to seas entering the Bay of Florida from the Gulf.

A striking peculiarity of these calcareous beach sands is their slight movement by the wind after the waves have heaped them up. Nowhere along the keys has the writer seen the sands moving before the wind, as do the siliceous sands on the ocean shore at Palm Beach. As Hunt observed, the calcareous sands, once packed, "resist the blasts of hurricanes and northers." 1

CORAL.

Along the arc of the keys from Soldier Key to the Tortugas, from 4 to 7 miles offshore, are the growing corals that form the Florida reef. This reef is of the barrier type and is separated from the keys by a shallow channel, extending from Soldier Key to the Marquesas. The reef is terminated by deep water west of the Tortugas. North of Biscayne Bay it dies away in scattered clumps and heads as the waters become too cool for vigorous growth. Fragments of reefbuilding corals come ashore on the beach opposite Hobe Sound station, and similar coral bowlders are said to have been washed. up by the sea as far north as Canaveral Bight.

Though of the barrier type, the Florida reef does not rise from the sea floor as an almost continuous wall broken by a few narrow

${ }^{1}$ Hunt, E. B., Origin, growth, substructure, and chronology of the Florida reef: Am. Jour. Sci., $2 d$ ser.s vol. 25,1863, p. 197. 
openings; rather comprises heads and patches of coral rising irregularly, with many intervals where the bottom is covered by calcareous sand and mud. These heads and patches are separated by breaks, some several miles long, where corals are few. The seaward face of these areas lies along an arc that in a rough way is concentric to the arc of the keys and corresponds to the outer edge of the old reef. Along it the corals have grown up from depths of 8 to 10 fathoms. Seaward the bottom falls away and the 100fathom line is within 4 to 10 miles of the line of the outer coral patches. Toward the land, in water 5 to 25 feet deep, heads and clumps of coral rise to the level of low tide several miles inside the arc of the outer patches.

At a few places along the reef, as at Sombrero Key, on patches reaching to tide level, the waves have washed up coral sand and bowlders enough to form keys a few rods across, with shifting shore lines. Thus the corals build a foundation for dry land, and the incipient land growth along the Florida reef led some of those who first wrote of the geology of Southern Florida to believe that the keys themselves were formed in the same way, without uplift of the coast, and that coral reefs had been the principal agency in extending the Florida peninsula southward.

WORM ROCK.

Aggregations of the limy tubes secreted by a mollusk were seen and described by Dall ${ }^{1}$ on the west coast. The writer saw many such masses. They are particularly noticeable around the shores of the outer keys between Cape Romano and Cape Sable. On the marly sand flats about Rabbit Key, between tide levels, the limy tubes form disconnected masses 2 feet thick and 50 feet wide.

OYSTER BANKS.

Banks of solidly packed oyster shells make reefs at the mouths of many rivers, particularly on the west coast. Good examples are found at Lostmans and Caloosahatchee rivers.

soILs.

The soils of southern Florida differ widely but in general may be roughly divided into gray sands, sandy clay, marl, soft rock, and peat. The gray sands have been described. Outside the Everglades they form the great part of the arable soil. The sandy clays, which are mostly sand, underlie many of the prairies in the flatlands. Marl is the soil of the mangrove islets and of the islands along the shore of the mainland on the south and west. Peat is found in the Everglades 
and in many coastal swamps. "Soft rock" is the term here applied to the partly decayed surface of the Miami and Key West.oolites and the Key Largo limestone. Trees and shrubs grow from bare surfaces of limestone, orange groves are planted in loose rock, and in places the Miami oolite is so soft it can be roughly plowed.

\section{STRUCTURE.}

The anticlinal structure plainly shown to the north by the distribution and order of the sedimentary beds that underlie the surface sands is not evident in southern Florida, though it is possible that an examination of the outcrops in the pinelands south of Caloosahatchee River may show that a broad low anticline can be traced as far as the Big Cypress.

So far as is now known, however, the rocks that show at the surface throughout the south end of the peninsula lie almost flat. Crossbedding with dips as high as $30^{\circ}$ may be seen in places; and local examples of apparent stratification with lesser dip but greater extent are not uncommon; but in general no well-marked evidence of regional folding is to be had from a study of rock exposures.

As the beds lie flat and their elevation above sea level is nowhere more than 25 feet and throughout most of the region is less than 15 feet, it is evident that a thin formation may cover a great extent of country and that any tilting or folding of unexposed beds must be inferred from what has been determined to the north or established through the comparison of carefully kept records of deep borings.

\section{GEOLOGIC HISTORY.}

By G. C. Matson and Samuel Sanford.

DATA.

The absence of pronounced deformation of the rocks and the low relief of the surface of Florida make it difficult to obtain continuous sections of beds. However, by observations of such exposures as are available and by the study of samples from wells it has been possible to obtain a fairly complete knowledge of the thickness, character, and relations of the successive formations from the early Oligocene down to the present time. This knowledge permits the formulation of a general sedimentary history of the State from the deposition of the oldest rocks exposed to the formation of the sand dunes and coquina of the present day.

\section{OLIGOCENE EPOCH.}

Vicksburg epoch.-As a result of the studies already made, certain broad generalizations relating to the changes that have taken place are possible, one of the most important being that the older rocks 
of the State were formed under conditions that were uniform over wide areas and that permitted the deposition of several hundred feet of homogeneous sediments, whereas the younger formations were laid down under conditions that varied greatly within short distances and that changed at frequent intervals. That the period of deposition of the Vicksburg group was a time of great uniformity in conditions over wide areas is well shown by the remarkable homogeneity of the beds of this age, which underlie practically the entire State. These beds are uniformly fine-grained and show little variation in chemical composition. Limestone predominates, but sand and clay occur in small quantities, the percentage of these impurities being larger in the upper beds. Terrigenous material shows an increased percentage toward the northern end of the State, where the proximity of older land afforded opportunity for the entrance of considerable sand and mud into the Vicksburgian sea. Toward the close of this period of deposition a shoaling of the seas appears to have permitted the entrance of the fresh-water shells and the land-derived sediments noticeable in the Ocala limestone of the Vicksburg group. The excellent preservation of many of the shells shows that the water must have been comparatively quiet during the deposition of the limestone. The inclusion of a small percentage of land-derived sediments and in some places of fresh-water shells shows that a portion of the limestones of Vicksburg age were probably deposited at no great distance from land. Concerning the deposition of sediments on the Floridian Plateau Vaughan says: ${ }^{1}$

The water over this plateau was shallow, probably in no place 100 fathoms deep; the bottom temperature was between $70^{\circ}$ and $80^{\circ} \mathrm{F}$; tropical currents passed over its surface; deposits of both terrigenous and organic origin accumulated on it, ranging in thickness from 100 to 200 feet near shore to the north to over 1,000 feet near its southern margin. As the water was shallow, the sea bottom must have been gradually depressed while the material accumulating on its surface was being deposited.

The shallow Vicksburgian sea was apparently comparatively free from sand and mud and the greater portion of the sediments consisted of finely divided calcium carbonate containing organic remains.

In a recent paper Vaughan ${ }^{2}$ discusses the precipitation of calcium carbonate from sea water. $\mathrm{He}_{\mathrm{e}}$ suggests that the precipitation of finely divided calcium carbonate similar to that found in the limestones of the Vicksburg group may be caused by an increase in the alkalinity of the sea water produced by the denitrifying action of bacteria:

The result of Drew's work ${ }^{3}$ as bearing on the problem of calcium carbonate precipitation has been definitely to show that in the tropical waters of the Atlantic

1 A contribution to the history of the Floridian Plateau: Pub. Carnegie Inst. Washington No. 133, 1910, pp. 181-182.

2 Read before the Geological Society of America, December, 1911, p. 7.

8 Year Book Carnegie Inst. Washington No. 10, 1911, pp. 149-154. 
Ocean denitrifying bacteria by increasing the alkalinity of the sea water cause turbidity of the water through the formation of calcium carbonate, which is in particles so finely divided that they either will not settle or settle with extreme slowness. Drew states that by the use of the centrifuge he was able to cause the precipitation of the finely divided material, or by adding finely powdered, hydrated $\mathrm{CaSO}_{4}$ or fine sand to such a culture, precipitation is caused by the aggregation of the $\mathrm{CaCO}_{3}$ around the insoluble particles as nuclei. Mr. Drew sent me a slide of this material precipitated in the manner last described, which Dr. F. E. Wright, of the Geophysical Laboratory, has examined for me and has submitted a report. The carbonate occurs, according to Dr. Wright, in the form of fine radial spherulites, or more rarely as individual crystals of rhombohedral outline. The spherulites are only approximately round and range in size from minute specks to grains one-tenth of a millimeter in diameter. This result bears on the origin of oolites and suggests a method of their formation. The activity of denitrifying bacteria, while great in tropical water, is much diminished or only slight in temperate or cold water.

This is the first definitely proven method by which calcium carbonate is chemically precipitated in large quantities in oceanic waters.

Recent studies of materials obtained by Vaughan from the sea bottom among the Florida Keys have shown that they contain a large amount of silica. The number of samples collected was 47 and more than 250 slides were examined microscopically. In one sample which consisted largely of quartz sand no tests of diatoms or spicules of sponges were seen, but in the others remains of these organisms were numerous.

The silica which occurred in the fine-grained limestones of Vicksburgian age, being amorphous, was readily dissolved by percolating waters and subsequently deposited, replacing the calcium carbonate of the limestone. This process appears to have been very active, for beds of chert a fraction of an inch to several feet in thickness are found to be very persistent at certain horizons; in fact, it is the chert beds that form the confining strata above the artesian water-bearing beds. The persistency of these beds may be due to deposition of large amounts of silica at certain horizons during sedimentation, but it is more probable that the silica was originally distributed throughout the limestone and that the chert beds merely represent the horizons along which the silica-bearing solutions circulated most freely.

Emergence.-The deposition of the limestones of the Vicksburg group was followed by a partial emergence of the land, as had been foreshadowed by the increase of terrigenous sediments and the appearance of fresh-water shells, which were doubtless washed into the sea from adjacent land areas during the deposition of the Ocala limestone. The extent of this emergence can only be conjectured, but it doubtless affected a considerable area north of Lake Okechobee, and it probably extended somewhat beyond the present boundaries of the State. 
The nature of the movement which closed the period of deposition of the Vicksburg group is somewhat obscure, though it was probably a continuation of the broad arching of the strata which had been initiated during an earlier epoch when the structural basin of the Gulf of Mexico was first formed. The irregularity of the surface of the rocks belonging to the Vicksburg along the east coast is in part due to the deformation which took place at this time and in part to subsequent erosion. Following this emergence came a period of denudation, when the surface of the land was carved into hills and valleys, the evidence of this being found in the uneven surface upon which the later beds were deposited. When compared with mountainous regions the relief of the surface produced during erosion was insignificant, though perhaps comparable with that of the same region to-day.

Apalachicola epoch.-The erosion interval that followed the deposition of the rocks of Vicksburgian age was followed by a period when the sea once more encroached upon the land to such an extent that a large part of Florida was probably submerged. During this time considerable thicknesses of clay, sand, and calcareous mud were laid down in the shallow water. In the east-central and south-central portions of the peninsula depositions of clay and sand predominated during the earlier part of this stage, and farther north and west similar deposits characterized its later part. The calcareous materials, which are found now in the form of marls and limestones, were especially important in the northern part of the State, but they were also deposited in smaller quantities farther south. Throughout the time represented by the Apalachicola group the conditions governing the deposition appear to have differed considerably in neighboring localities, but there was no such abrupt change as may be found along the present coast. The changes from sediments of one character to those of another were frequently abrupt, and during the entire time there was more or less intermingling of different kinds of sediments, giving rise to the marls, impure limestones, shales, and sands of this stage. The fuller's earth beds, which occupy considerable areas in the north-central part of the State, represent short intervals of uniform conditions controlling sedimentation, but these alternated with conditions permitting the deposition of sands and ordinary clays. In general the rocks of the Apalachicola group appear to have been marine, but during the latter part of the epoch some nonmarine sands were laid down in the Apalachicola Valley. During a portion of this time the central portion of the Florida Peninsula appears to have been an island separated from the mainland to the north by a shallow passage known as the Suwannee Strait, ${ }^{1}$ 
but the entire peninsula was probably submerged before the elose of Apalachicolan time.

The Hawthorn formation, which is largely clay, appears to havo been deposited at the southern edge of this strait, whereas farther west the deposition consisted of limestone and marl. The clay's and fuller's earth of the Alum Bluff and the Chattahoochee formations were deposited in this strait. At certain localities the conditions were especially favorable for the development of organic life and hence some beds are very fossiliferous, notable examples being the "silex bed" at Tampa and the Chipola marl, Oak Grove sand, and Shoal River marl members of the Alum Bluff formation. Associated with the other fossils in the "silex bed" was a large quantity of amorphous silica, probably in the form of sponge spicules and tests of microscopic plants. Subsequent solution and redeposit of this silica has given rise to the "silex." Silica is also present in the limestones at other localities, especially in the central part of the peninsula, but it is much less abundant than in the limestones of the Vicksburg group. Vaughan's summary of conditions of the Floridian Plateau at this time is as follows: ${ }^{1}$

The plateau in early Apalachicolan time had practically the same outline as at present; the depth of water north of Tampa was probably in no place over 100 feet. Coral reefs were present in southern Georgia across the base of the present peninsula and around Tampa; the temperature was tropical, the minimum for the year being at least as high as $70^{\circ} \mathrm{F}$; t the main movement of the ocean water was from the Tropics; the sediments consisted to a lesser degree of organic débris and were predominantly of terrigenous constituents.

In the later stage of Apalachicolan sedimentation the dome of Oligocene lying west of the present longitudinal axis of the peninsula had by further uplift increased in size and was separated from the mainland to the north by the Suwannee Strait.

There was differential earth movement, the sea bottom being depressed around Orange Island and between it and the shore of the mainland to the north, permitting additions to the thickness of Apalachicola sediments. During this later stage of the Apalachicola the oceanic waters of the region gradually cooled and coral reefs disappeared. The sediments were mostly of terrigenous origin and were laid down in shallow water.

\section{MIOCENE EPOCH.}

Physiographic changes.-The period of deposition represented by the beds of the Apalachicola group was terminated by an emergence of the northern and eastern parts of the State, but deposition may have continued on the southern margin of western Florida, where some evidence exists of a gradual transition between Oligocene and Miocene beds. The amount of erosion that took place at this time can not readily be determined, but the faunal break is so marked that it indicates important changes in the physical geography. It is not possible to state just how much Florida was directly affected

1 A contribution to the history of the Floridian Plateau: Pub. Carnegie Inst. Washington No, 133, 1910, p. 182. 
by the forces which produced the changes then taking place in the West Indies and Panama, but its general altitude was probably considerably altered.

Indirectly the elevation of the Isthmus of Panama at the close of the Oligocene affected Florida by changing the direction of ocean currents and thus producing a marked change in the fauna of the Miocene beds. Of the faunal changes at the close of the Oligocene Dall says: ${ }^{1}$

As indicated by the changes in the fauna, the physical changes attending the close of the Oligocene were at first slow, allowing a certain element of transition to appear in the Oak Grove or uppermost Oligocene fauna. At the last they appear to have been sudden, at least the change in the fauna on the Gulf coast was absolute and complete. The change was not only in the species and prevalent genera of the fauna, but a change from a subtropical to a cool temperate association of animals. Previously, since the beginning of the Eocene, on the Gulf coast the assemblage of genera in the successive faunas uniformly indicates a warm or subtropical temperature of water, and the sediments uniformly show, from the Jacksonian upward, a yellowish tinge due to oxidation. In the Oak Grove sands come the first indications of a change toward the gray of the Miocene marls. With the incursion of the colder water the change becomes complete. Not only do northern animals compose the fauna, but the southern ones are driven out, some of them surviving in the Antilles to return later. Some change along the northern coast permitted an inshore cold current to penetrate the Gulf, depositing on the floor of the shallow Suwannee Strait, separating the island of Florida from the continental shore, a thin series of Miocene sediments, which were also carried as far south as Lake Worth on the east coast of Florida and Tampa on the west coast, as shown by artesian boringe.

At the close of the Oligocene the State of Florida appears to have had the same general form that it now has, though its area was doubtless less than it is at the present. With the beginning of the Miocene came a submergence that appears to have reduced the land area to a narrow strip along the northern end of the State and a peninsula that was both shorter and narrower than it is at present. During part of this period the central portion of the peninsula may have been separated from the mainland by a shallow strait. The exact extent of the encroachment of the sea during Miocene times is difficult to determine because the deposits have been partly removed by subsequent erosion and their present extent is in many places obscured by younger beds.

Deposition.-During the deposition of the rocks belonging to the Miocene, the conditions in east and west Florida appear to have been unlike. In west Florida and as far eastward as the St. Johns Valley south of Palatka, the sediments consisted of soft shell marls containing a high percentage of sand and clay. The character of the materials shows that this marl was a shallow-water deposit which accumulated in such close proximity to the shore that a large proportion of the sediment is of land origin. 
In the northern part of the St. Johns Valley and extending southward along the east coast to near Lake Worth the Miocene is represented by an accumulation of sand and clay interbedded with more or less impure limestone. These sediments may have a thickness of nearly 500 feet at Jacksonville but are thinner toward the south. Limestone beds predominate toward the top of this series, but they are also found at various other horizons. In the Miocene, as in the preceding epoch, considerable amorphous silica appears to have been deposited. This silica was subsequently redeposited in the form of chert beds replacing limestone, and where the original limestone was sandy the resultant rock resembles a coarse quartzite. The marked thickening of these beds toward the north is probably due in part to the proximity of large land areas to supply the sediments, and in part to their deposition upon an uneven surface of the Oligocene limestones.

During this period the Suwannee Strait became closed, and the nonmarine sedimentation extended southward over considerable areas of Oligocene rocks. These sediments form part of the thick deposits of sand and clay extending from the northern boundary of the State southward nearly to the outcrops of the Miocene marls. This period of deposition was terminated by an emergence that was probably a renewal of the same processes of deformation that had been taking place since the early Oligocene. Vaughan ${ }^{1}$ has summarized the conditions during the Miocene with especial reference to ocean currents, as follows:

The plateau had approximately its present outline and thick deposits of arenaceous sands were formed practically to its southern limit, certainly as far south as the locality of Key Vaca; the sea was shallow, perhaps 25 fathoms is a safe maximum; there was depression coincident with deposition on the east coast; the waters were cold, a cold inshore countercurrent lowered the temperature to that of the region between Cape Hatteras, and Long Island. This southward-moving countercurrent, aided by winds and waves, is largely responsible for the greater thickness of sediments on the east than on the west coast, and it is the forerunner of the series of countercurrents so important in the later history of the region. Toward the close of the Miocene period uplift was again initiated, and the Suwannee Strait, should it not have been previously closed, was then assuredly above sea level, and the north and south Trail Ridge was formed. The uplift seems to have been greater on the east than on the west, for no Miocene is above sea level from Levy to Pasco counties on the west coast, while submerged Miocene is apparently present off the mouth of Tampa Bay.

\section{PLIOCENE EPOCH.}

Physiographic changes.-The deposition of rocks of Pliocene age began with an encroachment of the sea upon the margin of Florida until it probably covered all the southern end of the peninsula and extended northward beyond the latitude of Lake Okechobee. On the east coast the Pliocene sea occupied all the St. Johns River valley and

1 A contribution to the history of the Floridian Plateau: Pub. Carnegie Inst. Washington No. 133, 1910, pp. 182-183. 
it may also have covered the land east of this river. The present margin of western Florida was doubtless submerged, though the part extending from Tampa northward nearly to Apalachicola River may have been out of water. This is inferred from the fact that the surface formations in that region are believed to be Oligocene. However, it is possible that the absence of marine Pliocene beds is due to postPliocene erosion rather than to nondeposition.

Deposition.-During the Pliocene there was extensive deposition of the phosphate gravels known as the Bone Valley gravel ("land-pebble phosphates"). The conditions which permitted the deposition of this gravel appear to have been the low altitude of the land and consequent accumulation of products of mature weathering followed by slight submergence, which permitted the residual phosphates, sands, and clays to be assorted and redeposited by wave action. That there was complete weathering of the rocks from which the materials of the Bone Valley gravel were derived is shown by the facts that this formation contains the comparatively insoluble phosphate of lime, left by the solution of the limestones, and that the sands and clays are the resultants from the decomposition of other rocks and are not themselves subject to further weathering. The accumulation of such large quantities of residual products must have taken place under conditions that did not permit their ready removal, and such conditions would be most likely to be low altitude with abundant heat and moisture.

After the accumulation of the weathered materials a slight submergence was necessary to permit their erosion and redeposition in their present position. Evidence of the wave action is found in the poor assortment of the materials and in the cross-bedding of the sands and gravels. A gradual increase in altitude during the deposition of the Bone Valley gravel is indicated by the general variation from fine material near the base of the formation to coarser material above. The Pliocene ocean, according to Vaughan, ${ }^{1}$ presented some interesting peculiarities:

The general outline of the plateau remained as it was in Miocene time; the water was shallow, usually between 20 and 30 feet in depth; the temperature was tropical in the southern, the Caloosahatchee area; and warm, but slightly cooler, in the northeastern area, in the vicinity of Nashua. The oceanic current over the Pliocene bank must have been a warm countercurrent-a countercurrent because it brought sands from the north and deposited them on the Pliocene submarine bank.

While the Pliocene marine deposition was taking place important lacustrine and fluvial deposits were accumulating on the land surface above the sea.

Pliocene deposition was closed by another uplift of the plateau. Data for a precise estimate of the height of the land during this emergence are not available, but the evidence obtainable indicates that it was not over 200 or 250 feet as a maximum, and as the previous movements of the plateau were differential it is most probable that 
only portions were subjected to oscillations so great. Accompanying this oscillation a shallow syncline was developed along the axis now occupied by the Kissimmee River, with low anticlines on each side. Probably a third anticline was developed west of Peace Creek. The axes of these folds are parallel to the longitudinal axis of the Peninsula, and have been important in influencing the drainage courses of middle Florida.

PLEISTOCENE EPOCH.

Uplift.-Following the deposition of the Pliocene came an emerg-ence of the land that not only included the greater part of the present surface of the State but probably also a portion of the area that is now submerged. This emergence is regarded as belonging to the Pleistocene, though it might with equal propriety be regarded as Pliocene. The emergence gave the streams erosive power and caused extensive dissection of the Pliocene and older formations. It was during this period of erosion that the major features of the present topography were produced. Concerning the extent of the emergence, there is considerable diversity of opinion, and for this reason the views of some of the authors who have discussed the subject will be considered.

A view that has gained some credence is that Florida was at one time elevated over 2,000 feet above sea level. Such a Pleistocene elevation would have connected Florida with the island of Cuba; but in the course of his investigations of the geology of Cuba, Hill ${ }^{\mathbf{1}}$ found no evidence that there had ever been such connection. Moreover, the island of Cuba, according to this author, ${ }^{2}$ has undergone comparatively slight changes of level since the beginning of the Pleistocene. It is also worthy of note that the geologic history of Cuba has been very unlike that of Florida.

Shaler ${ }^{3}$ called attention to the fact that though the sediments of northern Florida and the adjacent States are marine they have been drained of their original content of salt water to a depth of nearly a thousand feet. In a later paper Shaler repeats this statement as evidence of recent extensive emergence of the peninsula of Florida, and also calls attention to the large submarine springs off the coast. He considers that these facts, together with the estuarine character of the lower portions of the stream valleys, indicate a subsidence of the land since the extensive uplift. That both emergence and subsequent submergence have taken place since the late Pliocene will scarcely be questioned. The only point in dispute is the magnitude of the movements.

The best known of the submarine springs is situated near St. Augustine. According to Capt. E. C. Allen, of that city, the orifice

${ }^{1}$ Hill, R. T., Notes on the geology of Cuba, based upon a reconnaissance made for Alexander Agassiz: Bull. Mus. Comp. Zool. Harvard Coll., vol. 16, No. 15, 1890, p. 285.

2 Idem, pp. 243-288.

${ }^{3}$ Shaler, N. S., Note on the value of the saliferous deposits as evidence of former olimatia eonditione: Proc. Boston Soc. Nat. Hist., vol. 24, 1890, p. 584.

$76854^{\circ}-$ WBP $319-13-14$ 
of the spring is about 60 feet across and the depth is about 200 feet. The depth of the sea at the point of emergence is said to be about 50 feet, and the water emerges with enough force to cause a distinct convexity of the surface during calm weather. According to some authorities it is difficult to row a small boat across the surface above the spring on account of the outward movement of the water from above the orifice.

There is no doubt that the marine strata of Florida contained salt water at the time of their deposition, and there is good evidence that the beds beneath the central part of the State have been drained of this water to a depth of several hundred feet. Owing to the fact that few deep wells have been cased for more than 200 to 300 feet, it is difficult to determine the character of the water from great depths because considerable fresh water almost universally enters the well near the surface and would serve to dilute any salt water obtained from below. Moreover, unless the head of the deep supplies was greater than that from shallower water-bearing strata, there would be a downward movement of the fresh water from the higher to the lower beds. However, the apparent absence of salt water in the deep wells of the northern part of Florida suggests that their included sea water has probably been drained out. The exact depth to which this process has extended is somewhat uncertain. Shaler's estimate of nearly 1,000 feet is probably too low rather than too high, for in a well at Sumterville ${ }^{1}$ hard sulphur water was encountered at 1,386 to 1,400 feet, and although the well was continued to a depth of nearly 2,000 feet no salt water was reported. The deep wells all penetrate limestones of Vicksburg age, and hence it is the beds of that age which have been drained of salt water. As a portion of these beds have been above sea level since Oligocene time, the salt water may have been removed before the Pleistocene. The magnitude of the emergence is not necessarily so great as 1,000 feet, because, given the necessary chance for escape, the salt water would probably be displaced by fresh water, provided the surface was high enough to afford a small hydrostatic pressure. The absence of impervious beds of clay above the submarine portion of the Oligocene limestones would permit the escape of the water; and hence a considerable thickness of the older rocks may have been filled with fresh water without being raised much above their present altitude.

As it is doubtful if the formation of large underground channels extends to great depths below sea level, the large springs point to considerable emergence. This emergence must have been of comparatively recent date, as otherwise the openings would have been choked during the deposition of the younger Tertiary formations. These

1 Fuller, M. L., and Sanford, Samuel, Record of deep-well drillings for 1905: Bull. U. S. Geol. Survey No. 298, 1906, p. 198 . 
facts suggest that the channels of the springs were formed during the post-Pliocene. It is believed that they date from the uplift which permitted the erosion of the deep valleys of the large streams of northern Florida.

Concerning the probable changes of level in Florida, Dall says: ${ }^{1}$

The on the whole remarkable horizontality of the Floridian strata indicates a freedom from violent changes of level from the time the "Peninsular" limestone first emerged from the sea. Land shells in the Ocala limestone show that then dry land existed. South of the Suwannee Strait, closed in late Miocene times, there is no evidence of subsequent submersion to any serious extent. Two gentle flexures run parallel with the peninsula, having the lake district between them; a tilting of, at the most, 30 feet, up at the east, down at the west, which may have been contemporaneous with the flexures; and, for the rest, very slow and slight but probably nearly continuous elevation never exceeding 100 feet and perhaps less than half that, with dry land and fresh-water lakes constantly existing since the Ocala Islands were raised above the sea; such is the geological history of the Florida Peninsula. Denudation of the organic limestones by solution rather than erosion is the prominent characteristic of the changes in the surface. Soft, crumbling under the finger nail, the rocks of the plateau, if lifted 5,000 or 6,000 feet, as claimed by Dr. Spencer, would have been furrowed by canyons and swept bodily into the sea. Indeed, to me the proposition is inconceivable as a fact and incompatible with every geologic and paleontologic fact of south Florida which has come to my knowledge.

The Pliocene beds were laid down when the altitude of the surface was low, and the subsequent uplift, to permit the streams to cut their valleys to their present depth, amounts to approximately 250 feet near the northern line of the State. As the streams appear to have cut below the levels of their present flood plains, this estimate may be regarded as too low by an amount which, owing to the absence of satisfactory data, is yet undetermined but is probably not large.

Submergence.-The erosion interval which began in the early Pleistocene or the late Pliocene was succeeded by a slight submergence which permitted the sea to cover the southern end of the State northward to some distance beyond Kissimmee, though the ridge upon which Lakeland is situated remained out of water in the form of an island. The St. Johns Valley was also occupied by the sea and the land to the east of it may have been again submerged. Along the Gulf coast a strip of land of varying width was also covered and the sea extended into the valleys of all the large streams, forming estuaries, which were more extensive than those of the present day.

In his discussion of the Pleistocene submergence Vaughan gives a brief summary of the marine conditions: ${ }^{2}$

The plateau throughout Pleistocene time preserved its general outlines. Shallowwater conditions prevailed over its entire submerged portion. In no place were the

1 Trans. Wagner Free Inst. Scl., vol. 3, pt. 6, 1903, pp. 1545-1546.

2 A contribution to the history of the Floridian Plateau: Pub. Carnegie Inst, Washington No. 133, 1910, pp. 183, 184 . 
known deposits laid down in water much deeper than 50 feet, and usually from barely below sea level to 25 or 30 feet. The temperature north of the latitude of the southern end of Lake Okechobee was slightly cooler than in Pliocene time, but it was still warm. In this shallow warm sea sediments of diverse kinds were deposited. Sands and shell marls are probably the most extensive, forming widespread deposits over almost the entire submarine bank. The sands extend beneath the limestone formations as far south as Miami and perhaps to the southern keys. Along the more northerly portions of the bank coquina accumulated. Along a curve, first southward and then bending westward, from Biscayne Bay, a coral reef flourished, separated by a channel of deeper water from the main bank, on which the Miami oolite was forming or had formed in shoal water, strongly agitated by currents. Along the southwestern portion of this bank, also in shoal water, the Lostmans River limestone accumulated. West of the coral reef, on an extensive flat in the shoal water over them, the Key West oolite was formed. Toward the close of the Pleistocene the previously formed sands, marls, and limestone southward beyond Miami received a thin coating of siliceous sand. Contemporaneous with this purely marine work, the terracing of rivers to the north was taking place.

Pleistocene time was closed by an uplift, which may have been intermittent or may have been accompanied by oscillations. There is some evidence of slight depression since the principal uplift. After this uplift the living coral reefs developed, the Everglades were formed, and the Florida of to-day was the result.

Terraces.-During the interval of extensive Pleistocene erosion the so-called Lafayette upland had been considerably dissected and its materials had been deposited in the valleys which were being excavated. Before the beginning of the cycle of submergence there was a large addition to the detrital surface materials in the form of coarse-grained sand that had accumulated as a result of weathering. The geographic extent of the submergence was extensive, for $t$ probably covered the major portion of the State below the 100-foot contour and possibly a somewhat greater area. The submergence permitted the waves of the Pleistocene sea to erode and redeposit the weathered materials that had accumulated on the surface, and in places unweathered portions of the older formations were reworked by the sea. The principal effect of the Pleistocene wave action was to cut away portions of the hills and to deposit the detritus in the depressions, thus producing a moderately level plain. The inner margin of this plain is marked by a low scarp and the outer edge descends by a similar scarp to the next lower plain.

Subsequent to the formation of the upper terrace two similar plains-the Tsala Apopka and the Pensacola terraces-have been formed at successively lower levels. The description and distribution of these terraces have been outlined in discussing the physiographic history of the State.

The Pleistocene terraces (pp. 31-35) were formed during comparatively late Pleistocene time. There is abundant evidence of a long interval of erosion preceding the formation of the oldest terrace, and the latter, where traced westward, is found to be as late in deposition as the main body of the loess of the Mississippi Valley. 
There is still some doubt as to the relations of the loess and the uppermost Pleistocene terrace, but all the evidence so far obtained indicates that if the two were not deposited coincidently the loess deposition preceded the terrace formation. If the main body of the loess is correlated with the closing stages of the invasion of the Iowan ice sheet into the northern portion of the United States the terracing must be largely post-Iowan.

There is a lack of information concerning the details of the late Pleistocene history. Shattuck, in discussing the Pleistocene of Maryland, separates the successive terraces by intervals of elevation and erosion. ${ }^{1}$ The rarity of good exposures in Florida, together with the general nature of the investigations, make it difficult to form an opinion on the exact sequence of events. As an alternative theory the formation of the terraces has been regarded as an episode in the emergence of the land after its maximum submergence. The erosion interval preceding the submergence is well established and the irregular surface produced by erosion is only imperfectly masked by the deposits of the oldest Pleistocene terrace. Erosion since the formation of the terraces is also evident and a Recent depression has transformed the lower ends of the valleys into estuaries; but of the physiographic history between the time of the formation of the highest and lowest terraces it is not possible to draw conclusions from observations in Florida.

Southern Florida.-Southern Florida presents conditions that do not permit differentiation of all the different Pleistocene terraces. In fact, only the Recent and the lowermost portion of the Pensacola terraces are represented in that area. However, the various Pleistocene formations probably include representatives of deposits made during the deposition of the uppermost portion of the Pensacola terrace and of the two older terraces. The earth movements indicated by conditions in southern Florida are a depression, probably the one initiating the formation of the Pleistocene terrace; an uplift, doubtless the one that closed the deposition of the Pensacola terrace materials; and a subsequent depression that permitted the submergence of a portion of the coastal lowland.

Though the Pleistocene limestone formations of southern Florida that have been described (pp. 175-191) apparently extend under wide areas, all except the Key Largo limestone are rather thin. They grow sandy toward the north, where they rest on less consolidated material or on formations containing sandy beds and are more or less covered by sand and marl.

At some places along the east coast well records show considerable thicknesses of coquina and beds of well-worn quartz sand and shell fragments; at others they reveal relatively thin beds of limestone 
with sands and gravels above and below. Along the east coast and on the keys are rock outcrops 15 feet or more above tide; along the west coast are none. The surface sands in some places form long, low ridges and in other places mounds 60 feet high. Many of these sand ridges rise from ground where growth by wind action is now impossible.

From the conditions thus summarized may be inferred a period of submarine upbuilding by quartz sands and limy material, which was moved southward by currents, and a period of gentle depression, of possibly 100 feet, during which beach or bar deposits thickened on the east coast, the coral reef grew and spread south of the mainland, and quartz sands and limy sands and muds accumulated in wide expanses of shallow water behind the bars and the reef on the west coast. There is no evidence in the fossil remains that the climate or the ocean water was colder than at present. In fact the growth of large heads of reef-building corals as far north as Hillsboro Inlet indicates warmer water.

Following this depression came an uplift of the land, perhaps of 100 feet, or perhaps more, above its present level. Beach sands, driven inland, formed dunes. The limestones were eroded by the sea and honeycombed by the downward movement of surface waters. Following this uplift came a slight depression, bringing the land to its present level.

These are the broader features of the changes indicated in Pleistocene time, but it is probable that neither depression nor uplift was uniform; there may have been pauses or even comparatively brief reversals of swing (certain features of the keys and their shores suggest more than one elevation above sea level), but nowhere is there indication of a great uplift.

\section{RECENT EPOCH.}

Northern and central Florida.-The slight submergence which has taken place in northern and central Florida in comparatively recent times has permitted the sea to enter the lower portions of the stream valleys and has covered a narrow belt of land along the entire coast. The small submerged valleys along the west coast were doubtless carved during the uplift just preceding this last submergence. That the movements which have taken place have not always affected the entire State uniformly appears probable, and this recent submergence of valleys on the west coast has been regarded as an example of unequal movement. The following statement by Dall ${ }^{1}$ illustrates one of the views which has gained wide credence:

The mapping out of the distribution of the different geological horizons from many isolated observations, $* * *$ taken into consideration with the observations of 
Shaler and others on the east coast, indicated that the peninsula of Florida has experienced a tilting by which the eastern margin has been elevated between 20 and 30 feet, while the western coast has been depressed about the same amount. This tilting is supposed to have taken place since the Pliocene. To the data of 1891, upon which the above generalization was based, Mr. Willcox has lately added observations which still further emphasize the fact. He finds that, of the streams falling into the Gulf of Mexico from the peninsula in the relatively shallow waters over the submerged plateau to the west, channels cut in the limestone may be traced for some distance. As these channels, too small to make any marked feature on the usual hydrographic chart, could not have been cut since the sea has covered the plateau, the inference is obvious that they were cut before the tilting of the peninsula, when the limestone was above the level of the sea.

The drowning of the St. Johns River valley, which permitted brackish water to extend far inland, beyond Jacksonville, shows that the east coast as well as the west has recently been depressed. The amount in either case was probably comparatively slight, though it is difficult to obtain precise data. However, as the channel of St. Johns River is at least 65 feet below sea level opposite Jacksonville, it is safe to assume a depression amounting to over 50 feet. An equal amount of submergence is suggested by the depth of water covering the submarine spring near St. Augustine, and a far greater depression is suggested by the depth of this spring, which, as already noted, is reported to be 200 feet; but this greater submergence probably took place before the deposition of the Pleistocene sands and marls.

Earth movements are doubtless taking place along the coast of Florida at the present time, but the rate of change is so slow that it is only under the most favorable conditions that the effects of the movements are noted. One of the earliest recorded observations on coastal changes was made by Gorrie ${ }^{1}$ in 1854 . According to this writer the coast at Apalachicola was gradually sinking during the 20 years preceding 1854 . The evidence upon which the conclusions were based was the increased depth of water on the bar at the South Pass to Apalachicola Bay; the submergence of tree trunks and roots; and permanent submergence of oyster reefs that were formerly exposed at every low tide. The increase in depth of water over the bar at the entrance of the harbor might be accounted for by the action of waves and currents. If the water of the bay was prevented from escaping readily it is possible that the water level might have been raised slightly, but the deepening of the pass across the bar should have furnished a free passage for the water, and hence the submergence of trees and oyster reefs was probably due to an actual change in the level of either land or water. The amount of submergence was estimated at 8 or 9 inches in 20 years, or approximately 7 feet per century. 
In 1902, Vaughan ${ }^{1}$ obtained information which indicates that the coast in the vicinity of St. Marks has been rising within the last half century. The evidence shows that a little pond which was formerly overflowed at high tide is now entirely drained and is not invaded by the sea except by a high tide coupled with a strong onshore wind that has been blowing for at least two days. The ordinary high tide is said to fall 300 yards short of reaching the pond, in spite of the fact that the connection with the sea is less obstructed than formerly. This change, which is estimated at 1 to $1 \frac{1}{2}$ feet since the fifties, is thought to indicate an emergence of the land at the rate of 2 to 3 feet per century.

These two cases indicate two opposite movements within a short distance of each other. At Apalachicola the observations cover about 20 years prior to 1854 and at St. Marks they cover the last half of the century. If the observations recorded should be given full credence, there would still remain a question as to whether there was a change in the direction of movement about the middle of the century or whether there are two opposite movements on the same coast.

The only record of recent movements on the east coast is contained in a brief note by Lewis, ${ }^{2}$ who reports the submergence of stumps of cedar trees at St. Augustine. The amount of the movement is not recorded.

Southern Florida.-Although the accumulated evidence shows that the Pleistocene and Recent history of Florida has been marked by no great disturbances, that the elevations or depressions of the land, though affecting great areas, have been relatively small in amount, and although there is no reason to suppose that the region will be violently disturbed in the immediate future, yet as the question of relative permanency of height of land is of importance because slight changes with respect to sea level will have a pronounced effect on the habitability of the coasts, the evidence available is briefly summarized.

That the coast line has been elevated the old coral reef of the Florida keys is abundant proof. That it has been slightly depressed since the maximum elevation is indicated by solution cavities in the limestones extending considerably below present water level and by the relation of the dunes to present shore lines.

As to more recent changes and the present movement the evidence of swamps, of shore lines, and of human records may be adduced. If the swamps are being depressed there should be tree trunks of the older forests buried beneath the sediments that have accumulated

\footnotetext{
1 Evidence of recent elevation of Gulf coast along the western extension of Florida: Science, new ser., No. 404 , vol. 16,1902 , p. 514 .

2 Lewis, E., Evidence of a probable modern change of level on the coast of Florida: Am. Jour. Sci., $2 d$ ser., vol. 41, 1866, p. 406.
} 
since the trees fell. The writer noted a thick stump in gray marl at one of the numerous entrances to Shark River, near the plant of the Minetto Lumber Co. It was about 3 feet below the present surface of an islet, which is covered by water at high tide. The evidence was not conclusive, as the stump might not have been where it grew. Still the present growth of the swamps favors a recent depression, as does the existence of mangrove swamps about the bases of sand dunes near the coast. The dunes evidently are younger than the Pleistocene limestones they overlie and in age are probably late Pleistocene. A depression of at least 10 feet between late Pleistocene and present time is indicated by the swamps fringing many dunes.

The testimony of the shore lines is contradictory. Possibly the best evidence is that of the series of low beach ridges extending from East Cape to North Cape on Cape Sable. This strip of foreland, having a steep beach of coarse shell sand facing the Gulf and falling off inland to a mangrove swamp flooded at spring tides, seems to show that there has been a slight sinking of the coast since waves started to heap up the sand. Other evidence of depression is found along the keys. At several places along the right of way of the Florida East Coast Railway peat beds, evidently representing former mangrove swamps, were found covered with beach rock or marl below tide level.

The human records to which appeal can be made are the numerous Indian mounds, or kitchen middens, composed chiefly of oyster shells, found at many places along the coast. (See p. 162.) Some of the mounds are of great size, notably the accumulation of shells on Chokoluskee Island, which covers nearly 100 acres to an average depth of 5 feet. Since the mounds stand in swamps the relation of the bottom layers of shells to present sea level and to the deposition of marl and vegetable matter in the surrounding swamps should be an index of any coastal rise or fall. An examination of mounds at Jupiter Inlet, in and near Chokoluskee Bay, and at Marco, however, gave fewer data than were anticipated. In places creek channels have cut into the mounds, in places wells have been sunk through them; consequently sections showing relations of the lowest layers of shells to sea level and to the underlying materials are not hard to find. The sections show that around the edges of the mounds there has been some burying of shells by wash, but the bottom layers rest on peat and marl at about low-water mark; so if the first Indian dwellings stood on posts in ground flooded at high tide, there is no sign of a measurable sinking of the coast since the time when the building of the mounds began.

Thus the evidence at hand shows that the coast of this part of Florida is not now rising but is stationary or sinking. If it is sinking, then the rate of depression is so slow that it can not be determined 
from human records which must antedate the discovery of America. A depression of the coast in Recent time is, however, beyond doubt. Topographic changes.-The Recent geologic and topographic changes of importance in northern Florida consist of the deposition of coquina, sand, marl, peat, and muck and the formation of sand dunes and ridges. Rapid deposition of sand and coquina is taking place along both the Atlantic and Gulf coasts, and more or less marl and partly decomposed organic matter in the form of peat and muck is being deposited in the marshes and lagoons. The formation of dunes and ridges of sand is especially active along the east coast as far south as Hobe Sound, and a similar action, on a much smaller scale, is taking place in the interior of the State. Solution and the consequent formation of underground channels, sink holes, and natural bridges doubtless began with the emergence of the calcareous rocks and is still going on. The effects of solution are shown by the emergence of water bearing mineral matter in solution and by the occasional subsidence of small areas.

In southern Florida in Recent time the Everglades formed to the south of a lake larger than the present Lake Okechobee. Sands and marls from the waste of the land and the ground-up remains of marine organisms and calcium carbonate precipitated from sea water were deposited along the shores of the mainland and keys. Pine forests covered the sand hills and the topography of the mainland assumed its present aspect. Near the Gulf Stream corals built the modern reef. Waves and currents shaped marls and sands into the atoll-like group of the Marquesas and piled up coarser materials to form the Tortugas.

The surficial limestones of southern Florida are, as a rule, soft and porous and are remarkably free from aluminous material; hence, they are easily disrupted by tree roots, readily dissolved by percolating surface water charged with carbon dioxide, and eroded without difficulty by waves and streams. The effects of solution are everywhere visible in the outcrops of oolite and coral rock; the potholes, natural wells, and springs show how active has been the work of underground water. The jagged surface of the Miami oolite (see pp. 177-180) and the bareness of its ridges show how easily it dissolves and how free the original sediments were from clay.

Along the coast, wherever rocks reach the water edge, the waves are eating them away. Tidal and wind-made currents carry off part of the waste in solution and part in suspension, and distribute the coarser detritus as sand.

Besides the currents and waves which assort, distribute, and pile up the waste of the land, organic agencies play an important part in extending the shore lines. In fact such agencies are of greater importance in south Florida than in any other part of the United 
States, for here coral polyps are building up rocklike ledges strong enough to stand, for awhile at least, the hammer of the breakers, and mangroves are arresting and holding finely divided material that had been swept about by currents. In addition, thick beds of oyster shells form banks, hard masses of "worm rock" (limy tubes secreted by mollusks, see p. 156) protect and extend shore lines, and perhaps most important of all the remains of the teeming vegetable and animal life of the salt water contribute in the aggregate an immense amount of material to the upbuilding of the land.

The lagoons or "rivers" of salt or brackish water back of the beaches are being filled by swamp growths. Although the tidal swing is small, the extent of the lagoons and the volume of water discharged at each ebb is sufficient to transport and assort lighter débris, but in the shaping of the coast the waves and alongshore currents play the chief part.

In the Bay of Florida, though the rocky shores of the coral islands show the rip of the sea, banks and marl flats are gaining and mangroves are vigorously extending the land. Tidal currents are the principal agencies of transportation along the south side of the bay, where under favoring conditions currents with velocities as high as 5 miles an hour rush through the openings between the keys. Along the north side of the bay tidal action is much weaker and winds and currents perform a proportionately larger part of the work. Wave action, though important, is limited by the shallowness of the bay.

From East Cape to North Cape a strip of shell sands, the Cape Sable foreland, has been pushed up from the bottom by the waves. Tidal action is strong; there is a pronounced tide rip past Middle Cape, though there is no dominant alongshore movement of sand north or south. From North Cape to Cape Romano stretches of beach are few; mangroves grow out of the water of the Gulf, and the shore line is extremely intricate. Tidal scour is strong at the inlets leading into Whitewater Bay, but to the north most of the entrances are obstructed by bars. From Cape Romano to the mouth of Caloosahatchee River the shore-line topography resembles that of the east coast. Long beaches of sand, spits, and bay bars denote adolescence. The predominant movement of sand alongshore, as shown by offsets and overlaps, is southward. This indicated southward drift is probably due to the effective onshore winds from the west and northwest rather than to a prevailing easterly movement of air currents. The great seas of hurricanes and northers are of chief importance in distributing and piling up the sands.

To the interplay of these agencies of waste and growth are due the peculiar features of the shore-line topography. The importance of these features has often been noted, but most accounts of the geology of the region have failed to discriminate sharply between the 
agencies that wear away the land and those that extend it, or have given undue importance to one cause in comparison with the others.

As an instance may be cited the southern growth of the mainland and the character of the mangrove islands along the northern part of the Bay of Florida and in Blackwater and Card sounds. The bedrock floor of limestone that outcrops in the Biscayne pineland, on Long Key, and adjoining keys in the Everglades, slopes gently to the south. On it the marls below the sandy beaches of Cape Sable, the marls of the prairie back of Flamingo, and the marls of the great mangrove swamp to the east and of the mangrove islands in the bay, have accumulated. Hence these islands and the projecting tongues of swamp along Blackwater Sound can hardly be, as some observers have held, erosion remnants of a formerly continuous land surface. Rather do they represent the work of agencies, which, if unchecked by a depression of the coast, will ultimately join the mainland to the keys. 


\title{
PART III.-UNDERGROUND WATER.
}

\author{
GENERAL FEATURES.
}

By G. C. Matson.

\section{SOURCE.}

The immediate source of potable water is the moisture precipitated from the atmosphere in the form of rain, dew, and snow. Of these, the last is important in Florida only at long intervals when an exceptionally cold season causes considerable snowfall near the northern boundary of the State. By far the most important source of potable underground water is the rainfall; but a considerable amount is contributed by the lower layers of the moisture-laden atmosphere when it comes in contact with the cool surface of the ground or enters the pores of the soil and is there cooled below the dew point.

As rainfall is the most important source of the underground water it is necessary to consider the amount of the precipitation in that form. In a large State like Florida it is difficult to estimate the average precipitation because conditions vary in different parts of its area. This variation is well shown by the average annual rainfall at the following localities: ${ }^{1}$

Rainfall at localities in Florida.

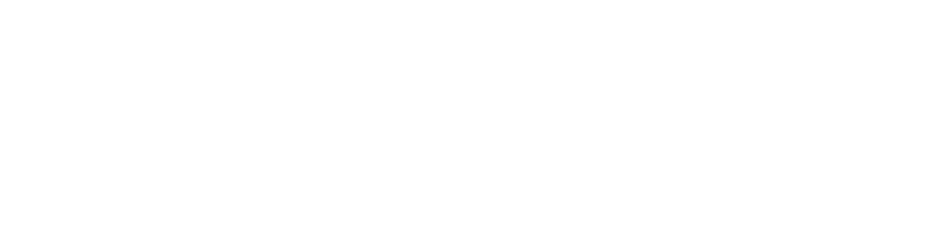

A comparison of the rainfall at these localities is not wholly satisfactory because no two amounts represent averages for the same number of years. All the records end with 1904, but each began at a different date, going back 33 years at Jacksonville, 17 at Jupiter, 34 at Key West, 5 at Tampa, and 25 at Pensacola.

If allowance be made for the fact that Key West lies some distance off the coast, where the conditions differ considerably from those of the mainland, it will be possible to form some idea of the average precipitation, and when all the factors are taken into account it seems safe to place it at about 52 inches for the entire State north of the 
keys. This does not mean that the rainfall of any particular year may not differ widely from this estimate; in Florida, as elsewhere, some years are exceptionally dry and in others precipitation is excessive.

The water which falls upon the surface is disposed of in three ways-by evaporation, by direct run-off, and by absorption. The amount which evaporates before it enters some of the drainage channels or is absorbed by the soil is so small that direct evaporation is unimportant.

The amount of water which escapes over the surface depends upon several factors, such as the rate of precipitation, the topography, and the texture of the surface and subsurface materials. Other things being equal, a slow precipitation upon a flat surface covered with porous soil, which, in turn, rests on porous rocks, will insure the maximum absorption, and, conversely, will permit the least.possible amount of surface r n-off. Probably no part of the country presents less favorable conditions for the escape of water over the surface than Florida, where the land is almost everywhere flat or gently rolling and is covered with a mantle of porous sand, which in turn rests on very porous limestone. Locally, of course, conditions may favor immediate run-off, as in some parts of the peninsula and over considerable areas in the northern and western portions of the State where the subsurface beds are of clay. Moreover, the limestones are not everywhere porous, and in some localities they contain accumulations of more or less impervious materials, such as dense marls and chert, which may act as obstacles to the downward movement of the ground waters and hence lead to early saturation of the surface beds, a condition naturally followed by the movement of water directly into surface streams and ponds. Locally, also, the surface is formed into depressions known as sink holes, which receive a large amount of water and convey it to underground drainage channels, thus lessening the amount of surface drainage. However, the local character of these obstructions prevents their greatly affecting the average absorption for the entire State, and it appears safe to estimate the direct run-off as low as about 2 inches per annum, or 4 per cent of the rainfall. This estimate should not be confounded with results determined by gaging streams, for in streams the measurements show not only the direct run-off, but in addition a much larger quantity of water which was first absorbed by the rocks and later returned to the surface by springs and seepage. It will thus be seen that the amount of underground water is greatly augmented each year. It might also be inferred that the amount of underground water is large, and this is true; nevertheless. the supply is by no means inexhaustible. 


\section{AMOUNT OF UNDERGROUND WATER.}

\section{IN THE EARTH AS A WHOLE.}

Considerable quantities of water occur in cavities and crevices in rocks, but by far the larger proportion occurs in the minute pores between the individual grains of porous rocks. The earth's crust is under enormous pressure at no great depth from the surface, and it has been estimated that at a depth of approximately 6 miles this pressure must be sufficient to close all openings. Numerous attempts have been made to estimate the amount of water contained in this comparatively thin outer zone, and conclusions have been reached which, though not susceptible of verification, are of sufficient interest to warrant recapitulation.

One of the earliest estimates of the quantity of water in the earth's crust is that of Delesse, ${ }^{1}$ who considered the amount sufficient to form a sheet of water on the surface of the earth more than 7,500 feet thick. Later estimates have been more conservative, but some of them are large. The most important are those of Slichter, ${ }^{2}$ who figured the depth of the sheet of water at 3,000 to 3,500 feet; Chamberlin and Salisbury, ${ }^{8}$ who put it at 800 to 1,600 feet; Van Hise, ${ }^{4}$ at 226 feet; and Fuller, ${ }^{5}$ at 96 feet.

\section{AMOUNT OF UNDERGROUND WATER IN FLORIDA.}

In attempting to apply these estimates to Florida, it was found that though the data for exact determination were wanting the amount of underground water was evidently greater than the average given by either Van Hise or Fuller. The thickness of the sands and porous limestones in Florida is known to exceed 1,200 feet, and, assuming an average porosity of 20 per cent of their volume, these rocks would contain enough water to cover the entire surface of the State to a depth of more than 240 feet. This estimate should not be taken as a measure of the amount of potable water, because the deeper waters of Florida are too highly mineralized to be classed as such.

The amount of underground water in Florida has been determined by assuming an average porosity of 20 per cent and considering the known thickness of the water-bearing sediments. This gives an amount which, though large, is probably very much below the actual quantity of water which lies below the surface of the State. However, from the standpoint of the consumer, this amount is far too

1 Delesse, Achille, Bull. Soc. géol. France, 2 d ser., vol. 19, 1861, p. 64.

2 Slichter, C. S., Motions of underground waters: Water-Supply Paper U. S. Geol. Survey No. 67, 1902, p. 14.

3 Chamberlin, T. C., and Salisbury, R. D., Geology, vol. 1, 1904, pp. 206, 207.

4 Van Hise, C. R., A treatise on metamorphism: Mon. U. S. Geol. Survey, vol. 47, 1904, pp. $128-129$.

5 Fuller, M. L., Total amount of free water in the earth's crust: Water-Supply Paper U. S. Geol. Survey No. 160, p. 72 . 
large, because the greater part of the supply is too saline to be of value. The thickness of the sediments containing potable water varies from practically zero on the keys to over 1,000 feet in the north-central part of the peninsula, and the average thickness is thought to be about 500 feet. Since only the surface waters in the southern part of the peninsula are sufficiently free from salt and other objectionable mineral matter to be classed as potable, this estimate may be regarded as generous. If the rocks which contain potable water are assumed to have a porosity of 20 per cent, the amount would be sufficient to cover the entire surface of the State to a depth of only 100 feet.

\section{EVAPORATION OF UNDERGROUND WATER.}

Most of the water which is absorbed by the soil is either lost to the air by evaporation or returned to the surface by means of springs and seeps.

Evaporation takes place directly to the air, which enters the pores of the soil and passes downward to the saturated or partly saturated beds; but the circulation of air through the soil is so slow that the amount of water lost in this manner is seldom important. A much larger quantity of water is lost by evaporation from the surface layers of the soil, the capillary movement of water from the lower to higher layers constantly renewing the supply at the top. The loss of water in this manner is influenced by temperature, humidity, and the texture of the surface layers; and consequently quantitative estimates are uncertain. The figures given below are taken from a table by King, ${ }^{1}$ and are intended to illustrate the effect of keeping the surface layers loose to a depth of 3 inches. King's experiments were made in North Carolina, but soils of similar character to those he examined are widely distributed in Florida.

The table given below shows the evaporation from the surfaces during 28 days, from July 17 to August 14, 1902, inclusive.

Evaporation from soils of different types.

[In inches.]

\begin{tabular}{|c|c|c|c|}
\hline \multirow[b]{2}{*}{$\begin{array}{c}\text { Surface condition. } \\
.\end{array}$} & \multicolumn{3}{|c|}{ Type of soil. } \\
\hline & $\begin{array}{l}\text { Sand } \\
\text { hill. }\end{array}$ & $\begin{array}{l}\text { Norfolk } \\
\text { sandy } \\
\text { loam. }\end{array}$ & $\begin{array}{l}\text { Norfolk } \\
\text { fine } \\
\text { sandy } \\
\text { loam. }\end{array}$ \\
\hline 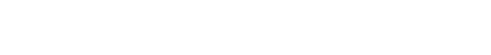 & $\begin{array}{r}1.880 \\
.205\end{array}$ & $\begin{array}{r}4.170 \\
.770\end{array}$ & $\begin{array}{l}6.515 \\
1.135\end{array}$ \\
\hline
\end{tabular}

These results are not susceptible of close application because of the great difference between the amount of evaporation from loose

1 King, F. H., Some results of investigation in soil management: Yearbook U. S. Dept. Agr., 1903, p. 159. 
soil and soil with compact surface; but since, in Florida, much of the surface is untilled, the evaporation for the whole State probably averages nearer the maximum than the minimum values given. The period of observation, from August 7 to August 14, falls in the hottest portion of the year, and this would give an abnormally high rate of evaporation, which might be in part counterbalanced by a high humidity accompanying the heavy precipitation of that part of the year. On the whole, an estimated surface evaporation of 20 inches for the entire year is thought to be conservative.

The quantity of water annually lost by evaporation from plants is sometimes regarded as insignificant; but this is by no means the case. The food which the plant derives from the soil is taken in solution in water, and this water, with the exception of what is built into the tissues of the plant itself, is largely evaporated from the surface of the leaves. Information concerning the quantity thus lost is fragmentary, and it is known that the amount differs with different kinds of plants and even with the same kind of plants under different conditions. The amount of water evaporated during the growth of a hay crop has been estimated at $5 \frac{1}{4}$ inches; and the evaporation from a wheat crop at $2 \frac{3}{4}$ inches. ${ }^{1}$ The early harvesting of the wheat crop permits the growth of another set of plants which probably remove nearly as much water from the earth as is evaporated by the wheat; and this raises the total evaporation from the area to about 5 inches per annum.

Assuming that the evaporation from a citrus tree is approximately equal to that from the European evergreen oak-that is, 500 pounds of water to each pound of dry leaves-Hilgard ${ }^{2}$ estimated the loss of water from a 15-year-old orange tree at 9 acre-inches. Riverside, Cal., where Hilgard worked, has an annual rainfall fully 15 inches less than the average precipitation in Florida and a higher evaporation. Hilgard also states that birch and linden trees give off 600 to 700 pounds of water per pound of dry leaves, oaks 200 to 300 pounds, and conifers only 30 to 70 pounds. Since much of the vegetation of Florida consists of pine trees, the average rate of evaporation from trees in the State probably approximates that given for conifers. A conservative estimate of the average evaporation from plants in Florida is estimated to be about 5 or 6 acre-inches per year. This amount, added to the.loss from the surface, is thought to equal approximately 25 acre-inches. Thus, though the annual addition to the underground water is enough to cover the State to a depth of over 4 feet, the actual increase in the amount available for wells and springs does not exceed about 2 feet.

${ }^{1}$ Galloway, B. T., and Woods, A. F., Water as a factor in the growth of plants: Yearbook U. S. Dept. Agr., 1894, p. 174.

2 Hilgard, E. W., Soils, Macmillan Co., 1906, p. 263.

$76854^{\circ}$ - WsP 319-13-15 


\section{DEPTH TO UNDERGROUND WATER.}

WATER TABLE.

Water absorbed by the soil moves downward until it reaches a level where the rocks are saturated. The upper surface of this saturated. zone is known as the water table. The water table is not, as its name suggests, an even surface, for it slopes upward from the sea, rising beneath the hills and sinking in the valleys and reproducing with diminished relief and softened outlines the general configuration

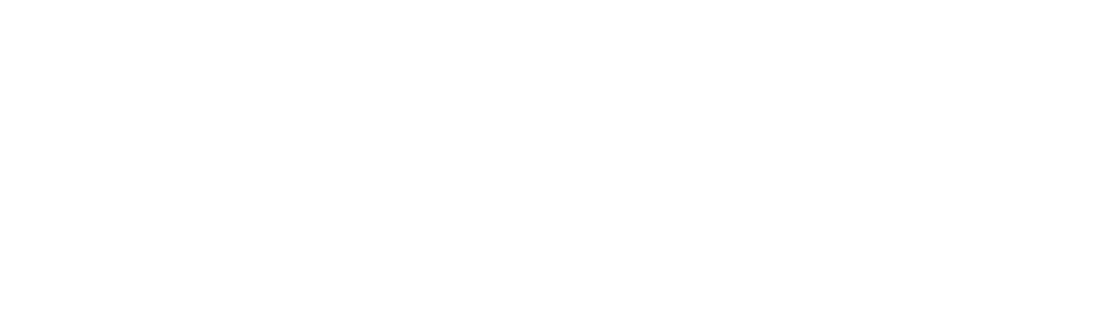

Figure 2.-Relation of underground-water level to Silver and Blue springs. Adapted from Sellards, E. H., Bull. Florida Geol. Survey No. 1, 1908, p. 32.

of the surface of the land. The details of the form of the water table are largely influenced by the amount of water absorbed and the freedom of movement to points of escape, such as seeps and springs. In an arid region, where the rainfall is slight, the water table sinks far below the surface and becomes comparatively flat; in a humid region frequent rains make abundant contributions to the underground water and help to maintain the water table near the surface.

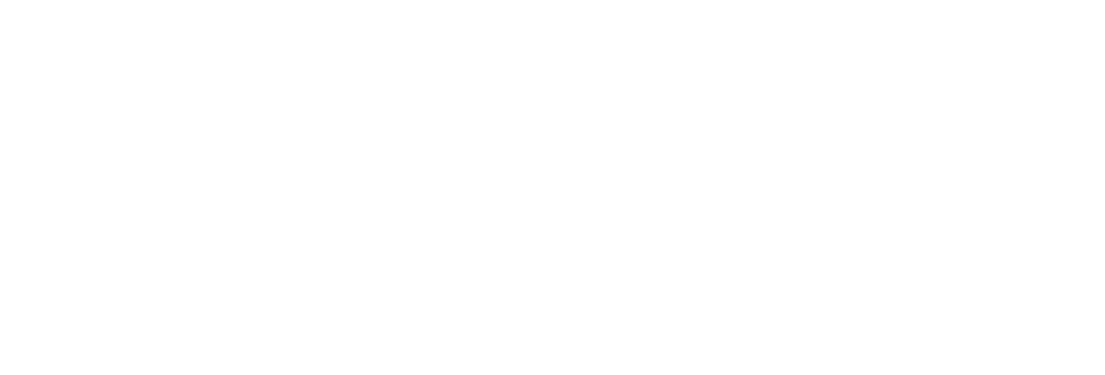

FIGURE 3.-Relation of underground-water level to surface contour in Suwannee and Columbia counties. Adapted from Sellards, E. H., Bull. Florida Geol. Survey No. 1, 1908, p. 32.

The influence of rock texture on the size of the openings has already been mentioned; and, since the size and form of the openings affect the rate of movement of the underground water, they have an important bearing on the form of the water table. Where the openings in the rock are large enough to permit the water to move freely, the water table will lose its inequalities under the influence of gravity. With the reduction of the size of the openings, friction retards the movement of the water, and finally, when the openings are of very 
small size, both friction and capillarity tend to counteract the effect of gravity and to cause the configuration of the surface of the water table to approximate that of the land.

The relation of the water table to springs, rivers, and lakes is similar to its relation to sea level. (See figs. 2, 3, and 4.) The underground-water level rises gradually from the borders of surface waters, as shown in figure 3 , which is a generalized profile across the peninsula, with the surface of the ground represented by a solid line and the water table by a dotted line. Since the slope of the water table is toward the surface waters it follows that the normal flow of the ground waters is toward the bodies of surface water. This normal flow, however, is sometimes reversed by a rapid rise in the level of the surface water. Periodical movements in the level of bodies of surface water, such as tides, are accompanied by corresponding fluctuations in the adjacent portion of the water table but are reduced in magnitude by friction.

Where a portion of the ground water encounters a relatively impervious bed, it may be prevented from reaching the main body of the ground water. In this case, a local water table is formed which is entirely independent of the level of the great body of the ground water. Such a phenomenon is known as a perched ${ }^{1}$ water table. (See fig. 4.) Usually more or less leakage to lower levels takes place from a perched water table because the material upon which the water rests is not wholly impervious.

\section{DEPTH OF POTABLE SUPPLIES.}

Although a complete discussion of the potability of the Florida waters is beyond the scope of this report, it is necessary to consider briefly the general factors controlling the occurrence of water containing a high content of mineral matter in solution. The rocks of Florida are all sedimentary and for the most part were deposited beneath the ocean. Such deposits are called marine and originally include sea water, which may be designated water of deposition.

1 Veatch, A. C., Underground water resources of Long Island, N. Y.: Prof. Paper U. S. Geol. Survey No. 44, 1906, p. 57.

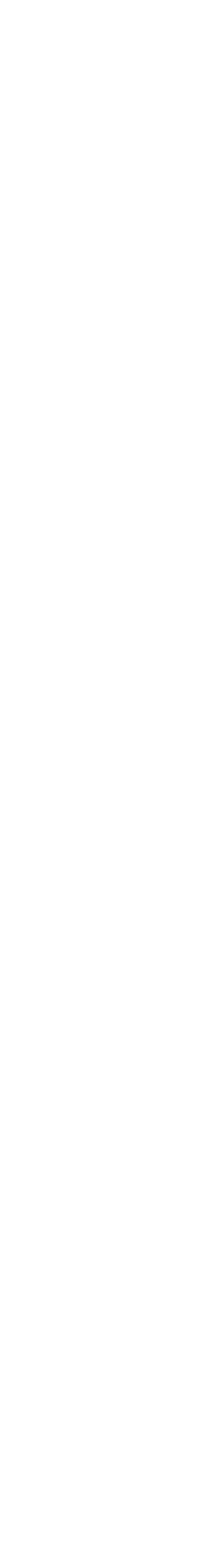


This included sea water may be gradually displaced by descending rain water-the rate of change depending on the freedom of drainage. Where the rocks are porous and the land high the water of deposition is soon removed, but a low altitude combined with dense rocks gives a very slow rate of escape. The process of removal may extend some distance below sea level provided porous materials emerge on the bottom of the ocean. The exact depth will be controlled by the relative weights of the colunins of fresh water beneath the land and the salt water at the point of emergence.

The greater height of the column of fresh water is partly offset by the increase of weight of the sea water caused by its high mineral content and by the friction of the water in the rocks. There must inevitably be a level where the opposing forces counterbalance each other and the underground water becomes nearly static. Below this level the water of deposition is scarcely disturbed, but its mineral character may be changed by osmotic action, by the solution of new substances, and locally by the deposition of some materials already in solution. In the older rocks of Florida the displacement of the water of deposition has been going on for a long time and the process has reached an advanced stage, but in the younger formations the time has been'so short that some of the saline water still remains in beds near the surface, though it has usually been more or less changed in composition by the addition of rain water.

In some localities a resubmergence of the older land has caused the rocks to become filled with a new supply of salt water, and hence the existence of such water does not necessarily mean that the conditions have always been unfavorable for its removal.

In the northern part of Florida the salt water has usually been displaced to depths of at least 1,000 feet, though locally, as at Chattahoochee, some of the water obtained within less than 1,000 feet of the surface is somewhat saline. The conditions are illustrated by the 1,100-foot well at Live Oak and the 1,001-foot well at Quincy, neither of which reports salt water. In the central part of the peninsula and extending as far south as Bartow and Mulberry, the conditions are similar to those in northern Florida. At Gainesville the well of the Diamond Ice Co. is 1,250 feet deep and encountered water that is slightly saline but that can be used as a city supply. At Plant City a 1,100-foot well procured fresh water, and, according to the reports from the drillers, a well 2,002 feet deep at Sumterville obtained no salt water, though this may not be correct as the well was not drilled for water and may not have been carefully tested to determine the quality of the water encountered.

In passing from the interior of the State toward the coast the depth to salt water diminishes until in many localities it may be 
encountered within less than 500 feet of the surface, though the depth to the strong brines is usually somewhat greater. Toward the south the horizons containing salt water lie nearer the surface, and it appears certain that on the southern end of the mainland and on the keys the fresh water is confined to the surficial rocks. This opinion was based largely on the increase toward the south in the percentage of salt in the deep wells and the diminishing depth to the saline water and is partly confirmed by the results obtained in drilling deep wells on the keys.

Local areas of salt water were noted, among them being the ones at Enterprise, Titusville, and south of Kissimmee. At Enterprise and Titusville the water probably obtains its salt from materials deposited during a Pleistocene submergence. South of Kissimmee the salt water does not appear to have been removed from the younger rocks. Conditions similar to those just mentioned are known to exist on many of the low islands and keys bordering the coast.

\section{CIRCULATION OF UNDERGROUND WATER.}

Although underground water often appears to be quiescent, in most localities it is moving very slowly through the rock toward some point of escape. The causes for this movement are several, but the most important is gravity. Gravity operates to bring underground water to the surface of the earth at a lower level than that of the place where it entered and so enables it to join the surface water or to evaporate. Capillarity brings water to the surface, where it is evaporated, or brings it within the reach of plants which return it to the air. Flowing wells, which seem to act in opposition to gravity, are realiy due to that force acting upon a body of water which elsewhere extends to a level higher than that of the mouth of the well. Pressure exerted on the water-bearing beds may be a cause of movement of water, but in Florida this force has no noticeable effect.

The rate of movement of underground water is determined by the same general factors that control the rate of movement of surface water, namely, friction and the slope of the water surface. The slope of the surface of the underground water (the water table) is generally slight but is in places high. Where the water table has a high slope the movement of the underground water might be expected to be rapid, but it is not necessarily so, because the friction is much greater underground than on the surface. In surface water the chief friction is that of the bed of the stream, whereas in underground water, except in caverns, it is that of the walls of innumerable small passages. In caverns the flow is comparable to that of surface streams, though where the channels are full there is the friction of the top of the channel in addition to that of the bottom and sides. The temperature 
has been found to have a marked influence in rate of flow, increased temperature promoting its circulation through the pores in the rocks.

It is difficult to compare the rate of flow of surface and underground water, but a safe generalization is that the movement of surface streams is to be measured in miles, and that of underground water through the pores of sands and limestones in feet or in inches.

\section{RECOVERY OF UNDERGROUND WATER.}

Recovery of underground water may be either natural or artificial; natural recovery may be either by seepage or springs and artificial by wells or infiltration galleries.

\section{NATURAL RECOVERY.}

\section{SEEPAGE.}

As the term seepage is commonly used it refers to water emerging from the earth in such a way that it does not form a stream. The presence of seepage is readily detected on many slopes where the surface soil is soft and boggy, but it is especially active at the contact between the water table and bodies of surface water such as streams and lakes. Seepage may be seen along many streams when the level of the surface water is sinking more rapidly than that of the ground water. Though usually inconspicuous, a large percentage of the water which enters the earth is returned to the surface by seepage. Seepage water also emerges on hillsides where the water in its downward course comes in contact with impervious materials such as clay beds.

Few seepage waters are highly mineralized, because in most localities they travel only. a short distance underground and in their course encounter little soluble matter. Much of the water derived from seepage on hillsides, however, is highly charged with organic matter which, in some localities, renders it somewhat objectionable. However, the water is seldom contaminated with substances dangerous to health except where it is obtained near dwellings.

\section{SPRINGS.}

Florida is noted for its springs, some of which, such as Silver Spring and Wekiva Spring (Pl. XVII, B, p. 234), are very large. Two principal types are represented within the State, those in which the water emerges from the small pores in the rock at some favorable point, generally on a hillside, and those in which it follows a definite underground channel to the surface. In springs of the latter type some water is supplied from small openings in the limestone, but a great deal of it comes from caverns.

Springs of the first type accur in all parts of the State, but are especially numerous in the north, where the Lafayette (?) formation 
lies near the surface. They occur on the hillsides or at the heads of ravines where the descending ground waters encounter relatively impervious materials. Though especially characteristic of the Lafayette (?) formation such springs also occur in the older Tertiary rocks and even in the sands of Quaternary age.

Springs of the second type occur in parts of north Florida but are best developed in the central and western parts of the peninsula, where some of them give rise to navigable streams. The principal rocks which afford large springs are the limestones of the Vicksburg and Apalachicola groups, and of these the soft porous Vicksburgian limestones present the most favorable conditions for good flows. The size of some of the springs shows that these limestones must contain large underground channels, even though some of the water may be supplied by small passages in the rock.

Some of the springs of Florida are remarkably free from mineral matter, but others contain large quantities of dissolved materials. Most water from the Lafayette (?) formation is but slightly mineralized, though locally it contains more or less lime, magnesia, and iron. The limestone waters also contain lime and magnesia and other soluble substances common in such rocks. The springs of many localities are charged with a large amount of hydrogen sulphide gas, which appears to be derived largely from the decomposition of organic matter contained in the limestone. Many of the sulphur springs of the State are highly esteemed for their medicinal qualities. In some localities the water also contains enough salt to make it more or less saline.

\section{ARTIFICIAL RECOVERY.}

\section{WELLS.}

TYPES.

Both shallow and deep wells are used in the artificial recovery of underground water. Infiltration galleries have nowhere been used for this purpose in Florida. Where practicable preference should be given to the deep wells, because they are least liable to be contaminated by impure surface water. Shallow wells may be either dug, driven, or bored. Deep wells, though usually drilled, may also be driven or bored.

The type of well to be sunk will depend upon the quantity, quality, and temperature of the water desired. A moderate quantity can usually be obtained from shallow dug or driven wells, but deeper wells will be needed for a large supply. If the water is intended for cooling, as, for example, in an ice factory, the most satisfactory supplies will be obtained at moderate depths. In general, it will also be found that the water from shallow wells contains less mineral 
matter than that from deep wells. In a densely populated region deep wells will be found most satisfactory as a source of drinking water, because when properly cased there is less danger of the water becoming polluted than in shallow wells. (See Pls. VI, B, p. 32; $\mathrm{XVI}, A$.)

POSITION OF WELLS.

Several considerations should govern the placing of a well, only one of which-convenience-has generally been regarded. Though convenience is by no means unimportant, the probable depth to water and the quality, quantity, and static head of the supply could profitably be kept in mind.

The depth to water is naturally influenced by the height of the surface, and, other things being equal, wells on higher ground must go deeper than those at lower levels to get the same amount of water. This statement may not hold for all wells drilled to the artesianwater beds, for these show marked differences in depth that are entirely independent of the surface configuration.

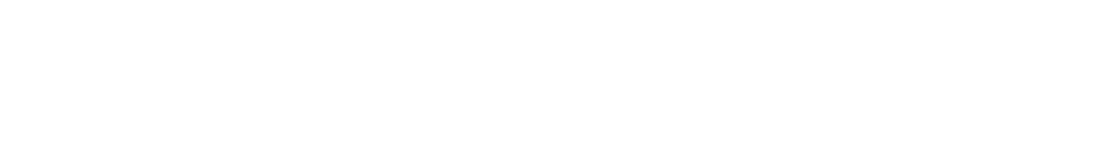

FIGURE 5.-Diagram showing importance of choosing proper locations for wells. $a$, Well improperly placed; $b$, well properly placed.

The static head of the water determines the height to which it will rise in the well, and should be carefully considered if a flowing well is expected. Moreover, in Florida a boring for a flowing well should if possible be made at a point where the water will rise 4 or 5 feet above the surface during a wet season, this margin being ordinarily sufficient to counterbalance a temporary decline of head caused by droughts.

If the water is to be used for domestic purposes and especially for drinking, several other factors must be considered, the most important being the possibility of pollution by impure surface drainage. This involves a consideration of the location of the intake and the direction of movement of the underground water. Since artesian wells are supplied by water which has moved for long distances through porous rocks, the supply is usually free from pollution, except as a result of imperfect casing, permitting the entrance of objectionable matter. The purity of the water from the artesian wells is due, in part, to the fact that it undergoes filtration during its passage through the minute pores of the rock.

Where the well is supplied by water which has only a short underground circulation, the source and direction of movement become very important. This is illustrated by figure 5 , where the movement 

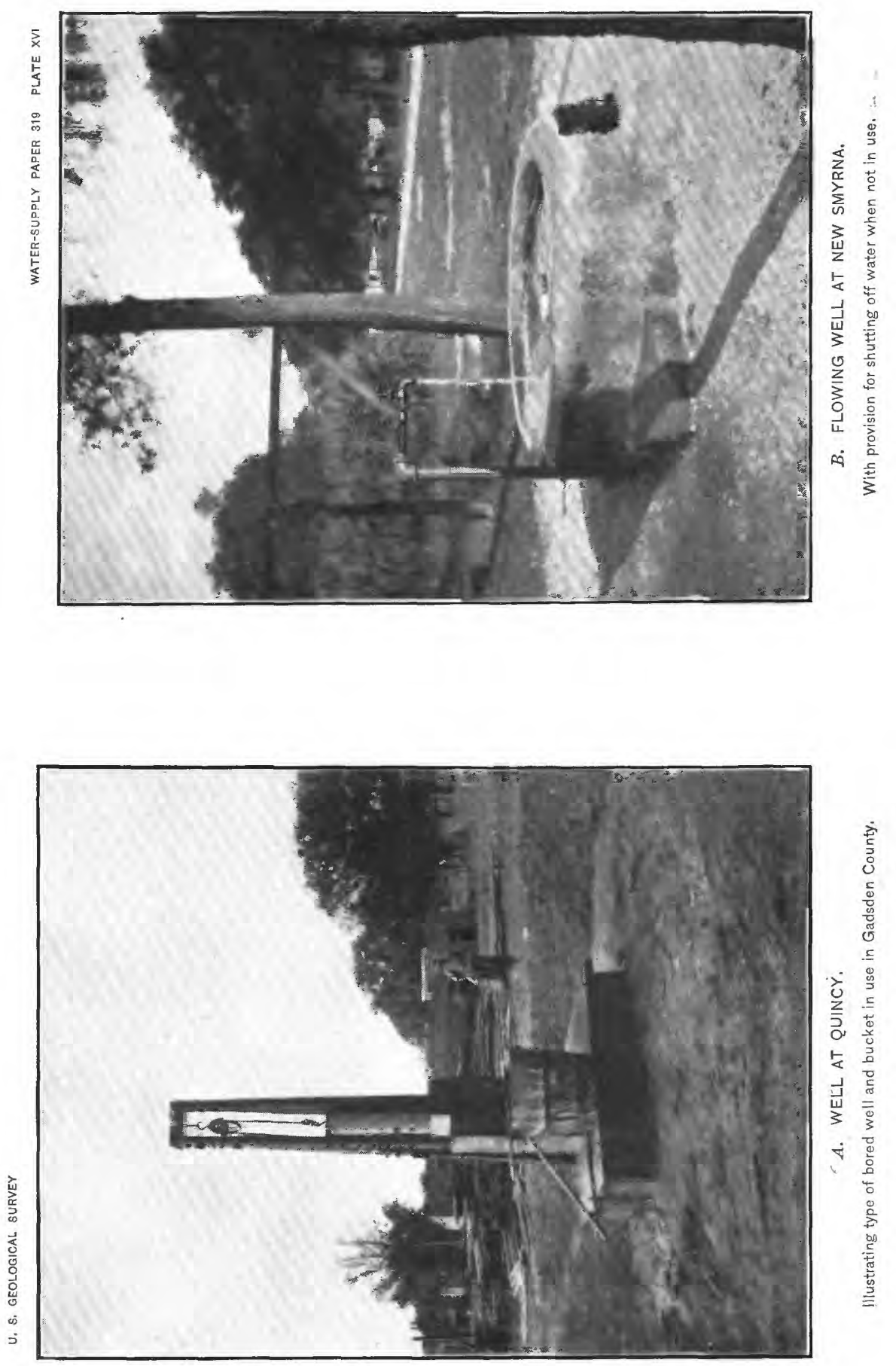
<smiles>C1CC1</smiles>

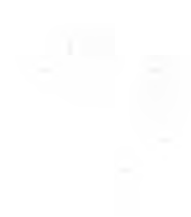


of the ground water is from the buildings toward the well at $a$, making the well liable to receive a constant supply of impure water, which may become dangerous whenever the polluting matter contains any of the germs of disease. The placing of the well at $b$ (fig. 5) would have obviated such a danger and insured a supply of pure water.

\section{METHODS OF WELL MAKING.}

The method to be used in sinking wells is determined by the character and depth of the well desired, the nature of the material to be penetrated, and the amount of money to be expended.

Dug wells.- Dug wells are excavated with a pick and shovel, and the loosened material is removed by a bucket and windlass. Dug wells are put down chiefly in unconsolidated materials and have the advantages of simplicity and ease of construction. Since dug wells are necessarily of large diameter, they offer a large surface for the entrance of water and hence are well adapted to deposits that yield their supply slowly. In depth few wells of this type exceed 40 or 50 feet and most of them are less than 30 feet deep.

One of the principal objections to the dug well is that it receives a large amount of water from near the surface and is therefore likely to become contaminated. It is probably no exaggeration to say that such wells have been a very prolific source of dissemination of typhoid fever.

In Florida the use of dug wells is almost wholly confined to the northern end of the State, where the settlements antedate the introduction of improved well-drilling machinery. A large number of these old wells are still in use, but they are gradually being replaced by wells of more modern type.

Bored wells.-Bored wells are constructed by the use of an earth auger operated by hand or power. The auger is turned by means of horizontal bars attached to a vertical rod, and must be raised frequently in order to remove the loosened material.

Bored wells are put down only in unconsolidated materials and range in diameter from 2 inches to a foot or more. Where the material is very soft, a casing having a diameter slightly greater than that of the auger is forced down around it to prevent the walls from caving. The casing is commonly made of wood, though in some wells tile is used. Wooden casing is not entirely satisfactory because it may permit the entrance of surface water unless it is well constructed and protected from decay. Tile is much more durable and hence more satisfactory. In most wells the exclusion of contaminated surface water would be rendered more certain if the joints between the successive sections of the casing were firmly cemented. Iron pipe may also be used for casing, but tile is equally good and is less expensive. 
Bored wells, when properly cased, form a very satisfactory means of supply.

In Florida bored wells are restricted almost wholly to the northern part of the State, where there is a thick mantle of incoherent sands and sandy clays. Few of these wells exceed 125 to 130 feet in depth.

Driven wells.-Wells are driven by forcing an iron pipe into unconsolidated materials. The pipe is commonly fitted with a perforated metal screen which tapers to a point and which permits the entrance of water and prevents the pipe from becoming clogged by sand or clay. Wells of this type are especially adapted to formations in which the permanent ground-water level is within less than 30 feet of the surface, so that the water can be raised by a suction pump. Driven wells of large diameter, however, may be fitted with force pumps, and hence they are adapted to formations where the water level lies below the limit for the successful operation of suction pumps.

In Florida few driven wells exceed 2 inches in diameter and most of them are comparatively inexpensive. In some places wells are sunk by driving a pipe into the ground and removing the sand or clay by means of a bucket, but this method is seldom employed in Florida.

Drilled wells.-Of the several types of drilling apparatus only two-the cable and the jet rigs ${ }^{1}$-are in common use in Florida. Both are well adapted to the soft rocks of most of the State, but the cable rig is most extensively used where wells are to be sunk to the artesian water beds of the Oligocene limestone. In the cable rig the cutting is done by means of a wedge-shaped piece of steel, which is raised and dropped by machinery. The cutting bit is usually attached to a bar which gives added weight and increases the force of the impact. The raising and lowering of the drilling tools is accomplished by means of a cable which passes over a pulley attached to a derrick. As the drill is dropped it is given a slight rotary motion by turning the cable. In some wells two bars are introduced between the cable and the drilling bit. These bars are linked together in such a way that a play of 6 or 8 inches is allowed and when the tools are lifted this play gives an upward jerk which helps to loosen the bit. In Florida these supplementary bars (called "jars") are usually omitted, as the rock is of such a character that there is little danger of the drill becoming fast in the hole. In using the cable rig it is necessary to withdraw the drill at frequent intervals and remove the broken rock from the bore by means of a sand bucket. In some types of rigs the drillings are removed automatically, but such drills have not been extensively used in Florida. In using the cable drill it is

1 For detailed discussion see Bowman, Isaiah, Well-drilling methods: Water-Supply Paper U. S. Geol. Survey No. 257, 1911. 
necessary to drive the casing to the first hard rock in order to exclude the soft surficial sands and clays. Below this few wells are cased, though some are continued with a casing of smaller diameter. Cable drills are especially adapted to drilling deep artesian wells, in which, in Florida, many beds of chert are encountered.

The jet process differs from the ordinary cable method in that the drill is not raised and dropped except where hard beds are encountered. The ordinary method is to force water into a small pipe which is fitted with a bit at the lower end. The force of the jet of water is directed against the bottom of the hole and helps to loosen the particles of clay and sand. The drill is slowly rotated just as in the use of the cable rig. The water rises in the bore and carries the loosened material with it to the surface.

Drilled wells are adapted to hard rocks and when properly cased are exceptionally free from danger of contamination by impure surface waters. Drilled wells are found in nearly all of the inhabited portions of the State, but they are especially numerous along the east coast, from Fernandina southward, in the St. Johns Valley, and along the west coast from Tampa to Fort Myers: In these localities large numbers of wells have been sunk to the artesian water beds. They not only supply houses, farms, and cities but also serve as valuable sources of water power.

\section{METHODS OF RAISING WATER.}

Where, as at numerous localities along the east coast and at Manatee and Fort Myers on the west coast, the static head is sufficient to raise the water to the height desired by the consumer, no special apparatus for raising water is needed. In such localities the water is piped to the points where it is to be used, and the natural head of the well furnishes the pressure. In this way the towns of Green Cove Springs, South Jacksonville, Fort Myers, and Freeport, and numerous minor places are furnished with all the conveniences of water systems without the necessity of pumping plants, tanks, or standpipes.

Where wells flow only a few feet above the surface, it is sometimes possible to force the water to higher levels by means of hydraulic rams or water wheels. This method, which has been adopted with very satisfactory results, enables the owner of a well to raise water to a considerable height above the well without additional expense beyond the cost of the hydraulic ram or water wheel. Many hotels and private houses along the east coast of Florida are equipped with raised tanks which are filled in the manner described above. In some localities enough water is raised to irrigate gardens and orange groves, but most supplies are too small for such purposes. 
Where wells do not flow or where the flow is not sufficient to meet the needs of the well owner, it is necessary to resort to some artificial means of raising water. The most common are the old-fashioned bucket and windlass or the hand pump. These two methods are satisfactory where a small amount of water is desired for domestic or farm use, but where large supplies are required some form of power pump, operated by steam or gasoline engines, is installed. In a few places windmills, water wheels, or electric motors are used to supply motive power. (See Pl. XVII, A.)

\section{UNDERGROUND WATERS OF CENTRAL AND NORTHERN} FLORIDA.

By G. C. Matson.

\section{ARTESIAN WATER.}

ARTESIAN REQUISITES.

The limestones of the Vicksburg group are the important artesian water-bearing beds of Florida. In fact, with a few exceptions the rocks of this group supply the water for the flowing wells of the State. The early theories concerning the cause of artesian pressure postulated

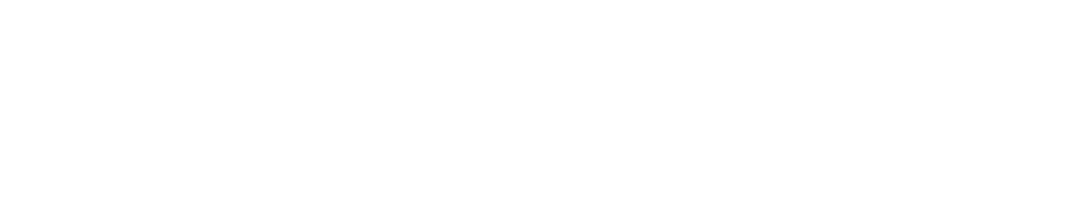

FTGURE 6.-Conditions governing the occurrence of artesian water in some parts of Florida.

a basin structure for the porous bed. However, this structure is now known to be uncommon and wholly unnecessary. It is certain that no such structure exists in the artesian areas of Florida. Another condition which gives rise to artesian waters is shown in figure 6 , which shows the water passing downward through inclined beds, forming an artesian slope. The porous bed may be terminated by impervious material or may be continued for a long distance.

Much water passing outward from the central portion of the peninsula of Florida descends beneath hard layers of chert, which offer considerable resistance to its upward movement. This condition is shown graphically in figure 6 , which is a vertical section extending from the central part of the peninsula eastward beyond the coast line. In this figure $a$ and $b$ represent water-bearing beds confined beneath relatively impervious beds of chert. Above $c$ is another porous bed which contains more or less water, which is not confined by dense rock. The conditions shown in this figure differ radically from some of the earlier ideas concerning the occurrence of 


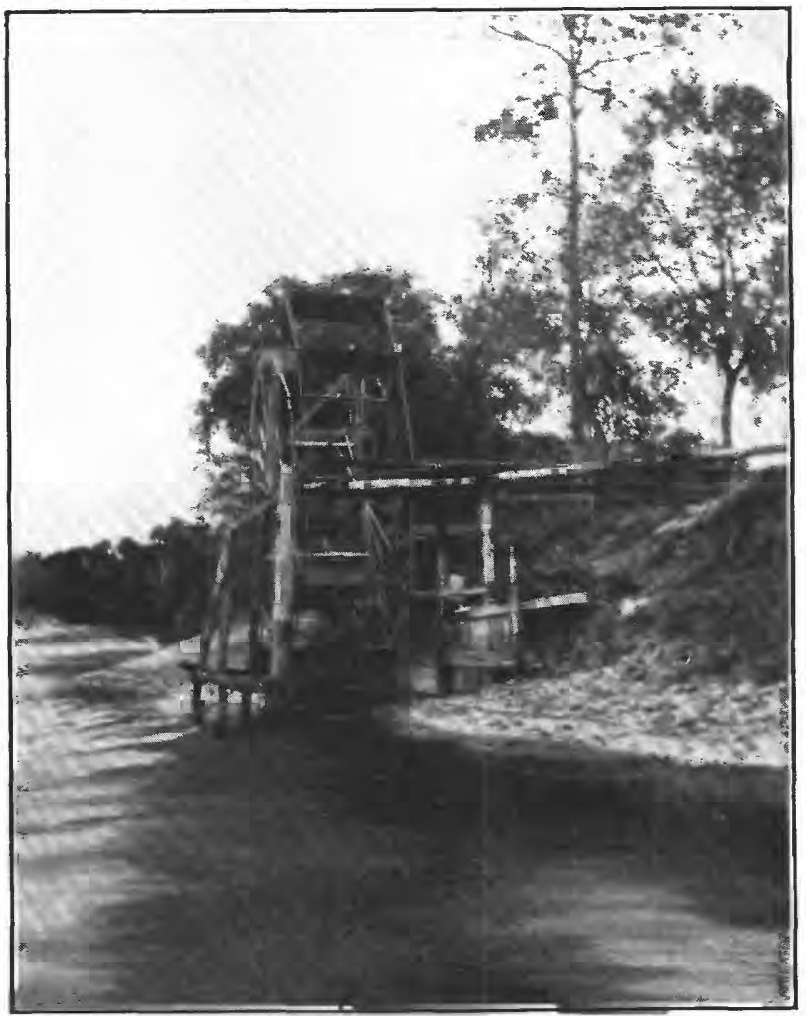

A. WATERWHEEL FOR PUMPING WATER, CALOOSAHATCHEE RIVER.

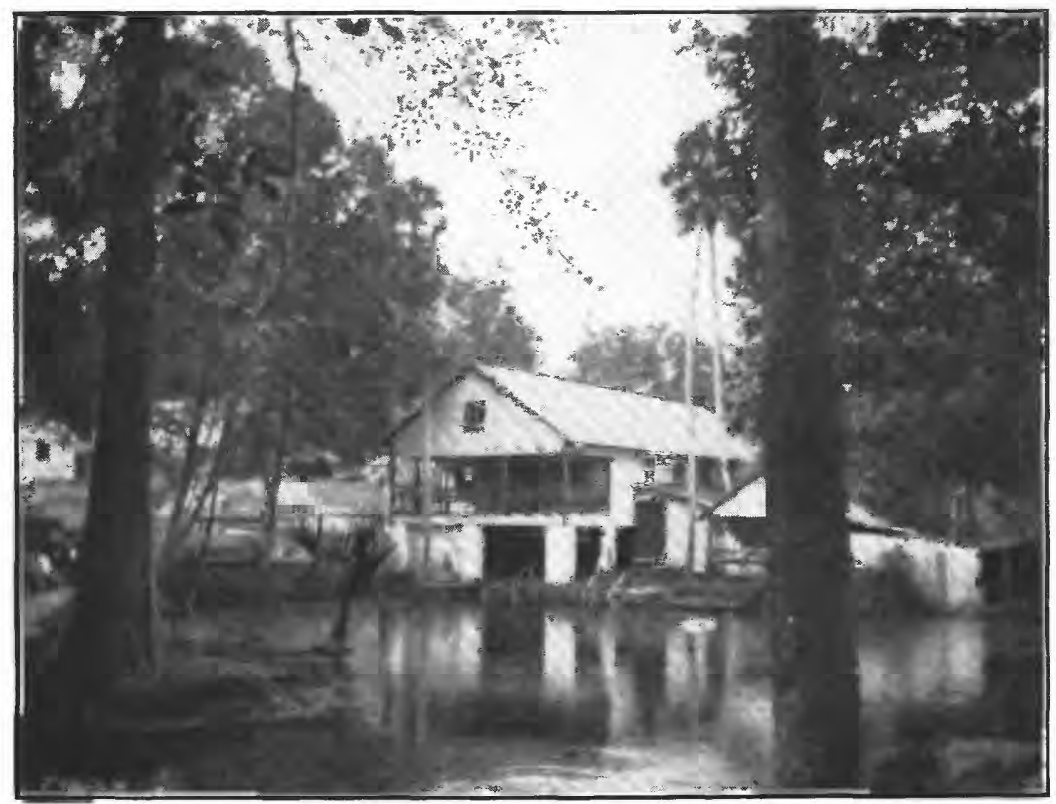

B. WEKIVA SPRING, SHOWING SPRING AND BATHHOUSE. 

artesian water, but the water confined within the porous layers $a$ and $b$ is under hydraulic pressure and is to be regarded as artesian, though in some parts of the section the pressure is not sufficient to lift it above the surface. This figure illustrates the conditions which control the occurrence of artesian waters in all the principal flowing-well areas of Florida. In many localities there are two or more artesian beds separated by successive layers of chert.

The occurrence of the artesian waters depends on several factors, which have sometimes been designated "artesian requisites." The first is an adequate rainfall to supply the water, and this requirement is met by the large annual precipitation of the region. The second requisite is a porous water bed, and this is furnished by the loosely aggregated limestones of the Vicksburg group. The third requisite is the practical exposure of the porous bed to form a catchment area. The principal catchment area of this limestone occupies a belt in the central portion of the peninsula and extends northward into Georgia. A subordinate area is located in west Florida, where it occupies a tract of land extending from near Chipley northward into Alabama. The fourth requisite is a confining layer of relatively impervious rock, which, as already explained, is furnished in Florida by layers of chert. In some places there is a second layer of chert below the artesian bed, but this is not essential, because the rocks below the artesian bed are saturated with water. The fifth requisite is an inclination of the water-bearing bed, and this is supplied by the dip of the limestone away from the center of the peninsula and outward from the adjacent mainland.

\section{HEAD OF ARTESIAN WATER.}

CONTROLLING FACTORS.

The principal factors which control the hydraulic pressure of the artesian water are the altitude of the water table beneath the catchment area, the resistance to the movement of water through the porous bed, and the perfection of the relatively impervious layer which caps the aquifer. Reference to the topographic map (Pl. I, in pocket) shows that the catchment area of the Vicksburg lies almost wholly below 200 feet and that the water table in the higher areas is some distance below the surface. The altitude of this water table is probably in few places above 150 feet, and over a large part of the central portion of the peninsula it is less than 100 feet above sea level. This explains why the artesian head in Florida is not so great as in regions where the catchment areas are located on the flanks of mountain ranges.

The resistance which the rock offers to the movement of the artesian water diminishes the head, and consequently, where the 
other factors are equal, the height to which the water will rise is controlled by the porosity of the rock and the distance of the well from the catchment area. If there is no change in the texture of the rock, the head will decline gradually in passing outward from the catchment area. Locally the head is greatly affected by the character of the confining layer. In some localities, where this layer is more or less broken and discontinuous, considerable water escapes and the hydraulic pressure in the surrounding area is lessened.

ARTESIAN HEAD IN FLORIDA.

Along the east coast.-The head of artesian water varies considerably along the east coast of Florida, the range being from 65 feet above sea level at Jacksonville to only a few feet above farther south. This variation was at first supposed to result from differences in the height of the catchment area. The water at Jacksonville is doubtless partly supplied from the outcrops of the Vicksburgian limestone in southern Georgia, where the land is high, and thus the theory that variations in the head are due to corresponding variations in the altitude of the catchment area appears to be partly substantiated. However, when an attempt is made to extend this explanation to the entire artesian belt of the east coast, it is at once apparent that other factors are also involved. At Jacksonville water will rise 65 feet

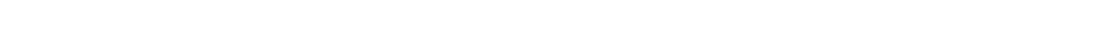
Seabreeze, 5 feet; and at Eau Gallie, 50 feet; this indicates that the head falls gradually and then rises again to more than 60 per cent of the maximum.

Aside from the influence of the altitude of the catchment area, the important factors which influence the head are the perfection of the confining bed and, to a less degree, the friction in the porous water-bearing bed. Doubtless the amount of friction varies from place to place, but as far as may be judged by the character of the rock its influence is for the most part of very little importance in determining the head. The perfection, however, of the confining bed which caps the artesian stratum has a very important bearing on the pressure. At St. Augustine and Daytona the decline in head appears to be largely due to this cause, as shown by the existence of the nearby large submarine springs. The most important of these is located off St. Augustine, and a similar spring is reported near Port Orange, which lies just south of Daytona. Though few springs are apt to exercise so wide an influence as is noted in the head of the wells along the east coast, it is probable that the known springs, large though they be, represent only a small portion of the total submarine discharge in the localities mentioned. At Daytona the presence of artesian water above the chert bed which caps the principal water bed suggests local imperfections which permit considerable leakage. 
This view is strengthened by the fact that the water above the chert bed possesses some of the mineral characteristics of that below, being charged with hydrogen sulphide.

Head in the interior.- - In the interior of the State the head of the artesian waters is in places high. At Sanford it is approximately 25 feet above sea level and at Kissimmee is about 75 feet above, this probably being the maximum head in the State. The conditions at Kissimmee are exceptionally favorable, for dense materials above the limestone reenforce the cap rock and thus effectually prevent leakage, and to the south the limestones are so deeply covered that leakage is prevented. In addition to the flowing wells from the Vicksburgian, the Quaternary and perhaps the younger Tertiary furnish flowing wells near Kissimmee.

Head in southern Florida.-The head of the artesian water diminishes to the south, and along the main chain of the keys the water will probably not rise above sea level.

Head on the west coast.-On the west coast of the peninsula the head of the artesian water increases toward the south. Thus at Tampa it is approximately 17 feet above sea level; at St. Petersburg it is also low; at Manatee and Bradentown it rises to about 25 feet, and at Fort Myers it reaches a maximum of nearly 45 feet. This increase in head is apparently due to the fact that the water-bearing rocks are more perfectly capped by the relatively impervious cherts and clays at Manatee, Bradentown, and Fort Myers than at Tampa and St. Petersburg. The efficiency of the cap rock seems to increase toward the south, where the dip of the artesian beds carries them to considerable depth below the surface. This is probably due in part to the greater thickness of superincumbent clays, and in part to the fact that the artesian beds have not been so extensively eroded as they have farther north; hence the chert beds are much more continuous.

In general the artesian areas of the Gulf coast of west Florida have a good head, and, so far as known, they present no unusual features. The beds yielding artesian water are probably in part younger than the Oligocene, but their exact age is not everywhere determinable. In the vicinity of Freeport the water rises to about 22 feet above sea level; at Apalachicola and Carrabelle it is reported to rise to a slightly less height but still to one sufficient to give good flowing wells.

CHANGES IN ARTESIAN HEAD.

The height to which the artesian water will rise is subject to certain changes, which may be due either to natural or artificial causes and which may be transitory or permanent.

Natural causes. - The variations most often noted in Florida are those caused by tidal fluctuation or by changes in rainfall. Variations in barometric pressure may temporarily affect the artesian 
head, but the magnitude of such changes is so slight that it is seldom noted. Tidal movements, however, affect the head and yield of wells near the coast so noticeably that the result is recognized by practically every owner of a flowing well near the sea. A rise of the tide causes a corresponding increase in the head and a fall of the tide is accompanied by a decline, the common range in Florida being from 1 to 2 feet. In some places where wells have sufficient head to bring the water near the surface at low tide flows may take place during high tide, and thus the wells flow intermittently. A well of this type is located near Hillsboro River at Tampa. The cause for tidal variations is to be found in the amount of pressure which the sea water exercises on the rock which caps the artesian beds. As the tide rises the height of the column of water pressing upon this cap rock is increased, and as it falls the height is diminished. The conditions governing the head at any particular locality are so nicely balanced that the additional weight of a column of water a few inches in height will produce a change in the height to which the water rises in adjacent wells.

Variations in the amount of rainfall produce a marked effect on the artesian head. This is noticed first on the outskirts of the artesian areas, where the hydrostatic pressure is just sufficient to produce a flow under the most favorable conditions. In such situations a marked deficiency in the amount of rainfall may cause the wells to cease to flow and the water level may sink a few feet below the surface. Wells which have stopped flowing during prolonged drought are by no means uncommon. With an increased rainfall the head may be restored and the water may again rise above the surface.

The changes in head are in part due to variations in the level of the water table beneath the catchment area and in part to the fluctuations in the height of the water table near the well, or to the weight of the water which has entered the ground. The variation in the height of the water table at the well is of minor importance and acts in much the same way as does the tide on the head of wells near the seashore. With increased rainfall the quantity of ground water in the vicinity of the well is augmented and the increased weight of the column of ground water upon the rock which caps the artesian beds adds to the hydraulic pressure of the water in those beds and increases the height to which it will rise in the well. The results of this pressure are usually felt within a very short time after a heavy rain and they may be of either long or short duration, depending entirely on whether the original level of the ground-water table is restored promptly. Fluctuations of this character may result as soon as water enters the soil and before it reaches the water table. In such cases the pressure is transmitted from the saturated upper 
layers of the soil to the water table by the air confined in the soil. The change produced by variations in the altitude of the water table beneath the catchment area takes place slowly, but under very favorable conditions it may materially raise the water level in the well. Thus wells which have ceased to flow during a period of low rainfall may begin to flow during a period of heavy precipitation. There are other natural causes for fluctuations of water levels in wells, among them being changes in temperature and clogging of the waterbearing rock.

Artificial causes.-Of the artificial causes which may produce changes in the head of artesian water, one of the most important is the large demand made by the flow of numerous wells, which may lower the head within a short time. Thus, at Daytona, where a large number of wells have been drilled within the city limits, the head is reported to have fallen more than 2 feet since the first wells were sunk. The decline in head of a well may sometimes be due to clogging of the bore by mud or sand, or even to the growth of microscopic plants. This last is extremely rare and changes due to clogging take place in few wells that are properly cased. Since decline in the head of water is accompanied by a decrease in the artesian area and diminution in the quantity of water obtained from the flowing wells, the change is usually stated in the amount of decrease in flow rather than in loss of head. Some excellent illustrations of this character are supplied by geologists who have investigated the water resources of areas in the valley of southern California. The following table, taken from a report by Mendenhall ${ }^{1}$ shows the decrease in water derived from the flowing wells and springs, and a corresponding increase in the amount of water pumped (developed water):

Relations of pumped water and water from flowing wells in southern California.

[In second-feet.]

\begin{tabular}{|c|c|c|c|}
\hline Date. & $\begin{array}{c}\text { Flowing } \\
\text { water. }\end{array}$ & $\begin{array}{c}\text { Devel- } \\
\text { oped } \\
\text { water. }\end{array}$ & Total. \\
\hline 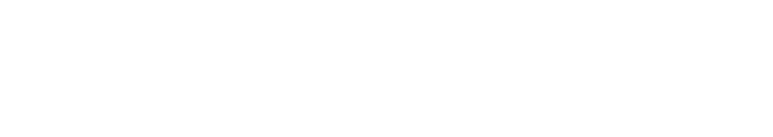 & \begin{tabular}{l|}
78.31 \\
44.68 \\
54.18 \\
38.52 \\
45.55 \\
38.62
\end{tabular} & $\begin{array}{r}66.38 \\
65.46 \\
71.42 \\
81.69 \\
109.70 \\
105.36\end{array}$ & $\begin{array}{l}144.69 \\
110.14 \\
125.60 \\
120.21 \\
155.25 \\
143.98\end{array}$ \\
\hline
\end{tabular}

Though little change has taken place in the total quantity of water used, the ratio of flowing water to pumped water has changed from 1 to 1 in 1891 to 1 to 3 in 1903 . This change is due to the fact that the head of the water diminished so that pumping was necessary to

1 Mendenhall, W. C., Hydrology of San Bernardino Valley, Cal.: Water-Supply Paper U. S. Geol. Survey No. 142, 1905, p. 63. 
get an adequate supply. The decline in head of wells is shown graphically by figure $7 .^{1}$

The conditions in California are exceptionally favorable for illustrating loss of head, because the rainfall is small and the effect of a large withdrawal of water is felt within a few years. In Florida, where the rainfall is very heavy, such changes would take place so slowly that they could be detected only by observations extending over a much longer period of time. However, there can be little doubt that the large supplies which are being withdrawn from the artesian beds of certain areas where irrigation is practiced will ulti-

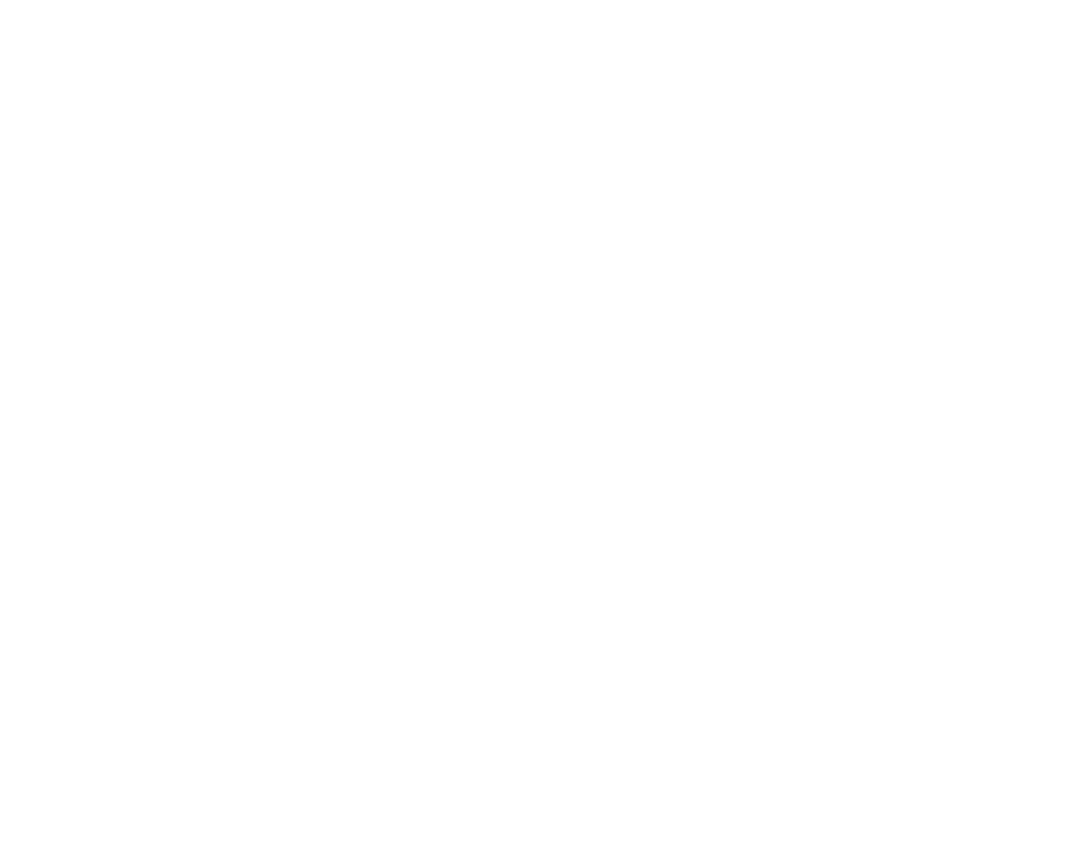

FIgURE 7.-Variation of water level in Johnson well, near San Bernardino, Cal.

mately lower the head of the artesian water. This lowering will not only operate to diminish the yield of wells, but it will cause wells on the higher ground near the borders of the artesian area to cease flowing. To prevent loss of head, wells should be closed when not in use. (See Pl. XVI, B, p. 230.)

One of the important factors operating to produce a change in the head of the water is the rate of withdrawing water by pumping. In Florida, pumping has not yet been done on a sufficiently large scale to produce marked effect on the ground-water table, but in some other States the water level has been materially lowered by this means. When a well which draws its supply from the ground water 
is pumped rapidly, a cone-shaped depression develops around the well in the surface of the water table, the size of the depression and the steepness of its slope depending chiefly on the rate of movement of the water toward the well and the rapidity with which it is removed. The effect of pumping a single well is usually local and its duration temporary, but when a large number of wells occupying a small area are pumped rapidly an extensive depression of the water table may result. In such areas, if the demand does not exceed the supply, no permanent lowering of the water table results. The length of time required for the original water level to be restored will depend on the rate of movement of water from the adjacent region into the area affected by pumping. Excessive pumping and unlimited flow from wells are the most important artificial causes for fluctuations in the level of the underground water, but many other factors are important. Among these are cultivation of the soil and obstruction to free movement of water to points of escape.

Cultivation, by loosening the surface material, may permit increased absorption, but unless the surface is kept loose the subsequent movement of water through the capillary pores of the soil and its evaporation from the surface may neutralize the effect. Different crops also have different effects on the ground-water level, for some plants remove more moisture from the soil than others. The effects of fertilizers vary with the kind and amount of material added to the soil. Some fertilizers increase absorption by increasing the size of the openings between the soil grains; others increase the amount of evaporation.

Obstructions to the percolation of ground water are dams, which raise the level of the surface water and the adjacent portion of the ground-water table, and irrigation, which practically raises the level of the ground water in the irrigated area by actual additions. However, few ehanges due to the irrigation and the construction of reservoirs and dams are of more than local importance, and, where the ground water is used, the amount withdrawn may more than counterbalance the rise due to these causes.

ARTESLAN FALLACIES.

The belief, prevalent in many parts of the country, that the head of water increases with the depth of the well has frequently been given weight by the fact that certain deep wells have a much greater head than the shallow wells of the same region, though ordinarily it appears to be merely a corollary of the theory that flowing wells can be obtained anywhere if wells are sunk to sufficient depths. At present no evidence exists that the head of the Florida waters increases below the level of the main water-bearing beds, and the sinking of wells far below the principal artesian stratums has commonly resulted 
in the discovery of highly mineralized waters rather than in an increased head. In some wells the failure to obtain flows may be due to defective casings, and in such the only remedy is to insert a watertight casing to the top of each successive water-bearing stratum, where there is more than one, in order to test the height to which the water from the different beds will rise.

\section{OCCURRENCE OF UNDERGROUND WATER.}

WATER-BEARING MATERIALS.

Character.-The mode of occurrence of underground water varies with the character of the materials. In Florida, the most important types of water-bearing deposits are limestones, sands, shell marls, and clays. Although some of these materials occur nearly pure, they are more commonly found mixed in different proportions. The water in the formations is included in openings ranging in size from the tiniest threads to caverns several hundred feet in diameter, which, though striking, contain, on the whole, much less water than is held in the small passages between the individual grains of the rock.

Sand and gravel.- Sand and gravel are excellent water-bearing materials, both for volume and quality of supply. The water occurs in openings between the grains and the amount in any particular bed depends on the pore space and the degree of saturation. The amount of pore space varies with the size and shape of the grains and it may equal or exceed 20 per cent of the volume of the materials. The largest pore space is found in even-grained sand or gravel; and the mixing of coarse and fine material reduces the size of the openings and lessens the total porosity. Much of the water held by sand and gravel is readily available to wells and springs, because the openings are large enough to allow the water to move freely under the influence of gravity. Some sands, however, are very unsatisfactory water beds because their grains are so small that it is impossible to exclude them from the pipes and pumps, where they are apt to do much damage either by clogging the well or by ruining the machinery. Water from sand is generally of excellent quality because the impurities are usually filtered from it during its passage through the small pores. An exception to this is found in the coarse-grained sands, where the passages are so large that the water receives little or no purification. Practically any type of well is satisfactory in sand and gravel, but drilled or driven wells are best, because they may be easily cased to prevent the entrance of surface drainage.

Clay.-Contrary to the usually accepted idea clays may contain an abundance of water. The amount of pore space may equal or exceed one-third of the volume of the material; but the amount of available water is much less than might be expected from such a high porosity, because the openings are so small that the water is held tenaciously 
and moves very slowly to points of escape. The water obtained from clays is usually highly mineralized because it has remained long in contact with the soluble mineral matter in the rock. If it is necessary to rely on clay beds for a water supply, dug wells will be found most satisfactory, for such wells afford a large surface for the entrance of water by slow seepage. Drilled, driven, or bored wells are apt to be unsuccessful.

Shell marl.-Shell marl is made up of shells more or less firmly embedded in a matrix of sand or clay. The shell marls of Florida have a sandy matrix and their water capacity may be nearly as great as that of sands. In general they contain more or less carbonate of lime, which occupies the space between the sand grains and diminishes the pore space. The quantity of water. derived from such materials is usually ample for ordinary domestic or farm uses. Wells of small diameter are nearly always successful where they penetrate the marls below the permanent water level, though where the materials are exceptionally close grained it may be necessary to sink dug wells. Carbonate of lime and other soluble compounds are abundant in the marls and the solution of these makes the water hard, the degree of hardness varying with the freedom with which the water circulates and the length of time it remains in contact with the soluble substances.

Limestone.-The water capacity of limestones differs with the character of the rock. In Florida many of the limestones are porous and contain large supplies of water occupying small openings between the grains of the rock. In addition they contain many crevices and caverns, which supply water readily to wells or give rise to springs, some of which are very large. (See pp. 228-229.) Where the small openings fail to yield sufficient water a well is usually continued until it reaches a crevice or a cavern. Owing to the irregular distribution of the underground channels, it is not possible to predict the depth at which one will be found, and wells a few feet apart may obtain their supplies at different depths. Most limestone waters are hard, because they contain materials dissolved from the rock. The most common mineral constituents of such waters are carbonates of lime and magnesia, but many other compounds are present in small quantities. Owing to the fact that surface water may enter the underground channels through open sinks, limestone waters are easily contaminated, especially near dwellings, and in.case of pollution have little opportunity for natural purification.

\section{WATER-BEARING FORMATIONS.}

GOVERNING CONDITIONS.

The hydrologic values of different stratigraphic units differ, depending on thecharacter, thickness, and position of the beds. The character of the beds is especially important, sandstones and porous lime- 
stones being better sources of water than dense limestones and clays; for example, the sands of the Alum Bluff formation or the porous Vicksburgian limestones are much more important water-bearing rocks than the clays of the Hawthorn formation or the dense limestones of the Chattahoochee formation.

The thickness of the different stratigraphic units may be important where the beds are near the surface; this fact is well shown by the Pleistocene sands, which may contain little or no water where they form a thin deposit on the upland, but which are the source of large supplies near the coast and in the southern part of the peninsula, where they attain considerable thickness. However, a thin porous bed lying below the level of the water table is in many places a very important aquifer.

The position of the water-bearing rocks generally has a marked relation to their water value. In the central part of the peninsula porous rocks of Vicksburg age lie partly above the level of complete saturation, and in places wells must be sunk some distance into the porous beds before they obtain permanent supplies. Nearer the coast the porous beds lie below the level of the water table and will yield an abundance of water throughout their thickness.

Close relation also exists between the quality of the water and the character and position of the beds. Water from insoluble materials, such as sands, is usually soft or only moderately hard; that derived from soluble rocks, such as limestones and marls, commonly contains considerable mineral matter and may be quite hard. The character of the beds may influence the quality of the water by controlling the rate of circulation, for, other factors being equal, the porous rocks will permit rapid circulation of the water and the amount of solution will be small, whereas the dense rocks will retain the water in contact with soluble matter for a longer period and thus afford opportunity for its being dissolved. The position of the water-bearing rocks may have an influence on the rate of circulation and thus affect the quality of the water. In varying positions the same water bed may yield water having different qualities, depending upon the rate of circulation and the distance the water has traveled through the rocks. In marine formations, such as are found in Florida, the quality may also be affected by the presence of included sea water, which has not been removed because the position of the beds does not permit it to escape readily.

In the discussion which follows the water values of the various stratigraphic units are outlined briefly; the detailed discussion of the quantity and quality of the water from the different waterbearing beds is given in the county descriptions. A general summary of the water-bearing formations is given in the following table: 
UNDERGROUND WATERS OF CEÑTRAL AND NORTHERN FLORIDA. 245

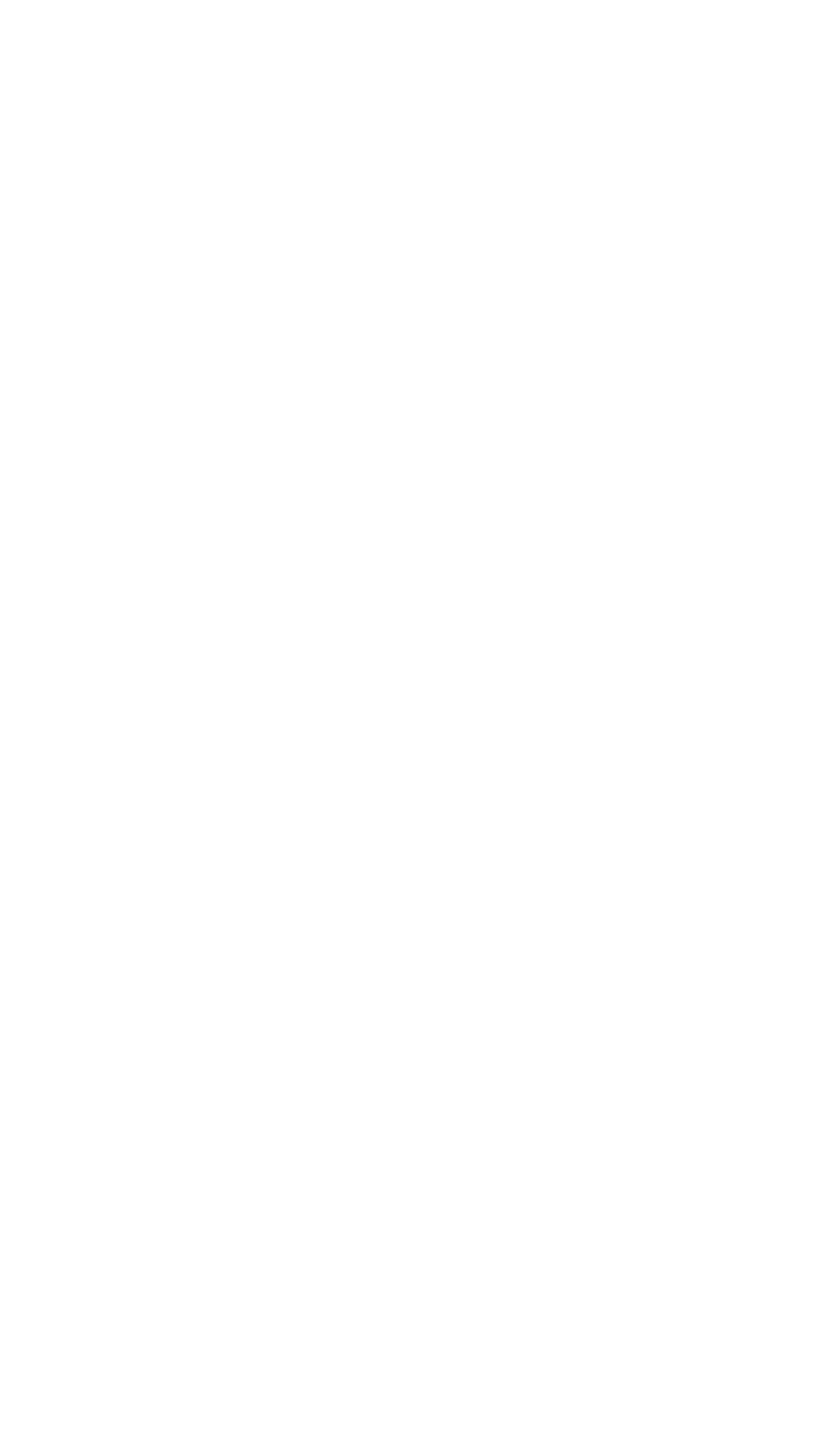




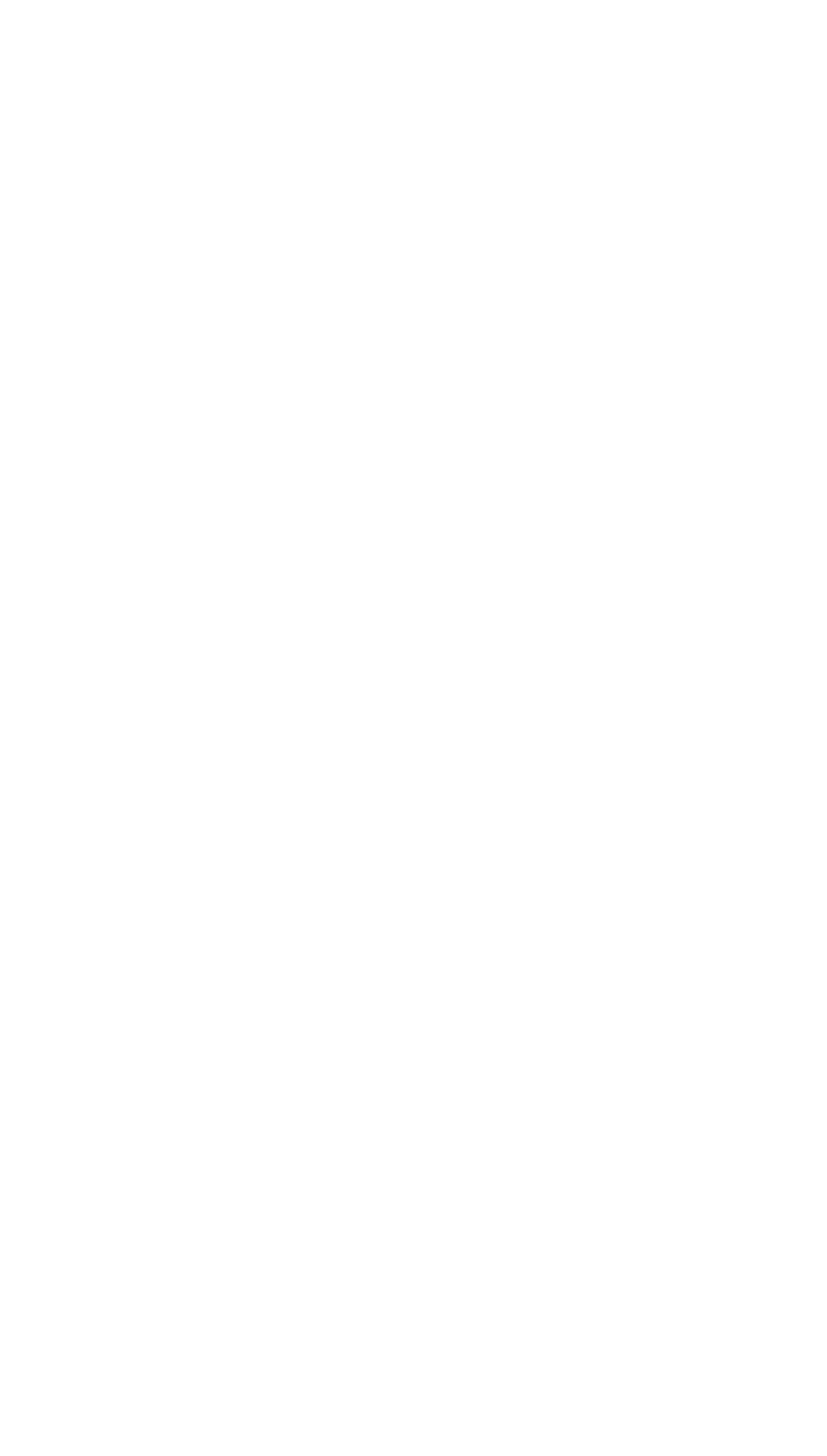


UNDERGROUND WATERS OF CENTRAL AND NORTHERN FLORIDA. 247
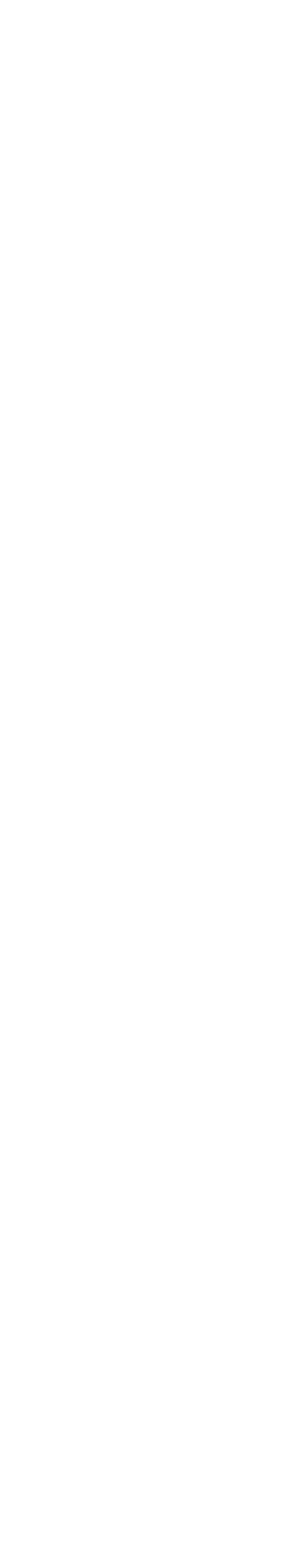
WATER IN THE OLIGOCENE SERIES.

IMPORTANCE.

Oligocene rocks contain the best water-bearing beds in Florida. The porous limestones of the Vicksburg group are not only the most important source in the large areas of flowing wells, but they also furnish the largest supplies in areas where wells do not flow. Moreover, the large springs of the State nearly all emerge from the Vicksburgian rocks, either directly or through openings in the younger formations. The Apalachicola group is a much less important source than the Vicksburgian limestones. The water capacity of its formations differs greatly, the best supplies being found in the limestones of the Chattahoochee formation and in the sands of the Alum Bluff formation. These two formations, though less important than the Vicksburgian limestones, are more valuable sources of supply than are some of the younger rocks.

WATER IN LIMESTONES OF THE VICKSBURG GROUP.

Although the large underground channels formed as a result of solution of the rocks of the Vicksburg group (pp. 25-29) are numerous, it is doubtful if their aggregate capacity is as great as that of the more or less minute passages between the individual grains of the limestone, which bear a striking resemblance to the water-bearing pores in sandstone. Though the limestones of the Vicksburg group contain layers of comparatively dense rock, as a whole they are open and porous, so that their water-bearing capacity is comparable to that of the important water-bearing sands farther north along the Atlantic coast. In some localities where the limestone is cavernous it probably contains a higher percentage of water than is held by an equal volume of sand.

The movement of the water through the Vicksburgian limestones takes place under the influence of gravity, and is in part in the form of underground streams, many of which have considerable volume, and in part as minute threads which pursue winding courses through the small pores of the rock. A large proportion of the water enters by percolation through the soil, but locally considerable quantities pass directly to the underground channels through sink holes. Thus, much of the water which enters the earth as sinking streams or by percolation from the lakes which occupy sink holes is added to the underground streams. This fact has an important bearing on the potability of the underground water, because sink holes are often filled with refuse which may contaminate the water and render it unfit for use.

Over a large part of the central portion of the peninsula, the underground waters of the limestones of the Vicksburg group lie several 
feet below the surface of the ground. The upper limit of the saturated zone forms a comparatively flat water table which, according to Sellards ${ }^{1}$ (see figs. 2 and 3, p. 224) bears little resemblance to the surface topography. Similar conditions prevail in the portion of theState lying north of a line passing from Duncan northeastward to Apalachicola River, and near the west coast from Wakulla County southward nearly to Pasco County.

WATER IN THE CHATTAHOOCHEE FORMATION.

The Chattahoochee formation is commonly a close-grained limestone or marl, which, although porous, will in places yield only a small quantity of water. This is due to the fact that in much of it the water occupies small openings where it is held with great tenacity. Nevertheless the Chattahoochee formation usually furnishes ample supplies for farm and domestic uses. Where large supplies are obtained the water is commonly found in what the driller regards as a cavity, some of which, however, are really well-defined channels in the limestone through which streams flow. The supply of water is governed by the size of the underground stream, many wells being drilled until two or more channels have been cut. The topography of the region where the Chattahoochee formation is near the surface is characterized by numerous sink holes, which bear testimony to the existence of many underground channels of considerable size. .

The water obtained from the Chattahoochee formation is generally considered to be of good quality. It usually contains more or less lime, magnesia, and other mineral substances common in limestone waters. Rarely it contains some hydrogen sulphide gas, and in such cases it resembles water from the limestones of the Vicksburg group. In general limestone waters, when obtained from underground streams, are more likely to be impure than waters from sandstone. Moreover, there is a much better opportunity for natural purification in sandstone than in limestone.

WATER IN THE HAWTHORN FORMATION.

The Hawthorn formation contains sand, clay, and limestone, and each of these materials will supply more or less water. The clay is not an important water-bearing bed because, though it contains a great deal of moisture, the supply available for wells and springs is very small. The limestones are similar in character to those of the Chattahoochee formation but are more broken and phosphatic and contain many pores and crevices which will hold water. The sands are important water-bearing beds, furnishing water for both wells and springs. They are usually so thin that the water supply is not large,

1 Sellards, E. H., Preliminary report on the underground water supply of central Florida: Bull. Florida State Geol. Survey No. 1, 1908, p. 32. 
but it is fairly constant in amount. Owing to the impurities in these sands the water derived from them is apt to be hard and to contain the same sort of mineral matter that is found in the limestone waters of the Hawthorn and Chattahoochee formations.

\section{WATER IN THE TAMPA FORMATION.}

The Tampa formation consists of limestones and clays; the former, being more or less porous in places, yield considerable water; the latter contain large quantities but yield little either to wells or springs. The limestones are separated by a layer of chert, sometimes known as the "Tampa silex bed," which is dense and relatively impervious, so that it prevents the rapid escape of moisture. The best water bed in the formation is that portion of the upper limestone which lies just above the chert. Aside from the water distributed through the limestone of the Tampa formation more or less water is present in the form of well-defined underground streams, similar to those which exist in the Chattahoochee formation. The quality of the water is much the same as that of the Chattahoochee formation, the mineral substances present being lime, magnesia, etc., and the water being as hard.

WATER IN THE ALUM BLUFF FORMATION.

The Alum Bluff formation ranges in composition from pure sand to pure clays and fuller's earth, but by far the most common material is a sand containing some clay or lime. The presence of marl is not uncommon, especially near the base and the top of the formation. Some nearly pure limestones are included in this formation, the most important being those at Sopchoppy and near Ellenton and southwest of Lakeland. The shell marls of Chipola River, of Shoal River, and of Oak Grove have been given separate names and are regarded as members of the Alum Bluff formation.

With such a varied composition the water-bearing capacities of the several members of the Alum Bluff formation necessarily differ. In general the formation contains an abundance of water, which occurs in the pores of the materials. The supplies are large in both sands and clays, though the wells that penetrate the sands yield better than those that enter the clays. Though comparatively thin this formation is widely distributed and is the source of supply of many wells in north-central Florida.

The composition of the water from the Alum Bluff formation varies with the nature of the material from which it is obtained, grading from the pure soft water of the sands to the hard lime and magnesia bearing water of the marls. The clays commonly supply hard water 
because they contain more or less carbonate of lime and other soluble mineral matter which is taken up as the water percolates through the small passages. Moreover, the water moves slowly through the clays, and hence is kept for a long time in close contact with the soluble mineral substances which they contain.

WATER IN THE MIOCENE SERIES.

CHARACTER.

The Miocene rocks of Florida contain far less important waterbearing beds than the Oligocene. The reasons for this are to be found chiefly in the diminished porosity of the younger rocks and their slight thickness and small areal distribution. With the increase of clay the openings which yield water are reduced both in size and number, and hence the Miocene marls and limestones, which contain considerable proportions of such material, are only moderately good sources of underground water. However, many of the shallow wells in the area where Miocene rocks are near the surface draw their supplies from the beds of this age.

WATER IN THE JACKSONVILLE FORMATION.

The Jacksonville formation contains several different kinds of rock, the most important being sand and clay arranged in alternating beds of moderate thickness. Limestones occur at numerous horizons, but most of them are impure and of small thickness. The principal water-bearing rocks of the formation are the sands and limestones. The clays are of little or no importance as aquifers, because they are too fine grained to yield water to wells and springs. Both the limestones and sands of this formation are impure, but they are sufficiently porous to permit the absorption and storage of considerable quantities of water, which they readily yield to both wells and springs.

The Jacksonville as a whole is of little importance except for shallow wells. Few deep wells obtain large supplies from it, and most wells penetrating it are continued to the excellent water-bearing limestones of the Vicksburg group. The limestones belonging to the Jacksonville formation yield hard water, but the sands in many places supply water which is practically free from mineral matter and is therefore regarded as soft.

WATER IN THE CHOCTA WHATCHEE MARL.

The waters of the Choctawhatchee marl have not been extensively exploited because the marl is usually a poorer water bearer than the underlying Alum Bluff formation or the overlying Pleistocene, but 
the marl supplies water to a few shallow wells and to numerous small springs. Only dug wells are large enough to afford enough surface for the entrance of water by soil seepage. The springs are commonly small, indeed they often represent mere seepage at the head of some ravine. The reason for the meagerness of the supplies is to be found in the close-grained character of the material, which causes it to hold water with considerable tenacity. The water is usually hard and bears a strong resemblance to that derived from the older limestones, though it is practically free from hydrogen sulphide and other gases which are common in some of the waters from the Vicksburgian limestones.

\section{WATER IN THE PLIOCENE SERIES.}

GENERAL CONDITIONS.

The hydrology of the Pliocene presents no exceptional features. The conditions closely resemble those found in the Miocene except that the Pliocene in many places contains a very high percentage of clay. This is particularly true of the Lafayette (?) formation, which forms the upland cover of considerable areas and is penetrated by many wells. The local differences in the Pliocene deposits have given rise to different hydrologic conditions, so that the rocks of the Pliocene may furnish much water in one locality and little in another.

WATER IN THE NASHUA AND CALOOSAHATCHEE MARLS.

The Nashua and Caloosahatchee marls are sandy shell marls which should yield considerable water, but their thickness is seldom great and they are not important water bearers, though where not too deeply buried they should prove valuable as sources of supply for shallow wells. At present the region underlain by the Pliocene marls is thinly settled and most of the wells reach water-bearing beds in the older rocks. The quality of the water from the Pliocene marls has not been determined, but the nature of the materials leaves little doubt that the water is hard.

WATER IN THE ALACHUA CLAY.

The Alachua clay is a thin deposit which occurs in more or less isolated patches. The sandy clays comprising the formation are sufficiently porous to absorb a large quantity of water, but they hold it so firmly in the minute openings between the grains of the clay that but little of it is available for wells. Owing to the fact that the formation occurs as discontinuous patches of slight thickness it is of practically no importance as a source of water. 
WATER IN THE BONE VALLEY GRAVEL.

The Bone Valley gravel consists of uncemented sand and phosphatic or quartzitic pebbles, in many places embedded in a matrix of marl or clay: The materials are sufficiently porous to yield moderate quantities of water for shallow wells. The region in which the formation is developed is characterized by deep wells sunk to supply phosphate mines, and hence little demand is made on the water in the gravel. The Bone Valley gravel is reported to supply moderately hard water, suitable for ordinary domestic and farm uses.

PLIOCENE (?) SERIES.

WATER IN THE LAFAYETTE (?) FORMATION.

The Lafayette (?) contains a large percentage of clay and is locally a poor water-bearing formation. However, sand lenses and beds hold some water which is readily available to shallow wells. The formation is the source of many excellent springs, though few of them are large. Apparently the water enters porous sands and sinks until it encounters relatively impervious clay. The springs occur where the impervious bed reaches the surface, which may be either on a slope or in a ravine. The erosion and redeposition of material has produced many porous sands which contain large quantities of water, but these sands are mostly of Pleistocene age.

The water from the Lafayette (?) formation varies greatly in the amount and character of its dissolved mineral matter. Some of it is soft, but in springs and shallow wells moderately hard water is common. In general the water from the Lafayette (?) formation is thought to contain less mineral matter than the water from some of the limestone beds, but this opinion lacks verification because of the lack of chemical analyses for comparison. The general opinion that the water contains iron is probably correct, though here again analytical evidence is lacking.

\section{PLEISTOCENE AND RECENT SERIES.}

The Quaternary formations are important locally as sources of underground water but are in general too thin to contain much water. Practically all Quaternary deposits of any considerable importance as sources of water belong to the Pleistocene. Locally, the Pleistocene beds attain a thickness of 50 to 100 feet or more, and in such places they usually yield abundant supplies to wells. Where the Pleistocene beds are too thin to yield much water they may serve a valuable hydrologic purpose by absorbing it. Their materials are open and porous and the passages between the separate grains are 
large enough to permit the absorbed water to sink rapidly, thus preventing early saturation of the surface layers, followed by excessive run-off.

The water from the Quaternary beds is usually soft, though the presence of marl and coquina at some localities should permit the solution of calcium carbonate and other constituents such as occur in these materials. Hard water may be expected in the Pleistocene of the coastal region where marls and limestones are found. Such waters are common in the northern part of the State, where many Pleistocene beds contain calcareous material derived from the erosion of the older rocks.

The redeposited materials from the Lafayette (?) formation occupy the slope and terraces of the valleys of the northern part of the State, where they supply abundant water to many springs and shallow wells. These supplies may usually be distinguished from those of the other Pleistocene deposits by their larger content of mineral matter, which renders the water hard.

In the vicinity of Kissimmee flowing wells are obtained from sands which are probably of Pleistocene age, though some of them may be Pliocene. Examples are to be seen in the shallower wells of the Lee-Parsons Cattle Co. and in some other shallow flowing wells near Kissimmee. In west Florida flowing wells from beds that may be of Pleistocene or of late Tertiary age are obtained on the shores of Pensacola Bay and as far eastward as Apalachicola. Most of these wells are confined to the low land near the coast and few yield abundantly. The water is commonly softer than that obtained by flowing wells from the Vicksburgian limestones, but it usually contains considerable hydrogen sulphide gas, doubtless derived from decaying organic matter scattered through thewaterbearing sands.

\section{PUBLIC WATER SUPPLIES.}

The accompanying table gives the statistics of public water supplies of towns and cities in central and northern Florida. 


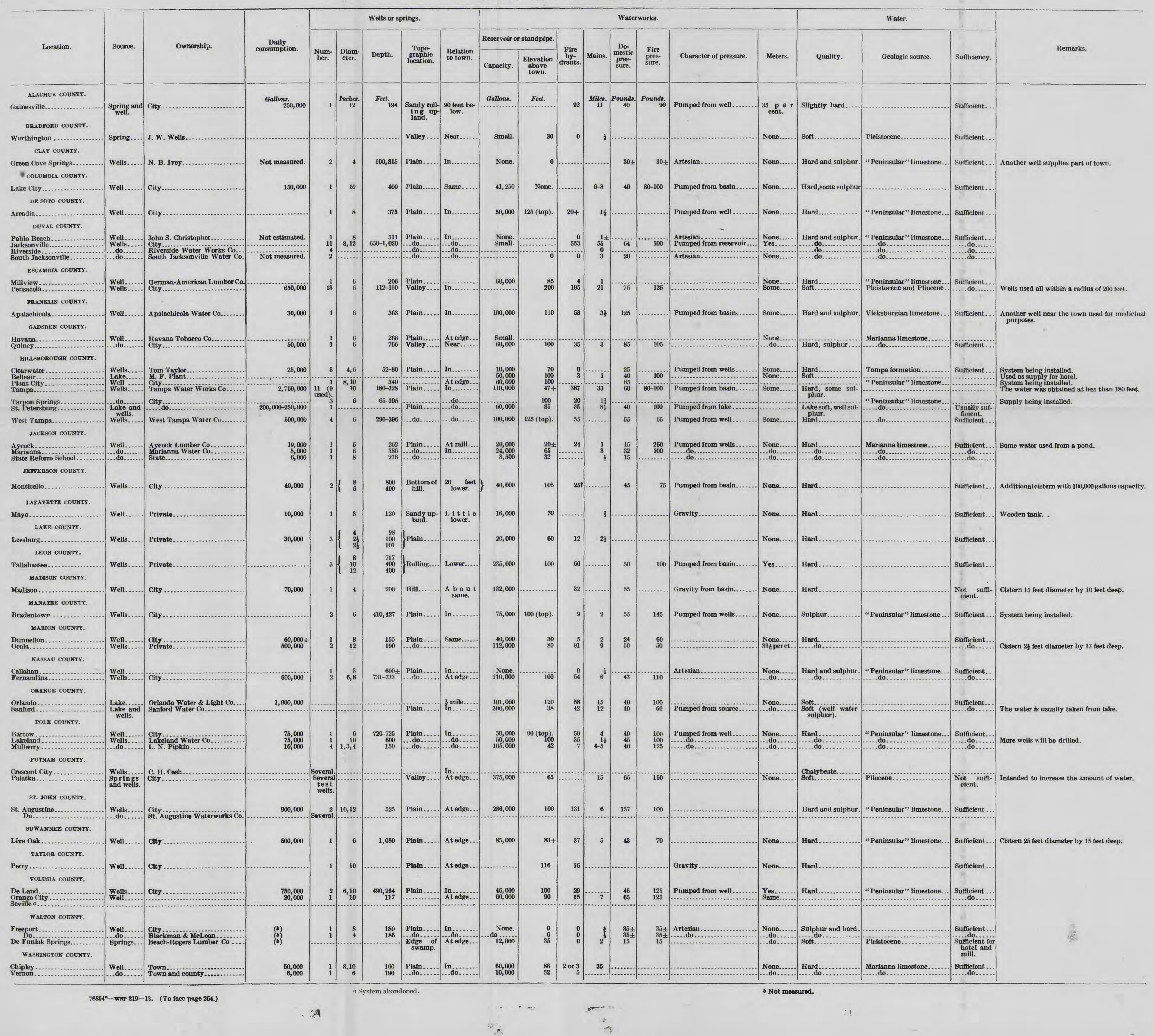




\section{SURFACE AND UNDERGROUND WATERS OF SOUTHERN FLORIDA.}

By Samere Sanford.

SOURCE.

Most of the water from shallow wells or from springs in southern Florida represents rain that fell at no great distance. Although the surficial limestones contain many solution cavities, and although circulation through these is comparatively free, yet the general elevation of the surface is so slight that long travel underground is presumably exceptional. Most of the rain that falls in the Everglades and most of the water that flows into them from Lake Okechobee is evaporated or reaches the sea or the Gulf by creeks and rivers, the part escaping underground being small-much smaller than the statements of some writers would indicate. Its unimportance is shown by the absence of springs of fresh water along great stretches of coast and by the many wells which have found salt water at shallow depths. The elevation of the Everglades is so slight and the limestones are so widely covered by marls and sands that direct underground transfer from the swamp to the ocean or the Gulf is difficult.

The deep waters under relatively high heads reached by the wells at Gomez, Hobe Sound, and Palm Beach on the east coast, and those at Marco and points northward on the west coast evidently do not come from the Everglades. They need a much higher source, and are supplied from beds containing water that owes its pressure to rainfall on the ridge of highland along the west side of the peninsula north of Lake Okechobee. (See p. 259.)

\section{WATER TABLE.}

Except under dunes, the higher portions of the sand plains, and the more elevated rock ridges, which form an insignificant portion of the total land surface of southern Florida, the water table everywhere lies close to the surface and rises above it over many hundred square miles during late summer and early fall. Because of the generally low elevation of the land and the extent of the nearly flat areas the upper surface of the ground water has little movement except in narrow areas near the coast. The water table is everywhere nearly flat. In the limestone, owing to the many free passages, it is even flatter than it is in the sands.

The rise and fall of the water table respond to the seasonal fluctuations of the rainfall, the amplitude of the yearly swing varying with the annual precipitation and the difference in rainfall between the wet and dry months of any given year. Also it is dependent to a certain degree on the geology and topography, being less in open$76854^{\circ}-$ WSP $319-13-17$ 
textured beds near the coast or stream channels than in fine deposits away from points of outflow.

Besides rainfall fluctuations other causes (pp. 224-225) affect the level of the ground water. Near the coast the most potent is the rise and fall of the tide, and particularly the periodic groups of maximum and minimum tides. At many shallow wells along the coast, including those not affected by direct infiltration of sea water, there is a perceptible rise and fall of water level that lags after the times of high and low tide, the lag being determined by the porosity of the water bed and the distance of the well from the shore line. Dr.Bessey, director of the Sub-Tropical Experiment Station, near Miami, stated that in a shallow well in the grounds of the station a few rods from the shore of Biscayne Bay, the time-amplitude curve of the height of the water in the well was much more abrupt on the rise than on the ebb. This variation probably is due in large measure to outflowing ground water and resembles the tidal curves of many surface streams. The writer observed the tidal lag of the water in pits and wells on Key Vaca and Big Pine Key but, as was to be expected from the small area of the keys, found no such regular variation of level as Bessey found at Miami.

Along the keys the fluctuations due to tides are naturally more marked than on the mainland. The tidal variations of the well water at Key West were noted by Tuomey. The rise of salt water in potholes and swamps along the keys, through underground passages, is a most striking feature of the semiannual periods of maximum high tides.

\section{SPRINGS.}

No such giant springs as are found in the central and northern parts of the State are known in southern Florida, and, indeed, springs of any size, except near Biscayne Bay, are rare. The reasons for this are obvious. The surface has slight elevation, hence underground circulation can not be vigorous. The Pleistocene limestones are readily dissolved and are full of solution passages, but few of these openings extend 20 feet below the surface, and the underground circulation is local rather than regional. Only in the Biscayne pine land have the rock ridges sufficient height to give the underground water a chance to erode connecting passages and gather water.

In southern Florida the Oligocene limestones, which are the great source of the giant springs of the region to the north, are deeply buried by sands and sandy marls, so that any water contained in them in large passages or openings must cross the bedding of many hundreds of feet of soft material containing clayey layers to reach the surface.

Springs of some size occur along the east coast, the largest flowing from the low ridges of Miami oolite near Biscayne Bay. Reports of 
giant springs under the ocean, though common, are difficult to verify. The writer does not know of such springs and is inclined to take reports regarding them with much reserve. Necessarily they would have their source in limestones buried under 800 feet or more of sediment, chiefly loose sands, and any water rising through these sands would escape as small seeps rather than bold flows and would mingle with the salt water in the beds before reaching the sea floor.

There are no true springs so far as known anywhere along the keys, though reports of such are even more plentiful than of big springs under the ocean north of Miami. It is not difficult to find fishermen who say they have seen water flowing from the sea bottom at such and such a place along the keys, and springs are frequently reported from Big Pine Key and Key West. An offer of a reward for the finding of a spring of fresh water on the keys or the adjacent sea bottom, however, secured no takers. The so-called springs on the keys are natural wells yielding more or less brackish water under no more head than that due to the rise of the water table from local rains, the rise and fall of the tides, and barometric fluctuations. The elevation of the keys is slight; their honeycombed limestones can not confine water, and surface springs, though possible after heavy rains, obviously can not be permanent.

Alongshore on the west coast springs are rare, as is to be expected from the slight elevation of the land, the thinness of the surficial limestones and the mantles of sand and marl extending below sea level. There are no springs of note between Cape Sable and Big Marco Pass. Vessels obtain water along this stretch of coast from a few shallow wells in beach ridges or from cisterns.

The cavernous or, rather, the honeycombed character of the Miami oolite in the Biscayne pineland about the margin of the southern Everglades, and on Long Key and its neighboring keys, and the many small sinks or potholes are the apparent basis for the reports of big springs in the Everglades. That there are springs just outside the eastern margin of the Everglades is well known; there is one, for instance, in Miami River just below the rapids from the pool back of the rock rim of the Everglades; but the existence of true springs in the main body of the saw grass, away from dry land, seems more than doubtful.

In times of high water there may be perceptible currents flowing from some of the potholes and natural wells near sloughs and rivers, but at such times it is difficult to separate surface from underground circulation; the limestone is full of holes and there is in places a sufficient gradient toward the watercourses for water to move freely underground. In times of low water, with the water in rock openings standing below the surface of the adjacent parts of the Everglades, the case is quite different. Out in the saw grass, where the water 
surface is nearly level, where there is no high ground near to supply shallow water under head, true springs of large size would seem to be limited to those that might come from the deeply buried limestones, and the thick cover of sand and marl makes negligible any possibility of bold flows from that source.

\section{WATER-BEARING FORMATIONS.}

OLIGOCENE SERIES.

Some of the geologic formations named in the description of the geology of southern Florida (pp. 167-199) are decidedly important water bearers, others are practically of no account, but no single formation yields potable water under the whole extent of the mainland.

Of the Oligocene limestones the Vicksburg group, the most notable and economically important water bearer in Florida, supplies a few wells on the east coast, which yield strong flows of saline sulphureted water that is too highly mineralized for general domestic use or for boiler supply. No well has reached these limestones on the east coast south of Palm Beach, and the only wells to reach them south of the mainland are at Key West and possibly at Knights Key. On the west coast the Vicksburgian limestone supplies many fine flowing wells in Lee County, particularly in and near Fort Myers. The waters there are decidedly less mineralized than on the east coast.

\section{MIOCENE AND PLIOCENE SERIES.}

The sands and sandy marls of Miocene and Pliocene age that form so large a part of the sections shown by deep wells on the east coast and along the keys are of slight consequence as sources of water supply. Though they are filled with water they do not yield it so freely to wells as do the Vicksburgian limestones. On the east coast no flows of consequence were found in the Miocene and Pliocene beds. On the west coast from Estero north a few wells find small flows of good water in the Miocene beds.

\section{PLEISTOCENE SERIES.}

As they lie near surface on the mainland of southern Florida and on the keys and have a possible maximum thickness of 125 feet, the Pleistocene beds are the sources of springs and the great reservoirs for shallow wells. They have been extensively developed, but can supply many times the amount of water now drawn from them. The quality of their waters varies decidedly. Wells in limestone yield supplies high in calcium and bicarbonate; many wells in the sands of the dunes and of the rolling sand plains yield water that is soft and of low mineralization. Because the waters lie near the surface they, particularly the limestone waters, are liable to pollution by privies, hogpens, and slop holes, and more care than is commonly taken should be exercised in locating and protecting wells. 


\section{ARTESIAN WATER.}

The factors that determine the presence of artesian water have already been discussed (pp. 234-235), but the extent of the area in southern Florida that is underlain by beds containing artesian water and the probable character of the artesian supplies are questions that merit consideration.

There is no area of high ground in southern Florida, and the larger part of the surface is less than 22 feet above sea level; hence the only possible source for flows with heads of over 30 feet, as those at Marco on the west coast, and Palm Beach on the east, is the high ground west and north of Lake Okechobee. This high ground is much nearer the west coast than the east and very much nearer the east coast than the southern end of the peninsula. Hence, conditions of porosity of water bed, slope, and tightness of cover being the same, higher heads, stronger flows, and better water are to be expected on the west coast than on the east, and lower heads and poorer water toward the south. Just how far south along the east coast or the west coast flowing wells can be had is somewhat conjectural, but it is safe to say from what is known of the topography and geology that deep wells can get water that will flow at the surface; that is, rise to 22 feet above tide, throughout Lee and Palm Beacb counties and the northwestern part of Dade County, or in a region northwest of a line drawn from Hillsboro Inlet to Pavilion Key. It is possible that water rising above sea level can be had as far south as Miami by wells 1,000 feet deep. The prognosis for quality is far less promising than that for strength 'of flow. The reported salinity of the water in the wells near the Devils Garden, west of the Everglades, and the high mineralization of the flows at Marco and Palm Beach offer little hope for flows of good potable or industrially valuable water from deeply buried beds at points near the shore anywhere around the southern end of the peninsula from Palm Beach to Naples.

\section{QUALITY OF WATER.}

The surface water of the Everglades and its connected sloughs and swamps is commonly clear but highly colored and is lower in mineral content than that of most wells in the region. This is contrary to the frequently expressed belief that such water is charged with calcium salts. Some small lakes in the rolling sand plains and among the ridges of the dunes east of the Everglades, occasionally connected with it by temporary arms across the flatlands, contain softer water than that of the Everglades.

The shallow limestones yield calcium bicarbonate waters of moderate mineral content except where contaminated by salt water. The normal supplies are used for domestic purposes, but for steaming they are rather high in scale-forming ingredients, and boiler compounds for softening them are consequently in common use. 
Many waters from the sands are low in total solids and good for domestic use or for boiler supply, though some are hard enough to necessitate softening.

The supplies from the Vicksburgian limestones on the east coast are salt, hard, sulphur waters of high mineral content. They are little used except for irrigating crops resistant to saline solutions. The deep waters of the west coast are similar in composition; some of them, like those at Fort Myers and at other places in Lee County, are used for domestic and industrial purposes, though they are more likely than the shallow waters to form hard scale and to be corrosive in boilers. Others are too salty for any use except bathing or closetflushing. It is important to note that only strong salt water has been drawn from deep borings on the keys. Many wells in limestone along the mainland shore, however, also are affected by salt water.

Assays by the writer of some waters from wells in southern Florida are given in the following table:

Assays of water from wells in southern Florida.

[Parts per million unless otherwise designated.]

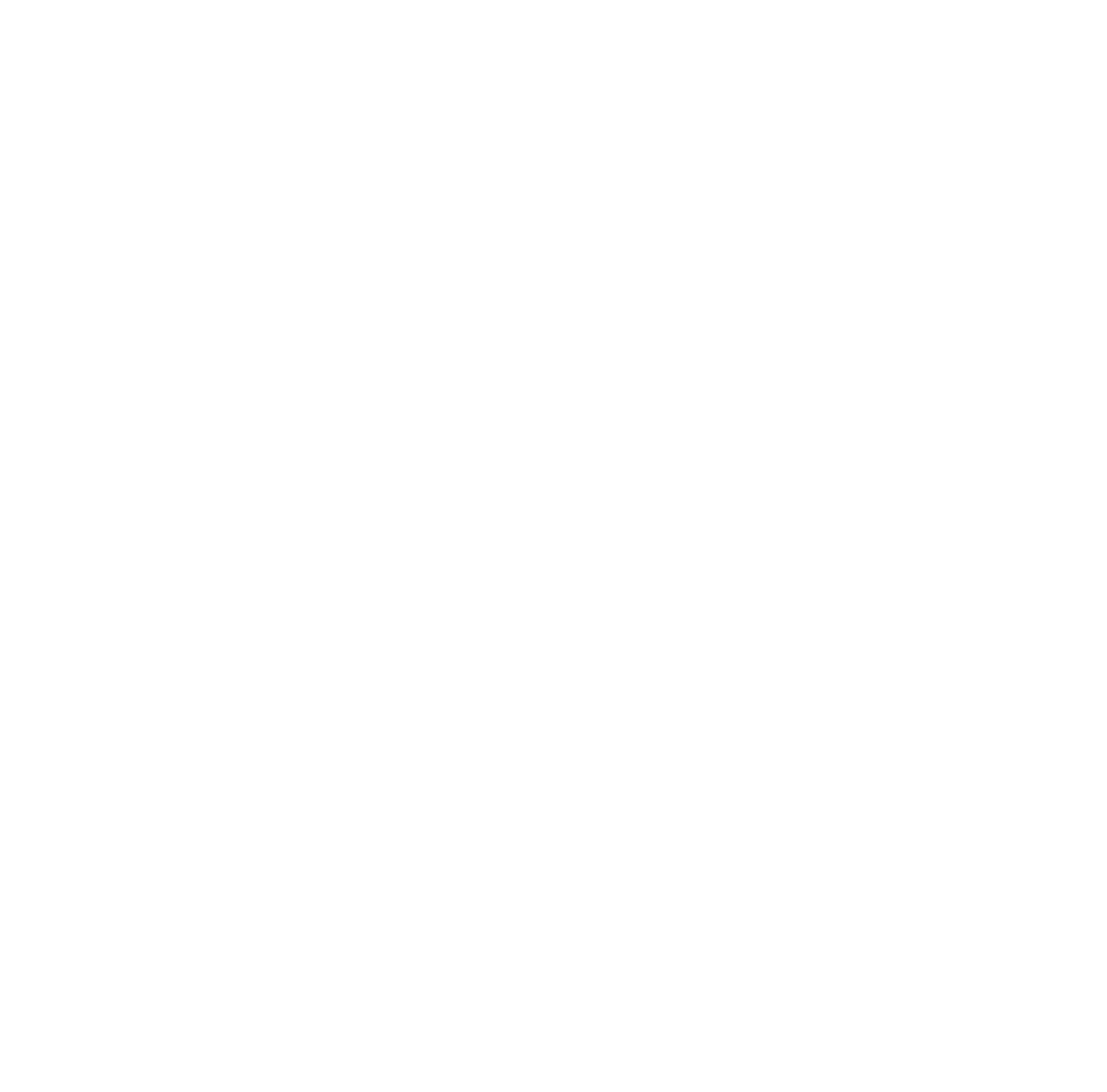

a Assays performed by Samuel Sanford according to methods outlined in Water-Supply Paper U. S. Geol. Survey No. 151, 1905. 
These assays show that the waters sampled are generally hard, that the hardness of the shallow waters is due to bicarbonate of lime, and that of the deep waters to bicarbonate and sulphate of lime, that the saltness (chlorine content) varies widely, and that at Marathon, on Key Vaca, all the water to a depth of nearly 500 feet is as salt as sea water.

\section{RELATIONS OF FRESH AND SALT WATER UNDERGROUND.}

Many of the conditions governing the occurrence of salt water in underground strata are not known at present, but some features of these phenomena, which are of the utmost economic importance in southern Florida, are explainable by the data obtained during this investigation.

The shallow salt waters found along the keys and at different places on the mainland of southern Florida are due to direct penetration of sea water into the underground strata, which commonly throughout this region are limestones full of seams and crevices that permit easy entrance of surface water. The keys, where the limestones are full of openings, may be completely underlain by salt water at about tide level; this is the condition on islands as wide as 3 or 4 miles in the Bermudas and also on many Florida keys. Where porous beds form the sea floor along the mainland coast salt water may likewise displace fresh water for some distance inland. Fresh water, percolating through the surface sands or passing through rock channels directly to the salt-water level, moves seaward above the saline solution by reason of its superior position and its lower specific gravity, but it also has a tendency to mix with the salt water through diffusion. Under these conditions the thinner the fresh-water sheet the less its seaward gradient, and the freer the underground circulation the greater is the admixture of salt with fresh water. Therefore, the chances of finding potable water are better in the sands of beach ridges and on sandy islets than in the open-textured limestones on the keys or near the coast of the mainland.

The deep salt waters of southern Florida may represent original sea water that was contained in the beds when they were deposited and has not been removed, or secondary sea water that penetrated beds containing fresh water during the depression of the land, or water originally fresh that has become saline by traversing saltbearing formations. Such formations are of different ages, from Oligocene to late Miocene or early Pliocene, and range in texture from limestones containing open passages to fine-textured sandstones and marls; and as they are found not only on islands but also at some distance inland it is unlikely that any one of the abovementioned causes of salinity applies to all of them. 
Except for deposits lying on or near the surface the materials from which the southern part of the State were constructed are of marine origin and once contained salt water. That large areas of these deposits do not now contain salt water for several hundred feet below sea level is evidence of an uplift sufficient to give fresh water active circulation to considerable depths. (See pp. 207-209.) During such uplifts and subsequent depressions saline material must have been leached from the marine beds under great areas by fresh water and the latter in turn displaced by sea water; changes from salt to fresh and to salt water again may have taken place several times. Consequently it is possible that none of the salinity now found on the mainland or the keys in, for instance, the Vicksburgian limestones, represent original sea water. Deeply buried beds are more likely to contain original sea water near the present shore line than inland and near areas of high land than in areas remote from high land. Similarly, deep-lying secondary salt water may occur under large areas of low ground rather than under high land and near the shore rather than inland.

Whether any given saline water represents original sea water, secondary influxes, or supplies that have acquired salt from the beds they have traversed is a question of some interest; and if the character of the water-bearing beds, their geologic history, and the chemical composition of their water were known it could be answered with some exactness. The decided differences in chemical composition and in concentration indicate diversity in derivation of salinity. Most salty flows in southern Florida do not resemble sea water in composition, for they are high in carbonates and low in sulphates and magnesium, whereas sea water is characterized by high sulphates, low carbonates, and magnesium in excess of calcium. The peninsula has evidently been raised above and depressed below its present level with resulting modification of underground circulation, and the salinity of the deep waters is probably due to secondary influxes during the last marked depression. 


\section{PART IV.-COUNTY DESCRIPTIONS.}

\section{ALACHUA COUNTY.}

By G. C. Matson.

GENERAL FEATURES.

Alachua County lies in the north-central part of the peninsula on the drainage divide between the Atlantic Ocean and the Gulf of Mexico. It comprises a portion of the upland known as the lake region, from the large number of lakes which apparently occupy depressions in the underlying limestones. The surface of the county consists of rolling pineland interspersed with level uplands and flat, marshy lowlands. A large depression south of Gainesville, formerly occupied by a lake, is now drained and is known as Paynes Prairie. The water entering this basin passes to an underground channel through an open hole known as Alachua sink. Many other sink holes exist in different parts of the county, an especially interesting one being the Devils Mills Hopper, northwest of Gainesville, with a diameter of a few hundred yards and a depth of over 100 feet. It receives the drainage of springs and commonly contains a small quantity of water which gradually escapes to an underground stream. A sink south of the town of Alachua affords entrance to the cavern known as Warrens Cave, which is reported to be accessible for more than a mile from the opening.

GEOLOGY.

The surface deposits of Alachua County consist of gray sands underlain by older rocks of differing composition. Sands lying below the 100 -foot contour were probably deposited in lakes or in shallow marine waters, but those lying above that contour are largely residual products left by the decomposition of older geologic formations. The Alachua clay occurs in the form of small and unimportant patches of bluish sandy clay lying in depressions in the underlying rocks. The Alum Bluff and Hawthorn formations are well developed in the northern half of the county, where they consist of sands, clays, and limestones, the latter largely cherty and in places more or less phosphatic. Smaller areas of these formations rest on the Vicksburgian limestones in the southern part of the county, where they form more or less discontinuous patches or ridges. The .Vicksburgian limestones underlie the entire surface of the county, but they are usually covered by other formations or by residual sands of the younger formations. 
The surficial sands in few places exceed 50 feet in thickness, though locally they may be somewhat thicker; they average probably less than 30 feet. The Alum Bluff and Hawthorn formations and the Alachua clay are generally thin, though locally the Hawthorn formation may exceed 100 feet. A thickness of several hundred feet has been assigned to the Vicksburgian limestones, but the exact amount is not known because the deepest wells terminate in rocks that appear to be of this age. From samples obtained in drilling wells it has been possible to construct the sections given below, and, though some of the correlations are more or less uncertain, the descriptions show the general character of the rocks penetrated.

Log of the well of Diamond Ice Co. at Alachua.

\begin{tabular}{|c|c|c|}
\hline & Thickness. & Depth. \\
\hline $\begin{array}{l}\text { Sand, brown } \\
\text { Clay, soft, brown } \\
\text { Limestone, soft, white. } \\
\text { Limestone, hard, gray } \\
\text { Limestone, hard, brownish white. } \\
\text { Limestone, hard, gray, containing layers of blue fint. }\end{array}$ & $\begin{array}{r}\text { Feet. } \\
7 \\
15 \\
58 \\
100 \\
20 \\
50\end{array}$ & $\begin{array}{r}\text { Feet. } \\
7 \\
22 \\
80 \\
180 \\
220 \\
270\end{array}$ \\
\hline
\end{tabular}

Water-bearing beds were encountered between 50 and 120 feet and between 250 and 270 feet. The beds from 1 to 22 feet appear to be residual. The limestones of the Vicksburg group were encountered at 22 feet and continued to the bottom of the well.

Log of the well of C. E. Milton at Micanopy.

\begin{tabular}{|c|c|c|}
\hline & Thickness. & Depth. \\
\hline & Feet. & Feet. \\
\hline 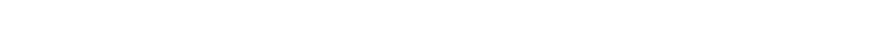 & 1 & $\begin{array}{l}1 \\
3\end{array}$ \\
\hline Sand, dark gray; partly consolidated.... & $\mathbf{3}$ & 6 \\
\hline 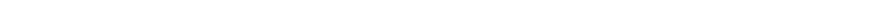 & 5 & 11 \\
\hline Sand, gray; containing small percentage of clay $\ldots \ldots \ldots \ldots \ldots \ldots \ldots \ldots$ & 4 & 15 \\
\hline Sand, gray; containing some clay with yellow streaks due to the presence of iron 0 & 2 & 17 \\
\hline $\begin{array}{l}\text { Sand, light yellow, and clay } \ldots \ldots \ldots \\
\text { Clay, light gray to white; containing some sand }\end{array}$ & 18 & 35 \\
\hline $\begin{array}{l}\text { Clay, light gray to white; containing some sand.... } \\
\text { Sand, white..................................... }\end{array}$ & $\frac{2 \frac{1}{2}}{1}$ & $\begin{array}{l}37 \frac{1}{2} \\
39\end{array}$ \\
\hline 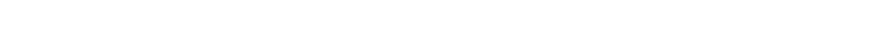 & $1^{2}$ & 40 \\
\hline 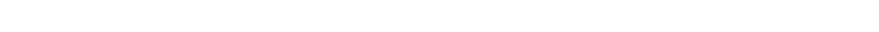 & 8 & 48 \\
\hline 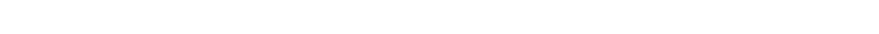 & 1 & 49 \\
\hline 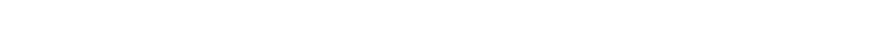 & $\begin{array}{l}3 \\
3\end{array}$ & $\begin{array}{l}52 \\
55\end{array}$ \\
\hline 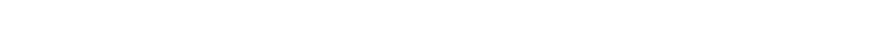 & 12 & 67 \\
\hline Limestone, brownish gray; containing some sandy clay $\ldots \ldots \ldots \ldots \ldots \ldots \ldots \ldots$ & 4 & 71 \\
\hline Clay, fine grained, light gray, and limestone................ & 4 & 75 \\
\hline Limestone, light gray to white................... & 14 & 89 \\
\hline Limestone, soft, white........... & 7 & 96 \\
\hline 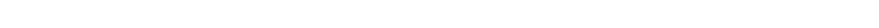 & 5 & 101 \\
\hline Limestone, light gray; containing fossils. $\ldots \ldots \ldots \ldots$ & ${ }^{49}$ & 150 \\
\hline estone, white; with few foss & & $150 \frac{1}{2}$ \\
\hline
\end{tabular}

The material from 1 to 6 feet may be Pleistocene sand, and that from 6 to 17 feet may be Alachua clay, or a portion of the upper Oligocene. The beds between 17 and 52 feet probably represent the 
Hawthorn formation. Limestone of the Vicksburg group appears to have been encountered at about 52 feet. Characteristic Vicksburgian iossils were obtained between 89 and $150 \frac{1}{2}$ feet.

Log of well of F. P. Henderson at Arno.

\begin{tabular}{|c|c|c|}
\hline & Thickness. & Depth. \\
\hline 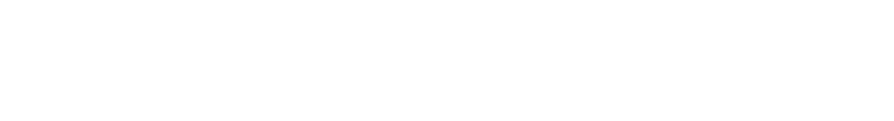 & Feet. $\begin{array}{r} \\
55 \\
5 \\
6 \\
6 \\
6\end{array}$ & $\begin{array}{r}\text { Feet. } \\
55 \\
60 \\
74 \\
82\end{array}$ \\
\hline
\end{tabular}

The samples from this well are incomplete. Apparently the Vicksburgian limestones were encountered at less than 55 feet and they continued to the bottom of the well.

\section{WATER SUPPLY.}

Source.-The surficial sands, the Alum Bluff formation, and the Hawthorn formation will supply some water, and though the quantity is seldom large the water level lies near the surface, so that the wells may be easily pumped. The Alachua clay contains very little water, and this fact, together with the limited distribution of the formation, makes it of little value. The Vicksburgian limestones are the most important water-bearing formations in Alachua County. The depth necessary to secure good supplies from the limestones is in few places more than 100 to 150 feet, and locally it is less than 50 feet. The Vicksburgian limestones also furnish water for numerous valuable springs.

Quality.-The sands furnish soft water, but the supplies from the Hawthorn formation are hard. All the waters obtained from the Vicksburgian limestones are hard, but the quantity of inorganic material in solution is not great enough seriously to interfere with their use for ordinary purposes.

Development.-The yield of wells which penetrate the Vicksburgian limestones is large and the information at present available appears to indicate that the quantity is sufficient to meet all reasonable demands. The water level is near enough to the surface to make pumping inexpensive. There is no probability that flowing wells can be generally obtained in Alachua County, and hence there is little incentive to drill to great depths. Very deep wells would be apt to encounter highly mineralized water, unfit for ordinary use, and it is doubtful if the head would be materially greater than that of the supplies now utilized. The greatest opportunity for improvement is in the prevention of pollution, which could be done by using casings to exclude surface water from the wells, and by preventing waste products from entering water beds through open sinks or drainage wells. 
Among the springs large enough to be important is the Boulware Spring, which furnishes water for the city of Gainesville, the Poe and Magnesia springs at Hawthorn, and the springs at High Springs and Traxler. Aside from the springs at Gainesville many of the others might be utilized either as sources of water supply or as pleasure or health resorts.

General water resources in Alachua County.

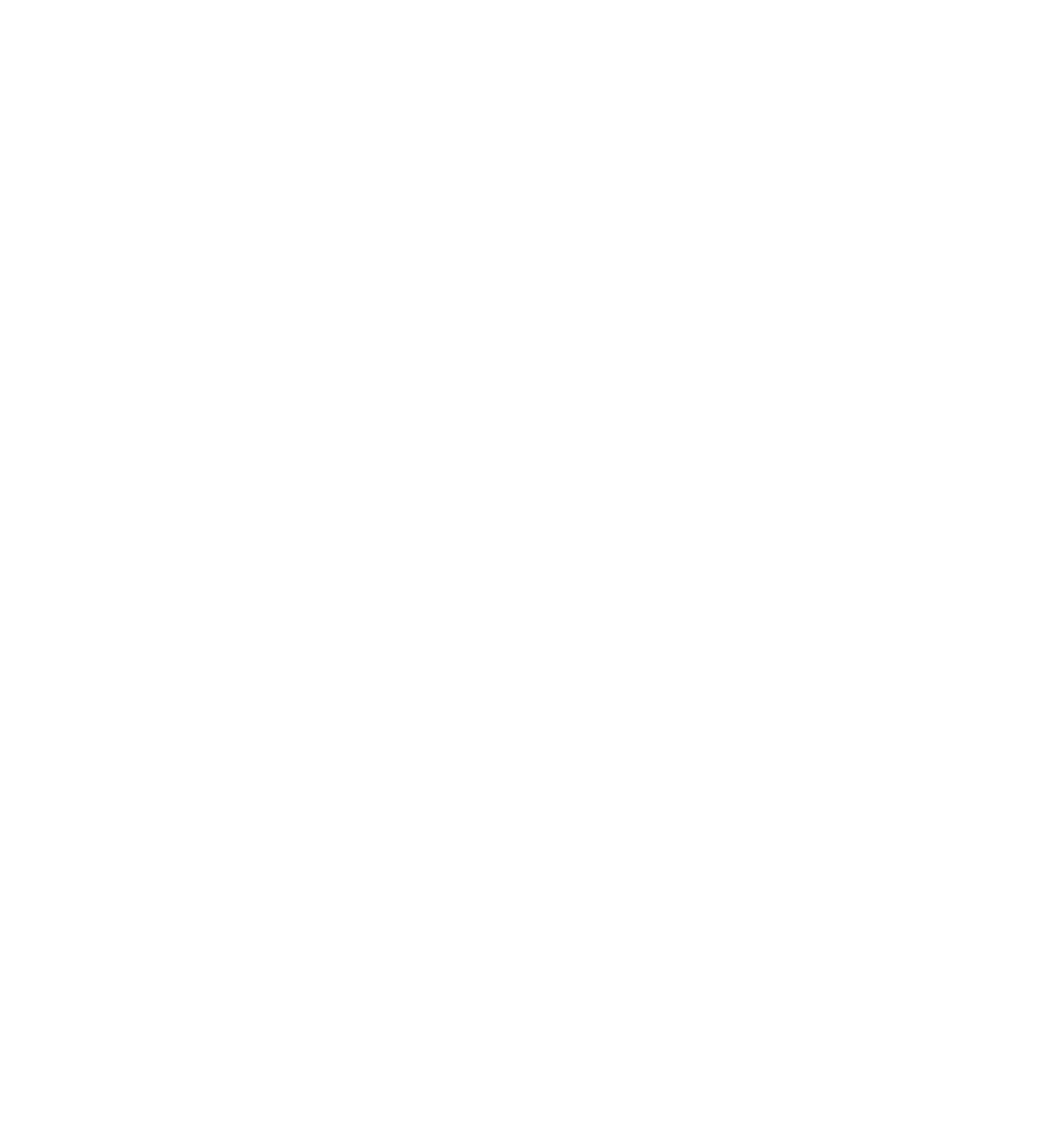


Typical wells in Alachua County.

\begin{tabular}{|c|c|c|c|c|c|c|c|c|c|c|c|c|c|c|c|c|c|}
\hline \multirow{2}{*}{$\begin{array}{l}\text { Nearest town or } \\
\text { post office. }\end{array}$} & \multirow{2}{*}{$\begin{array}{l}\text { Direction and } \\
\text { distance. }\end{array}$} & \multirow{2}{*}{ Owner. } & \multirow{2}{*}{ Driller. } & \multirow{2}{*}{$\begin{array}{l}\text { Date } \\
\text { sunk. }\end{array}$} & \multirow{2}{*}{ Type of well. } & \multirow{2}{*}{ Use of well. } & \multirow{2}{*}{ Depth. } & \multirow{2}{*}{ Diame- } & \multirow{2}{*}{ Casing. } & \multirow{2}{*}{$\begin{array}{c}\text { Eleva- } \\
\text { tion } \\
\text { above } \\
\text { sea. }\end{array}$} & \multicolumn{2}{|c|}{ Head- } & \multirow{2}{*}{$\begin{array}{c}\text { Depth } \\
\text { to } \\
\text { rock. }\end{array}$} & \multirow{2}{*}{$\left|\begin{array}{c}\text { Depth } \\
\text { to prim- } \\
\text { cppal } \\
\text { supply. }\end{array}\right|$} & \multirow{2}{*}{$\underbrace{\text { Quality of }}_{\text {water. }}$} & \multirow{2}{*}{$\begin{array}{c}\text { Yield } \\
\text { per minute. }\end{array}$} & \multirow[b]{2}{*}{ Remarks. } \\
\hline & & & & & & & & & & & $\begin{array}{c}\text { Above } \\
\text { sea. }\end{array}$ & $\begin{array}{c}\text { Below } \\
\text { surface. }\end{array}$ & & & & & \\
\hline \multirow{8}{*}{$\begin{array}{r}\text { Alachua.............. } \\
\text { Do.............. } \\
\text { Do........... }\end{array}$} & \multirow{2}{*}{$\begin{array}{l}\text { 1 mile south........ } \\
\text { Near................ }\end{array}$} & \multirow{2}{*}{$\begin{array}{l}\text { Alachua Ice Co.... } \\
\text { Belt \& Petit...... } \\
\text { Miss S. Barton.... }\end{array}$} & W. F. Hamilton.. & 1904 & Drilled.... & Manufacturing ics. & $\begin{array}{l}\text { Feet. } \\
216\end{array}$ & $\begin{array}{c}\text { Inches. } \\
6\end{array}$ & $\begin{array}{l}\text { Feet. } \\
\text { F...... }\end{array}$ & $\begin{array}{l}\text { Feet. } \\
70\end{array}$ & $\begin{array}{l}\text { Feet. } \\
21 \frac{1}{3}\end{array}$ & $\begin{array}{c}\text { Fect. } \\
583\end{array}$ & $\begin{array}{l}\text { Feet. } \\
\text { Fet. }\end{array}$ & Feet. & Hard. & Gallons. & \\
\hline & & & 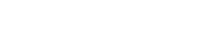 & …..... & Driven.... & Hiousehold..................... & $\begin{array}{l}68 \\
118\end{array}$ & $\begin{array}{l}2 \\
2\end{array}$ & & & & $\begin{array}{l}28 \\
106\end{array}$ & & $\cdots$ & ‥do... & a. & \\
\hline & Near......... & 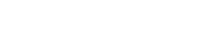 & ;....do..... & ......... & $\begin{array}{l}\text {.....do.. } \\
\text {.....do... }\end{array}$ & Stock and general. & $\begin{array}{l}40 \\
40\end{array}$ & $\begin{array}{l}2 \\
2\end{array}$ & & $a 54$ & $a 30^{\circ}$ & 24 & & t & $\cdots$ do.. & & \\
\hline & mile south. & F. E. Williams..... & \%....do.... & 1905 & …..do. & Household....... & 60 & $\overline{2}$ & ..... & 67 & 30 & $\begin{array}{l}50 \\
37\end{array}$ & & . & ...do.: & & \\
\hline & Near......... & S. W. Ban. Knight. & James Hancock... & 1900 & ....do... & Public.................. & $\begin{array}{l}\infty \\
55\end{array}$ & $\frac{2}{2}$ & 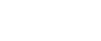 & $\cdots \cdots \cdots$ & .... & $\begin{array}{l}73 \\
28\end{array}$ & & & $\begin{array}{l}\text {...do.. } \\
\text { ‥do.. }\end{array}$ & & \\
\hline & & Mrs. M. Dowil... & 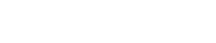 & $\begin{array}{l}1907 \\
. \ldots \ldots\end{array}$ & Natural.: & | General............. & & 36 & & $\cdots 84^{\prime}$ & $55 \frac{1}{4}$ & $\begin{array}{l}35 \\
283\end{array}$ & $\begin{array}{r}50 \\
7\end{array}$ & $\cdots \cdot$ & ado. & & Do. \\
\hline & is mile north west. & $\begin{array}{l}\text { S.A.L. Rg....... } \\
\text { S. Frei. }\end{array}$ & $\begin{array}{l}\text { James Hancock... } \\
\text { Milton Brown.... }\end{array}$ & $\begin{array}{l}1896 \\
1891\end{array}$ & …ddo... & $\begin{array}{l}\text { Drinking... } \\
\text { General... }\end{array}$ & $\begin{array}{l}61 \\
53 \\
80\end{array}$ & $\stackrel{2}{2}$ & 53 & & & $\begin{array}{l}40 \\
35\end{array}$ & 39 & 61 & ..do... & & $\begin{array}{l}\text { Protective clay. } \\
\text { Do. }\end{array}$ \\
\hline & $\begin{array}{l}3 \frac{3}{2} \text { mile northeast.. } \\
2 \frac{1}{2}\end{array}$ & $\begin{array}{l}\text { Geo. L. Taylor.... } \\
\text { Venable............... } \\
\text { Atlantic Lumbr }\end{array}$ & James Hancock... & 1903 & $\begin{array}{l}\text { Driven. } \\
\text { Drilled. }\end{array}$ & $\cdots \cdot$ & $\begin{array}{r}50 \\
116\end{array}$ & $\mathbf{3}_{3}^{2}$ & 50 & $\cdots \cdots$ & .... & $\begin{array}{r}0.35 \\
28\end{array}$ & $40^{\circ}$ & ..... & Hard........ & N........ & No protective clay. \\
\hline 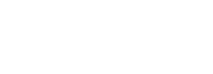 & 1 mile west... & \begin{tabular}{|c|} 
Atlantic Lumber \\
Co. \\
Gainesville IceCo.b \\
Cummer Lumber
\end{tabular} & owners............ & 1906 & Drilled... & $\begin{array}{l}\text { Ice manufacturing } \\
\text { Phosphate min- }\end{array}$ & $\begin{array}{l}300 \\
106\end{array}$ & $\begin{array}{r}6 \\
12\end{array}$ & & & & $\begin{array}{l}40 \\
47\end{array}$ & & 106 & $\begin{array}{l}\text { Sulphur.. } \\
\text { Hard.... }\end{array}$ & Many. & Incrusts boilers. \\
\hline 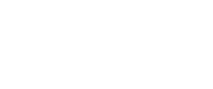 & $\frac{1}{2}$ mile east... & $\begin{array}{l}\text { Co. } \\
\text { High springs }\end{array}$ & owners.............. & 5000 & Drmed. & $\begin{array}{l}\text { ing. } \\
\text {.....do.................... }\end{array}$ & 9 & & & & & 0 & & 95 & ...do..... & Many. & $\begin{array}{l}\text { Second supply at } 47 \\
\text { feet. }\end{array}$ \\
\hline $\begin{array}{l}\text { Clyatt.... } \\
\text { Do... }\end{array}$ & & F. H. Clyatt......... & H. D. Lewis....... & 1896 & Driven..... & Irrigation ......... & 62 & 3 & & 100 & 68 & 32 & & & & & \\
\hline $\begin{array}{r}\text { Do.......... } \\
\text { Dutton....... }\end{array}$ & 1 mile west.... & 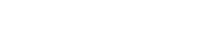 & summer Bros...... & 1896 & $\begin{array}{l}\text { …..do.. } \\
\text { …do.do.. }\end{array}$ & Household......... & $\begin{array}{l}55 \\
62\end{array}$ & $\frac{2}{2}$ & & $\begin{array}{r}103 \\
90\end{array}$ & $\begin{array}{l}68 \\
70\end{array}$ & ${ }_{20}^{35}$ & & ... & $\begin{array}{l}\text { Hard.. } \\
\text {...do... }\end{array}$ & …..... & \\
\hline Dutton........ & $\frac{1}{8}$ mile south... & $\begin{array}{l}\text { Dutton Phosphate } \\
\text { Co.b }\end{array}$ & ............................. & & & Washing phos- & 119 & 12 & & & & 50 & 44 & 50 & ...do.... & 1,000 & \\
\hline Do......... & $1 \frac{1}{2}$ miles west... & .....do... & $\begin{array}{l}\text { Claude B. Ander- } \\
\text { son. }\end{array}$ & 1905 & Drilled............ & 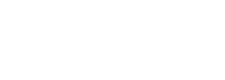 & 180 & 12 & 40 & 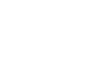 & 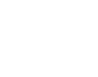 & 50 & 30 & 50 & & 600 & $\begin{array}{l}\text { Starts in sand. Water } \\
\text { from Vicksburgian } \\
\text { limestones. }\end{array}$ \\
\hline Evinston...... & Near.................. & J. L. Wolfenden $b_{-.}$ & $\cdots .$. & & (n...................... & House and farm... & 126 & 2 & & & & 60 & 120 & 120 & & & $\begin{array}{l}\text { Some water below } \\
\text { principal supply. }\end{array}$ \\
\hline Gainesville.. & $\frac{1}{2}$ mile southwest.. & $\begin{array}{l}\text { American Oil \& } \\
\text { Chemical Co. }\end{array}$ & W. F. Hamilton.. & 1890 & Drilled.............. & Ice manufacturing. & 347 & 8 & $\begin{array}{r}140 \text { or } \\
160\end{array}$ & $126 \pm$ & $50 \pm$ & $76 \pm$ & & ..... & Hard...... & …...... & \\
\hline $\begin{array}{l}\text { Do........ } \\
\text { Do....... } \\
\text { Do...... }\end{array}$ & 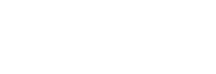 & $\begin{array}{l}\text { Citt.................. } \\
\text { Diamond Toe } \\
\text { B. F. Williamson }\end{array}$ & 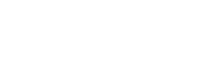 & 1907 & $\begin{array}{l}\ldots \ldots \text { do... } \\
\text { Drillied... }\end{array}$ & $\begin{array}{l}\text { City supply........ } \\
\text { Ice manulacturing. } \\
\text { Manufacturing.... }\end{array}$ & $\begin{array}{l}194 \\
316 \\
276\end{array}$ & $\begin{array}{r}12 \\
8 \\
8\end{array}$ & $\begin{array}{r}160 \\
150 \\
160\end{array}$ & $\begin{array}{r}82 \\
178 \\
180\end{array}$ & $\begin{array}{r}50-68 \\
55 \\
52\end{array}$ & $\begin{array}{r}31,32 \\
78 \\
128\end{array}$ & $\cdots .$. & 194 & \begin{tabular}{l}
..do... \\
\hdashline do. \\
$\cdots$ do
\end{tabular} & 300 & Protective clay. \\
\hline $\begin{array}{l}\text { Haile ....................... } \\
\text { High Springs... }\end{array}$ & 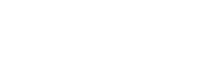 & 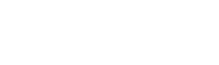 & s. w. Young...... & 1908 & $\begin{array}{l}\text { Drme.... } \\
\ldots \ldots . \text { do.... } \\
\cdots . . \text { do... }\end{array}$ & $\begin{array}{l}\text { Manufacturing..... } \\
\text { Household........ }\end{array}$ & $\begin{array}{r}276 \\
264 \\
45\end{array}$ & $\begin{array}{l}8 \\
2 \\
2\end{array}$ & & & & $\begin{array}{r}128 \\
46 \\
30\end{array}$ & 140 & & $\begin{array}{l}\text { \%do... } \\
\cdots \text { do... } \\
\ldots \text { do... }\end{array}$ & & Do. \\
\hline Melrose.... & & High Springs Ice & & 1902 & …............................ & & 70 & 4 & & & & 28 & & & ...do............. & & \\
\hline Do & Mear.................... & \begin{tabular}{c} 
С. P. Huffman.... \\
\hdashline$\ldots$ do..................
\end{tabular} & 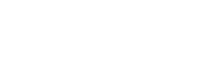 & $\begin{array}{l}1892 \\
1897\end{array}$ & $\begin{array}{l}\text { Driven........ } \\
\text { Oppen and driven. }\end{array}$ & 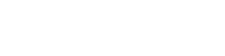 & $\cdots$. & $\begin{array}{l}1 \frac{1}{4} \\
13\end{array}$ & & & & 38 & & & $\begin{array}{l}\text { Sulphur... } \\
\text { Soft....... }\end{array}$ & & \\
\hline Do.... & i mile west. & $\begin{array}{l}\text { S. G. Gay } \\
\text { C. E. Melton............ }\end{array}$ & Dibble \& Earnest. & 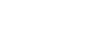 & 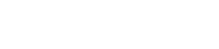 & 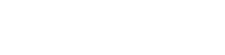 & $\begin{array}{r}60 \\
151\end{array}$ & $\begin{array}{l}2 \\
5 \frac{8}{8}\end{array}$ & & $\begin{array}{l}100 \\
110\end{array}$ & $\mathbf{7 2}$ & 38 & & & $\begin{array}{l}\text { Hard........ } \\
\ldots \text {..do........ }\end{array}$ & $\cdots \cdot \cdot$ & \\
\hline Do.... & $\begin{array}{l}2 \frac{1}{1} \text { miles northwest. } \\
\frac{2}{2} \text { miles southeast. }\end{array}$ & $\begin{array}{l}\text { Dr. Montgomery .. } \\
\text { M. E. Schlater b... }\end{array}$ & Brown Bros........ & & 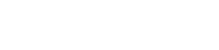 & Sprigating and & $\begin{array}{r}91 \\
160\end{array}$ & $\begin{array}{l}3 \\
5\end{array}$ & & 100 & 35 & $\begin{array}{c}65 ? \\
0\end{array}$ & & 150 & ...do....... & Many. & \\
\hline Newberry..... & 3 blocks south.... & 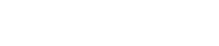 & & & & Aban & $60 \pm$ & & & 72 & & & 5 & & & & \\
\hline & 6 miles northwest. & $\begin{array}{l}\text { Julia Gray } \\
\text { M. Langford............... }\end{array}$ & 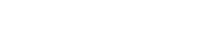 & $\begin{array}{l}1906 \\
\ldots \ldots\end{array}$ & 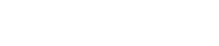 & Housel & $\begin{array}{r}52 \\
102\end{array}$ & $\begin{array}{l}2 \\
2\end{array}$ & & 69 & 35 & $\begin{array}{r}34 \\
\ldots \ldots\end{array}$ & $\begin{array}{l}22 \\
96\end{array}$ & & ...do... & & \\
\hline Do............... & $\begin{array}{l}1 \text { mile northwest.. } \\
1 \text { mile northwest.. }\end{array}$ & $\begin{array}{l}\text { a. W. Livingston. } \\
\text { John McDowell... }\end{array}$ & 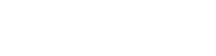 & 1896 & Dug 39 feet; bored & $\begin{array}{l}\text { Household................. } \\
\text { Phosphate ming. }\end{array}$ & $\begin{array}{r}55 \\
119\end{array}$ & $\begin{array}{r}\overline{2} \\
10\end{array}$ & $\cdots \cdot \cdot$ & 72 & $34-32$ & $\begin{array}{r}38-40 \\
38\end{array}$ & & iiig & (..do..... & 800 & Incrusts boilers. \\
\hline Do...... & 1 mile west........ & …..do...................... & .....do................ & & $\begin{array}{l}80 \text { feet. } \\
\text { Dug } 39 \text { feet; bored }\end{array}$ & ....do.... & 110 & 10 & & & & 40 & $\cdots$ & 110 & ...do..... & & Incrusts boilers, second \\
\hline Do......... & 6 miles west....... & D. McKinmon \& & G. W. Livingston. & & Driven............. & Turpentine still... & 102 & 2 & & & & 32 & 23 & & & & ;0 feet. \\
\hline Do......... & 2 miles northwest. & c. F. Weston...... & Owner............... & 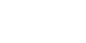 & Dug 38 foet; bored & Phosphate mining. & 123 & 12 & & $\cdots$ & & 37 & $\cdots$ & 123 & Hard.... & & Second supply at 37 \\
\hline Do........... & 2 miles northwest. & $\begin{array}{l}\text { C.D. May.............. } \\
\text { G.D. Younglove }\end{array}$ & G. W. Livingston. & 1899 & Driven... & $\begin{array}{l}\text { Household......... } \\
\text { W ashing phos- }\end{array}$ & $\begin{array}{l}113 \\
120\end{array}$ & $\begin{array}{r}2 \\
10\end{array}$ & & 76 & 36 & $\begin{array}{l}40 \\
40\end{array}$ & $\dddot{40}$ & $100^{\circ} \longrightarrow{ }^{1}$ & ...do......... & Many. & \\
\hline Osceola......... & $\frac{1}{2}$ mile southwest.. & Royal Phosphate & & & $400 \ldots$ & 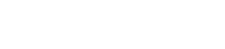 & 140 & 8 & & & & 50 & & 140 & & & \\
\hline $\begin{array}{l}\text { Paimer.............. } \\
\text { Do.......... } \\
\text { Rocheli } 9 . \ldots\end{array}$ & f mile north....... & $\begin{array}{l}\text { Dr. Strataway.... } \\
\text { J. E. Weigelsworth. }\end{array}$ & $\begin{array}{l}\text { James Hancock... } \\
\text { Owner............ }\end{array}$ & $\begin{array}{l}1898 \\
1902\end{array}$ & $\begin{array}{l}\text { Drilled............... } \\
\text { Open................ }\end{array}$ & & $\begin{array}{r}145 \\
31\end{array}$ & 2 & 135 & & & $\begin{array}{r}120 \\
27\end{array}$ & $\begin{array}{r}130 \\
31\end{array}$ & & $\begin{array}{l}\text { Hard..... } \\
\ldots \text {. do...... }\end{array}$ & & No protective clay. \\
\hline $\begin{array}{l}\text { Rohehelle............. } \\
\text { Traxler........... }\end{array}$ & 2 miles north.......... & $\mid$ & & 1898 & 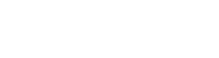 & $\begin{array}{l}\text { Locomotives....... } \\
\text { Domestic.......... }\end{array}$ & $\begin{array}{l}325 \\
112\end{array}$ & 6 & & $\begin{array}{c}80 \\
a 100+\end{array}$ & 70 & 10 & & & ...do...... & c 200,000 & $\begin{array}{l}\text { Deepest well in neigh- } \\
\text { borhood. Starts in }\end{array}$ \\
\hline $\begin{array}{l}\text { Tyler........... } \\
\text { Wades....... }\end{array}$ & Near......................... & Tyler Lumber Co. & G. W. Livingston. & 1904 & ....do........................ & Sawmill & 88 & $\frac{43}{2}$ & & & & 4 & & & ...do. & $\cdots \cdot \cdot$ & \\
\hline Do.............. & 24 miles southwest. & $\begin{array}{l}\text { Rley \& Anderson. } \\
\text { F. M. Ramsay.... }\end{array}$ & owner..................... & 1903 & 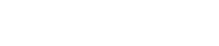 & $\begin{array}{l}\text { Housenald..... } \\
\text { Irrigation.... }\end{array}$ & $\infty$ & ${ }_{4}^{2}$ & & $\begin{array}{l}69 \\
65\end{array}$ & $\begin{array}{l}31 \\
61\end{array}$ & $\begin{array}{r}38 \\
4\end{array}$ & $\cdots$ & 54 & Hard, sul- & 120 & \\
\hline 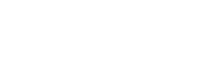 & $\begin{array}{l}21 \text { milles southwest. } \\
\text { Near................... }\end{array}$ & wiloox Ćhemical & a. W. to tivingston. & $\begin{array}{l}1900 \\
1908\end{array}$ & 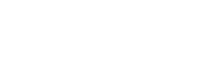 & Distillation of tur- & 48 & $\frac{4}{7}$ & …..... & $90 \pm$ & $62 \pm$ & $\begin{array}{l}28 \\
25\end{array}$ & 34 & $\begin{array}{l}48 \\
49\end{array}$ & 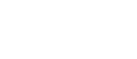 & $\begin{array}{l}200 \\
\cdots \cdots .\end{array}$ & Second supply at 25 \\
\hline Willeford....... & & Atlantic Lumber & & & ...do. & & 148 & 2 & & & & 5 & No & & Soft..... & & \\
\hline & 2 miles north...... & $\begin{array}{l}\text { Co. Green....... } \\
\text { Chas. Green... }\end{array}$ & & .... & ....do.... & Turpentine still... & 79 & 2 & & & & 38 & & & Hard..... & & \\
\hline 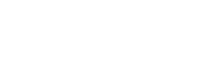 & t mile north....... & E. T. Finklen...... & Owner... & $1900^{\circ}$ & Driven... & & & 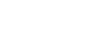 & & & & & & & ...do.. & & \\
\hline Do............... & mile south........ & J. A. Roseborough. & Turner... & 1906 & Drilled... & Abandoned..... & & $2 \mathbf{t}$ & & & & $\cdots$ & 60 & & ...do & & \\
\hline
\end{tabular}


Springs in Alachua County.

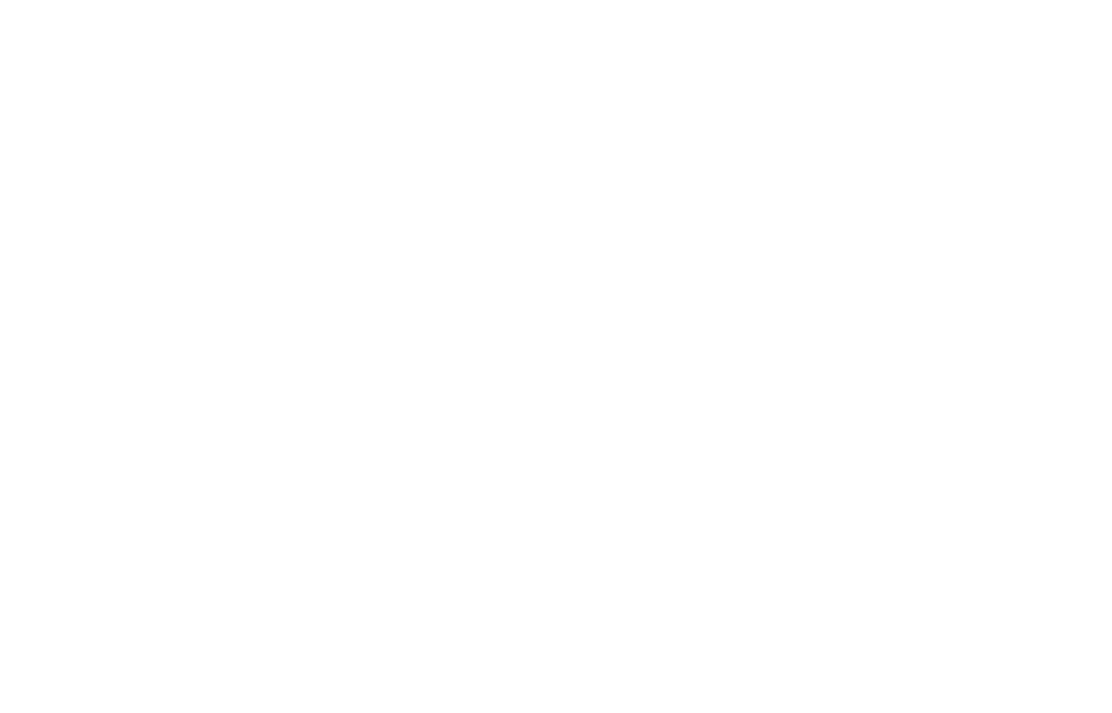

\section{BAKER COUNTY.}

By G. C. Matson.

\section{GENERAL FEATURES.}

Baker County lies in the northeastern part of the State and extends about 25 miles southward from the Georgia-Florida line. The county contains no large streams, but a portion of its eastern boundary is formed by St. Marys River, and a branch of this stream crosses its southern end. Olustee Creek heads in Ocean Pond and flows southwestward to Suwannee River. Okefenokee Swamp, which occupies a large area in Georgia, extends a short distance across the boundary line into Baker County, but with this exception the surface of the county is rolling and well drained.

\section{GEOLOGY.}

Loose gray sands form the entire surface of Baker County. Beneath are red and yellow sands and sandy clays referred to the Lafayette (?) formation, and beneath the latter are rocks of Oligocene age. So far as is now known, no rocks of Miocene age are exposed in the county, and if any exist they are probably effectually concealed by the younger beds. The Oligocene rocks are covered by the younger formations, but their presence beneath the surface is readily inferred from the known stratigraphy. 
The gray sand which covers the surface of the county is in few places more than a few feet thick, and in many places on the upland is less than 5 feet. The sands and sandy clays of the Lafayette (?) formation have a maximum thickness of over 50 feet but do not average more than 25 to 30 feet. No direct information is available concerning the thickness of the Oligocene formations in Baker County, but from conditions in neighboring counties the thickness of the Vicksburgian limestones should amount to several hundred feet.

\section{WATER SUPPLY.}

Source.-Nearly all the wells in Baker County obtain their supplies from the red and yellow sand and sandy clays, though a few wells may draw from the surficial gray sand and some of the deeper wells may reach the older geologic formations. The amount of water supplied by the sands is sufficient for domestic and farm uses and in a few localities is large. The water level is near enough to the surface to make pumping easy, and in most wells suction pumps are used.

Quality.-The shallow-well water is reported to be soft, but water from deeper wells would doubtless be hard and in some localities might contain hydrogen sulphide.

Development.-In Baker County the water now being used is taken from shallow wells which may be subject to pollution, especially when located near dwellings. The Vicksburgian limestones underlie the county, and would form a much better source of supply, though the water would undoubtedly be hard and might contain some sulphur, especially near the eastern boundary of the county. The depth to this limestone can not be stated with certainty, but wells drilled on the uplands should encounter it between 250 and 500 feet. Flowing wells can not be obtained, but the water should rise near enough to the surface to be raised with deep-well pumps. The quantity available would be practically unlimited.

The town of Macclenny owns a driven well $1 \frac{1}{4}$ inches in diameter and 23 feet deep, the water of which it uses for drinking. The elevation of the well is 125 feet above sea level and the head is several feet below the surface. The water, which is soft, comes from sands. 
General water resources of Baker County.

\begin{tabular}{|c|c|c|c|c|c|c|c|c|}
\hline \multirow{2}{*}{ Town. } & \multirow{2}{*}{$\begin{array}{c}\text { Topographic } \\
\text { location. }\end{array}$} & \multirow{2}{*}{\multicolumn{2}{|c|}{ Source of water. }} & \multirow{2}{*}{\multicolumn{2}{|c|}{$\begin{array}{c}\text { Surface } \\
\text { formation. }\end{array}$}} & \multicolumn{3}{|c|}{ Shallow wells. } \\
\hline & & & & & & Depth. & Supply. & $\begin{array}{l}\text { Quality } \\
\text { of water. }\end{array}$ \\
\hline $\begin{array}{l}\text { Macclenny ... } \\
\text { Olustee........ } \\
\text { Sanderson.... }\end{array}$ & $\begin{array}{l}\text { Level....... } \\
\ldots . . \text { do........ } \\
\ldots . . \text { do....... }\end{array}$ & \multicolumn{2}{|c|}{$\begin{array}{l}\text { Driven and dug } \\
\text { wells. } \\
\ldots \ldots \text { do.................... } \\
\text { Driven and drilled } \\
\text { wells. }\end{array}$} & \multicolumn{2}{|c|}{ 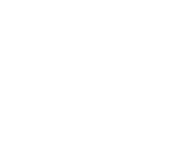 } & $\begin{array}{c}\text { Feet. } \\
10-40 \\
8-12\end{array}$ & $\begin{array}{l}\text { Ample.... } \\
\ldots \text { do } \ldots . . . . \\
\ldots \text { do....... }\end{array}$ & $\begin{array}{l}\text { Soft. } \\
\text { Do. }\end{array}$ \\
\hline Town. & \multicolumn{2}{|c|}{ Principal water bed. } & $\begin{array}{c}\text { Depth } \\
\text { of } \\
\text { deepest } \\
\text { wells. }\end{array}$ & $\begin{array}{c}\text { Average } \\
\text { thick- } \\
\text { ness } \\
\text { of sand. }\end{array}$ & $\begin{array}{c}\text { Depth } \\
\text { to } \\
\text { water. }\end{array}$ & \multicolumn{3}{|c|}{ Remarks. } \\
\hline $\begin{array}{l}\text { Macclenny ... } \\
\text { Olustee....... } \\
\text { Sanderson.... }\end{array}$ & \multicolumn{2}{|c|}{$\begin{array}{l}\text { "Peninsular" lime - } \\
\text { stone. } \\
\ldots \ldots \text { do }\end{array}$} & $\begin{array}{r}\text { Feet. } \\
40 \\
\\
\\
83\end{array}$ & $\begin{array}{c}\begin{array}{c}\text { Feet. } \\
10 \pm \\
\\
\text { Thin. }\end{array} \\
\text { The }\end{array}$ & $\begin{array}{l}\text { Feet. } \\
\text { Few. } \\
\cdots \\
\cdots\end{array}$ & \multicolumn{2}{|c|}{$\begin{array}{l}\text { Supply constant; } \\
\text { system. } \\
\text { No sewerage system. } \\
\text { Do. }\end{array}$} & no sewerage \\
\hline
\end{tabular}

\section{BRADFORD COUNTY.}

By G. C. Matson.

\section{GENERAL FEATURES.}

Bradford County lies near the northern end of the peninsula and includes some of the highest land in that part of the State. Trail Ridge, which forms the divide between the Atlantic and the Gulf drainage, is a long narrow upland extending nearly north and south near the eastern border of the county. Highland, Clay County, 210 feet above sea level, is situated on this upland. The surface of the county is rolling and well drained, though it includes a few small ponds and lakes, especially on the upland.

\section{GEOLOGIC FORMATIONS.}

Distribution.-The surface of Bradford County is covered with a mantle of gray sand which forms a thin coating on red and yellow sands and sandy clays that are referred to the Lafayette (?) formation. Rocks of Miocene age belonging to the Jacksonville formation are doubtless present, but as yet they have not been observed. The formations of the Apalachicola group probably underlie a large part of the surface of the county; beneath these are the Vicksburgian limestones.

Thickness.-Owing to the absence of good well logs, the thickness of the various formations could not be satisfactorily determined. The gray sand probably averages less than 5 feet, and the subjacent 
red and yellow sands and sandy clays in few places exceed 50 to 65 feet. It is thought that the Apalachicola group may reach its maximum thickness in Trail Ridge, but this could not be confirmed because it was impossible to obtain a record of the deep well at Starke. There is no reason to doubt that the Vicksburgian limestones, as at St. Augustine, have a thickness of several hundred feet.

\section{WATER SUPPLY.}

Source.- The Lafayette (?) formation furnishes water for the shallow wells in Bradford County. Many of the deeper wells appear to obtain water from the Jacksonville or from the formations of the Apalachicola group, but in many wells considerable doubt exists concerning the exact source of the supply. The deep well at Starke must penetrate some distance into the Vicksburgian limestones, and presumably it obtains its water supply from them.

Quality.-In Bradford County the water from the Lafayette (?) formation is reported to be soft, but that from all the deep wells is hard. One well, near Providence, is reported to have encountered salt water and another to have procured water containing sulphur, but such waters appear to be rare, though they doubtless occur throughout the county at a depth of several hundred feet.

Development.-Few of the shallow wells of Bradford County exceed 30 feet in depth, and some of them are less than 10 feet. The depth to water varies with the nature of the materials and the topographic situation, but in few wells is it more than a few feet. Most of the deep wells are less than 150 feet, though one at Starke is 529 feet. Water in the deep wells stands some distance below the surfacein some nearly 100 feet, but in most from 50 to 70 feet below. This makes it necessary to use deep-well pumps and increases the cost of raising the water; but in spite of the added expense these wells are believed to be much more desirable than the shallow, because they are freer from danger of contamination by surface drainage.

Springs are numerous in Bradford County, but few of them are large. The most important are the two Heilbron Springs, near Starke, and the Worthington Spring, near the town of the same name. The water from one of the Heilbron Springs was formerly bottled and sold for medicinal use. Worthington Spring is a health and pleasure resort. The water is used as a source of public supply and for a swimming pool; some of it is bottled for the market. 


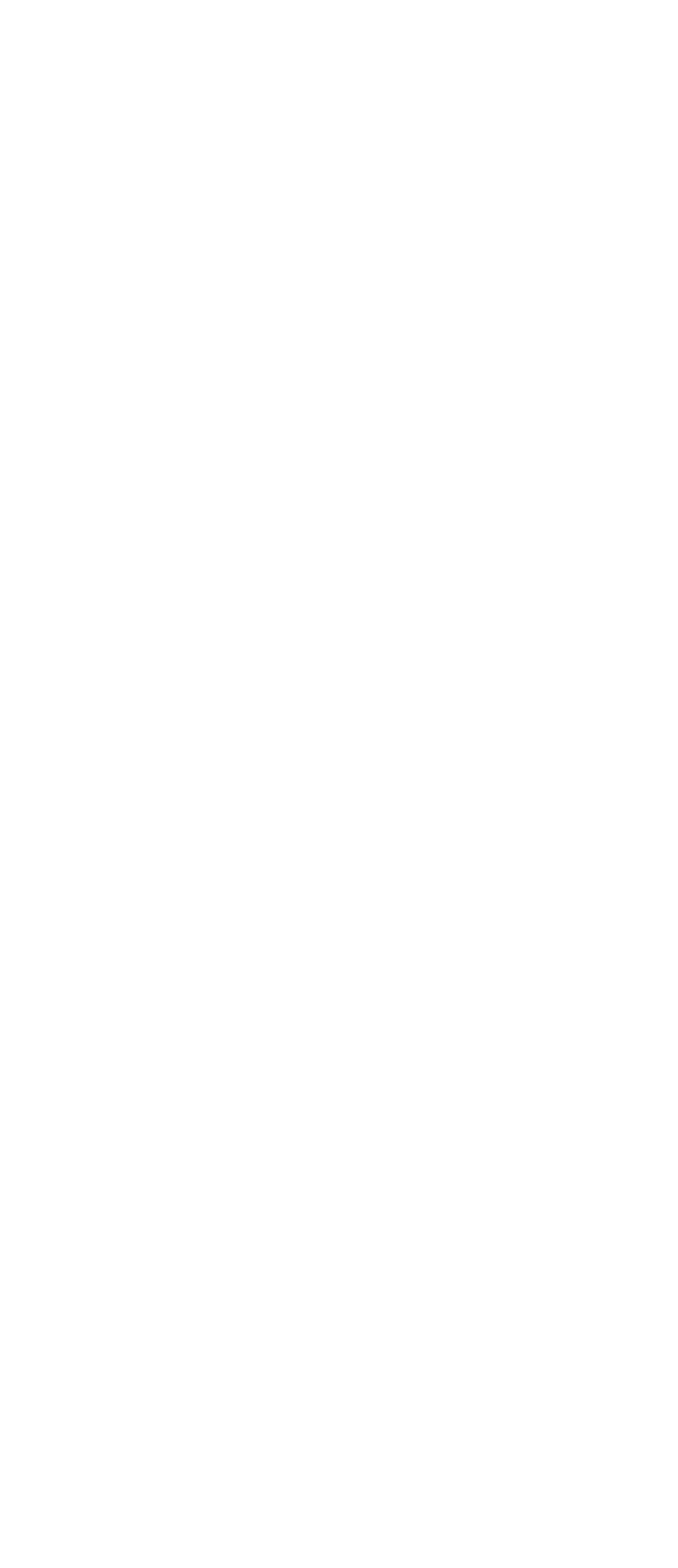



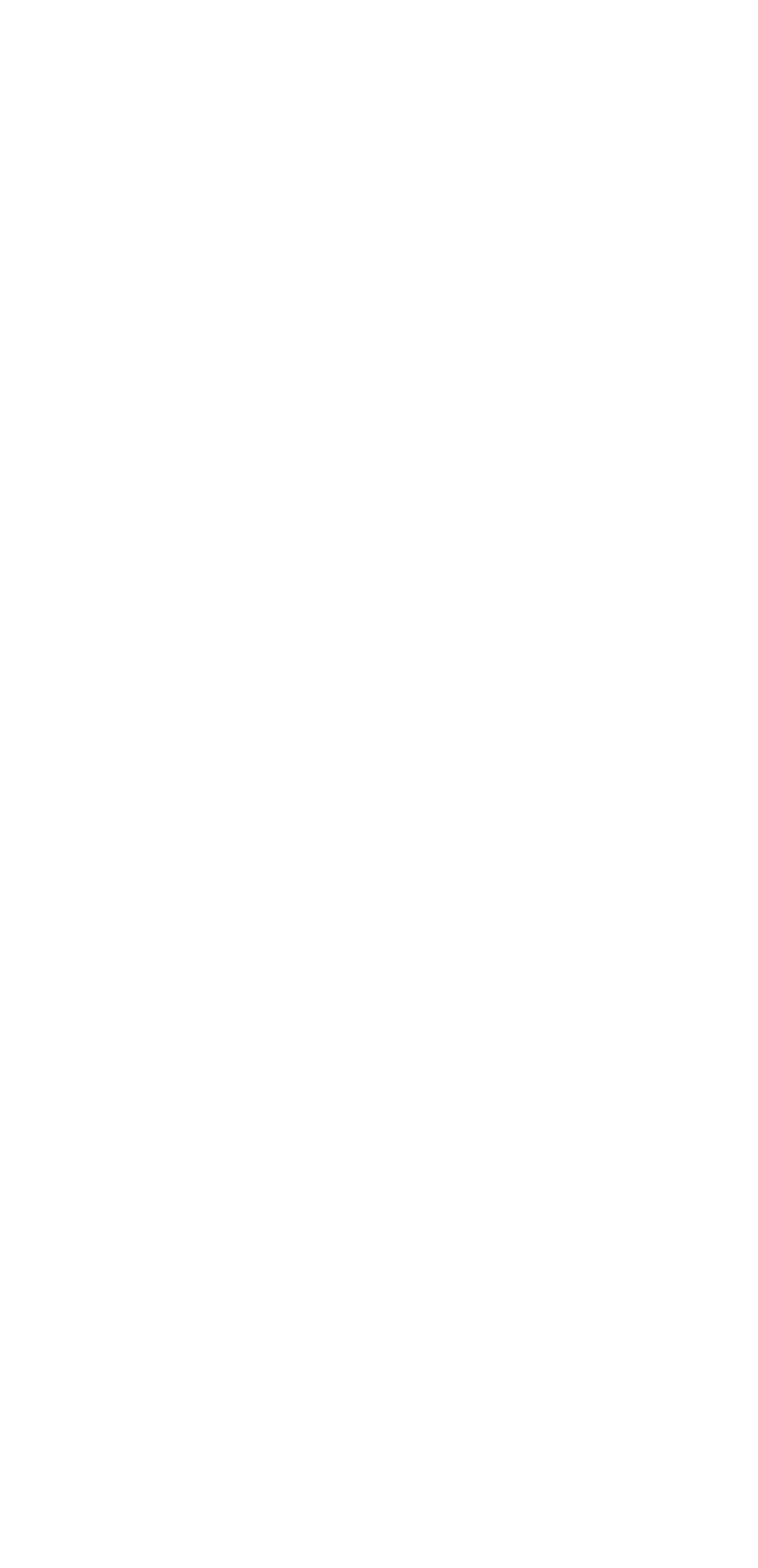


\section{BREVARD COUNTY.}

By G. C. Matson.

\section{GENERAI FEATURES.}

Brevard County occupies a long narrow strip of the mainland on the east side of the peninsula, and includes a large island (Merritts) and some smaller islands and bars. Its surface is a flat plain less than 50 feet-over large areas less than 25 feet-above sea level. Swamps and shallow lakes are numerous, some of them being of considerable size. The most important inland body of water is Lake Washington, near the source of St. Johns River. Some smaller lakes west of Titusville are of interest because they contain brackish water, probably derived from springs and seeps, that have leached salt from sands and muds deposited on broad tidal floods or in lagoons formed when the land was slightly lower than it is at present. Many of the lakes are but a few inches deep and exist only during wet weather.

The only important stream in Brevard County is St. Johns River, which heads in the county and flows west of north, roughly paralleling the coast for a long distance before it turns eastward to the Atlantic.

\section{GEOLOGY.}

The surface deposits of Brevard County consist of light-gray Pleistocene sands. Beneath these sands are marls, limestones, or coquina, which in some places lie close to the surface and in others are buried beneath several feet of the sand. These subsurface materials vary from place to place. West of Eau Gallie a soft shell marl consists of well-preserved remains of shellfish, similar to those now living on the adjacent coast, embedded in a matrix of nearly pure sand; and along the coast extensive exposures of coquina are composed of loosely cemented shells and shell fragments mixed with more or less sand. This coquina extends for some distance inland, in some places, as at Mims and near Titusville, forming ridges beneath the sand. A hard compact limestone underlies Merritts Island, and extends beneath Indian River.

Both limestone and coquina are regarded as Pleistocene, though they are older than the surface sands. Beneath them are sands and clays, which probably represent the Pliocene and Miocene, but which, in the absence of satisfactory evidence, must be regarded as of doubtful age. At a depth of approximately 200 feet limestones and cherts, clearly of Vicksburg age, are encountered.

The sections given below show the general character of the subsurface formations at certain localities in Brevard County. The thickness of the Vicksburgian limestones is not known, but to judge 
from well samples obtained farther north it may amount to several hundred feet. The aggregate thickness of all the younger formations in few localities exceeds 200 feet.

Log of Mrs. May Young's well, East Eau Gallie (sec. 21, T. 27 S., R. 37 E.).

\begin{tabular}{|c|c|c|}
\hline & Thickness. & Depth. \\
\hline 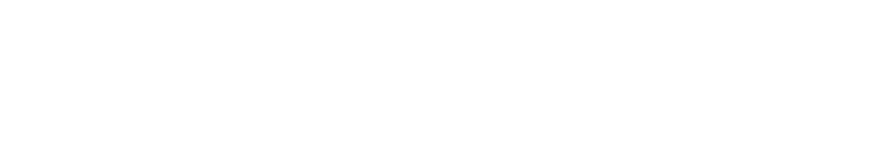 & $\begin{array}{r}\text { Feet. } \\
95 \\
25 \\
55 \\
55 \\
85\end{array}$ & $\begin{array}{r}\text { Feet. } \\
95 \\
120 \\
175 \\
230 \\
315\end{array}$ \\
\hline
\end{tabular}

The fossils obtained between 230 and 315 feet are characteristic of the Ocala limestone and it is probable that the top of this limestone was encountered between 175 and 230 feet.

Sellards has furnished the $\log$ of a well on the island opposite Melbourne.

Log of well on island opposite Melbourne.

\begin{tabular}{|c|c|c|}
\hline & Thickness. & Depth. \\
\hline 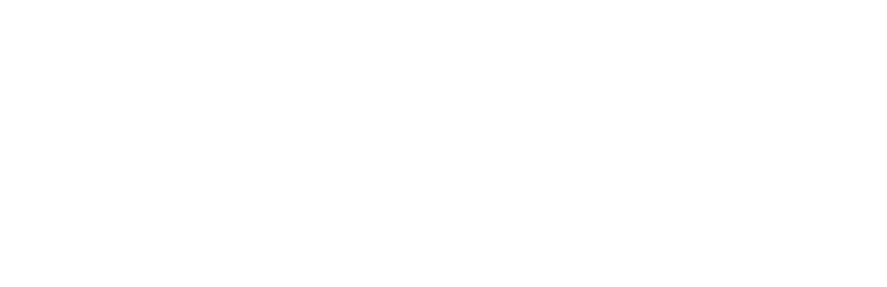 & $\begin{array}{r}\text { Feet. } \\
3 \\
8 \\
10 \\
30 \\
5 \\
63 \\
54 \\
\\
\frac{1}{2} \\
\frac{3}{3} \\
46^{3} \\
46 \\
96\end{array}$ & $\begin{array}{r}\text { Feet. } \\
3 \\
11 \\
21 \\
51 \\
56 \\
119 \\
173 \\
173 \frac{1}{2} \\
174 \frac{1}{6} \\
174 \frac{8}{6} \\
220_{6}^{6} \\
316_{6}^{5}\end{array}$ \\
\hline
\end{tabular}

From the soft limestone at $\mathbf{2 2 2}$ feet Sellards identified nummulites, which indicates that the rock belongs to the Ocala limestone of the Vicksburg group.

A well at Canaveral Lighthouse is reported to have penetrated the following materials:

Log of well at Canaveral Lighthouse.

\begin{tabular}{|c|c|c|}
\hline & Thickness. & Depth. \\
\hline 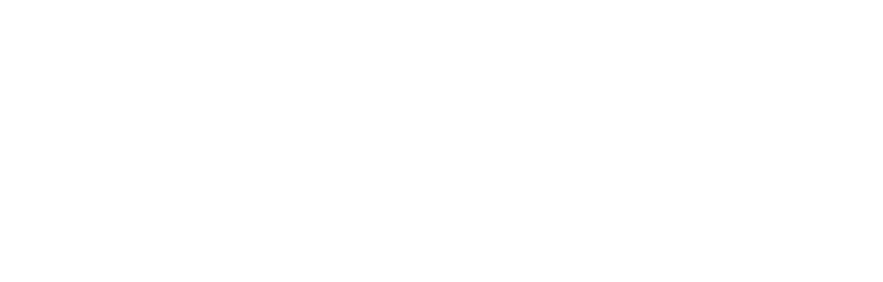 & $\begin{array}{r}\text { Feet. } \\
2 \\
2 \\
20 \\
25 \\
15 \\
1 \\
10 \\
10 \\
40 \\
10 \\
50 \\
128\end{array}$ & $\begin{array}{r}\text { Feet. } \\
2 \\
4 \\
24 \\
49 \\
64 \\
65 \\
75 \\
85 \\
125 \\
135 \\
185 \\
313\end{array}$ \\
\hline
\end{tabular}


It is difficult to decide from this log where the Vicksburgian limestones were encountered, but they probably include all of the last 128 feet of the section.

At Eau Gallie well logs indicate considerable variation in the character of the materials penetrated. A generalized log of wells of this locality was supplied by Capt. Alexander Near, who has drilled many deep wells.

Generalized $\log$ of wells at Eau Gallie.

\begin{tabular}{|c|c|c|}
\hline & Thickness. & Depth. \\
\hline 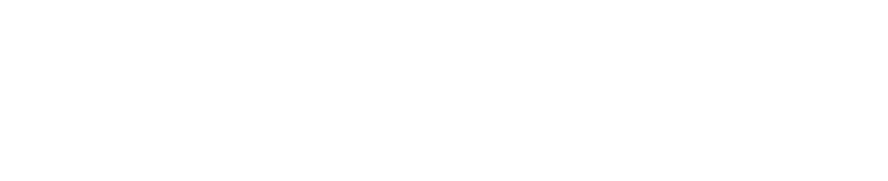 & $\begin{array}{r}\text { Feet. } \\
65 \\
100 \\
65 \\
7-\frac{5}{7} \\
6-1 \\
75 \\
185\end{array}$ & $\begin{array}{r}\text { Feet. } \\
65 \\
165 \\
230 \\
231 \\
232 \\
307 \\
492\end{array}$ \\
\hline
\end{tabular}

The bluish clay forming the third member of this log is of variable thickness and is sometimes entirely wanting. It probably represents the Miocene or upper Oligocene. The Vicksburgian limestones appear to have been encountered at about 230 feet.

WATER SUPPLY.

Source.-In Brevard County there are two principal sources of water. Shallow wells obtain ample supplies from the Pleistocene sands, and deep wells find water in the limestones of the Vicksburg group. These limestones yield a very large supply under head sufficient to give strong flows several feet above the surface. These facts are shown in the accompanying table of well records (p. 276) and though it is apparent that there is considerable variation in the yield and head of the different wells, yet for many the estimates are probably below the maximum. This is especially true of the height to which the water will rise; the head given being generally the height to which the water does rise and not the height to which it would rise if the casing were extended higher above the surface. The most reliable information indicates that the head at Eau Gallie is about 50 feet above sea level. Elsewhere in the county the water does not rise so high, though it flows several feet above the surface along the entire eastern border.

The head of the water from the Pleistocene sands is not sufficient to furnish flows except on very low ground. The only flowing well from this deposit is in low ground in the village of Melbourne and its yield is comparatively small.

The water level in the nonflowing wells is near the surface, and the water can be readily raised by small hand pumps. 
Quality.-The water from the Pleistocene sands is usually soft, but in some localities it may be rendered objectionable by the presence of organic matter. This is especially true in the vicinity of Titusville, where shallow well water is reported to contain acid, which is presumably derived from the palmetto trees. Locally this water supply may also become contaminated by drainage from dwellings. The Vicksburgian limestones furnish hard sulphur water, which is satisfactory for general uses except where it contains an excessive quantity of salt. In one area in the vicinity of Titusville all of the deep waters are more or less saline. Probably the maximum salinity is reached at Titusville, and the water becomes purer both north and south from that locality. At Sharpes, although it still contains considerable quantities of salt, it is fairly satisfactory for use in irrigating orange groves and is used to a considerable extent for domestic supplies. The area yielding salt water is reported to extend northward nearly to Oak Hill, but in that direction the well records are few and the quality of the water is not well known.

At Courtenay, on Merritts Island, the water is satisfactory for irrigation and can be used for domestic supply; at Canaveral Lighthouse a satisfactory supply of water is obtained from Vicksburgian (?) limestones. South of Sharpes some of the deeper wells are said to contain saline water, though most of the flowing wells yield water satisfactory for all general uses. The cause for the salinity of the limestone waters in the vicinity of Titusville is not entirely clear, but it may be due to the leaching of salt from the Pleistocene sands near the western border of the county, or the beds may have been filled with salt water when this region was submerged during Pleistocene time. It is worthy of note that the head of the artesian water at Titusville is only a few feet above sea level, and this suggests that the artesian beds are not protected by a continuous layer of hard rock.

Development.-Springs are not important sources of water in Brevard County, but both shallow and deep wells are extensively utilized. The shallow wells range in depth from 15 to 25 feet; a few do not exceed 10 feet, and the deeper ones are about 30 feet. The water obtained from these wells is ample for all ordinary purposes, but in some places are subject to pollution from impure surface waters sinking into the sand and descending to the permanent groundwater level.

Along the east coast wells 150 to 250 feet deep may yield flowing water, but larger supplies must be obtained by deep drilling. Some of the wells are 300 to 500 feet deep, but supply water highly mineralized. Near Titusville satisfactory artesian supplies can not be obtained. Southward along the coast hard sulphur water is usually encountered at depths between 150 and 250 feet, and farther inland similar sup- 
Principal wells of Brevard County.

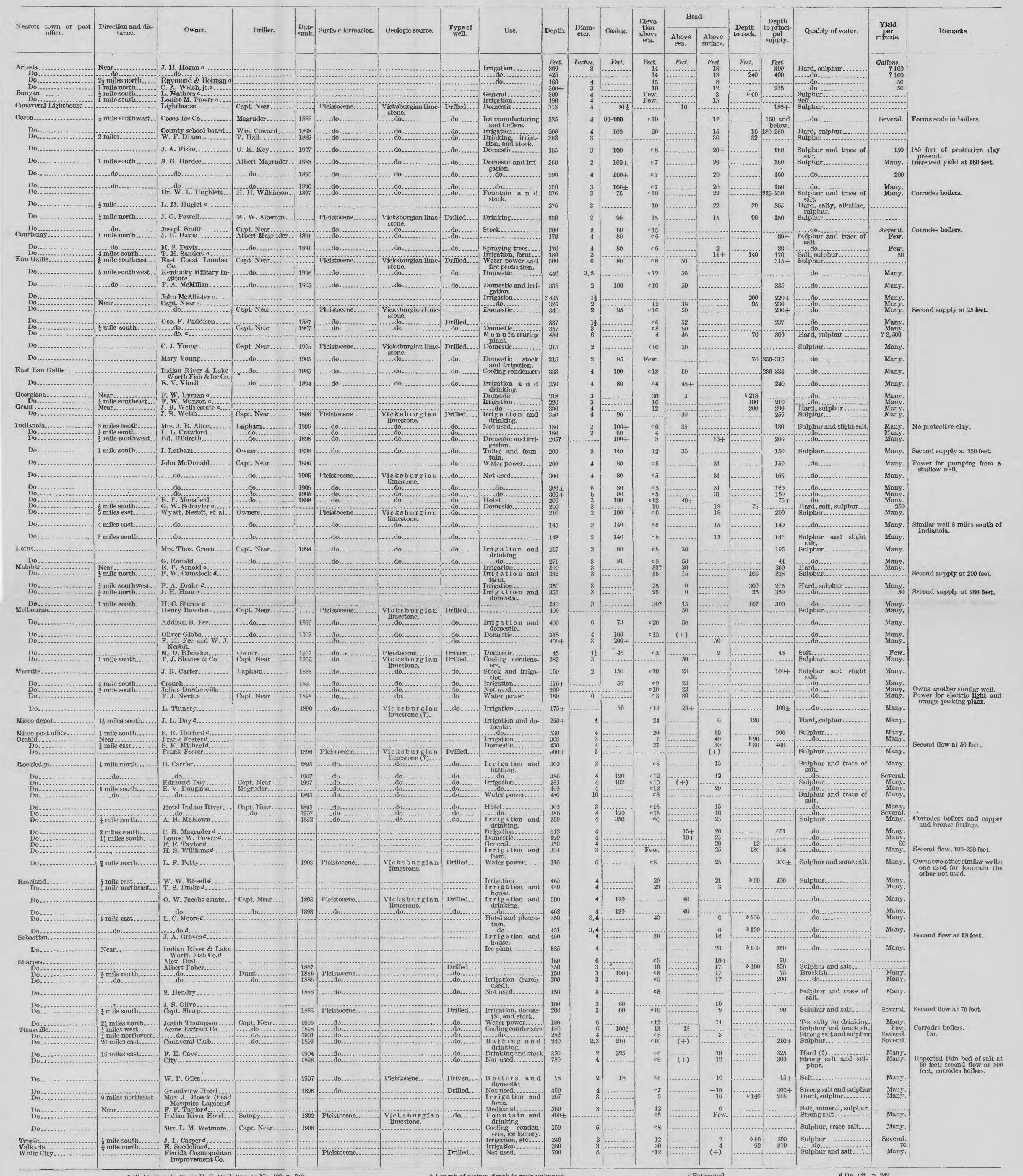


plies could doubtless be obtained. There are no public water supplies in Brevard County, and Titusville is the only town likely to need such a supply in the near future. Owing to the fact that the deep water at this locality is saline, it will be necessary to rely on shallow wells. A satisfactory supply from this source can probably be obtained a short distance from the town.

General water resources of Brevard County.

\begin{tabular}{|c|c|c|c|c|c|c|c|c|c|c|c|}
\hline \multirow{2}{*}{ Town. } & \multirow{2}{*}{$\begin{array}{c}\text { Topo- } \\
\text { graphic } \\
\text { loca- } \\
\text { tion. }\end{array}$} & \multirow{2}{*}{\multicolumn{4}{|c|}{ Source of water. }} & \multirow{2}{*}{\multicolumn{2}{|c|}{ Surface formation. }} & \multicolumn{4}{|c|}{ Shallow wells. } \\
\hline & & & & & & & & Depth & h. Supply & $\begin{array}{l}\text { Quality } \\
\text { of water. }\end{array}$ & $\begin{array}{c}\text { Principal } \\
\text { water beds. }\end{array}$ \\
\hline Cocoa....... & Plain. & \multicolumn{4}{|c|}{$\begin{array}{l}\text { Drilled and dug wells } \\
\text { and cisterns. }\end{array}$} & \multicolumn{2}{|c|}{ Pleistocene sand. } & $\begin{array}{r}\text { Feet. } \\
14-30\end{array}$ & Large. & Soft..... & \multirow{2}{*}{$\begin{array}{l}\text { "Peninsu- } \\
\text { lar" lime- } \\
\text { stone. } \\
\text { Do. } \\
\text { Do. }\end{array}$} \\
\hline $\begin{array}{l}\text { Courtenay.. } \\
\text { Eau Gallie.. }\end{array}$ & ...do... & \multicolumn{4}{|c|}{$\begin{array}{c}\text { Driven and drilled } \\
\text { wells. }\end{array}$} & & (n) & $\begin{array}{l}12-24 \\
18-30\end{array}$ & $\begin{array}{l}\text { Ample } \\
\text {...do... }\end{array}$ & \multirow{5}{*}{$\begin{array}{c}\text {.do..... } \\
\text { Slightly } \\
\text { hard. } \\
\text { Soft..... } \\
\text { Slightly } \\
\text { hard. } \\
\text { Soft...... } \\
\text {... do..... }\end{array}$} & \\
\hline Indianola... & ...do... & \multirow{4}{*}{\multicolumn{4}{|c|}{$\begin{array}{l}\text { Drilled and dug wells } \\
\text { and cisterns. } \\
\text { Driven and drilled } \\
\text { wells. } \\
\text { Driven wells. ....... } \\
\text { Driven and drilied } \\
\text { wells and cisterns. }\end{array}$}} & .....do.. & & \multirow{4}{*}{$\begin{array}{r}12-30 \\
12-30 \\
15-20 \\
8-20\end{array}$} & ...do... & & Do. \\
\hline Melbourne.. & ...do... & & & & & ......do. & & & ...do... & & Do. \\
\hline \multirow{2}{*}{ Mitusville.... } & ...do... & & & & & $d$ & & & ...do... & & Do. \\
\hline & ...do... & & & & & & & & $0 \mid \ldots$ do... & & Do. \\
\hline \multirow{2}{*}{ Town. } & \multicolumn{6}{|c|}{ Deep wells. } & \multirow{2}{*}{$\begin{array}{l}\text { Aver- } \\
\text { age } \\
\text { thick- } \\
\text { ness } \\
\text { of } \\
\text { sand. }\end{array}$} & \multirow{2}{*}{$\begin{array}{l}\text { Depth } \\
\text { to } \\
\text { water. }\end{array}$} & \multirow{2}{*}{$\begin{array}{c}\text { Sewerage } \\
\text { system. }\end{array}$} & \multirow{2}{*}{\multicolumn{2}{|c|}{ Remarks. }} \\
\hline & \multicolumn{2}{|c|}{ Depth. } & Susply. & $\begin{array}{c}\text { Head } \\
\text { above } \\
\text { sea. }\end{array}$ & \multicolumn{2}{|c|}{$\begin{array}{l}\text { Quality of } \\
\text { water. }\end{array}$} & & & & & \\
\hline Cocoa. & \multirow{4}{*}{\multicolumn{2}{|c|}{$\begin{array}{c}\text { Feet. } \\
170-350 \\
170 \pm \\
170 \pm \\
315-500 \\
210 \\
315-400\end{array}$}} & \multirow{4}{*}{$\begin{array}{l}\text { Large. } \\
\text { Good.. } \\
\text { Large. } \\
\text { Good.. } \\
\text { Large. }\end{array}$} & $\begin{array}{l}\text { Feet. } \\
\cdots\end{array}$ & \multirow{2}{*}{\multicolumn{2}{|c|}{$\begin{array}{l}\text { Sulphur } \\
\text { some salt. }\end{array}$}} & $\begin{array}{l}\text { Feet. } \\
\text {. }\end{array}$ & \multirow{4}{*}{$\begin{array}{r}\text { Feet. } \\
10-15 \\
\\
5-8 \\
25 \\
6-10 \\
12-25\end{array}$} & \multirow{4}{*}{ 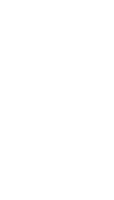 } & \multicolumn{2}{|c|}{ Supply constant. } \\
\hline Courtenay.- & & & & & & & & & & & \\
\hline $\begin{array}{l}\text { Eau Gallie. } \\
\text { Indianola.. }\end{array}$ & & & & $\begin{array}{l}50 \pm \\
\ldots \ldots\end{array}$ & & . do......... & $\begin{array}{r}65 \pm \\
\ldots \ldots \ldots\end{array}$ & & & Do. & \\
\hline Melbourne. & & & & $50 \pm$ & $\cdots \cdots$ & ........... & 30 & & & $\begin{array}{l}\text { One } 40-\mathrm{fo} \\
\text { ground } \\
\text { flow. }\end{array}$ & $\begin{array}{l}\text { ot well on low } \\
\text { has a weak }\end{array}$ \\
\hline \multirow{2}{*}{$\begin{array}{l}\text { Mims } \\
\text { Titusvilie... }\end{array}$} & & & & & & & $20 \div$ & $10-12$ & ...do...... & & \\
\hline & $282-7$ & $30(?)$ & Large. & $5+$ & $\begin{array}{r}\text { Salt } \\
\text { pl }\end{array}$ & $\begin{array}{l}\text { t and sul- } \\
\text { hur. }\end{array}$ & $10+$ & $8-15$ & ...do..... & & \\
\hline
\end{tabular}

\section{CALHOUN COUNTY.}

By G. C. Matson.

GENERAL FEATURES.

Calhoun County comprises a long narrow area-in few places exceeding 25 miles in width-lying on the west side of Apalachicola River and extending 30 to 40 miles northward from the Gulf of Mexico. The southern part of the county contains extensive swamps and, along Chipola River, some large bodies of stagnant water, the most noteworthy being Dead Lake. Toward the northern boundary the surface of the county becomes rolling and rises to an altitude of 
over 150 feet, forming a more or less dissected upland, which extends northward into Jackson County. All the large streams are bordered by flat terraces, which merge seaward into broad plains sloping gently toward the coast.

\section{GEOLOGY.}

Below the 100-foot contour the surface deposits of Calhoun County are composed of gray Pleistocene sands. On the upland in the northern part of the county similar sands of residual origin are underlain by red and yellow sands and sandy clay that are referred to the Lafayette (?) formation. In the latitude of Blountstown and Clarksville a belt of Choctawhatchee marl at least 10 or 12 miles wide extends across the entire county. The Alum Bluff formation lies near the surface north of the exposures of the Choctawhatchee marl and dips thence gently southward. The sands of the Alum Bluff are well exposed in the vicinity of Carr and the underlying marl belonging to the same formation is exposed nearer Chipola River. The Chattahoochee formation underlies the entire county and rises near the surface in the extreme northern part. It outcrops along Chipola River north of the Alum Bluff exposures. The entire surface is underlain by the Vicksburgian limestones, but these rock's are deeply buried beneath the Chattahoochee and younger formations.

On the uplands in the northern part of the county the gray sands are in few places more than 2 or 3 feet thick, but farther south gray sands of Pleistocene age may measure over 50 feet. The Choctawhatchee marl probably has an average thickness of less than 50 feet and the sands and marls of the Alum Bluff formation probably do not exceed 40 feet. The thickness of the Chattahoochee formation in Calhoun County is somewhat uncertain but may amount to as much as 200 feet; beneath it the Vicksburgian limestones extend downward to a depth of several hundred feet.

WATER SUPPLY.

Source.-All geologic formations in Calhoun County contain more or less water. On the uplands the gray sands are so thin that they are of little importance, but toward the south sands of Pleistocene age will supply an abundance of water. The Lafayette (?) formation yields large supplies of water throughout the upland portion of the county. The Choctawhatchee marl probably contains considerable water, but is penetrated by few wells. The limestones of both the Chattahoochee formation and of the Vicksburg group are good aquifers. The supplies in the last named are probably exceptionally large; but, so far as known, no wells are deep enough to reach them.

Quality.-The Pleistocene sands and the sands and clays of the Lafayette (?) formation contain soft water which is well adapted to 
all purposes except where its sanitary character is impaired by the percolation of impure surface drainage. All the older geologic formations should contain hard water, but as there are no wells procuring water from these rocks it is necessary to judge the character of the supplies by wells in adjoining counties. The Vicksburgian limestones will doubtless supply sulphur water; and, in the extreme southern part of the county, might yield saline water.

Development.-Shallow wells obtain abundant water at depths ranging from 10 to 35 feet. The water is generally regarded as excellent, though locally, near dwellings or other sources of pollution, it may be contaminated. Where wells are properly cased and the water is obtained from beneath clay beds or other dense material there is little danger of contamination by impure surface water. Water obtained in sands that are not capped by impervious material may receive surface drainage, and imperfect casings are always a menace unless the wells are at considerable distances from any source of pollution. In the shallow wells, the water stands sufficiently near the surface to be readily raised by buckets or suction pumps. No deep wells are reported from Calhoun County, but it should be possible to obtain good supplies of hard water within 100 or 200 feet of the surface throughout the upland portion of the county. Flowing wells could probably be obtained on the low ground near the coast at depths ranging from 300 to 400 feet. These wells should supply water similar to that from the flowing wells at Apalachicola.

General water resources of Calhoun County.

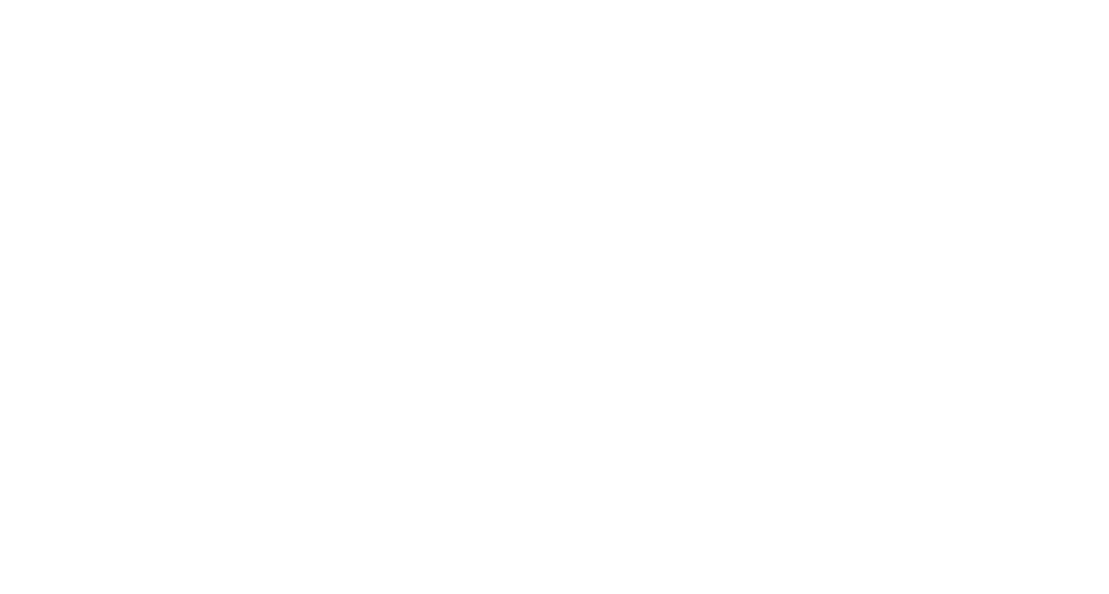




\section{CITRUS COUNTY.}

By G. C. Matson.

\section{GENERAL FEATURES.}

Citrus County extends from the Gulf coast eastward to Withlacoodhee River. Near the coast the land lies in a broad terrace which rises approximately 20 to 25 feet above sea level and represents an ancient sea bottom. It is bordered on the landward side by a more or less well defined scarp which separates it from the higher land to the east. Along Withlacoochee River is a broad terrace, which is several miles wide in the vicinity of Inverness, where it is occupied by Tsala Apopka Lake. In the vicinity of Dunnellon this terrace narrows appreciably but continues westward and merges with a terrace extending along the coast. In the vicinity of Dunnellon the terrace has an altitude of 40 to 60 feet. Some higher hills 70 to 100 feet above sea level are thought to represent remnants of a still higher terrace of marine origin.

The interior of Citrus County is characterized by irregular rounded hills and depressions, representing sink holes; many of the latter are occupied by lakes. The sink-hole topography and large springs show the great extent of the underground drainage.

\section{GEOLOGY.}

The terraces of Citrus County are composed of gray Pleistocene sands which more or less effectually conceal the underlying materials. On the uplands there are several feet of gray or yellow sand representing the insoluble materials remaining after the solution of the limestone and the weathering of the old siliceous formations. Some of this sand is yellow because of the presence of small amounts of hydrated iron oxide.

Nearly all of Citrus County is underlain at moderate depths by the soft porous limestones of Vicksburg age, though in a few localities hard limestones intervene between the sands and the Vicksburgian limestones. These hard limestones have been referred to the Hawthorne formation and may be correlated with similar rocks that are widely distributed throughout the central section of the peninsula.

The thickness of the gray Pleistocene sand is usually small, the average being probably not much in excess of 25 feet, though locally it may be somewhat greater, especially where there are sand dunes. The yellow residual sands are commonly less than 15 to 20 feet in thickness and in some places they are wanting. The Hawthorn formation, where present, is represented by a few feet of hard limestone. The thickness of Vicksburgian limestones in Citrus County has not been determined, but it should amount to several hundred feet. 


\section{WATER SUPPLY.}

Source.-Citrus County has only two important sources of underground water. The gray and yellow sands yield an abundant supply for shallow wells, but the best water-bearing formations are the Vicksburgian limestones, which contain very large quantities of water and lie at moderate depths.

Quality.-The surficial sands yield soft water. The Vicksburgian limestones supply moderately hard water, and deeper wells ị the formations of this age may encounter sulphur or salt water. Water from the limestones is usually free from danger of pollution and is generally considered safer than that from the shallow wells.

Development.-The water of the shallow wells is all derived from surficial beds and, though generally satisfactory, it is not so safe for domestic supply as the water of the deeper wells. Abundant water is generally obtained at depths less than 150 feet in the limestones, and many wells drilled to them do not exceed 100 feet. In general the water, though hard, is free from sulphur and other objectionable mineral matter. Two miles north of Crystal River a well drilled to a depth of 1,900 feet yielded flowing water, but unfortunately its water contained much salt and other mineral matter that rendered it unfit for use.

Citrus County has a large number of springs, some of which are of sufficient volume to give rise to good-sized streams; such, for example, as Crystal River. The estimated flow of the principal spring is 200,000 gallons per minute and the stream is large enough to be navigable for small steamers. A spring 7 miles south of Homosassa is the source of Chassahowitzka River. 


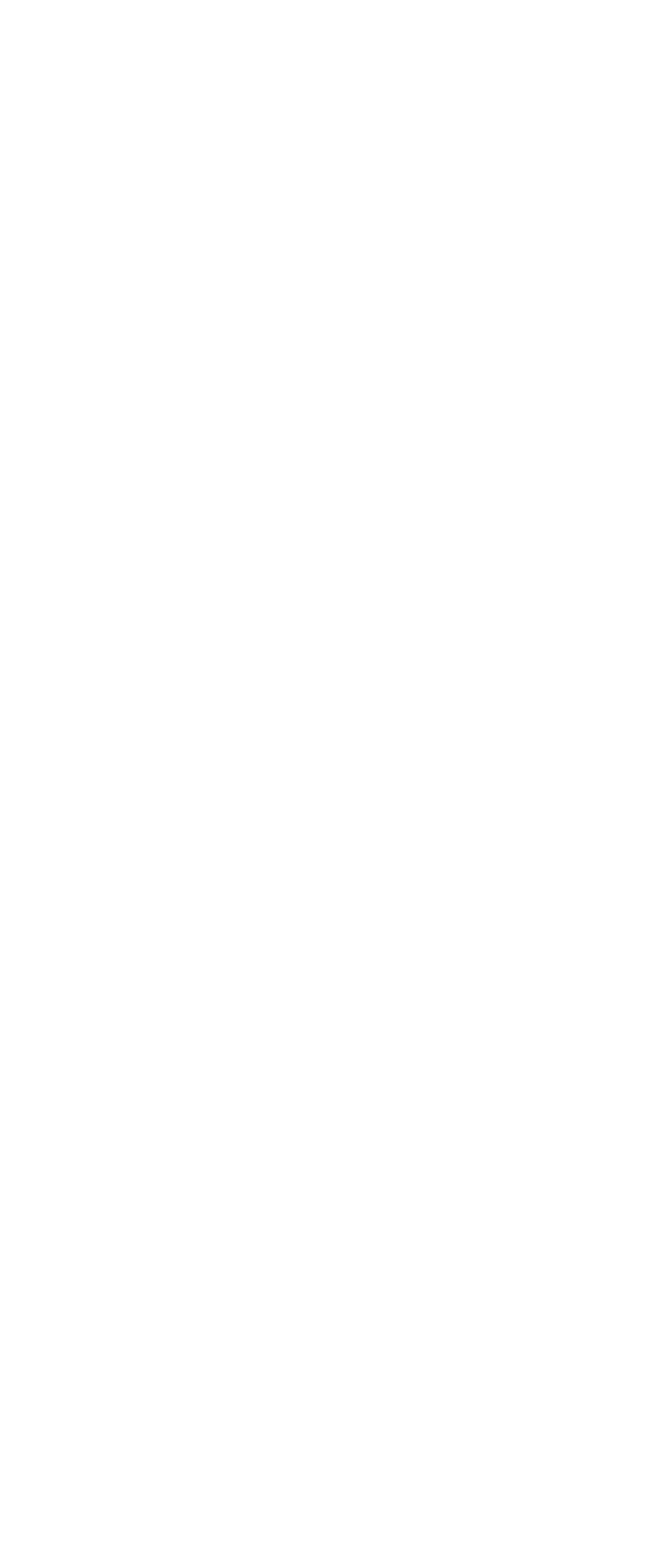


Typical wells of Citrus County.

\begin{tabular}{|c|c|c|c|c|c|c|c|c|c|c|c|c|c|c|c|c|c|}
\hline \multirow{2}{*}{$\begin{array}{l}\text { Nearest town or } \\
\text { post office. }\end{array}$} & \multirow{2}{*}{$\begin{array}{l}\text { Direction and } \\
\text { distance. }\end{array}$} & \multirow{2}{*}{ Owner. } & \multirow{2}{*}{ Driller. } & \multirow{2}{*}{$\begin{array}{c}\text { Date } \\
\text { sunk. }\end{array}$} & \multirow{2}{*}{$\begin{array}{l}\text { Type of } \\
\text { well. }\end{array}$} & \multirow{2}{*}{ Use. } & \multirow{2}{*}{ Depth. } & \multirow{2}{*}{$\begin{array}{l}\text { Diame- } \\
\text { ter. }\end{array}$} & \multirow{2}{*}{ Casing. } & \multirow{2}{*}{$\begin{array}{l}\text { Eleva- } \\
\text { tion } \\
\text { above } \\
\text { sea. }\end{array}$} & \multicolumn{2}{|c|}{ Head- } & \multirow{2}{*}{$\begin{array}{c}\text { Depth } \\
\text { to } \\
\text { rock. }\end{array}$} & \multirow{2}{*}{$\left|\begin{array}{c}\text { Depth } \\
\text { to } \\
\text { princi- } \\
\text { pal- } \\
\text { supply. }\end{array}\right|$} & \multirow{2}{*}{ Quality of water. } & \multirow{2}{*}{$\mid \begin{array}{c}\text { Depth } \\
\text { to } \\
\text { second } \\
\text { sup- } \\
\text { plies. }\end{array}$} & \multirow{2}{*}{ Remarks. } \\
\hline & & & & & & & & & & & $\begin{array}{l}\text { A bove } \\
\text { sea. }\end{array}$ & $\begin{array}{c}\text { Below } \\
\text { surface. }\end{array}$ & & & & & \\
\hline Crystal River. & $\begin{array}{l}1 \frac{1}{2} \text { miles south. } \\
\frac{2}{2} \text { miles north }\end{array}$ & W. H. Espey & E. H. McIlvane. & 1906 & $\begin{array}{l}\text { Driven. } \\
\text { Drilled. }\end{array}$ & General... & $\begin{array}{l}\text { Feet. } \\
90\end{array}$ & $\begin{array}{r}\text { Inches. } \\
2\end{array}$ & Feet. & Feet. & & 70 & Feet. & $\begin{array}{l}\text { Feet. } \\
\quad 90\end{array}$ & Hard. & Feet. & \multirow{11}{*}{ Yields many gallons per minute } \\
\hline $\begin{array}{l}\text { Etna ........... } \\
\text { Floral City... } \\
\text { Folicia........ }\end{array}$ & 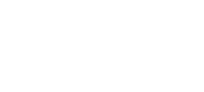 & $\begin{array}{l}\text { Horn Naval Stores Co } \\
\text { Bradey Phosphate Co } \\
\text { Dunno do } \\
\text { Dilon Phosphate }\end{array}$ & 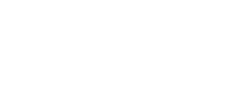 & $\begin{array}{l}1003 ? \\
1901 \\
1905\end{array}$ & 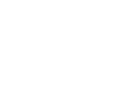 & $\begin{array}{l}\text { Turpentine still. } \\
\text { Phoshate mining } \\
\text { Drinking, principaliy } \\
\text { Washing phosphate }\end{array}$ & $\begin{array}{r}1,90 \\
970 \\
130 \\
380\end{array}$ & $\begin{array}{r}2 \\
8 \\
2 \\
8\end{array}$ & $\begin{array}{r}97 \\
50 \\
125\end{array}$ & & & $\begin{array}{r}58 \\
35 \\
40 \\
60\end{array}$ & 300 & $\begin{array}{l}97 \\
138 \\
130 \\
360\end{array}$ & 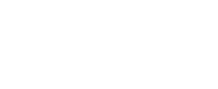 & $40 \pm$ & \\
\hline $\begin{array}{r}\text { Floral City.... } \\
\text { Do......... } \\
\text { Do......... }\end{array}$ & $\begin{array}{l}2 \text { miles southwest.. } \\
1_{1}^{\frac{1}{4}} \text { miles west } \ldots . . . . .\end{array}$ & $\begin{array}{l}\text { Co.a } \\
\text { Pradley Phosphate Co. } \\
\text { Dutton Phosphate Co. } \\
\text { E. W Graham }\end{array}$ & $\begin{array}{l}\text { McIver \& MacKay.... } \\
\text { A. C. Johnson............ } \\
\text { J. Tooke }\end{array}$ & $\begin{array}{l}1907 \\
1905 .\end{array}$ & $\begin{array}{l}\text { Drilled.... } \\
\ldots \text { do........ }\end{array}$ & $\begin{array}{l}\text { Phosphate mining.... } \\
\text { Drinking, principaliy }\end{array}$ & $\begin{array}{l}197 \\
147 \\
90\end{array}$ & $\begin{array}{r}12 \\
2 \\
2\end{array}$ & $\begin{array}{r}80 \\
142 \\
90\end{array}$ & & & $\begin{array}{l}12 \\
40 \\
30\end{array}$ & & $\begin{array}{l}197 \\
147 \\
90\end{array}$ & 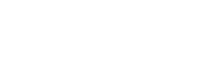 & $\begin{array}{l}55 \pm \\
40 \\
35\end{array}$ & \\
\hline $\begin{array}{r}\text { Do } \\
\text { Do...... } \\
\text { Do.... } \\
\text { Holder.... }\end{array}$ & 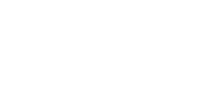 & $\begin{array}{l}\text { Co. } \\
\text { Duto atton Phosphate Co. } \\
\text { Chas. Wolfe. } \\
\text { Buttgenbach Phos- }\end{array}$ & 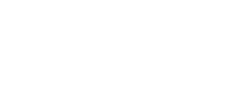 & $\begin{array}{l}1906 \\
1900 \\
1906\end{array}$ & \begin{tabular}{|l}
$\ldots$ do....... \\
\hdashline$\ldots$ do...... \\
Driven.... \\
Drilled...
\end{tabular} & 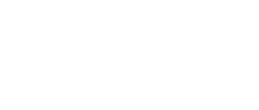 & $\begin{array}{l}122 \\
142 \\
981_{2}^{2} \\
100\end{array}$ & $\begin{array}{r}12 \\
10 \\
2 \\
12\end{array}$ & \begin{tabular}{c}
60 \\
\hdashline $88 \frac{1}{2}$ \\
42
\end{tabular} & $\begin{array}{c}b 65 \\
b_{65}\end{array}$ & -20 & $\begin{array}{l}45 \\
35 \\
82 \\
45\end{array}$ & & $\begin{array}{c}122 \\
142 \\
98 \frac{1}{2} \\
100\end{array}$ & 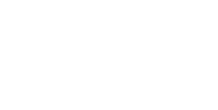 & $\begin{array}{l}50 \pm \\
30\end{array}$ & \\
\hline \multirow{2}{*}{ 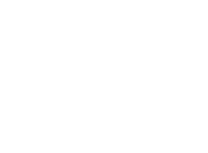 } & \multirow{2}{*}{ 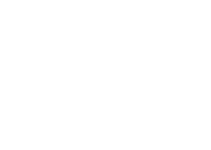 } & 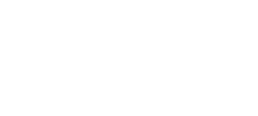 & 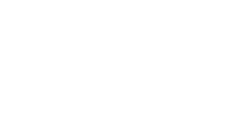 & $\begin{array}{l}1906 \\
1907 \\
1901\end{array}$ & $\begin{array}{l}\ldots \text { do } \ldots . . . \\
\ldots \text { do } \\
\ldots \text { do...... } \\
\ldots \text { do..... }\end{array}$ & \begin{tabular}{l}
$\ldots \ldots$ do $\ldots . . . . .$. \\
\hdashline$\ldots$ do.......... \\
\hdashline Public.........
\end{tabular} & $\begin{array}{l}145 \\
98 \\
121 \\
75\end{array}$ & $\begin{array}{r}12 \\
12 \\
8 \\
-2\end{array}$ & $\begin{array}{l}75 \\
76 \\
35\end{array}$ & & & $\begin{array}{r}54 \\
30 \\
54 \\
-64\end{array}$ & & $\begin{array}{r}145 \\
98 \\
121\end{array}$ & $\begin{array}{l}\text {....do- } \\
\text { a.do. } \\
\text { a.do. } \\
\text { ‥do. }\end{array}$ & 60 & \\
\hline & & W. M. and J.C. East- & E. H. Mcilvane.. & $1907^{-1}$ & Driven..... & General...................... & 130 & $\dddot{2}$ & 120 & & & .... & $\cdots$ & 130 & Hard..... & $\ldots$ & \\
\hline Do... & .....do............... & F.M. Long................... & .....do............ & 1907. & ..do.... & ....do................ & 70 & 2 & 69 & & & $\begin{array}{l}60 \\
57\end{array}$ & 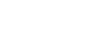 & 70 & ...do........ & $\ldots$ & \\
\hline $\begin{array}{l}\text { Inverness. } \\
\text { Do.... }\end{array}$ & Nearr. & 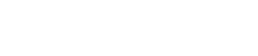 & 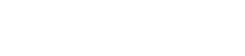 & $\begin{array}{l}1900^{\circ} \\
1907\end{array}$ & $\left|\begin{array}{l}\text { Dried..... } \\
\text { Drivan.... } \\
\cdots \text { do......... }\end{array}\right|$ & 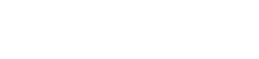 & $\begin{array}{r}60 \\
66 \\
.72\end{array}$ & $\begin{array}{r}2 \\
2\end{array}$ & 76 & $070^{\circ}$ & & & & 76 & 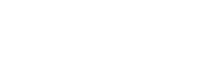 & 50 & \\
\hline $\begin{array}{l}\text { Do..... } \\
\text { Danto... } \\
\text { Do }\end{array}$ & Near miles northwest.. & & 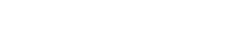 & $\begin{array}{l}1907 \\
1907 \\
1007\end{array}$ & & 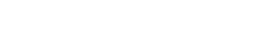 & $\begin{array}{r}67 \\
125\end{array}$ & \begin{tabular}{l|l}
2 \\
2 \\
2
\end{tabular} & . 60. & & & $\begin{array}{r}45 \\
105\end{array}$ & & $\begin{array}{r}67 \\
125\end{array}$ & $\begin{array}{l}\text { Hard ..... } \\
\ldots \ldots \text {..do... }\end{array}$ & 40 & \\
\hline & & & $\begin{array}{l}\text { W. A. Allen.......... } \\
\text { W.do............... }\end{array}$ & ${ }_{1906}^{1902}$ : & 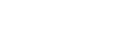 & $\begin{array}{l}\text { Housshold................. } \\
\text { Not used........... }\end{array}$ & ${ }_{80}^{97}$ & $\begin{array}{l}2 \\
2\end{array}$ & 97 & & & $\begin{array}{r}89 \\
\ldots . . \\
\end{array}$ & & & W.do. & & \\
\hline Maple. & $4 \frac{1}{2}$ miles northwest. & w. H. Hiller................ & L. Parnell........... & 1905 & Drilled.... & Domestic.............. & 115 & 2 & 115 & & & 60 & & $\cdots$ & Hard.... & & \\
\hline
\end{tabular}





\section{CLAY COUNTY.}

By G. C. Matson.

\section{GENERAL FEATURES.}

Clay County lies on the west side of St. Johns River near the northern end of the State. A narrow belt bordering the river is only 20 to 30 feet above sea level, but to the west the land rises in the form of a bluff about 20 feet high. Beyond this bluff a flat terrace extends westward several miles, finally giving place to another terrace 30 to 40 feet higher. Still farther inland is an area of high land that has been deeply dissected by streams. Near the western border of the county is the narrow Trail Ridge, which forms a high divide between the streams draining to the Gulf of Mexico and those tributary to St. Johns River. The eastern slope of this divide is trenched by the valleys of the streams tributary to Black Creek, a branch of St. Johns River.

\section{GEOLOGY.}

The terraces of Clay County are covered by gray Pleistocene sand which masks the underlying formations except in some of the valleys. On the uplands gray residual sands are underlain by red and yellow sands and sandy clays that are referred to as the Lafayette (?) formation, though evidence for their exact correlation is lacking.

Limestone belonging to the Jacksonville formation is exposed in the valley of Black Creek from about 5 miles above the Atlantic Coast Line Railroad bridge to some distance beyond Middleburg. This limestone doubtless underlies a large part of the county, but outside the valley of Black Creek it is concealed by sands. Well samples obtained at Jacksonville and St. Augustine indicate that the Jacksonville formation also contains clays and sands, but these materials have not been observed at the surface. in Clay County. Oligocene formations underlie the entire county; but, with the exception of the Alum Bluff formation which is exposed in the western portion of the county, they are not exposed and no satisfactory samples of them could be obtained. The rocks belonging to the Apalachicola group resemble those of the Jacksonville formation so closely that it is impossible to distinguish them in drillers' descriptions. The Vicksburgian rocks of Clay County are similar to those that underlie the remainder of the peninsula. They consist of soft gray to white limestones containing some layers of dark-colored chert.

The thickness of the various geologic formations represented in Clay County can be estimated only approximately. The sands and clays that form the surface and subsurface materials probably have an average thickness of about 50 feet except in the valleys of the streams, where they have been wholly or partly removed by erosion. The combined thickness of the rocks belonging to the Apalachicola 
group and the Jacksonville formation is about 300 to 350 feet and the thickness of the Vicksburgian limestones is several hundred feet.

WATER SUPPLY.

Source.-The water supplies of Clay County are obtained either from shallow wells in the sands or from deep wells penetrating the older geologic formations. The water in the shallow wells comes largely from the yellow and red sands underlying the surficial gray sands, though in a few places the gray sands may themselves yield water. The deep wells derive their water almost wholly from the Vicksburgian limestones; the quantity available is usually large and the head is sufficient to furnish good flows in the valleys of the larger streams. A few shallow flowing wells, especially those located near Middleburg, appear to obtain water from some porous bed in the Jacksonville formation, but in general this formation is not an important source of water.

Quality.-The water from the shallow wells is commonly soft. The deep wells supply sulphur water containing considerable mineral matter. In a few localities this water is reported to be soft, though in comparison with the shallow-well water all the water from the deep wells is hard. When properly cased the deep wells are practically free from danger of contamination by surface drainage except where impure water may be allowed to flow into wells that reach the source of supply.

Development.- In the towns along St. Johns River deep wells are the principal source of supply, but in the remainder of the county most of the wells are shallow. The deep wells yield supplies that for all practical purposes may be considered inexhaustible, though a large increase in the number of wells might cause a diminution in the head and yield if they were allowed to flow continuously. The table of well records indicates in a general way the depth at which supplies may be obtained, though it is seldom possible to make accurate forecasts because the depth to water-bearing beds varies within short distances. The head of the water in Clay County is sufficient to give good flows in the valleys of the streams, but it is doubtful if any important flowing wells can be obtained where the ground is more than 50 feet above' sea level. Apparently flowing wells may be obtained on higher ground in the northern than in the southern part of the county. Flowing wells can not be obtained on the highlands in the western part of Clay County, but good supplies of sulphur water may be had by drilling to the Vicksburgian limestones, which should be encountered at a slightly greater depth than in the St. Johns Valley.

Springs are numerous in Clay County and some of them are important. Green Cove Spring, on the west bank of St. Johns River, gives an excellent flow of sulphur water, which emerges from a nearly circular orifice, several feet deep. The spring furnishes water to a 
Typical wells of Clay County.

\begin{tabular}{|c|c|c|c|c|c|c|c|c|}
\hline $\begin{array}{l}\text { Nearest town nor post } \\
\text { offifece. }\end{array}$ & Direction and distance. & Owner. & Driller. & $\begin{array}{l}\text { Date } \\
\text { sunk. }\end{array}$ & $\begin{array}{l}\text { Surfacac for- } \\
\text { mation. }\end{array}$ & $\begin{array}{l}\text { Geoulogie } \\
\text { source. }\end{array}$ & $\begin{array}{c}\text { Type of } \\
\text { well. }\end{array}$ & Use. \\
\hline Green Cove Springs. & 10 miles northeast. & Delvach \& Edwards.. & Merwin... & 1907 & Pleistocene.. & 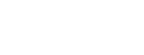 & & \\
\hline & $\begin{array}{l}5 \text { milies west } \\
8 \text { miles southwest. }\end{array}$ & Edwards \& co... & $\ldots$.... do.... & 1907 & $\begin{array}{lll}\cdots \text { do } \\
\text { do }\end{array}$ & 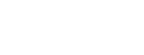 & & Turpentin still. \\
\hline 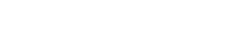 & $\frac{1}{2}$ mile southwest..... & $\begin{array}{l}\text { Buddington } \\
a\end{array}$ & N. B. vey.... & 0 & Pleistocene & 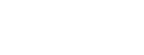 & Driilia." & All purposes.... \\
\hline $\begin{array}{l}\text { Do } \\
\text { Maglia springs. }\end{array}$ & Nërar. & 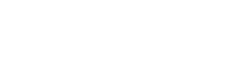 & ...do.... & 1894 & …..... & $\begin{array}{l}\text { stotone. } \\
\text {..too. } \\
\text { do }\end{array}$ & . .do.... & 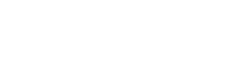 \\
\hline $\begin{array}{l}\text { Maxilie: } \\
\text { Maxvile: }\end{array}$ & & 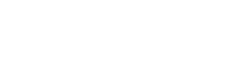 & & 1882 & …do... & 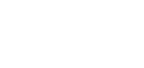 & Drifted. & \\
\hline $\begin{array}{l}\text { Middideburg............... } \\
\text { Orange Parka........ }\end{array}$ & $\begin{array}{l}\text { Near- } \\
1 \text { mile east..................... }\end{array}$ & 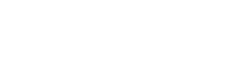 & & $1890 ?$ & Pleistocene. & Vieksur & $\cdots \cdots$ & $\begin{array}{l}\text { Domemestite. } \\
\text { Drinking.: }\end{array}$ \\
\hline Do. & & H. J. Berry ..... & & 1897 & ...do.. & 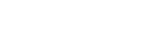 & & Domestic and irriga \\
\hline $\begin{array}{l}\text { Do.: } \\
\text { Do.: }\end{array}$ & . & 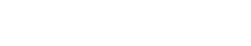 & ......... & $\begin{array}{l}1897 \\
1897\end{array}$ & .....do... & 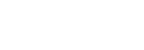 & & 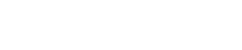 \\
\hline $\begin{array}{l}\text { Do....: } \\
\text { Do..: }\end{array}$ & Near:- & $\begin{array}{l}\text { Mrs. Helen H Hall.: } \\
\text { Wm. Maiefridtt.: }\end{array}$ & Hugh Partridge... & $\begin{array}{l}1897 \\
1895 ?\end{array}$ & ....do... & 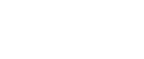 & & $\begin{array}{l}\text { ing. } \\
\text { Domemetic and irizag }\end{array}$ \\
\hline $\begin{array}{l}\text { Do.. } \\
\text { Do.: }\end{array}$ & & 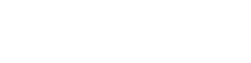 & & 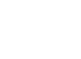 & "Plieisiocene & & & $\begin{array}{l}\text { Domestic garden...... } \\
\text { Not tused.. }\end{array}$ \\
\hline $\begin{array}{l}\text { Do...: } \\
\text { Do... }\end{array}$ & 1 mile southeast... & $\begin{array}{l}\text { G. M. Sandt } d x \\
\text { A. A. Van Buren }\end{array}$ & & 18853 & Píeistocoene. & $\begin{array}{l}\text { stone. } \\
\text { ivicksbin }\end{array}$ & & $\begin{array}{l}\text { Domestic.... } \\
\text { Domestic an ir }\end{array}$ \\
\hline & & $\begin{array}{l}\text { West Bros. } \\
\text { d.c. Wood............... }\end{array}$ & & $i_{i}^{i} 9 \eta^{\circ}$ & 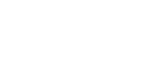 & 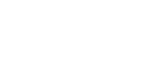 & & ח.do..... \\
\hline & Near... & 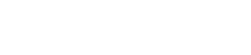 & |üerwin.......... & & "Pleisistocene.. & vicksur & "D̈riiieä.:" & 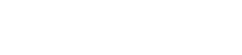 \\
\hline $\begin{array}{l}\text { Wost ionoi. } \\
\text { Williams crossing.... }\end{array}$ & mile orth............ & 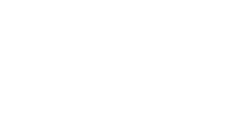 & Mèrwin.... & $\begin{array}{l}19003 \\
-19006\end{array}$ & 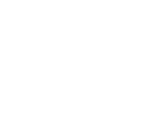 & 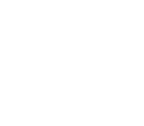 & ...do.....: & 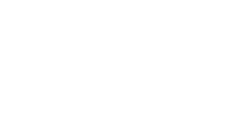 \\
\hline
\end{tabular}
$a$ Water-Supply Paper U. S. Geol. Survey No. 102, p. 242.
$b$ Estimated
$c$ By barometer.

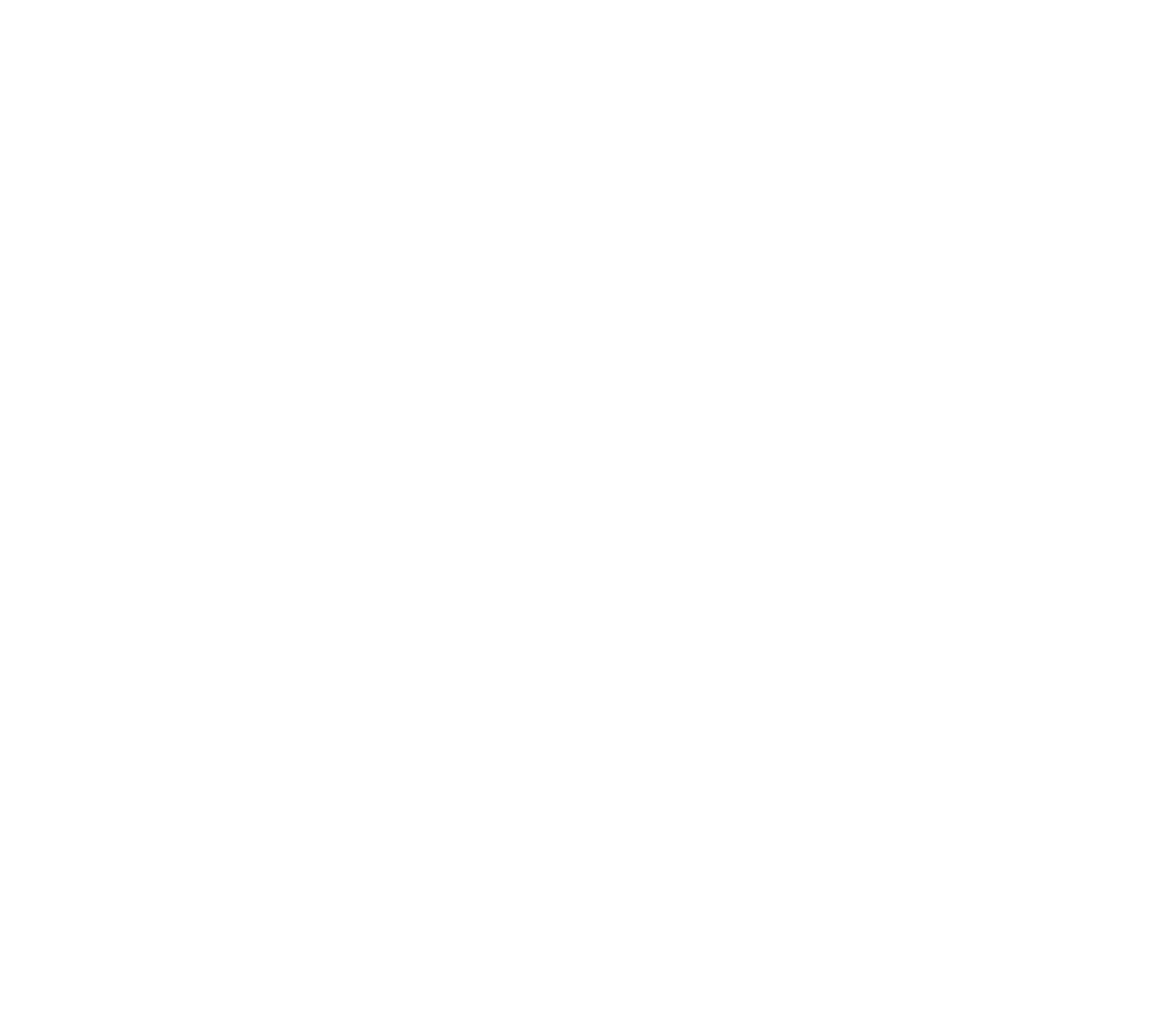

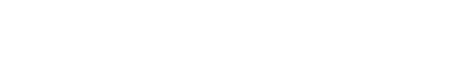



bathhouse and a large swimming pool appurtenant to a botel. The water is thought to have medicinal value.

Magnolia Springs, just north of Green Cove Springs, is a resort of considerable note. The water is obtained from artesian wells penetrating the Vicksburgian limestones. The flow is large and the quality excellent. In the western part of the county, about 6 miles from Starke, a spring, known as the Peck Mineral Spring, is also the center of a health and pleasure resort.

General water resources of Clay County.

\begin{tabular}{|c|c|c|c|c|c|c|c|c|c|c|}
\hline \multirow{2}{*}{ Town. } & \multirow{2}{*}{$\begin{array}{l}\text { Topo- } \\
\text { graphic } \\
\text { location. }\end{array}$} & \multirow{2}{*}{\multicolumn{2}{|c|}{$\begin{array}{l}\text { Source of } \\
\text { water. }\end{array}$}} & \multirow{2}{*}{$\begin{array}{l}\text { Surface } \\
\text { mate- } \\
\text { rial. }\end{array}$} & \multirow{2}{*}{\multicolumn{2}{|c|}{$\begin{array}{c}\text { Surface } \\
\text { formation. }\end{array}$}} & \multicolumn{4}{|c|}{ Shallow wells. } \\
\hline & & & & & & & Dopth. & Supply. & $\begin{array}{l}\text { Qual- } \\
\text { ity of } \\
\text { water. }\end{array}$ & $\begin{array}{c}\text { Principal } \\
\text { water beds. }\end{array}$ \\
\hline \multirow{2}{*}{$\begin{array}{l}\text { Highland } \\
\text { Orange } \\
\text { Park. }\end{array}$} & Rolling . & \multirow{2}{*}{\multicolumn{2}{|c|}{ D r rilied and }} & Sand.. & \multirow{2}{*}{\multicolumn{2}{|c|}{ Pleistocene. }} & Freet. & & & \multirow[b]{2}{*}{$\begin{array}{l}\text { "Peninsular" } \\
\text { limestone. }\end{array}$} \\
\hline & Plain.... & & & ...do... & & & $28-35$ & Moderato & Good.. & \\
\hline \multirow{2}{*}{ Town. } & \multicolumn{5}{|c|}{ Deep wells. } & \multirow{2}{*}{$\begin{array}{l}\text { Depth } \\
\text { to } \\
\text { rock. }\end{array}$} & \multirow{2}{*}{$\begin{array}{l}\text { Depth } \\
\text { to } \\
\text { water. }\end{array}$} & \multirow{2}{*}{$\begin{array}{l}\text { Sewer- } \\
\text { age } \\
\text { systom. }\end{array}$} & \multirow{2}{*}{\multicolumn{2}{|c|}{ Remarks. }} \\
\hline & Depth. & $\begin{array}{l}\text { Sup- } \\
\text { ply. }\end{array}$ & $\begin{array}{c}\text { Head } \\
\text { (above } \\
\text { sea). }\end{array}$ & \multicolumn{2}{|c|}{$\begin{array}{l}\text { Quality. } \\
\text { of water. }\end{array}$} & & & & & \\
\hline Highland & $\begin{array}{l}\text { Feet. } \\
\text {.......... }\end{array}$ & & $\begin{array}{l}\text { Feet. } \\
. \ldots \ldots\end{array}$ & & & Feet. & Feet. & & \multirow{2}{*}{\multicolumn{2}{|c|}{$\begin{array}{l}\text { Reported no deep well at } \\
\text { Highland. } \\
\text { Excellent water obtained } \\
\text { at } 30-35 \text { leet; supply is } \\
\text { constant. }\end{array}$}} \\
\hline $\begin{array}{l}\text { Orange } \\
\text { Park. }\end{array}$ & $350-500$ & Large. & $+60,65$ & $\begin{array}{l}\text { Sulphur } \\
\text { hard. }\end{array}$ & and & 30 & $12 \pm$ & None.... & & \\
\hline
\end{tabular}

Springs in Clay County.

\begin{tabular}{|c|c|c|c|c|c|c|c|c|c|c|}
\hline Name. & \multicolumn{2}{|l|}{ Owner. } & \multicolumn{2}{|c|}{$\begin{array}{l}\text { Nearest town } \\
\text { or post office. }\end{array}$} & $\begin{array}{l}\text { Direc- } \\
\text { tion and } \\
\text { distance. }\end{array}$ & $\begin{array}{c}\text { Dis- } \\
\text { charge } \\
\text { per } \\
\text { minute. }\end{array}$ & $\begin{array}{l}\text { Topo- } \\
\text { graphic } \\
\text { surround- } \\
\text { ings. }\end{array}$ & Use. & \multicolumn{2}{|c|}{ Emergence. } \\
\hline $\begin{array}{l}\text { Green Cove } \\
\text { Springs. } \\
\text { M a g n o l i a } \\
\text { Springs. } \\
\text { Peck Mineral } \\
\text { Springs. }\end{array}$ & \multicolumn{2}{|c|}{$\begin{array}{l}\text { O. D. Setta... } \\
\text { C. L. Peck.... }\end{array}$} & \multicolumn{2}{|c|}{$\begin{array}{c}\text { Green Cove } \\
\text { Springs. } \\
\text { Magnolia } \\
\text { Springs. }\end{array}$} & 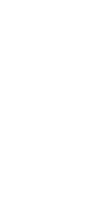 & $-\mid \begin{array}{c}\text { Gallons. } \\
500 \\
250+ \\
20\end{array}$ & $\begin{array}{l}\text { Plain...... } \\
\text {...do........ } \\
\text { In ravine.. }\end{array}$ & $\begin{array}{l}\text { Hotel, drink- } \\
\text { ing; bot- } \\
\text { tling. } \\
\text { D rinking } \\
\text { and bath- } \\
\text { ing. } \\
\text { Drinking.... }\end{array}$ & \multicolumn{2}{|c|}{$\begin{array}{l}\text { Boils from } \\
\text { hole } 60 \text { feet } \\
\text { deep. } \\
\text { F l o w in g } \\
\text { well. }\end{array}$} \\
\hline Name. & Source. & $\begin{array}{l}\mathrm{Va} \\
\text { tior } \\
\text { flo }\end{array}$ & & Improve & ments. & $\begin{array}{l}\text { Quality } \\
\text { of water. }\end{array}$ & $\begin{array}{l}\text { Tem- } \\
\text { pera- } \\
\text { ture. }\end{array}$ & \multicolumn{2}{|c|}{$\begin{array}{l}\text { Trade name of } \\
\text { water. }\end{array}$} & $\begin{array}{c}\text { Re- } \\
\text { marks. }\end{array}$ \\
\hline $\begin{array}{l}\text { Green Cove } \\
\text { Springs. } \\
\text { M a g n o } 1 \text { i a } \\
\text { Springs. } \\
\text { Peck Mineral } \\
\text { Springs. }\end{array}$ & $\begin{array}{l}\text { Vicksburg- } \\
\text { ian lime- } \\
\text { stone. } \\
\text {...do....... }\end{array}$ & $\ldots d$ & $\begin{array}{l}0 . \\
0 . . \\
0 . .\end{array}$ & \multicolumn{2}{|c|}{ 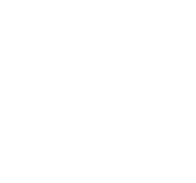 } & $\begin{array}{c}\text { Clear and } \\
\text { colorless. }\end{array}$ & ${ }^{\bullet} F$ & $\begin{array}{l}\text { Sulpho - Magne } \\
\text { Water. } \\
\text { Magnolia Spr } \\
\text { Water......... } \\
\text {................ }\end{array}$ & $\begin{array}{l}\text { ing } \\
\cdots . . . \\
\cdots\end{array}$ & $\begin{array}{l}\text { (a) } \\
\text { (a) }\end{array}$ \\
\hline
\end{tabular}




\section{COLUMBIA COUNTY.}

By G. C. Matson.

\section{General Features.}

Columbia County comprises a narrow strip in the northern part of the State, extending from the Georgia-Florida line southward for about 40 miles and having a maximum width of 18 to 20 miles. The northeastern part of the county is swampy, but farther south the surface is rolling and well drained; in the southern half sink holes indicate the presence of many underground streams of considerable size. The north-central part drains westward to Suwannee River and the southern part southward to Olustee Creek and Santa Fe River.

A narrow strip along Santa Fe River and some of its tributaries is less than 50 feet above sea level, but the greater part of the county rises to an altitude exceeding 100 feet. A broad tract in the central part is more than 150 feet above sea level, and uplands in the vicinity of Lake City are more than 200 feet above sea level.

\section{GEOLOGY.}

Below the 100-foot contour the surface deposits of Columbia County consist of gray sands of Pleistocene age, and on the uplands similar sands of residual origin are underlain by red and yellow sands and sandy clays referred to the Lafayette (?) formation. In the southern part of the county, where the Lafayette (?) formation is not present, the gray sands rest on yellow sands formed by the decomposition of the older formations.

The Jacksonville formation has not been recognized in Columbia County, though it is possible that it is represented by some of the limestone on the upland near Lake City. The Apalachicola group is represented by clays, sands, and marls of the Alum Bluff formation and by limestones and sands of the Hawthorn formation. Both of these formations are exposed in the valley of Suwannee River at White Springs, and the limestones and cherts of the Hawthorn formation are exposed near Lake City, High Springs, Bass, Lake City Junction, and Fort White. The Vicksburgian limestones underlie the entire county and are near the surface from Bass to the southern boundary of the county. The Ocala limestone, the youngest formation of the Vicksburg group, is exposed in the phosphate mines near Fort White.

Over most of the uplands the gray sands are from 3 to 5 feet thick, though locally they are somewhat thicker. The sands and sandy clays of the Lafayette (?) formation are in few places more than 50 feet thick, and they probably average less than 30 feet. In the valley of Suwannee River the Alum Bluff formation is about 100 
Typical wells of Columbia County.

\begin{tabular}{|c|c|c|c|c|c|c|c|c|c|c|c|c|c|c|c|c|c|}
\hline \multirow{2}{*}{$\begin{array}{l}\text { Nearest town or } \\
\text { post office. }\end{array}$} & \multirow{2}{*}{$\begin{array}{l}\text { Direction and } \\
\text { distance. }\end{array}$} & \multirow[b]{2}{*}{ Owner of well. } & \multirow[b]{2}{*}{ Driller. } & \multirow{2}{*}{$\begin{array}{l}\text { Date } \\
\text { sunk. }\end{array}$} & \multirow[b]{2}{*}{$\begin{array}{c}\text { Type of } \\
\text { well. }\end{array}$} & \multirow[b]{2}{*}{ Use. } & \multirow[b]{2}{*}{ Depth. } & \multirow[b]{2}{*}{$\begin{array}{c}\text { Diam- } \\
\text { eter. }\end{array}$} & \multirow[b]{2}{*}{ Casing. } & \multirow{2}{*}{$\begin{array}{l}\text { Eleva- } \\
\text { tion- } \\
\text { above } \\
\text { sea. }\end{array}$} & \multicolumn{2}{|c|}{ Head- } & \multirow{2}{*}{$\begin{array}{l}\text { Depth } \\
\text { to } \\
\text { rock. }\end{array}$} & \multirow{2}{*}{$\begin{array}{c}\text { Depth } \\
\text { to } \\
\text { prin- } \\
\text { cipal } \\
\text { sup- } \\
\text { ply. }\end{array}$} & \multirow[b]{2}{*}{ Quality of water. } & \multirow{2}{*}{$\begin{array}{c}\text { Yield } \\
\text { per } \\
\text { minute. }\end{array}$} & \multirow[b]{2}{*}{ Remarks. } \\
\hline & & & & & & & & & & & $\begin{array}{l}\text { Above } \\
\text { sea. }\end{array}$ & $\begin{array}{c}\text { Below } \\
\text { sur- } \\
\text { face. }\end{array}$ & & & & & \\
\hline Bass..... & Near...... & E. M. Curington. . & C. M. Ray.. & 1907 & Driven.... & General.. & \multirow{13}{*}{$\begin{array}{c}\text { Feet. } \\
75 \\
44 \\
62 \\
68 \\
54 \\
78 \\
68 \\
520 \\
132 \\
400+ \\
400 \\
122 \\
134 \\
103 \\
107 \\
108 \\
120 \\
108 \\
121 \\
82\end{array}$} & \multirow{4}{*}{$\begin{array}{r}\text { Inches. } \\
2 \\
2 \\
2 \\
2 \\
2\end{array}$} & Feet. & Feet. & Feet. & \multirow{6}{*}{$\begin{array}{r}\text { Feet. } \\
60 \\
40 \\
55 \\
58 \\
41 \\
63 \\
61 \\
100 \\
109\end{array}$} & Feet. & \multirow{4}{*}{$\begin{array}{r}\text { Feet. } \\
65 \\
42 \\
55 \\
60\end{array}$} & & Gallons. & \multirow{13}{*}{$\begin{array}{l}\text { Second supply at } 13 \text { feet. } \\
\text { Second supply at } 15 \text { feet. }\end{array}$} \\
\hline $\begin{array}{l}\text { Do... } \\
\text { Brown ... }\end{array}$ & ;...do..... & $\begin{array}{l}\text { W. H. Weeks..... } \\
\text { w. H. Allen.... }\end{array}$ & ….do......... & $\begin{array}{l}1907 \\
1906\end{array}$ & ...do...... & .....do........ & & & $\begin{array}{l}44 \\
51\end{array}$ & 106 & $\ldots \ldots . .$. & & $\ldots$. & & ....do...... & & \\
\hline $\begin{array}{l}\text { Do... } \\
\text { Fort White }\end{array}$ & …..do... & cido ............. & & 1906 & \#do.............. & ఝ. do ..... & & & 53 & 100 & & & & & (....do.... & & \\
\hline $\begin{array}{l}\text { tr White } \\
\text { Do.... }\end{array}$ & i mile northeast.. & John Coon............... & & & $\begin{array}{l}\text { Drilled..... } \\
\text {...do...... }\end{array}$ & Public.... & & & & & & & & & (...ddo... & & \\
\hline $\begin{array}{l}\text { Do.... } \\
\text { ke City. }\end{array}$ & & $\begin{array}{l}\text { Methodist parsonage... } \\
\text { W.T. Adams a. }\end{array}$ & C. M. Ray ........ & 1904 & & $\begin{array}{l}\text { Household.............. } \\
\text {. }\end{array}$ & & \multirow{3}{*}{$\begin{array}{r}\mathbf{2} \\
10 \\
2 \\
\cdots \\
10\end{array}$} & 2 & & …... & & 58 & 60 & ........... & & \\
\hline Do....... & 2 miles west.. & J.R. Coombs a............ & & $\cdots$ & & \multirow{2}{*}{$\begin{array}{l}\text { Hrinking and stock } \\
\text { City supply... }\end{array}$} & & & & $\cdots \cdot>>>+2>$ & & & 52 & 109 & \multirow{2}{*}{ Hard, sulphur..... } & \multirow{2}{*}{ Many. } & \\
\hline Do......... & $\frac{1}{2}$ mile north.. & City........................ & W. F. Hamilton. & 1907 & Drilled.. & & & & 100 & 200 & & $\cdots$ & & & & & \\
\hline Do....... & 2 miles west.. & J. R. Coombs. . & C. M. Ray.......... & 1903 & Driven... & General............. & & 11 & ${ }_{24}^{98}$ & & & 110 & 80 & 118 & Hard............ & & \\
\hline Do............. & 10 miles south.... & H. W. Lamb.......... & .....do..................... & 1900 & ...do....... & Household........... & & $\begin{array}{l}2 \\
1 \\
\end{array}$ & $\begin{array}{c}104 \\
30\end{array}$ & & .. & 128 & 76 & 128 & ....do....... & & \\
\hline 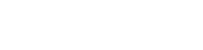 & 1 mile northeast. & $\begin{array}{l}\text { Jno. Strange } a_{\ldots \ldots \ldots \ldots \ldots} \\
\text { Eliz. Bryan } a \ldots \ldots \ldots \ldots\end{array}$ & ......................... & & …........ & & & $\begin{array}{l}2 \\
2 \\
2\end{array}$ & & 150 & & & & & Hard & & \\
\hline Do................ & 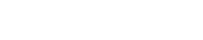 & J. W. Dowling a & & & & Plantation... & & 2 & & 100 & & 70 & $\begin{array}{r}40 \\
40\end{array}-10$ & 70 & …do................. & Several. & \\
\hline Winfield.......... & & D. G. Rivers.............. & C.M. Ray................... & & Driven... & General....... & & $\begin{array}{l}2 \\
2\end{array}$ & & $\begin{array}{l}150 \\
126\end{array}$ & 66 & 60 & & & Hard............... & & \\
\hline Do............ & $\begin{array}{l}\frac{3}{2} \text { mile south........ } \\
2 \text { miles west....... }\end{array}$ & $\begin{array}{l}\text { J. L. Roberts } \\
\text { Union Church (coi.).... }\end{array}$ & 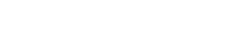 & $\begin{array}{l}1899 \\
1905\end{array}$ & ...do....... & 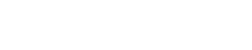 & & $\begin{array}{l}2 \\
2\end{array}$ & $\begin{array}{r}r 15 \\
80\end{array}$ & & & $\begin{array}{l}70 \\
85\end{array}$ & 82 & $\begin{array}{c}121 \\
88\end{array}$ & ....do........ & & \\
\hline
\end{tabular}

76854 - WSP 319-13. (To face page 286.)

a Water-Supply Paper U. S. Geol. Survey No. 102, p. 244. 

feet thick, but farther south it has been entirely removed by erosion. The exposures of the Hawthorn formation in few places amount to more than 20 or 25 feet, and the maximum thickness in Columbia County may be less than 50 feet. The underlying Vicksburgian limestones doubtless have a thickness of several hundred feet, but their exposures do not as a rule exceed a few feet.

WATER SUPPLY.

Source.-The water supply of the northern part of Columbia County probably comes from the sands of the Lafayette (?) formation or the underlying Alum Bluff formation. However, little definite information could be obtained, as there are few wells. Many of the wells in the southern part of the county procure abundant supplies from the Vicksburgian limestones, and some of them probably obtain water from the Hawthorn formation. The deep well at Lake City penetrates the Vicksburgian limestones, from which it doubtless receives its principal supply.

Quality.-The water from the shallow wells which penetrate the Lafayette (?) or the Alum Bluff formation is generally soft. The Vicksburgian limestones yield moderately hard water, with sulphur in some localities.

Development.--In Columbia County shallow wells are an important source of water, though the sanitary character of their supplies is sometimes doubtful. Deep wells are most numerous in the southern part of the county, and the water, though hard, is considered better than that from the shallow wells, because there is little danger of pollution, except in a few localities where sewage is allowed to enter waterbearing beds. The practice of permitting impure surface water or sewage to enter the ground through sinks and wells should be prohibited, because it is apt to pollute the underground water and render it unfit for use.

Flowing wells can not be obtained in Columbia County, but satisfactory supplies may be procured from the Vicksburgian limestones, at depths ranging from less than 100 feet in the southern part of the county to over 200 feet in the northern part.

Lake City has the only public water supply in Columbia County. The system is owned by the town, and the water is obtained from a deep well, which penetrates the Vicksburgian limestones. The water is hard and contains some sulphur but is said to be satisfactory.

Springs are numerous in Columbia County, especially in the southern half of the county. Itchatucknee Spring, 6 miles southwest of Fort White, flows 180,000 gallons per minute and is the most important spring in the county. The water, which is hard and is colored amber by organic matter, comes from Oligocene limestones, doubtless of Vicksburg age. The water boils up from hammock land and flows a small stream. Its temperature is $74^{\circ} \mathrm{F}$. 
General water resources of Columbia County.

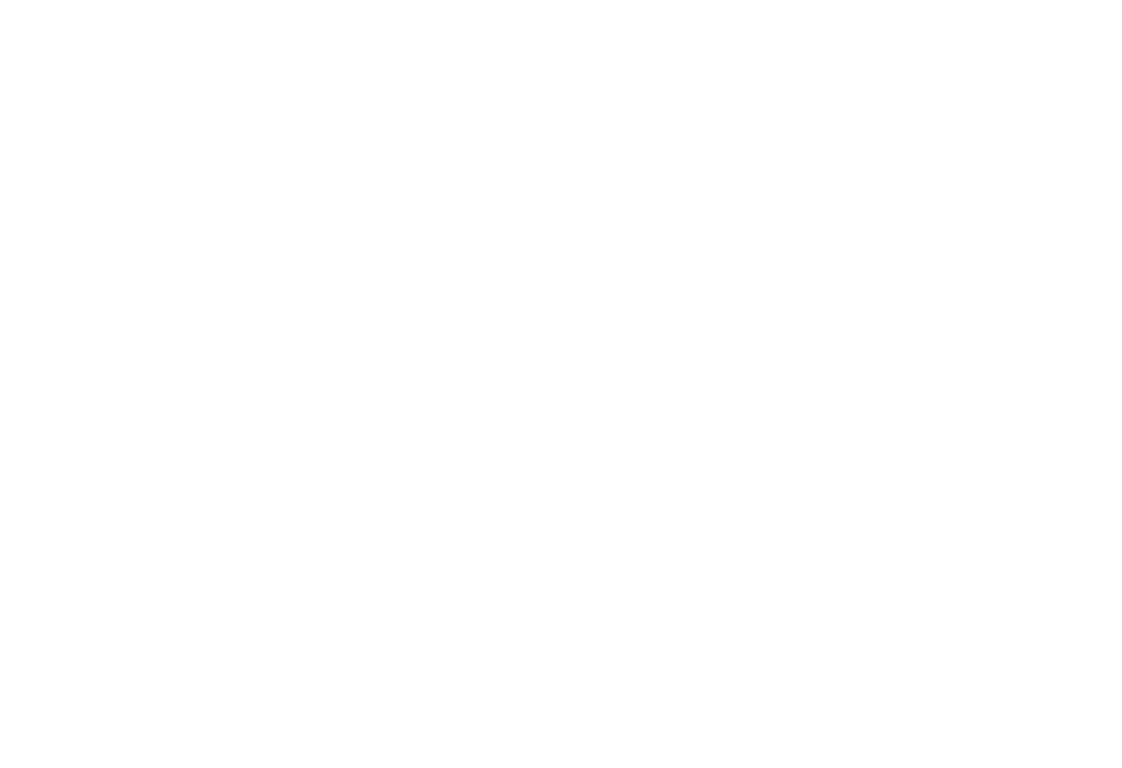

\section{DADE COUNTY.}

By Samuel Sanford.

\section{GENERAL FEATURES.}

Except in the cities and villages along or near the line of the Florida East Coast Railway, Dade County is sparsely inhabited, much the greater part of its area Iying within the Everglades. Several short rivers and creeks, New, Middle, and Miami rivers, Snake and Arch creeks, and others, flow from the Everglades into Atlantic Ocean or Biscayne Bay, and at the south end of the county Taylor River flows into the Bay of Florida. The relief is slight, reaching a maximum of possibly 30 feet and probably averaging less than 15 feet.

\section{GEOLOGY.}

Coquina is found along the ocean at many places from the north line of the county southward, the last reported outcrop south being on Virginia Key. Marls lie about the lagoons back of the beaches. Except for the low ridges of Miami oolite, sands cover most of the surface between the coastal swamps and the Everglades. The oolite lies in a strip about 10 miles wide at Fort Lauderdale and perhaps 20 miles wide at Miami, extending from near Dania to Long Siding, and thence southwest to beyond Long Key. Peat, resting for the most part on sands, overlies the oolitic and nonoolitic limestones of the Everglades. 
Nothing definite is known of the character, thickness, and structural relations of the Pliocene and Miocene beds and no borings in the county have gone deep enough to reach the Oligocene beds.

\section{WATER SUPPLY.}

Source.-No very deep wells yielding potable water had been sunk in 1908 in the county, and all the water-bearing beds utilized are classed as Pleistocene. They include Miami oolite, surficial sands, coquina, sandy marls with thin layers of limestones, and more or less compacted mixtures of quartz sand and shell fragments that do not outcrop.

Springs.-Along the rock ridges of the Biscayne pineland are a number of springs, some of considerable size. The largest noted rises on the west side of the crest of the ridges just north of Miami and flows into a swamp from Miami River. It is supplied by rainfall on the slightly higher ground of the pineland. No special use is made of it. Other springs are found along the bay side, some of which may be supplied by water from the Everglades. On the property of Kirk Monroe, at Cocoanut Grove, are several springs, one or two of which emerge below tide level. A few of the bay side springs are used for domestic supplies and by fishermen. Once they were of more importance, because of the scarcity of fresh water for vessels plying along the coast of southern Florida. Their waters are clear but rather hard.

There are said to be springs in the ocean bottom off Fort Lauderdale and elsewhere, but the evidence needs confirmation. The writer doubts the existence of large offshore springs anywhere along the coast of the county.

Wells.-The commonest wells in Dade County consist of $1 \frac{1}{2}$ or 2 inch pipe driven into the sand or worked down into the oolite. As water, except in the higher rock ridges or in dunes, in few places lies over 10 feet below surface, the cost of these wells is small. Wells over 50 feet deep are sunk by percussion or combined jet and percussion rigs; there are probably not more than 15 such wells in the county.

The deepest well in the county, 387 feet, was sunk on the ocean beach 2 miles east of Fort Lauderdale and half a mile north of the House of Refuge. It found nothing but salt water. Vaughan obtained the following partial record from E. T. King, the driller:

Partial log of well east of Fort Lauderdale.

\begin{tabular}{|c|c|c|}
\hline & Thickness. & Depth. \\
\hline 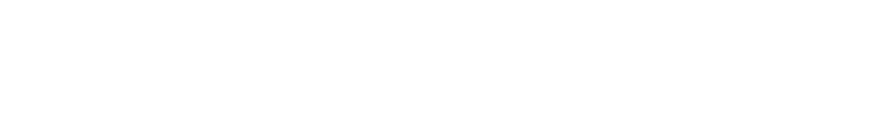 & Feet. \begin{tabular}{r|}
60 \\
1 \\
29 \\
290
\end{tabular} & $\begin{array}{r}\text { Feet. } \\
60 \\
61 \\
90 \\
387\end{array}$ \\
\hline
\end{tabular}


From the same driller Vaughan obtained the following record of a well at Fort Lauderdale:

Log of well of P. N. Bryan, Fort Lauderdale.

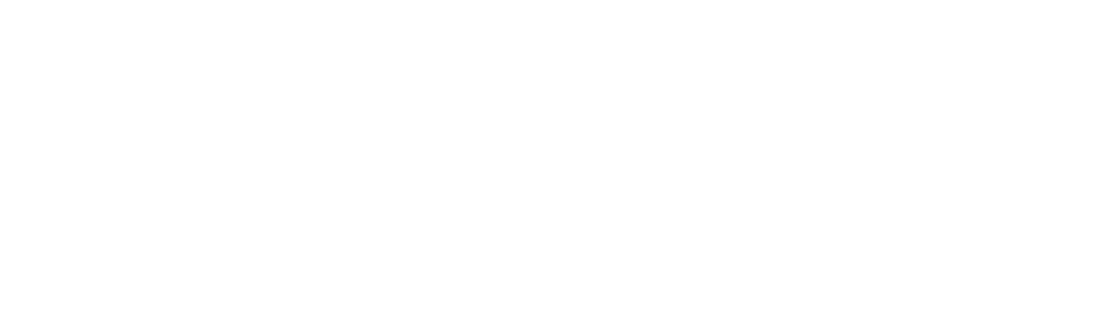

Most wells at Fort Lauderdale strike rock within 17 feet of the surface. The following record, also furnished by Mr. King, shows a notable depth to hard rock and a possible absence of oolite. The well is near the drainage canal, in what was swampy ground.

Log of well 8 miles west of Fort Lauderdale.

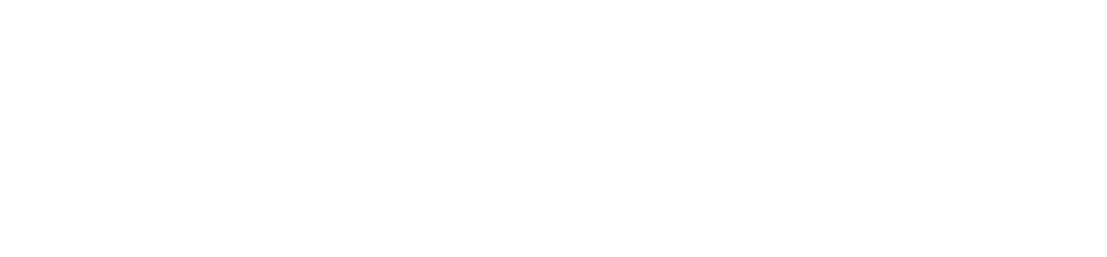

The water, which is slightly hard but of good quality for domestic use, flows over the casing, which is about 2 feet above sea level.

At Dania two wells are over 50 feet deep; others in the city and near by are much shallower, averaging less than 20 feet. The following record of the well used for the city supply was furnished to Vaughan by the driller, E. T. King:

Log of city well at Dania.

\begin{tabular}{|c|c|c|}
\hline & Thickness. & Depth. \\
\hline 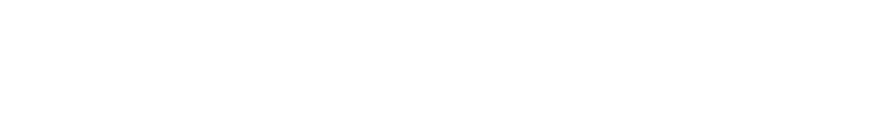 & \begin{tabular}{r|} 
Feet. \\
6 \\
40 \\
34 \\
8
\end{tabular} & $\begin{array}{r}\text { Feet. } \\
\quad 6 \\
46 \\
80 \\
88\end{array}$ \\
\hline
\end{tabular}

A gasoline engine drives a pump that raises the water to an elevated tank 35 feet high, whence it is distributed to about 40 families. The water is called soft.

The wells between Dania and the vicinity of Miami call for little comment, the only one over 50 feet deep in 1908 being that of Dr. 
J. N. McGonigle at Buena Vista, 3 miles north of Miami, which is about 55 feet deep.

About $1 \frac{1}{2}$ miles north of Miami are four 6-inch wells that are used by the Miami Water Co. to supply the city. The water flows into an underground reservoir or large well, whence it is carried by pipe to the pumping station in the city and pumped to a large standpipe and distributing mains. In 1908 probably 2,000 people used this water for domestic supply. It is also used for boiler supply by several industrial plants, by steamboats, and the railway. Its quality is essentially the same as that of water from the well at Buena Vista. In fact, all shallow limestone waters in Dade County, away from the sea, probably differ little and resemble the Buena Vista and Miami well waters.

The following generalized record of one of the wells shows the character of the materials penetrated:

Generalized log of well of Miami Water Co., near Miami.

\begin{tabular}{|c|c|c|}
\hline & Thickness. & Depth. \\
\hline Limestone, oolitic............. & Feet. & Feet. \\
\hline 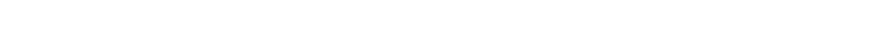 & $\begin{array}{l}15 \\
30\end{array}$ & \\
\hline 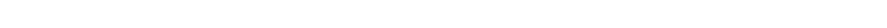 & $\mathbf{2}$ & 47 \\
\hline 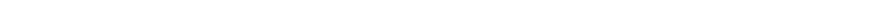 & 30 & \\
\hline 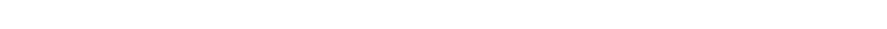 & 10 & 87 \\
\hline 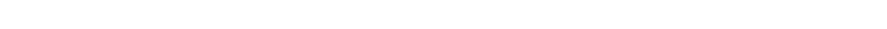 & 2 & 89 \\
\hline
\end{tabular}

The driller's log of one of the shallower wells was as follows:

Log of well of Miami Water Co., near Miami.

\begin{tabular}{|c|c|c|}
\hline & Thickness. & Depth. \\
\hline 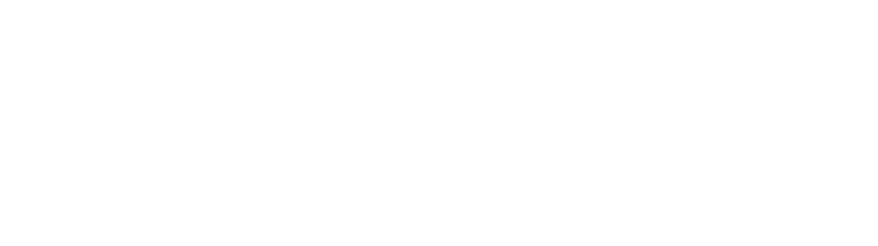 & Feet. $\begin{array}{r}3 \\
7 \\
3 \\
7 \\
7 \\
20 \\
10 \\
4 \\
2 \\
8\end{array}$ & $\begin{array}{r}\text { Feet. } \\
3 \\
10 \\
13 \\
20 \\
27 \\
47 \\
57 \\
61 \\
63 \\
71\end{array}$ \\
\hline
\end{tabular}

In Miami many wells have been sunk for domestic supply or other purposes; they are mostly shallow-under 25 feet. A few wellsnotably a large dug well at the ice factory-are reported to get salt under heavy pumping. The ice plant well is perhaps a quarter of a mile from the shore of Biscayne Bay, and the bottom of the well is about 10 feet below sea level. A field assay of the water is given on page 260 .

South of Miami numerous wells have been drilled or bored in the oolite. Depths to water vary with the elevation of the surface. 
A few wells on rock ridges between Miami and Cocoanut Grove are 35 feet deep; some near the shore get salty at times. South of Cocoanut Grove, at Keys, Perrine, Naranja, and Homestead, wells are mostly 8 to 15 feet deep, the deepest, 35 feet, being at a quarry for railroad ballast at Keys.

Artesian prospects.-The outlook for obtaining supplies of potable water near the coast in Dade County by wells deep enough to reach the Vicksburgian limestone, struck at over 900 feet at Palm Beach, is distinctly unfavorable. Flows may be had, but the water is certain to be highly mineralized. The best prospects are for wells about 100 feet deep and situated a little back from the shore, like those at Fort Lauderdale, Dania, and Miami, but the water may not rise above the surface. In the northern part of the county, toward its western boundary, the chance of getting potable water from the Vicksburg group is much better, but the surface waters are so good that deep drilling is unnecessary. There is practically no chance of finding good water by drilling on any of the keys east of Biscayne Bay. 
DADE COUNTTY゙.

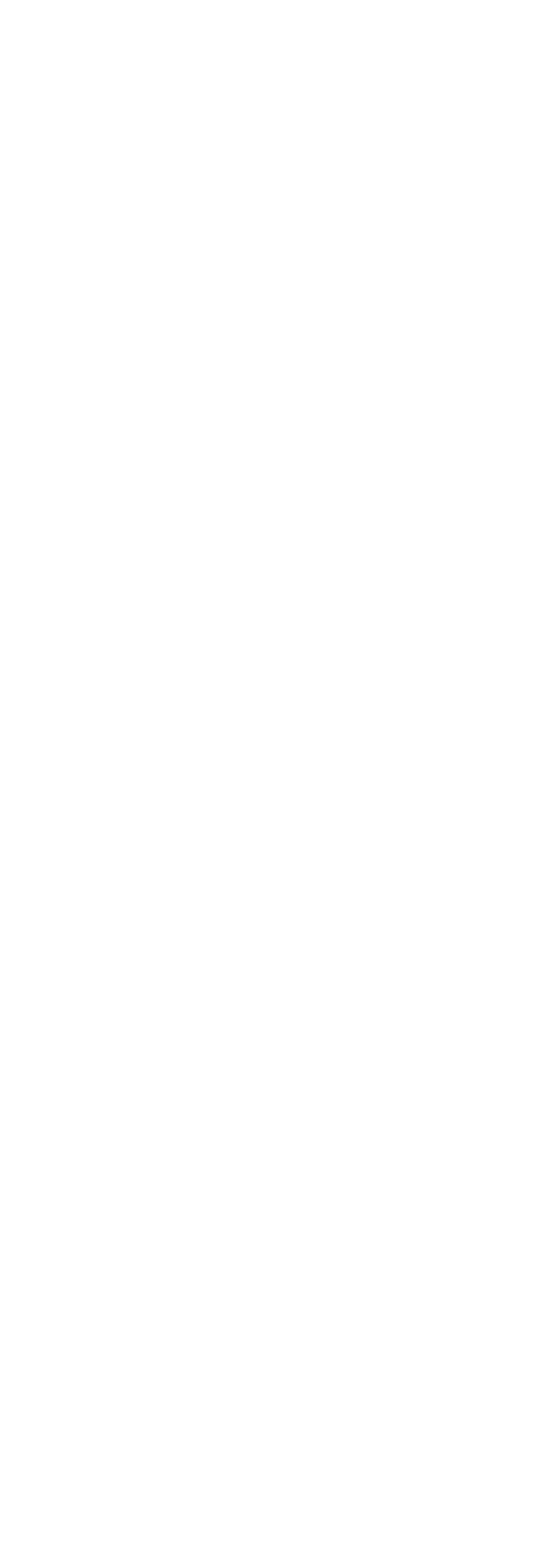




\section{DE SO'TO COUNTY.}

By G. C. Matson.

\section{GENERAL FEATURES.}

De Soto County extends from Lake Okechobee and Caloosahatchee River northward for over 50 miles with a width of about 30 miles. Near the coast the low surface rises 20 to 25 feet above sea level, forming a broad terrace of Pleistocene age, which extends up Peace River but narrows appreciably toward the head waters of that stream. It also extends several miles northward from Caloosahatchee River, reaching the low lands bordering Lake Okechobee and Kissimmee River. In the vicinity of Lake Okechobee and Lake Istopoga the surface is low and flat and is covered by a luxuriant growth of saw grass and other aquatic plants. The central portion of the county is a high rolling upland, containing numerous depressions occupied by lakes. Lakes and swamps are also common in the southern half of the county.

\section{GEOLOGY.}

Below the 100-foot contour the surface deposits of De Soto County consist of gray Pleistocene sand except in the vicinity of the large lakes, such as Lake Okechobee, where there are areas of peat and muck. Beneath the Pleistocene sands of the western part of the county are beds of Pliocene age, which belong almost wholly to the Caloosahatchee marl, except near the northern end of the county, where there are small patches of land-pebble phosphate belonging to the Bone Valley gravel. Beneath the Bone Valley gravel are limestone, sands, and clays of the Alum Bluff formation. Sands of the Alum Bluff probably reach the surface in the central portion of the county. The Tampa formation is not exposed, but it underlies the surface at no great depth. The Vicksburgian limestones extend beneath the entire county but are deeply buried under the younger formations.

It is difficult to give any correct estimate of the thickness of the various geologic formations in De Soto County, because few natural exposures exceed 10 feet and the well logs are difficult to interpret. In the western part of the county the Pleistocene gray sands are generally more than 20 feet thick, and farther east, especially in the vicinity of Lake Okechobee, their thickness probably exceeds 100 feet. The Caloosahatchee marl is but a few feet thick where it is exposed in the valley of Peace River, but it doubtless thickens toward the east. The thickness of the Alum Bluff and the Tampa formations can not be accurately determined, but it may exceed 300 feet in the western part of the county; no figures are available outside the 
Typical wells of De Soto County.

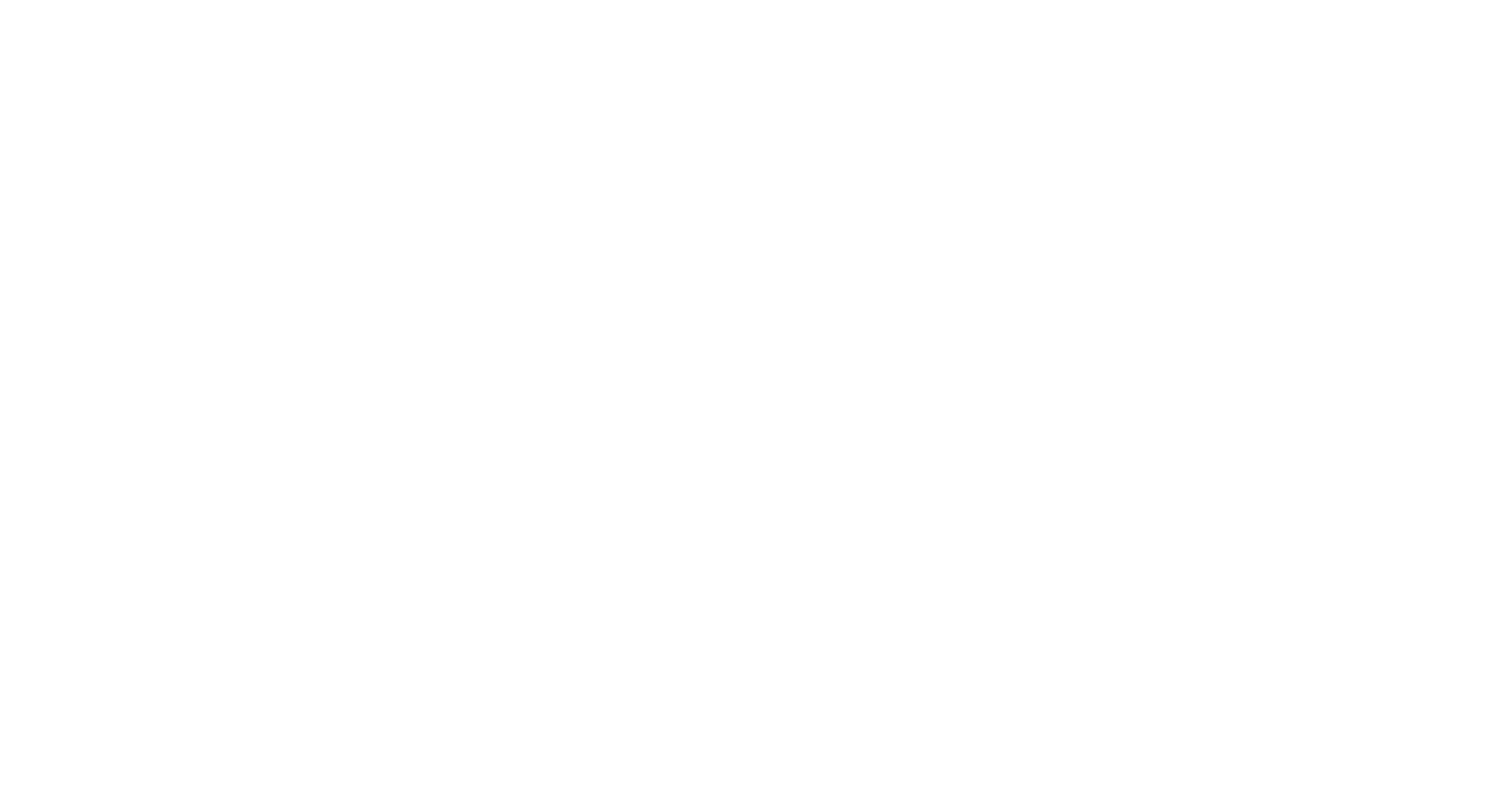



valley of Peace River. Here, as elsewhere in the peninsula, the Vicksburgian limestones should have a maximum thickness of several hundred feet.

\section{WATER SUPPLY.}

Source.-The surficial sands are an important source of underground water in the settled portions of De Soto County. The Caloosahatchee marl and Bone Valley gravel yield some water, but it is doubtful if these two formations are of more than local importance. The best aquifers are the Vicksburgian limestones, which furnish large quantities of water to the deep wells used for the phosphate mines and for municipal supplies.

Quality.-The surficial sands furnish soft water suitable for all purposes. Moderately hard water should be obtained from the Caloosahatchee marl and the Bone Valley gravel, but as yet no definite information concerning this is available. The Vicksburgian limestones yield hard sulphur water.

Development.-Shallow wells obtain abundant water at depths ranging from 10 to 25 feet, though a few have been sunk 40 to 80 feet deep. The deeper supplies are probably more desirable than the shallow because they are presumably purer. The deep wells range from 100 to 300 feet in depth, and a few wells have been drilled to over 800 feet and some at the phosphate mines exceed 500 feet. The head of the water is sufficient to raise it about 40 feet above sea level and hence flowing wells may be obtained on low ground. Good flows have been obtained in the valley of Peace River, at Arcadia, Bowling Green, Fort Ogden, Hickman, Hull, Liverpool, Nocatee, Wauchula, and Zolfo. Good flowing wells have also been drilled in the vicinity of Charlotte Harbor and flows are to be expected in a large area near Kissimmee and Caloosahatchee rivers. In the vicinity of Charlotte Harbor and in the valley of Peace River the water is hard and contains sulphur, but it is satisfactory for all general uses. Toward the south end of the county and in the valley of Kissimmee River the artesian waters probably contain more or less salt, but they may be fit for use. 
General water resources of De Soto County.

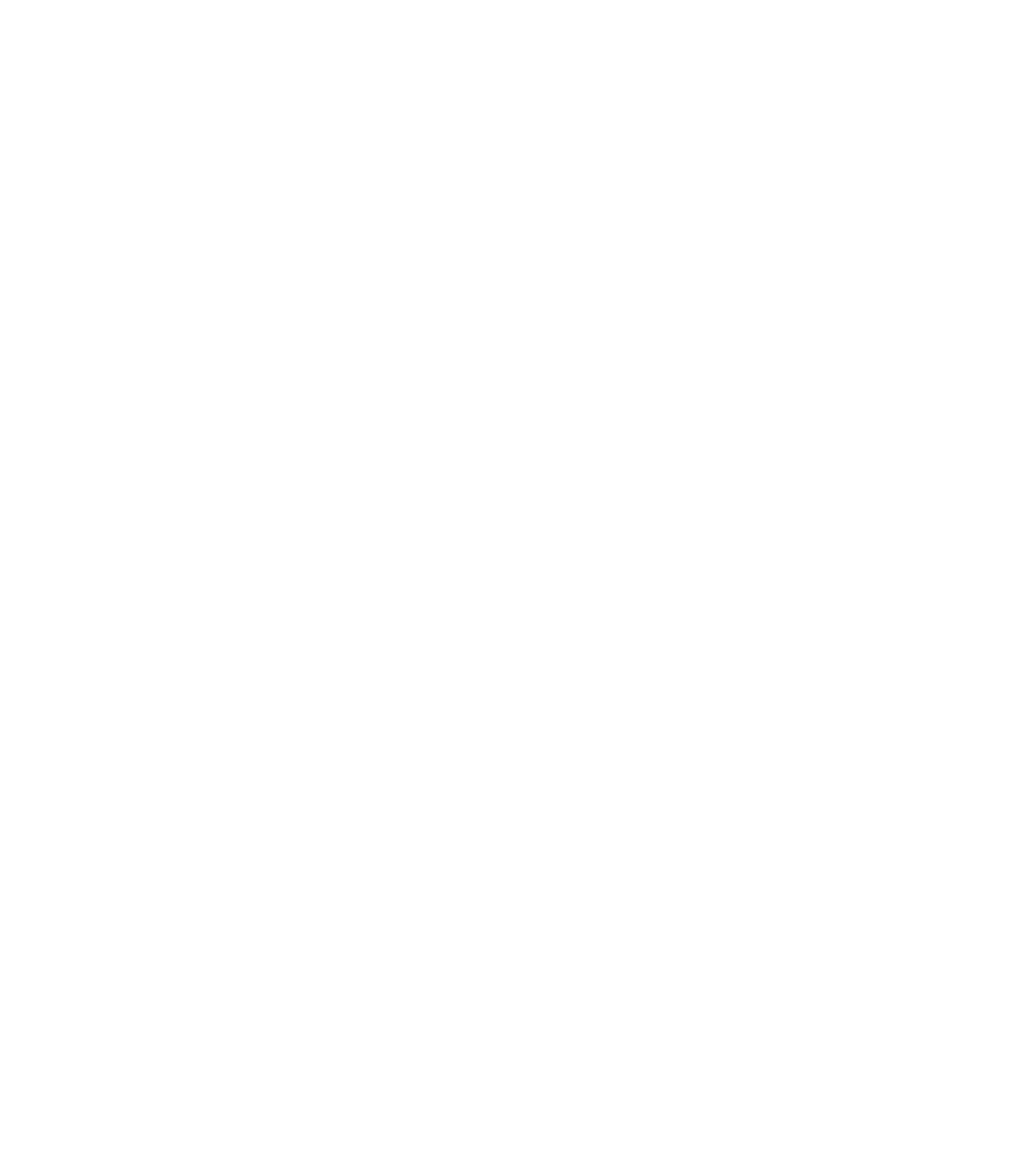

\section{DUVAL COUNTY.}

By G. C. Matson.

\section{GENERAL FEATURES.}

Duval County comprises a large area in northeast Florida extending from the coast westward to the highlands which form the axis of the peninsula. The surface of the county shows considerable variation, altitudes ranging from a few feet along the coast and in the valley of St. Johns River to nearly 200 feet above sea level in the southwest corner of the county. The transition from the lower to the higher levels is in part by broad, nearly level terraces. The lowest terrace 
extends inward several miles from the coast and occupies a large area bordering St. Johns River. Little of it lies more than 20 feet above sea level, but its inland margin is marked by an increase in altitude-in some places to over 40 feet. A second terrace borders the first and has an altitude of 40 to 60 feet above sea level. Between this terrace and the upland is a third terrace, with an altitude of 70 to 100 feet above sea level. Near the southwest corner of the county the land is somewhat hilly, and the extreme corner of the county touches the high divide known as Trail Ridge. The county has few streams, butit contains broad areas that are flat and swampy. However, there are no lakes of any considerable size except those that form part of St. Johns.River, and there does not appear to be a great amount of underground drainage through caverns such as characterize the lake region to the south and west.

GEOLOGY.

A large part of the surface deposits of Duval County consists of gray sands of Pleistocene age. These sands are underlain by red, yellow, and mottled sands and sandy clays which have been referred to the Lafayette (?) formation and regarded as Pliocene, though in the absence of fossils their exact age can be inferred only from their relations to the underlying and overlying formations. A great thickness of limestones, shales, and sands, lying beneath the sands and clays of Pleistocene and Pliocene age, belongs to the Jacksonville formation. The type locality of this formation is at Jacksonville, where it was encountered in digging a basin at the city waterworks. The log of the Jacksonville well (p. 124) shows the general character of the formation and indicates that it may have a thickness of at least 461 feet. The Hawthorn formation may be represented by beds of clay and limestone, but there is some doubt as to its presence in the Jacksonville well; toward the south and west it is extensively developed and it not improbably extends into Duval County. The entire county is underlain by the Vicksburgian limestones, but they are so deeply buried that their presence can be detected only in artesian-well drillings.

The Pleistocene gray sand is comparatively thin, probably in few places exceeding 30 feet and averaging not more than 20 feet. The underlying red, yellow, and variegated sands of Pliocene age may in some localities be 30 or 40 feet thick. At Jacksonville their thickness appears to be about 20 feet. The thickness of the Jacksonville formation may be nearly 500 feet, though from the conditions at St. Augustine it is inferred that it thins toward the south. The Hawthorn formation is apparently thin. The Vicksburgian limestones have been penetrated in wells for several hundred feet without 
reaching the underlying formation. The following well logs show the thickness of the formations at different places:

Log of the 8-inch artesian well a of the Seaboard Air Line Railway shops, at Jacksonville.

\begin{tabular}{|c|c|c|}
\hline & Thickness. & Depth. \\
\hline Sand, with a few feet of clay near the surface & Feet. & Feet. \\
\hline Clay & 10 & 36 \\
\hline Clay, soft, with thin layers of rock, varying from 2 to 12 inches thick......... & 39 & 75 \\
\hline 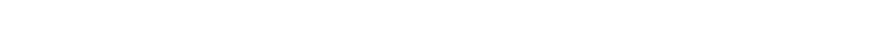 & $\begin{array}{l}15 \\
20\end{array}$ & $\begin{array}{r}90 \\
110\end{array}$ \\
\hline 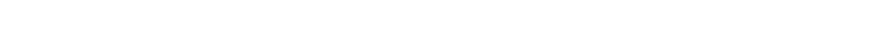 & 60 & 170 \\
\hline 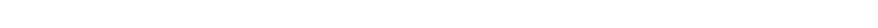 & 40 & 210 \\
\hline $\begin{array}{l}\text { Shell rock } \\
\text { Clay, sandy }\end{array}$ & 11 & 211 \\
\hline 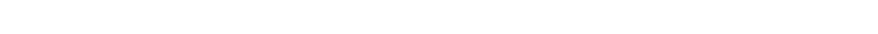 & 11 & $\begin{array}{l}222 \\
233\end{array}$ \\
\hline Clay, soft.............. & 3 & 236 \\
\hline 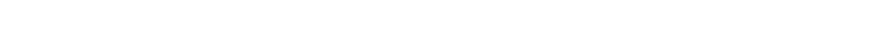 & 4 & 240 \\
\hline $\begin{array}{l}\text { Clay, } \\
\text { Clay, stiff }\end{array}$ & $\begin{array}{l}5 \\
8\end{array}$ & $\begin{array}{l}245 \\
253\end{array}$ \\
\hline Sandstone & 15 & 268 \\
\hline 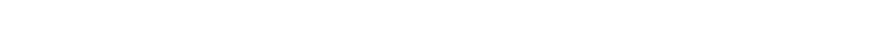 & 72 & 340 \\
\hline 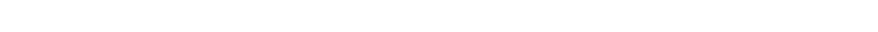 & $\stackrel{0}{3}$ & $\begin{array}{l}345 \\
348\end{array}$ \\
\hline Sand, coarse, gray; flow is gallons per minute. & 5 & 353 \\
\hline Stone and clay; in layers................... & 27 & 380 \\
\hline 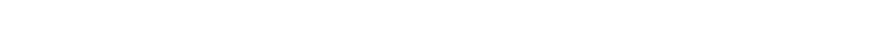 & 3 & 383 \\
\hline Clay, nard....................... & 36 & $\begin{array}{l}392 \\
428\end{array}$ \\
\hline Clay, soft, sandy... & 4 & 432 \\
\hline Clay, tough & & 435 \\
\hline $\begin{array}{l}\text { Sandstone, blue } . . . \ldots \ldots \ldots \ldots \\
\text { Pipe clay, hard }\end{array}$ & $\underset{47}{2}$ & $\begin{array}{l}437 \\
484\end{array}$ \\
\hline 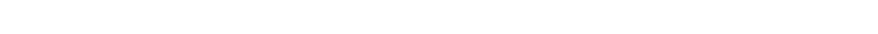 & 4 & 488 \\
\hline Shell rock...................................... & 2 & 490 \\
\hline 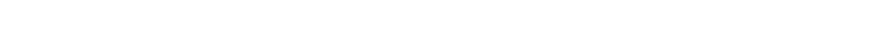 & $\begin{array}{l}4 \\
3\end{array}$ & $\begin{array}{l}494 \\
497\end{array}$ \\
\hline Porous rock; flow 1,000 gallons per minute...... & 21 & 518 \\
\hline 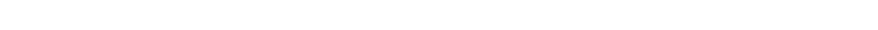 & 6 & 524 \\
\hline Rock, porous; flow 1,000 to 1,500 gallons per minute...... & & 708 \\
\hline
\end{tabular}

a Casing, 8-inch, to 499 feet.

Log of well of Florida East Coast Railway at Mayport.

\begin{tabular}{|c|c|c|c|c|c|}
\hline & Thickness. & Depth. & & Thickness. & Dépth. \\
\hline 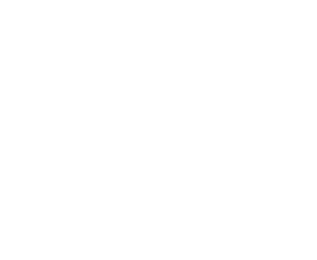 & $\begin{array}{r}\text { Feet. } \\
58 \\
3 \\
23 \\
3 \\
73 \\
5 \\
35 \\
40 \\
35 \\
5 \\
70\end{array}$ & $\begin{array}{r}\text { Feet. } \\
58 \\
61 \\
84 \\
87 \\
160 \\
165 \\
200 \\
240 \\
275 \\
280 \\
350\end{array}$ & 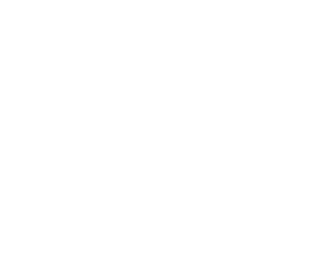 & $\begin{array}{r}\text { Feet. } \\
3 \\
10 \\
3 \\
9 \\
5 \\
20 \\
40 \\
7 \\
180 \\
3\end{array}$ & $\begin{array}{r}\text { Feet. } \\
353 \\
363 \\
366 \\
375 \\
380 \\
400 \\
440 \\
447 \\
627 \\
630\end{array}$ \\
\hline
\end{tabular}


Log of well of Florida East Coast Railway at Burnside.

\begin{tabular}{|c|c|c|c|c|c|}
\hline & Thickness. & Depth. & & Thickness. & Depth. \\
\hline & Feet. & Feet. & & Feet. & Feet. \\
\hline Sand......... & 35 & 35 & Clay....... & 15 & 385 \\
\hline Clay ............ & 12 & 47 & Rock................ & 2 & 387 \\
\hline Soapstone. & 43 & 90 & Sand... & $\overline{3}$ & 390 \\
\hline Clay ......... & 50 & 140 & Rock... & 1 & 391 \\
\hline Rock, soft....................... & 15 & 155 & Clay..... & 4 & 395 \\
\hline Clay ........ & 5 & 160 & Rock. & 1 & 390 \\
\hline Rock, soft.... & 10 & 170 & Clay... & 2 & 398 \\
\hline Sand and clay. & 15 & 185 & Rock... & 6 & 404 \\
\hline Sand.......... & 25 & 210 & Water. & 6 & 410 \\
\hline 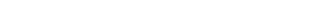 & 65 & 275 & Rock... & 2 & 412 \\
\hline Rock. & 5 & 280 & Water..... & 38 & 450 \\
\hline Clay... & 10 & 290 & Rock, soft & 40 & 490 \\
\hline Rock. & 2 & 292 & Rock, hard. & 30 & 520 \\
\hline Clay..... & 12 & 304 & Water...... & 20 & 540 \\
\hline (n................. & 5 & 310 & Rock.......... & 5 & 545 \\
\hline Rock ....... & 1 & 311 & Unknown .... & & \\
\hline Clay $\ldots \ldots \ldots \ldots \ldots \ldots \ldots \ldots \ldots$ & $\overline{9}$ & 320 & Rock....... & $\overline{3}$ & 550 \\
\hline 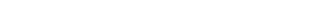 & 20 & 340 & Unknown .. & 5 & 555 \\
\hline 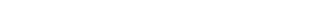 & 10 & 350 & Rock........ & 5 & \\
\hline Sand...... & 7 & 357 & 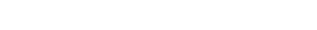 & 2 & 562 \\
\hline Clay ... & 4 & 361 & Rock................. & $\overline{3}$ & 565 \\
\hline 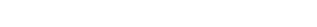 & 2 & 303 & Rock, soft................ & 10 & 575 \\
\hline Clay $\ldots \ldots \ldots \ldots \ldots \ldots \ldots$ & 6 & 369 & Rock, hard.$\ldots \ldots \ldots \ldots \ldots$ & 9 & 584 \\
\hline Rock ...................... & 1 & 370 & & & \\
\hline
\end{tabular}

Partial $\log$ of well of city of Jacksonville.

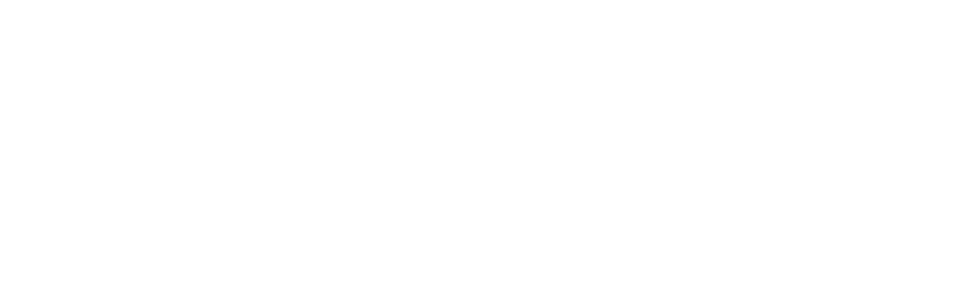

The soft white limestone encountered beneath the last silicified layer yields a strong flow of sulphur water. The log of this well is incomplete, though the conditions are doubtless similar to that shown by the log given on page 124. The soft white limestone at the bottom of the well contains fossils indicating Vicksburg age. The material from 375 to 506 feet probably represents the Jacksonville formation, though the lower part may belong to the Hawthorn formation.

WATER SUPPLY.

Source.-The Pleistocene and Pliocene sands furnish an abundant supply of water for shallow wells. The water table usually stands within a few feet of the surface and suction pumps may be used advantageously. Because of the small cost and the ease with which the water may be raised, shallow wells are extensively used for domestic and farm supplies. The sand beds in the Jacksonville formation are water bearing, but the supplies are seldom utilized; the head is sufficient to bring the water near the surface in the vicinity of Baldwin and to give flowing wells on low ground some miles southeast of that town. 
The best water supplies of the county are obtained from the Vicksburgian limestones, the water in which is under sufficient pressure to yield strong flows near the coast and in the St. Johns River valley.

Quality.-Pleistocene and Pliocene sands yield soft water. Little is known concerning the quality of the water yielded by the Jacksonville formation; in the well at Yellow Water Schoolhouse it yielded soft water, but it appears probable that it also yields hard water from certain of its limestone beds. The Vicksburgian limestones furnish hard water containing hydrogen sulphide, and some of the very deep wells have found saline water in these formations.

Development.--Shallow wells ranging in depth from 5 to 60 feet are used in several parts of Duval County but most commonly 15 to 25 feet deep. The deeper wells are usually sunk in order to obtain more or better water. Shallow wells are regarded as satisfactory if they are located some distance from buildings or if the aquifers are capped by impervious clay that excludes impure surface drainage. In the vicinity of Baldwin much water is obtained from the Jacksonville formation at 80 to 100 feet.

Flows may be expected from the Jacksonville only on low ground and they appear to be largely confined to the western part of the county. The well of $\mathrm{H}$. J. Reid at Mandarin obtains water from this formation at 157 feet, but the water does not have sufficient head to rise to the surface.

A large number of wells have been drilled to the Vicksburgian limestones and obtain large supplies. In the vicinity of Jacksonville the water has a head of about 65 feet above sea level, sufficient to give flows strong enough to be used for water power. The water contains a large quantity of inorganic material, including sulphur, but is usually regarded as satisfactory. Flowing wells from this formation are most numerous in the vicinity of Jacksonville and in the villages along the coast; they range in depth from slightly less than 500 feet to more than 1,000 feet.

Jacksonville, South Jacksonville, Riverside, and Pablo Beach all have public water supplies obtained from wells penetrating the Vicksburgian limestones. The water is regarded as satisfactory for all purposes and the quantity is practically unlimited. At Jacksonville the water is permitted to flow into a reservoir from which it is pumped into distributing mains. At Pablo Beach and South Jacksonville the water flows directly from the wells into the mains, and the systems depend on the artesian head for pressure. Practically no information could be obtained concerning the public supply of Riverside.

No large springs are reported from Duval County, but small springs are not uncommon. 
Typical wells of Duval County.

\begin{tabular}{|c|c|c|c|c|c|c|c|c|c|c|c|c|c|c|c|c|c|c|c|c|}
\hline \multirow[b]{2}{*}{$\begin{array}{l}\text { Nearest town or post } \\
\text { office. }\end{array}$} & \multirow[b]{2}{*}{ Direction and distance. } & \multirow[b]{2}{*}{ Owner. } & \multirow[b]{2}{*}{ Driller. } & \multirow[b]{2}{*}{$\begin{array}{l}\text { Date } \\
\text { sunkt. }\end{array}$} & \multirow[b]{2}{*}{$\begin{array}{l}\text { Surface forma- } \\
\text { tion. }\end{array}$} & \multirow[b]{2}{*}{ Geologic source. } & \multirow[b]{2}{*}{$\begin{array}{l}\text { Type of } \\
\text { well. }\end{array}$} & \multirow[b]{2}{*}{ Use. } & \multirow[b]{2}{*}{ Depth. } & \multirow[b]{2}{*}{$\left|\begin{array}{c}\text { Diam- } \\
\text { eter. }\end{array}\right|$} & \multirow{2}{*}{ Casing. } & \multirow{2}{*}{\begin{tabular}{|c|} 
Elevar \\
tiou \\
bove \\
sear.
\end{tabular}} & \multicolumn{2}{|c|}{ Head- } & \multirow{2}{*}{$\begin{array}{l}\text { Depth } \\
\text { to } \\
\text { rock. }\end{array}$} & \multirow{2}{*}{$\begin{array}{l}\text { Depth } \\
\text { to pin- } \\
\text { coppal } \\
\text { cuppply. }\end{array}$} & & & & \\
\hline & & & & & & & & & & & & & $\begin{array}{c}\text { Above } \\
\text { sea. }\end{array}$ & \begin{tabular}{|c|} 
Above \\
of bolew \\
surface.
\end{tabular} \mid & & & Quality of water. & 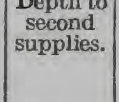 & $\begin{array}{l}\text { Yield per } \\
\text { minute. }\end{array}$ & Remarks. \\
\hline Baldwin. & $\frac{1}{2}$ mile north........ & Atlantic Coast Line & & & Pleistocene... & Jacksonville formation.. & Drilled.. & Locomotives... & $\begin{array}{l}\text { Feet. } \\
100 \pm \pm\end{array}$ & $\begin{array}{l}\text { Inches. } \\
3\end{array}$ & $\begin{array}{l}\text { Feet. } \\
\text { Fin. }\end{array}$ & $\begin{array}{l}\text { Fete } \\
\text { Level. }\end{array}$ & $\begin{array}{l}\text { Feet. } \\
\text {. }\end{array}$ & $\begin{array}{l}\text { Feet. } \\
-4\end{array}$ & Feet. & Feet. & & Feet. & Gallons. & \\
\hline $\begin{array}{l}\text { Do... } \\
\text { Do } \ldots\end{array}$ & .....do................. & seaboard Air Line & Stafford .. & $\begin{array}{l}1907 \\
1898\end{array}$ & ....do......... & \begin{tabular}{|l} 
Vicksburgian limestone?. \\
Jacksonville formation_..
\end{tabular} & D̈rilied.: & $\begin{array}{l}\text { Not used......... } \\
\text { Locomatives... }\end{array}$ & $\begin{array}{c}580 \\
92\end{array}$ & \begin{tabular}{|l}
5,3 \\
5
\end{tabular} & $\begin{aligned} 511 \\
92\end{aligned}$ & $\underset{\substack{\text { Level, } \\
a 47}}{a, 7}$ & & to & & 92 & & & Many. & Reported a failure. \\
\hline Do... & 6 miles southeast.. & 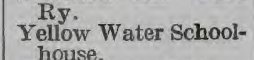 & $\ldots$ & 1006 & 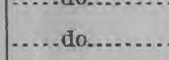 & 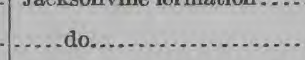 & ado..... & & $80 \pm$ & & & $\begin{array}{l}a 40 \\
a 40\end{array}$ & & + & & s & Solt............ & & mazay. & \\
\hline Bayard....... & & Cotter, Lucas \& Co..... & & & .............. & Vicksburgian limestone?.. & ...do... & Boilers, domestic, etc.. & $500 \pm$ & 4 & & & & +several. & & & sulphur....... & & Many. & No action in boilers. \\
\hline East Mayport. & & $\begin{array}{l}\text { Florida East Coast } \\
\text { Ry. }\end{array}$ & & & ....do..... & 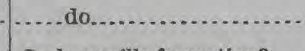 & ...do.... & Locomotives............ & 600 & & & ${ }^{a}{ }^{10}$ & & + & & & $\cdots .$. & $\cdots$ & Many. & \\
\hline $\begin{array}{l}\text { Floral Blinfi. } \\
\text { Fort Georete: } \\
\text { Jacksonville. }\end{array}$ & 2 miles east............. & 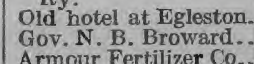 & Hugh Partridge.. & $1890^{\circ}$ & $\begin{array}{l}\text { do.... } \\
\cdots \text { dow... }\end{array}$ & $\begin{array}{l}\text { Jacksonville formation? } \\
\text { vickssurgian limestone. } \\
\text { do }\end{array}$ & dow.... & \begin{tabular}{|l|} 
Not used... \\
\hdashline do
\end{tabular} & 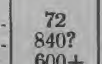 & 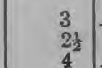 & 600 & $\mathrm{Few}_{5}$ & & $\begin{array}{l}\text { - Few. } \\
+ \\
+40+ \\
+40+\end{array}$ & & $\begin{array}{l}{ }^{600+}+1 \\
{ }_{300}\end{array}$ & Sulphur.. & & Many. & Ferms smate in brilers \\
\hline Do............ & 2 miles northeast.... & Atlantic Cosst Line & & & a....... & $\ldots$ do & ado... & ers. & 708 & 6 & & 14 & & +50 & & 487 & & 300,399 & 400 & Formerly belonged to Hayward \& Bostwick. \\
\hline Do. & & Armour \& Co.................. & Hugh Partridge... & 1902 & ....do... & …...do... & ...do... & Drinking and manu- & 685 & 4 & 400 & 14 & 40 & 40 & & 650 & Sulphur.... & 350 & 300 & \\
\hline Do.. & 11 miles east-northeast. & R. F. Barker............... & & $188 \overline{5}$ & $\ldots$ do.... & ......do.... & ...do... & $\begin{array}{l}\text { Domestibi, stock, and } \\
\text { imingation, }\end{array}$ & 525 & 4 & 400 & Few. & & 55 & & & .................. & & & \\
\hline $\begin{array}{l}\text { Do... } \\
\text { Do... } \\
\text { Do }\end{array}$ & 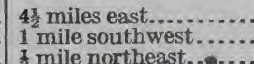 & $\begin{array}{l}\text { F. . . T. Bowden- } \\
\text { John C. Christopher } b \\
\text { Citizens Gas Co }\end{array}$ & Joyce.... & & …do............... & 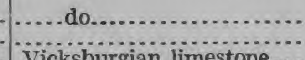 & ...do....... & 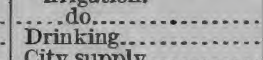 & $\begin{array}{c}652 \\
616\end{array}$ & $\begin{array}{l}6 \\
4 \\
6\end{array}$ & 400 & $\mathrm{Few}_{8}$ & & $\begin{array}{l}30 \pm \\
+2\end{array}$ & 39 & 600 & ....do..... & 420510 & Many. & \\
\hline $\begin{array}{l}\text { Do... } \\
\text { Do... }\end{array}$ & 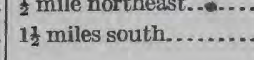 & 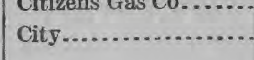 & R.N. Ellis... & 1903 & Plestocene.... & Vickssurglan limestone. & 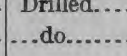 & $\begin{array}{l}\text { ilyy supply......... } \\
\text { Domestic and stock.. }\end{array}$ & $\begin{array}{l}800 \\
980\end{array}$ & 10 & 45 & $\begin{array}{l}4 \\
3\end{array}$ & ...... & 58 & ..... & $865-970$ & ............. & $\left\{\begin{array}{r}40-44 \\
510-722\end{array}\right\}$ & 1,380 & \\
\hline Do.. & & ....do.. & & 1905 & ....do... & ....do... & ...do... & City supply...... & 984 & 10 & 494 & 5 & 55 & 50 & & $\left\{\begin{array}{l}524, \\
750^{2} \\
860\end{array}\right.$ & & & 1,215 & \\
\hline Do.. & $\begin{array}{l}\text { Seventh and Silver } \\
\text { strente }\end{array}$ & City waterworks... & & & ....do... & ......do...... & ...do... & Public supply..... & 980 & 12 & & Few. & & & & $\begin{array}{l}{ }^{4} 8800 \\
850\end{array}$ & sulphur.... & $700 \pm$ & & \\
\hline $\begin{array}{l}\text { Do.. } \\
\text { Do.: }\end{array}$ & 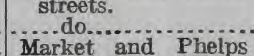 & do..................... & & & .... do... & .....do.......... & ...do... & ....do........................ & $\frac{990 \pm}{980}$ & 10 & & $\begin{array}{l}\text { Few- } \\
\text { Few }\end{array}$ & & & & & . do do.............. & $700+$ & & \\
\hline Do..... & $\begin{array}{l}\text { stretets } \\
\text { Hubbard near Phelps }\end{array}$ & : & ……... & & $\ldots$ do..... & ..... do..... & $\ldots$ do... & -... do & 980 & 10 & & Few. & & 50 & & 850 & .... do & $\begin{array}{l}700 \pm \\
700 \pm\end{array}$ & $\begin{array}{l}1,000 \\
1,000\end{array}$ & \\
\hline Do.... & 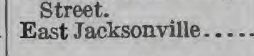 & $\begin{array}{l}\text { Commercial I Tee \& Fer- } \\
\text { tijiper Co }\end{array}$ & & & .....do..... & ......do...... & $\ldots$........ & Ice manufacturing..... & 650 & & & Few. & & + & & & & & (c) & \\
\hline Do.... & $\begin{array}{l}5 \text { miles northeast....... } \\
3 \text { miles east }\end{array}$ & $\begin{array}{l}\text { Cummer Lumber Co.. } \\
\text { G.M.Diven } b \ldots\end{array}$ & Wade & & …do..... & ......do.... & ...do.... & $\begin{array}{l}\text { Boilers and drinkring.. } \\
\text { Trivartion }\end{array}$ & $500+$ & 6 & & $a_{20}$ & & +30 & & & Sulphur... & & & Forms seale in boilers. \\
\hline & $\begin{array}{l}3 \text { milies east............ } \\
\text { Near.......... }\end{array}$ & 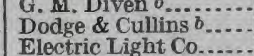 & & & & & & 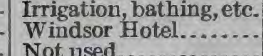 & $\begin{array}{l}800 \\
746 \\
705 \\
702\end{array}$ & $\begin{array}{l}6 \\
8 \\
8\end{array}$ & 4000 & $\begin{array}{r}20 \\
9\end{array}$ & & 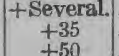 & & \begin{tabular}{c}
$800 ?$ \\
\hdashline 506 \\
5
\end{tabular} & ido....... & 50 & $\begin{array}{l}\frac{M}{\text { Many. }} \text { Many: } \\
\text { Manyi }\end{array}$ & Protentive olloy a $975+$ cot \\
\hline & $\begin{array}{l}\text { ii miles easit: } \\
2 \text { miles west.: }\end{array}$ & $\mid$ & B. F. Partridge... & $\begin{array}{l}19922 \\
\text { iago5 } \\
1005\end{array}$ & 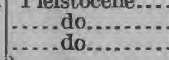 & 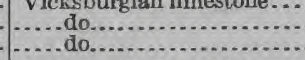 & 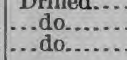 & 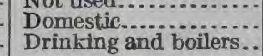 & 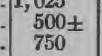 & $\begin{array}{l}8 \\
8\end{array}$ & . & Hew: & & $\begin{array}{l}75 \pm \\
+5\end{array}$ & & $\begin{array}{c}500 \pm \\
500 \pm\end{array}$ & 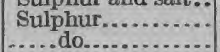 & & & 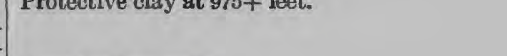 \\
\hline & & $\begin{array}{l}\text { Florida cee Manufac- } \\
\text { turing Co. }\end{array}$ & Niel Prince...... & $\left\{\begin{array}{l}1902- \\
1900 \\
\text { 1000 }\end{array}\right.$ & \} & Jacksonville formation.. & ...do.... & Boilers.................... & $80 \pm$ & $2 \mathrm{2}$ & $80 \pm$ & Few. & & - & & $80 \pm$ & & & Many. & Four shallow wells. \\
\hline $\begin{array}{l}\text { Do. } \\
\text { Do.: } \\
\text { Don }\end{array}$ & & 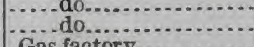 & & 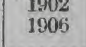 & …do. do. & $\begin{array}{l}\text { Vicksburgian limestone. } \\
\text { i..do do.... }\end{array}$ & ;.do.: & Ice manufacturing...... & ${ }_{752}^{630}$ & & & $\begin{array}{l}\text { Few: } \\
\text { Few }\end{array}$ & & $\ldots$ & $\cdots \cdots$. & & $\mid \begin{array}{l}\text { Sulphur... } \\
\text { :...do. }\end{array}$ & & Many. & \\
\hline $\begin{array}{l}\text { Do. } \\
\text { Do. }\end{array}$ & 2 miles northeast..... & $\begin{array}{l}\text { Gas factory } \\
\text { Howard \& Bostwick, } \\
\text { in.b }\end{array}$ & & & & .....do.... & & \begin{tabular}{|l|} 
Public supply...... \\
Domestic..........
\end{tabular} & $\begin{array}{l}750 \\
708\end{array}$ & $\begin{array}{l}8 \\
6\end{array}$ & .... & Few & & $\stackrel{+}{+50}$ & $37 \div$ & $487^{\circ}$ & süphur.: & $300-399^{\circ}$ & 400 & \\
\hline $\begin{array}{l}\text { Do.... } \\
\text { Do... }\end{array}$ & 22 miles west.......... & $\begin{array}{l}\text { Jatebsonville Brick Co. } \\
\text { Jacklconville } \\
\text { Ellectric }\end{array}$ & Hugh Partridge. & 1903 & $\begin{array}{l}\text { Pleistocene.... } \\
\text { :. do }\end{array}$ & \begin{tabular}{|l|l} 
Jacksononille formation...... \\
Vicksburbian limestone..
\end{tabular} & $\begin{array}{l}\text { Drilled... } \\
\text { adow.... }\end{array}$ & "Drinking, manulac- & $\frac{70}{730}$ & $\frac{2}{10}$ & 70 & $3^{-0}$ & & $\begin{array}{r}-16 \\
-47\end{array}$ & & 385 & ...do do.... & & $\underset{1,500}{\operatorname{Many}}$ & \\
\hline Do...... & & $\begin{array}{l}\text { Merrili Stevens Manu- } \\
\text { Meracturing Co. }\end{array}$ & |..... do.................... & & ................... & ...do do & ...do.... & $\begin{array}{l}\text { surning and power. } \\
\text { shipbuilding yards... }\end{array}$ & $750 \pm$ & 6 & & Few. & & + & & $550 \pm$ & .....do........ & & & Pressure, 24 pounds per square inch. \\
\hline & 9 miles northeast. & 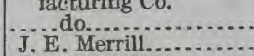 & & & & & & Domostic........................ & - $\begin{array}{r}750 \\
750\end{array}$ & & & $\begin{array}{l}\text { Several. } \\
\text { Few. }\end{array}$ & & $+\stackrel{+60 \pm}{+}$ & & $550+$ & ....................... & $\cdots .$. & Many. & Pressure, 24 ? pounds per scuare inch. \\
\hline $\begin{array}{l}\text { Do. } \\
\text { Do. } \\
\text { Do. }\end{array}$ & 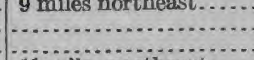 & D. . . Mitchelit..... & Hugh Partridge.. & & $\begin{array}{l}\text { do. } \\
\text { do. } \\
\text { do. }\end{array}$ & & & 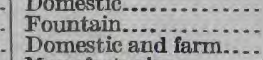 & $\begin{array}{l}7500 \\
8500 \\
750\end{array}$ & $\begin{array}{l}6 \\
8,6 \\
8,6\end{array}$ & & $\begin{array}{c}\text { rew. } \\
a 10 \\
a 10\end{array}$ & & + Many. & & ….... & sulphur............ & & $\begin{array}{l}\text { Many: } \\
300\end{array}$ & Reported pressure, 27 pounds per square inch. \\
\hline & 13 miles northeast.... & Peoples Ire Co........... & & 1800 & ‥do.. & & & 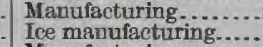 & $=628$ & $\begin{array}{c}6 \\
5 \\
5\end{array}$ & & $\begin{array}{l}\text { Few: } \\
\text { Few: }\end{array}$ & & & & & Hard, sulphin: & & 500 & \\
\hline $\begin{array}{l}\text { Do.: } \\
\text { Do.: }\end{array}$ & $\begin{array}{l}\text { Tile westi } \\
\text { Forest and Mytile } \\
\text { Fotset and }\end{array}$ & $\begin{array}{l}\text { Refrigerator Ice Co } \\
\text { R i ver s id e Water }\end{array}$ & $\begin{array}{l}\text { N. S. Ware... } \\
\text { Partinidge.... }\end{array}$ & $\begin{array}{l}{ }_{1902}^{1902} \\
1896\end{array}$ & ...do.. & ando... & $\begin{array}{ll}\cdots \text { do... } \\
\cdots \text { do... }\end{array}$ & \begin{tabular}{|l|} 
Manufacturing.............. \\
Public supply
\end{tabular} & $\begin{array}{l}744 \\
9500\end{array}$ & $\begin{array}{c}6 \\
\ldots . \\
.\end{array}$ & 440 & Few. & 62 & + & & 630 & $\begin{array}{l}\text { Hard, sulphur . } \\
\text { H....do........ }\end{array}$ & & Many. & Pressure, 18 pounds per square inch. \\
\hline $\begin{array}{l}\text { Do........... } \\
\text { Do....... }\end{array}$ & \begin{tabular}{|l} 
stretets \\
2 miles southwest......
\end{tabular} & $\begin{array}{l}\text { Works Co } \\
\text { Riverside Wor Co. } \\
\text { Sout ho Jacksonville }\end{array}$ & ....do................. & 1895 & .....ас.......... & .............. & ...do........ & 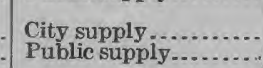 & $\begin{array}{l}720 \\
850\end{array}$ & $\begin{array}{c}10 \\
6\end{array}$ & ${ }^{70}$ & 20 & & $\begin{array}{r}48 \\
+15\end{array}$ & & $\begin{array}{lll}600-700 \\
800\end{array}$ & …................... & None. & $\begin{array}{r}811 \\
\text { Many. }\end{array}$ & The company owns another similar well. \\
\hline Do. & & 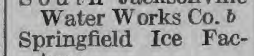 & Partridge ...... & 1907 & Pleistocene... & Vicksburgian limestone. & Drilled.. & Iee manufracturing...... & 665 & 6 & & Few. & & + & & & & & 400 & \\
\hline Do. & & \begin{tabular}{|l|l} 
tory \\
Merril Stevens...........
\end{tabular} & ....do............... & 1889 & ......do........ & 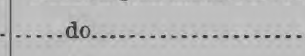 & ........... & Domestic and manu- & 669 & 6 & 400 & 5 & & 62 & & 500 & Sulphur... & & 800 & \\
\hline Do... & $2 \frac{2}{2}$ miles northeast... & $\begin{array}{l}\text { Wilion \& \& Toomer Fer- } \\
\text { tilizer Co. }\end{array}$ & ....do............ & 1904 & .....do... & ......do.... & ..do.. & $\begin{array}{l}\text { Drinkining and manu- } \\
\text { facturmg. }\end{array}$ & 798 & 6 & 60 & & & 50 & & 796 & .....do.... & & & \\
\hline $\begin{aligned} \text { Do... } \\
\text { Do.. } \\
\text { Don }\end{aligned}$ & imile southwest. & 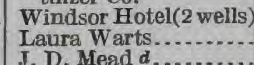 & & $18866^{\circ}$ & . do... & (....do....... & . .do... & 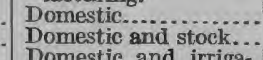 & $\begin{array}{l}746 \\
689 \\
695\end{array}$ & $\begin{array}{l}8 \\
6\end{array}$ & 60 & $\begin{array}{l}\text { a } 15 \\
\text { Few. }\end{array}$ & & ${ }_{30 \pm}^{+35}$ & & 650 & …do... & 50 & & \\
\hline $\begin{array}{l}\text { Mandarin...... } \\
\text { Do........ }\end{array}$ & & & Partridge.. & 1905 & & & & $\begin{array}{l}\text { Domestic and irriga- } \\
\text { tion. } \\
\text { Domestic...................... }\end{array}$ & ${ }_{60003}^{625}$ & & & & & $\stackrel{+40}{+}$ & & & & & Many. & \\
\hline $\begin{array}{l}\text { Mo........... } \\
\text { Manhaittan Beach. }\end{array}$ & & 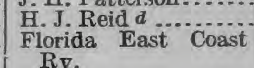 & & . & 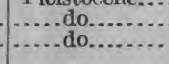 & $\begin{array}{l}\text { Jacksonvilile formation } \\
\text { Vicksburgian limestone.... }\end{array}$ & $\begin{array}{ll}\text { ndow... } \\
\cdots \text { dow... }\end{array}$ & 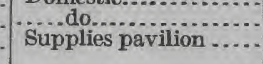 & $\begin{array}{l}157 \\
600\end{array}$ & $\begin{array}{l}\frac{2}{12} \\
4^{2}\end{array}$ & & $\begin{array}{l}12 \\
a 10 \\
a 10\end{array}$ & & $+\frac{1-2}{+ \text { Many. }}$ & $150^{\circ}$ & ist & $\begin{array}{l}\text { Soft } \\
\text { Sulphur... }\end{array}$ & & $\begin{array}{l}\text { Many. } \\
\text { Many. }\end{array}$ & \\
\hline 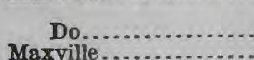 & & 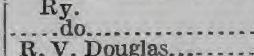 & Henry Van Dorn... & 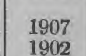 & & do do & & Turpentine stiil...... & $\frac{600}{650+}$ & 4 & 394 & $a_{10}$ & & $+\underline{+47}$ & $\ldots \ldots .$. & ....... & $\ldots \ldots \ldots \ldots \ldots . .$. & ......... & $230 \pm$ & Corrodes boilers. \\
\hline Maxport......... & & 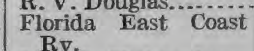 & B. F. Partridge.... & 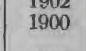 & & $\cdots g$ & (no.... & . & 630 & 6 & & & & +55 & & & & & & Do. \\
\hline $\begin{array}{l}\text { Pablo Beach.... } \\
\text { Do........ }\end{array}$ & & $\begin{array}{l}\text { Johin G. Christopher.. } \\
\text { Florida East Coast }\end{array}$ & $\cdots \cdots$ & 1885 & 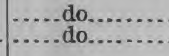 & 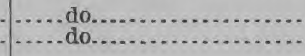 & do..... & $\begin{array}{l}\text { Public supply........ } \\
\text { Supplies pavilion.... }\end{array}$ & ${ }_{400 \pm}^{511}$ & ${ }_{4}^{8}$ & 265 & $\begin{array}{ccc}a & 10 \\
a & 10\end{array} \mid$ & & $\begin{aligned}+30+ \\
+ \text { few }\end{aligned}$ & & & Sulphur... & & Many. & Three wells drilled near did not affect yield. \\
\hline Plummer..... & & J. R. B. Batchelder $d \ldots . . .$. & & & & & & $\begin{array}{l}\text { Domestic and irriga- } \\
\text { tion. }\end{array}$ & 600 & 4 & & 18 & & +20 & 400 & $500+$ & Hard, sulphur .. & & & \\
\hline $\begin{array}{l}\text { Do } \\
\text { St. Nicholas.......... }\end{array}$ & & $\begin{array}{l}\text { J. Cronind a.... } \\
\text { Mrs: Mary P. Cum- }\end{array}$ & & & & & & Irrigation.................. & $\begin{array}{l}700 \\
678\end{array}$ & $\begin{array}{l}8 \\
6\end{array}$ & & 25 & & $\begin{aligned}+0 \\
+30\end{aligned}$ & 618 & 619 & . do & 80 & $\begin{array}{l}\text { Many. } \\
\text { Many. }\end{array}$ & \\
\hline $\begin{array}{l}\text { Do............. } \\
\text { South Jacksonvile. }\end{array}$ & & 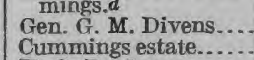 & & & $\begin{array}{l}\text { Pleistocene.... } \\
\text { Pandowa }\end{array}$ & $\begin{array}{l}\text { Vicksburgian limestone.. } \\
\end{array}$ & \begin{tabular}{|l|l} 
Drilled.... \\
Ndow....
\end{tabular} & Irrigation, bathing, etc. & 800 & & & $a 20$ & & $\begin{array}{c}\text { Several. } \\
+40+ \\
+40+\end{array}$ & & $\frac{500 \pm}{550}$ & & & Many. & \\
\hline & i mile east... & 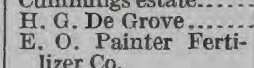 & B. F. Partididge: & $\begin{array}{l}18907 \\
1907\end{array}$ & …do... & & & $\begin{array}{l}\text { Domestic and stock... } \\
\text { Water power......... }\end{array}$ & 600 & $\left(e^{6}\right.$ & $6000 \pm$ & $\begin{array}{rl}a & 15 \\
a 3 & \\
a 3 & \end{array}$ & & $\begin{array}{l}+40+ \\
+30 \\
+46\end{array}$ & & 2600 & Hiard, sulphur ... & ${ }_{575}+10$ & $\begin{array}{r}\operatorname{many} \\
1,200 \\
1,000\end{array}$ & \begin{tabular}{|l} 
Forms scale in boilers. \\
Pressure, 20 pounds per qquare inch.
\end{tabular} \\
\hline Dho Do............ & 21 miles south... & 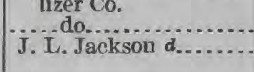 & Harold Simson..... & & ....do... & …do...... & ...do..... & Domestic & $\begin{array}{l}625 \\
128\end{array}$ & in: & $\cdots \cdots .$. & 100 & & $+40+$ & & & Hard, sulphur ... & & 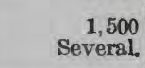 & \\
\hline
\end{tabular}

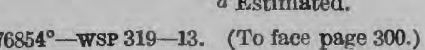


General water resources of Duval County.

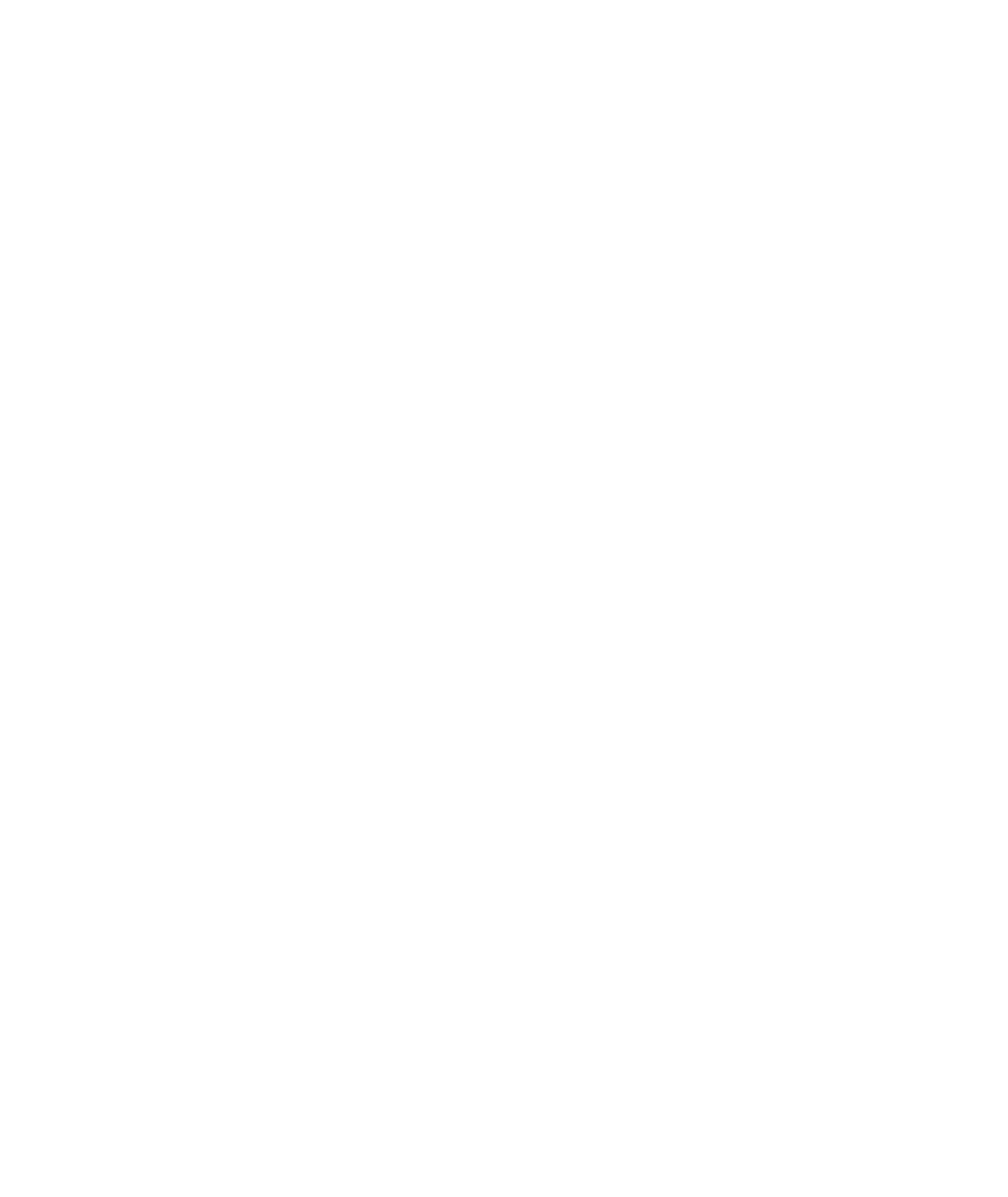

ESCAMBIA COUNTY.

\author{
By G. C. Matson.
}

\title{
GENERAL FEATURES.
}

Escambia County, which lies in the extreme western part of Florida, comprises a narrow area extending from the Gulf of Mexico northward to the Alabama line. Its western boundary is formed by Perdido River and its eastern boundary by Escambia River. The southern part of the county is more or less deeply indented by bays and includes a narrow island, some 40 miles long, which incloses a body of water known as Santa Rosa Sound. Altitudes in the county 
range from a few feet above sea level near the Gulf to more than 250 feet near the northern boundary. In the southern part of the county is a broad flat terrace which extends several miles in from the coast and merges into narrow terraces that extend inland along the principal streams. Near the coast the altitude of the terrace probably does not exceed 25 feet, but it apparently increases slightly toward the north. A similar terrace at a somewhat higher level extends across the southern part of the county and along each of the principal streams. Much of the surface consists of high rolling uplands, which are dissected in the vicinity of the large streams but which elsewhere form extensive plains. The uplands form part of the broad plain that extends northward from the northern end of the State into Alabama and Georgia. Lakes and swamps are comparatively rare except near the coast, where the surface is so flat that bodies of shallow water accumulate during the rainy season.

\section{GEOLOGY.}

The lowland of Escambia County is mantled by gray Pleistocene sands, thin near the uplands and thick near the coast. In the uplands a few feet of gray sand rests on red and yellow sands, sandy clays, and sandstones referred to the Lafayette (?) formation. These deposits are extensively developed in the northern part of the county and extend several miles beyond Muscogee. Little is known concerning the geologic formations underlying the surficial sands and sandy clays. Recent well drilling in the valley of Escambia River has shown the presence of considerable deposits of gray micaceous sand and marl 100 to 200 feet below the surface. Samples obtained in drilling wells at Cantonment and Pensacola indicate that sands and marls of Pleistocene, Pliocene, and Miocene age are well developed, especially in the southern half of the county. The well at Cantonment also encountered a light-gray to white limestone, and from knowledge of the geologic succession farther eastward it is inferred to belong to the Chattahoochee formation. The Vicksburgian limestones are doubtless present, but they are so deeply buried beneath the younger rocks that they have probably not been reached by any of the wells.

Concerning the thickness of most of the geologic formations underlying Escambia County no reliable information is available. On the uplands the average thickness of the residual gray sands is probably less than 5 feet; farther south sands of Pleistocene age attain a maximum thickness of over $100^{\circ}$ feet and pass downward into interbedded sands. marls, clays, and gravels at least 900 feet thick. 
The following section shows the thickness of the formations at the places named:

Log of well at Cantonment.

Clay.

Sands, coarse, and fine gravel

Clays, variegated

Sands, coarse, and fine gravel.

Clay, yellowish.

Clay, yellow.

Gravel.

Clay.

Gravel

Clay.....

Sand, fine, gray, with smali gravel at bottom

Sayd, yellowish; gravel at bottom

Clay, greenish; shells at bottom.

Sand, fine, green.

Clay, gray, with shells...

Sand, fine, gray

Sayd, fine.

Clay, gray, with large shells

Gravel, coarse.

Rock..

Clay, green.

Sand, fine.

Rock.

Clay.

Rock

Rock.

Clay.

Rock.

Clay.

Rock

Sand, gray

Rock phosphate

Clay, shaly

Rock phosphate

Rock.

Clay.

Rock.

Clay.

Rock

Rock

Clay.

Rock

Clay.

\begin{tabular}{|r|r}
\hline Thickness. & Depth. \\
\hline Feet. & Feet. \\
67 & 67 \\
3 & 70 \\
80 & 150 \\
10 & 160 \\
40 & 200 \\
10 & 210 \\
20 & 230 \\
10 & 240 \\
30 & 270 \\
15 & 285 \\
15 & 300 \\
60 & 360 \\
10 & 370 \\
50 & 420 \\
200 & 620 \\
60 & 680 \\
50 & 730 \\
10 & 740 \\
150 & 890 \\
10 & 900 \\
90 & 990 \\
10 & 1,000 \\
11 & 1,001 \\
593 & 1,061 \\
15 & 1,076 \\
1 & 1,077 \\
20 & 1,097 \\
10 & 1,107 \\
15 & 1,122 \\
10 & 1,132 \\
60 & 1,192 \\
3 & 1,195 \\
45 & 1,240 \\
5 & 1,245 \\
30 & 1,275 \\
20 & 1,295 \\
45 & 1,340 \\
12 & 1,352 \\
5 & 1,357 \\
25 & 1,382 \\
3 & 1,385 \\
15 & 1,400 \\
3 & 1,403 \\
15 & 1,418 \\
5 & 1,423 \\
5 & 1,428 \\
2 & 1,430 \\
5 & 1,435 \\
& \\
&
\end{tabular}

Log of the well of Lee \& Co., $4 \frac{3}{4}$ miles south of Pensacola.

\begin{tabular}{|c|c|c|}
\hline & Thickness. & Depth. \\
\hline & Feet. & Feet. \\
\hline 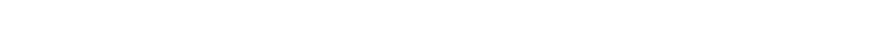 & & \\
\hline $\begin{array}{l}\text { Sand, } \\
\text { Sand, }\end{array}$ & $\stackrel{5}{23}$ & $\begin{array}{r}6 \\
29\end{array}$ \\
\hline Clay, dark, sandy & 43 & 72 \\
\hline 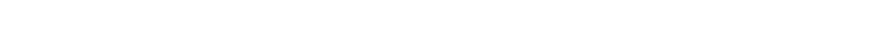 & 14 & 86 \\
\hline 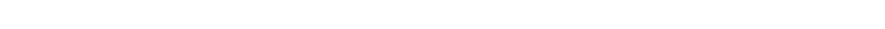 & 20 & 106 \\
\hline 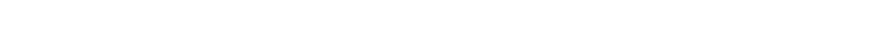 & 84 & 190 \\
\hline 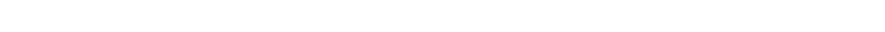 & 46 & 236 \\
\hline 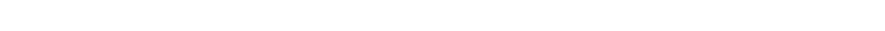 & 20 & 256 \\
\hline 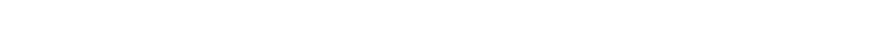 & 29 & 276 \\
\hline 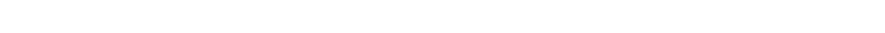 & 14 & 290 \\
\hline 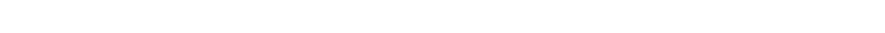 & 16 & 306 \\
\hline 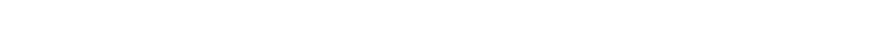 & 20 & $\begin{array}{l}326 \\
342\end{array}$ \\
\hline Clay, dark, sandy & 48 & 390 \\
\hline 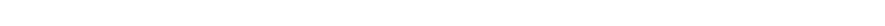 & 2 & 392 \\
\hline Clay or shale, dark, sandy . . & 132 & 524 \\
\hline Sand, coarse, with gravel. . . . . . . . & 2 & 526 \\
\hline 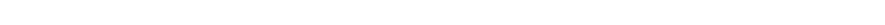 & 17 & 043 \\
\hline 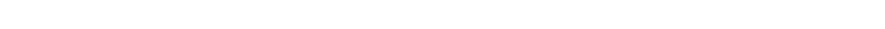 & 68 & 1,011 \\
\hline
\end{tabular}


WATER SUPPLY.

Source.-Probably all the geologic formations underlying Escambia County are water-bearing, but it is frequently impossible to determine the exact bed from which wells obtain water. On the upland most of the shallow wells doubtless procure water from the Lafayette (?) formation and on the lowland from the Pleistocene sands. The deeper wells penetrate the older formations.

Sands and marls in the Escambia Valley furnish large supplies of water which head several feet above the surface.

Quality.-In most places the Pleistocene sands and the Lafayette ( ?) formation furnish soft water, but locally the water from the Lafayette (?) is said to be slightly hard. All of the older geologic formations supply hard water, though in some wells the amount of inorganic material is so small as to be unimportant. A few of the drilled wells yield sulphur water and some of the very deep ones salt water.

Development.-Most shallow wells obtain large supplies of water at depths ranging from 15 to 50 feet, though some of them have been sunk 65 to 100 feet. The water from the shallow wells is used for all purposes and is regarded as satisfactory, though supplies obtained near dwellings or other sources of pollution may be unsafe for domestic use. Drilled wells range in depth from less than 100 feet to more than 1,600 feet, but the deeper ones yield water too saline to be used. Excellent flowing wells have been obtained at Pine Barren at about 150 feet and at 181 feet at Mulat. These are among the best flowing wells in western Florida. The public water supply at Pensacola is taken from wells 112 to 150 feet deep. The water is said to be soft and the quantity is ample for the needs of the city.

General water resources of Escambia County.

\begin{tabular}{|c|c|c|c|c|c|c|c|c|c|c|c|}
\hline \multirow{2}{*}{ Town. } & \multirow{2}{*}{\multicolumn{2}{|c|}{$\begin{array}{l}\text { Topographic } \\
\text { location. }\end{array}$}} & \multirow{2}{*}{\multicolumn{2}{|c|}{ Source of water. }} & \multirow{2}{*}{\multicolumn{2}{|c|}{$\begin{array}{l}\text { Surface for- } \\
\text { mation. }\end{array}$}} & \multicolumn{5}{|c|}{ Shallow wells. } \\
\hline & & & & & & & Dep & & Supply & y. $\begin{array}{c}\text { Quality of } \\
\text { water. }\end{array}$ & $\begin{array}{c}\text { Principal } \\
\text { water beds. }\end{array}$ \\
\hline Blufisprings & \multicolumn{2}{|c|}{ Plain.......... } & \multirow{3}{*}{\multicolumn{2}{|c|}{$\begin{array}{l}\text { W ells a n d } \\
\text { springs. } \\
\text { Dug and drilled } \\
\text { wells. } \\
\text { Wells........... }\end{array}$}} & \multirow{3}{*}{\multicolumn{2}{|c|}{ 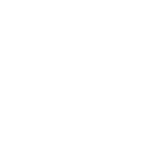 }} & \multicolumn{2}{|c|}{$\begin{array}{l}\text { Feet. } \\
15-40\end{array}$} & Large.. & \multirow{2}{*}{$\begin{array}{l}\text { Soft; some } \\
\text { hard. } \\
\text { Hard...... }\end{array}$} & \multirow{4}{*}{$\begin{array}{l}\text { Marianna } \\
\text { limestone. } \\
\text { Do. } \\
\text { Do. } \\
\text { Do. } \\
\text { Do. }\end{array}$} \\
\hline Century.... & \multirow{2}{*}{\multicolumn{2}{|c|}{ Gently rolling. }} & & & & & \multicolumn{2}{|c|}{$28-43$} & $\ldots$ do.... & & \\
\hline \multirow{2}{*}{$\begin{array}{l}\text { Goulding... } \\
\text { Millview... } \\
\text { Molino..... }\end{array}$} & & & & & & & \multicolumn{2}{|c|}{$50-65$} & Ample. & Soft........ & \\
\hline & \multicolumn{2}{|c|}{ Plain............ } & \multicolumn{2}{|l|}{ Wells. } & Sand... & & \multicolumn{2}{|c|}{$25-32$} & Ample. & e. Soft... & \\
\hline \multirow[b]{2}{*}{ Town. } & \multicolumn{3}{|c|}{ Deep wells. } & \multirow{2}{*}{$\begin{array}{l}\text { A ver- } \\
\text { age } \\
\text { thick- } \\
\text { ness of } \\
\text { sand. }\end{array}$} & \multirow[b]{2}{*}{$\begin{array}{c}\text { Depth to } \\
\text { water. }\end{array}$} & \multirow{2}{*}{\multicolumn{2}{|c|}{$\begin{array}{c}\text { Increase } \\
\text { or de- } \\
\text { crease of } \\
\text { supply. }\end{array}$}} & \multirow{2}{*}{\multicolumn{2}{|c|}{$\begin{array}{l}\text { Sewerage } \\
\text { system. }\end{array}$}} & \multirow{2}{*}{\multicolumn{2}{|c|}{ Remarks. }} \\
\hline & Depth. & Supply. & $\begin{array}{l}\text { Qual- } \\
\text { ity of } \\
\text { water. }\end{array}$ & & & & & & & & \\
\hline Bluffsprings & $\begin{array}{r}\text { Feet. } \\
\quad 40\end{array}$ & \multirow[b]{2}{*}{ Good.. } & \multirow[b]{2}{*}{ Hard. } & \multirow[t]{2}{*}{$\begin{array}{l}\text { Feet. } \\
2-12\end{array}$} & \multirow{2}{*}{$\begin{array}{l}\text { Slight.... } \\
\text { None.... } \\
\text {...do..... }\end{array}$} & \multicolumn{2}{|c|}{ None.... } & & Teet. & $\begin{array}{l}\text { Some large spr } \\
\text { mile from }\end{array}$ & $\begin{array}{l}\text { ings about I } \\
\text { ailroad sta }\end{array}$ \\
\hline $\begin{array}{l}\text { Century ..... } \\
\text { Goulding ... }\end{array}$ & 85 & & & & & $\begin{array}{l}\ldots \text { do } \\
\ldots \text { do } \\
\ldots \text { do }\end{array}$ & & & $2-18$ & & \\
\hline Molino & 32 & & & & slight... & & $\cdots .$. & & 10 & $\begin{array}{l}\text { Some surface } \\
\text { by a mill. }\end{array}$ & water used \\
\hline
\end{tabular}


Typical wells of Escambia County.

\begin{tabular}{|c|c|c|c|c|c|c|c|c|c|c|c|c|c|c|c|c|c|c|}
\hline $\begin{array}{l}\text { Nearest town or } \\
\text { post office. }\end{array}$ & $\begin{array}{l}\text { Direction and } \\
\text { distance. }\end{array}$ & Owner. & Driller. & $\begin{array}{l}\text { Date } \\
\text { sunk. }\end{array}$ & $\begin{array}{l}\text { Surface } \\
\text { formation. }\end{array}$ & Geologic source. & $\begin{array}{l}\text { Type of } \\
\text { well. }\end{array}$ & Use. & Depth. & \begin{tabular}{|c|} 
Diam- \\
eter.
\end{tabular} & Casing. & $\begin{array}{l}\text { Flevar } \\
\text { tilon } \\
\text { tabove } \\
\text { sea. }\end{array}$ & $\begin{array}{l}\text { Head, above and } \\
\text { below surface. }\end{array}$ & $\begin{array}{c}\text { Depth } \\
\text { to } \\
\text { prin- } \\
\text { cipal } \\
\text { supply. }\end{array}$ & Quality of water. & $\begin{array}{c}\text { Depth } \\
\text { to } \\
\text { second } \\
\text { sup. } \\
\text { ply. }\end{array}$ & $\begin{array}{c}\text { Yield } \\
\text { per } \\
\text { marte. }\end{array}$ & Remarks. \\
\hline Bluffsprings. & Sec. 23, T. 5 N., R. & Fisher Bond.... & Owner..... & 1900 & Pleistocene... & Lafayette (?) for- & Bored.... & Domestic and stock... & $\begin{array}{l}F_{\text {eet. }} \\
115\end{array}$ & $\begin{array}{c}\text { Incheses. } \\
16\end{array}$ & $\begin{array}{c}\text { Feet. } \\
115\end{array}$ & $\begin{array}{l}\text { Feet. } \\
a \text { 280 }\end{array}$ & ${ }_{-106}$ Feet. & Feet. & Hard..... & Feet. & Gallons. & \\
\hline Do........ & $\begin{array}{l}3 \mathrm{w}, \text { T. } 5 \text { N., R. } \\
\text { sec. } 34, \text { T. }\end{array}$ & W. A. Jones........ & ......do............... & 1904 & ......do......... & 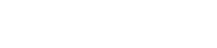 & ...do....... & .....do................... & 143 & 11 & 137 & $\ldots .$. & -40 & & ......do.............. & $m+2>$ & & \\
\hline Do... & 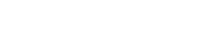 & P. R. MacNeal ................ & …..do.............. & 1905 & ....do..... & …..do..... & ...do..... & …...do.............. & 102 & 16 & 102 & $a_{220}$ & -96 & .... & .....do............... & & & \\
\hline $\begin{array}{l}\text { Century... } \\
\text { Gomldin.. }\end{array}$ & & $\begin{array}{l}\text { Alger-Sullivan Lumber Co... } \\
\text { Southern Brick Co }\end{array}$ & & & ....do... & .....do...... & $\ldots$....... & & 82 & $\frac{1 \frac{1}{2}}{2}$ & 82 & 90 & $-20+$ & 82 & Soft ............. & 16 & & \\
\hline $\begin{array}{l}\text { Musogeo.:. } \\
\text { Do }\end{array}$ & zilie west... & Southern States Lumber Co.: & Frank Suter. & $1898^{\circ}$ & …do. & & ado... & $\begin{array}{l}\text { Drinking. } \\
\text { Fire protection................ }\end{array}$ & $\begin{array}{c}1175 \\
175 \\
160\end{array}$ & $\begin{array}{l}25 \\
22 \\
25\end{array}$ & $\begin{array}{l}1100 \\
160\end{array}-x$ & ${ }_{20}^{b i 2}$ & $\begin{array}{l}-47 \\
+38 \\
+38\end{array}$ & $\because \cdots$. & Sulphur.. & $\dddot{i 60}$ & 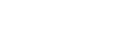 & Forms little scale. \\
\hline Northrop.... & if mile......... & Stephen Lee............. & & ...... & Pleistocene... & & Drilled... & Bottling..................... & 1,030 & 政 & (31,030. & & +60 & & & & 150 & \\
\hline $\begin{array}{l}\text { Do } \\
\text { Pensacoia. }\end{array}$ & \%outheast. & 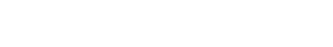 & & i 19007 & (…do........ & & ‥do........ & Drinking. & $\begin{array}{l}155 \\
133\end{array}$ & $6^{\frac{12}{2}}$ & 155 & & $\begin{array}{l}-2 \\
-8\end{array}$ & 155 & $\begin{array}{l}\text { Sulphur. } \\
\text { solt..... }\end{array}$ & . & & \\
\hline Do... & & Escambia Oll Co.......... & $\ldots \ldots \ldots$ & $\cdots \cdots$ & ......do......... & Oligocene (?)... & ...do........ & Not used............ & 1.320 & 然 & $\begin{array}{l}198 \\
400 \pm\end{array}$ & $\mathbf{0}$ & 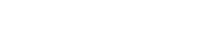 & 198 & SSoft at 70, good at 198, & ${ }_{70}^{70}$ & Many. & \\
\hline & & Fort MoRea................ & 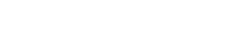 & 1904 & .....do......... & Miocene...... & $\ldots$.......... & Use in fort..... & ${ }_{225}^{425}-30$ & $\begin{array}{l}8 \\
8\end{array}$ & $\begin{array}{l}1,100 \pm \\
425\end{array}$ & & 0 & 385 & sulphur..................... & ${ }_{200}^{1,00}$ & Good. & small flow. \\
\hline Do... & 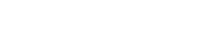 & 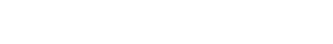 & . & $\cdots$ & (ndo........ & (n..do... & lin & Domestic, ex $x$ e e p t & 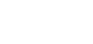 & 6 & & $\begin{array}{r}05 \\
b 50\end{array}$ & $\begin{array}{l}-24 \\
-24\end{array}$ & & Hard... & & & \\
\hline Do.. & Near..... & $\begin{array}{l}\text { Garfield Ioe Co.c........ } \\
\text { Iceompanv }\end{array}$ & TR K Koeler. & & & & Driliea.... & Ice manufirecturing..... & $\begin{array}{r}306 \\
128 \\
195\end{array}$ & & & $\mathrm{Few}_{b 20}$ & $\begin{array}{r}-16 \\
0\end{array}$ & & & 19\%- & 55 & \\
\hline $\begin{array}{l}\text { Do... } \\
\text { Do... } \\
\text { D. }\end{array}$ & & 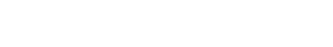 & 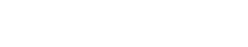 & 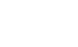 & P...do............. & 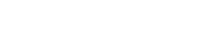 & (...do...... & & 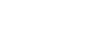 & $\begin{array}{l}6 \\
8 \\
6\end{array}$ & $125-132$ & ${ }_{200}{ }_{0}^{20}$ & -3 & $\begin{array}{l}125 \\
125\end{array}$ & 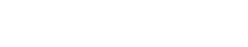 & 120 & Many: & $\begin{array}{l}\text { Three werls. } \\
\text { Do. }\end{array}$ \\
\hline Do.... & & 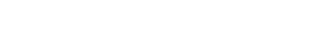 & & & & & ...do............. & & 305 & 3 & 300 & $\dddot{6}$ & -24 & & $\ldots$ do...... & & & \\
\hline & & Navy yard $d \ldots \ldots \ldots \ldots \ldots \ldots$ & United States Navy.. & & (n) & $\begin{array}{l}\text { Oligocene. } \\
\ldots \ldots \text { do..... }\end{array}$ & ...do........ & & $\begin{array}{l}1,400 \pm \\
1,300 \pm\end{array}$ & & & & & & Salt ......... & & & \\
\hline & & , do & ....oo. & 1907 & . & (............. & ...do......... & & $\begin{array}{l}1,010 \\
1,010\end{array}$ & & & & & & & & & \\
\hline $\begin{array}{l}\text { Do....... } \\
\text { Do...... }\end{array}$ & 9 miles northeast. & R. E. Ëobles \& Son............. & & $1900^{\circ}$ & …do............ & $\begin{array}{l}\text { Pleistocenen } \\
\text { …do...... }\end{array}$ & Driven. & Boilers and drinking. & $\begin{array}{c}2200 \\
52\end{array}$ & 2 & 52 & \pm 2 & $\dddot{+1}$ & 52 & sightily hard.... & & "severail: & Flow increases at high tide; water \\
\hline Do. & 21 miles north & $\begin{array}{l}\text { Pensacola Developpment Co.c.. } \\
\text { Pensacola Oil Milic }\end{array}$ & & & & & & & 1,620 & $\frac{41}{9}$ & & $\begin{array}{l}\text { Few. } \\
\text { Few: }\end{array}$ & & & & & & \\
\hline & 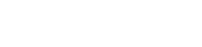 & Pensacola Tar \& Turpentine & & $19000^{\circ}$ & Pieistoceno... & Pieistocene.... & Örilied... & Boilers and drinking. & ${ }_{73}^{200}$ & 4 & $70^{\circ}$ & b10 & ${ }_{-8}^{+30}$ & & & & & Two wells. \\
\hline Do.. & 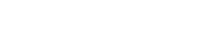 & 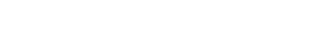 & . & 1904 & ......do......... & .....do.............. & ...do....... & Not used............... & 278 & 6 & 278 & $b 10$ & & 70 & & & & Attempt to get flow, but no increase in \\
\hline Do...... & $6 \frac{1}{2}$ miles northeast & 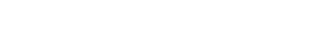 & …............. & 1906 & ......do....... & .....do.......... & Driven... & Boilers and drinking. & 53 & 2 & 53 & $b_{3}$ & +4 & 53 & & & 6 & $\begin{array}{l}\text { headd below } 70 \text { feet. } \\
\text { Three wells. }\end{array}$ \\
\hline Do......... & & Pensacola Water Co........... & & ision & .....do.... & …......... & Driven & $\begin{array}{l}\text { Public supply............. } \\
\text { Dritring and wash }\end{array}$ & .112-150 & $\begin{array}{cccc}6 \\
{ }_{11}\end{array}$ & $\mid 12-150$ & $b_{30}$ & $-8-12$ & $\mid 112-135$ & Sott. & & & Thirteen wells. Water forms no scale. \\
\hline Do.......... & $\ldots \ldots \ldots \ldots$ & Fort Pickens.................. & & & ....do....... & ......do.... & ...do....... & ....do................... & 315 & 3 & 216 & $b_{5}$ & -24 & & & & & \\
\hline
\end{tabular}

76854 - wap 319-13. (To face page 304.) 



\section{FRANKIIN COUNTY.}

By G. C. Matson.

\section{GENERAL FEATURES.}

Franklin County is on the Gulf coast at the mouth of Apalachicola River. The surface is low and flat and includes extensive areas of swamp land. A large part of the county is only a few feet above sea level and its greatest altitude is probably not over 25 feet. The coast is bordered by two long narrow islands-St. George Island and Dog Island-which inclose St. George Sound and Apalachicola Bay.

\section{GEOLOGY.}

In Franklin County the older geologic formations are concealed by sands of Pleistocene age. At the surface these sands are light gray, but they give place below to darker sands, which may be Pliocene but are at present of undetermined age. Beneath them are the "Sopchoppy limestone" and the limestones of the Chattahoochee formation, which in turn are underlain by limestones of Vicksburgian age.

As satisfactory well logs are lacking the thickness of the various formations can not be determined. The well of the Carrabelle Oil \& Development Co., at Carrabelle, passed through about 70 feet of sand and then entered the "Sopchoppy limestone." The "Sopchoppy" and Chattahoochee appear to have continued to a depth of at least 240 feet. Some of the deep wells at Apalachicola probably penetrate the Vicksburgian limestones, but in the absence of samples it is impossible to tell at what depth these rocks were reached. The following sections show the thickness at the points given:

\section{Partial log of the well of the Carrabelle Oil \& Development Co.}

[From samples in possession of the U.S. Geological Survey.]

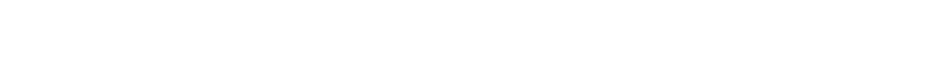

Sand, dark brown $\ldots \ldots \ldots \ldots \ldots \ldots \ldots \ldots \ldots \ldots \ldots \ldots, 49-50$

Sand, dark brown ............................ $58-60$

Sand, light yellow, coarse; and fine gravel with some shell fragments ......................................... $65-67$

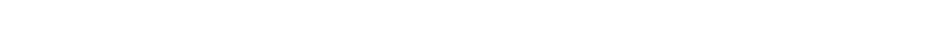

Same; with shell fragments......................... $69-70$

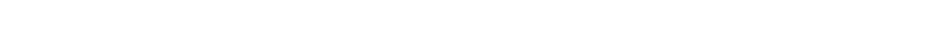

Same; with casts of shells.......................... $78-84$

Clay, greenish; containing limestones................. 100-110

Limestone, dark gray, granular..................... 120-125

Limestone, dark gray................................ 139-141

Limestone, light gray............................... 140-144

Limestone, porous, gray.............................. 146-149

Limestone, light gray............................. 159-160

Clay, dark gray; shell fragments...................... 194-195

Same........................................ 209-210.

Limestone, light gray, granular...................... 220-222

Limestone, light gray, porous..................... 230-240 
Log of the well of the Apalachicola Ice Co., at Apalachicola.

[By George H. Whiteside.]

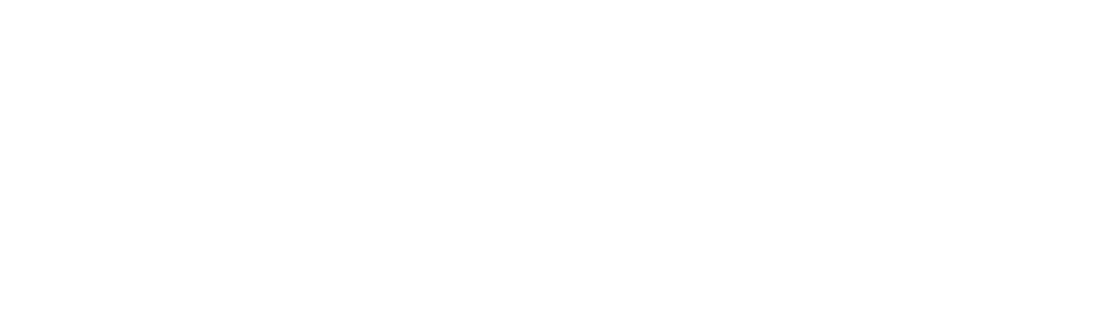

The first water was encountered between 40 and 70 feet and two other supplies were obtained at about 96 and 115 feet. Water under sufficient head to flow at the surface was procured at 325 feet and at 375 feet. A flow of about 40 gallons per minute of sulphur water was obtained at 375 feet from a bed of gravel. Although the well was continued to a depth of 450 feet no other water beds were encountered.

\section{WATER SUPPLY.}

Source.-The Pleistocene sands of Franklin County contain an abundance of soft water which is available for shallow wells. Beneath these sands the limestones of upper Oligocene age ("Sopchoppy limestone" and Chattahoochee formation) contain large quantities of water. The Vicksburgian limestones are also an excellent source of supply and they furnish good flowing wells on the low ground near the coast. The exact head of the water is somewhat uncertain, but flows may possibly be obtained as high as 25 or 30 feet above sea level; good flows, however, are certain only on low ground.

Quality.-The Pleistocene sands yield soft water which is well adapted to all domestic and farm uses. The water from the upper Oligocene limestones is always hard, but it is generally regarded as satisfactory. The Vicksburgian limestones yield hard sulphur water, and some deep wells near the coast obtain water containing large quantities of salt that unfits it for ordinary use.

Development.-Shallow wells ranging in depth from 8 to 30 feet are numerous and the water level is sufficiently near the surface to make pumping easy. In the vicinity of Apalachicola and Carrabelle several deep wells have been sunk, most of which furnish an abundance of satisfactory water, though one of the wells belonging to the city of Apalachicola encountered very strong salt-sulphur water unfit for ordinary use. The city water supply of Apalachicola is obtained from a well 360 feet deep; like most water from the other deep wells, the water contains some sulphur but is extensively used throughout the town. 
FRANKLIN COUNTY.

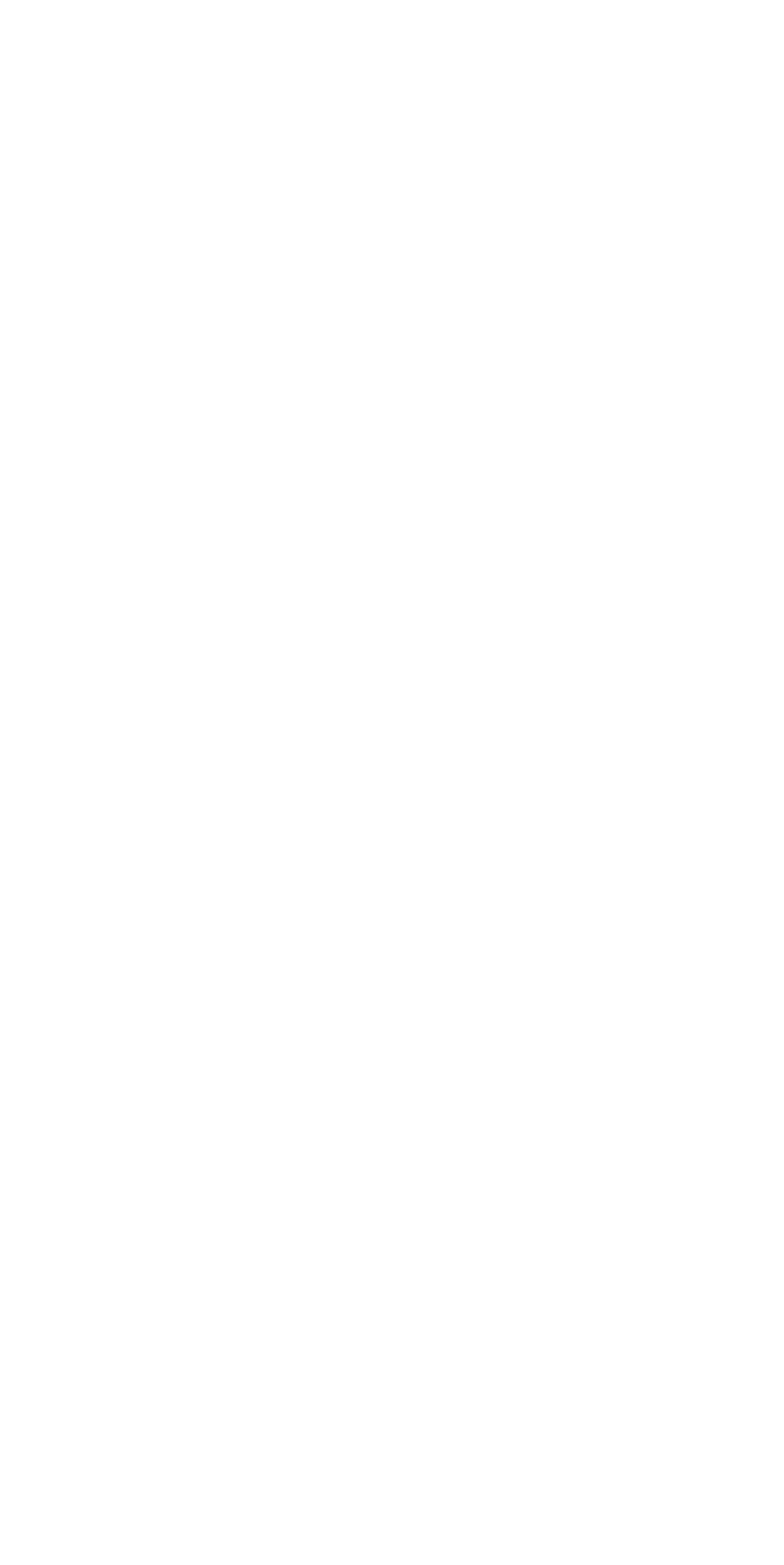


General water resources of Franklin County.

\begin{tabular}{|c|c|c|c|c|c|c|c|c|c|c|}
\hline \multirow{2}{*}{ Town. } & \multirow{2}{*}{\multicolumn{2}{|c|}{$\begin{array}{c}\text { Topographic } \\
\text { location. }\end{array}$}} & \multirow{2}{*}{\multicolumn{3}{|c|}{ Source of water. }} & \multirow{2}{*}{\multicolumn{2}{|c|}{$\begin{array}{l}\text { Surface for- } \\
\text { mation. }\end{array}$}} & \multicolumn{3}{|c|}{ Shallow wells. } \\
\hline & & & & & & & & Depth. & Supply. & $\begin{array}{l}\text { Quality of } \\
\text { water. }\end{array}$ \\
\hline $\begin{array}{l}\text { Apalachicola... } \\
\text { Carrabelle..... }\end{array}$ & \multicolumn{2}{|c|}{$\begin{array}{l}\text { Plain....... } \\
\text { Sand dunes.. }\end{array}$} & \multicolumn{3}{|c|}{$\begin{array}{l}\text { Driven and drilled wells, pub- } \\
\text { lic supply. } \\
\text { Driven, drilled, and dug wells. }\end{array}$} & \multicolumn{2}{|c|}{$\begin{array}{l}\text { Ple is t o cene } \\
\text { sand. } \\
\ldots . \text { do.......... }\end{array}$} & $\begin{array}{r}\text { Feet. } \\
8-90 \\
16-30\end{array}$ & $\begin{array}{c}\text { Large. } \\
\text {...do... }\end{array}$ & Soft. \\
\hline \multirow{2}{*}{ Town. } & \multicolumn{5}{|c|}{ Deep wells. } & \multirow{2}{*}{$\begin{array}{c}\text { Av- } \\
\text { erage } \\
\text { thick- } \\
\text { ness } \\
\text { of } \\
\text { sand. }\end{array}$} & \multirow{2}{*}{$\begin{array}{l}\text { Depth } \\
\text { to } \\
\text { water. }\end{array}$} & \multirow{2}{*}{$\begin{array}{c}\text { In- } \\
\text { crease } \\
\text { or de- } \\
\text { crease } \\
\text { of } \\
\text { supply. }\end{array}$} & \multirow{2}{*}{\multicolumn{2}{|c|}{ Sewerage system. }} \\
\hline & Depth. & Supp & bly. & $\begin{array}{c}\text { Head } \\
\text { (above } \\
\text { sea). }\end{array}$ & Quality of water. & & & & & \\
\hline $\begin{array}{l}\text { Apalachicola... } \\
\text { Carrabelle...... }\end{array}$ & $\begin{array}{r}\text { Feet. } \\
365 \\
265\end{array}$ & $\begin{array}{l}\text { Larg } \\
\ldots \text { do. }\end{array}$ & e... & $\begin{array}{r}\text { Feet. } \\
15 \pm \\
\ldots\end{array}$ & $\begin{array}{l}\text { Salt and sulphur.. } \\
\text { Sulphur.......... }\end{array}$ & $\begin{array}{c}\text { Feet. } \\
\cdots \\
50 \pm\end{array}$ & $\begin{array}{l}\text { Feet. } \\
2-5 \\
10-15\end{array}$ & $\begin{array}{l}\text { None.. } \\
\text {...do... }\end{array}$ & $\begin{array}{l}\text { Small. } \\
\text { None. }\end{array}$ & \\
\hline
\end{tabular}

\section{GADSDEN COUNTY.}

By G. C. Matson.

\section{GENERAL FEATURES.}

Gadsden County occupies a large area between Apalachicola and Ochlockonee rivers in the northern part of the State. Its surface is a deeply dissected upland, which over extensive areas rises more than 250 feet above sea level and at Gretna is slightly more than 300 feet in altitude. Along Ochlockonee and Apalachicola rivers well-defined terraces generally more than a mile in width rise 40 to 100 feet above sea level.

\section{GEOLOGY.}

Gray sand of Pleistocene age covers the lowland, and gray or pink residual sand mantles the upland. Beneath this sand are yellow and red sands and sandy clays, which are referred to the Lafayette (?) formation and are underlain by sand, clay, and fuller's earth beds belonging to the Alum Bluff formation. The Chattahoochee underlies the Alum Bluff formation and rests on Vicksburgian limestones. All these formations occur beneath the uplands, but in the stream valleys some of them have been eroded away. Thus on the western border of the county Apalachicola River has removed all the younger formations and has cut deeply into the Chattahoochee formation, and on the eastern border Ochlockonee River has removed all formations younger than the Alum Bluff. Many of the smaller streams have cut their valleys through the Lafayette (?) formation and into beds belonging to the Alum Bluff formation.

The average thickness of the Pleistocene sands is probably less than 5 feet and locally is only a few inches. In some places the Lafayette (?) formation may be more than 50 feet thick, but its average is 
probably less than 30 to 40 feet. The thickness of the Alum Bluff and Chattahoochee formations has not been accurately determined, but each of them probably exceeds 100 feet. At Quincy the Vicksburgian limestones were reached at a depth of less than 490 feet, and there was no indication that the base of the limestone had been reached at a depth of 1,001 feet.

Partial log of the well of the Owl Commercial Co., at Quincy.

Quartz sand, fine to coarse, white................. $101-449$

Clay, yellow................................ 110

Limestone, white, soft, sandy, or marl................ $118-123$

Clay, light brownish............................. 131 $\frac{1}{2} \quad 154$

Limestone, soft, white, light gray, and greenish; lots of fossil shells..................................... $191-200$

Limestone, hard, light brownish; lots of shells........... 200

Limestone, soft, white, and greenish clay............ 200 - 210

Clay, dark brown............................. $260-263 \frac{1}{2}$

Quartz sand, medium white; bits of limestone and dark-

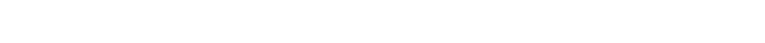

Sand, coarse, light gray, or greenish, limy, or soft sandy

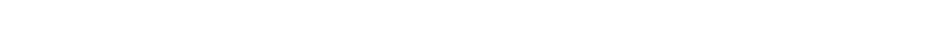

Limestone, hard, porous, gray, and brownish............ $289-290$

Same; partly silicified.......................... 290 29.

Limestone, soft, porous, white..................... $302-309$

Limestone, soft, light drab, sandy.................... $315-316$

Limestone, soft, light drab...................... $319-322$

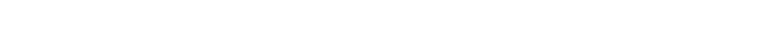

Marl, gray, sandy............................... $391-392$

Marl, light gray, sandy, or soft limestone........... $410-412$

Marl, light drab, or soft limestone................. 442

Clay or soft shale, light gray and greenish, limy........ $453-454$

Limestone, porous, white....................... $470-474$

Limestone, white and light, porous................. $476-480$

Limestone, hard and soft, light brownish............... $491-495$

Same; fragments of shells and coal (?)................ $495-505$

Same...................................... 506 - 507

Same; hard layer, more or less crystalline............. $508-529$

Limestone, brown, porous, sugary looking............ $562-566$

Same.................................... $566-574$

Limestone; white and light brownish; made up of bits of shells, Bryozoa and Nummulites . . ................. 576

Same; white and light brownish..................... 591 - 593

Limestone, light brown, porous, sugary looking; denser and gray in places.................................. $618-625$

Limestone, light brown, porous, sugary .............6 $623-637$

Limestone, light brownish, porous.................672-680

Limestone, light brownish.....................6.693 699

Limestone, white; with numerous fragments............ $699-704$

Same; with Orbitoides (?)...................... $705-713$

Limestone, porous, light brownish................. 728

Same; with Orbitoides (?); has siliceous strata ......... $749-755$

Same; with bits of shells, Bryozoa, and Nummulites....... 755 - 766 


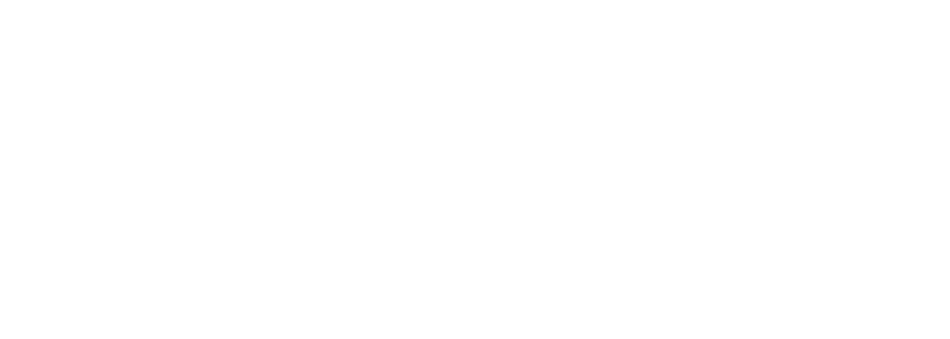

From 491 to 529 feet belongs to the Orbitoides zone of the Vicksburgian, as shown by Bryozoa determined by Bassler.

\section{WATER SUPPLY.}

Source.-Good water should be obtained from all the geologic formations in Gadsden County, though the Pleistocene sands are usually too thin to be important, and the water capacity of several of the other formations has not been satisfactorily determined. Most of the shallow wells obtain water from the Lafayette (?) formation, though a few of them may penetrate the Alum Bluff. The Chattahoochee will supply an abundance of water at most localities, and the Vicksburgian limestones will yield very large quantities for deep wells.

Quality.-The water from the Lafayette (?) formation is usually soft, though locally it may be moderately hard. The older formations, as a rule, yield only hard water, but at some localities the water obtained from the Alum Bluff formation may be soft. The water from the Vicksburgian limestones may also be sulphurous and at Chattahoochee it is saline.

Development.-In Gadsden County good supplies of soft water may usually be obtained by wells less than 50 feet deep, but the sanitary quality of this water may be questionable where the wells are located near buildings. Many wells range from 50 feet to somewhat more than 100 feet in depth, and these are regarded as more desirable than the shallower wells; because most of the water beds are covered by one or more layers of clay, which exclude surface water. Wells exceeding 200 feet in depth have been drilled at Havana, Chattahoochee, and Quincy. The deeper wells at Quincy yield sulphur water and the water from the deep well at Chattahoochee is saline. However, the water obtained by the deep wells at Quincy can be used, and that from the well at Chattahoochee has improved since the well was first drilled. (See Pl. XVI, $A$, p. 230.) 
GADSDEN COUNTY.

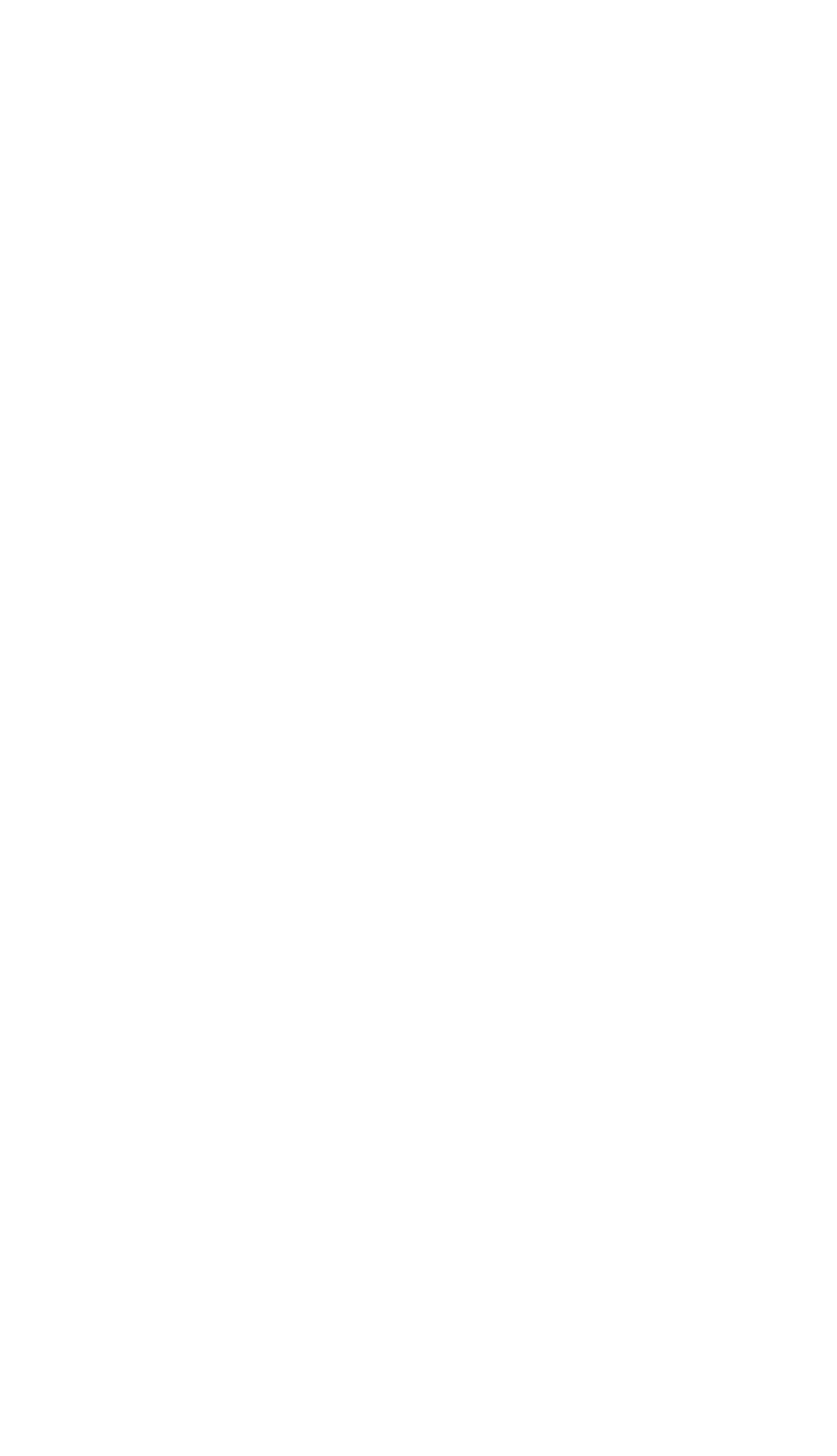


General water resources of Gadsden County.

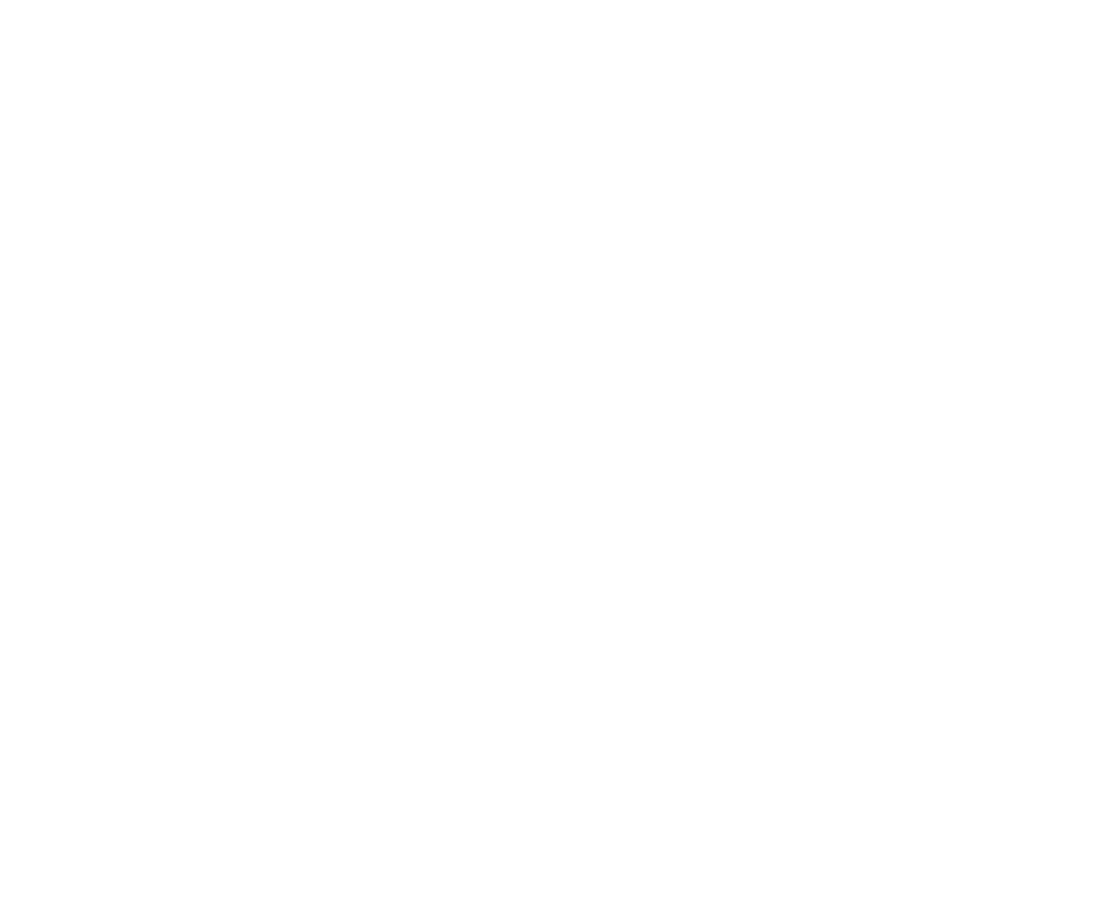

\section{HAMILTON COUN'TY.}

By G. C. Matson.

\section{GENERAL FEATURES.}

Hamilton County comprises an area less than 20 miles in average width, bordering the Georgia line for a distance of over 40 miles. The surface is generally rolling and well drained, but in the vicinity of Jasper and toward the northwest corner sink holes and other depressions give rise to lakes and swamps. Octahatchee Lake near the northwest corner lies in a depression formed by the solution of limestone and drains through a sink into an underground channel. During dry seasons nearly all of the water escapes, leaving only a small pond in the lowest part of the basin.

Except in a narrow belt along the streams, the surface of the county is more than 100 feet above sea level, and a large tract of land in the central part of the county is more than 150 feet in altitude.

\section{GEOLOGY.}

The lowlands of Hamilton County are covered by a thin mantle of gray Pleistocene sand and the uplands by a thin layer of residual sand underlain by red and yellow sands and sandy clays which are 
referred to the Lafayette (?) formation. At White Springs the surficial sands and clays rest on blue and gray sands, clays, and marls belonging to the Alum Bluff formation. The Alum Bluff extends northward into Georgia and is an important source of water in the eastern part of the county.

Another important water bed, which is exposed at White Springs, is the Hawthorn formation. It consists of sands and silicified limestones belonging stratigraphically below the Alum Bluff formation. Toward the western part of the county the Hawthorn formation is represented by the limestones exposed at Suwannee and these doubtless extend northward to the State line. The Vicksburgian limestones underlie the entire county, but they are covered by younger formations.

The light-gray or red sands that form a continuous mantle over the surface of the county are as a rule only a few feet thick. The underlying red and yellow sands and clays probably average less than 30 feet in thickness, though in places they reach a maximum of more than 50 feet. At White Springs the Alum Bluff formation is about 100 feet thick, and at the same locality the thickness of the Hawthorn formation is at least 25 feet. However, the Hawthorn formation probably thickens toward the north and west. The Vicksburgian limestones are doubtless several hundred feet thick, but definite information concerning them is lacking.

WATER SUPPLY.

Source.-The sands of the Lafayette (?) formation yield considerable water of excellent quality and are probably much more extensively used than any other formation in the county. However, the underlying Hawthorn and Alum Bluff formations are reached by many wells and are the most important water-bearing beds now being exploited in the county. The sands of the Alum Bluff are important as a source of water in the eastern part of the county, but westward they appear to thin out, and the wells penetrate the limestones and sands of the Hawthorn formation. The Vicksburgian limestones would also yield an abundant supply of water and may possibly be penetrated by one or two of the very deep wells.

Quality.-The water obtained from the shallow wells is soft, but that from all the deep wells is hard and some of it carries hydrogen sulphide.

Development.-Wells 100 to 150 feet deep usually yield good supplies of hard water, but locally deeper ones have been sunk. Water usually rises to within 50 to 60 feet of the surface, though in a few localities it comes much nearer. At Jasper the well of the City Power Co. is reported to have a depth of 450 to 500 feet and to yield 
sulphur water. The well doubtless penetrates the Vicksburgian limestones, and it would be possible to sink wells to these rocks in any part of the county. They will supply a large amount of water, but it is doubtful if the head would be so great as in the shallow wells.

Springs are numerous and some of them are large. The most important is White Spring, on the bank of the Suwannee, which boils up through a large circular hole in the rock and forms a stream of moderate size. A pavilion has been built about the point of emergence. The water is used largely for bathing and drinking and is thought to have considerable medicinal value, especially in the treatment of rheumatism and similar diseases. It contains a large amount of sulphur and other mineral matter such as lime and magnesia, together with smaller quantities of other inorganic material. The water probably comes from the Vicksburgian limestones and escapes at this locality because of a hole in the chert bed that caps the limestone. 


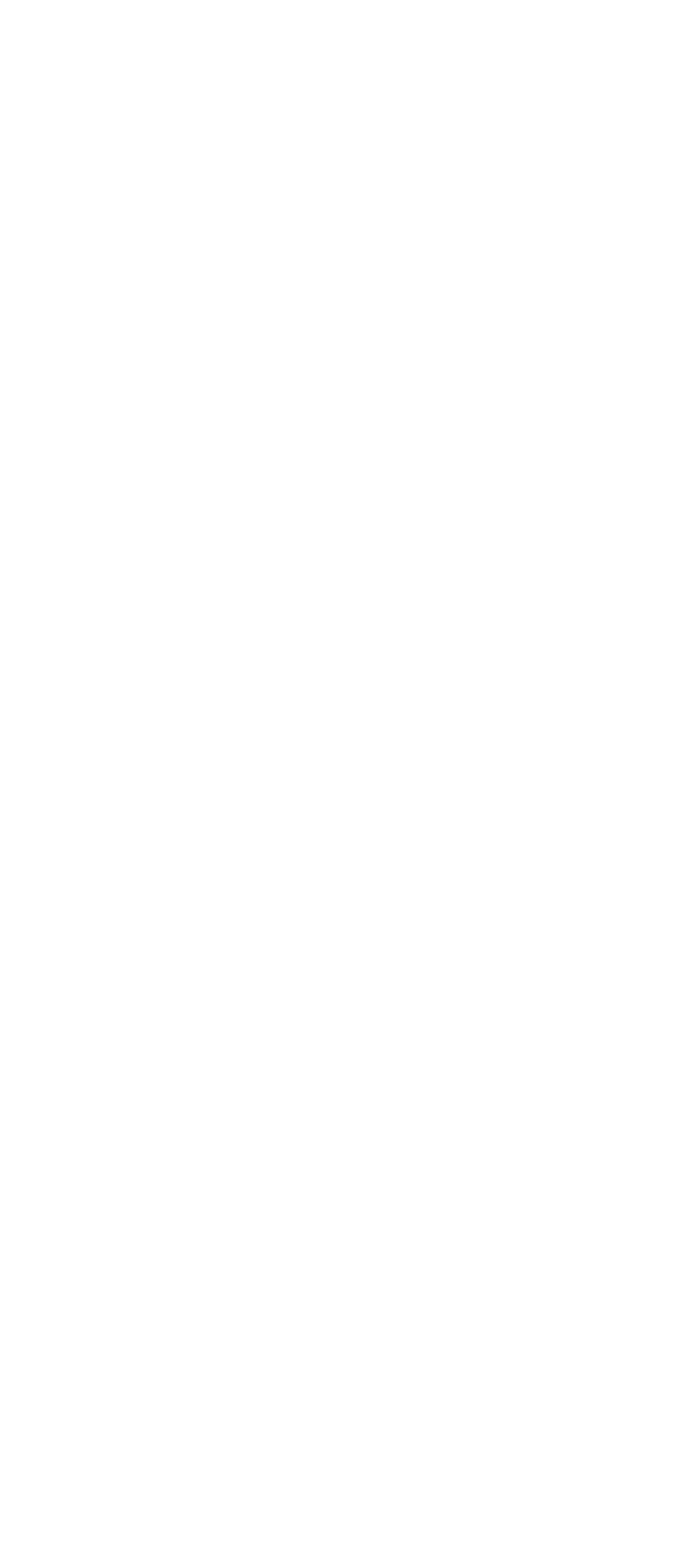




\section{HERNANDO COUNTY.}

By G. C. Matson.

GENERAL FEATURES.

Hernando County lies in the western part of the peninsula, extending from the Gulf coast east to Withlacoochee River. Near the coast the surface of the county is a low, nearly level plain, 20 to 25 feet above sea level. Along Withlacoochee River a terrace rising 40 to 60 feet above sea level represents a former level of the river. It extends down the river, where it doubtless unites with a terrace bordering the coast. Remnants of a similar terrace with an altitude of 70 to 100 feet may be seen at many points. The interior of the county is rolling and consists of high rounded hills interspersed with basin-shaped depressions or sinks. A few of these sink holes are occupied by lakes and ponds, but most of them are dry. The range in altitude between depressions and hills frequently amounts to over 100 feet, and the hills themselves may rise to nearly 200 feet above sea level. The sink holes were formed by the breaking down of the roofs of caverns, and they bear testimony to the great extent of the underground drainage. Throughout the upland portion of the county nearly all the rainfall passes to the underground channels in the limestone.

\section{GEOLOGY.}

The terraces in Hernando County are covered by a thin deposit of gray Pleistocene sand and the uplands by a thin coating of gray or yellow residual sands.

In the vicinity of Brooksville and in the southeastern part of the county the sands are underlain by limestones, sands, and clays belonging to the Hawthorn and Alum Bluff formations. The exact distribution of these formations in Hernando County has not been determined in detail, but small deposits are known to occupy many of the higher hills. The Vicksburgian limestones are the subsurface formations over a large part of the county; they underlie the Hawthorn where that formation is present and doubtless reach the surface in some of the streams near the western edge of the county. They are exposed in most of the phosphate mines.

The gray residual sand probably averages less than 5 feet in thickness, but locally the sands of Pleistocene age may attain 25 to 30 feet. The yellow sands are commonly from 20 to 30 feet thick, though locally they are much thinner and in some places are entirely wanting. The thickness of the Alum Bluff formation has not been ascertained and that of the Hawthorn formation is difficult to determine; in the vicinity of Brooksville the latter may exceed 100 feet, but at many 
places in the county it is represented by only a few feet of hard cherty limestone. The Vicksburgian limestones doubtless attain a thickness of several hundred feet in Hernando County.

WATER SUPPLY.

Source.-There are only two important water-bearing formations in Hernando County-the surficial sands and the Vicksburgian limestones. The sands are important sources of supply for many shallow wells, and the limestones are penetrated by nearly all of the deep ones. Both formations yield an abundance of water, and the supplies from both are extensively utilized.

Quality.-The sands furnish soft water. The deeper supplies are hard, but they are regarded as satisfactory for all purposes.

Development.-Shallow wells usually obtain water within a few feet of the surface and the supplies are ample for the needs of a family or for farm use. The water is easily raised either by small suction pumps or by the old-fashioned bucket. The greatest objection to the use of these wells is the difficulty of excluding impure surface water. The deep wells of Hernando County range from about 75 to 280 feet and many of them are less than 150 feet. They secure large quantities of water suitable for domestic or industrial uses.

Springs are numerous and some of them are of considerable size. Weekewachee Spring, 8 miles southeast of Bay Port, has an estimated flow of 100,000 gallons per minute and gives rise to a good-sized stream. A small sulphur spring, 2 miles northeast of Bay Port, has an estimated flow of 10,000 gallons per minute. Neither of these springs is used. 


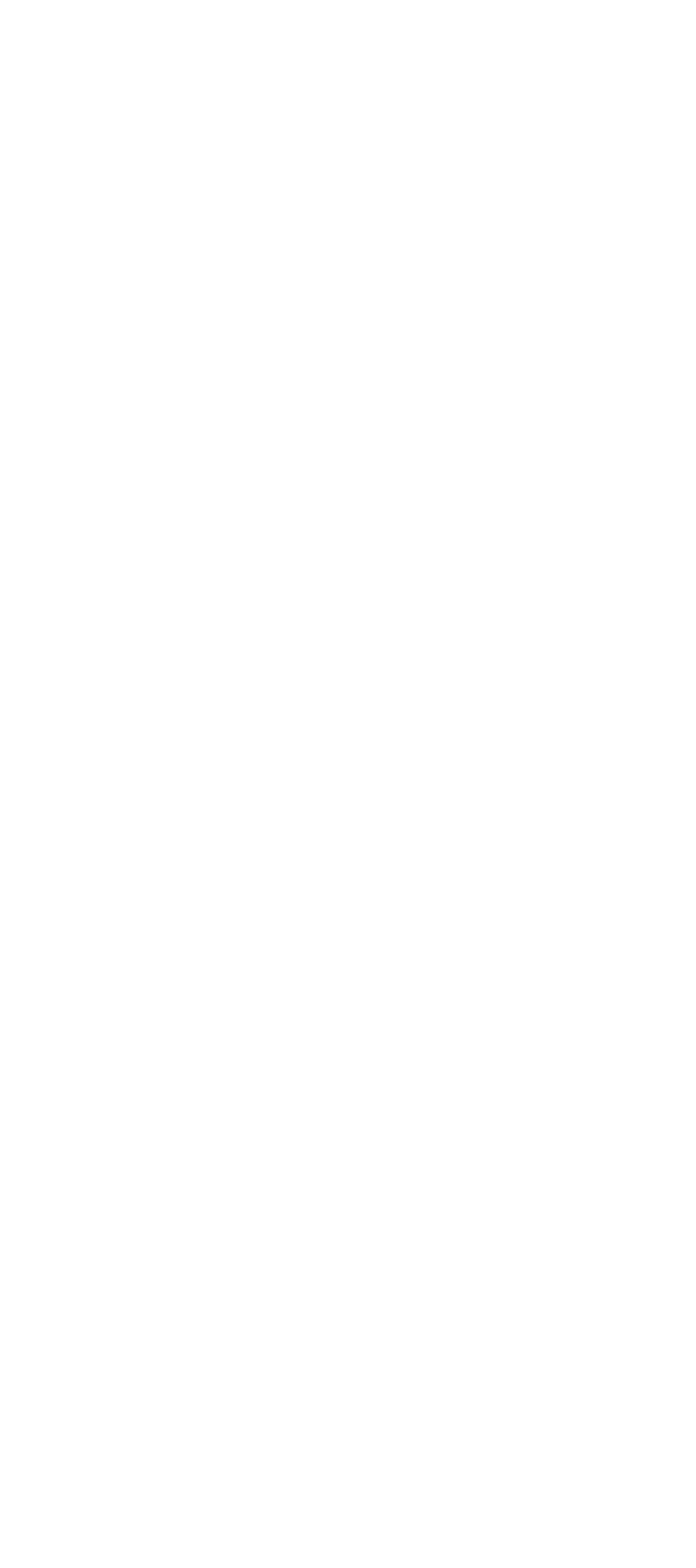


General water resources of Hernando County.

\begin{tabular}{|c|c|c|c|c|c|c|c|c|c|}
\hline \multirow{2}{*}{ Town. } & \multirow{2}{*}{$\begin{array}{l}\text { Topo- } \\
\text { graphic } \\
\text { location. }\end{array}$} & \multirow{2}{*}{$\begin{array}{c}\text { Source of } \\
\text { water. }\end{array}$} & \multirow{2}{*}{\multicolumn{2}{|c|}{ Surface formation. }} & \multicolumn{5}{|c|}{ Shallow wells. } \\
\hline & & & & & Supply. & \multicolumn{2}{|c|}{$\begin{array}{l}\text { Quality of } \\
\text { water. }\end{array}$} & \multicolumn{2}{|c|}{$\begin{array}{l}\text { Principal } \\
\text { water bed. }\end{array}$} \\
\hline $\begin{array}{l}\text { Brooksville........ } \\
\text { Croom ............. } \\
\text { Istachatta........ }\end{array}$ & $\begin{array}{c}\text { Hilly....... } \\
\text { Rolling.... } \\
\ldots \ldots\end{array}$ & \begin{tabular}{|c|c} 
Wells... & C \\
$\ldots$. do...... & S \\
$\ldots . . . . . .$. &..
\end{tabular} & \multicolumn{2}{|c|}{$\mid \begin{array}{c}\text { Clays. . . . . . . . . } \\
\text { Sand } \ldots \ldots \ldots \ldots \ldots \ldots\end{array}$} & $\begin{array}{l}\text { Good. } \\
\cdots \ldots \\
\cdots \ldots\end{array}$ & \begin{tabular}{l|l}
$\ldots$ & \multicolumn{1}{|c}{ Partly } \\
\hdashline$\ldots$ & $\ldots \ldots$ \\
\hdashline$\ldots$ & $\ldots \ldots$ \\
\end{tabular} & $\begin{array}{l}\text { oft } \ldots . . . \\
\ldots \ldots\end{array}$ & \multicolumn{2}{|c|}{$\begin{array}{l}\text { Limestone. } \\
\text { Do. } \\
\text { Do. }\end{array}$} \\
\hline \multirow{2}{*}{ Town. } & \multicolumn{5}{|c|}{ Deep wells. } & \multirow{2}{*}{$\begin{array}{l}\text { Depth to } \\
\text { rock. }\end{array}$} & \multirow{2}{*}{\multicolumn{2}{|c|}{$\begin{array}{l}\text { Depth to } \\
\text { water. }\end{array}$}} & \multirow{2}{*}{$\begin{array}{l}\text { Sewerage } \\
\text { system. }\end{array}$} \\
\hline & Depth. & Supply. & $\begin{array}{c}\text { Head } \\
\text { above sea. }\end{array}$ & $\begin{array}{l}\text { Qu } \\
\text { of } \mathrm{W}\end{array}$ & $\begin{array}{l}\text { ality } \\
\text { vater. }\end{array}$ & & & & \\
\hline $\begin{array}{l}\text { Brooksville. . . . . } \\
\text { Croom. ........... } \\
\text { Istachatta........ }\end{array}$ & $\begin{array}{r}\text { Feet. } \\
226 \\
75 \\
\ldots \ldots\end{array}$ & $\begin{array}{l}\text { Abundant. } \\
\ldots \text { do......... } \\
\ldots \text { do........ }\end{array}$ & $\begin{array}{r}\text { Feet. } \\
18-20 \\
\cdots \ldots\end{array}$ & \multicolumn{2}{|c|}{$\begin{array}{c}\text { Hard...... } \\
\ldots . \text { do....... } \\
\ldots . \text { do....... }\end{array}$} & \begin{tabular}{c}
\multicolumn{2}{c}{$\begin{array}{c}\text { Feet. } \\
0-100\end{array}$} \\
$\cdots \cdots$
\end{tabular} & $\begin{array}{r}\text { Feet } \\
\cdots \\
15\end{array}$ & -20 & $\begin{array}{l}\text { None. } \\
\text { Do. } \\
\text { Do. }\end{array}$ \\
\hline
\end{tabular}

Springs of Hernando County.

\begin{tabular}{|c|c|c|c|c|c|c|c|}
\hline Name. & Owner. & $\begin{array}{l}\text { Nearest post } \\
\text { office. }\end{array}$ & \multicolumn{2}{|c|}{$\begin{array}{c}\text { Direction and } \\
\text { distance. }\end{array}$} & $\begin{array}{c}\text { Discharge } \\
\text { per minute. }\end{array}$ & $\begin{array}{l}\text { Topographic } \\
\text { surroundings. }\end{array}$ & Emergence. \\
\hline $\begin{array}{l}\text { Weekewachee. } \\
\text { Sulphur......... }\end{array}$ & $\begin{array}{l}\text { Wild e n and } \\
\text { McClure. } \\
\text { S. V. Varn.... }\end{array}$ & $\begin{array}{l}\text { Bay Port... } \\
\text {...do....... }\end{array}$ & $\begin{array}{l}8 \text { miles sol } \\
\text { east. } \\
2 \text { miles no } \\
\text { east. }\end{array}$ & uth- & $\begin{array}{c}\text { Gallons. } \\
100,000 \pm \\
10,000 \pm\end{array}$ & Sandy scrub. & Boils. \\
\hline Name. & Geologic source. & $\begin{array}{l}\text { Quality } \\
\text { of water. }\end{array}$ & $\begin{array}{c}\text { Tempera- } \\
\text { ture. }\end{array}$ & Nat & ure of stream. & Rer & marks. \\
\hline $\begin{array}{l}\text { Weekewachee.. } \\
\text { Sulphur........ }\end{array}$ & $\begin{array}{c}\begin{array}{c}\text { Oligocene lime- } \\
\text { stone. }\end{array} \\
\ldots \ldots \ldots \ldots \ldots \ldots\end{array}$ & .. $\begin{array}{l}\text { Hard.... } \\
\text { Sulphur. }\end{array}$ & ${ }^{\circ} F$ & $\begin{array}{c}\text { Sma } \\
\mathrm{m} \\
\text { Ent } \\
\mathrm{G}\end{array}$ & $\begin{array}{l}\text { illes to Gulf. } \\
\text { ileam inlet from } \\
\text { ers. } \\
\text { alf. }\end{array}$ & $\begin{array}{c}\text { No improve } \\
\text { not used. } \\
\text { Do. }\end{array}$ & ments; spring \\
\hline
\end{tabular}

\section{HILLSBOROUGH COUNTY.}

By G. C. Matson.

\section{GENERAL FEATURES.}

Hillsborough County comprises a large area on the Gulf coast. Tampa Bay extends a long distance into it, forming an excellent harbor. West of this bay a broad peninsula rises to a maximum height of over 50 feet. A series of low islands border the coast and inclose narrow sounds of shallow water.

East and north of Tampa the surface becomes gently rolling, but toward the southeast it is generally flat and locally swampy. A broad terrace borders the coast and extends along Hillsboro River. Near Tampa this terrace is hardly more than 20 to 25 feet above sea level; another terrace along the river lies at an altitude of 40 to 60 feet at Thonotosassa; and a still higher one probably occurs in Hillsborough County, but it has not yet been discriminated. 


\section{GEOLOGY.}

The lowlands of Hillsborough County are covered by gray sand of Pleistocene age, locally underlain by red and yellow sands and clays derived from decomposition of the underlying rock. The uplands have a coating of gray or light-yellow sand of residual origin.

Near the southeast corner of the county an area is underlain by land-pebble phosphates belonging to the Bone Valley gravel. This* formation is extensively developed in the eastern part of the county, and is much less important here than in the adjoining portion of Polk County. Beneath the Bone Valley gravel are phosphatic limestones, sands, and clays belonging to the Alum Bluff formation. The Tampa formation underlies the entire surface of the county, resting unconformably upon the soft porous Vicksburgian limestones. These limestones are not exposed in Hillsborough County; in the northern part they are buried beneath 100 to 150 feet and in the southern part probably by a still greater thickness of younger rocks.

The average thickness of the Pleistocene gray sands is probably less than 25 feet, and the light-colored residual sands and clays are thin. The thickness of the Alum Bluff formation could not be learned. The Tampa formation is thought to attain a maximum thickness of somewhat more than 130 feet. As there are no good sections, a large portion of this formation is known only from well logs. The most satisfactory log is that of the well at the Tampa waterworks (p. 106). The Vicksburgian limestones probably attain a thickness of several hundred feet, but no information is available concerning the exact depth to the base of these formations. The following sections show thicknesses at the points named:

Log of E. C. Stewart's well at Plant City.

\begin{tabular}{|c|c|c|}
\hline & Thickness. & Depth. \\
\hline 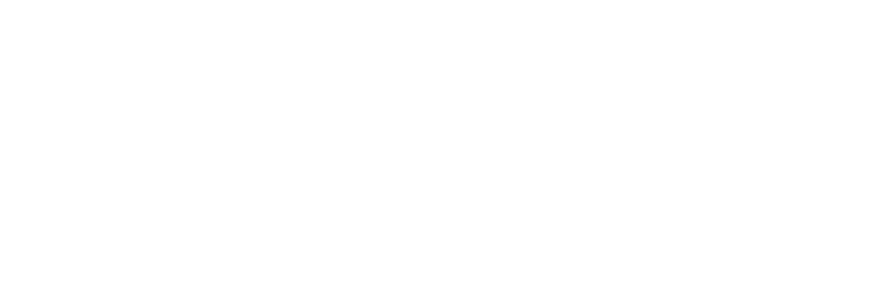 & Feet. $\begin{array}{r}1 \\
5 \\
14 \\
29 \\
21 \\
45 \\
2 \\
53 \\
23 \\
67 \\
59 \\
61\end{array}$ & $\begin{array}{r}\text { Feet. } \\
1 \\
6 \\
20 \\
49 \\
70 \\
115 \\
117 \\
170 \\
183 \\
250 \\
309 \\
370\end{array}$ \\
\hline
\end{tabular}


Log of the city well at Plant City.

Soil

Clay, red; changing gradually to white.

Clay, white; with small pebbles; phosphate

Marl.

Shell rock, hard

Shell rock, as in soft layer.

Shell rock, hard

Shell rock, much harder, flinty

Sand, loose, fine.

Shell and soft rock, in alternating layers

Shell rock, with a few phosphatic pebbles.

Quicksand, loose.

Shell rock, hard

Shell rock, hard; some layers contain hard flint

Cavity with an especially good supply water

\begin{tabular}{|r|r} 
Thickness. & Depth. \\
\hline Feet. & Feet. \\
2 & 2 \\
22 & 24 \\
16 & 40 \\
20 & 60 \\
10 & 70 \\
30 & 100 \\
17 & 117 \\
7 & 124 \\
4 & 128 \\
52 & 180 \\
40 & 220 \\
25 & 245 \\
45 & 290 \\
50 & 340 \\
1 & 341 \\
&
\end{tabular}

Log of the well at Fort De Soto.

[From samples of drillings furnished by $\mathrm{s}$. W. Bryan.]

Sand, fine, white; fragments of shells.

Sand, mixed fine white and dark colored; with fragments of shells

Sand, dark gray to greenish gray; partly consolidated

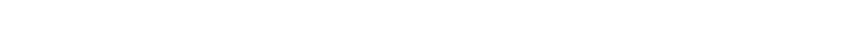

Limestone, dense, gray, and granular gray sandstone; numerous shells...............

Limestone, light gray, porous

Limestone, mixed light and dark gray

Shells and shell fragments. .

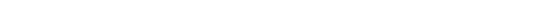

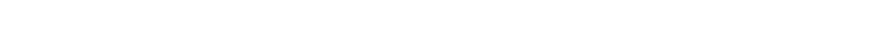

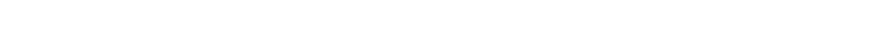

limestone, fine white

Limestone, light dove-colored

(l)

Marl, thin, granular; containing sand.

Sand, pale yellow.

Limestone, granular, light gray

Sand, fine, gray, gray granular limestone, and wine-colored silex

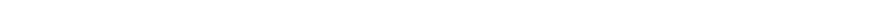

Limestone, fine, gray, sandy.

Sand, light gray...

Limestone, porous, white.

Limestone, coarse grained, gray . . . . . . . . . .

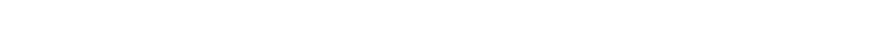

Chert, dark gray

Limestone, light gray.

Limestone, white.......

Limestone, pinkish gray.

Limestone, very fine grained, dense, white

Limestone, coarse grained, brownish gray

Limestone, light gray .........................

To judge from the samples, many of those below 200 feet contain material that has fallen from above, and the absence of characteristic fossils, together with this mixing of materials from various levels, makes it difficult to determine the thickness of the various formations. From the conditions at Tampa it is believed that this well penetrated a considerable depth into the Vicksburgian limestones. The wine-colored chert encountered between 240 and 260 feet should belong to the Tampa formation and represent the bed exposed at Ballast Point, but this would indicate a remarkably steep dip for Florida, and possibly the chert has fallen from a higher horizon. 
WATER SUPPLY.

Source.-The surficial sands contain an excellent supply of soft water which may be obtained within a few feet of the surface. The Bone Valley gravel is not important as a water-bearing formation. The Alum Bluff and Tampa formations contain considerable quantities of water but have no persistent layers of porous rock and the occurrence of water is somewhat uncertain. The Vicksburgian limestones are the most important source of supply and contain an abundance of water that may be obtained by drilling from 100 to 200 feet, except on the uplands and in the southern portion of the county, where the depth to good water-bearing beds is greater.

Quality.-The water from the surficial sands is usually soft and is regarded as satisfactory. That from the Alum Bluff and Tampa formations is hard water but is suitable for domestic or industrial uses. The Vicksburgian limestones supply hard sulphur water. In most localities this water is usable, but in a few places it is too highly mineralized. Deep wells at the power house of the Tampa Electric Co. yield strongly saline water. However, such supplies are rare and the water from the Vicksburgian limestones is usually better than that from the other formations because there is less danger of its becoming polluted by impure surface drainage.

Development.- Shallow wells usually obtain ample supplies within 50 feet of the surface and many of them do not exceed 10 to 15 feet in depth. A few have been drilled to depths of over 100 feet, passing through good aquifers in the sands and entering the underlying limestones. Most of the deeper wells go down for 100 to 200 feet, though a few have been sunk for several hundred feet. The deepest well reported is 3 miles southeast of Plant City and is owned by the Coronet Phosphate Co. It is 1,100 feet deep and will supply over 1,000 gallons per minute. Deep wells have been sunk in Tampa, but it is seldom necessary to drill to more than 250 feet. Flowing wells may be obtained on low ground near the coast at St. Petersburg, Tampa, and Ybor City. A small flow has also been procured at Dunedin. At St. Petersburg and Tampa the flows are obtained from the Vicksburgian limestones, but at Dunedin the water probably comes from the Tampa formation. An unsuccessful attempt was made to obtain a flowing well at Clearwater, a well being drilled 740 feet without encountering water that would rise to the surface. However, no attempt was made to case this well so as to test the head of the water from the different aquifers, which were encountered at 85 , 250 , and 350 feet. The water from a depth of 85 feet rose to about sea level and the supplies from the lower beds did not show any great increase in head, but this may have been due to the fact that the water from the deeper beds escaped through the porous layer at 
Typical wells of Hillsborough County.

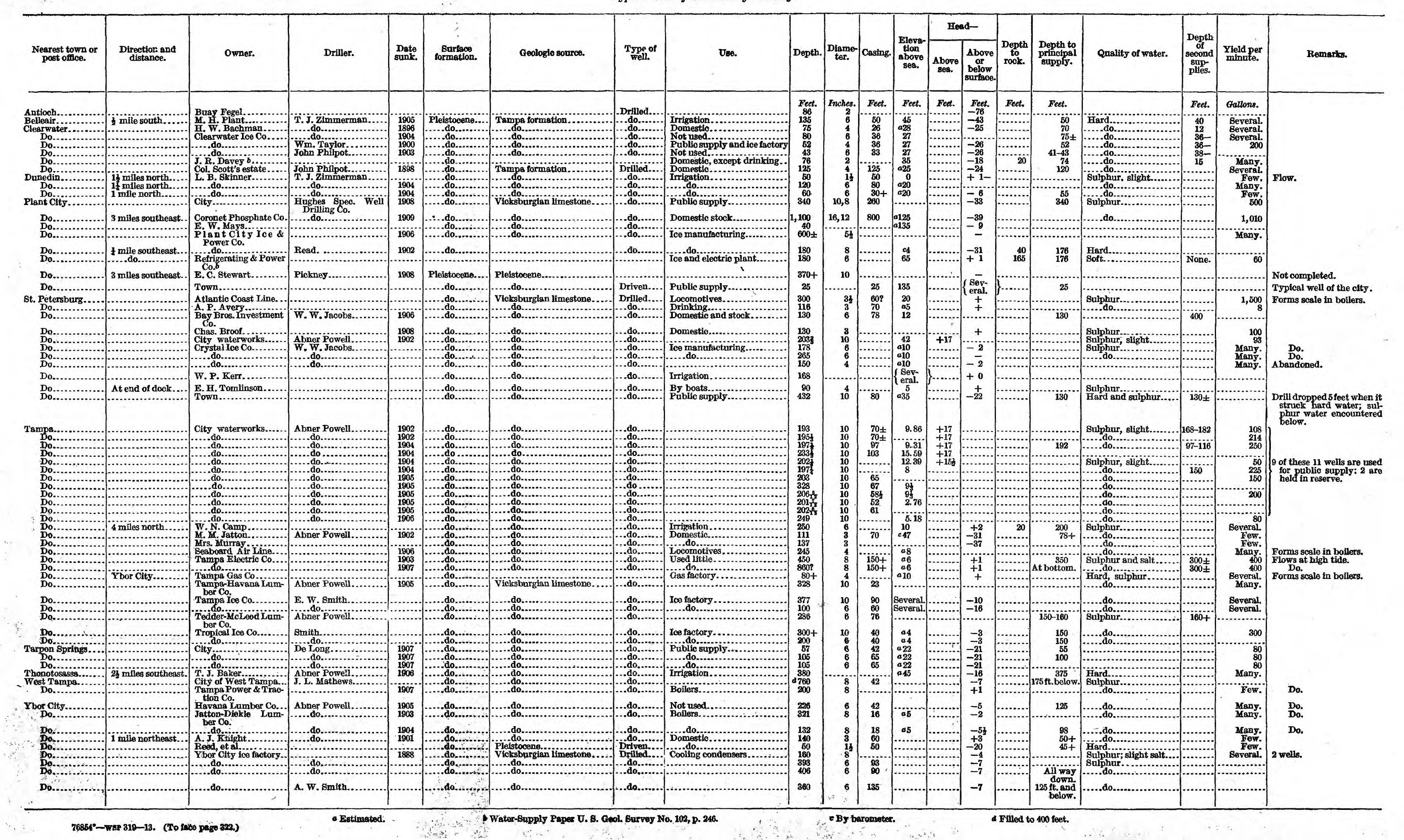



85 feet. The water obtained at 250 feet contained sulphur and that at 350 feet was a very strong brine. The most favorable location for flowing wells at Clearwater is on low ground, as the water from the Vicksburgian limestones at St. Petersburg and Tampa does not rise high above sea level and its head would probably be slightly lower at Clearwater. Flowing wells should be obtained on the low ground near the shores of Tampa Bay, and the head will probably be greater near the southern end of the county than it is at Tampa.

Hillsborough County contains excellent springs, the most important being Tampa Sulphur Spring and Green Spring (Espiritu Santo Spring). Both of these springs are used as centers for resorts and are supplied with hotels and bathhouses. The Tampa Sulphur Spring emerges from a hole in the limestones of the Tampa formation and has a very large flow. At Green Spring there are several points of emergence and the flow is small; the water is highly charged with sulphur and salt and is thought to have medicinal properties. Near Belleair a small spring which emerges in the edge of the bay has been surrounded by a concrete wall and is pumped to the Belleair Hotel, where it is used for drinking.

Belleair has a public water supply taken from a small lake. The water is used chiefly for the Belleview Hotel and is very satisfactory. The public supplies at Plant City, Clearwater, Tampa, West Tampa, and Tarpon Springs are all obtained from wells. The waterworks at Plant City is supplied by a single well penetrating the Vicksburgian limestones. At Clearwater three wells ranging in depth from 52 to 80 feet draw from the Tampa formation; the quantity of water is ample and the quality satisfactory for all general purposes At Tarpon Springs three wells, ranging in depth from 65 to 105 feet, probably draw from the Vicksburgian limestones. The West Tampa water supply is obtained from wells and is ample for the needs of the city. The Tampa Waterworks Co. has 11 wells ranging in depth from 180 to 328 feet, but only 9 of them are in use; tests to determine their yield indicate that the limestones at that locality contain very large quantities of water. At St. Petersburg the public supply is obtained in part from wells and in part trom a lake; the system is capable of furnishing a very large amount of water of excellent quality. 
General water resources of Hillsborough County.

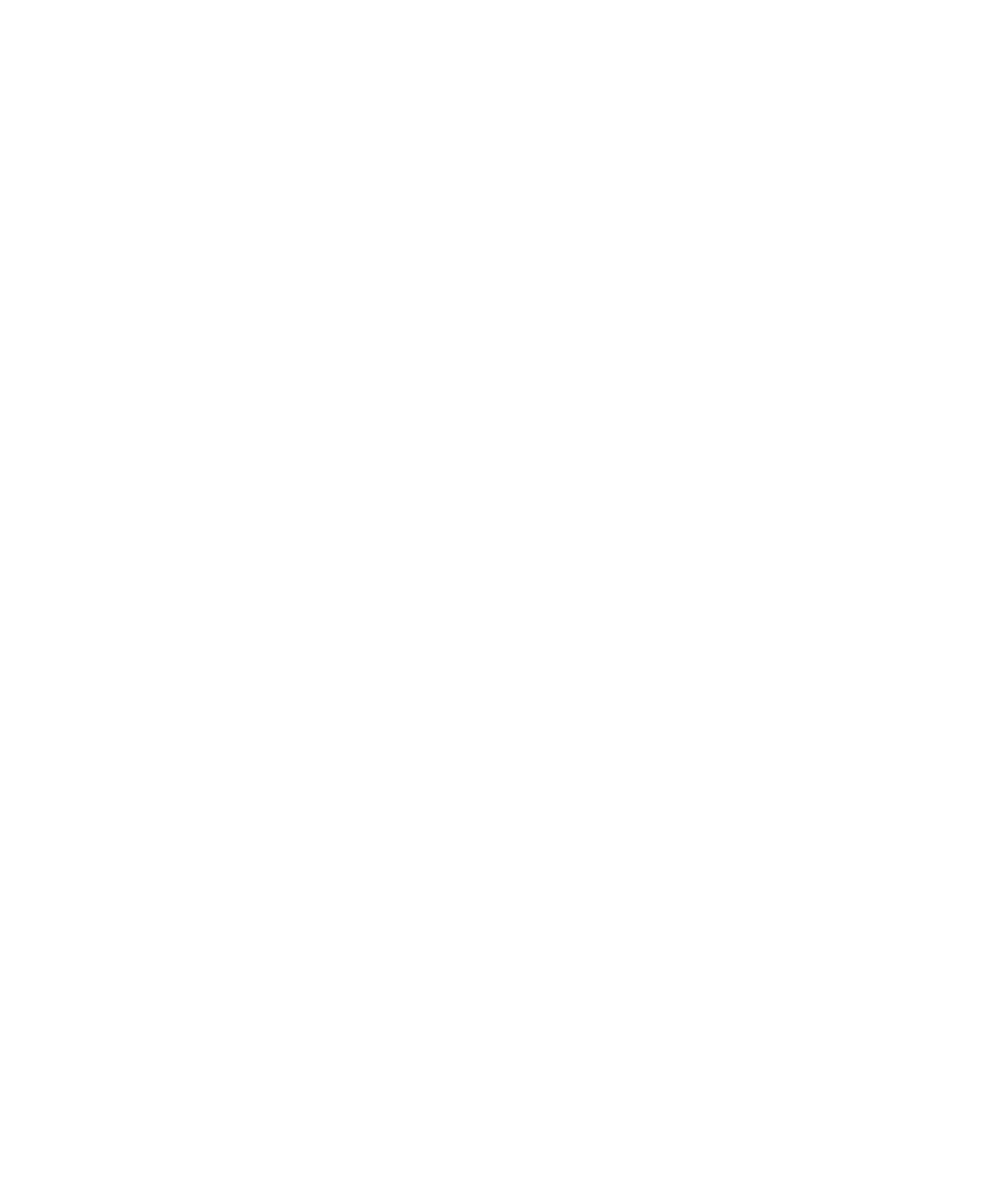

Springs of Hillsborough County.

\begin{tabular}{|c|c|c|c|c|c|c|c|}
\hline Name. & Owner. & $\begin{array}{c}\text { Nearest } \\
\text { post office. }\end{array}$ & $\begin{array}{l}\text { Direction } \\
\text { and } \\
\text { distance. }\end{array}$ & $\begin{array}{l}\text { Dis- } \\
\text { charge } \\
\text { per } \\
\text { mim- } \\
\text { ute. }\end{array}$ & $\begin{array}{l}\text { Topo- } \\
\text { graphic } \\
\text { surround- } \\
\text { ings. }\end{array}$ & Use. & Emergence. \\
\hline $\begin{array}{l}\text { Belleair Spring.... } \\
\text { Espiritu Santo or } \\
\text { Green Spring. }\end{array}$ & $\begin{array}{l}\text { M.H.Plant } \\
\text { Capt. J. } \\
\text { Tucker. }\end{array}$ & $\begin{array}{l}\text { Belleair... } \\
\text { s a f e t } y \\
\text { Harbor. }\end{array}$ & $\begin{array}{c}{ }^{\frac{1}{2}} \operatorname{mil}^{\text {mile }} \\
\text { south. } \\
\cdots \cdots\end{array}$ & $\begin{array}{r}\text { Gallons. } \\
3,000- \\
4,000 \\
20\end{array}$ & \begin{tabular}{|} 
Plain....... \\
$\ldots$ do.........
\end{tabular} & $\begin{array}{c}\text { Drinking.. } \\
\text { Hotel and } \\
\text { b a th }-\end{array}$ & $\begin{array}{l}\text { Boils up at } \\
\text { edge of sea. } \\
\text { Boils up at } \\
\text { edge of bay. }\end{array}$ \\
\hline $\begin{array}{l}\text { Tampa Sulphur } \\
\text { Spring. }\end{array}$ & $\begin{array}{c}\text { J o s i a h } \\
\text { Richards. }\end{array}$ & Tampa.... & $6 \underset{\text { north. }}{\mathrm{miles}}$ & 65,000 & ...do........ & $\begin{array}{l}\text { Clubhouse, } \\
\text { hotel, } \\
\text { sw im: } \\
\text { m ing } \\
\text { pool. }\end{array}$ & $\begin{array}{l}\text { Boils up from } \\
\text { hole. }\end{array}$ \\
\hline
\end{tabular}


Springs of Hillsborough County-Continued.

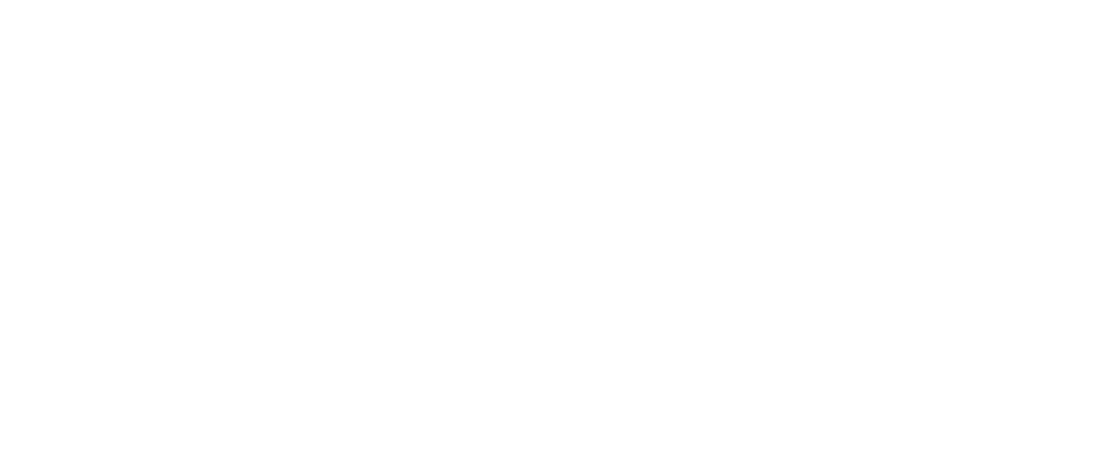

\section{HOLMES COUNTY.}

By G. C. Matson.

\section{GENERAL FEATURES.}

Holmes County borders the Georgia line, extending from Holmes Creek westward some distance beyond Choctawhatchee River. Its surface consists of rolling uplands which locally rise to altitudes of more than 250 feet. All the large streams are bordered by broad terraces of level land, which merge with other terraces along the coast. Extensive swamps lie along some of the streams and smaller ones occur in many localities.

\section{GEOLOGY.}

Gray sands of Pleistocene age form the surface deposits on the terrace in Holmes County, and the uplands are covered by lightcolored residual sands, through which outcrop red and yellow sands and sandy clays belonging to the Lafayette (?) formation and rocks of other underlying formations. In a large portion of the county the Lafayette (?) formation is underlain by the Alum Bluff formation and this formation rests on the Chattahoochee. In the valleys of some of the streams near the northern boundary the Vicksburgian limestones immediately. underlie the surficial sands, but elsewhere these limestones are buried beneath the Chattahoochee and younger formations.

The residual sands are comparatively thin, probably averaging less than 5 feet, though locally they may amount to several feet. An average thickness of 30 feet is probably a fair estimate for the gray sands of Pleistocene age, and the Lafayette (?) formation, though locally these may reach a maximum of over 50 feet. The Chattahoochee may have a maximum thickness of over 200 feet, though over a large part of the county it is probably much thinner. The thickness of the Vicksburgian limestones is undetermined. 


\section{WATER SUPPLY.}

Source.-The Pleistocene sands are not important water beds except where they are unusually thick, but the Lafayette (?) formation contains an abundance of water available for shallow wells. Valuable water beds occur in the Alum Bluff, Chattahoochee, and Vicksburgian formations. The Vicksburgian limestones are the best source of water because they contain very large supplies that may be easily pumped.

Quality.-The surficial sands contain soft water. Both the Chattahoochee and the Vicksburgian limestones supply hard water but are subjected to so much less danger of pollution that their waters are usually more desirable than those from the surficial sands.

Development.-In Holmes County shallow wells usually obtain ample supplies of soft water within 10 to 35 feet of the surface. Only two deep wells are reported; the Sessons-Whited Co.'s well found an abundant supply of hard water at the bottom in Vicksburgian limestone at 398 feet; and James Williams's well at Eleanor obtained an excellent supply from the same limestones at 275 feet.

Typical wells of Holmes County.

\begin{tabular}{|c|c|c|c|c|c|c|c|c|c|c|c|}
\hline $\begin{array}{l}\text { Nearest } \\
\text { town or } \\
\text { post } \\
\text { office. }\end{array}$ & $\begin{array}{l}\text { Direction } \\
\text { and } \\
\text { distance. }\end{array}$ & \multicolumn{2}{|c|}{ Owner. } & \multicolumn{2}{|c|}{ Driller. } & $\begin{array}{l}\text { Date } \\
\text { sunk. }\end{array}$ & $\begin{array}{l}\text { Surface } \\
\text { forma- } \\
\text { tion. }\end{array}$ & \multicolumn{2}{|c|}{$\begin{array}{l}\text { Geologic } \\
\text { source. }\end{array}$} & $\begin{array}{l}\text { Type } \\
\text { of well. }\end{array}$ & Use. \\
\hline Bonifay... & $\begin{array}{l}\frac{1}{2} \mathrm{mile} \\
\text { south. }\end{array}$ & \multicolumn{2}{|c|}{$\begin{array}{l}\text { S e s s o n s - } \\
\text { Whited Co. } \\
\text { Jas. Williams. }\end{array}$} & \multicolumn{2}{|c|}{$\begin{array}{l}\text { F. J. White } \\
\& \text { Co. } \\
\text {.....do........ }\end{array}$} & 1906 . & $\begin{array}{c}\begin{array}{c}\text { Pleisto- } \\
\text { cene. }\end{array} \\
\text {...do...... }\end{array}$ & \multicolumn{2}{|c|}{ 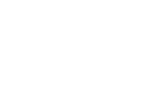 } & $\begin{array}{c}\text { Drilled } \\
\text {...do... }\end{array}$ & $\begin{array}{c}\text { Boilers and } \\
\text { drinking. } \\
\text { Do. }\end{array}$ \\
\hline \multicolumn{2}{|c|}{$\begin{array}{l}\text { Nearest town or } \\
\text { post office. }\end{array}$} & 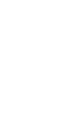 & 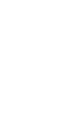 & : & 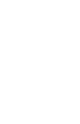 & 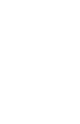 & $\begin{array}{l}\text { Qual- } \\
\text { ity of } \\
\text { water. }\end{array}$ & 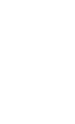 & 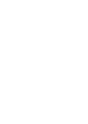 & \multicolumn{2}{|c|}{ Remarks. } \\
\hline \multicolumn{2}{|c|}{ Bonifay.... } & $\begin{array}{l}\text { Feet. } \\
398 \frac{1}{2}\end{array}$ & $\begin{array}{l}I n . \\
8\end{array}$ & $\begin{array}{l}\text { Feet. } \\
170 \pm\end{array}$ & $\begin{array}{l}\text { Feet. } \\
10 \pm\end{array}$ & $\begin{array}{l}\text { Feet. } \\
398\end{array}$ & Hard. & Feet. & $\begin{array}{r}\text { Gallons. } \\
125\end{array}$ & \multirow{2}{*}{\multicolumn{2}{|c|}{$\begin{array}{l}\text { Forms scale in } \\
\text { boilers. }\end{array}$}} \\
\hline Eleanor. . & & 275 & 6 & 275 & 30 & 275 & ...do... & 219 & $\ldots . .$. & & \\
\hline
\end{tabular}

General water resources of Holmes County.

\begin{tabular}{|c|c|c|c|c|c|c|c|}
\hline \multirow{2}{*}{ Town. } & \multirow{2}{*}{$\begin{array}{c}\text { Topo- } \\
\text { graphic } \\
\text { location. }\end{array}$} & \multirow{2}{*}{ Source of water. } & \multirow{2}{*}{$\begin{array}{l}\text { Surface for- } \\
\text { mation. }\end{array}$} & \multicolumn{4}{|c|}{ Shallow wells. } \\
\hline & & & & Depth. & Supply. & $\begin{array}{l}\text { Quality of } \\
\text { water. }\end{array}$ & $\begin{array}{c}\text { Principal } \\
\text { water beds. }\end{array}$ \\
\hline Argyle.. & & $\begin{array}{l}\text { Dug and driven } \\
\text { wells. }\end{array}$ & $\begin{array}{c}\text { Pleistoce ne } \\
\text { sand and } \\
L \text { a f a - }\end{array}$ & $\begin{array}{l}\text { Feet. } \\
17-22\end{array}$ & Good.. & Soft... & $\begin{array}{r}\text { Marianna } \\
\text { limestone. }\end{array}$ \\
\hline $\begin{array}{l}\text { Eleanor } \\
\text { Ponce de Leon. }\end{array}$ & Plain..... & $\begin{array}{l}\text { Drilled well .......... } \\
\text { Dug and driven }\end{array}$ & Pleistocene & $\begin{array}{l}15-35 \\
12-25\end{array}$ & $\begin{array}{l}\text {...do... } \\
\ldots \text {... do... }\end{array}$ & Hard ...... & $\begin{array}{l}\text { Do. } \\
\text { Do. }\end{array}$ \\
\hline Westville.. & ..do.... & 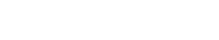 & $\begin{array}{l}\text { sand. } \\
\ldots . . . . . . . . . . . \\
\end{array}$ & $12-26$ & ...do.. & $\begin{array}{c}\text { nard. } \\
\ldots . . . . . . . .\end{array}$ & Do. \\
\hline
\end{tabular}


General water resources of Holmes County-Continued.

\begin{tabular}{|c|c|c|c|c|c|c|}
\hline \multirow{2}{*}{ Town. } & \multicolumn{2}{|c|}{ Deep wells. } & \multirow{2}{*}{$\begin{array}{l}\text { A verage } \\
\text { thickness } \\
\text { of sand. }\end{array}$} & \multirow{2}{*}{$\begin{array}{l}\text { Depth to } \\
\text { water. }\end{array}$} & \multirow{2}{*}{$\begin{array}{l}\text { Increase or decrease } \\
\text { of supply. }\end{array}$} & \multirow{2}{*}{$\begin{array}{l}\text { Sewerage } \\
\text { system. }\end{array}$} \\
\hline & Depth. & Supply. & & & & \\
\hline $\begin{array}{l}\text { Argyle.......... } \\
\text { Eleanor ........ } \\
\text { Ponce de Leon. } \\
\text { Westville....... }\end{array}$ & $\begin{array}{l}\text { Feet. } \\
\ldots \ldots \\
275\end{array}$ & Abundant.... & $\begin{array}{c}\text { Feet. } \\
20+ \\
40+ \\
25+ \\
25+\end{array}$ & $\begin{array}{l}\text { Feet. } \\
10 \pm \\
10 \pm \\
10 \\
6 \pm\end{array}$ & 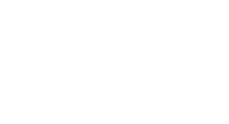 & $\begin{array}{l}\text { None. } \\
\text { Do. } \\
\text { Do. } \\
\text { Do. }\end{array}$ \\
\hline
\end{tabular}

\title{
JACKSON COUNTY.
}

\author{
By G. C. Matson.
}

\section{GENERAL FEATURES.}

Jackson County is on the west side of Apalachicola River in northern Florida. Its surface is generally rolling, but it has some flat areas and extensive swamps - as northwest of Cottondale and south of Cypress, for instance. There are also swamps and lakes in the northeastern part of the county.

Wide areas of upland that rise over 150 feet above sea level have been eroded into a topography characterized by flat-topped hills and steep-sided valleys. Along all the large streams broad flat terraces represent former water levels. They widen toward the coast and finally merge with seaward-facing terraces which represent former extensions of the sea upon the margin of the land.

The county is bordered by Apalachicola River and Holmes Creek and is crossed by Chipola River. These streams receive the surface drainage through a number of small tributaries. The many sink holes in the region where the Vicksburgian limestones are near the surface indicate the existence of extensive underground channels, some of which, like the cavern near Marianna, are accessible. About 6 miles north of Marianna a natural bridge spans Chipola River, but is submerged when the water is high, because the channel in the limestone is not large enough to accommodate all the water.

\section{GEOLOGY.}

The terraces of Jackson County are covered by gray sands of Pleistocene age. The uplands are underlain by red and yellow sands and sandy clays referred to the Lafayette (?) formation. Sands belonging to the Alum Bluff formation are present on the west side of the Chipola River in the southern part of the county, though the area where they are exposed is small.

In a large part of the county the Chattahoochee formation underlies the red and yellow sands and sandy clays, but locally these rocks are wanting, and the surficial deposits rest on the Vicksburgian lime- 
stones. This is the case near the northern boundary of the county in the valleys of all the large streams. The Vicksburgian limestones also lie near the surface in the vicinity of Cottondale and Kynesville.

The red and yellow sands and sandy clays referred to the Lafayette (?) formation in few places attain a thickness of over 30 feet, though locally they may amount to over 50 feet. The sands of the Alum Bluff formation are approximately 30 to 35 feet thick near the southern edge of the county, but farther north they are entirely wanting. The Chattahoochee formation may attain a thickness of over 100 feet near the southern edge of the county, but it thins toward the north. There is considerable uncertainty concerning the thickness of the Vicksburgian limestones; but it amounts to at least 250 feet.

Mr. John Johnson's well near Yon shows the general character of the rocks in the south-central part of the county. After penetrating 40 feet of red sandy clay (Lafayette (?) formation) it enters a white marly limestone with some chert beds (Chattahoochee formation) and remains in it to the bottom at 150 feet. A good supply of water was encountered in a 4-foot channel at 128 feet. A channel $3 \frac{1}{2}$ feet in diameter was penetrated at 138 feet, and a third of unknown size was reached at 146 feet.

\section{WATER SUPPLY.}

Source.-All the geologic formations represented in Jackson County contain more or less water. The surficial sands and sandy clays yield an abundant supply for shallow wells and are regarded as excellent aquifers. Near the southern boundary the sands of the Alum Bluff formation furnish water for a few shallow wells, but their areal distribution is small and they are relatively unimportant. The limestones of the Chattahoochee formation are important waterbearing rocks, but the water occurs in underground channels irregularly distributed; hence it is sometimes difficult to find large supplies, and many wells are sunk to the underlying Vicksburgian limestones. The latter are the most important water rocks in the county, and wells which penetrate them have never failed to obtain large quantities of water.

Quality.-The water in the surficial sands and the sands of the Alum Bluff formation is soft. Both the Chattahoochee formation and the Vicksburgian limestones ordinarily yield hard water, but the water from a few wells penetrating these formations is reported to be soft.

Development.-Shallow wells usually obtain ample supplies at depths ranging from 20 to 40 feet; some, however, obtain abundance within a few feet of the surface and others have to go down to 60 feet. Most of the drilled wells are 100 to 200 feet deep, though 
Typical wells of Jackson County

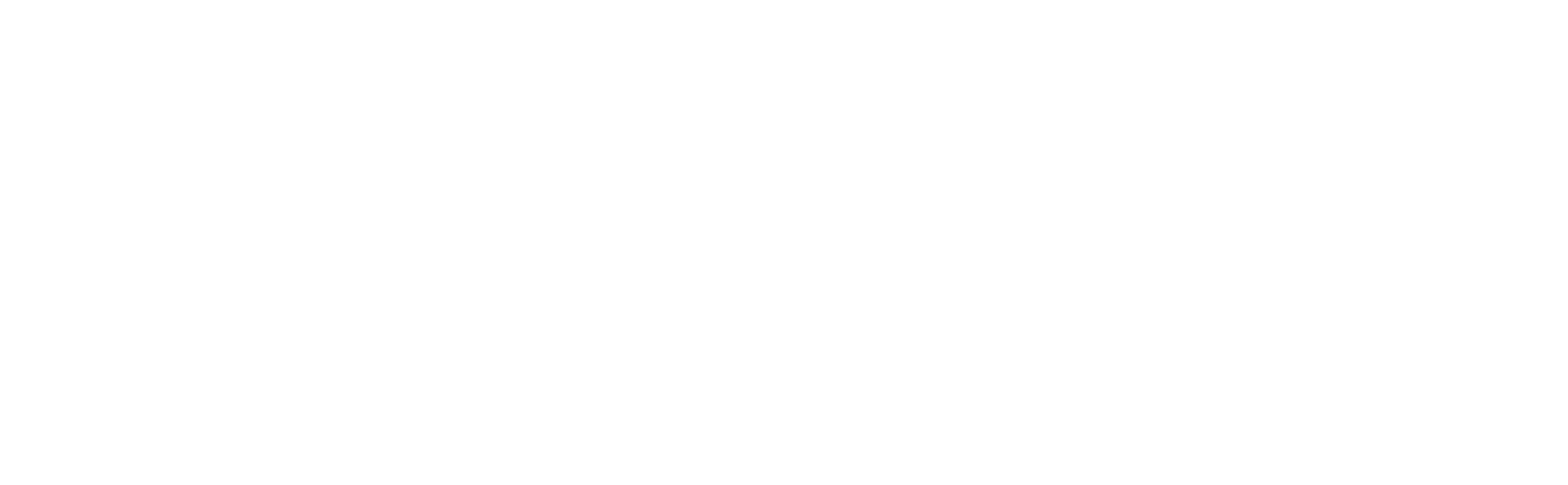

$76654^{\circ}-$ WsP 319-13. (Ta face page 328) 

some find good water within less than 100 feet of the surface, and several exceed 200 feet. The public well at Campbellton is 315 feet deep, and the city supply at Marianna is obtained from a well 386 feet deep. The only flowing well in the county is at Graceville, where water of excellent quality has sufficient head to rise about 6 feet above the surface. It is possible that other flowing wells might be obtained in some of the stream valleys, but the conditions are too uncertain to permit safe predictions.

There are three public water supplies in Jackson County, all obtaining water from drilled wells which penetrate the Vicksburgian limestones. The largest system is at Marianna and is owned by the Marianna Water Co. The water is hard but of fair quality and is ample in quantity. Many of the inhabitants, however, prefer to use water from private wells, and the average daily consumption from the city supply is small. The Aycock Lumber Co. has a well which supplies its lumber camp, to which the water is distributed through mains. The State Reform School has its own supply, obtained from a well on the premises; the quantity is ample and the quality satisfactory.

General water resources of Jackson County.

\begin{tabular}{|c|c|c|c|c|c|c|c|}
\hline \multirow[b]{2}{*}{ Town. } & \multirow{2}{*}{$\begin{array}{l}\text { Topographic } \\
\text { location. }\end{array}$} & \multirow{2}{*}{$\begin{array}{l}\text { Source of } \\
\text { water. }\end{array}$} & \multirow{2}{*}{$\begin{array}{c}\text { Surface } \\
\text { formation. }\end{array}$} & \multicolumn{4}{|c|}{ Shallow wells. } \\
\hline & & & & Depth. & Supply. & $\begin{array}{c}\text { Quality of } \\
\text { water. }\end{array}$ & $\begin{array}{c}\text { Principal } \\
\text { water bed. }\end{array}$ \\
\hline Alliance.... & Plain........... & $\begin{array}{l}\text { Dug and driven } \\
\text { wells. }\end{array}$ & $\begin{array}{l}\text { P l e is to- } \\
\text { cene sand } \\
\text { and La- } \\
\text { fayette(?) }\end{array}$ & \begin{tabular}{|l} 
Feet. \\
$18-20$
\end{tabular} & Ample.. & Soft.... & $\begin{array}{c}\mathrm{M} \text { a r ia n n a } \\
\text { limestone. }\end{array}$ \\
\hline Bonifay .... & Hilly.... & .....do... & ..do........ & $7-45$ & ...do...... & Hard... & Do. \\
\hline $\begin{array}{c}\text { Ca mpbell- } \\
\text { ton. } \\
\text { Cottondale }\end{array}$ & Rolling.. & ...... do... & $\begin{array}{l}\text { P l e is to- } \\
\text { cene sand. }\end{array}$ & $20-60$ & Good.... & ...do....... & Do. \\
\hline Cypress..... & Gently roliing. & Dug and bored & 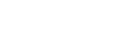 & $\begin{array}{l}40-50 \\
20-60\end{array}$ & Moderate & Soft........ & $\begin{array}{l}\text { Do. } \\
\text { Do. }\end{array}$ \\
\hline Graceville.. & Plain........... & Dug and drilled & ... do........ & $20-40$ & Good... & Hard... & Do. \\
\hline $\begin{array}{l}\text { Grand Rdg. } \\
\text { Greenwood }\end{array}$ & 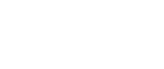 & Dug and one & ...do......... & $\begin{array}{l}20-40 \\
50-80\end{array}$ & Ample.. & $\begin{array}{l}\text { Soft.......... } \\
\text {...do....... }\end{array}$ & $\begin{array}{l}\text { Do. } \\
\text { Do. }\end{array}$ \\
\hline Marianna.. & Hilly.......... & $\begin{array}{l}\text { Dug and drilled } \\
\text { wells; public } \\
\text { supply. }\end{array}$ & $\begin{array}{l}\mathrm{Pl} \text { e is to- } \\
\text { cene and } \\
\mathrm{L} \text { a f a- }\end{array}$ & $35-60$ & Good.... & Hard..... & Do. \\
\hline Sneads..... & Gently rolling . & $\begin{array}{l}\text { Dug and drilled } \\
\text { wells. }\end{array}$ & $\begin{array}{l}\text { Ple is to- } \\
\text { cene. }\end{array}$ & $20-60$ & Ample. & $\begin{array}{l}\text { Some soft, } \\
\text { mo ostly } \\
\text { hard. }\end{array}$ & Do. \\
\hline
\end{tabular}


General water resources of Jackson County-Continued.

\begin{tabular}{|c|c|c|c|c|c|c|c|c|}
\hline \multirow{2}{*}{ Town. } & \multicolumn{4}{|c|}{ Deep wells. } & \multirow{2}{*}{$\begin{array}{c}\text { Average } \\
\text { thick- } \\
\text { ness of } \\
\text { sand. }\end{array}$} & \multirow{2}{*}{$\begin{array}{l}\text { Depth to } \\
\text { water. }\end{array}$} & \multirow{2}{*}{$\begin{array}{l}\text { Increase or de- } \\
\text { crease of supply. }\end{array}$} & \multirow{2}{*}{$\begin{array}{l}\text { Sewerage } \\
\text { system. }\end{array}$} \\
\hline & Depth. & Supply. & $\begin{array}{c}\text { Head } \\
\text { above } \\
\text { sea. }\end{array}$ & $\begin{array}{c}\text { Quality } \\
\text { of } \\
\text { water. }\end{array}$ & & & & \\
\hline \multirow{4}{*}{$\begin{array}{l}\text { Alliance.... } \\
\text { Bonifay.... } \\
\text { C a mpbell- } \\
\text { ton. } \\
\text { Cottondale. } \\
\text { Cypress.... }\end{array}$} & Feet. & & Feet. & & Feet. & Feet. & None... & \multirow{7}{*}{ 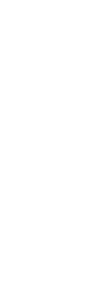 } \\
\hline & $398 \frac{1}{2}$ & Good.... & & Hard.... & $45+$ & $5-30$ & ... do....... & \\
\hline & $315^{-}$ & Large .... & & ...do...... & Thin. & $10+$ & Slight........... & \\
\hline & $\begin{array}{l}80-135 \\
60-300\end{array}$ & $\begin{array}{l}\ldots \text { do...... } \\
\ldots \text {...do..... }\end{array}$ & & ...do...... & $\underset{40 \pm}{\text { Thin. }}$ & $\begin{array}{l}8-20 \\
\text { Varies. }\end{array}$ & Varies with rain- & \\
\hline \multirow{3}{*}{$\begin{array}{l}\text { Graceville.. } \\
\text { Grand Rdg- } \\
\text { Greenwood } \\
\text { Marianna... } \\
\text { Sneads..... }\end{array}$} & $90-150^{262 \frac{1}{2}}$ & ...do..... & $6+$ & ...do...... & \multirow{3}{*}{$\begin{array}{c}\text { Thin. } \\
30+ \\
10-30 \\
20+ \\
50 \pm\end{array}$} & \multirow{3}{*}{$\begin{array}{r}10 \pm \\
30 \pm \\
50 \pm \\
20-30 \\
60+\end{array}$} & $\begin{array}{l}\text { Slight............ } \\
\text { Due to weather.. }\end{array}$ & \\
\hline & 386 & Large... & & Hard.... & & & slight.............. & \\
\hline & $100-200$ & ...do..... & & ...do..... & & & Due to weather. & \\
\hline
\end{tabular}

\section{JEFFERSON COUNTY.}

By G. C. Matson.

\section{GENERAL FEATURES.}

Jefferson County occupies a comparatively narrow area in northern Florida, extending from the Georgia line southward to the Gulf of Mexico. Its surface varies from a low plain rising only a few feet above sea level to rolling uplands with an altitude of over 200 feet, the southern end being a low sandy terrace 20 to 30 feet above tide. Farther inland there is a second terrace of 40 to 60 feet in altitude and a third with an altitude of 70 to 100 feet. The lower terrace in the southern part of the county contains many swamps, and the upper terraces, though in few places swampy, have some lakes. The largest-Lake Miccosukee-appears to occupy a depression in the limestone which underlies the second terrace; it drains southward to a sink hole communicating with an underground stream. St. Marks and Aucilla rivers receive a large part of the drainage of the county, though in the southern part some small streams flow directly to the Gulf.

\section{GEOLOGY.}

On the terraces the Pleistocene gray sands form the surface deposits, and in the northern part of the county the surface is formed by residual sands underlain by red and yellow sands and sandy clays referred to the Lafayette (?) formation. The sands and clays of the Alum Bluff formation may underlie the Lafayette (?) formation in some of the upland near the northern boundary of the county, but their presence is not easily determined. The entire county is underlain at no great depth by the Chattahoochee formation, but this formation is seldom seen except in the depressions where the over- 
lying formations have been removed by erosion. Beneath the Chattahoochee are the Vicksburgian limestones, but these rocks are too deeply buried to be exposed.

In the southern part of the county the gray sands of Pleistocene age may reach a maximum thickness of over 50 feet. The thickness of the Lafayette (?) formation averages less than 30 feet and the maximum probably does not exceed 50 feet. The Alum Bluff formation if present is comparatively thin, but the Chattahoochee formation may amount to over 100 feet. The Vicksburgian limestones are doubtless several hundred feet thick.

WATER SUPPLY.

Source.-Water in Jefferson County is chiefly obtained from the surficial sands, which furnish an abundant supply within a few feet of the surface and are extensively drawn upon throughout the county. Deeper supplies are obtained from the Chattahoochee formation and the Vicksburgian limestones. The quantity of water obtained from these formations is very large, but the head of that in the Vicksburgian limestones is not great enough to bring it to the surface on the upland near the northern edge of the county.

Quality.-The surficial sands usually furnish soft water. The water from the limestones of the Chattahoochee formation is moderately hard but is satisfactory. The Vicksburgian limestones also furnish hard water free from sulphur near the northern end of the county, though farther south sulphur water will probably be obtained in deep wells penetrating these limestones.

Development.-Shallow wells form the principal means of water supply throughout a large part of Jefferson County. They commonly range from 15 to 30 feet in depth, though a few are as much as 60 feet deep. The water is suitable for all domestic and industrial uses, and the water level is near enough to the surface to make pumping easy. Where such wells are used care should be taken to locate them far enough from buildings and other sources of pollution to avoid danger of contaminated surface water mingling with the supply of the well.

Only three deep wells are reported from Jefferson County, two of them located at Monticello and one at Lamont. The deepest well in the county, the 800 -foot well at Monticello, is used for a public water supply; it may be supplemented by a second well 400 feet in depth that is held in reserve in case the first well should not furnish enough water. These wells probably penetrate the Vicksburgian limestones; they furnish moderately hard water, but the supply is régarded as satisfactory for domestic and industrial purposes. The quantity is ample to meet all the needs of the town and the water 
system is good. The well at Lamont is only $132 \frac{1}{2}$ feet deep and probably obtains its supply from the Chattahoochee formation. The water is hard but is regarded as very satisfactory. At Monticello the head of the water from the Vicksburgian limestone is sufficient to bring it within about 150 feet of the surface. It is possible that flowing wells might be obtained in the extreme southern end of the county, where the surface is low, but it would be necessary to drill to a depth of 350 to 450 feet.

Jefferson County contains a number of small springs and some of considerable size. The most important are Walker Spring, 8 miles south of Lamont; Cassidy Spring, $1 \frac{1}{2}$ miles south of Wacissa; and Big Blue Spring, 2 miles south of Thomas City. The water from Walker Spring is used for drinking and is reported to be hard and to contain some sulphur. The other springs mentioned also supply hard sulphur water, but they are not used. 

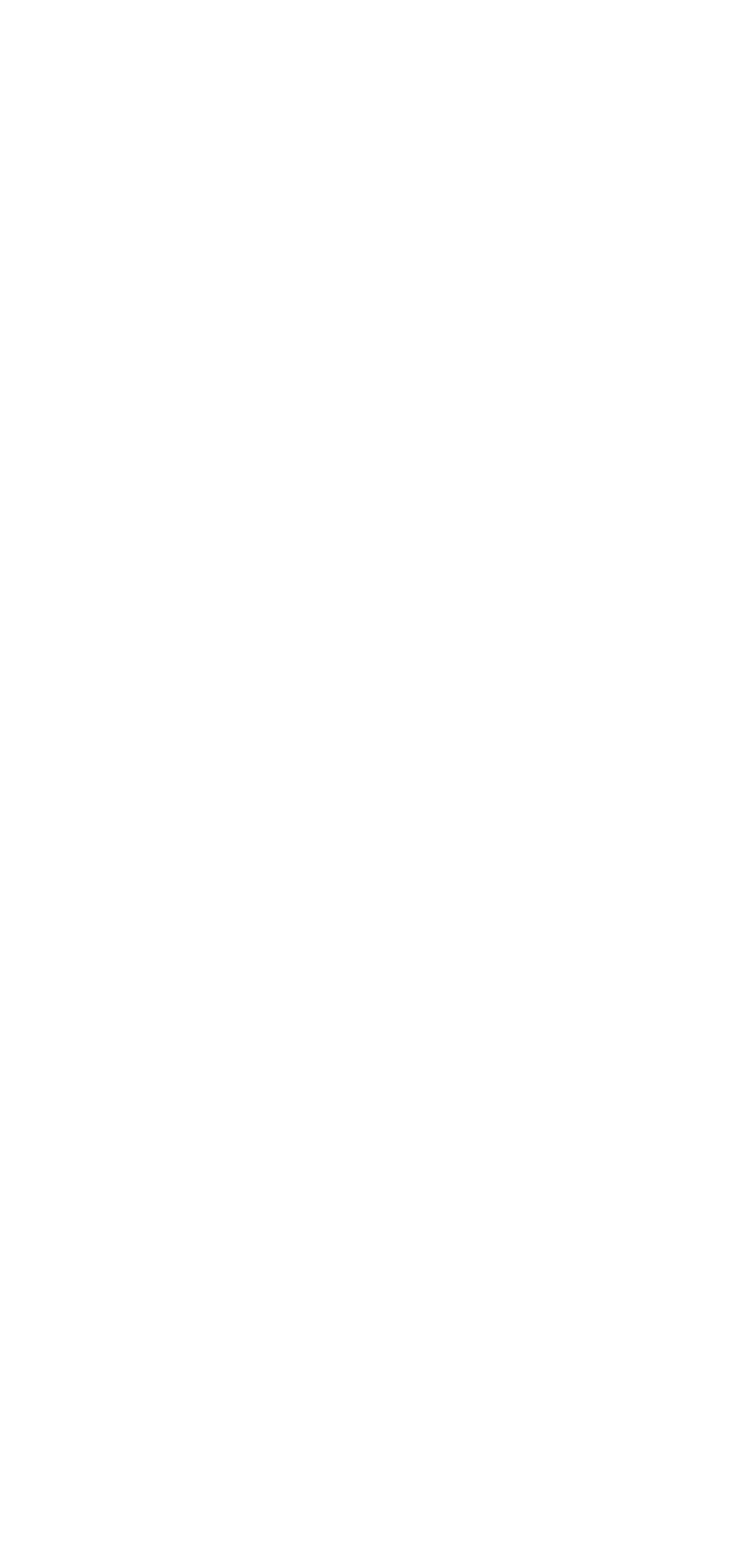
GEOLOGY AND GROUND -WATERS OF FLORIDA.

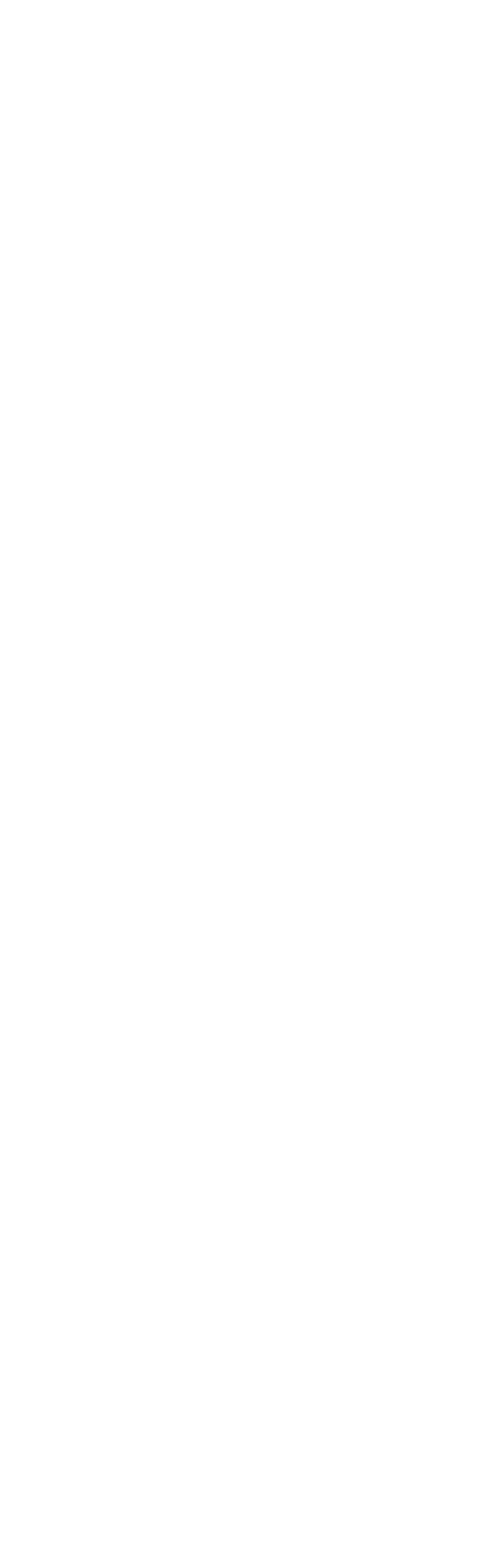




\section{LAFA YETTE COUNTY.}

By G. C. Matson.

GENERAL FEATURES.

Lafayette County borders the Gulf coast near the northern end of the peninsula, extending over 50 miles northward between Suwannee and Steinhatchee rivers. Its surface is made up of broad terraces, the lowest rising only a few feet above sea level, the altitude increasing gradually back from the coast. A second terrace begins several miles inland and extends for a long distance and is succeeded by a still higher terrace. More than one-half the surface lies between 50 and 100 feet above sea level and a considerable area is less than 25 feet. Swamps occupy a large area near the northern end of the county and extend southward and southeastward a distance of over 30 miles. Near the eastern border there are many lakes of moderate size.

GEOLOGY.

The Pleistocene terraces of Lafayette County are covered by gray sand underlain by older sands and marls. Beneath the surficial sands lie the sands and clays of the Alum Bluff formation and the limestones of the Hawthorn formation; near the southeastern corner of the county the Vicksburgian limestones are believed to be near the surface.

In the absence of satisfactory well samples, it has been practically impossible to obtain information concerning the thickness of the subsurface materials of Lafayette County. To judge from conditions in adjoining counties, the surficial sands may attain a thickness of more than 50 feet and the Alum Bluff and Hawthorn formations probably 200 feet. There is no question that the Vicksburgian limestones, which underlie the county, have a thickness of several hundred feet.

\section{WATER SUPPLY.}

Source.-The surface sands form an excellent source of water supply, in Lafayette County, and doubtless many of the wells obtain water from the Alum Bluff and the Hawthorn formations. The Vicksburgian limestones are the best water-bearing beds of the county, but as yet the water from them has not been extensively developed.

Quality.-The sands supply soft water. Hard water, which may contain sulphur in some localities, is to be expected from the Hawthorn formation. The Vicksburgian limestones will doubtless supply hard sulphur water and in some localities salt water.

Development.--Few of the shallow wells of Lafayette County exceed 30 feet in depth, and they obtain an abundance of soft water 
which is utilized for domestic and farm supplies. Near the northern end of the county several wells have been sunk to a depth of 50 to 90 feet and a few exceed 100 feet. These wells obtain large quantities of hard water, which rises within 20 to 40 feet of the surface. The water level in the shallow wells is sufficiently near the surface to permit it to be raised by means of suction pumps, but in the deep wells it is necessary to use some kind of a deep-well pump. Mayo is the only town in the county having a public water supply. The water is obtained from a flowing well 120 feet deep, and the supply is ample for the present needs of the town. A wooden tank has been built, from which distribution is made by gravity. 
LAFAYETTE COUNTY.

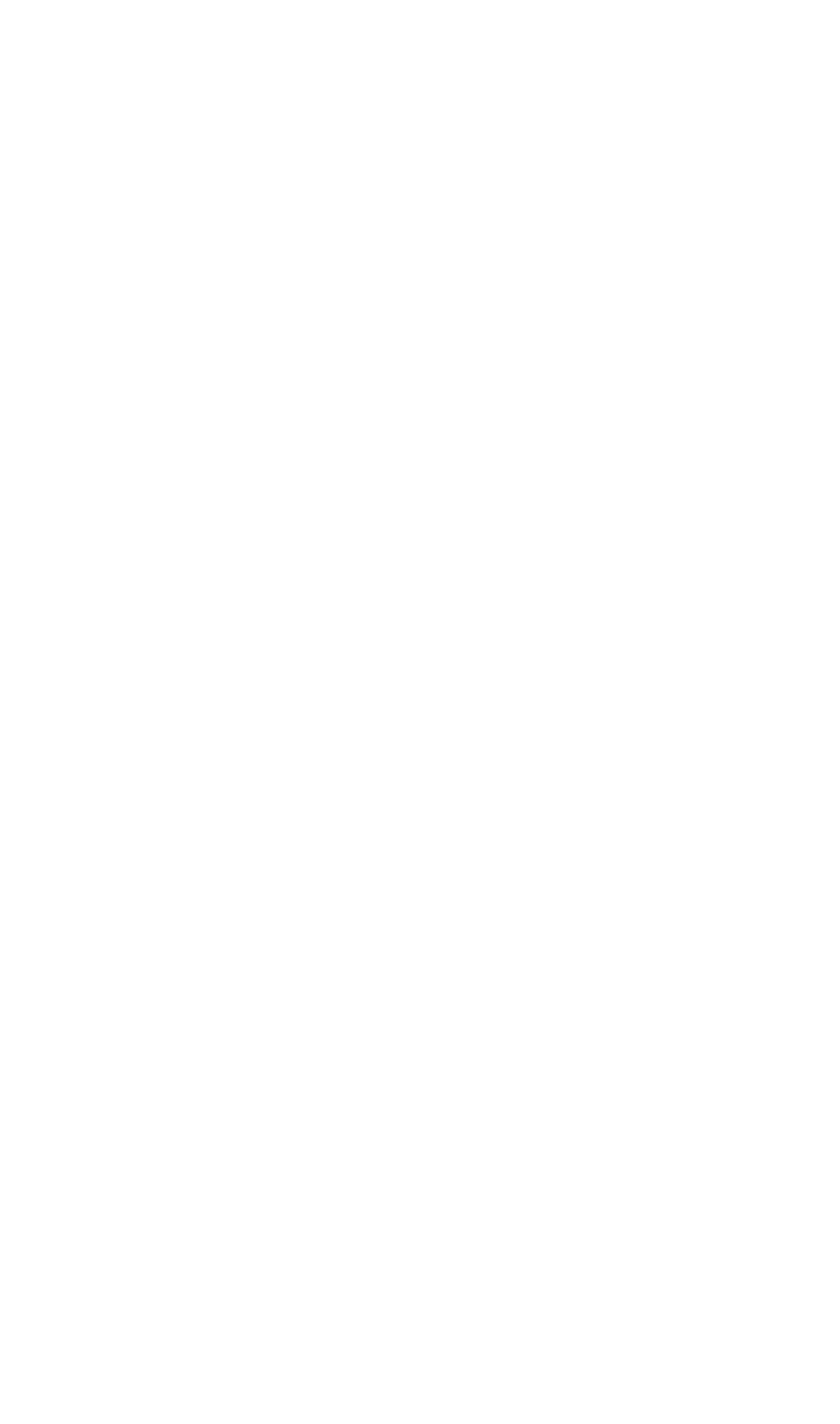




\section{LAKE COUNTY.}

By G. C. Matson.

\section{GENERAL FEATURES.}

Lake County, in the nor th-central portion of the peninsula, occupies a part of the lake region and extends eastward to St. Johns River. A narrow belt along St. Johns River lies 20 to 30 feet above the stream and forms a well-defined terrace separated from the higher land to the west by an abrupt scarp. Another terrace has an altitude of 40 to 60 feet, and a third, more poorly defined, rises to 70 to 100 feet. In the north-central and southeastern portions of the county the upland has an altitude of over 100 feet.

The surface of the county is dotted with lakes and, near the southwest corner, with extensive swamps. Many small lakes occupy sinks in the limestones, and some of the larger ones are in broad depressions which may be largely due to solution. Large streams are generally absent within the county, a condition apparently due to the existence of extensive underground drainage systems.

\section{GEOLOGY.}

The surface formation of Lake County is of gray sand, underlain by gray, yellow, brown, and pink sands, locally more or less clayey, which are the weathered products of the underlying rocks. Near St. Johns River Pleistocene sands rest on the shell marl of Pliocene age (Nashua marl). The exact distribution of the Nashua marl has not been determined, but the formation may extend some distance west of the river and may also underlie the swampy uplands at the extreme southern end of the county. The Miocene shell marl (Choctawhatchee marl) has not been found in Lake County, but that it probably underlies the areas covered by the Nashua marl is inferred from the fact that it occurs to the eastward in St. Johns Valley and to the southward at Kissimmee. The Alum Bluff formation is represented by sands and clays and fullers' earth resting on the Hawthorn formation. The Hawthorn formation consists of sands and locally of clays and impure limestones. The sands are remarkable for their beautiful coloring, ranging from gray through various shades of pink, buff, yellow, and brown; the colors are doubtless due to the action of the weather on the impurities of the original rock. Beneath the Hawthorn formation lie the porous gray to white Vicksburgian limestones. They consist of alternating beds of soft and hard rock with some layers of chert and some black grains, which are probably phosphate.

The thickness of the Pleistocene sands in few places exceeds 30 feet, and the Pliocene marls probably average less than 25 feet. The sands and clays of the Alum Bluff formation are over 100 feet 
thick, and the Hawthorn formation has a thickness of nearly 100 feet at some localities but is much thinner in the valleys where it has been partly removed by erosion. The Vicksburgian limestones are known to have a thickness of several hundred feet in the peninsula generally, but no direct information concerning their thickness could be obtained in Lake County because drilling there has always stopped as soon as porous water beds were encountered.

Some idea of the thickness and character of several of the formations in Lake County may be gathered from the well logs given below:

Partial log of the well of Charles G. Megargie, at Eustis.

Sand, coarse grained, brown........................ $3-30$

Sand, coarse grained, gray ......................... $80-90$

Limestone, soft, light gray........................... 146-154

Limestone, hard, light gray; with shell fragments characteristic of the Ocala limestone............................. 154-163

The well whose record follows is about 200. yards north of the C. G. Megargie well above.

Log of J. J. Harrison's well at Eustis.

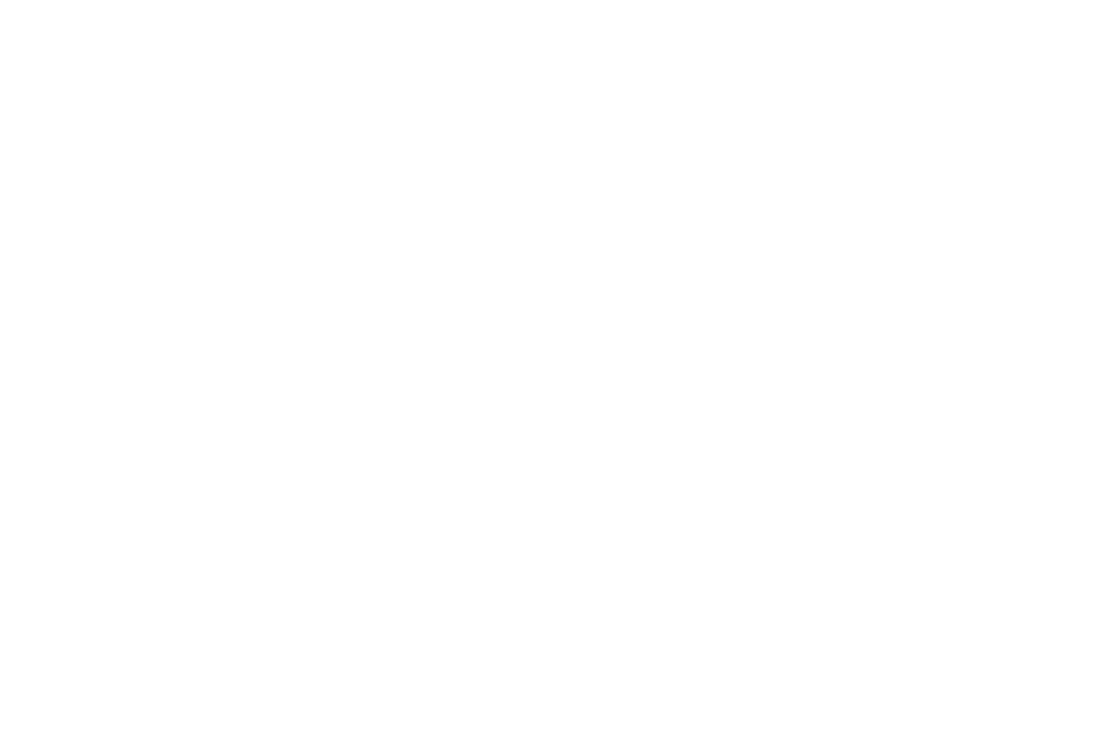

The first water was found at 45 feet and other supplies at intervals to 77 feet. It rose 15 feet above the point where it was first encountered. There was a slight additional supply between 89 and 90 feet, and another at 124 feet. The principal supply was reached at 174 feet and the water rose within 41 feet of the surface. All the water in this well is reported to be soft. The Vicksburgian limestones were probably encountered at a depth of about 131 feet. 
Log of Malone Sweet's well at Eustis.

\begin{tabular}{|c|c|c|}
\hline ' & Thickness. & Depth. \\
\hline Sand, dark. & Feet. & Feet. \\
\hline Sand, yellow.......... & $\frac{1}{2}$ & $\mathbf{3}$ \\
\hline 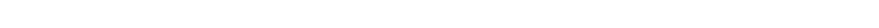 & 21 & 24 \\
\hline Sand, fine grained, yellow; containing pebbles..................... & 16 & 40 \\
\hline 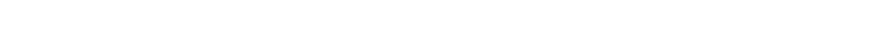 & 1 & 41 \\
\hline 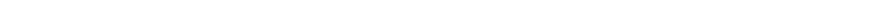 & $3 \frac{1}{2}$ & \\
\hline
\end{tabular}

Water was encountered between 32 and 40 and between 41 and $44 \frac{1}{2}$ feet. The first supply rose 10 feet in the well and the second $14 \frac{1}{2}$ feet. The yield is small.

Log of well of S. M. Weld at Mount Dora.

\begin{tabular}{|c|c|c|}
\hline & Thickness. & Depth. \\
\hline No samnles. & Feet. & Feet. \\
\hline Sand, medium grained, buff..... & & 10 \\
\hline 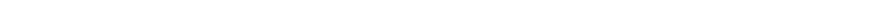 & 8 & 18 \\
\hline Sand, mixed fine and coarse grained, light buff. & & 22 \\
\hline Sand, fine grained, light brown................. & 10 & 32 \\
\hline Sand, fine grained, pink; a little clay ........ & 10 & 42 \\
\hline Sand, fine, yellow; a little clay ................ & 13 & 55 \\
\hline Sand, fine grained, buff .................. & 9 & 64 \\
\hline 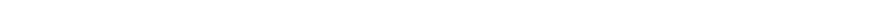 & $\mathbf{9}$ & 73 \\
\hline 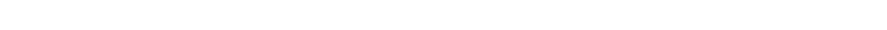 & 12 & 85 \\
\hline 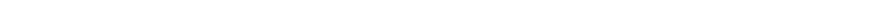 & 7 & 92 \\
\hline Sandstone, soft; contaming lime and clay $(\operatorname{marl}) \ldots \ldots \ldots \ldots \ldots \ldots$ & & 97 \\
\hline Marl, drab, sandy & 10 & 107 \\
\hline 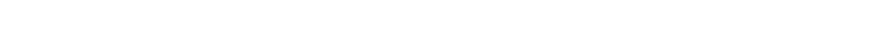 & 18 & 125 \\
\hline Sandstone, light brown to gray; containing lime. $\ldots \ldots \ldots \ldots \ldots \ldots$ & 18 & 143 \\
\hline 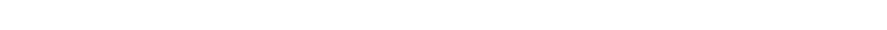 & 37 & 180 \\
\hline Limestone, gray; fragments of shells. . & & 181 \\
\hline
\end{tabular}

The Vicksburgian limestones probably lie between 107 and 125 feet.

Log of well of Mr. Blake at Grand Island.

\begin{tabular}{|c|c|c|}
\hline & Thickness. & Depth. \\
\hline No record.... & Feet. ${ }_{18}$ & Feet. \\
\hline 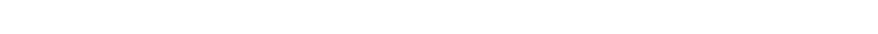 & 17 & $\begin{array}{l}35 \\
43\end{array}$ \\
\hline Sand, very fine, pink................. & 8 & 43 \\
\hline Sand, very fine, pale pink. ............. & 17 & 70 \\
\hline 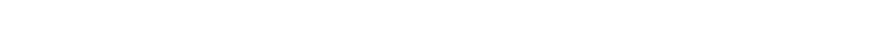 & 5 & 75 \\
\hline 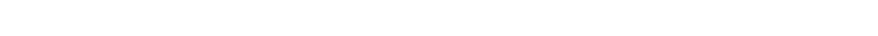 & $\begin{array}{r}11 \\
3\end{array}$ & $\begin{array}{l}96 \\
99\end{array}$ \\
\hline & & \\
\hline
\end{tabular}


Log of well of the Florida Fertilizer Co. at Grand Island.

[From samples in possession of the U. S. Geological Survey.]

\begin{tabular}{|c|c|c|}
\hline & Thickness. & Depth. \\
\hline & Feet. & Feet. \\
\hline 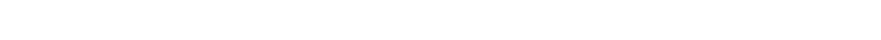 & $\begin{array}{r}4 \\
15\end{array}$ & 19 \\
\hline 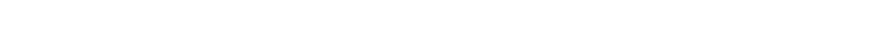 & 12 & 31 \\
\hline 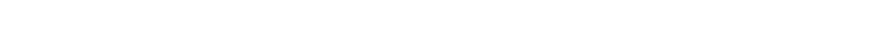 & 39 & 70 \\
\hline Sand, fine, pink. & 14 & 84 \\
\hline $\begin{array}{l}\text { Sand, medium, pink } \\
\text { Sand, coarse, reddish brown }\end{array}$ & 8 & 92 \\
\hline 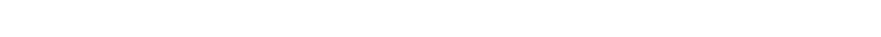 & 10 & 103 \\
\hline 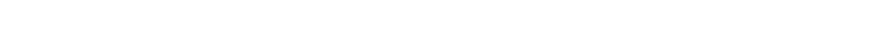 & 13 & 116 \\
\hline 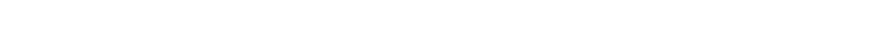 & $\begin{array}{l}7 \\
4\end{array}$ & 123 \\
\hline 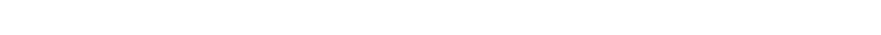 & $\begin{array}{l}\mathbf{4} \\
\mathbf{3}\end{array}$ & 130 \\
\hline 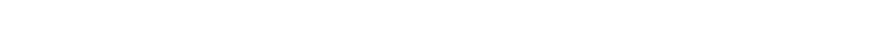 & 8 & 138 \\
\hline 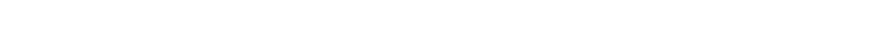 & 5 & 143 \\
\hline 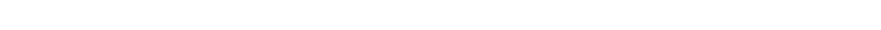 & 11 & 164 \\
\hline 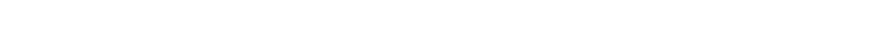 & 6 & 170 \\
\hline 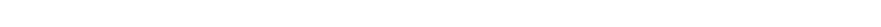 & 13 & 183 \\
\hline 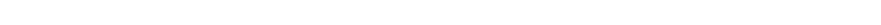 & & \\
\hline
\end{tabular}

Water was reported at 100 feet, and the principal supply was encountered at 183 feet.

WATER SUPPLY.

Source.-Neither the Pleistocene gray sands nor the Pliocene shell marls are important water-bearing formations, though they may furnish some water for shallow wells. The Alum Bluff and Hawthorn formations furnish considerable water at moderate depths, but the principal source of supply is the Vicksburgian limestones. These rocks underlie the entire county and are generally reached by wells at moderate depths.

Quality.-The shallow wells of Lake County obtain soft water, but the deep wells, especially those entering the Vicksburgian limestones, get only hard. Some of the water from the Vicksburgian limestones contains hydrogen sulphide. The water from the large springs is moderately hard.

Development.-In Lake County good supplies of soft water are obtained by wells ranging in depth from 10 to 50 feet, the common depth being less than 30 feet. The Hawthorn formation supplies some water within 100 feet of the surface, but most wells are sunk to a somewhat greater depth. Many of them enter the Vicksburgian limestones, where they obtain large supplies of hard water, much of which contains more or less sulphur.

Deep wells encounter large supplies of hard water between 75 and 300 feet. Sulphur occurs in the water of many of the deeper wells, and some of them obtain two or more supplies of different mineral characters; the shallow supplies may be soft and the deeper waters hard or sulphur bearing. Such wells yield water which is a composite of all the supplies encountered, unless casings are inserted to exclude some of them. 
Flowing wells may be obtained on the low terrace which borders St. Johns River, and should flow freely to a height of at least 20 feet above the river. The amount of water supplied by these wells will vary with local conditions but should usually be large. The quality of the supply is indicated by the well at Astor, which yields hard sulphur water. Flows occur sporadically in the lake region, but they depend on local conditions and there is no possibility of telling where they may be obtained.

Leesburg has the only public water supply in Lake County. The. system is owned by a private company and is well equipped. The water, which is taken from three wells, 98, 100, and 101 feet deep, is hard but is reported to be satisfactory and ample in quantity.

Springs are numerous in Lake County, but none of them are extensively used. Two of the most important are the Big Spring near Okahumpka and the Seminole Spring near Sorrento. Both yield hard sulphur water and flow good-sized streams. The estimated flow of the Big Spring is 15,000 gallons per minute, and that of the Seminole Spring is 25,000 gallons. These springs might serve as centers for resorts if hotels and bathhouses were constructed near them. 
Typical wells of Lake County.

\begin{tabular}{|c|c|c|c|c|c|c|c|c|c|c|c|c|c|c|c|c|c|}
\hline \multirow[b]{2}{*}{$\begin{array}{l}\text { Nearest town or } \\
\text { post office. }\end{array}$} & \multirow[b]{2}{*}{$\begin{array}{l}\text { Direction and } \\
\text { distance. }\end{array}$} & \multirow[b]{2}{*}{ Owner. } & \multirow[b]{2}{*}{ Driller. } & \multirow[b]{2}{*}{$\begin{array}{l}\text { Date } \\
\text { sunk. }\end{array}$} & \multirow[b]{2}{*}{$\begin{array}{c}\text { Type of } \\
\text { well. }\end{array}$} & \multirow[b]{2}{*}{ Use. } & \multirow[b]{2}{*}{ Depth. } & \multirow[b]{2}{*}{\begin{tabular}{|c|} 
Diam- \\
eter.
\end{tabular}} & \multirow[b]{2}{*}{ Casing. } & \multirow[b]{2}{*}{ 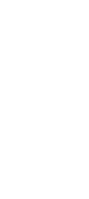 } & \multicolumn{2}{|c|}{ Head- } & \multirow[b]{2}{*}{$\begin{array}{c}\text { Depth } \\
\text { to } \\
\text { rock. }\end{array}$} & \multirow{2}{*}{$\begin{array}{c}\text { Depth } \\
\text { to } \\
\text { princi- } \\
\text { pal } \\
\text { supply. }\end{array}$} & \multirow[b]{2}{*}{$\begin{array}{c}\text { Pro- } \\
\text { tectimg } \\
\text { class } \\
\text { present. }\end{array}$} & \multirow[b]{2}{*}{ Quality of water. } & \multirow[b]{2}{*}{ Remarks. } \\
\hline & & & & & & & & & & & $\begin{array}{c}\text { Above } \\
\text { sea. }\end{array}$ & $\begin{array}{c}\text { Above } \\
\text { or } \\
\text { burfow } \\
\text { surface. }\end{array}$ & & & & & \\
\hline $\begin{array}{l}\text { Astor ...... } \\
\text { Astor Park.. } \\
\text { Entsis }\end{array}$ & 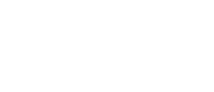 & 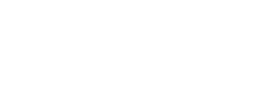 & $\begin{array}{l}\text { S. H. Hoagland. } \\
\text {....do................ }\end{array}$ & $\begin{array}{l}1905 \\
1905\end{array}$ & $\begin{array}{l}\text { Drilled.. } \\
\cdots \text { do...... }\end{array}$ & $\begin{array}{l}\text { Hotel.................. } \\
\text { Abbandoned.... } \\
\text { Hotel }\end{array}$ & $\begin{array}{r}\text { Feet. } \\
82 \\
185 \\
74\end{array}$ & $\begin{array}{r}\text { Inches. } \\
3 \\
2 \\
2\end{array}$ & $\begin{array}{r}\text { Feet. } \\
75 \\
125\end{array}$ & $\begin{array}{r}\text { Feet. } \\
15\end{array}$ & $\begin{array}{l}\text { Feet. } \\
29\end{array}$ & $\begin{array}{r}\text { Feet. } \\
+14 \\
\pm \\
\pm 3\end{array}$ & Feet. & Feel. & & $\begin{array}{l}\text { Hard, sulphur . } \\
\text {.... do ............. }\end{array}$ & Second supoly at 54 \\
\hline & & Dibble \& Earnest $a \ldots$ & Owners. & 1907 & ..do.. & Domestic........... & 173 & $5 \mathbf{5}$ & 134 & & & -62 & & 170 & Yes. & & feet. \\
\hline $\begin{array}{l}\text { Fruitland iark. } \\
\text { Grand lsland ...... }\end{array}$ & tuile southwosit. & 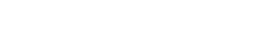 & Dïbïbie a karnest. & 1906 & irilied:. & 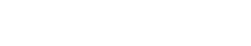 & $\begin{array}{l}134 \\
186 \\
\end{array}$ & $\begin{array}{l}3 \\
3 \\
58\end{array}$ & i ï & 200 & & -30 & & $\begin{array}{l}124 \\
186\end{array}$ & & Sulpur... & \\
\hline Ladylase. & 1 mile east.............. & Susan W. Teague...... & D. & 我 & . & Domestic........................... & 176 & 等 & & & $\cdots$. & $-40^{\circ}$ & & 40 & & Sulphur.... & \\
\hline $\begin{array}{l}\text { Loesburg.. } \\
\text { Do.... }\end{array}$ & $\begin{array}{l}\text { 2 miles west.... } \\
\text { 2i.......... }\end{array}$ & 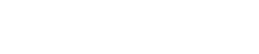 & John Heaton... & $\begin{array}{l}1887 \\
1906\end{array}$ & 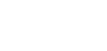 & 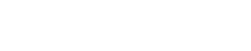 & 175 & 4 & \%4 & & & $\begin{array}{l}-18 \\
-16\end{array} \mid$ & & 175 & Yes.. & Hardo.... & Second supply at 125 \\
\hline Do... & $\frac{1}{8}$ mile south... & Leesburg Ice Co... & ......do....... & & ..do.. & I c e manulacturing, & 93 & 4 & 95 & 87 & 67 & -20 & & 95 & Yes.. & $\ldots$.......... & \\
\hline 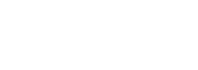 & milo northwest.: & $\begin{array}{l}\text { M. Mo Held: } \\
\text { S. M. Borton: }\end{array}$ & $\begin{array}{l}\text { A.s. Hardman } \\
\text { Dibbile \& Earnest............. } \\
\text { Manuel. }\end{array}$ & $\begin{array}{l}1892 \\
1905 \\
1901\end{array}$ & $\begin{array}{l}\text {..do....... } \\
\cdots \text { do........ }\end{array}$ & 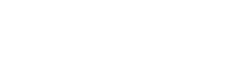 & $\begin{array}{c}101 \\
180 \\
110\end{array}$ & $\begin{array}{ll}2 \frac{2}{2} \\
6^{2}\end{array}$ & $\begin{array}{r}95 \\
114 \\
110\end{array}$ & \begin{tabular}{c}
87 \\
\hdashline 9. \\
99
\end{tabular} & $\begin{aligned} 67 \\
\cdots \\
\cdots \\
72\end{aligned}$ & $\begin{array}{l}-20 \\
-60 \\
-27\end{array}$ & $\because 85$ & $\begin{array}{cc}1180 \\
110\end{array}$ & $\begin{array}{l}\text { Yes... } \\
\text { Y̌es... }\end{array}$ & $\begin{array}{l}\text {...do..... } \\
\cdots \text { do..... }\end{array}$ & \\
\hline & 3 miles... & & Harold Simson..... & & & Domestic and stock... & & & & & & & & & & & $\begin{array}{l}\text { Starts in Pleistocene. } \\
\text { Water from Vicks- } \\
\text { burgian limestones }\end{array}$ \\
\hline $\begin{array}{l}\text { Sorrento } \\
\text { St. Franeis........................... }\end{array}$ & 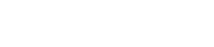 & 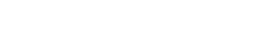 & Owner.... & $\begin{aligned} 1907 \\
\ldots 10 .\end{aligned}$ & (...do.... & $\begin{array}{l}\text { Housshold.... } \\
\text { Drinking.... }\end{array}$ & $\begin{array}{l}103 \\
115\end{array}$ & $\frac{2}{3}$ & 67 & & & $\begin{array}{r}-70 \\
+3\end{array}$ & iij & iiï & Yes.. & $\begin{array}{l}\text { Hard .... } \\
\text { Sulphur. }\end{array}$ & \\
\hline $\begin{array}{l}\text { Tavares.................. } \\
\text { Whitney......... }\end{array}$ & 率 mine east........... & $\begin{array}{l}\text { Osceola Hotel... } \\
\text { J. Bphinx...... }\end{array}$ & S. Heaton............................. & $\begin{array}{l}1890^{\circ} \\
1906\end{array}$ & $\begin{array}{l}\text { Drilied: } \\
\ldots \text { do ..... }\end{array}$ & $\begin{array}{l}\text { Hotel........... } \\
\text { Brick piant.. }\end{array}$ & 243 & $\frac{2}{3}$ & ${ }_{240}^{124}$ & 66 & & $-\mathrm{ii}$ & & 年4 & Tyas... & $\begin{array}{l}\text { Soff................ } \\
\text { Hard.......... }\end{array}$ & \\
\hline
\end{tabular}

76854 - WsP 319-13. (To face page 342.)

a. Water-Supply Paper U. s. Geol. Survey No. 102, p. 246. 

LAKE COUNTY.

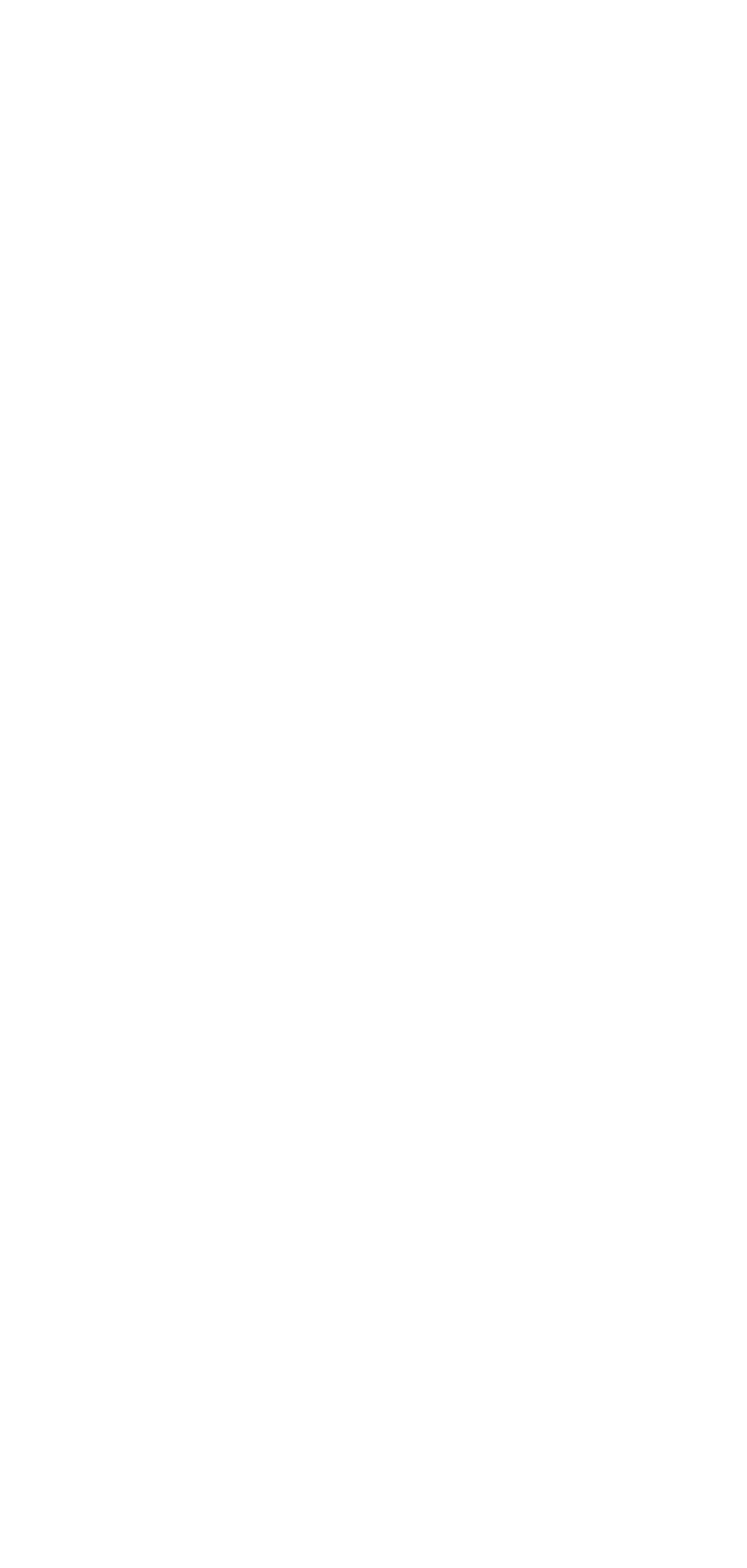




\section{LEE COUNTY.}

By Samuel Sanford.

GENERAL FEATURES.

Much the greater part of Lee County lies in a region of pine islands, cypress strands, and open prairies, and is sparsely inhabited. Only a small portion of it is within the Everglades, but the total extent of cypress swamp is very large, both the Okaloocoochee Slough and the Big Cypress lying within the county. Mangrove swamps fringe the coast from Chokoloskee to Gordon Pass. To the north is a coastal belt of sandy pineland that widens rapidly north of Estero, and is over 40 miles wide along the north line of the county. In San Carlos Bay and about Pine Sound and Charlotte Harbor are many islands, some sandy and comprising little swamps flooded at high tides. The settlements, of which the city of Fort Myers is the most important, are situated almost wholly along the coast or along Caloosahatchee River. The average elevation of the surface is low, less than 20 feet; elevations over 50 feet are limited to dunes. Several short rivers emptying into passages back of the Ten Thousand Islands head in the prairies or cypress swamps; Caloosahatchee River, which rises in Lake Hicpochee and empties into San Carlos Bay, traverses the north side of the county.

\section{GEOLOGY.}

Except for the outcrops of Pliocene beds along Caloosahatchee River, the known surface formations of Lee County are of Recent or Pleistocene age, comprising peat, sands, marls, and limestone. The Lostmans River limestone, here and there grading into sand or marl, underlies much of the region between the coast and the Everglades. Nothing is known of the southward extent of the Pliocene beds (Caloosahatchee marl) in the county. The thickness of the Miocene sands and marls can not be determined from the evidence available, nor have samples enough been saved from deep borings to permit definite statements regarding the thickness of the Apalachicola group or the depth to the Vicksburgian limestone. The anticlinal structure shown to the north extends across the county, the axis of the fold being near the coast. The eastward slope of the top of the Vicksburgian limestone is apparently about 5 to $\dot{8}$ feet to the mile. There has been a little late folding - as shown by the gentle flexures of the Pliocene and Pleistocene outcrops on Caloosahatchee River (p. 136).

\section{WATER SUPPLY.}

Source and quality.-Shallow wells find water in the Pliocene sandy marls outcropping on Caloosahatchee River, in the Pleistocene limestones, sands, and sandy marls, and in the sands of the coastal islands 
some of which may be classified as Recent. The water varies in character but in general is hard. As it lies near the surface it is cheaply developed.

The Miocene marls and sands and the upper Oligocene marls and limestones yield flows in places, notably about Fort Myers and the mouth of Caloosahatchee River. The flows are not so copious as those from the Vicksburgian limestone, but the waters liave much the same cliaracter, being hard and sulphur bearing. The chlorine content is highest in wells on coastal islands. In the eastern part of the county the Miocene and upper Oligocene formations are of less importance as water bearers; wells in the cattle ranges west of the Everglades did not get flows from them.

The clief source of flowing water in the county is the Vicksburgian limestone, which at the north side of the county lies 300 feet below the surface along the extension of the anticlinal fold of west-central Florida, but which dips to the east and to the west and may be 1,000 feet below the surface in the southeast corner of the county. Depths to flows differ greatly within short distances, owing to the erratic distribution of water-bearing porous beds or open crevices. (See p. 248.) These flows are often copious, averaging over 100 gallons per minute from a 3-inch well at ground level, and the heads are fairly ligh, averaging fully 25 feet above tide. The waters vary somewhat in mineral content, but all are hard and sulpliur bearing. A few wells, particularly those on coastal islands, yield water too salt for domestic use, and many wells show an increase in chlorine content with deptl.

Springs from the Pleistocene sands and limestones are found in places but are small and of no special interest or economic importance.

Development.-Shallow dug or driven wells are the chief sources of domestic supply. Few of them are over 25 feet deep and the average depth is 5 to 20 feet. The driven wells, as throughout soutlern Florida, are mostly equipped with pitclier pumps and cost but little to complete.

Most of the deep drilled wells are 3 inches in diameter. Their cost differs because of differences in the character of the beds penetrated. A driller may sink over 300 feet in a week and then spend an equal length of time in penetrating a flinty stratum a few feet thick. Most wells are cased to the Vicksburgian limestones, where the water is obtained from these; and to the water bed if drawing on Miocene or upper Oligocene sands and marls.

Deptlis vary greatly owing to the erratic distribution of waterbearing crevices or porous layers, and the anticlinal structure. Flows from the Vicksburgian limestone have been obtained at from 300 to over 900 feet. The total number of deep. wells in the county is 
unknown. They have been drilled from Marco to the north line of the county, and from islands outside of Charlotte Harbor to the prairies west of the Everglades, but nearly all are along Caloosahatchee River or near its mouth. (See Pl. XVII, $A$, p. 234.) Details of some are given in the table.

The only attempts at deep drilling reported from the southern part of the county are at Marco and Everglade. The Everglade well showed the following section:

Record of well of G. W. Storter, at Everglade.

Marl, light gray.

Limestone, soft, b̈lue

Sand, fine, white or bluish, siliceous

\begin{tabular}{|r|r}
\hline Thickness. & Depth. \\
\hline Feet. & Feet. \\
8 & 8 \\
32 & 40 \\
40 & 80 \\
\hline
\end{tabular}

The sand is full of salt water. The well is situated in a small area of arable land on an island of marl about 2 feet above high tide. A hand rig was used, and drilling was abandoned because of the troublesome character of the sand, which flowed freely yet packed firmly in the casing.

The following record of the well at Marco was given from memory by the driller, H. Seniff:

Record of well of W. D. Collier, at Marco.

\begin{tabular}{|c|c|c|}
\hline & Thickness. & Depth. \\
\hline 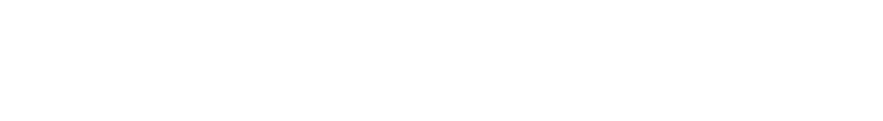 & $\begin{array}{r}\text { Feet. } \\
15 \\
300 \\
15 \\
105\end{array}$ & $\begin{array}{r}\text { Feet. } \\
15 \\
315 \\
330 \\
435\end{array}$ \\
\hline
\end{tabular}

Statements regarding the depth reached by this well differ, but it evidently reached a porous limestone overlain by marl and sand. The driller abandoned work after striking the salt water at the bottom and breaking a drill rod. The owner subsequently ran a 2 -inch pipe down to the main flow and utilized it for a bathroom supply at his residence. The strong flow is decidedly salt, as is shown by the field assay on page 260. A well on the slope of the sand dune at Caximbas obtains good water at 15 feet.

The next deep wells reported along the coast to the north are at Estero. The record of one well, given from memory by the driller, is as follows:

Record of well of Koreshan Unity, at Estero.

\begin{tabular}{|r|r} 
Thickness. & Depth. \\
\hline Feet. & Feet. \\
18 & 18 \\
15 & 33 \\
100 & 133 \\
152 & 285
\end{tabular}


The water is hard and sulphur-bearing but not salt and is used for various purposes.

A number of wells have been drilled about San Carlos Bay, off the mouth of Caloosahatchee River. Details of most of these are given in the table. There are two wells at Punta Rasa. The following record of one of them was given by the driller, $\mathrm{H}$. Seniff:

Record of well of $H$. W. Towles, at Punta Rasa.

Shells

Sand, white.

Limestone, white, water

\begin{tabular}{|r|r} 
Thickness. & Depth. \\
\hline Feet. & Feet. \\
9 & 9 \\
110 & 119 \\
113 & 232 \\
\hline
\end{tabular}

This well is used for watering stock. The water is hard, sulphurbearing, and brackish. The results of a field assay of a sample are given in the table on page 260 , as are the results of an assay of a sample from the 140-foot well at the hotel near by.

The driller, James Sykes, gave the following record of a well on a key near Punta Rasa:

Record of well at Fish Factory Key, near Punta Rasa.

\begin{tabular}{|c|c|c|}
\hline & Thickness. & Depth. \\
\hline Sand. & Feet. ${ }_{106}$ & Feet. \\
\hline Rock, blue, and sand ........................ & $\begin{array}{r}5 \\
167\end{array}$ & 111 \\
\hline Rock, hard, dark, water in a cavity.... & & 280 \\
\hline
\end{tabular}

There are two deep wells on Sanibel Island. One, near the center of the eastern part of the island, is owned by E. R. Bailey and is 420 feet deep. It is cased for 250 or 300 feet. The flow of 5 gallons a minute at 5 feet below sea level is strongly saline and is not utilized. A small flow of fresh water was reported at about 200 feet. No record was kept of the strata penetrated but, according to the owner, the material washed up was chiefly sand. Shallow wells on Sanibel Island get good water at 10 feet.

The other well, near the west end of the island, was not completed early in June, 1908, though several flows had been found, as the owners, who had sunk the well for irrigating supplies, wanted more water than had been obtained. The driller, D. Towles, gave the following record:

Record of well of Hope \& Heller, at Sanibel Island.

\begin{tabular}{|r|r} 
Thickness. & Depth. \\
\hline Feet. & Feet. \\
120 & 120 \\
75 & 195 \\
149 & 344 \\
246 & 590 \\
&
\end{tabular}


Small flows of water were found at 180 and 250 feet. At 344 feet the total flow from the 4-inch pipe at an elevation of 5 feet above mean high tide, was 20 gallons per minute. At 480 feet the total flow was 60 gallons. The character of the water is shown by the field assay in the table (p. 260).

The 605-foot well on Buck Key, one-half mile east of Captiva, was sunk to irrigate an orange grove. The record compiled from the driller's statement and from samples was given in the discussion of the geology of southern Florida (p. 173). A slight flow was struck at 260 feet and a stronger one at 300 feet. The water, as shown by field assay (p. 260), is the least saline of any sampled from wells on coastal islands in Lee County.

The following record of a well in the extreme northwest corner of the county, on Josephi Island, near the mouth of Charlotte Harbor, was given by James Sykes, the driller.

Record of well on Josephi Island.

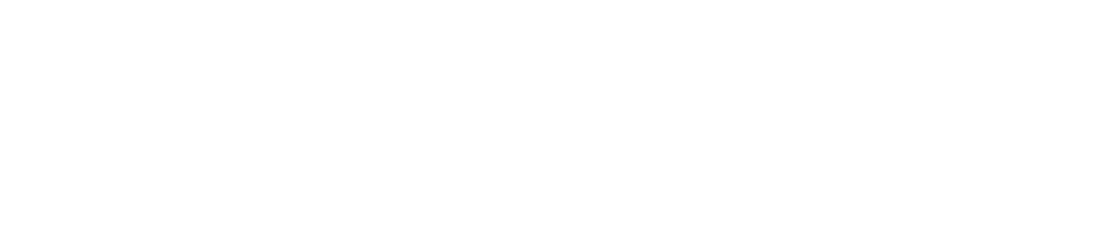

Of the many wells drilled in Fort Myers only a small number are listed in the table. Drillers' statements regarding formations penetrated do not harmonize, but this is to be expected, as written records have not been kept. Clapp compiled the following generalized section from data furnished him:

Generalized section at Fort Myers.

\begin{tabular}{|c|c|c|}
\hline & Fee & et. \\
\hline$n$ & & 40 \\
\hline 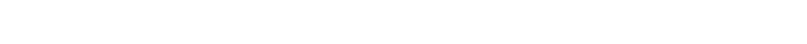 & & 50 \\
\hline Sand rock, soft, white to brown $\ldots \ldots \ldots \ldots \ldots \ldots \ldots$ & 2 & -10 \\
\hline Quicksand..................... & & 30 \\
\hline Shell rock. . . . . . . . . . . . . . & 40 & -80 \\
\hline Marl, blue, plastic $\ldots \ldots \ldots \ldots \ldots \ldots \ldots \ldots$ & & 60 \\
\hline 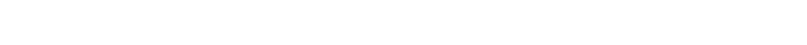 & 40 & -100 \\
\hline 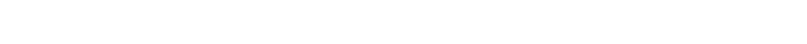 & 18 & -27 \\
\hline 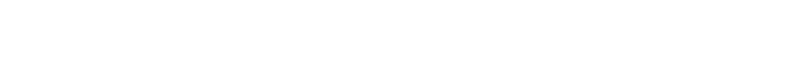 & 200 & -300 \\
\hline 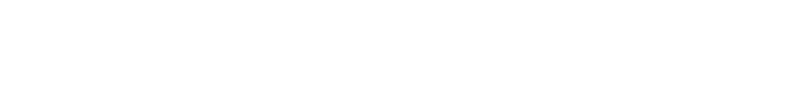 & & $\begin{array}{l}-4 \\
-\quad 2 \\
-\quad 3\end{array}$ \\
\hline
\end{tabular}


Typical wells of Lee County

\begin{tabular}{|c|c|c|c|c|c|c|c|c|c|c|c|c|c|c|c|c|c|c|c|}
\hline \multirow[b]{2}{*}{$\begin{array}{l}\text { Nearest town or } \\
\text { post office. }\end{array}$} & \multirow[b]{2}{*}{$\begin{array}{l}\text { Direction and } \\
\text { distance. }\end{array}$} & \multirow[b]{2}{*}{ Owner. } & \multirow[b]{2}{*}{ Driller. } & \multirow[b]{2}{*}{$\begin{array}{l}\text { Date } \\
\text { sunk. }\end{array}$} & \multirow[b]{2}{*}{$\begin{array}{c}\text { Surface } \\
\text { formation. }\end{array}$} & \multirow[b]{2}{*}{$\begin{array}{l}\text { Geologic } \\
\text { source. }\end{array}$} & \multirow{2}{*}{$\begin{array}{l}\text { Type of } \\
\text { well. }\end{array}$} & \multirow[b]{2}{*}{ Use. } & \multirow[b]{2}{*}{ Depth. } & \multirow[b]{2}{*}{$\begin{array}{c}\operatorname{Diame}_{\text {ter. }} \\
\text { ten }\end{array}$} & \multirow{2}{*}{ Casing. } & \multirow{2}{*}{$\begin{array}{c}\text { Eleva- } \\
\text { tion } \\
\text { above } \\
\text { sea. }\end{array}$} & \multicolumn{2}{|c|}{ Head- } & \multirow{2}{*}{$\begin{array}{l}\text { Depth } \\
\text { to } \\
\text { rock. }\end{array}$} & \multirow{2}{*}{$\begin{array}{c}\text { Depth } \\
\text { to } \\
\text { prini- } \\
\text { pal } \\
\text { supply. }\end{array}$} & \multirow[b]{2}{*}{ Quality of water. } & \multirow[b]{2}{*}{$\begin{array}{l}\text { Yield per } \\
\text { minute. }\end{array}$} & \multirow[b]{2}{*}{ Remarks. } \\
\hline & & & & & & & & & & & & & $\begin{array}{l}\text { A bove } \\
\text { sea. }\end{array}$ & \begin{tabular}{|l} 
Above \\
surface.
\end{tabular} & & & & & \\
\hline & & Capt. Hall... & Owner........ & & Pleistocene... & Pleistocene.... & & & $\begin{array}{l}\text { Feet. } \\
80 \pm\end{array}$ & \begin{tabular}{|l|} 
Inches. \\
........
\end{tabular} & \begin{tabular}{|l|} 
Feet. \\
\end{tabular} & Feet. & Feet. & $\begin{array}{l}\text { Feet. } \\
++\end{array}$ & Feet. & Feet. & & Gallons. & \\
\hline Buckingham.: & (i inile............ & W. L. Harris. & Wm. Towles. & 1907 & .....do............ & $\begin{array}{l}\text { Vic ksburgian } \\
\text { limestone. }\end{array}$ & & Irrigation.: & & 4 & & & & & & & & & \\
\hline $\begin{array}{l}\text { Do.......... } \\
\text { tero......... }\end{array}$ & is mile south... & F. J. Wilson $a \ldots$ & & & & & & & ${ }_{007}^{407}-10-30$ & 3 & & 16 & & +0 & & 407 & Hard............. & 200 & \\
\hline & & Koreshan Unity.: & owner.......................... & 1905 & Pleistocene... & …….... & Drilied... & Domestic and stock... & $\begin{array}{l}190 \\
193 \\
330\end{array}$ & $\begin{array}{l}3 \\
3 \\
4\end{array}$ & 75 & 610 & +22 & & ......... & 193 & sulpur.................... & Many. & \\
\hline $\begin{array}{l}\text { Do........ } \\
\text { Do Myers. }\end{array}$ & Finilessouthwest... & $\ldots$ & ….do........................ & $\begin{array}{l}1903 \\
1903 \\
1\end{array}$ & ….do............. & & …do....... & 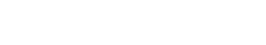 & 然30 & 年 & 85 & $\begin{array}{l}010 \\
b 15\end{array}$ & $\begin{array}{l}+28 \\
+25\end{array}$ & & $\dddot{0}$ & $\begin{array}{l}2900 \\
200 \\
440\end{array}$ & 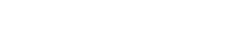 & Many: & Socond ounle at 400+ foet \\
\hline Do.................. & t miles east............. & $\begin{array}{l}\text { Col. Casseweil. } \\
\text { Cost. Con a }\end{array}$ & LeeCounty Weil Drill- & i9007 & Pleistocene.. & Vic ssburgian & Drilied.: & lirigation...: & 545 & $3_{3}^{2}$ & 200 & & $\begin{array}{l}+4 \\
+45\end{array}$ & & 496 & ${ }_{527}^{496}$ & Sulphur; some salt.. & $\begin{array}{l}110 \\
175\end{array}$ & Second supply at $400+$ foet. \\
\hline $\begin{array}{l}\text { Do............. } \\
\text { Do......... }\end{array}$ & & City $\ldots \ldots . . . .$. & 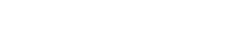 & & .....do........ & $\begin{array}{l}\text { limestone. } \\
\text { l....do................. }\end{array}$ & ...do.. & Public supply....... & 570 & $\frac{43}{6}$ & $\frac{350}{350}$ & $b 15$ & +45 & & & $\begin{array}{c}540 \\
500\end{array}$ & Sulphur; slight salt. & 500 & \\
\hline & & 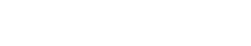 & …do & $\dddot{0}$ & (n.do.. & 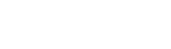 & (ndo..... & Fire protection................... & $\begin{array}{l}587 \\
487\end{array}$ & $\begin{array}{ll}6 \\
\frac{64}{2}\end{array}$ & $\begin{array}{l}350+ \\
450+\end{array}-2$ & $\begin{array}{r}r 15 \\
0\end{array}$ & $\begin{array}{l}+45 \\
+45\end{array}$ & & ….... & $\begin{array}{l}540 \\
453\end{array}$ & …do................. & $\begin{array}{l}500 \\
600\end{array}$ & \\
\hline $\begin{array}{l}\text { Do.: } \\
\text { Do.: }\end{array}$ & 1 mile east... & 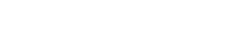 & 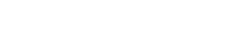 & 1907 & Pliestrone & 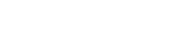 & Driilod. & 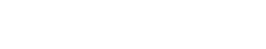 & $\begin{array}{l}814 \\
406 \\
648\end{array}$ & 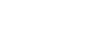 & & $\because \dddot{0} \ddot{0}$ & 4 & $+20^{\circ}$ & 150 & $\begin{array}{l}\text { (c) } \\
403\end{array}$ & 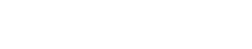 & $\begin{array}{r}300 \\
1500\end{array}$ & \\
\hline Do & 1 nile southwest & 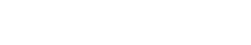 & ing Co. & & 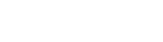 & $\begin{array}{l}\text { 1imestone. } \\
\text { lime. }\end{array}$ & Drillea... & Jrrlogtion and stock & Sio & & & 012 & $+40 \pm$ & & & & Sulpnur.............. & 1,000 & \\
\hline Do................... & 9 miles east......... & Harris.......... & Leecounty Weli Drili: & 1907 & Pleistocene.... & vicisburgian & Drilied... & Irrigation..................... & 617 & 3 & $\dddot{213}$ & & +45 & & $\cdots \cdots$ & 600+ & Sulphur; some salt.: & $\begin{array}{l}160 \\
500\end{array}$ & \\
\hline $\begin{array}{l}\text { Do... } \\
\text { Do... }\end{array}$ & & $\begin{array}{l}\text { E. E. Heitman... } \\
\text { R.A. Henderson. }\end{array}$ & 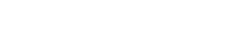 & $\begin{array}{l}1903 \\
1907 \\
-1903\end{array}$ & 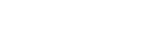 & 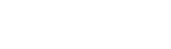 & ...do...... & 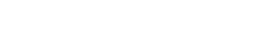 & $\begin{array}{l}474 \\
572\end{array}$ & ${ }_{2}^{2}$ & 470 & $b 14$ & +45 & & & & $\ldots .$. do................ & & \\
\hline Do.: & 7.5 miles southeast. & 列. A. Hendley..... & 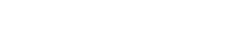 & 1905 & …do................. & …...do............. & ....do....... & sstock & 列1 & $3_{3}^{2}$ & 420 & & $+2+$ & $\cdots$ & …... & $\begin{array}{l}560 \\
918\end{array}$ & mrackish...................... & Many. & \\
\hline Do.: & 9 miles east....... & John T. Murphy. & Lee county Weli Drili: & 1907 & Pleistocene... & vicissurgian & Drilied.. & Irrigation................. & 年40 474 & $\begin{array}{l}5 \\
4\end{array}$ & $180^{\circ}$ & & $\begin{array}{r}0.45 \pm \\
+45\end{array}$ & +90 & & (c) & Sulphur; some salt. & ${ }_{400}^{200}$ & \\
\hline $\begin{array}{l}\text { Do.. } \\
\text { Do.: }\end{array}$ & 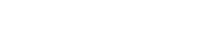 & 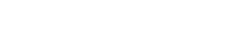 & 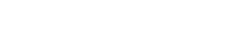 & $\begin{array}{l}1907 \\
1905\end{array}$ & $\begin{array}{l}\text {....do..... } \\
\ldots \text {.do..... }\end{array}$ & $\begin{array}{l}\text {....doo............ } \\
\text { ….do......... }\end{array}$ & $\begin{array}{l}\text {...do.... } \\
\ldots \text {.do.... }\end{array}$ & Domestic and stock. & $\begin{array}{l}596 \\
700\end{array}$ & $\frac{4}{3}$ & $\begin{array}{l}180 \\
255\end{array}$ & 615 & $\begin{array}{r}+45 \pm \\
\ldots \ldots\end{array}$ & & & $\begin{array}{l}\text { (c) } \\
700\end{array}$ & 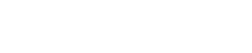 & $\begin{array}{r}400 \\
\text { Many. }\end{array}$ & \\
\hline & 4 miles anst........... & $\begin{array}{l}\text { Royal Palm Hotei.: } \\
\text { Judge Tice. }\end{array}$ & 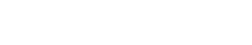 & $\begin{array}{l}1907 \\
1906\end{array}$ & 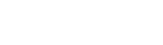 & ,..do... & (d) & 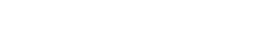 & $\begin{array}{l}493 \\
514\end{array}$ & $\begin{array}{l}3 \\
3\end{array}$ & $\begin{array}{l}255 \\
200\end{array}$ & & $\begin{array}{r}+45 \\
+45\end{array}$ & & $\ldots \ldots$ & $\begin{array}{l}490 \\
550\end{array}$ & 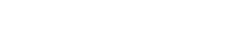 & $\begin{array}{l}250 \\
250\end{array} \mid$ & \\
\hline $\begin{array}{l}\text { Do.... } \\
\text { Do... }\end{array}$ & 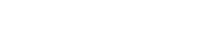 & 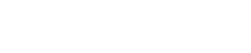 & 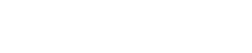 & $\begin{array}{l}1905 \\
1905\end{array}$ & …............. & 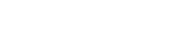 & 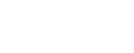 & 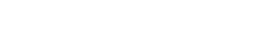 & $\begin{array}{l}691 \\
721\end{array}$ & $\frac{3}{3}$ & 辎50 & …..... & $\begin{array}{l}+40 \pm \\
+40 \pm \\
+40 \pm\end{array}$ & & $\cdots \cdots$ & & sulphur and sait...... & $\begin{array}{l}\text { Many. } \\
\text { Many. }\end{array}$ & $\begin{array}{l}\text { Quicksand to water rock. } \\
\text { Do. }\end{array}$ \\
\hline $\begin{array}{l}\text { Do............ } \\
\text { Do.......... }\end{array}$ & $\begin{array}{l}\text { T. } 46 \mathrm{~S} ., \mathrm{R} .33 \mathrm{E} \\
\text { T. } 47 \mathrm{~F} ., \\
\text {. }\end{array}$ & W. H. Towlos..... & J. Henry ..................... & 1005 & ….......... & vic isburgian & Drilied... & 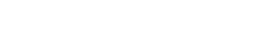 & & & $647 ?$ & ...... & $\stackrel{+50}{+}$ & & & & Sulphur and sait... & Many. & $\begin{array}{l}\text { Do. } \\
\text { Do. }\end{array}$ \\
\hline $\begin{array}{l}\text { Do........ } \\
\text { Do...... }\end{array}$ & 6 milices east & 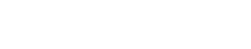 & Owner. & $\begin{array}{l}1908 \\
1005\end{array}$ & $\begin{array}{l}\text { Pleistocene... } \\
\text { do }\end{array}$ & 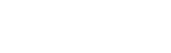 & $\begin{array}{l}\ldots \text { do......... } \\
\ldots \text { do }\end{array}$ & $\begin{array}{l}\text { Domostic and stock... } \\
\text { Irrication }\end{array}$ & $\begin{array}{l}600 \\
400\end{array}$ & ${ }_{43}^{2}$ & 160 & $b_{12}$ & $\dddot{0} \dddot{0}$ & & & & 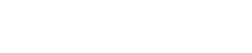 & $\begin{array}{l}\text { Several. } \\
450\end{array}$ & \\
\hline Do............... & 3 miles east...... & ......do.................... & 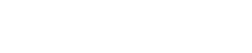 & & ....do...... & ....do... $\quad$ > $>$ > & ...do....... $\quad$ > & Bottling............ & 525 & 2 & & & +45 & & & & do $-2+2-1$ & 150 & \\
\hline & 4 miles east...... & w. C. Washburn... & .....do................. & 1905 & ....do...... & ....do..... & $\ldots$ do...... & Irrigation................... & $\begin{array}{l}540 \\
600\end{array}$ & ${ }_{43}^{3}$ & $\begin{array}{l}285 \\
400\end{array}$ & .... & $\begin{array}{r}795 \\
45 \\
45\end{array}$ & & $\cdots \cdots$ & 490 & 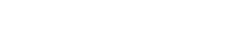 & 100 & \\
\hline Do.. & 9 miles east...... & Hon. Frank Wilson. & 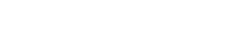 & 1907 & Pleistocene... & Vicksburgian & Driiled.: & 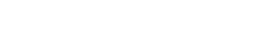 & 400 & $3^{\frac{\pi}{3}}$ & 200 & 0. & $\begin{array}{r}+40 \\
+45\end{array}$ & ‥ & ….... & 400 & Sulphur; some salt.. & 200 & \\
\hline ort To........................ & .............. & $\begin{array}{l}\text { J..J. Wooddward....... } \\
\text { E. E. G Goodno.......... }\end{array}$ & ….do..................... & ${ }_{1892}^{1907}$ & …do...... & 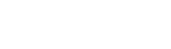 & ...do....... & Drinking and stock. & $\frac{421}{375}$ & 3 & 160 & $\because \dddot{c}_{0}$ & +45 & & ..... & (c) & Sudo.... & 150 & \\
\hline $\begin{array}{l}\text { Maraco. } \\
\text { Punta Rasa.............. }\end{array}$ & mile east........ & $\begin{array}{l}\text { W. D. Collier........ } \\
\text { G. W. Schultaz.... }\end{array}$ & Wm. Towles........ & $\begin{array}{l}1806 \\
1896\end{array}$ & …do..... & …................. & (ado...... & $\begin{array}{l}\text { Bathing, etc........... } \\
\text { Hotel ............... }\end{array}$ & $\begin{array}{l}460 \\
140\end{array}$ & ${ }_{3}^{-3}$ & 350 & 3 & $\dddot{6}$ & $\begin{array}{r}10 \\
+\end{array}$ & $300^{\circ}$ & 300 & .....do...................... & & Not completed. \\
\hline & m.m. & 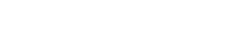 & & & & & Drilled.. & & $\begin{array}{l}205 \\
125\end{array}$ & $\begin{array}{l}3 \\
3\end{array}$ & 100 & 5 & & +3 & ….... $>$ > $>2$ & 120 & 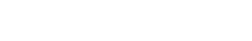 & $\begin{array}{l}6 \\
2\end{array}$ & \\
\hline $\begin{array}{l}\text { St. Jome.... } \\
\text { Sames.. }\end{array}$ & & Town. & Hั Partriage.............. & $1886^{\circ}$ & $\begin{array}{l}\text { Recent......... } \\
\text { Pleistocene.. }\end{array}$ & 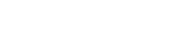 & $\ldots$ do _... & $\begin{array}{l}\text { Fish facktory ...... } \\
\text { Public well ..... }\end{array}$ & 年86 & $\begin{array}{l}3 \\
6 \\
6\end{array}$ & & $\begin{array}{l}b_{10}^{2} \\
b 10\end{array}$ & 22 & $\begin{array}{r}20 \\
+5 \\
\end{array}$ & & & sulphir... & & \\
\hline Sanibel........... & Center............ & F. P. Bailey & & 10007 & & $\begin{array}{l}\text { limestone. } \\
\text { do? }\end{array}$ & Drillea.. & Irrigation & 420 & & ?.... & & & & & & Brackish ___ & & \\
\hline Do.................. & $x_{0}$ & Harry Bailey............... & Lee County Wëil Driil- & 1905 & ....do............. & 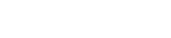 & ‥do....... & Not used.................... & 500 & $\dddot{2}$ & & $\cdots \cdot$ & $\cdots \cdots$ & 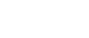 & .... & 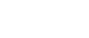 & 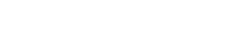 & & \\
\hline Do... & West end.......... & Hope \& Heller........ & 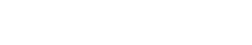 & 1908 & ............. & .....do....... & ...do....... & $\ldots$ do................... & $600+$ & 3 & 340 & 5 & & 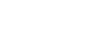 & & & Hard................... & & \\
\hline Useppa Island... & 1 mile east......... & w. н. Towles............. & (2................ & ...... & Pleistocene... & .....do......... & ...do...... & ........................ & 列 & 3 & & & & $+20+$ & & & .......... & Many. & \\
\hline $\begin{array}{l}\text { Do............... } \\
\text { Captiva.......... }\end{array}$ & $\begin{array}{l}1 \frac{1}{13} \text { miles from bay.. } \\
\frac{1}{3} \text { mile east........ }\end{array}$ & $\begin{array}{l}\text { Useppa Inn......... } \\
\text { W.H. Knowles... }\end{array}$ & Jas. Sykes.................. & 1908 & (....do........ & $\begin{array}{l}\text { n...do.9..... } \\
\text { …do....... }\end{array}$ & $\begin{array}{l}\text {...do....... } \\
\text {...do...... }\end{array}$ & 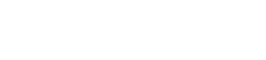 & $\begin{array}{l}\frac{400 \pm}{600} \\
605\end{array}$ & $\begin{array}{l}3 \\
3\end{array}$ & ....... & $\dddot{b}$ & & $\begin{array}{r}+10 \\
10\end{array}$ & & & Salt_.................. & ${ }^{i} i 0_{0}$ & $\begin{array}{l}\text { Said to be too salt for drinking. } \\
\text { No salt water below } 60 \text { feet. }\end{array}$ \\
\hline
\end{tabular}



The following record of the deepest well at Fort Myers was given by the driller, $H$. Seniff.

Record of well of W. H. Towles, at Fort Myers.

\begin{tabular}{|c|c|c|}
\hline & Thickness. & Depth. \\
\hline "Hardpan," sand with muck.. & Feet. 2 & Feet. \\
\hline 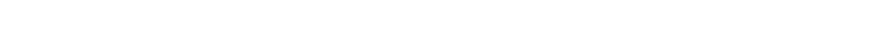 & 88 & 90 \\
\hline 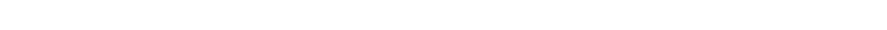 & 2 & \\
\hline 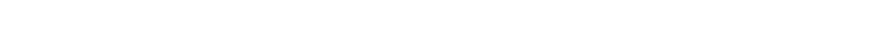 & 60 & 152 \\
\hline 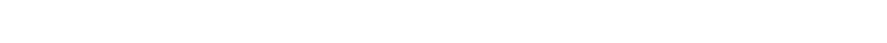 & $\begin{array}{l}12 \\
60\end{array}$ & $\begin{array}{l}164 \\
224\end{array}$ \\
\hline 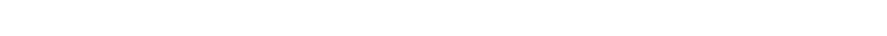 & 120 & 344 \\
\hline 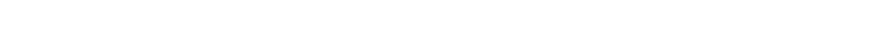 & 80 & 424 \\
\hline 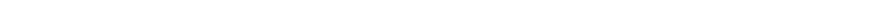 & & 1,060 \\
\hline
\end{tabular}

This well was not completed when the above record was noted, June 6, 1908. It was then cased to a little over 500 feet and flowed a strong stream from between 680 and 960 feet, chiefly from the latter depth. The general character of the hard sulphur water is indicated by the field assay in the table on page 260. The deep waters from different flows show considerable differences.

Particulars of some of the wells on Caloosahatchee River above Fort Myers are given in the table. No detailed records of these wells are at hand.

Among the most interesting wells in southern Florida are those drilled on the eastern side of Lee County in the cattle ranges of the prairies in the pinelands west of the Everglades. Though records were not kept, the wells are of interest because of their depth and the facts reported regarding the geology and underground waters. The driller found nothing hard near the surface in any of the wells, but went through a great thickness of sands which he called "quicksands." These were coarse, white to dark, and were full of water but did not yield flows. In view of the general character of the Pliocene and Miocene beds to the north it seems probable that a considerable part of the so-called sand was really marl. Some particulars of these wells are briefly summarized below:

Details of wells southeast of Fort Myers.

[In feet.]

\begin{tabular}{|c|c|c|c|}
\hline Location (T. S., R. E.). & $\begin{array}{c}\text { Depth to } \\
\text { rock. }\end{array}$ & $\begin{array}{l}\text { Depth to } \\
\text { flow. }\end{array}$ & $\begin{array}{l}\text { Depth of } \\
\text { well. }\end{array}$ \\
\hline 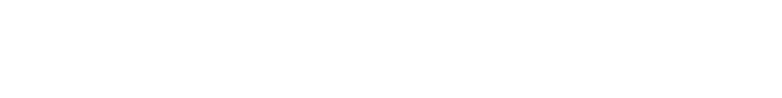 & $\begin{array}{l}825 \\
680 \\
600 \\
718\end{array}$ & $\begin{array}{l}921 \\
691 \\
600 \\
720\end{array}$ & $\begin{array}{l}921 \\
691 \\
647 \\
720\end{array}$ \\
\hline
\end{tabular}

The water from all these wells, though drunk by stock, is said to be salty. No analyses have been reported. 
Artesian prospects.-Flows under considerable head can be had from the Vicksburgian limestones throughout Lee County. The quality of the water deteriorates toward the southeast, as the limestone is more and more deeply buried, but usable water can probably be obtained anywhere in the western half of the county north of Naples, except in scattered areas on off-lying keys. The cattle range wells in T. 46 S., R. 33 E., T. 47 S., R. 31 E., and T. 48 S., R. 31 E., indicate the quality of the water to be expected along the eastern side of the north half of the county, though the quality should be better toward the northern boundary.

Toward the south line of the county the deep water becomes more mineralized, and there is slight chance of getting potable water at Chokoluskee and Everglade from deep wells. Shallower wells are not likely to furnish fresh water in the keys of the Ten Thousand Islands.

\section{LEON COUNTY.}

By G. C. Matson.

\section{GENERAL FEATURES.}

Leon County, in the northern part of Florida, includes a portion of the broad upland that extends from east of Monticello westward to Pensacola. This upland has been deeply eroded by streams and is now gently rolling, with many rounded hills that rise 100 feet or more above the adjacent valleys. The city of Tallahassee stands on a remnant of this upland and the hill in the central portion of the town has an altitude of about 200 feet.

Broad depressions, which may be in part due to solution, are occupied by lakes, the most important of which are Lake Lafayette, near Tallahassee, and Lakes Jackson and Iamonia, in the northern part of the county. There are many similar but smaller lakes and some of them are thought to occupy sink holes in the underlying limestone. Lake Miccosukee, near the northeast corner of the county, occupies a broad depression in limestone of the Chattahoochee formation and drains to an underground channel in the same formation. In the southern part of the county a broad terrace rises from 60 to 80 feet above sea level and extends northward beyond Tallahassee. Along Ochlockonee River another terrace ranges in altitude from 40 to 60 feet above sea level and has a breadth of about a mile.

\section{GEOLOGY.}

The terrace formation in Leon County consists of gray Pleistocene sand which rests unconformably upon the older deposits. On the uplands there are red and yellow sands and sandy clays referred to the Lafayette (?) formation. This formation underlies the entire upland portion of the county and eroded materials from it are 
frequently found beneath the gray sands of the terraces. Southwest of Tallahassee there are numerous exposures of gray shell marl (Choctawhatchee marl). This formation may be seen at Black's sawmill and at numerous other localities in the vicinity of Holland post office. It is also known to extend along Ochlockonee River as far south as Bloxham.

Where the Choctawhatchee marl is absent, the Lafayette (?) formation rests on blue or gray sands and clays belonging to the Alum Bluff formation, which in turn rest on the hard light-colored limestones of the Chattahoochee formation.

The Vicksburgian limestones underlie the entire county, but they are so deeply buried that their presence can be detected only in the drillings from such wells as the one at the city waterworks in Tallahassee. The sands and clays referred to the Lafayette (?) formation are well exposed in the vicinity of Tallahassee and on the slopes of the hills throughout the northern part of the county. The Alum Bluff and Chattahoochee formations are seldom seen, but some small exposures of the formation appear on the hillsides and numerous others along Ochlockonee River.

The gray sands of Pleistocene age are commonly thin, though locally they may attain a thickness of over 20 feet. The Lafayette (?) formation probably averages less than 30 feet in thickness, but it may reach a maximum of over 50 feet. The Choctawhatchee marl is at least 30 feet thick in the vicinity of Black's sawmill, but toward the north it is much thinner, its maximum thickness being probably less than 50 feet. In Leon County the thickness of the older geologic formations has not been determined, but it is thought that the deep wells at Tallahassee pass through the Chattahoochee formation and enter the Vicksburgian limestones.

\section{WATER SUPPLY.}

Source.-All the geologic formations occurring in Leon County contain more or less water. Throughout the upland portion of the county the red and yellow sands and sandy clays of the Lafayette (?) formation supply the water for shallow wells. The Choctawhatchee marl is not an important aquifer, though it supplies a few shallow wells near Ochlockonee River. Good supplies of water should be obtained from the sandy beds of the Alum Bluff formation, but it is difficult to determine by means of well records whether the water comes from these beds or from the overlying Lafayette (?) formation. Both the Chattahoochee formation and the Vicksburgian limestones are excellent sources of water, but the Vicksburgian beds are most important because they contain much larger quantities than the $76854^{\circ}-$ wsP $319-13-23$ 
Chattahoochee. However, the limestones of the Chattahoochee formation are encountered near the surface and many wells do not penetrate to the underlying Vicksburgian rocks.

Quality.-The water obtained from the Lafayette (?) formation is usually soft, though that from the deeper wells may be moderately hard. Both the Choctawhatchee marl and the Alum Bluff formation should furnish water containing but small quantities of mineral matter. The water from both the Chattahoochee formation and the Vicksburgian limestones is hard.

Development.-Most shallow wells obtain good supplies of water within 20 or 30 feet below the surface throughout the county. For this reason but few deep wells have been drilled except in places where large quantities of water are needed for industrial or for city supplies. At Chaires the Seaboard-Air Line Railway has a well about 35 feet deep which obtains an abundance of water from limestone of the Chattahoochee formation. The same formation probably supplies water for one or two of the deep wells in Tallahassee. The wells of the Tallahassee Waterworks Co. probably penetrate the Vicksburgian limestones and these rocks are believed to be the sources of the principal supply. The water supply for Tallahassee is taken from a well 717 feet deep, and the quantity is ample for all purposes. Two auxiliary wells, each 400 feet deep, may be drawn upon if the well now in use should prove inadequate. 


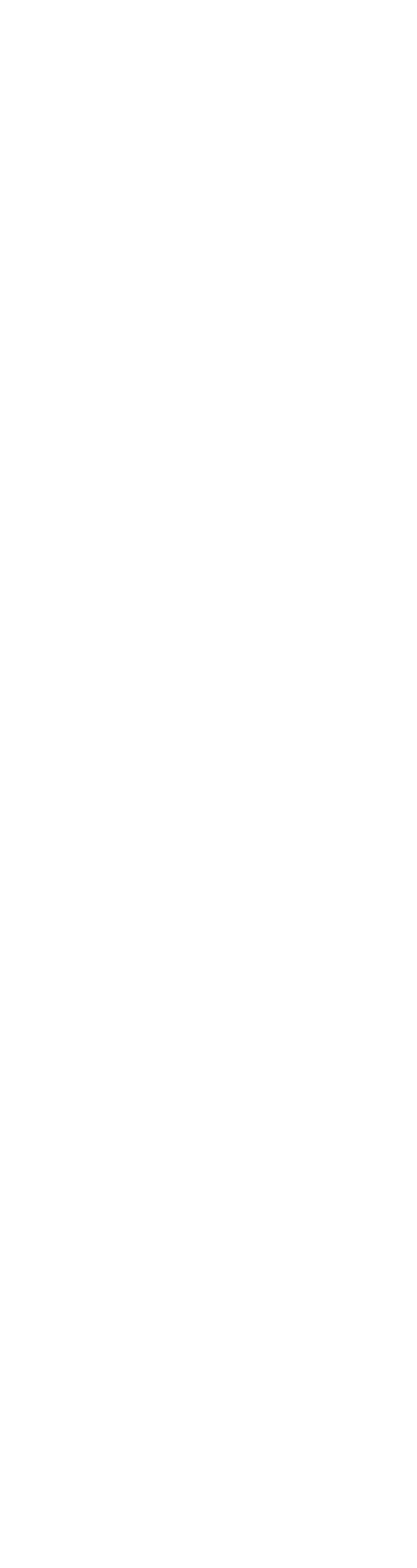

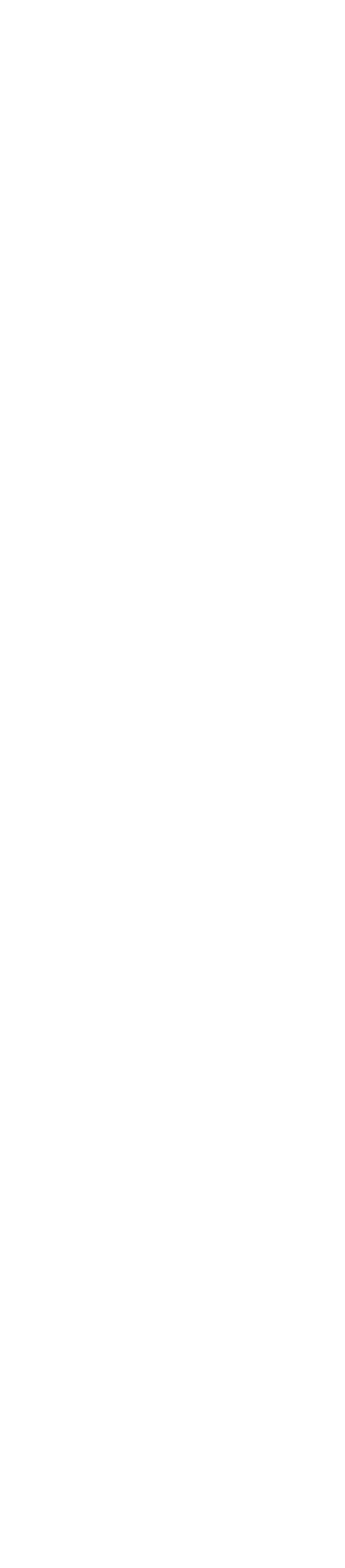




\section{LEVY COUNTY.}

By G. C. Matson.

\section{GENERAL FEATURES.}

Levy County occupies a large area on the Gulf Coast of the peninsula and extends eastward to the border of the lake region. The surface is low and flat near the coast but becomes more gently rolling farther inland. In the eastern half of the county lakes and sink holes are interspersed with rounded hills. A large portion of the county lies below the 50-foot contour, but near the northeast corner the surface is more than 100 feet above sea level, and similar highland areas are numerous in the adjoining counties to the east and south.

\section{GEOLOGY.}

Below the 100-foot contour the county is mantled by gray Pleistocene sand which is either underlain by the porous Vicksburgian-limestones or by limestones and clays of the Apalachicola group. Near Levyville there is an area where the Hawthorn formation is believed to be present. The Alum Bluff formation underlies a portion of the county. Some small patches of Alachua clay are known near Suwannee River and in the northeastern part of the county.

The average thickness of the Pleistocene sands is probably not more than 20 to 30 feet, though the maximum may be somewhat greater than 50 feet. Both the Alachua clay and the Hawthorn formation are thin, the former being probably less than 15 feet thick and the latter in fow places exceeding 40 to 50 feet. The thicknesses of the Alum Bluff formation and of the Vicksburgian limestones are not known, though that of the latter is believed to be several hundred feet.

\section{WATER SUPPLY.}

Source.-The three important sources of water in Levy County are the sands of the Alum Bluff formation, the sands of the Pleistocene, and the Vicksburgian limestones. None of the other formations represented in the county are important; though locally they may supply water for a few wells. The sands of the Alum Bluff and of the Pleistocene are the source of most of the water used for domestic purposes and for stock. The Vicksburgian limestones furnish water for a number of deeper wells and are especially important as a source of supply for industrial purposes.

Quality.-The Pleistocene sands yield soft water which is generally regarded as excellent. The Vicksburgian limestones yield hard water. Near Cedar Key brackish and salt waters have been encountered in the limestones; but the wells there were sunk to a depth of over 800 feet and may have been heedlessly drilled past beds which would supply fresh wator. 
Development.-The shallow wells of Levy County range in depth from 10 to 40 feet. They supply nearly all the water that is used in the county and are generally satisfactory, though for domestic use the hard water from the deeper wells is probably more desirable. Drilled and driven wells range in depth from about 40 to 865 feet, but the most of them are less than 100 feet. These wells yield hard water which is generally used for boilers, turpentine stills, or like purposes. At Cedar Key two wells, drilled to 830 and 865 feet, have been abandoned because the water contained so much salt that it was unfit for use. It is very doubtful if such wells would be satisfactory near the coast. However, near the eastern border of the county deep waters should be practically free from salt. There is little possibility of obtaining flowing wells anywhere in Levy County.

Levy County contains a number of excellent springs, some of which are of considerable size. The Blue Spring near Bronson is estimated to flow 25,000 gallons, and the Wekiva Spring near Otter Creek over 35,000 gallons per minute. The water from a small spring near Levyville is used for drinking, but none of the large springs are utilized. 


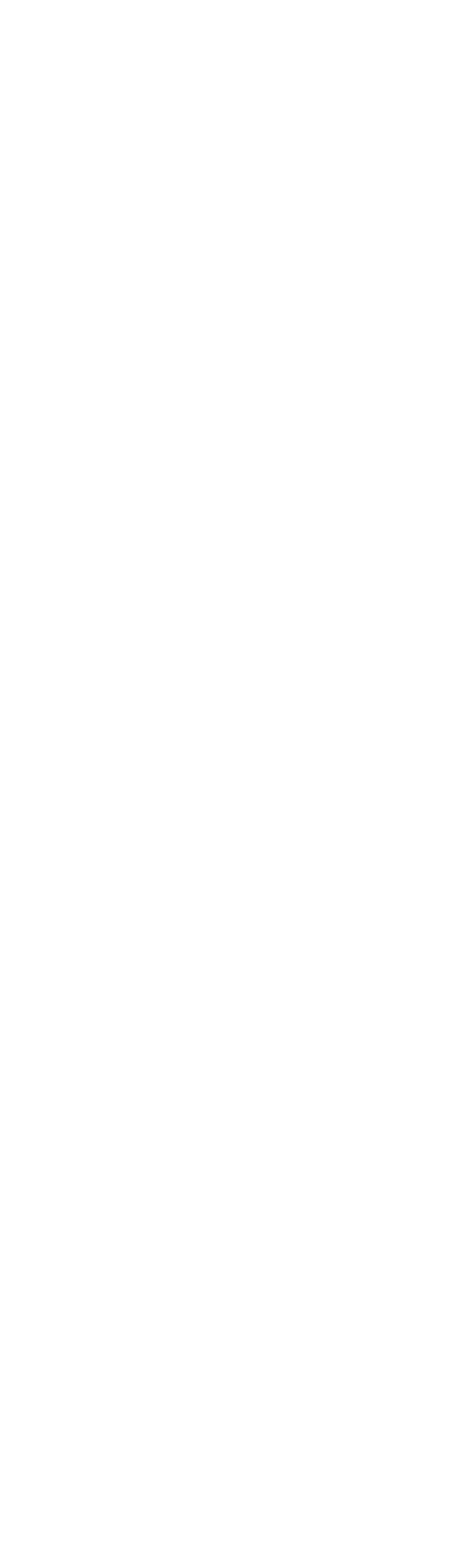

\begin{tabular}{|c|c|}
\hline & 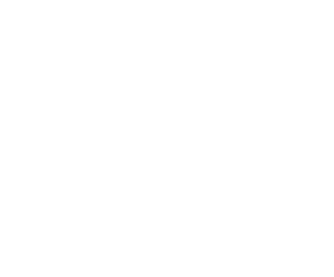 \\
\hline$\frac{8}{5}$ & 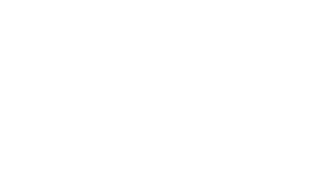 \\
\hline 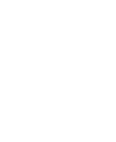 & 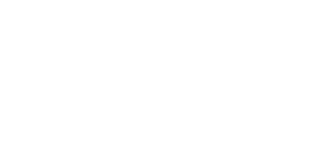 \\
\hline 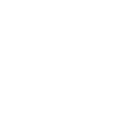 & 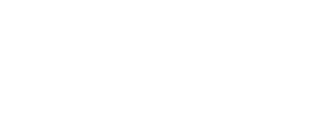 \\
\hline 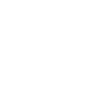 & 离 \\
\hline 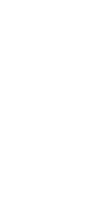 & 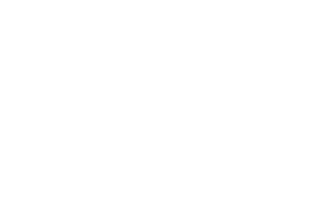 \\
\hline 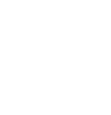 & 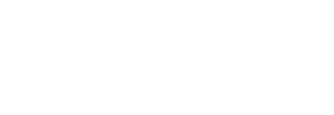 \\
\hline 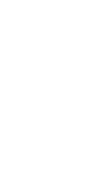 & 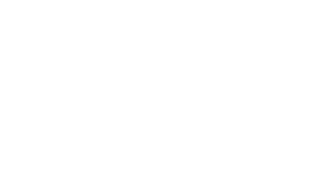 \\
\hline 害 & 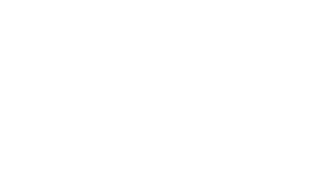 \\
\hline 催 & 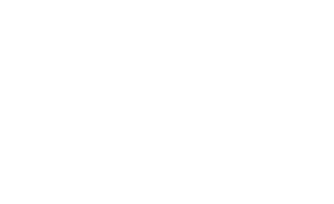 \\
\hline & \\
\hline
\end{tabular}


Typical wells of Levy County.

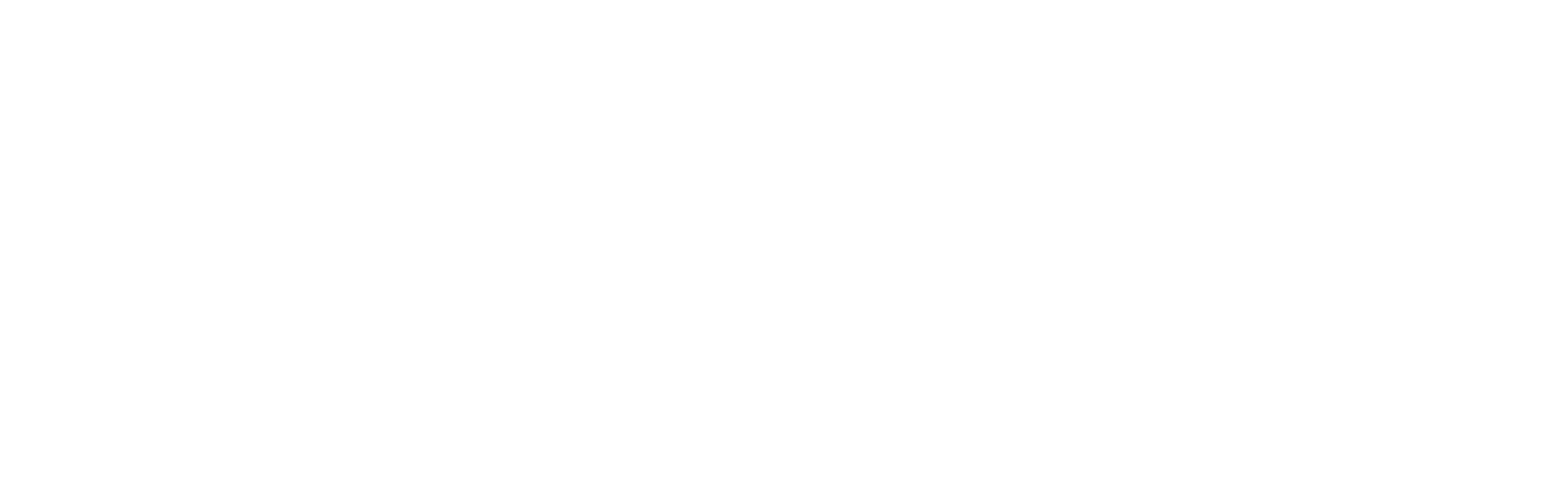

76854는 Wse 319-13. (To face page 356.) 



\section{LIBERTY COUNTY.}

By G. C. Matson.

\section{GENERAL FEATURES.}

Liberty County occupies a large area between Apalachicola and Ochlockonee rivers. The surface varies greatly in altitude, ranging from 25 feet above sea level near the southern boundary to over 250 feet on the uplands at the north. The broad terrace which occupies so large an area in the counties to the east and south doubtless extends into the southern part of Liberty County, and it is known to border Apalachicola and Ochlockonee rivers. Two other terraces of Pleistocene age occur in this county, but their distribution has not been ascertained.

The uplands in the northern part of Liberty County form a plain rising over 250 feet above the sea and sloping gently toward the south. The major streams of the county have eroded broad valleys across this plain and small tributary streams have cut narrow steepsided channels into it. In some localities the descent from this plain to the lowlands bordering the Gulf is abrupt, but elsewhere it is a gentle slope interrupted by broad terraces.

\section{GEOLOGY.}

The lowlands of Liberty County are mantled with gray Pleistocene sand. The uplands are thinly coated with residual sand, underlain by red and yellow sands and sandy clays belonging to the Lafayette (?) formation, which in turn is underlain by older rocks of Miocene and Oligocene age. The Miocene beds of Liberty County comprise soft clays and marls belonging to the Choctawhatchee marl, which underlies the southern portion of the upland but probably does not extend to the northern border of the county. The Alum Bluff formation underlies the Lafayette (?) formation in the north but farther south it passes beneath the Choctawhatchee marl. The Chattahoochee formation lies beneath the Alum Bluff formation throughout the upland portion of the county, but it is not exposed except along Apalachicola River and some of its principal tributaries. Beneath the Chattahoochee are the Vicksburgian limestones, but these rocks do not reach the surface in Liberty County. The lowlands forming the southern portion of the county are probably underlain by both the Chattahoochee and the Vicksburgian limestones, but there are no exposures and no well records in that region, and hence no information can be obtained concerning these rocks.

The thickness of the Pleistocene sands is probably in some places more than 50 feet, but they average less than 30 feet. The average thickness of the Lafayette (?) formation is less than 30 feet, though 
locally it is greater than 50 feet. The Alum Bluff formation may be over 100 feet thick and the Chattahoochee over 250 feet, but there is little definite information concerning either of them.

WATER SUPPLY.

Source.-The Pleistocene sands yield abundantly within a few feet of the surface, the sands of the Lafayette (?) formation contain an abundance of water available for wells of moderate depth, and both the Choctawhatchee marl and the Alum Bluff formation should furnish large supplies of water, but neither of these formations has been penetrated in Liberty County. In adjoining counties the Chattahoochee and the Vicksburgian limestones furnish large quantities of water and the conditions are equally favorable for obtaining good supplies in Liberty County.

Quality.-The water from the Pleistocene sands and the Lafayette (?) formation is usually soft, but all the older formations will doubtless supply hard water.

Development.-Good supplies of water may be obtained at 10 to 50 feet throughout the upland portion of Liberty County. In the lowlands similar supplies should be obtained in shallow wells. No deep wells have been reported, but such wells should be successful, though it is doubtful if the head of the water is sufficient to give flows, except perhaps in the stream valleys near the southern end of the county. The Vicksburgian limestones, the best water-bearing beds, should be reached in wells at 400 to 600 feet on the upland and 300 to 400 feet on the lowland. The head is sufficient to raise the water from these rocks over 20 feet above sea level, and hence wells drilled on the lowland may be easily pumped; but in wells drilled on the upland the water level will be so far beneath the surface that pumping may be difficult.

General water resources of Liberty County.

\begin{tabular}{|c|c|c|c|c|c|c|c|}
\hline \multirow[b]{2}{*}{ Town. } & \multirow{2}{*}{$\begin{array}{c}\text { Topo- } \\
\text { graphic } \\
\text { location. }\end{array}$} & \multirow{2}{*}{$\begin{array}{l}\text { Source of } \\
\text { water. }\end{array}$} & \multirow{2}{*}{$\begin{array}{c}\text { Surface } \\
\text { formation. }\end{array}$} & \multicolumn{4}{|c|}{ Shallow wells. } \\
\hline & & & & Supply. & $\begin{array}{c}\text { Quality of } \\
\text { water. }\end{array}$ & \multicolumn{2}{|c|}{$\begin{array}{l}\text { Principal water } \\
\text { beds. }\end{array}$} \\
\hline $\begin{array}{l}\text { Bristol......... } \\
\text { Estiffanulga... }\end{array}$ & $\begin{array}{l}\text { Plain...... } \\
\text {...do...... }\end{array}$ & $\begin{array}{l}\text { Wells.... } \\
\text {...do.... }\end{array}$ & $\begin{array}{l}\text { Sand...... } \\
\ldots \text {. do....... }\end{array}$ & $\begin{array}{l}\text { Feet. } \\
20-40 \\
30-52\end{array}$ & $\begin{array}{l}\text { Soft... } \\
\ldots \text { do... }\end{array}$ & \multicolumn{2}{|c|}{$\begin{array}{l}\text { Vicksburgian lime } \\
\text { stone. } \\
\text { Do. }\end{array}$} \\
\hline Town. & Depth. & Supply. & \multicolumn{2}{|c|}{$\begin{array}{l}\text { Quality of } \\
\text { water. }\end{array}$} & $\begin{array}{l}\text { Depth to } \\
\text { rock. }\end{array}$ & $\begin{array}{l}\text { Depth to } \\
\text { water. }\end{array}$ & $\begin{array}{l}\text { Sewerage } \\
\text { system. }\end{array}$ \\
\hline $\begin{array}{l}\text { Bristol.......... } \\
\text { Estiffanuiga... }\end{array}$ & $\begin{array}{r}\text { Feet. } \\
\quad 40 \\
52\end{array}$ & $\begin{array}{l}\text { Large..... } \\
\ldots . . d 0 . . . . .\end{array}$ & \multicolumn{2}{|c|}{$\begin{array}{c}\text { Hard and sulphur... } \\
\ldots \ldots \text {. do................... }\end{array}$} & $\begin{array}{r}\text { Feet. } \\
40+ \\
52+\end{array}$ & $\begin{array}{l}\text { Feet. } \\
15-20 \\
20-30\end{array}$ & $\begin{array}{l}\text { None. } \\
\text { Do. }\end{array}$ \\
\hline
\end{tabular}




\section{MADISON COUNTY.}

By G. C. Matson.

\section{GENERAL FEATURES.}

Madison County occupies a roughly rectangular area in the northcentral part of Florida, extending about 25 miles southward from the Georgia line. A large portion of the surface is more than 100 feet, and some tracts are more than 150 feet, above sea level. A broad belt of swamp land extends from the south-central part of the county. northward beyond the Seaboard Air Line Railway. Lakes are numerous, both north and south of Madison, but none of them are large. Near the southern boundary of the county the valleys of Suwannee and Aucilla rivers are both less than 50 feet above sea level.

\section{GEOLOGY.}

Below the 100-foot contour the surface deposit of Madison County consists of a thin covering of Pleistocene gray sand, which obscures the underlying formations except where these have been locally exposed by erosion or artificial excavations. On the uplands there is a surficial mantle of gray residual sand underlain by red, yellow, and mottled sands and sandy clays, referred to the Lafayette (?) formation, though their exact correlation is uncertain. Rocks of Oligocene age underlie the formations just described. The Alum Bluff formation is represented by sands and clays which occur on some parts of the upland. The limestones of the Hawthorn formation are exposed on Suwannee River near Ellaville, and they doubtless underlie the entire county at moderate depths. Beneath the Hawthorn formation lie the soft, light-colored Vicksburgian limestones.

The average thickness of the Pleistocene gray sands in Madison County is less than 25 feet, and that of the sands and sandy clays referred to the Lafayette (?) formation is probably less than 50 feet. No well logs have been c.btained, and it is impossible to give satisfactory estimates of the thickness of the older geologic formations.

\section{WATER SUPPLY.}

Source.-An abundance of water is obtained from the red and yellow sands of the Lafayette (?) formation, and some is said to be derived from the sandy clays of the same formation. The sandy beds of the Alum Bluff formation doubtless furnish water for some of the wells, but it is difficult to tell from the well records whether the supplies come from this formation or from the overlying Lafayette (?) formation. The Hawthorn formation yields large quantities of water and may supply the deeper wells of the county. The 
best sources of water in Madison County are the Vicksburgian limestones, though it is doubtful if many of the wells are deep enough to reach these rocks.

Quality.-The water from the sands of the Lafayette (?) formation and the Alum Bluff formation is generally soft, though locally it may contain enough mineral matter to be moderately hard. The Hawthorn formation yields hard water, and similar supplies are to be expected from the Vicksburgian limestones. Deep wells in the lastnamed formation should encounter sulphur water containing considerable quantities of mineral matter.

Development.-The shallow wells of Madison County obtain enough water for ordinary domestic and farm uses. They range in depth from 10 feet to nearly 50 feet, and wells less than 30 feet deep are common. The water level lies so near the surface that pumping is easy, and the supplies should be entirely satisfactory except where there is danger of contamination by impure surface drainage.

Few of the deeper wells exceed 100 feet, though some are more than 200 feet deep. The supply is large, and although the water is hard it is regarded as satisfactory. The presence of clays above the water-bearing beds prevents pollution by surface water, and hence these wells are suitable for domestic supply.

Springs are numerous in Madison County, but most of them are small and few are extensively used. Among those noted was one near Ellaville and one $3 \frac{1}{2}$ miles west of Pinetta (the Cherry Lake Spring). The latter is used for bathing and drinking, and, although the flow is small, a bathhouse has been constructed. The water contains some sulphur and its temperature is $68^{\circ}$. 
Typical wells of Madison County.

\begin{tabular}{|c|c|c|c|c|c|c|c|c|c|c|c|c|c|c|c|c|c|}
\hline \multirow{2}{*}{$\begin{array}{l}\text { Nearest } \\
\text { town. }\end{array}$} & \multirow{2}{*}{$\begin{array}{l}\text { Direction and } \\
\text { distance. }\end{array}$} & \multirow[b]{2}{*}{ Owner. } & \multirow[b]{2}{*}{ Driller. } & \multirow{2}{*}{$\begin{array}{l}\text { Date } \\
\text { sunk. }\end{array}$} & \multirow{2}{*}{$\begin{array}{l}\text { Type of } \\
\text { well. }\end{array}$} & \multirow{2}{*}{ Use. } & \multirow[b]{2}{*}{ Depth. } & \multirow{2}{*}{$\begin{array}{c}\text { Diam- } \\
\text { eter. }\end{array}$} & \multirow[b]{2}{*}{ Casing. } & \multirow{2}{*}{$\begin{array}{l}\text { Eleva- } \\
\text { tion- } \\
\text { above } \\
\text { sea. }\end{array}$} & \multicolumn{2}{|c|}{ Head- } & \multirow{2}{*}{$\begin{array}{l}\text { Depth } \\
\text { to } \\
\text { rock. }\end{array}$} & \multirow{2}{*}{$\begin{array}{l}\text { Depth } \\
\text { to } \\
\text { princi- } \\
\text { pal } \\
\text { supply. }\end{array}$} & \multirow{2}{*}{$\begin{array}{c}\text { Pro- } \\
\text { tecting } \\
\text { clays } \\
\text { present. }\end{array}$} & \multirow{2}{*}{$\begin{array}{l}\text { Quality } \\
\text { of } \\
\text { water. }\end{array}$} & \multirow[b]{2}{*}{ Remarks. } \\
\hline & & & & & & & & & & & $\begin{array}{l}\text { Above } \\
\text { sea. }\end{array}$ & $\begin{array}{l}\text { Below } \\
\text { surface. }\end{array}$ & & & & & \\
\hline \multirow{2}{*}{$\begin{array}{l}\text { Ellaville.... } \\
\text { Do...... }\end{array}$} & \multirow{3}{*}{ Near... } & \multirow{3}{*}{ 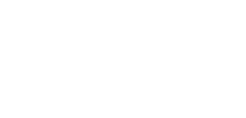 } & \multirow{2}{*}{$\begin{array}{l}\text { W. B. Hicks... } \\
\text { Owners......... }\end{array}$} & \multirow[b]{2}{*}{1900} & \multirow[b]{2}{*}{ Driiled.... } & \multirow{2}{*}{$\begin{array}{l}\text { Turpentine still........ } \\
\text { General................ }\end{array}$} & \multirow{2}{*}{$\begin{array}{r}\text { Feet. } \\
100 \\
100\end{array}$} & \multirow{2}{*}{$\begin{array}{r}\text { Inches. } \\
\mathbf{4} \\
\mathbf{3}\end{array}$} & \multirow{2}{*}{$\begin{array}{l}\text { Feet. } \\
{ }_{40} 0.0\end{array}$} & \multirow{3}{*}{$\begin{array}{r}\text { Feet. } \\
99 \\
99\end{array}$} & Feet. & Feet. & Feet. & Feet. & & & \\
\hline & & & & & & & & & & & 64 & 35 & "ï & $\mathrm{n}^{-}$ & Y̌s... & Hard... & \\
\hline$\underset{\text { Do......... }}{\text { Greanilie }}$ & & & 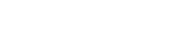 & $\begin{array}{l}1900 \\
1906\end{array}$ & $\begin{array}{l}\ldots \text {..do... } \\
\ldots \text { do... }\end{array}$ & 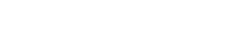 & 100 & 2 & 100 & & 64 & 35 & 12 & $\because \dddot{m}$ & Yes.. & $\ldots$ do..... & \\
\hline $\begin{array}{l}\text { Greanville... } \\
\text { Do...... }\end{array}$ & f milesouthwest... & $\begin{array}{l}\text { W. Bishop...... } \\
\text { M. A. McDaniel... }\end{array}$ & $\begin{array}{l}\text { G. P. Payne.... } \\
\text { Bond \& Payne. }\end{array}$ & $\begin{array}{l}1906 \\
1908-200\end{array}$ & $\begin{array}{l}\text {...do. } \\
\text {..do. }\end{array}$ & $\begin{array}{l}\text { Dranage.. } \\
\text { General... }\end{array}$ & ${ }_{99}^{205}$ & ${ }_{2}^{2}$ & & & & 60 & $\begin{array}{r}200 \\
80\end{array}$ & 205 & Y̌s.. & ...do...... & \\
\hline $\begin{aligned} & \bar{D} 0 . . . . . \\
& \text { Lee.......... }\end{aligned}$ & Near ................... & $\begin{array}{l}\text { C. M. Stokes..... } \\
\text { Geo. Brown }\end{array}$ & พ̈. B. Hicks.... & $\begin{array}{l}1908 \\
1907\end{array}$ & $\begin{array}{l}\text {...do. } \\
\ldots \text { do. }\end{array}$ & (2....do..... & 104 & $\underset{2}{2}$ & $\begin{array}{r}101 \\
55\end{array}$ & & & $\begin{array}{l}60 \\
40\end{array}$ & 90 & 103 & 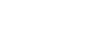 & ...do...... & \\
\hline Do.. & .....do.... & W. J. Greer.... & $\ldots$ & 1907 & …do. & a......... & 107 & 2 & $\begin{array}{r}00 \\
100 \\
20\end{array}$ & & & $\begin{array}{l}40 \\
45\end{array}$ & $\dddot{60}$ & & Yes.: & רdo.... & \\
\hline $\begin{array}{l}\text { Do.. } \\
\text { Do. }\end{array}$ & …do... & $\begin{array}{l}\text { Lee Ginning Co.......... } \\
\text { G. B. Haven.... }\end{array}$ & $\begin{array}{l}\text { Jack Newman.. } \\
\text { Owner. }\end{array}$ & $\begin{array}{l}1896 \\
1907\end{array}$ & ado. & $\begin{array}{l}\text { Ginning. } \\
\text { General. }\end{array}$ & $\begin{array}{r}76 \\
108\end{array}$ & 2 & $\begin{array}{l}60 \\
98\end{array}$ & & & 50 & & - & $\begin{array}{l}\text { Yes. } \\
\text { Yes. }\end{array}$ & ‥do.. & \\
\hline Do. & 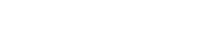 & Dr.c. W.Johnston... & W. B. Hicks.... & 1905 & (...do.. & .....do & 70 & 2 & 69 & & & 50 & $\dddot{40}$ & 70 & Yes.: & lo. & \\
\hline Do. & 4 miles east..... & Wells \& Shaw........ & $\ldots . \mathrm{do}$ & 1906 & …do.. & & 87 & 3 & 56 & & & 40 & 36 & $\cdots \cdots$ & Yes.. & $\because$ do... & \\
\hline Lovett.. & Near............... & Fender .............. & $\begin{array}{l}\text { G.P. Payne.... } \\
\text { Bond \& Payne. }\end{array}$ & 1906 & ...do- & $\begin{array}{l}\text { Turpentine still........ } \\
\text { General. }\end{array}$ & 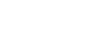 & 2 & $\begin{array}{r}90 \\
142\end{array}$ & & & 46 & 90 & 99 & Yes.. & Soft.... & \\
\hline Madison. & & City.............. & & 1904 & ado. & City and railroad sup. & 240 & & & 175 & $95-85$ & $80-90$ & & & $\begin{array}{l}\text { Yes.. } \\
\text { Yes.. }\end{array}$ & H....... & Incrusts boilers. Yields 92 \\
\hline Do.. & $1 \frac{3}{2}$ miles west... & R. V. Dial... & J. T. Sharpe... & 1806 & ...do. & 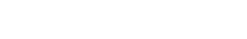 & 70 & 3 & 60 & & & & 38 & & & do. & gallons per minute. \\
\hline & 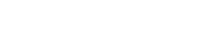 & G. P. Kelloy..... & J. T. Sharpe... & $\begin{array}{l}1906 \\
1907\end{array}$ & $\begin{array}{l}\text {...do.. } \\
\ldots \text { do. }\end{array}$ & 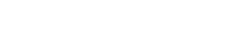 & $\begin{array}{r}115 \\
52\end{array}$ & $\begin{array}{l}4 \\
3\end{array}$ & 78 & & & 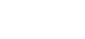 & 52 & $\because \dddot{0}$ & Yes. & $\begin{array}{l}\text {...do.. } \\
\text { odo. }\end{array}$ & \\
\hline & (.................. & Merchants Hotel .. & F. D. Ferrell. & 1900 & …do.. & Disposal of sewage.. & 85 & $\begin{array}{l}0 \\
4\end{array}$ & & & & 15 & & 52 & Y̌s. & $\ldots$ do $\ldots$ & \\
\hline & $1 \frac{1}{2}$ miles west..... & $\overline{\mathrm{B}}$. M. Taylor....... & J. T. Sharpe.. & 1906 & ...do. & Drainage.................. & 65 & 4 & 40 & & & 35 & 40 & & Yes.: & $\ldots$ do.. & \\
\hline & 9 miles south & н. Р. Thompson... & 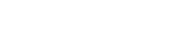 & $\begin{array}{l}1900 \\
1907\end{array}$ & ...do... & Drinking..... & $\begin{array}{l}60 \\
152\end{array}$ & $\begin{array}{l}4-2 \\
3\end{array}$ & $\begin{array}{l}40 \\
70\end{array}$ & & ….... $>3$ & $\begin{array}{r}35 \\
113\end{array}$ & $\begin{array}{l}40 \\
70\end{array}$ & 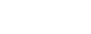 & $\begin{array}{l}\text { Yes.. } \\
\text { Yes. }\end{array}$ & ...do.. & \\
\hline & 2 miles northwest. & Allie Sanders....... & …...do.. & 1907 & a.do.: & Drainage. & 70 & 8 & 35 & & & & 35 & & Yes... & …do.. & \\
\hline & ...do................. & I do shaw.............. & .....do... & ${ }_{1907}^{1907}$ & $\ldots$ do.. & Genera..... & $\frac{1288}{155}$ & ${ }_{3}^{2}$ & 120 & & & 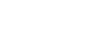 & $\begin{array}{l}120 \\
101\end{array}$ & & Yes.. & ...do... & \\
\hline Pinetta...... & Near.......... & J. Cowart.... & 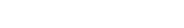 & 1907 & Driven.... & .....do.......... & 35 & $\stackrel{0}{2}$ & ${ }_{30}^{102}$ & & ........ & $\begin{array}{r}140 \\
10\end{array}$ & None. & $\cdots_{35}$ & Yes.-. & Soft..... & \\
\hline Sirmans..... & 2 miles east.. & R. P. Henry.. & Bond \& Payne. & 1907 & Drilled.: & 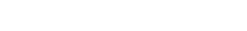 & $121 \frac{1}{2}$ & 2 & 120 & & ?........ & 30 & 120 & $120 \frac{1}{2}$ & Yes... & Hard... & \\
\hline Do....... & $\frac{1}{t}$ mile north....... & K. Myric....... & G. P. Payne... & 1905 & …do.. & Turpentine still........ & $\begin{array}{l}125 \\
871\end{array}$ & ${ }_{2}^{2}$ & 112 & & …....... & 14 & & $\cdots \cdots$ & Yes.. & ...do...... & \\
\hline Red Oak.... & 2 miles north... & s. Sheffeild............... & ................ & 1904 & ado. & Drinkmg & $61^{2}$ & 2 & 35 & & $\cdots$ & ${ }_{3}^{14}$ & & $\begin{array}{l}81 \\
58\end{array}$ & $\begin{array}{l}\text { YeS.- } \\
\text { Yes. }\end{array}$ & Medium. & \\
\hline & .....do................. & Pen. Strickland ... & .....do....... & 1904 & & General & 78 & 2 & 59 & & & 2 & & 68 & & …do..... & \\
\hline
\end{tabular}

76854 - WSP $319-13$. (To face page 360.) 

MADISON COUNTY.

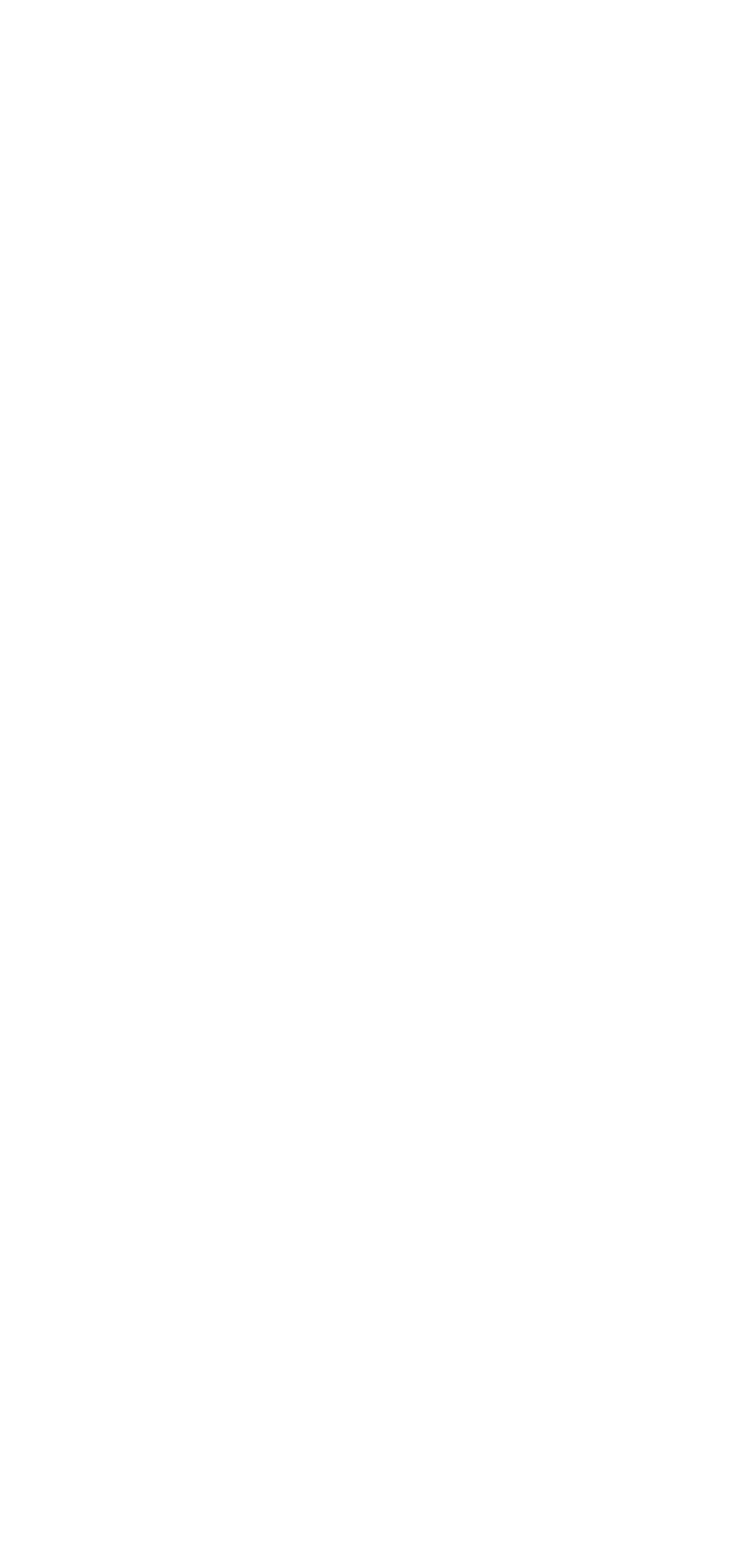




\section{MANATEE COUNTY.}

By G. C. Matson.

\section{GENERAL FEATURES.}

Manatee County occupies the greater portion of the area between Tampa Bay and Charlotte Harbor and extends more than 30 miles inward from the coast. Some long narrow islands or keys are separated from the mainland by shallow bays and sounds. Near the coast the land rises from a few feet to about 25 feet above sea level and forms an extensive plain representing the former extension of the sea upon the land. This terrace appears along some of the streams but is not so well developed here as farther north. Another terrace 40 to 60 feet above sea level is widely developed. The northeastern part of the county lies more than 50 feet above sea level and perhaps some of the higher hills near the northeastern corner of the county have altitudes of 100 feet or more. The drainage of the county is chiefly through Manatee, Little Manatee, and Myakka rivers. Near the northern boundary there are several good-sized lakes, and ponds and swamps are common throughout the southern half of the county.

\section{GEOLOGY.}

Nearly the entire surface of Manatee County is covered by gray sands of Pleistocene age, underlain by yellow or brown sands which closely resemble the surface sands and probably owe their color to iron oxide. Near the southern boundary the Caloosahatchee marl may underlie the surface sands, but in the absence of exposures and satisfactory well records their existence in that area can only be inferred from their presence on the lower course of Myakka River. Upper Oligocene limestones, lying approximately at the horizon of the Alum Bluff formation, occur on Manatee River in the vicinity of Ellenton. They are covered by a few feet of fuller's earth, which probably belongs to the same formation. The Tampa formation may underlie the county but is not exposed and can be inferred only from its relation to the Alum Bluff formation. Beneath the Tampa formation lie the Vicksburgian limestones, which have been reached by wells at several points along the coast beyond the southern limits of the county.

The surficial sands of Manatee County are comparatively thick, though locally, as in the vicinity of Ellenton, they may amount to only 2 or 3 feet. The maximum thickness is at least 50 feet and the average is probably greater than 25 feet. The Tampa and Alum Bluff formations attain a thickness of over 250 feet in the vicinity of Ellenton and are probably more than 200 feet thick throughout a large part of the county. The base of the Vicksburgian limestones 
is not known to have been reached in any of the deepest wells and it is safe to infer a thickness of several hundred feet for these limestones. The following log shows geologic conditions on Terra Ceia Island:

Log of well of A. D. Wright, Terra Ceia Island.

\begin{tabular}{|c|c|c|c|c|c|}
\hline & Depth. & Thickness. & & Depth. & Thickness. \\
\hline 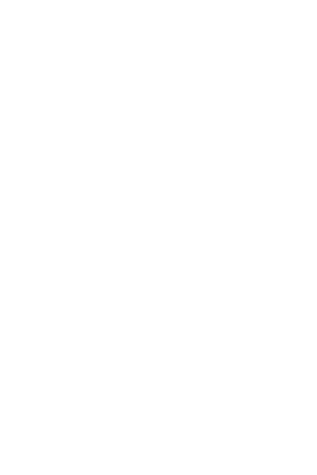 & $\begin{array}{r}\text { Feet. } \\
\cdot 4 \\
2 \\
10 \\
16 \\
9 \\
22 \\
6 \\
4 \\
3 \\
1 \\
2 \\
1 \\
2 \\
1 \\
2 \\
5 \\
47 \\
2 \\
10 \\
4 \\
3\end{array}$ & $\begin{array}{r}\text { Feet. } \\
4 \\
6 \\
16 \\
32 \\
41 \\
43 \\
49 \\
53 \\
56 \\
57 \\
59 \\
60 \\
62 \\
63 \\
65 \\
70 \\
117 \\
119 \\
129 \\
133 \\
136\end{array}$ & 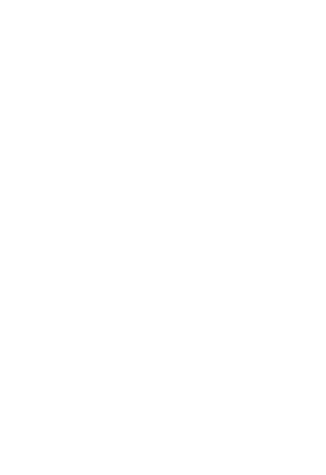 & $\begin{array}{r}\text { Feet. } \\
6 \\
6 \\
1 \\
18 \\
15 \\
12 \\
1 \\
5 \\
6 \\
2 \\
2 \\
18 \\
37 \\
9 \\
4 \\
5 \\
47 \frac{1}{2}\end{array}$ & $\begin{array}{r}\text { Feet. } \\
142 \\
148 \\
149 \\
167 \\
182 \\
194 \\
195 \\
200 \\
206 \\
208 \\
210 \\
228\end{array}$ \\
\hline
\end{tabular}

The artesian water beds were found at 289 feet. The rock contained in the above section is largely limestone, though it contains some thin beds of chert. The clay is apparently a soft marl.

In the vicinity of Palmetto and Bradentown the first strong flows are encountered at about 260 feet and this is regarded as the approximate depth to the Vicksburgian limestones. Doubtless these rocks occur a few feet above the water bed.

\section{WATER SUPPLY.}

Source.-The surficial sands supply large quantities of water throughout the county and the upper Oligocene limestones are also locally important water-bearing beds. The best aquifers of Manatee County are the Vicksburgian limestones, which supply large quantities of water suitable for domestic use or for irrigation. Good flowing wells have been obtained from the Vicksburgian limestones at different points along the coast.

Quality.-The surficial sands yield soft water suitable for all purposes, and are generally regarded as satisfactory. The upper Oligocene limestones supply hard water which contains hydrogen sulphide at some places. Hard sulphur water is found in the Vicksburgian limestones and, in some localities, salt water also.

Development.-Throughout a large part of Manatee County soft water can be obtained at depths ranging from 5 to 25 feet and these supplies are extensively developed, especially for domestic and farm uses. A few drilled wells may reach a depth of 50 to 75 feet, but in 
such places satisfactory water-bearing beds can generally be found nearer the surface. The flowing wells range in depth from 200 to over 500 feet and furnish large quantities of water. In the northern end of the county the head is sufficient to give flows at a height of approximately 32 feet above sea level, and toward the south the altitude to which the water will rise slightly increases. A large number of flowing wells have been drilled in the vicinity of Manatee, Bradentown, Ellenton, Terra Ceia, Oneco, Sarasota, Fruitville, and Parish. Flows could doubtless be obtained along the entire coast in this county. Wells on low ground in the interior of the county might obtain flowing water, but in most places the water would not have sufficient head to reach the surface. However, even in the higher parts of the county the sulphur waters from the Vicksburgian limestones will rise near enough to the surface to be easily pumped.

Bradentown has a public water supply obtained from two drilled wells 410 to 427 feet in depth. The system is said to give excellent satisfaction. The quantity of water is ample and its quality is good.

General water resources of Manatee County.

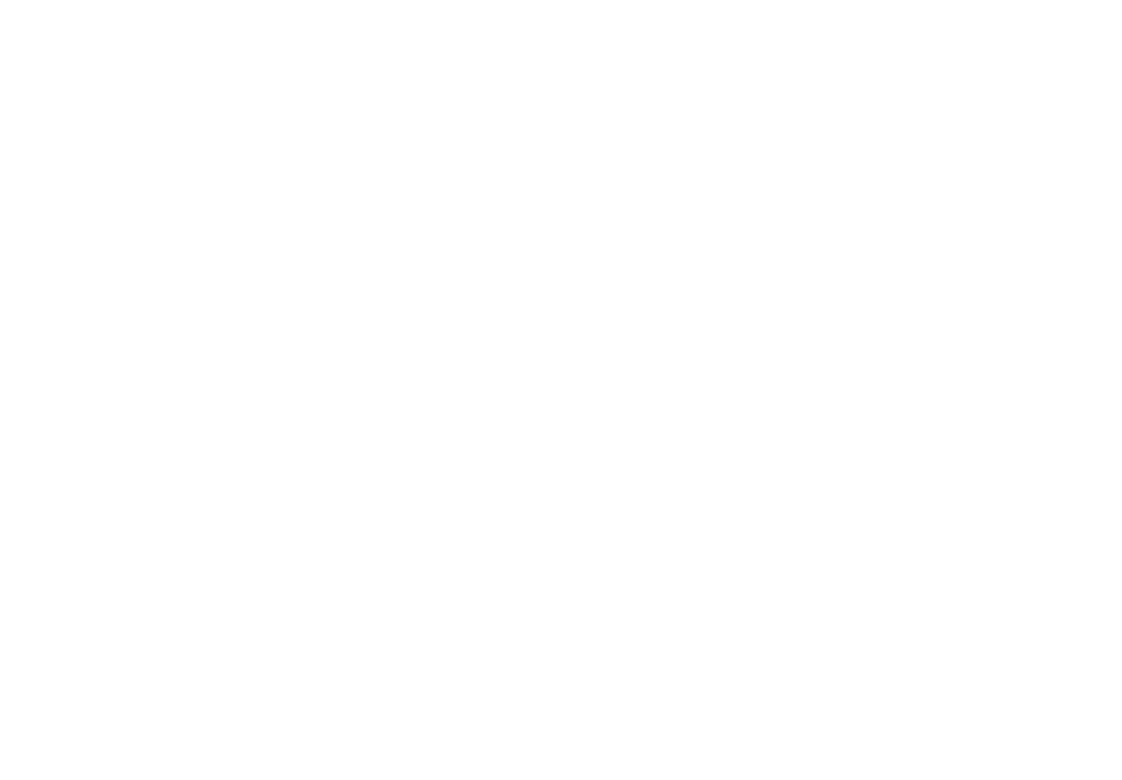


Typical wells of Manatee County.

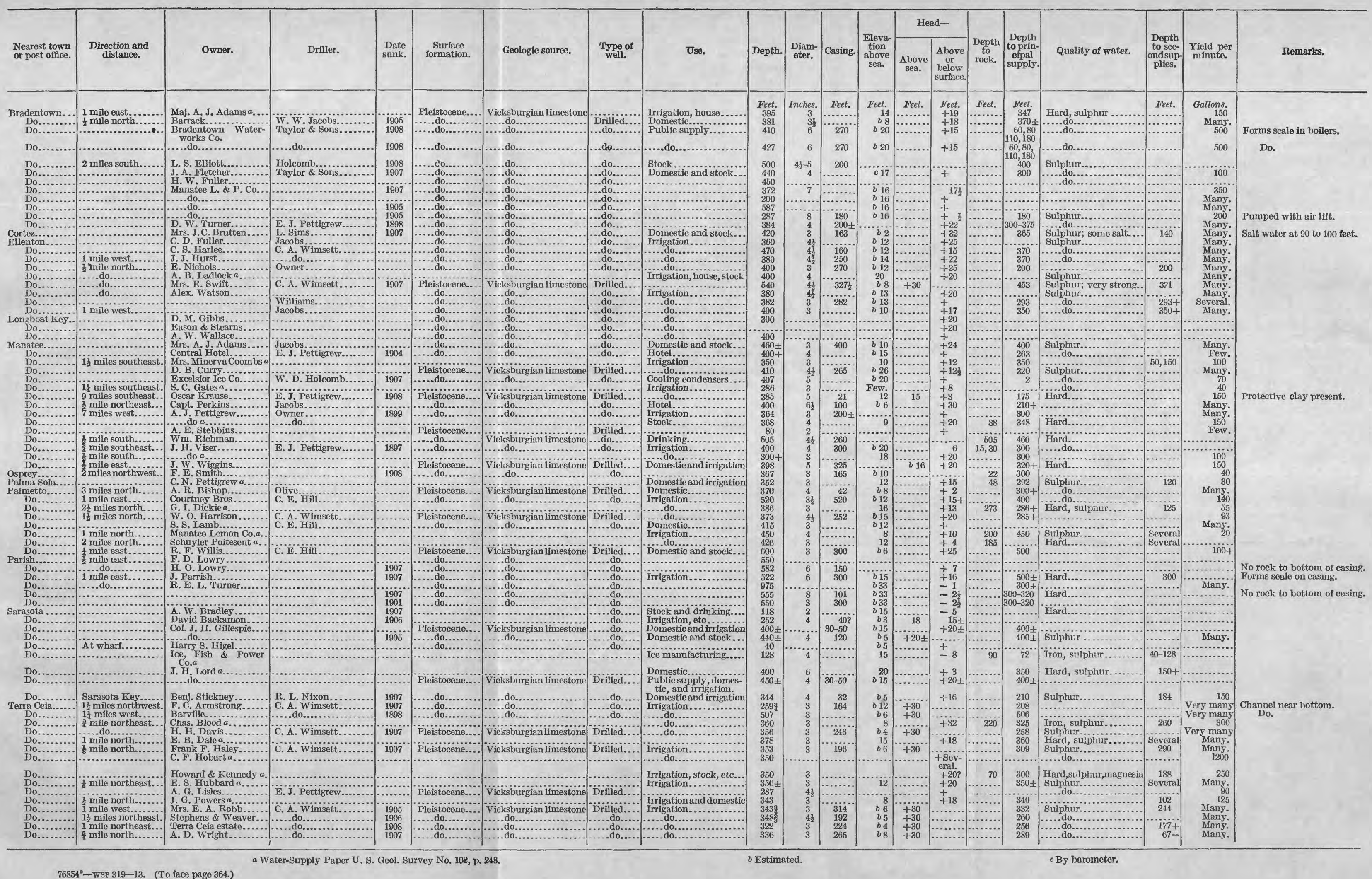





\section{MARION COUNTY.}

By G. C. Matson.

GENERAL FEATURES.

Marion County is in the north-central portion of the peninsula and includes a portion of the central lake region. The surface is very irregular, the higher hills rising above 150 feet and the lowest valleys being less than 50 feet above sea level. Much of the drainage is through underground channels in the limestone. At many points of emergence the underground streams.form very large springs. The existence of the underground channels is shown by numerous sinkhole depressions, which may contain lakes but which are usually dry. In some localities the water that enters the depressions drains to the underground channels through open holes, but in most places it escapes by seepage through the sands.

\section{GEOLOGY.}

Gray sand, largely derived from the weathering of the Alum Bluff formation, mantles the surface of Marion County and is commonly underlain by yellow or brown sands. A narrow strip along the eastern border of the county is underlain by shell marls of Pliocene age (Nashua marl), but it is doubtful if these beds extend far from St. Johns River and they are so thin as to be of no hydrologic value.

In the eastern half of the county the limestones, sands, and clays of the Hawthorn and Alum Bluff formations occupy large areas. The Vicksburgian limestones immediately underlie the surface sands in the western part of the county, and they dip eastward from the vicinity of Ocala, passing beneath the Hawthorn formation.

The average thickness of the gray sand is probably more than 20 feet, though over large areas the underlying rock is near the surface. In favorable situations the thickness of the yellow residual sand may amount to over 20 feet, but it is usually only a few feet. The Miocene and Pliocene beds are probably less than 25 feet thick. The Hawthorn formation may reach a thickness of more than 100 feet near the eastern boundary of the county, but it thins to a few feet farther west. The Vicksburgian limestones probably extend to a depth of several hundred feet. The following log of a well at Ocala was furnished by Sellards:

Description of samples from well at Ocala.

Limestone, soft, white, granular; apparently Vicksburg; contains many Foraminifera and fragments of shells............... 50

Same; possibly somewhat harder but not materially different.... 75

Same........................................ 100

Limestone like above predominates; fragments of blue-gray limestone like the following are included.................... 
Limestone, hard, blue-gray predominates; some fragments of the white limestone; unbroken piece indicates that these blue fragments are embedded in a light-colored matrix................

Limestone, white; possibly somewhat more granular but otherwise not differing from above..............................

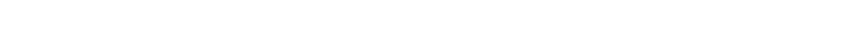

Limestone, a gray or light blue-gray, compact; not unlike that at

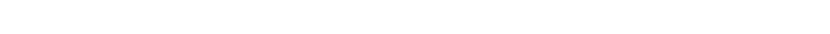

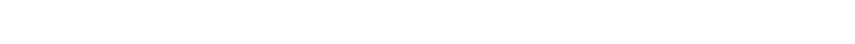

Limestone, gray, very compact; sample contains one very porous

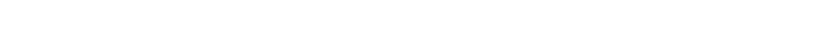

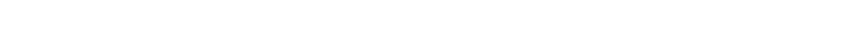

Limestone, porous, white; appearing nearly cream yellow in the

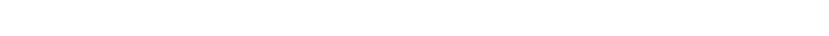

Similar to last in character but darker, nearly cream yellow......

Limestone, brown, apparently rather porous; darker than last....

Limestone, brown and light colored mixed, the brown predominating; a few grains of silica......................... 460

Limestone, dark brown, porous.................... 480

Limestone, dark brown.......................... 500

The white limestone with some gray to 375 feet is doubtless Vicksburg. The light to dark-brown limestone found below may belong to the same group.

\section{WATER SUPPLY.}

Source.-The surficial sands, especially the yellow residual sands, supply water to shallow wells. Deeper supplies come either from limestone and sand of the Hawthorn formation or from the Vicksburgian limestones, the Vicksburgian being by far the best source of supply, though good wells may also be obtained in the Hawthorn formation.

Quality.-The surface sands yield soft water. The water from Hawthorn and Vicksburgian rocks is invariably hard; some wells carry hydrogen sulphide and others are excessively salty, but fortunately this latter condition is rare.

Development.-Many wells of Marion County are less than 100 feet in depth, yet they supply an abundance of water. Few exceed 200 feet. No flowing wells are apt to be obtained on the uplands in this county, but the head below the surface is usually less than 50 feet, though, locally, it may amount to nearly 100 feet. This head should permit the successful operation of deep-well pumps. Near St. Johns River it should be possible to obtain good flowing wells on low ground, and though the exact head of the water is not known it would probably rise from 20 to 30 feet above the river. The water would contain considerable sulphur and other mineral matter but not in quantity great enough to interfere with its use. 
Typical wells of Marion County.

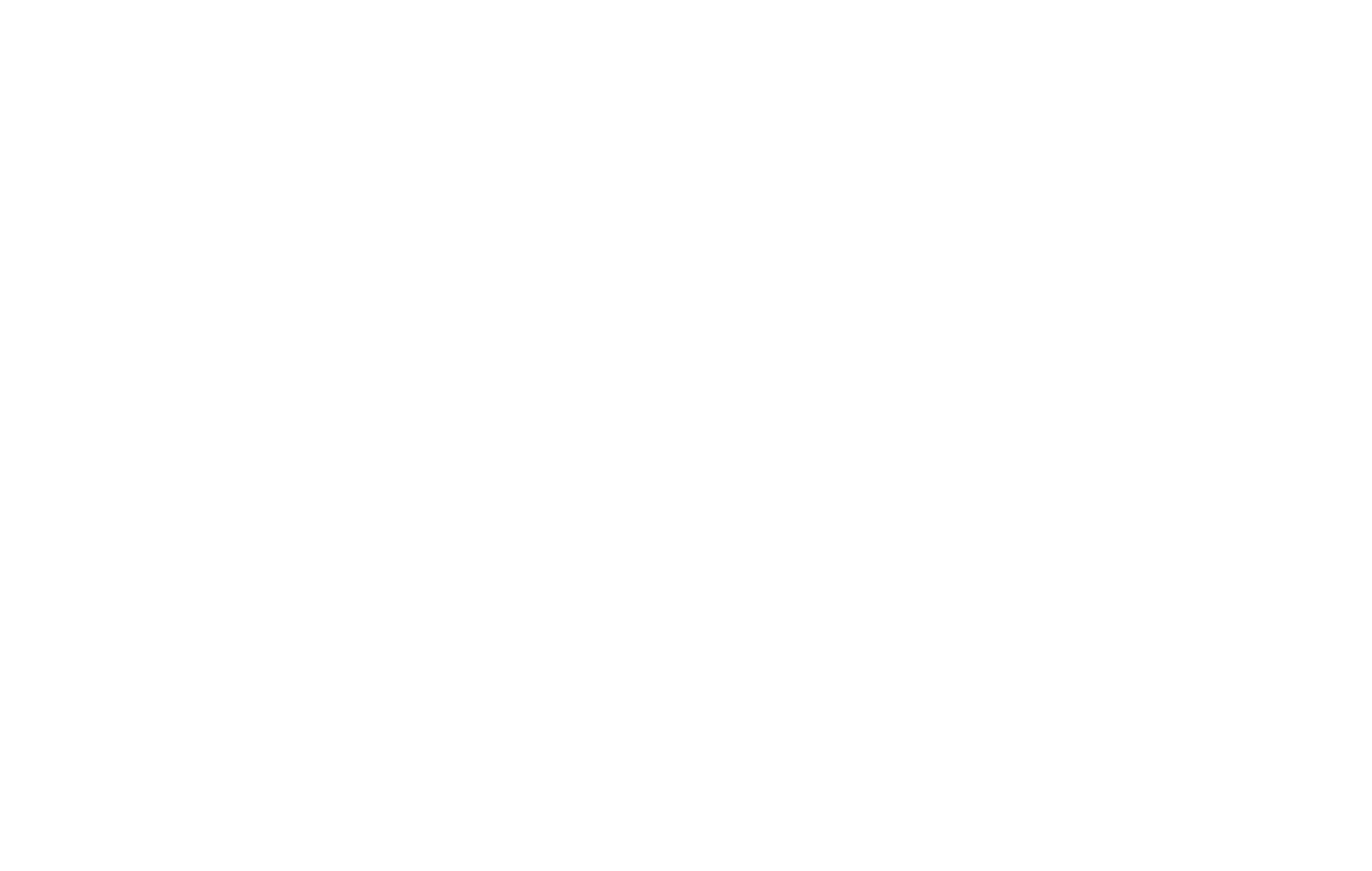


Springs are numerous and some of them are very large. Silver Spring, a short distance from Ocala, is the largest and most important. This spring is supplied by water which emerges through several openings into a basin-shaped depression having an area of several acres and a depth of over 35 feet. The volume of flow is about 385,000 gallons per minute and this is sufficient to form a stream-Silver Spring Run-which is large enough to float good-sized passenger and freight steamers. The stream has a depth of about 8 or 9 feet in the center of the channel and a length of nearly 10 miles to its junction with Ocklawaha River. The water from Silver Spring is noted for its clearness; objects on the bottom of the pool are distinctly visible and fish may be seen swimming about in the run. The source of this spring is the porous and cavernous Vicksburgian limestones; much of the water enters the ground within a few miles of the spring, and as it does not travel far through the soluble limestones it is only slightly hard.

Blue Spring near Juliette supplies a large stream, estimated at nearly 350,000 gallons per minute. Orange Spring, one-fourth mile north of Orange Springs, has a comparatively small discharge estimated at about 2,240 gallons per minute; the water contains sulphur and is used for bathing. A saline spring near Norwalk has a flow estimated at 84,000 gallons per minute.

Both Ocala and Dunnellon have public water supplies which use water from wells drilled into Vicksburgian limestones. The water is reported to be moderately hard, but the supplies are adequate for the needs of the towns and the quality is satisfactory, though the water from the deep well at Ocala contains some salt. In both cities shallow wells are used by individual families, but the sanitary character of the water is doubtful. The deep-well water should be safe, provided care is taken to prevent surface water and sewage from entering the waterbearing rocks.

$76854^{\circ}-$ WsP $319-13-24$ 


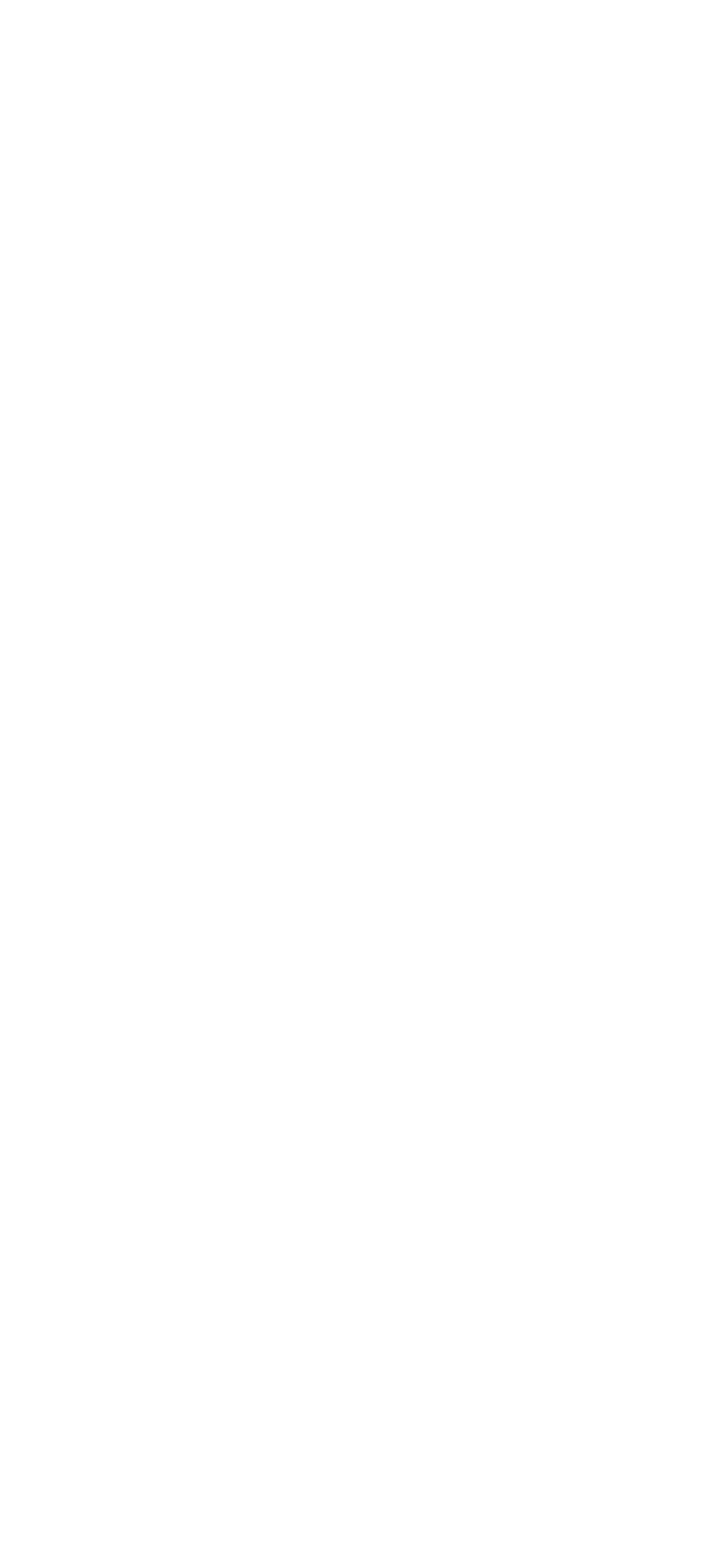




\begin{tabular}{|c|c|c|c|}
\hline 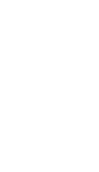 & \multicolumn{3}{|c|}{ 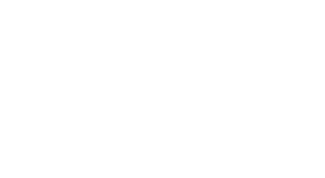 } \\
\hline 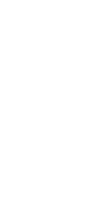 & 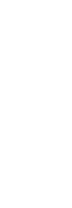 & 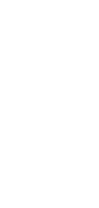 & \\
\hline 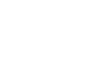 & ब्वित & : & $\mathbb{N}$ \\
\hline 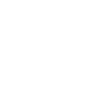 & $\begin{array}{c}\vdots \\
\vdots \\
\vdots \\
\text { 总 }\end{array}$ & 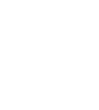 & 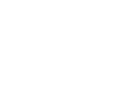 \\
\hline 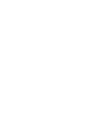 & 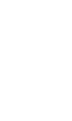 & $\begin{array}{l} \\
\vdots \\
\vdots \\
\vdots \\
\vdots \\
0\end{array}$ & \\
\hline 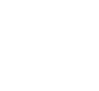 & 苛 & \begin{tabular}{cc}
$\vdots$ & $\vdots$ \\
$\vdots$ & $\vdots$ \\
\hdashline & $\vdots$ \\
$\vdots$ & $\vdots$
\end{tabular} & ؛ִ \\
\hline 品 & 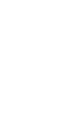 & 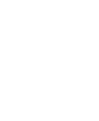 & 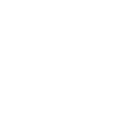 \\
\hline 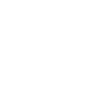 & 苛 & 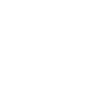 & 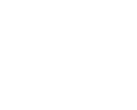 \\
\hline 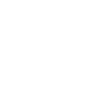 & 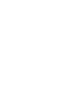 & 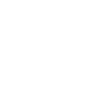 & $\begin{array}{l}\text { H } \\
\text { ô } \\
\text { â } \\
\text { ô }\end{array}$ \\
\hline 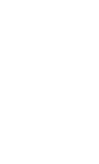 & $\begin{array}{c}\vdots \\
\vdots \\
\vdots \\
\$ \\
\text { z }\end{array}$ & 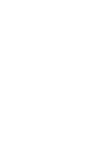 & 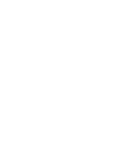 \\
\hline 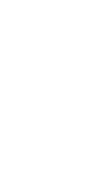 & 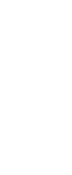 & 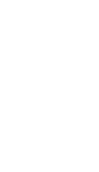 & 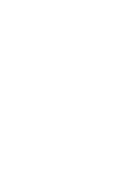 \\
\hline 它 & $\begin{array}{c}\vdots \\
\vdots \\
\vdots \\
\vdots\end{array}$ & 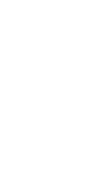 & 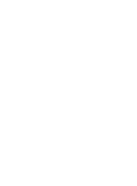 \\
\hline $\begin{array}{l}\text { हี่ } \\
\text { Z } \\
\text { Z }\end{array}$ & $\begin{array}{c}\vdots \\
\vdots \\
\vdots \\
\text { 苗 }\end{array}$ & 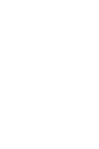 & 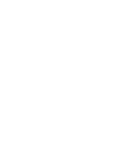 \\
\hline
\end{tabular}




\section{MONROE COUNTY.}

By Samuel Sanford.

GENERAL FEATURES.

Monroe County comprises the extreme southwestern part of the Florida Peninsula and the keys south and southwest of the Bay of Florida. Nearly all the mainland is swamp and much of it is within the Everglades. Except for the sandy strip at Cape Sable and the tracts of prairie near Flamingo, there is very little arable land. The principal settlements on the mainland are near Flamingo and at the mouth of Shark River. The only inhabitants of a large area are Indians. On the keys there are settlements on Key Largo, Plantation Key, Long Key, Grassy Key, Key Vaca, Big Pine Key, and Key West; on the last named is the city of Key West, the county seat and the only large settlement in the county.

The mainland lies very low; there is probably no point with an elevation of 20 feet above tide, and the average elevation is less than 15 feet. Most of the coast is a swamp fringed with mangrove islands. Whitewater Bay, though over 20 miles long, contains few wide stretches of open water and is largely a maze of shallow lagoons and mangrove islets.

\section{GEOLOGY.}

In the Everglades peat beds rest on sand, marl, and the Lostmans River limestone. The latter underlies the mainland coast and extends an undetermined distance inland and under the Bay of Florida. Marls, more or less peaty in places, form the coastal islands north of the bay. Their maximum known thickness is 15 to 20 feet about the mouth of Shark and Lostmans rivers. Quartz sands are not conspicuous north of the bay except at Cape Sable and on scattered beaches facing the Gulf. South of the bay the Key Largo limestone outcrops or underlies sand or limy marl on the keys of the main chain between Bahia Honda and the east line of the county; and from Big Bahia Honda to Boca Grande the surface or subsurface rock is the Key West oolite. No rocks older than Pliocene outcrop in the county. The character, thickness, and relations of the Pliocene, Miocene, and Oligocene beds, as shown by drilling, has been discussed elsewhere (pp. 173-174).

\section{WATER SUPPLY.}

Source and quality. - The only wells on the mainland yielding potable water are those in the sands of the beach ridges at Cape Sable. No deep wells have been sunk, and it is doubtful if the Oligocene formations contain good water or if higher formations will yield flows. 
Along the keys south of the Bay of Florida fairly good water is found in the Pleistocene limestones, the best being in the key having the largest extent of land above high tide--Big Pine Key. On all the keys the occurrence of fresh water, the quality of which varies greatly, is limited to a zone a few feet or even inches thick, near sea level. The water in the potholes and natural wells on most of the keys is decidedly brackish because of the entrance of sea water through the honeycombed limestones.

Development.-Springs have been reported on Big Pine Key and Key West and in the sea bottom elsewhere, but no true springs were found. The "springs" used by settlers are natural wells a few feet deep. There may be a perceptible surface flow from open passages on Big Pine Key during the rainy season, when the fresh-water level is high, but the proved occurrence of salt water below the fresh for hundreds of feet and the permeability of the sands lying below the surficial oolite and coralline limestones make it certain no deepseated springs of fresh water occur along the keys.

No wells on the mainland except those at Cape Sable yield fresh water. Wells near Flamingo find salt water in the limestone below the marl. The best of the Cape Sable wells are near Middle Cape and are but 5 feet deep. The water from them is hard and is said to get brackish in dry seasons, but it was fresh in May, 1908, after a long period of deficient rainfall. It is also said to be affected by high tides. Wells about 4 feet deep in the beach ridges of Lostmans, Panther, and Pavilion keys yield fresh or only slightly brackish water, but deeper ones have always yielded salt water and all become brackish in extremely dry weather. The deepest hole reported is less than 50 feet deep.

Numerous natural wells and a few shallow dug wells along the main line of the keys south of the Bay of Florida from Key Largo to Key West yield water which, though brackish except after heavy rains, is used by the crews of fishing boats and by the few dwellers on the keys. The best water tested by the writer was from a natural well belonging to W. H. Knowles, on Big Pine Key. Its chlorine content was 400 parts per million. Most of the shallow wells at Key West yield water of poor quality, more or less brackish and as a rule liable to pollution.

All deep drilled wells along the keys have yielded salt water from about sea level to over 2,000 feet, the greatest depth reached.

The city of Key West has no public supply of drinking water. The water from the deep well drilled in 1895 was formerly used for sprinkling the streets and fighting fires, but the mains are now supplied with sea water from a pumping plant at the navy yard. Nearly everybody uses cistern water for drinking and cooking. Large cis- 
terns have been constructed at the navy yard and the United States Military Reservation and private dwellings are similarly equipped. Three plants in the city sell distilled water manufactured from ocean or well water.

On the southern coast of the mainland and on the west coast keys in Monroe County there is little chance of finding fresh water by drilling. The hard limestones underlying the surface marls are undoubtedly underlain at no great depth by marls and sands filled with brackish or salt water. Drilling through these marls and sands is likely to prove difficult and expensive, and the saltness of the water from the deep well at Marco offers no hope for fresh water at points along the shores of the Gulf or of the Bay of Florida. Enough work has been done on the keys south of the bay to show how slight is the chance of getting potable supplies from deep wells. This is particularly true of Key West, where remoteness from the mainland and especially from any region elevated enough to supply water under pressure sufficient to carry it under the Bay of Florida, and the saltness of the water found by the wells already sunk, indicate that deep drilling will prove futile.

Typical wells of Monroe County.

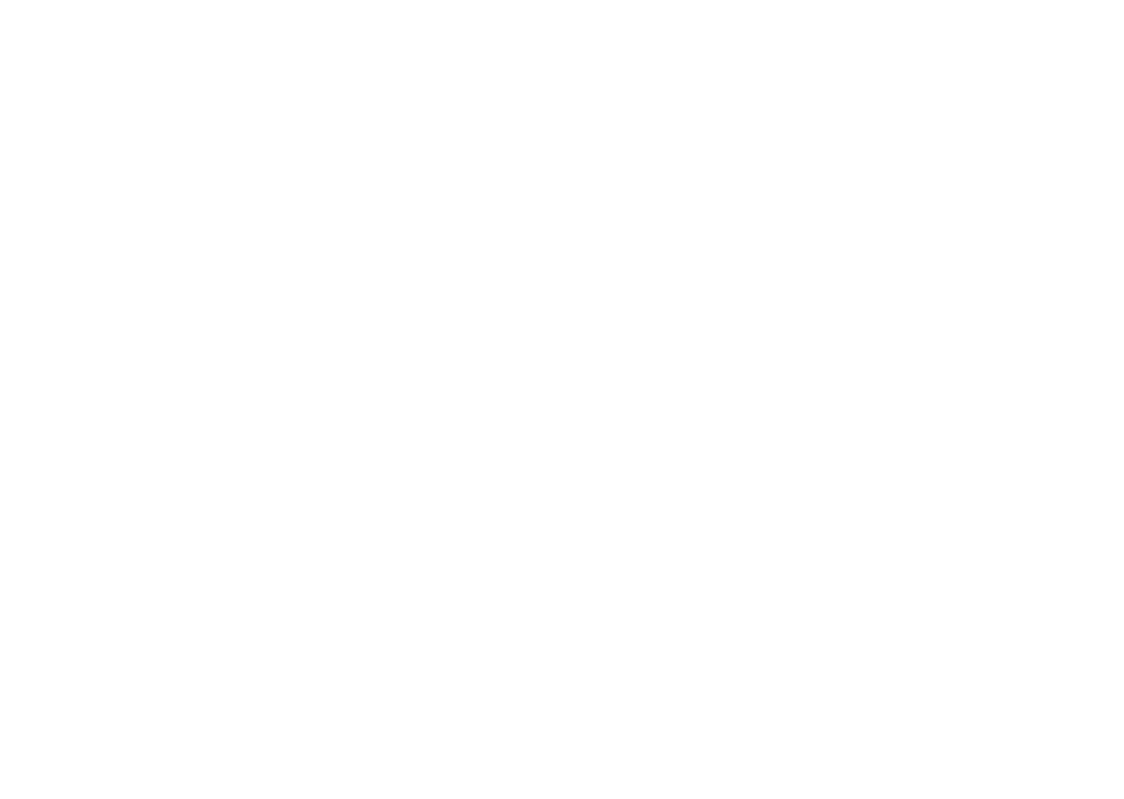




\section{NASSAU COUNTY.}

By G. C. Matson.

\section{GENERAL FEATURES.}

Nassau County comprises a tract of moderate elevation in the extreme northeast corner of Florida, between St. Marys River and the ocean. A large part of its surface is flat and rises only a few feet above sea level. This lowland area represents a broad terrace formed beneath the sea; most of its surface is less than 25 feet above sea level.

Near the western edge of the county a tract of higher land, with an altitude of 40 to 60 feet, represents another terrace. A third terrace, still farther inland, is 70 to 100 feet in altitude and forms a relatively narrow plain extending northward from the south line of the county.

Several streams of moderate size head in the county and flow either to St. Marys River or directly to the ocean.

Sink-hole topography, such as characterizes the lake region in the central part of the peninsula, is notably lacking in Nassau County. Some broad tracts of poor drainage form more or less extensive swamps, the largest being in the northwest. The county includes a large island (Amelia), which is separated from the mainland by a narrow sound known as Amelia River.

\section{GEOLOGY.}

Gray Pleistocene sand thinly mantles the surface of the county and more or less completely obscures the underlying formations. Beneath the Pleistocene sands are red and yellow sands and sandy clays, which have been correlated with the Lafayette (?) formation farther westward. These sands and sandy clays are referred tentatively to the Pliocene, but the absence of fossils makes their correlation more or less uncertain. At intervals along St. Marys River in the western part of the county dense gray limestone, marly clays, and some sand of uncertain age are exposed.

The Hawthorn formation and the Vicksburgian limestones are deeply buried by younger formations, but they doubtless underlie the entire county at a depth of a few hundred feet.

In thickness the Pleistocene sands are generally thin, in few places exceeding 20 to 25 feet. The underlying red and yellow sands may reach a thickness of 20 to 30 feet, and the limestones, sands, and clays of the Jacksonville and Hawthorn formations probably attain a maximum thickness of over 500 feet. However, but little definite information concerning the thickness of any of the subsurface formations can be obtained. The Vicksburgian limestones are known to 
attain a thickness of several hundred feet in the counties to the south and they are probably equally thick in Nassau County.

Log of city waterworks well at Fernandina.

\begin{tabular}{|c|c|c|}
\hline & Thickness. & Depth. \\
\hline Sand and shale..... & Feet. & $\begin{array}{l}\text { Feet. } \\
120\end{array}$ \\
\hline $\begin{array}{l}\text { Rock .... } \\
\text { Sand and clay.................. }\end{array}$ & & $\begin{array}{l}125 \\
135\end{array}$ \\
\hline Sand.............................. & & $\begin{array}{l}1805 \\
185\end{array}$ \\
\hline 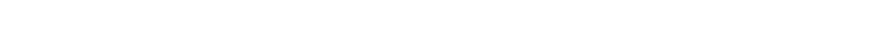 & & \\
\hline Green clay....... & 112 & 512 \\
\hline $\begin{array}{l}\text { Rock } \\
\text { Blue clay } \ldots \ldots \ldots \ldots\end{array}$ & 27 & 544 \\
\hline 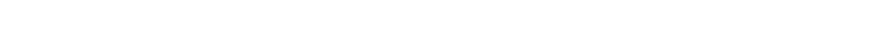 & 22 & 566 \\
\hline Shell and "coral" rock, water-bearing; flow 28,000 gallons per hour............ & & \\
\hline
\end{tabular}

WATER SUPPLY.

Source.-The Pleistocene and Pliocene sands of Nassau County supply large quantities of water at a moderate depth. The Jacksonville formation furnishes more or less water at varying depths, but the supplies are seldom utilized because they do not have sufficient head to furnish flows except possibly on very low ground. The Vicksburgian limestones are the best water-bearing rocks and they supply a large quantity of water for flowing wells at numerous points on the lower terraces. The exact height to which the water will rise has not been determined but is probably at least 50 to 60 feet above sea level.

Quality.-The water from the Pleistocene and Pliocene sands is soft and is usually regarded as satisfactory for all general purposes. The deeper supplies are all hard and most of them contain hydrogen sulphide. Very deep wells in this county, like the deepest wells in Jacksonville, would doubtless find salt water.

Development.-Most of the water used for ordinary domestic and farm purposes is obtained from wells 5 to 30 feet in depth.

One of the city wells at Fernandina, only 110 feet deep, probably draws its water supply from the Jacksonville formation. All the other deep wells reported in the county appear to obtain water from the Vicksburgian limestones and the supplies are usually large. Good flows can be obtained except on some of the high land in the western part of the county.

Both Callahan and Fernandina have public water supplies from deep wells. At Callahan water is obtained from a single well about 600 feet in depth and 3 inches in diameter; there is no pumping plant, the pressure being supplied by the artesian head. At Fernandina two wells, 731 to 733 feet deep, supply a large system with water ample for all purposes.

No large springs are reported from Nassau County, but small ones are numerous. 
Typical wells of Nassau County .

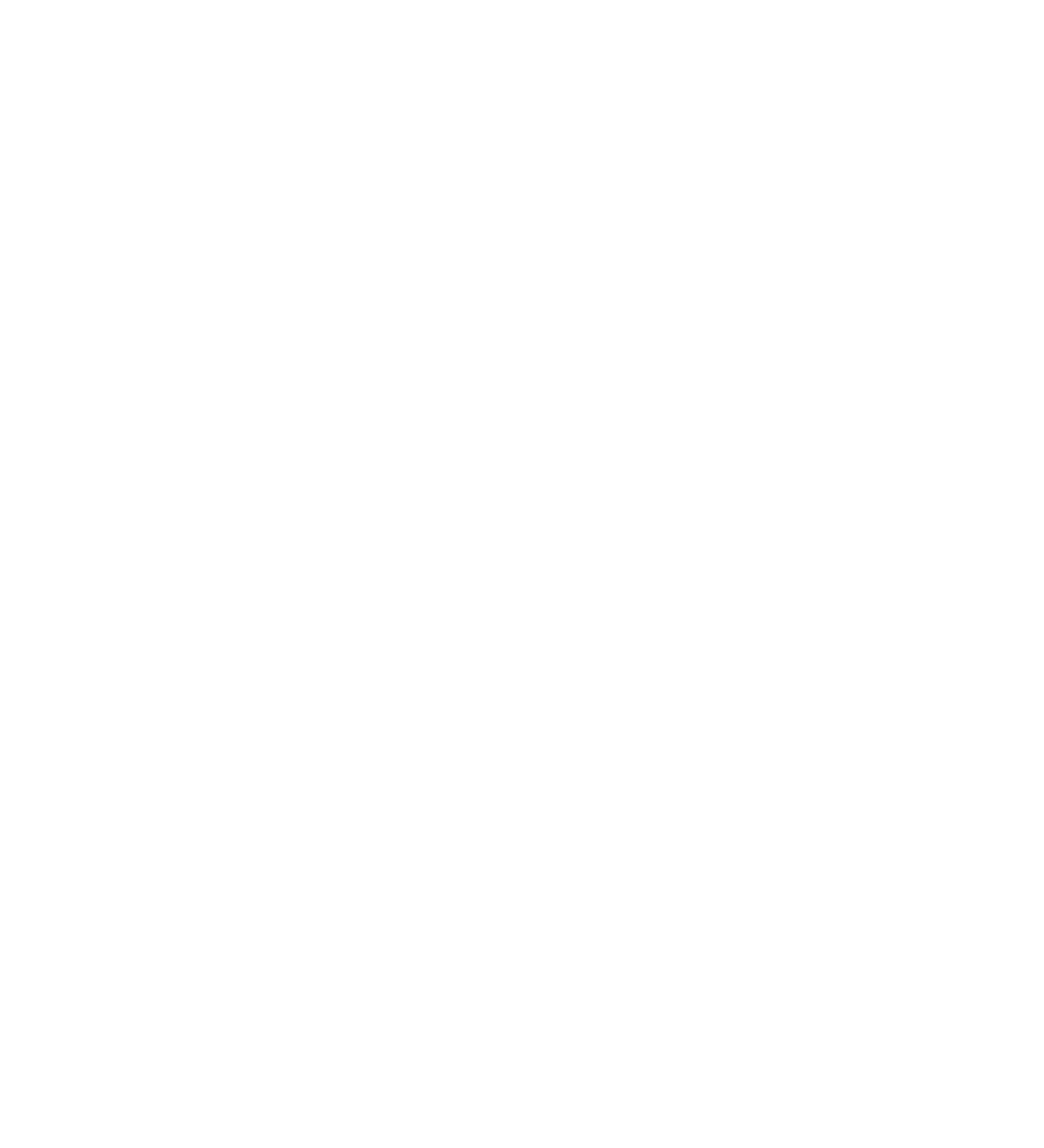

$a$ Estimated.

General water supplies in Nassau County.

\begin{tabular}{|c|c|c|c|c|c|c|}
\hline \multirow{2}{*}{ Town. } & \multirow{2}{*}{$\begin{array}{l}\text { Topographic } \\
\text { location. }\end{array}$} & \multirow{2}{*}{ Source of water. } & \multirow{2}{*}{$\begin{array}{l}\text { Surface forma- } \\
\text { tion. }\end{array}$} & \multicolumn{3}{|c|}{ Shallow wells. } \\
\hline & & & & Depth. & Supply. & $\begin{array}{c}\text { Principal water } \\
\text { beds. }\end{array}$ \\
\hline $\begin{array}{l}\text { Callahan. } \\
\text { Fernan- } \\
\text { dina. }\end{array}$ & $\begin{array}{l}\text { Plain............ } \\
\text { Low sand } \\
\text { dunes. }\end{array}$ & $\begin{array}{l}\text { Public and shallow } \\
\text { wells; cisterns: } \\
\text { Public supply, } \\
\text { shallow wells; } \\
\text { deep wells and } \\
\text { cisterns. }\end{array}$ & $\begin{array}{l}\text { Pleistocene.... } \\
\text {.....do......... }\end{array}$ & $\begin{array}{l}\text { Feet. } \\
10-30 \\
5-20\end{array}$ & $\begin{array}{l}\text { Moderate...... } \\
\text { Ample........ }\end{array}$ & $\begin{array}{c}\text { "Peninsular" } \\
\text { limestone. } \\
\text { Do. }\end{array}$ \\
\hline
\end{tabular}


General water supplies in Nassau County-Continued.

\begin{tabular}{|c|c|c|c|c|c|c|c|}
\hline \multirow{2}{*}{ Town. } & \multicolumn{3}{|c|}{ Deep wells. } & \multirow{2}{*}{$\begin{array}{l}\text { Thickness } \\
\text { of sand. }\end{array}$} & \multirow{2}{*}{$\begin{array}{l}\text { Depth to } \\
\text { water. }\end{array}$} & \multirow{2}{*}{$\begin{array}{l}\text { Increase or } \\
\text { decrease of } \\
\text { supply. }\end{array}$} & \multirow{2}{*}{ Sewerage system. } \\
\hline & Depth. & Supply. & $\begin{array}{c}\text { Head above } \\
\text { sea. }\end{array}$ & & & & \\
\hline $\begin{array}{l}\text { Callahan } \\
\text { Fern a n- } \\
\text { dina. }\end{array}$ & $\begin{array}{c}\text { Feet. } \\
600 \pm \\
730-760\end{array}$ & $\begin{array}{l}\text { Large..... } \\
\ldots . . \text { do..... }\end{array}$ & $\begin{array}{r}\text { Feet. } \\
35+ \\
2\end{array}$ & $\begin{array}{r}\text { Feet. } \\
30 \\
120\end{array}$ & Feet. & $\begin{array}{l}\text { None...... } \\
\text {...do...... }\end{array}$ & $\begin{array}{l}\text { None. } \\
\text { Discharges in to } \\
\text { river. }\end{array}$ \\
\hline
\end{tabular}

\section{ORANGE COUNTY.}

By G. C. Matson.

\section{GENERAL FEATURES.}

Orange County occupies a large area near the eastern border of the peninsula. It lies partly in the lake region and extends eastward to St. Johns River, where a belt of lowland forms a broad terrace. This terrace is less than 25 feet above sea level and rises abruptly to a more extensive plain 40 to 60 feet above the sea. Toward the west another terrace rises to a height of 70 to 100 feet, and this terrace is bordered by the elevated lands in the central and western portions of the county. The upland rises to over 100 feet above the ocean and is marked by numerous depressions occupied by lakes. The largest of these bodies of water-Lake Apopka-lies partly in Lake County. Small lakes are numerous in the central part of the county and extensive swamps occur farther eastward.

A large depression near Orlando formerly drained through an open sink. A few years ago the opening became clogged and the depression filled with water, submerging a portion of a suburb known as Jonestown. It finally became necessary to sink wells to drain the depression, and according to Sellards ${ }^{1}$ five of these wells are still in operation. Four of them are near the original sink, where they reach an underground channel at a depth of 140 feet, and the fifth is one-half mile west of the sink, where porous rock was encountered at 340 feet.

\section{GEOLOGY.}

The surface deposits of Orange County consist of gray Pleistocene sand, underlain by yellow sands and sandy clays derived from the weathering of the subjacent rocks. The northwestern part of the county is covered by the limestones, clays, and sands of the Alum Bluff and Hawthorn formations. Near the northwest corner of the county the Hawthorn formation is thin, but it thickens toward the southeast, where it dips beneath younger beds. The surface sands in the southern and southeastern parts of the county conceal

1 Sellards, E. H., Preliminary report on the underground water supply of central Florida: Eull. Florida State Geol. Survey No. 1, 1908, p. 63. 
the older formations, but the presence of Pleistocene, Pliocene, and Miocene shell marls in the wells at Kissimmee suggests that these beds are probably represented in eastern and southern Orange County; however, satisfactory exposures or well samples are lacking. The Vicksburgian limestones underlie the entire county and may reach the surface at some localities northwest of Orlando. They are buried beneath the younger formations toward the eastern edge of the county.

The thickness of the surficial sands is in few places great. The Pleistocene gray sand probably averages less than 25 feet, except near the southern edge of the county, where it is much thicker. The yellow residual sands are commonly less than 20 feet thick. The thickness of the Alum Bluff and the Hawthorn formations is in few places great, but the underlying Vicksburgian limestones probably have a total thickness of several hundred feet.

WATER SUPPLY.

Source.-In Orange County the Pleistocene gray sand and the residual sands and clays form an important source of water for shallow wells. Deeper wells commonly penetrate the Vicksburgian limestones, though in some localities they stop short of these beds, and in such places they obtain water from porous rocks belonging to the Alum Bluff or Hawthorn formations. In the southeastern parts of the county the Pliocene and Miocene beds may be valuable aquifers, but as yet that region has not been settled, and their water value has not been determined.

Quality.-The surficial deposits furnish an abundance of soft water. The deep water beds, especially those in the Vicksburgian limestones, furnish hard water that may contain sulphur and, in the deepest beds, doubtless does contain salt. However, the Vicksburgian limestones furnish the best water in the county because they are free from danger of contamination by polluted surface drainage except where impure water is permitted to enter the ground through open sinks or drainage wells.

Development.-Shallow wells, ranging in depth from 7 to 40 feet, are uniformly successful in this county. The water level is in few places more than 8 to 15 feet from the surface, but in the vicinity of Lake Mary and elsewhere on high ground it is from 20 to 35 feet deep.

The deep wells range in depth from 65 to 550 feet, but they are commonly from 100 to 200 feet. They obtain large supplies, and in St. Johns Valley the head is sufficient to give flows on ground less than about 20 feet above the river. Good flows are reported from wells near Lakes Monroe and Jessup. The area near Lake Monroe contains several hundred wells, in or near the city of Sanford, most of which are used for subirrigation of market gardens, a purpose for which the water is admirably adapted because it has a uniform 
temperature, which promotes the growth of the vegetables and prevents their being harmed by slight frosts. The large demands on the artesian beds at this locality may lower the head and diminish the quantity of water, but as yet no change has been noted. Outside St. Johns Valley the head of the water brings it so near to the surface that it can be pumped with ease, and hence irrigation is extensively practiced. In some localities shallow wells supply water for irrigation, and the yield of such wells is often large.

There are some excellent springs in Orange County, though but few of them are used. In the largest, Wekiva Spring or Clay Spring, located 5 miles northeast of Apopka, the water emerges in a basin about 30 feet in depth and forms a good-sized stream tributary to St. Johns River. The spring is owned by Judge W. S. Bullock. A hotel and a bathhouse have been built at the spring. The water, which is from the Vicksburgian limestone, is hard and contains some sulphur. Its temperature is about $75^{\circ} \mathrm{F}$. The flow is constant and the water is not muddy after rains. (See Pl. XVII, $B$, p. 234.) A number of other large springs exist in this part of the county. At Altamonte Springs a small spring is used to supply a hotel.

Sanford and Orlando have public water supplies that are regarded as satisfactory; at each the water is taken from a lake, though Sanford has an auxiliary supply from wells. The lake water is soft, but the wells at Sanford furnish a hard sulphur water, a fact which probably accounts for the use of the lake water.

General water resources of Orange County.

\begin{tabular}{|c|c|c|c|c|c|c|c|}
\hline \multirow[b]{2}{*}{ Town. } & \multirow[b]{2}{*}{$\begin{array}{c}\text { Topographic } \\
\text { location. }\end{array}$} & \multirow[b]{2}{*}{ Source of water. } & \multirow[b]{2}{*}{$\begin{array}{c}\text { Surface } \\
\text { forma- } \\
\text { tion. }\end{array}$} & \multicolumn{4}{|c|}{ Shallow wells. } \\
\hline & & & & Depth. & Supply. & $\begin{array}{c}\text { Quality } \\
\text { of } \\
\text { water. }\end{array}$ & $\begin{array}{c}\text { Principal } \\
\text { water beds. }\end{array}$ \\
\hline Apopka. & Plain. & Driven and dug & Pleisto- & $\begin{array}{l}\text { Feet. } \\
10-40\end{array}$ & Ample. & Soft.. & "Peninsular' \\
\hline $\begin{array}{l}\text { Fort Reed....... } \\
\text { Goldsboro...... }\end{array}$ & $\begin{array}{l}\text { Ridge... } \\
\text { Plain... }\end{array}$ & $\begin{array}{l}\text { wells. } \\
\text { Driven wells........ } \\
\text { Drilled and driven }\end{array}$ & $\begin{array}{c}\text { cene. } \\
\ldots \text { do } \ldots . . . \\
\cdots \text { do..... }\end{array}$ & $\begin{array}{r}12-20 \\
7-15\end{array}$ & Good.... & ‥do.. & $\begin{array}{l}\text { Do. } \\
\text { Do. }\end{array}$ \\
\hline $\begin{array}{l}\text { Lake Mary ... } \\
\text { Longwood... } \\
\text { Maitland..... }\end{array}$ & $\begin{array}{l}\text {.....do........ } \\
\text { Gently undu- }\end{array}$ & 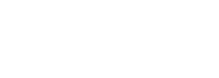 & $\begin{array}{l}\ldots \text { do } \ldots \\
\ldots \text { do.... } \\
\ldots \text { do.... }\end{array}$ & $\begin{array}{l}21-40 \\
15-35 \\
20-30\end{array}$ & $\begin{array}{l}\text {.do..... } \\
\text { Ampie. } \\
\text { Moderate }\end{array}$ & \begin{tabular}{l}
..do.. \\
\hdashline do... \\
$\cdots$ do..
\end{tabular} & $\begin{array}{l}\text { Do. } \\
\text { Do. } \\
\text { Do. }\end{array}$ \\
\hline Осоее..... & $\begin{array}{l}\text { lating plain } \\
\text { Plain....... }\end{array}$ & $\begin{array}{l}\text { drilled wells. } \\
\text { Driven and dug }\end{array}$ & $\because$ do... & $12-20$ & Ample. & ...do.. & Do. \\
\hline Orlando.. & & $\begin{array}{l}\text { wells. } \\
\text { Driven and drilled }\end{array}$ & ...do... & $10-35$ & & & \\
\hline Do... & Plain....... & Public supply and & $\ldots$ do.... & $15-25$ & & Good.. & Do. \\
\hline Oviedo...... & Gentleslope. & Dug and drilled & ...do... & $12-35$ & & Soft... & Do. \\
\hline Sanford... & Plain....... & $\begin{array}{l}\text { wrilled wells, public } \\
\text { supply; driven }\end{array}$ & ...do... & $17-25$ & Ample.. & ...do.. & Do. \\
\hline Spears Grove.. & ....do...... & Driven and drilled & ...do... & $8-15$ & Good... & ...do.. & Do. \\
\hline Winter Park. & Gently undu- & Driven and drilled & ...do... & $19-37$ & Moderate & ...do.. & Do. \\
\hline Winter Garden. & $\begin{array}{l}\text { 1aing ptain } \\
\text { Plain........ }\end{array}$ & Driven wells.. & ...do... & $14-27$ & Ample.. & ...do.. & Do. \\
\hline
\end{tabular}


Typical wells of Orange County.

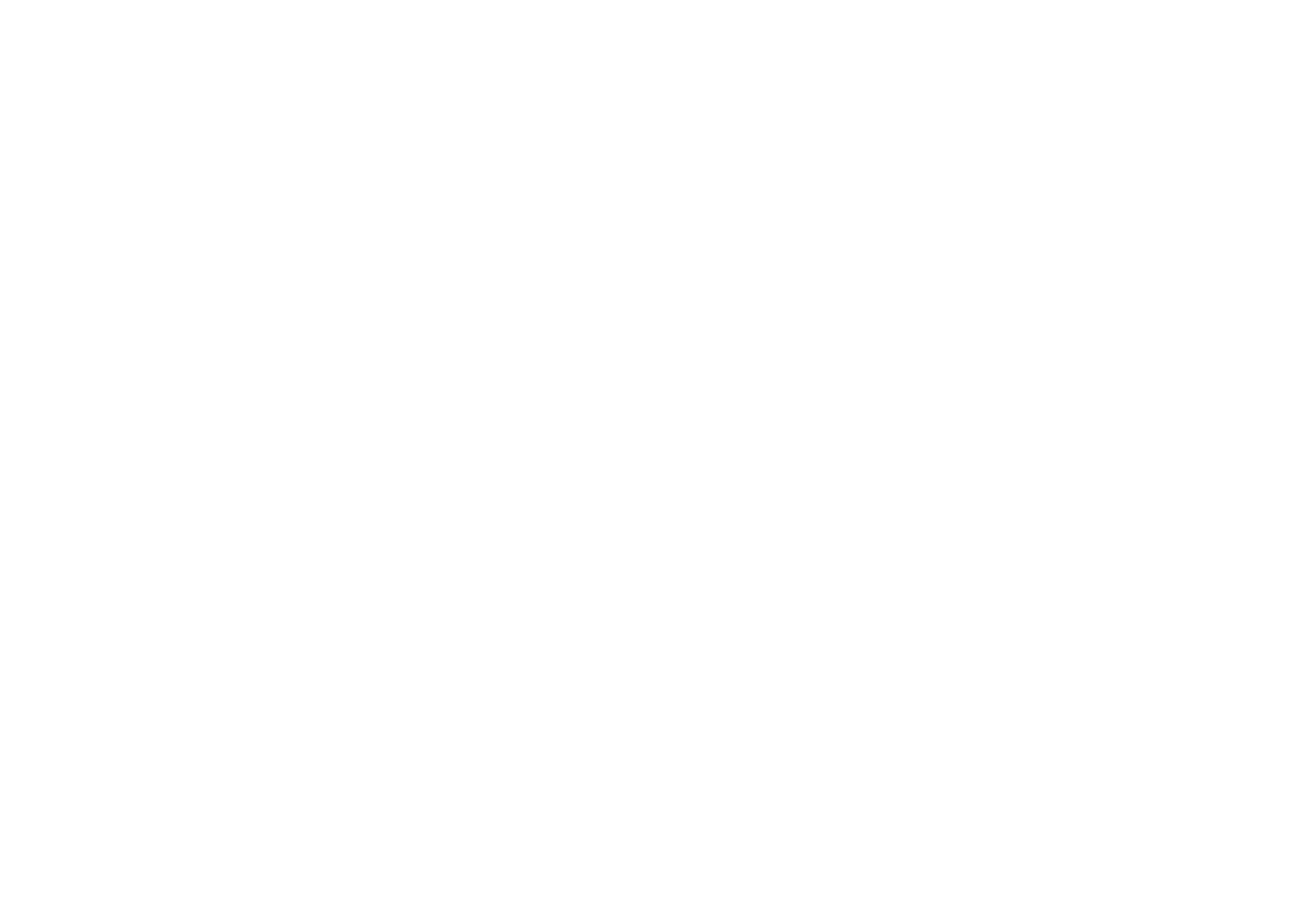


General water resources of Orange County-Continued.

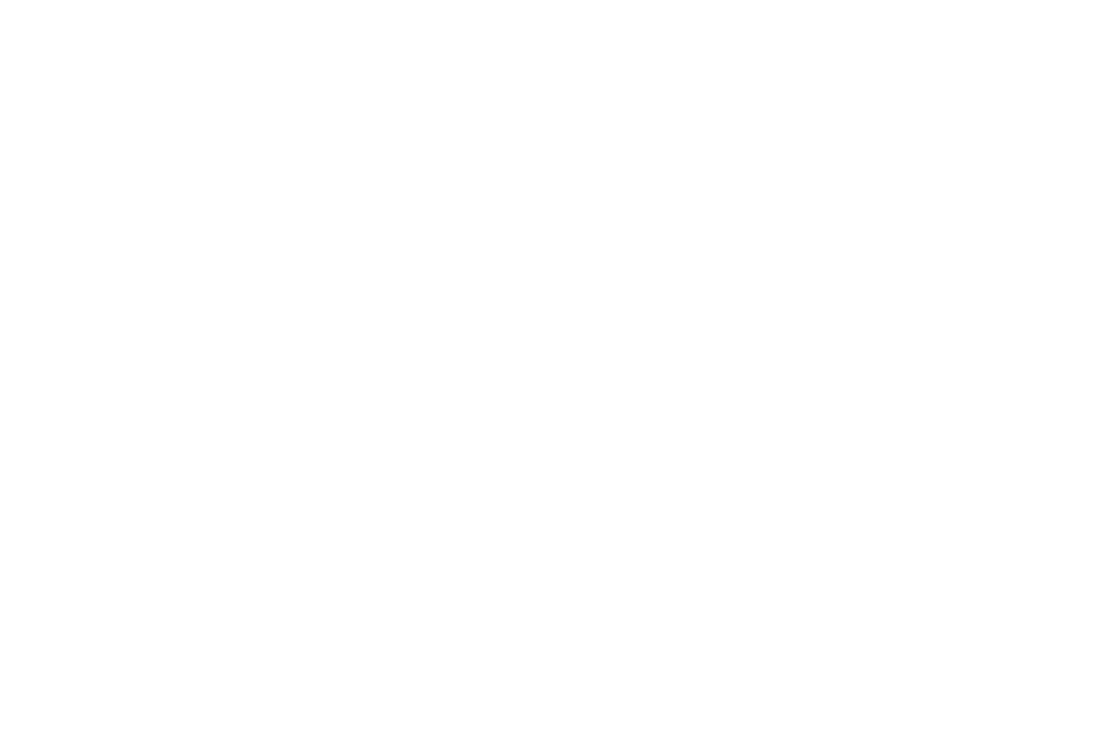

\section{OSCEOLA COUNTY.}

By G. C. Matson.

\section{GENERAL FEATURES.}

Osceola County lies between St. Johns and Kissimmee rivers and extends from Lake Okechobee northward nearly 75 miles. The surface includes three broad terraces, which are believed to represent former levels of the sea. The lowermost of these terraces is from 20 to 40 feet above sea level and extends from Lake Okechobee a short distance northward. In the eastern part of the county this terrace probably appears in the St. Johns Valley. The second terrace has an altitude of 40 to 60 feet, and a third is represented by the broad plain upon which the town of Kissimmee is located. The upper terrace has an altitude of 70 to 100 feet above sea level, and the northwestern corner of the county probably rises above the level of this terrace.

Lake Okechobee and several of the smaller lakes occupy depressions in the sand which forms the lowermost terrace. Similar depressions in the upper terrace have given rise to lakes, among them being Lake Tohopekaliga and several smaller lakes. All the terraces contain numerous broad depressions occupied by swamps.

GEOLOGY.

The surface deposit of Osceola County consists of gray sand of Pleistocene age. Locally recent deposits of peat and muck occupy 
depressions in the sand. In the hammocks near Kissimmee River Eldridge found fragments of limestone containing fresh-water shells believed to be of Pleistocene age. In discussing the Pleistocene and Pliocene geology reference was made (p. 141) to fossils collected from wells near Kissimmee. The fossils indicated that the beds at a depth of 96 feet were Pleistocene and that those at 150 feet were Pliocene. The Miocene marl is believed to be present beneath the Pliocene. The Hawthorn formation has not been identified with certainty in any of the wells, but it probably underlies the county and is in turn underlain by Vicksburgian limestones.

Little definite information can be obtained concerning the thickness of the different geologic formations in Osceola County. One astonishing fact is the great thickness of the Pleistocene sands and shell marls. At Kissimmee, for example, these deposits are at least 96 feet thick, and the maximum may be considerably greater. At Kissimmee the 300-foot well of Franz Agnew is believed to have reached the Vicksburgian limestones, though this statement is merely tentative.

\section{WATER SUPPLY.}

Source.-The Pleistocene sands are water-bearing in Osceola County and in many places furnish good supplies within a few feet of the surface. Both Pliocene and Miocene sands and marls probably yield abundant water, and some of the flows south of Kissimmee are believed to be furnished by these formations. Nothing is known concerning the water capacity of the Hawthorn formation, but the Vicksburgian limestones should furnish abundance, with sufficient head to give good flows on low ground.

Quality.-The water from the Pleistocene sand is soft. The beds of Pliocene and Miocene age and the Vicksburgian limestones furnish water which is moderately hard and is usually salty.

Development.-At Kissimmee wells at 4 to 15 feet deep obtain water, and good supplies could probably be obtained in all parts of the county within 40 or 50 feet of the surface. Several deep wells are less than 150 feet in depth, and only a few wells exceed 300 feet. Good flows can be obtained where the surface does not rise more than 72 feet above sea level, and in some places flows have been obtained on slightly higher ground.

Although no attempts have been made to procure flowing water near the southern end of the county, there is little doubt that flows could be obtained. The water, however, might be too saline for use. This is inferred from the fact that the salinity appears to increase toward the south, the wells south of Kissimmee containing much more salt than those at the town. 
Typical wells of Osceola County.

\begin{tabular}{|c|c|c|c|c|c|c|c|c|c|c|c|c|c|c|c|c|c|c|}
\hline $\begin{array}{l}\text { Nearest town } \\
\text { or post office. }\end{array}$ & $\begin{array}{l}\text { Direction and dis- } \\
\text { tance. }\end{array}$ & Owner. & Driller. & $\begin{array}{l}\text { Date } \\
\text { sunk. }\end{array}$ & $\begin{array}{c}\text { Surface forma- } \\
\text { tion. }\end{array}$ & Geologic source. & $\begin{array}{l}\text { Type of } \\
\text { well. }\end{array}$ & Use. & Depth. & \begin{tabular}{|c|} 
Diame- \\
ter.
\end{tabular} & Casing. & $\begin{array}{c}\text { Fleva- } \\
\text { tion } \\
\text { above } \\
\text { sea. }\end{array}$ & \begin{tabular}{|c} 
Head \\
above \\
or \\
below \\
surface.
\end{tabular} & Depth & $\begin{array}{c}\text { Depth } \\
\text { to prin- } \\
\text { cippal } \\
\text { supply. }\end{array}$ & $\begin{array}{l}\text { Mineral character of } \\
\text { water. }\end{array}$ & $\begin{array}{c}\text { Depth } \\
\text { to } \\
\text { second } \\
\text { sup- } \\
\text { plies. }\end{array}$ & $\begin{array}{l}\text { Yield per } \\
\text { minute. }\end{array}$ \\
\hline Campbell. & $\$$ mile north..... & Bunn, Deen \& Co. $a$. & & & & & & Boiler and domestic & $\begin{array}{l}\text { Feet. } \\
130\end{array}$ & $\begin{array}{r}\text { Inches. } \\
1 \frac{1}{4}\end{array} \mid$ & Feet. & Feet. & $\begin{array}{l}\text { Feet. } \\
+2\end{array}$ & $\begin{array}{r}\text { Feet. } \\
90\end{array}$ & $\begin{array}{l}\text { Feet. } \\
130\end{array}$ & Sulphur.. & Feet. & Gallons. \\
\hline Kissimmee. & 2 miles southeast. & Franz Aguew.: & & & Pleistocene.. & Vicksburgian lime- & Drilled.. & Domestio and irriga- & 300 & 4 & $\cdots$ & 665 & & & 150 & & & \\
\hline & & 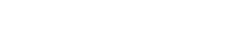 & $\begin{array}{l}\text { Frank Bass.......... } \\
\text { John Anderson. }\end{array}$ & $\begin{array}{l}1901 \\
1901\end{array}$ & …do ..... & 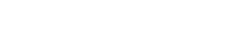 & \begin{tabular}{l}
.....do...... \\
\hdashline$\ldots$ do.....
\end{tabular} & $\begin{array}{l}\text { thon. } \\
\text { Dometic and stock... }\end{array}$ & $\begin{array}{l}196 \\
184\end{array}$ & $\begin{array}{c}13 \\
13 \\
1 \\
\end{array}$ & $\begin{array}{l}113 \\
135\end{array}$ & $\begin{array}{ll}b & 65 \\
b & 65\end{array} \mid$ & $\begin{array}{l}-1 \\
-5\end{array}$ & & 120 & Sulphur... & $8+$ & $\begin{array}{l}\text { Few. } \\
\text { Several. }\end{array}$ \\
\hline $\begin{array}{l}\text { Do... } \\
\text { Do.. }\end{array}$ & 4 miles south........... & 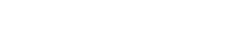 & N. F. Bass....... & $\begin{array}{l}1898 \\
1900\end{array}$ & $\begin{array}{l}\ldots . . . \text { do... } \\
\ldots \ldots \text {...do.. }\end{array}$ & Pleistocene & $\begin{array}{l}\text { Driven..... } \\
\text { Drilled.... }\end{array}$ & 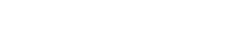 & $\begin{array}{l}132 \\
100\end{array}$ & $\begin{array}{c}2_{2}^{2} \\
1 \frac{1}{4}\end{array}$ & $\begin{array}{r}132 \\
96\end{array}$ & $\begin{array}{c}a \\
b\end{array}$ & & & & a....do.: & & $\begin{array}{l}15 \text { and } 16 . \\
\text { Few }\end{array}$ \\
\hline $\begin{array}{l}\text { Do... } \\
\text { Do... }\end{array}$ & & County-... & Anderson.... & 1907 & & & & Domestic............................. & $\begin{array}{l}180 \\
309\end{array}$ & $\frac{12}{4}$ & 140 & $\begin{array}{l}b 65 \\
65\end{array}$ & $-\frac{1}{4}$ & & $\begin{array}{l}140 \\
140\end{array}$ & 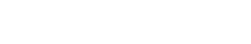 & 10 & Several. \\
\hline Do...... & Near..... & 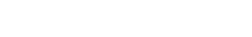 & co. Newlands.. & & Plaistocene... & Miocene.... & Drilled... & 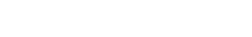 & 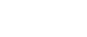 & 4 & & 665 & $+1+$ & 140 & & sulphur, slight salt... & & Many. \\
\hline $\begin{array}{l}\text { Do.... } \\
\text { Do }\end{array}$ & & $\begin{array}{l}\text { Kissimmee Lumber Co } \\
\text { John M. Lee.................. }\end{array}$ & $\begin{array}{l}\text { John Anderson..... } \\
\text {. }\end{array}$ & 1907 & …do $\ldots \ldots$. & ….do & …..do..... & $\begin{array}{l}\text { Drinking } \\
\text { Domestic and stock. }\end{array}$ & $\begin{array}{l}144 \\
176\end{array}$ & $\begin{array}{c}1 \frac{1}{2} \\
1 \frac{3}{3}\end{array}$ & $\begin{array}{r}60 \\
140\end{array}$ & $\begin{array}{l}c 55 \\
b 65 \\
b 65\end{array}$ & $\begin{array}{l}+4 \\
-1\end{array}$ & & $\begin{array}{l}120 \\
140\end{array}$ & $\begin{array}{l}\text { Sulphur, slight........ } \\
\text { Sulonur, }\end{array}$ & $\begin{array}{l}10+ \\
10+\end{array}$ & Few. \\
\hline & Bec. $13, \mathrm{~T}, 27 \mathrm{~S}, \mathrm{R}$ & Lee Parsons Cattle Co. & c. O. Newlands... & & …...do........ & Pleistocene............ & …............ & Stock..................... & & $1 \frac{2}{4}$ & & & +1 & & & Sulphur, slight sait... & & Many. \\
\hline $\begin{array}{l}\text { Do... } \\
\text { Do... }\end{array}$ & Seed 18, , T. 27 s., & $\begin{array}{l}\text {....do. } \\
\text { a.do. }\end{array}$ & \begin{tabular}{l}
....do $\ldots \ldots \ldots \ldots . .$. \\
\hdashline$\ldots$ do
\end{tabular} & & ...do- & Miocene? & do.. & ...do & 97 & $\frac{14}{2}$ & & & +1 & & & $\ldots d c$ & & Many. \\
\hline Do... & $\begin{array}{l}\text { R. } 29 \mathrm{E} \\
\text { R.do }\end{array}$ & ....do.. & ......do. & & & ....do.? & & do & 349 & & & & & & & do & & Many. \\
\hline & sec. 30, T. 27 s., & $\begin{array}{l}\text {....do... } \\
\text { …do.. }\end{array}$ & $\begin{array}{l}\ldots \text { ado.: } \\
\cdots \cdots \text { do }\end{array}$ & & ר......... & 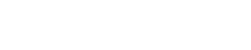 & 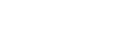 & $\begin{array}{l}\cdots \text {...do } \ldots \\
\cdots \cdots \text {.do } \ldots \\
\cdots \cdots\end{array}$ & $\begin{array}{l}210 \\
200 \\
226\end{array}$ & $\begin{array}{l}\frac{1}{2} \\
\frac{1}{2} \\
1 \frac{1}{4}\end{array}$ & & & $\stackrel{+}{+}$ & & & $\begin{array}{l}\text { a.d.do. } \\
\text { …do. } \\
\cdots \ldots \text { do. }\end{array}$ & $\cdots$ & $\begin{array}{l}\text { Many. } \\
\text { Many. }\end{array}$ \\
\hline Do..... & Sec. 6 , T. 28 S., R. & ....do............... & .....do.... & & ....do..... & Pleistocene.......... & .....do.... & .....do.... & 65 & $1 \frac{1}{4}$ & & & + & & & .....do.... & & Many. \\
\hline & 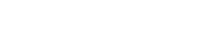 & ...do do.............. & & & 年 & $\ldots . .0$ & & $\ldots . . d$ & 70 & $1 \frac{1}{4}$ & & & $t$ & & & .....do.. & & Many. \\
\hline & Sec. 27, T. 27 S., & $\ldots$...do.... & W...do. & & ...do. & .... do- & ...do. & .....do. & 60 & $1 \frac{1}{4}$ & & & t & & & …do. & & Many. \\
\hline Do.. & 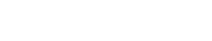 & ....do........ & .....do...... & & ...do... & .....do.... & ...do... & ....do... & 55 & $1 \frac{1}{4}$ & & & + & & & .....do..... & & Many. \\
\hline Do... & Sec. $30, T .27 \mathrm{~s}$., & ....do......... & .....do..... & & .....do... & & .....do.... & .....do........ & 210 & $1 \frac{1}{4}$ & & & + & & & .....do... & & Few. \\
\hline Do..... & Sec. 14, T. $27 \mathrm{~S}$. , & .....do............. & .....do...... & & .....do.... & & .....do.... & .....do........ & 160 & $1_{4}^{1}$ & & & + & & & .....do..... & & Several. \\
\hline Do... & …do...................... & .....do.......... & .....do... & & .....do.... & Vicksburgian lime- & .....do.... & Domestic and stock. . & 600 & 6 & $400+$ & ${ }^{b} 72$ & $-1 \frac{1}{2}$ & & 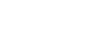 & Sulphur................. & & Several. \\
\hline $\begin{array}{l}\text { Do......... } \\
\text { Do........ }\end{array}$ & 8 miles south....... & $\begin{array}{l}\text { W. A. McCool. } \\
\text { Moon \& Adams Colery }\end{array}$ & 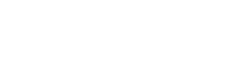 & 1908 & $\begin{array}{l}\text {....do.... } \\
\ldots \text { do.. }\end{array}$ & 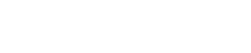 & $\begin{array}{l}\ldots . . \text { do } \ldots . . . \\
\ldots . . \text { do.... }\end{array}$ & 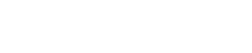 & $\begin{array}{l}415 \\
265\end{array}$ & ${ }_{4}^{2}$ & $\begin{array}{l}150 \\
145\end{array}$ & $\begin{array}{l}b 72 \\
b 75\end{array}$ & 一集 & & $160+$ & .....do ... & & $\begin{array}{l}\text { Several. } \\
\text { Several. }\end{array}$ \\
\hline $\begin{array}{l}\text { Do. } \\
\text { Do. }\end{array}$ & & G. F. Parker................ & N. F. Bass..... & & ....do. & $\cdots$ & ...do- & $\underset{\text { Domestic... }}{\text { Dof }}$ & 187 & & & 65 & +3 & & & Sulphur, slight salt.. & & Many. \\
\hline & & School district.... & N.C. Bryant.. & & ר...do: & Vicksburgian lime- & do. & Dṛ̛inking..... & 政 & $.4^{\frac{12}{2}}$ & 210 & 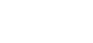 & $\begin{array}{l}+4 \\
+3+\end{array}$ & & $210+$ & 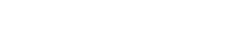 & & $\begin{array}{l}\text { Many. } \\
\text { Many. }\end{array}$ \\
\hline & क & $\begin{array}{l}\text { Atlantic Coast Line.. } \\
\text { Thurman \& Lull }\end{array}$ & ….do...... & & lo. & ....do................ & $\begin{array}{l}\text {...do. } \\
\ldots \text { do. }\end{array}$ & $\begin{array}{l}\text { Drinking and stock... } \\
\text { Hotel... }\end{array}$ & $\begin{array}{l}487 \\
400\end{array}$ & $\frac{4}{4}$ & 200 & $\begin{array}{l}65 \\
67 \\
67\end{array}-$ & $\begin{array}{l}+3+ \\
+3+\end{array}$ & & $200+$ & & & Many. \\
\hline 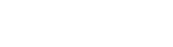 & $\begin{array}{l}1 \text { mile northwest. } \\
\text { Sec. } 19, \text { T. } 27 \mathrm{~S} .\end{array}$ & $\begin{array}{l}\text { Paul Yates } \\
\text { G. W. Hopkins a.......... }\end{array}$ & Anderson.. & 1905 & . & & & $\begin{array}{l}\text { Domestic................. } \\
\text { Stock. }\end{array}$ & $\begin{array}{l}\frac{140}{262} \\
-\end{array}$ & ${ }_{4}^{1 \frac{1}{4}}$ & 120 & $\begin{array}{l}b 60 \\
20\end{array}$ & $\mid \begin{array}{l}+1 \\
+6\end{array}$ & 96 & 120 & Sulphur. & 7 & $\begin{array}{l}\text { Reveral. } \\
\text { Severa }\end{array}$ \\
\hline Narcosse日..... & 2 miles north....... & E. Nelson Fell .......... & C. $O$. Nowlands... & & Pleistocene.. & & Drilled... & Domestic and stock.... & 196 & $1 \frac{1}{4}$ & $\cdots$ & e 70 & +0 & & $\cdots$ & .....do... & & Several. \\
\hline & & & & 1003 & & $\begin{array}{l}\text { stone? } \\
\text { stand }\end{array}$ & 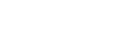 & & & & 296 & & & & 400 & & 290 & Several. \\
\hline Do..... & 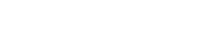 & United Land Co..... & .....do... & 1906 & .....do.... & & ....do... & ....do.. & $200 \pm$ & 2 & & c 75 & -13 & & & do. & & Several. \\
\hline
\end{tabular}


General water resources of Osceola County.

\begin{tabular}{|c|c|c|c|c|c|c|c|c|c|c|}
\hline \multirow{2}{*}{ Town. } & \multirow{2}{*}{$\begin{array}{l}\text { Topo- } \\
\text { graphic } \\
\text { location. }\end{array}$} & \multirow{2}{*}{\multicolumn{2}{|c|}{$\begin{array}{l}\text { Source of } \\
\text { water. }\end{array}$}} & \multirow{2}{*}{$\begin{array}{l}\text { Surface for- } \\
\text { mation. }\end{array}$} & \multicolumn{6}{|c|}{ Shallow wells. } \\
\hline & & & & & Depth. & \multicolumn{2}{|c|}{ Supply. } & \multicolumn{2}{|c|}{$\begin{array}{l}\text { Quality of } \\
\text { water. }\end{array}$} & $\begin{array}{c}\text { Principal } \\
\text { water beds. }\end{array}$ \\
\hline $\begin{array}{l}\text { Kissimmee... } \\
\text { Narcoossee ... }\end{array}$ & Plain.... & \multicolumn{2}{|c|}{$\begin{array}{c}\text { Driven and } \\
\text { drilled } \\
\text { wells. } \\
\ldots . . . \text { do..... }\end{array}$} & $\begin{array}{l}\text { Pleistocene.. } \\
\text {.....do...... }\end{array}$ & & \begin{tabular}{l|l}
-35 & $\ldots . . c$
\end{tabular} & le... & Sof & & $\begin{array}{c}\text { "Peninsular" } \\
\text { limestone. } \\
\text { Do. }\end{array}$ \\
\hline \multirow{2}{*}{ Town. } & \multicolumn{5}{|c|}{ Deep wells. } & \multirow{2}{*}{$\begin{array}{l}\text { Average } \\
\text { thicke } \\
\text { ness } \\
\text { of sand. }\end{array}$} & \multirow{2}{*}{\multicolumn{2}{|c|}{$\begin{array}{l}\text { Depth to } \\
\text { water. }\end{array}$}} & \multirow{2}{*}{\multicolumn{2}{|c|}{ Remarks. }} \\
\hline & Depth. & Supply. & $\begin{array}{c}\text { Head } \\
\text { (abov } \\
\text { sea). }\end{array}$ & \multicolumn{2}{|c|}{ Quality of water. } & & & & & \\
\hline $\begin{array}{l}\text { Kissimmee... } \\
\text { Narooossee... }\end{array}$ & $\begin{array}{c}\text { Feet. } \\
80-487 \\
200+\end{array}$ & $\begin{array}{l}\text { Large... } \\
\text {...do.... }\end{array}$ & $\begin{array}{l}\text { Feet. } \\
70 \pm \\
70 \pm\end{array}$ & \multicolumn{2}{|c|}{$\begin{array}{l}\text { Sulphur; some salt } \\
\text { Sulphur............... }\end{array}$} & $\begin{array}{l}\text { Feet. } \\
3-10+ \\
30 \pm\end{array}$ & \multicolumn{2}{|c|}{$\begin{array}{r}\text { Feet. } \\
-3-8 \\
8-10\end{array}$} & \multicolumn{2}{|c|}{$\begin{array}{l}\text { No sewerage system. } \\
\text { Do. }\end{array}$} \\
\hline
\end{tabular}

PALM BEACH CÖUNTY.

By Samuel Sanford.

GENERAL FEATURES.

Palm Beach County lies north of Dade County, its northern boundary extends to the north end of Lake Okechobee, and it includes within its borders a large section of the Everglades and most of the Allapattah Flats. In the southern part of the county the Everglades extend almost to the ocean shore; farther north the expanse of relatively dry land is much wider, but there are few settlements more than 10 miles from the railway along the coast. The average elevation of the surface is under 25 feet, the highest points being in the dune ridges west of Hobe Sound. Loxahatchee, Jupiter, and Hillsboro rivers are the principal streams flowing from the Everglades.

\section{GEOLOGY.}

Most of the islands or barrier beaches along the coast have coquina outcropping or lying below the Recent beach sands. Peaty deposits and marl lie in the swamps about the sounds back of the beaches. Gray sands mantle the country between the coast and the prairies along the Everglades. Inland the sands in places, notably west of Gomez, contain considerable clay. The Palm Beach limestone outcrops in a few places near the eastern margin of the Everglades and extends westward under them an unknown distance. All the above deposits are of Pleistocene age. The exact thickness of the Pliocene, Miocene, and upper Oligocene deposits is undetermined, and little is known of their structure. The samples from the Palm Beach well (p. 168) give the only recorded information regarding the depth to the Vicksburgian limestone at any point in the county. The average southeastward slope of the top of the limestone from near its outcrop in Pasco County to Palm Beach is apparently about $5 \frac{1}{2}$ feet to the mile, but 
that the top of the limestone maintains a uniform dip is very doubtful. The meager information obtained regarding the deep wells in the cattle ranges west of the Everglades in Lee County indicates that the top of the limestone is warped and is not a plane of even slope. The depth to the limestone at any point in the county except Palm Beach and its immediate vicinity can not be predicted from the data available, but it is everywhere hundreds of feet below the surface.

WATER SUPPLY.

Source.-Sands, sandy marls, coquina, and limestones, all classed as Pleistocene, are the important sources of underground supply. The Vicksburgian limestone is tapped by a few wells in the northern half of the county.

There are a few springs of no particular importance along the shores of lagoons. Most are of small flow.

Details of the deep flowing wells near Gomez, Hobe Sound, and Palm Beach are given in the table on page 384 . The log of the Palm Beach well appears on page 168. This well and the well east of Hobe Sound are of some interest, as they were sunk on islands. The wells are so deep and the bodies of water separating the islands from the mainland are so narrow that the island location does not determine the quality of the water. The water from the well near Gomez, a mile inland, was highly mineralized, according to report.

Driven or bored wells 10 to 125 feet deep yield waters that differ with the location, depth, and character of the water bed.

Two wells on Loxahatchee River are of more than average depth. One 2 miles west of West Jupiter found salt water; the driller, W. O. Weybrecht, of West Palm Beach, gave the following log:

Log of well of W. Dimmock, 2 miles west of West Jupiter.

\begin{tabular}{|c|c|c|}
\hline & Thickness. & Depth. \\
\hline 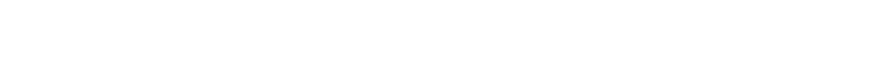 & ${ }^{\text {Feet. }}{ }_{40}$ & $\begin{array}{r}\text { Feet. } \\
40 \\
101\end{array}$ \\
\hline
\end{tabular}

Another well at an orange grove 4 miles farther west yields good, though slightly sulphureted water. The driller reported the following section:

Record of well of Leinhart \& Dimmock, 6 miles west of West Jupiter.

\begin{tabular}{|c|c|c|}
\hline & Thickness. & Depth. \\
\hline 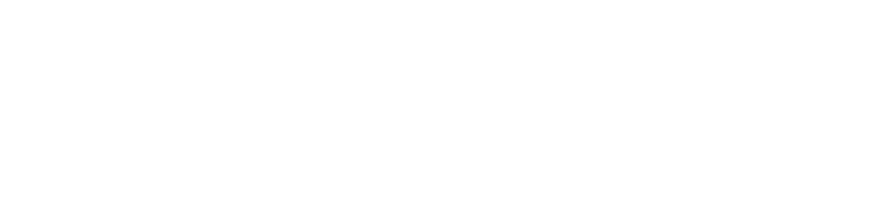 & $\begin{array}{c}\text { Feet. } \\
4.5 \\
2 \\
\mathbf{3} .5 \\
4 \\
\mathbf{3} \\
\mathbf{3} \\
\mathbf{4} \\
\mathbf{2 . 5}\end{array}$ & $\begin{array}{l}\text { Feet. } \\
4.5 \\
6.5 \\
44 \\
48 \\
51 \\
54 \\
58 \\
60.5\end{array}$ \\
\hline
\end{tabular}


The shell bed at $4 \frac{1}{2}$ feet yielded numerous well-preserved marine shells of living species.

A dug and driven well 65 feet deep on top of the dune ridge back of Hobe Sound station yields excellent water.

In the vicinity of Palm Beach and West Palm Beach are many shallow wells and a number 50 feet or more deep. Those at West Palm Beach are reported to show decided differences in depth to rock at points a short distance apart. One of several at the ice plant shows the following succession, according to the driller:

Record of well at ice plant, West Palm Beach.

Sand, hard, gray.

Quicksand, with reddish sand at $28-30$ feet

Sandrock

\begin{tabular}{|r|r} 
Thicknoss. & Depth. \\
\hline Feet. & Feet. \\
20 & 20 \\
12 & 32 \\
18 & 50 \\
\hline
\end{tabular}

Three water-bearing beds are reported at West Palm Beach within 100 feet of surface. The above well tapped the second. Most driven wells go to the first at about 10 feet.

A mile west of West Palm Beach the Model Land Co. sunk two wells in search of a possible supply for the city and for Palm Beach. 'The wells were not developed. The following $\log$ is compiled from the notes of the driller, $\mathrm{H}$. Walker, and from samples. The sands are siliceous.

Record of No. 2 well of Model Land Co., a mile west of West Palm Beach.

Sand, fine to medium, yellowish

Sand, and marine shells (shell marl)

Sand, with hard nodules and shell fragments

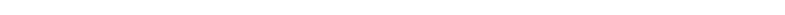

Limestone, hard gray, fossiliferous.

Beach sand, full of marine shells.

Sand and gravel (sand and fine gravel with with sand)................................

Sand, medium, gray (many hard nodnles and worn shell fragments).

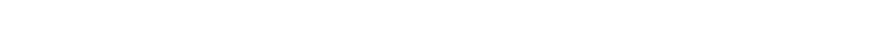

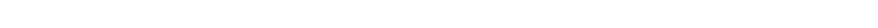

Sand, loose; water bed.

\begin{tabular}{|r|r} 
Thickness. & Depth. \\
\hline Freet. & Feet. \\
25 & 25 \\
5 & 30 \\
17 & 47 \\
2 & 49 \\
6 & 55 \\
15 & 70 \\
4 & 74 \\
10 & 84 \\
6 & 90 \\
4 & 94 \\
4 & 98 \\
& \\
\hline
\end{tabular}

South of West Palm Beach few wells call for special mention, the great majority being under 20 feet deep. The driller, E. T. King, furnished the following record of one near Hypoluxo:

Record of well of Andrew Garnett, 2 miles west of Hypoluxo.

Sand, yellow, surface

\begin{tabular}{|r|r}
\hline Thickness. & Depth. \\
\hline Feet. & Feet. \\
6 & 6 \\
32 & 38 \\
24 & 72 \\
\hline
\end{tabular}


The same driller furnishes the following log of a well near Delray: Record of well of O. Eleasen, west of Delray.

\begin{tabular}{|c|c|c|}
\hline & Thickmess. & Depth. \\
\hline 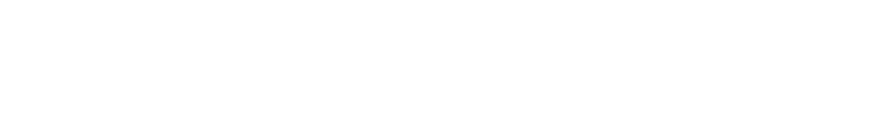 & Feet. $\begin{array}{r}40 \\
3 \\
65 \\
11\end{array}$ & $\begin{array}{r}\text { Feet. } \\
40 \\
43 \\
108 \\
119\end{array}$ \\
\hline
\end{tabular}

Few wells in Delray are over 20 feet deep. A canning factory gets a sufficient supply of water from a 4 -inch well about 30 feet deep.

Artesian prospects.-The yield and quality of water obtainable near the coast by deep drilling has been demonstrated at Palm Beach, Hobe Sound, and Gomez. There is every reason to believe that the deep water is more strongly mineralized south of West Palm Beach. Better water can be had toward Lake Okechobee. As in Dade County, the most promising sources of supply are the sands, marls, limestone, and shell beds'from 50 to about 150 feet below surface. Good water that will not rise above the surface can be obtained in many places by wells 5 to 20 feet deep in the surficial sands and limestones. On coastal islands and in places on the mainland near the shore wells may yield salty or brackish water from a few to several hundred feet below sea level.

Typical wells of Palm Beach County.

\begin{tabular}{|c|c|c|c|c|c|c|c|c|}
\hline $\begin{array}{l}\text { Nearest town } \\
\text { or post office. }\end{array}$ & $\begin{array}{l}\text { Direction } \\
\text { and dis- } \\
\text { tance. }\end{array}$ & Owner. & Driller. & $\begin{array}{l}\text { Date } \\
\text { sunk. }\end{array}$ & $\begin{array}{l}\text { Surface } \\
\text { forma- } \\
\text { tion. }\end{array}$ & $\begin{array}{c}\text { Geologic } \\
\text { source. }\end{array}$ & $\begin{array}{c}\text { Type of } \\
\text { well. }\end{array}$ & Use. \\
\hline Delray ........ & Near.... & $\begin{array}{l}\text { Delray Can- } \\
\text { ning Co. } \\
\text { O. Eleasen.... }\end{array}$ & E. T. King & & $\begin{array}{l}\text { Pleisto- } \\
\text { cene. }\end{array}$ & $\begin{array}{l}\text { Pleisto- } \\
\text { cene. } \\
\text { Pleisto- }\end{array}$ & Drilled. . & $\begin{array}{l}\text { Boiler can- } \\
\text { ning veg- } \\
\text { etables } \\
\text { andfruit. } \\
\text { Domestic. }\end{array}$ \\
\hline Gomez...... & $\begin{array}{l}\frac{1}{2} \mathrm{millo}_{\text {east. }} \\
2 \text { miles }\end{array}$ & $\begin{array}{l}\text { Indian River } \\
\text { Land Assoc. }\end{array}$ & & & ...do... & $\begin{array}{c}\text { cene(?) } \\
\text { vicks- } \\
\text { burgian } \\
\text { lime- } \\
\text { stone. } \\
\text {...do..... }\end{array}$ & & \\
\hline Hobe Sound. & 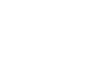 & T. A. Snyder.. & & & ...do. & $\ldots$ do.... & Drilled.. & Irrigation. \\
\hline Hypoluxo.... & 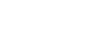 & $\begin{array}{l}\text { Andrew Gar- } \\
\text { nett. }\end{array}$ & E.T. King & & ...do.. & $\begin{array}{l}\text { Pleisto- } \\
\text { cone. }\end{array}$ & & \\
\hline Palm Beach. . & 1 mile & C. I. Cragin.... & & & ...do. & $\begin{array}{l}\text { Vicks- } \\
\text { burgian } \\
\text { lime- } \\
\text { stone. }\end{array}$ & ... do. & Irrigation. \\
\hline $\begin{array}{l}\text { Do....... } \\
\text { Do....... }\end{array}$ & $\begin{array}{l}2 \text { miles } \\
\text { north- } \\
\text { west. } \\
1 \text { mile }\end{array}$ & $\begin{array}{l}\text { Munyon....... } \\
\text { C. I. Cragin ... }\end{array}$ & $\begin{array}{c}\text { W.O.Wey- } \\
\text { brecht. }\end{array}$ & 1899 & & ……..... & & \\
\hline $\begin{array}{l}\text { West Jupiter. } \\
\text { Do........ }\end{array}$ & $\begin{array}{l}\text { north. } \\
6 \text { miles } \\
\text { west. } \\
2 \text { miles }\end{array}$ & $\begin{array}{l}\text { Leinhart \& } \\
\text { Dimmock. } \\
\text { W. Pennock.. }\end{array}$ & $\begin{array}{c}\text { W.O.Wey- } \\
\text { brecht. } \\
\text {...do........ }\end{array}$ & $\begin{array}{l}1908 \\
1903\end{array}$ & $\begin{array}{c}\text { Pleisto- } \\
\text { cene. } \\
0 . . .\end{array}$ & $\begin{array}{c}\text { Pleisto- } \\
\text { cene. } \\
\ldots . . . . .\end{array}$ & Drilled.. & Domestic. \\
\hline $\begin{array}{l}\text { West Palm } \\
\text { Beach. }\end{array}$ & 1 mile & $\begin{array}{l}\text { M ode } 1 \text { Land } \\
\text { Co. (2 wells). }\end{array}$ & H. Walker & $\begin{array}{l}1906 \\
1905\end{array}$ & $\begin{array}{l}\text { Pleisto- } \\
\text { cene. }\end{array}$ & $\begin{array}{l}\text { Pleísto- } \\
\text { cene. }\end{array}$ & Drilled. . & \\
\hline
\end{tabular}


Typical wells of Palm Beach County-Continued.

\begin{tabular}{|c|c|c|c|c|c|c|c|c|c|c|}
\hline \multirow[b]{2}{*}{$\begin{array}{l}\text { Nearest town } \\
\text { or post office. }\end{array}$} & \multirow[b]{2}{*}{ 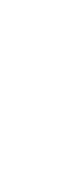 } & \multirow[b]{2}{*}{ 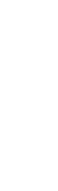 } & \multirow[b]{2}{*}{ 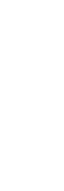 } & \multirow{2}{*}{ 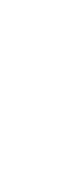 } & \multicolumn{2}{|c|}{ Head- } & \multirow{2}{*}{ 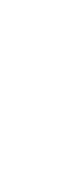 } & \multirow{2}{*}{ 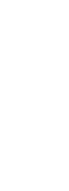 } & \multirow[b]{2}{*}{$\begin{array}{l}\text { Quality } \\
\text { of water. }\end{array}$} & \multirow[b]{2}{*}{ Remarks. } \\
\hline & & & & & 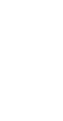 & 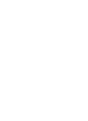 & & & & \\
\hline Delray. & $\begin{array}{r}\text { Feet. } \\
30\end{array}$ & $I n$ & Feet. & Feet. & Feet. & Feet. & Feet. & Feet. & & Yield large. \\
\hline Do... & 119 & & & & & & & & $\begin{array}{l}\text { Fresn... } \\
\text { Fresh.. }\end{array}$ & Yeld large. \\
\hline 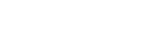 & 1,200 & 4 & {$[\ldots \ldots$} & $\ldots$ & ..... & Flows. & ..... & ... & Saline... & Not used. \\
\hline $\begin{array}{l}\text { Hobe Sound... } \\
\text { Hypoluxo. }\end{array}$ & $1,100+$ & $\because$ & & 20 & & Flows. & & & $\ldots$ do $\ldots . .$. & \\
\hline $\begin{array}{l}\text { Hypoluxoo.... } \\
\text { Palm Beach.. }\end{array}$ & $\begin{array}{r}62 \\
1,212\end{array}$ & 4 & 1,000 & 4 & $\dddot{38}$ & 34 & $\begin{array}{r}32 \\
\ldots . . .\end{array}$ & 1,212 & $\begin{array}{l}\text { Fresh.. } \\
\text { Saline } \\
\text { sul }\end{array}$ & $\begin{array}{l}\text { Yields } 250 \text { gallons } \\
\text { per minute. }\end{array}$ \\
\hline Do......... & 125 & 2 & & 5 & & & 2 & & $\begin{array}{l}\text { palt.... } \\
\text { salt. }\end{array}$ & Not used. \\
\hline $\begin{array}{l}\text { Do......... } \\
\text { West Jupiter. }\end{array}$ & $\begin{array}{l}1,300+ \\
59 \frac{1}{2}\end{array}$ & $\ddot{2}$ & 57 & $\dddot{8}$ & $\dddot{6}$ & ${ }^{+}-2$ & 57 & 57 & Hära, & \\
\hline Do...... & 60 & 2 & & & & & & & $\begin{array}{l}\text { Salt.... } \\
\text { Salsa. }\end{array}$ & \\
\hline $\begin{array}{l}\text { West Palm } \\
\text { Beach. }\end{array}$ & $\begin{array}{l}99 \\
87\end{array}$ & \} & $\begin{array}{l}47 \\
30\end{array}$ & 15 & & & $\begin{array}{l}47 \\
40\end{array}$ & $\begin{array}{l}99 \\
87\end{array}$ & Fresh.. & $\left\{\begin{array}{l}\text { Not u sed; yield } \\
\text { large. }\end{array}\right.$ \\
\hline
\end{tabular}

PASCO COUNTY.

By G. C. Matson.

GENERAL FEATURES.

Pasco County is on the west coast of the peninsula. The western part of the county is a broad plain rising from 20 to 25 feet above sea level, and this plain is bordered by successive terraces ranging in altitude from 40 to 60 and from 70 to 100 feet. The relief of these plains is very slight, but farther inland the surface becomes gently rolling with smoothly rounded hills and basin-shaped depressions. This topography results from the collapse of the roofs of underground channels forming sink holes. In many localities the depressions are occupied by ponds or lakes, but in Pasco County most of the sink holes are dry. The only important surface streams in the county are Pithlachascotee and Hillsboro rivers, and neither of these drains a large area. Anclote River drains the extreme southwestern corner of the county.

\section{GEOLOGY.}

The surface materials of Pasco County consist of gray sands underlain by red and yellow sands containing in some localities a slight proportion of clay. The surficial deposits are underlain by limestones of Oligocene age. In the eastern part of Pasco County the limestones of the Tampa and Hawthorn formations lie near the surface. The Vicksburgian limestones are near the surface in the western part of the county, but farther east they are partly covered by the younger limestones.

The thickness of the surficial deposits is in few places great, and exposures of the underlying limestones are not uncommon. The Hawthorn and Tampa formations are commonly thin, though near 
the southeast corner of the county the limestones and clays of the Tampa formation attain a maximum thickness of perhaps over 100 feet. The Vicksburgian limestones should have a thickness of several hundred feet, but there are no well records to prove it.

\section{WATER SUPPLY.}

Source.-The surficial sands commoniy furnish an ample supply of water for shallow wells, and the Tampa formation may also yield some water at moderate depths, but the best water-bearing formations of the county are the Vicksburgian limestones. In the western part of the county and in some localities in the eastern part the Vicksburgian limestones may be penetrated by wells less than 100 feet in depth.

Quality.-The surficial sands furnish soft water, but nearly all the deeper wells yield hard water.

Development.-On low ground few shallow wells of Pasco County exceed 30 feet in depth and many of them are not over 10 feet. The water level is near the surface, and hence suction pumps are commonly used. The supplies obtained by these wells are large enough to meet all the ordinary domestic requirements. Many deep wells go down less than 100 feet, though a few go considerably deeper. All the water from the deep wells is hard but is generally considered satisfactory. These wells will supply large quantities of water, and hence they are utilized for industrial purposes. Very deep wells may yield highly mineralized water, and as there is little or no probability of their giving flows there is no incentive to drill to great depths.

Typical wells of Pasco County.

\begin{tabular}{|c|c|c|c|c|c|c|c|}
\hline $\begin{array}{l}\text { Nearest town } \\
\text { or post office. }\end{array}$ & $\begin{array}{l}\text { Direction and } \\
\text { distance. }\end{array}$ & Owner. & Driller. & $\begin{array}{l}\text { Date } \\
\text { sunk. }\end{array}$ & Type. & Use. & Depth. \\
\hline Dade City.. & Near.... & City........ & W. A. Spark- & 1905 & Driven.. & Public...... & $\begin{array}{r}\text { Feef. } \\
53\end{array}$ \\
\hline 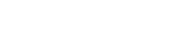 & $\begin{array}{l}\frac{1}{4} \\
\frac{1}{2} \\
\text { mile south }\end{array}$ & $\begin{array}{l}\text { Henry Cray... } \\
\text { Muller \& Zins- }\end{array}$ & $\begin{array}{l}\text {....do... } \\
\text {.....do... }\end{array}$ & $\begin{array}{l}1906 \\
1907\end{array}$ & Đodo.... & & $\begin{array}{l}74 \\
45\end{array}$ \\
\hline Ehren.... & $\begin{array}{l}\text { east. } \\
\text { Near.......... }\end{array}$ & $\begin{array}{l}\text { ser. } \\
\text { Gulf Cypress } \\
\text { Co. }\end{array}$ & $\begin{array}{l}\text { T. J. Zimmer- } \\
\text { man. }\end{array}$ & & ...do. & $\begin{array}{c}\text { facturimg. } \\
\text { Sawmill..... }\end{array}$ & $150 ?$ \\
\hline & .....do... & $\begin{array}{l}\text { Aripeka saw- } \\
\text { mill. }\end{array}$ & J. D. Allen.... & 1904 & ...do. & ... do ... & 120 \\
\hline $\begin{array}{l}\text { Do..... } \\
\text { Herndon.. }\end{array}$ & i...do.......... & Rice \& Phelpsa & .....do... & 1904 & $\begin{array}{l}\ldots \text { do } \\
\ldots . .\end{array}$ & Turpentine & $\begin{array}{r}96 \\
120\end{array}$ \\
\hline Odessa.... & Near.... & Gulf Pine Co.. & $\begin{array}{l}\text { T. J.Zimmer- } \\
\text { man. }\end{array}$ & 1907 & Drilled.. & Sawmill.... & 104 \\
\hline $\begin{array}{l}\text { Pasco.......... } \\
\text { Pasadena.... }\end{array}$ & $\begin{array}{l}\ldots . . \text { do....... } \\
\ldots \ldots \text { do...... }\end{array}$ & $\begin{array}{l}\text { S. S. Goffin... } \\
\text { The Spencer } \\
\text { well. }\end{array}$ & ì. c. Bryant... & $\begin{array}{l}1902 \\
1894\end{array}$ & $\begin{array}{l}\text {..do... } \\
\ldots \text {..do... }\end{array}$ & $\ldots$ do $\ldots . . . \ldots$ & $\begin{array}{r}270 \\
6300\end{array}$ \\
\hline Port Richey.. & 4 miles north.. & $\begin{array}{l}\text { Stubbs Bros. } \\
\& \text { Co. }\end{array}$ & J. D. Allen.... & 1906 & ...do. . & $\begin{array}{l}\text { Turpentine } \\
\text { still sup- } \\
\text { ply. }\end{array}$ & 147 \\
\hline Richland....... & Near...... & $\begin{array}{l}\text { Atlantic Coast } \\
\text { Line. }\end{array}$ & ......do.......... & 1898 & ...do.... & Locomotives & 90 \\
\hline St. Leo..... & .....do........ & Dr. J. F. Cor- & Owner......... & 1900 & ...do.... & Domestic... & 75 \\
\hline San Antonio.... & ....do......... & Convent....... & T. J.Zimmer- & 1906 & $\ldots$ do.... & General..... & 98 \\
\hline Do.... & 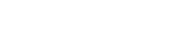 & J. S. Flanagan. & W. A. Spark- & 1906 & ...do.... & Irrigation... & 85 \\
\hline Trilby... & Near.......... & $\begin{array}{l}\text { Atlantic Coast } \\
\text { Line. }\end{array}$ & $\begin{array}{l}\text { W.A.J. Pres- } \\
\text { cott. }\end{array}$ & 1907 & ...do... & Locomotives & 31 \\
\hline
\end{tabular}


PINEllas COUNTY.

Typical wells of Pasco County-Continued.

\begin{tabular}{|c|c|c|c|c|c|c|c|c|c|c|}
\hline \multirow[b]{2}{*}{$\begin{array}{l}\text { Nearest town or } \\
\text { post office. }\end{array}$} & \multirow[b]{2}{*}{ 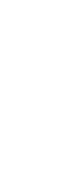 } & \multirow[b]{2}{*}{$\begin{array}{l}\text { 递 } \\
\text { : }\end{array}$} & \multirow{2}{*}{ 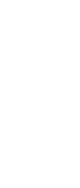 } & \multicolumn{2}{|c|}{ Head- } & \multirow[b]{2}{*}{ 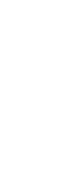 } & \multirow{2}{*}{ 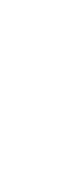 } & \multirow{2}{*}{$\begin{array}{l}\text { Pro- } \\
\text { tecting } \\
\text { clays } \\
\text { pres- } \\
\text { ent. }\end{array}$} & \multirow[b]{2}{*}{$\begin{array}{l}\text { Quality of } \\
\text { water. }\end{array}$} & \multirow[b]{2}{*}{$\begin{array}{c}\text { Yield } \\
\text { per } \\
\text { minute. }\end{array}$} \\
\hline & & & & $\begin{array}{l}8 \\
\$ \\
\infty \\
0 \\
8 \\
8 \\
8 \\
8\end{array}$ & 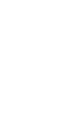 & & & & & \\
\hline Dade City.... & Inches. & Feet. & $\begin{array}{l}\text { Feet. } \\
\text { Fe.... }\end{array}$ & $\begin{array}{l}\text { Feet. } \\
\text { F. }\end{array}$ & $\begin{array}{l}\text { Feet. } \\
30-35\end{array}$ & Feet. & $\begin{array}{c}\text { Feet. } \\
\mathbf{5 0}\end{array}$ & Yes. & Hard.. & $\begin{array}{l}\text { Gallons. } \\
\text {............. }\end{array}$ \\
\hline $\begin{array}{l}\text { Do............. } \\
\text { Do.......... }\end{array}$ & $\begin{array}{l}2 \\
6\end{array}$ & $\begin{array}{l}55 \\
45\end{array}$ & $\dddot{88}$ & $73-71$ & $15-17$ & & 45 & & Hard & $\ddot{100}$ \\
\hline $\begin{array}{l}\text { Ehren } . . . . . \ldots \ldots \\
\text { Fivay.............. }\end{array}$ & $\begin{array}{l}3 \\
8\end{array}$ & $\cdots \ldots$ & 90 & & 8 & & $\cdots$ & $\mathrm{Ye}$ & ... do. & ....... \\
\hline $\begin{array}{l}\text { Do......................... } \\
\text { Herndon }\end{array}$ & & 40 & & & $\begin{array}{r}6 \\
50\end{array}$ & 120 & & & Soft, min- & Many. \\
\hline $\begin{array}{l}\text { Odessa............. } \\
\text { Pasco............ }\end{array}$ & $\begin{array}{l}4 \\
3\end{array}$ & $\begin{array}{r}35 \\
270\end{array}$ & $\begin{array}{r}b 57 \\
110\end{array}$ & $b 46$ & 11 & & 20 & & Hard..... & \\
\hline Pasadena......... & 8 & 170 & & & $\begin{array}{l}00 \\
86\end{array}$ & 150 & 270 & Yes.. & ..do.... & \\
\hline Port Richey..... & 6 & 30 & …... & & 14 & $\ldots$. & 147 & No... & . do... & \\
\hline d....................... & $\begin{array}{l}8 \\
3\end{array}$ & $7 i^{\circ}$ & $b 93$ & 63 & 30 & & & & ...do. & \\
\hline tonio.......... & $?$ & $98 ?$ & 191 & 159 & $\begin{array}{l}32 \\
25 ?\end{array}$ & & $\begin{array}{l}73 \\
98 ?\end{array}$ & Yes... & ...do....... & \\
\hline $\begin{array}{l}\text { Do... } \\
\text { Trilby... }\end{array}$ & 2 & 82 & & & 8 & & 85 & Yes.. & ...do. & \\
\hline Trilby... & 10 & 19 & 59 & 54 & 5 & & & & . do. . & \\
\hline
\end{tabular}

a Water-Supply Paper U. S. Geol. Survey No. 102, p. 250.

b Estimated.

General water resources of Pasco County.

\begin{tabular}{|c|c|c|c|c|c|c|}
\hline \multirow{2}{*}{ Town. } & \multirow{2}{*}{$\begin{array}{l}\text { Topographic } \\
\text { location. }\end{array}$} & \multirow{2}{*}{\multicolumn{2}{|c|}{ Source of water. }} & \multirow{2}{*}{$\begin{array}{l}\text { Surface } \\
\text { formation. }\end{array}$} & \multicolumn{2}{|c|}{ Shallow wells. } \\
\hline & & & & & Depth. & Supply. \\
\hline $\begin{array}{l}\text { Dade City...... } \\
\text { Hudson ........ } \\
\text { Lacoochee...... } \\
\text { Pasco .......... } \\
\text { Richland....... } \\
\text { 8an Antonio... } \\
\text { St. Leo.......... } \\
\text { Trilby ......... }\end{array}$ & 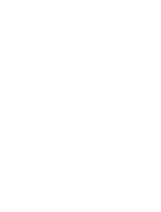 & 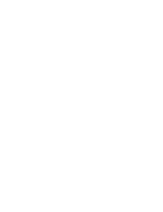 & $\begin{array}{l}\ldots \ldots \\
\ldots \ldots \ldots \\
\ldots \ldots \ldots \\
\ldots \ldots \ldots \\
\ldots \ldots \ldots\end{array}$ & $\begin{array}{l}\text { Clays........... } \\
\text { Some clays.... } \\
\text { Clays.............. } \\
\text { Some clays..... } \\
\text { Clays............ } \\
\ldots . . \text { do........... } \\
\ldots . \text { do }\end{array}$ & 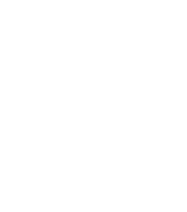 & $\begin{array}{c}\text { Fair. } \\
\text { Fair. } \\
\text { Do. } \\
\text { Do. }\end{array}$ \\
\hline \multirow{2}{*}{ Town. } & \multicolumn{2}{|c|}{ Shallow wells. } & \multicolumn{3}{|c|}{ Deep wells. } & \multirow{2}{*}{$\begin{array}{c}\text { Sewerage } \\
\text { system. }\end{array}$} \\
\hline & $\begin{array}{l}\text { Quality of } \\
\text { water. }\end{array}$ & $\begin{array}{c}\text { Principal } \\
\text { water beds. }\end{array}$ & Depth. & Supply. & $\begin{array}{l}\text { Quality of } \\
\text { water. }\end{array}$ & \\
\hline $\begin{array}{l}\text { Dade City...... } \\
\text { Hudson ........ } \\
\text { Lacoochee...... } \\
\text { Pasco.......... } \\
\text { Richland....... } \\
\text { San Antonio... } \\
\text { 8t. Leo.......... } \\
\text { Trilby ......... }\end{array}$ & $\begin{array}{c}\text { Some soft.... } \\
\ldots \ldots \ldots\end{array}$ & 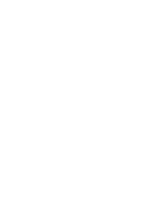 & $\begin{array}{r}\text { Feet. } \\
157 \\
90 \\
970 \\
90 \\
165 \\
75 \\
85\end{array}$ & 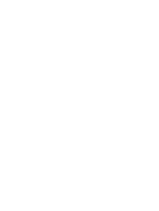 & 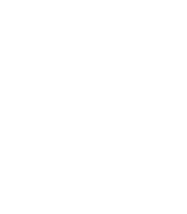 & \begin{tabular}{c|c}
.. & None. \\
.. & Do. \\
Do. \\
.. & Do. \\
Do. \\
.. & Do. \\
Do. \\
Do.
\end{tabular} \\
\hline
\end{tabular}

\section{PINELLAS COUNTY.}

Pinellas County was recently formed from a portion of Hillsborough County. Its wells have already been described. (See pp. 319-325.) 


\section{POLK COUNTY.}

By G. C. Matson.

GENERAL FEATURES.

Polk County is in the south-central portion of the peninsula. The surface ranges in altitude from less than 70 feet to more than 200 feet above sea level. The marine terrace which is well developed at Kissimmee extends into the eastern and southern parts of the county. There are also narrow terraces along Peace River and the other large streams. East of Bartow some areas rise over 150 feet above sea level and similar upland tracts occur in the western and northern parts of the county. At Lakeland a narrow ridge rises to an altitude of over 200 feet.

Lakes are numerous on the terrace in the eastern and southern parts of the county, where they occupy depressions in the sand. On the upland some of the many lakes appear to be due to depressions in the surface sands; but others occupy sink holes formed by the solution of the underlying limestones.

GEOLOGY.

The surface of Polk County is mantled with gray sand, which obscures the underlying formations, except where it has been removed by erosion or by artificial means. Beneath this sand at some localities lie deposits of land-pebble phosphates-Bone Valley gravel. The Bone Valley gravel is best developed from near Lakeland southward beyond Bartow; extensive areas of it lie west of Bartow and smaller tracts northeast and south of the town. Marls of Pliocene and Miocene age probably extend into the eastern part of the county; but their existence can be inferred only from their occurrence in Osceola County. Limestone belonging to the Hawthorn formation (?) was encountered in one of the phosphate mines near Bartow, and the formation possibly underlies the county. The Vicksburgian limestones are reached in all the deep-drilled wells and they extend beneath the entire county but are so deeply buried that they are only known from well records.

The thickness of the several geologic formations in Polk County has been only approximately determined. In the western part of the county the gray sands average less than 10 feet, but near the eastern boundary they attain a maximum thickness of perhaps over 100 feet. In some places the Bone Valley gravel is over 30 feet thick, but it probably averages about 20 feet. The Pliocene and Miocene marls are thought to underlie the eastern portion of the county, but no information is available as to their thickness. The thickness of the Hawthorn formation and the Vicksburgian limestones is uncertain, but it probably amounts to several hundred feet. 
Log of the well of Smith \& Marshall, at Arcadia.

No samples.

Sand, light brown.

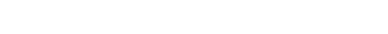

Sand, gray

Limestone, light gray

Sand, dark gray ........

Limestone, light gray

Limestone, mixed

Limestone, mixed light and dark gray

Limestone, light gray; fragments of dark-colored chert.

Limestone, light gray

Limestone, light gray; fragments of darker chert.

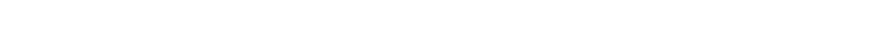

Limestone, granular, light brown...

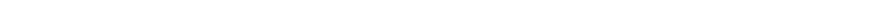

Limestone, fine grained, gray.........

Limestone, light gray.

No samples.

.

Limestone, very fine grained, light gray.

Limestone, porous, white.

This well doubtless penetrates some distance into Vicksburgian limestone, but the exact depth to these rocks is uncertain.

WATER SUPPLY.

Source.-The surficial sands are the source of an abundant supply of water throughout the county. Locally the Bone Valley gravel may yield water, but it is not regarded as an important waterbearing formation. The Hawthorn formation may also supply water, but it is difficult to determine whether the water comes from this formation or from the underlying Vicksburgian limestones. The limestones of Vicksburg age are the most important water-bearing rocks of the county and supply large quantities for deep-drilled wells.

Quality.-The surficial sands furnish soft water, but all the older geologic formations yield hard water.

Development.-Shallow wells range in depth from 15 to 30 feet and obtain an abundance of water in all the settled portions of the county. Some wells have been driven for 60 to 80 feet, but good water is generally found near the surface.

At Carters Mill several wells 50 feet or less in depth, obtain flowing water, and in the vicinity of Loughman many good supplies are obtained at 80 to 100 feet. The water at these localities contains a slight amount of sulphur but is unusually free from other mineral matter. Wells on low ground near Nichols and Mulberry also obtain flows, but the head is not sufficient to yield flows on the upland in the western part of the county. On the low ground near Kissimmee River in the eastern part of the county flowing wells similar to those in Osceola County could probably be drilled. In Polk County deep wells have been drilled by several of the phosphate companies and all of them 
have obtained large quantities of water, which rises within easy pumping distance of the surface. These wells penetrate the Vicksburgian limestones and indicate the character of the water which may be obtained from these formations throughout the western half of the county. Near the eastern edge of the county much of the deep water is likely to contain salt and some of it may be too saline for use. Bartow, Lakeland, and Mulberry each have public supplies obtained from wells. The water is hard, but it is satisfactory for all general purposes and the supplies are reported to be ample.

General water resources of Polk County.

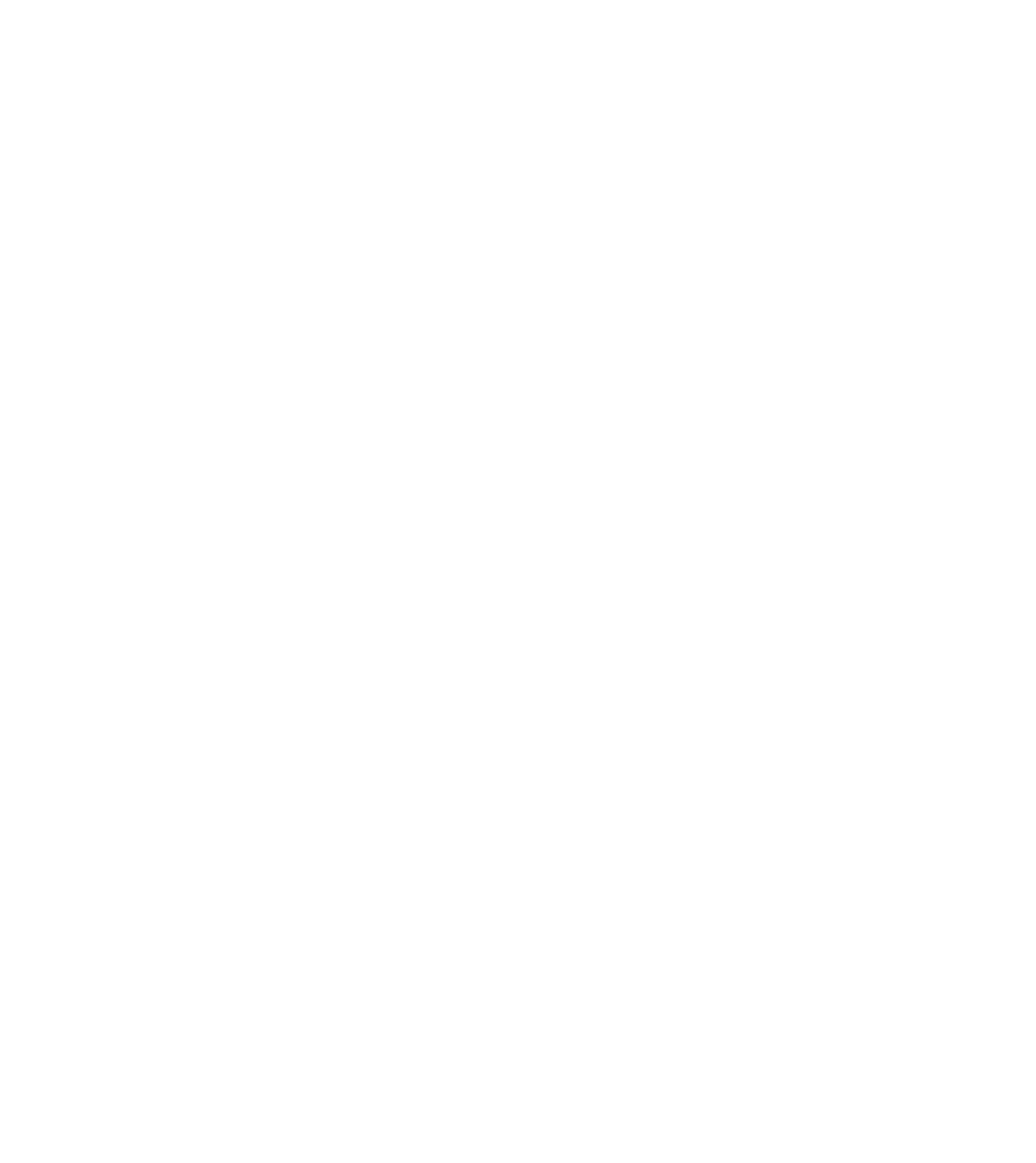


Typical wells of Polk County.

\begin{tabular}{|c|c|c|c|c|c|c|c|c|c|c|c|c|c|c|c|c|c|c|c|c|}
\hline \multirow[b]{2}{*}{$\begin{array}{l}\text { Nearest town or } \\
\text { post offlce. }\end{array}$} & \multirow[b]{2}{*}{$\begin{array}{l}\text { Direction and } \\
\text { distance. }\end{array}$} & \multirow[b]{2}{*}{ Owner. } & \multirow[b]{2}{*}{ Driller. } & \multirow[b]{2}{*}{$\begin{array}{c}\text { Date } \\
\text { sunk. }\end{array}$} & \multirow[b]{2}{*}{$\begin{array}{c}\text { Surface formar. } \\
\text { tion. }\end{array}$} & \multirow[b]{2}{*}{ Geologie source. } & \multirow[b]{2}{*}{$\begin{array}{l}\text { Type of } \\
\text { well. }\end{array}$} & \multirow[b]{2}{*}{ Use. } & \multirow[b]{2}{*}{ Depth. } & \multirow[b]{2}{*}{$\mid$} & \multirow[b]{2}{*}{ casing. } & \multirow[b]{2}{*}{$\begin{array}{l}\text { Eleva- } \\
\text { tilion } \\
\text { above } \\
\text { sea. }\end{array}$} & \multicolumn{2}{|c|}{ Head- } & \multirow[b]{2}{*}{$\begin{array}{c}\text { Depth } \\
\text { to } \\
\text { rock. }\end{array}$} & \multirow[b]{2}{*}{$\begin{array}{l}\text { Depth to prin- } \\
\text { oipal supply. }\end{array}$} & \multirow[b]{2}{*}{ Quality of wates. } & \multirow[b]{2}{*}{\begin{tabular}{|c|c} 
Depth \\
to opsoc \\
ond \\
pup- \\
plieg.
\end{tabular}} & \multirow[b]{2}{*}{$\begin{array}{l}\text { Yield per } \\
\text { minute. }\end{array}$} & \multirow[b]{2}{*}{ Remarks. } \\
\hline & & & & & & & & & & & & & $\begin{array}{c}\text { Above } \\
\text { sea. }\end{array}$ & $\begin{array}{l}\text { Above } \\
\text { bolow } \\
\text { serre. } \\
\text { sace. }\end{array}$ & & & & & & \\
\hline $\begin{array}{l}\text { Bartow..... } \\
\text { Do...... }\end{array}$ & & $\begin{array}{l}\text { City } a \ldots . . . \\
\ldots . . . d 0 . . .\end{array}$ & Hampton.: & 1904 & Pleistocene... & Vioksburgian ime- & Drilied.... & $\begin{array}{l}\text { City supply........ } \\
\text { …do............. }\end{array}$ & $\begin{array}{l}\text { Feet. } \\
\text { 190. } \\
720\end{array}$ & 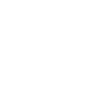 & $\begin{array}{l}\text { Feet. } \\
\cdots \\
\cdots 20\end{array}$ & \begin{tabular}{|l} 
Feet. \\
130 \\
\\
\end{tabular} & Feet. & $\begin{array}{c}\text { Feet. } \\
-20 \\
-6\end{array} \mid$ & Feet. & $\begin{array}{l}\text { Feet. } \\
\cdots \cdots \\
720\end{array}$ & $\begin{array}{l}\text { Hard } \\
\text { Salphur, slight ..... }\end{array}$ & Feet. & $\begin{array}{r}\text { Gallons. } \\
300 \\
400\end{array}$ & \multirow{9}{*}{$\begin{array}{l}\text { Forms seale in boilers. } \\
\text { Do. }\end{array}$} \\
\hline Do....... & 6 miles southwest. & \begin{tabular}{|l|} 
Dominion Phosphate \\
Co.
\end{tabular} & C. E. Reed... & 1006 & .....do......... & stone. & .....do.... & Phosphatemining and & 286 & 6,3 & & $b 115$ & & -48 & & Near bottom. & Sulphur.................. & & 500 & \\
\hline $\begin{array}{l}\text { Do } \\
\text { Bone Vallèy. }\end{array}$ & 1 mile northeast... & $\begin{array}{l}\text { E. C. Skippers......... } \\
\text { Prairie Pebble Phos- }\end{array}$ & $\begin{array}{l}\text { Hughos opeoiaity } \\
\text { Well Drilling Co. }\end{array}$ & 1908 & …do. & $\begin{array}{l}\ldots . . . \text { do } \ldots . . . \\
\cdots . . \text { do } \ldots . . .\end{array}$ & $\begin{array}{l}\text {.....do.... } \\
\text { …do.... }\end{array}$ & $\mid \begin{array}{l}\text { Condersers. .................... } \\
\text { Phosphate mining.... }\end{array}$ & $\begin{array}{l}725 \\
560\end{array}$ & $\begin{array}{r}3 \\
10\end{array}$ & 100 & & & $\begin{array}{l}-60 \\
-20\end{array}$ & & & $\begin{array}{l}\text { Sulphur, slight..... } \\
\text { Sulphur.......... }\end{array}$ & & $5500^{\circ}$ & \\
\hline Bowling Green. & & 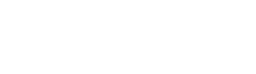 & 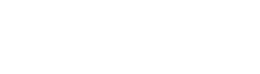 & 1908 & $\begin{array}{l}\text {...do... } \\
\cdots . \text { do.. }\end{array}$ & ….do $\ldots . .$. & (....do...... & Domestio, stooci, and & $\begin{array}{l}620 \\
279\end{array}$ & ${ }_{4}^{10}$ & $\begin{array}{r}100 \\
50\end{array}$ & $\dddot{a}$ iio & & $\begin{array}{l}-20 \\
-26\end{array}$ & & $2 \pi g^{\prime}$ & …do.................... & 2001 & $80+$ & \\
\hline 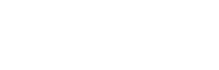 & 5 miles northwest & $\begin{array}{l}\text { T. R. Starke................... } \\
\text { Tighlman Phospate }\end{array}$ & Highos speciaity & $\cdots:$ & (...do.: & V̈ickssburgian lime: & …..do.....: & irigation. & $\begin{array}{l}143 \\
687\end{array}$ & $\begin{array}{r}3 \\
10^{3}\end{array}$ & & $b 110$ & & -10 & & & & & & \\
\hline & $3 \frac{1}{3}$ miles northwest. & 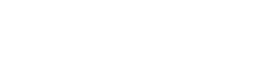 & 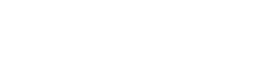 & 1908 & ....do... & 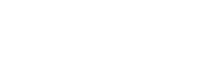 & & $\begin{array}{l}\text { Drinkingand boilers... } \\
\text { Drinking............ }\end{array}$ & 垔75 & 10,8 & $\begin{array}{r}825 \\
6110\end{array}$ & & & & & & Sulphur.......... & & 800 & \\
\hline $\begin{array}{l}\text { Carters Miil.............. } \\
\text { Eagle Lake........ } \\
\text { Fort Meade.......... }\end{array}$ & & 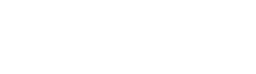 & C... E.eed.:. & iต̈oi" & 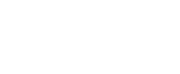 & 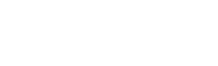 & 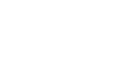 & 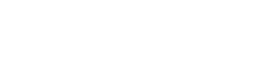 & 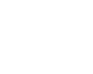 & $\begin{array}{c}3 \\
1 \\
4 \\
10 \\
10\end{array}$ & $\begin{array}{r}5100 \\
532\end{array}$ & $\cdots 100$ & & $\begin{array}{c}+2 \\
-30 \\
-30\end{array}$ & $\ldots$ & $\begin{array}{r}50 \\
132\end{array}$ & 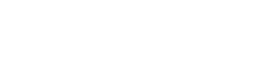 & $\cdots$ & Several. & \\
\hline Do.................................. & & 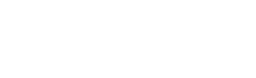 & & & $\begin{array}{l}\text { N...do.. } \\
\text { …do... }\end{array}$ & $\begin{array}{l}\text { Vickssurgian lime- } \\
\text { stono. } \\
\text { stodo....................... }\end{array}$ & & & & & & & & & & & Sulphur........... & & $\begin{array}{l}\text { Several. } \\
\text { Several. }\end{array}$ & \\
\hline Do......... & & 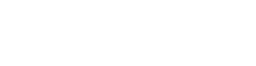 & & 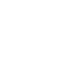 & 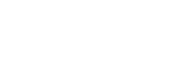 & , & , ado..... & & ${ }^{4} 450^{\circ}$ & 10 & & & & & & & …do................... & …. & Many. & \\
\hline Do.......... & .......... & Tighlman Phosphate & & 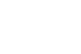 & ....do............ & Pleistoconeno............... & ....do..... & 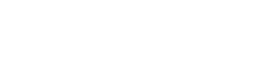 & $150 \pm$ & 2 & & & & & & & .....do ............ & 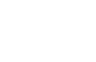 & ........... & 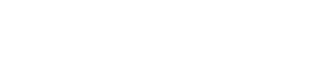 \\
\hline Do ....... & & 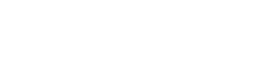 & & 1907 & .....do.... & & .....do... & Irrigation... & 150 & 4 & 140 & & & & & . & Hard.... & & & $\begin{array}{l}\text { ing on low ground; only } \\
\text { low in this locelitity } \\
\text { water encountered at 140, }\end{array}$ \\
\hline $\begin{array}{l}\text { Jane Jay...... } \\
\text { Do...... }\end{array}$ & $\frac{1}{\text { mile south.. }}$ & $\begin{array}{l}\text { Frank Bryan..................... } \\
\text { International Phos- }\end{array}$ & & 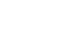 & ....do....... & & ....do $\ldots$ & ....,do & 172 & $\dddot{2}$ & 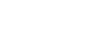 & $\because 00$ & & $\begin{array}{c}-11 \\
-4\end{array}$ & & & Sulphur..... & ....... & Many. & \\
\hline Kingstogd... & & $\begin{array}{l}\text { phate Co } \\
\text { Palmetto Phosphate }\end{array}$ & & 1000 & & & & & 160 & 6 & & $\rho_{90}$ & & & & & & & 250 & \\
\hline $\begin{array}{l}\text { Lakeland.... } \\
\text { Do...... }\end{array}$ & & City & c̈. E. Reed................ & $\begin{array}{l}1892 \\
1995\end{array}$ & Pleistocene.... & Pleistocene......... & $\begin{array}{l}\text { Driven.... } \\
\text { Driton }\end{array}$ & Drinking and stock.. & 32 & 14 & 30 & 210 & & -15 & & & & & Fow. & \\
\hline Do......... & & Lakeland Refrigerator & & 1003 & .....do... & 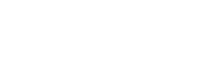 & Drilled.... & $\begin{array}{l}\text { Publio supply........... } \\
\text { Cooling condensers }\end{array}$ & 485 & $10^{\circ}$ & 300 & $200 \pm$ & & -75 & & 485 & Hard..... & & $200 \pm$ & \\
\hline $\begin{array}{l}\text { Loughman... } \\
\text { Do....... }\end{array}$ & & 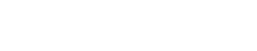 & & & & & & Min, boilers ........... & & 4 & ${ }^{336}$ & $200 \pm$ & & -100 & & & $\ldots . . . d 0 \ldots$ & & (2007+ & \\
\hline $\begin{array}{l}\text { Do....... } \\
\text { Do..... }\end{array}$ & & 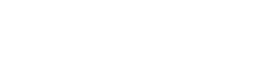 & Bowen............... & 1906 & Pleistoceno.... & Pleistoceno(?).... & Drilled.... & Drinking.................... & 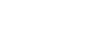 & $\begin{array}{ll}2 \\
1 \frac{1}{3}\end{array}$ & iiï & & & $\begin{array}{r}+10 \\
-8\end{array}$ & $\cdots .$. & iii & suiphur, sighti... & $10-50$ & Fow: & \\
\hline Medulla.... & & Medula Phosphate Có. & ; & $\begin{array}{l}1904 \\
1908\end{array}$ & (n)......... & Vioksburgianime & 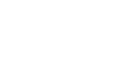 & 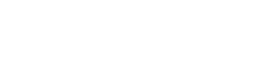 & $\begin{array}{l}\frac{123}{116} \\
600+\end{array}$ & $\begin{array}{c}11 \\
10 \\
10\end{array}$ & $\begin{array}{l}110 \\
100\end{array}$ & & ..... & $\begin{array}{r}-15 \\
-8\end{array}$ & $\cdots$ & $\begin{array}{l}110 \\
100\end{array}$ & 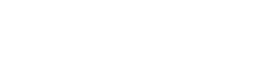 & $\begin{array}{l}10-50 \\
10-50\end{array}$ & $\begin{array}{l}\text { Few: } \\
\text { Few. }\end{array}$ & Not oompleted. \\
\hline 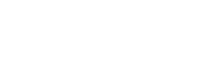 & & $\begin{array}{l}\text { E. H. Dudiey............ } \\
\text { Palmetto Phosphate }\end{array}$ & $\begin{array}{l}\text { W. J.J. Whidden..... } \\
\text { C. E. Reed.............. }\end{array}$ & 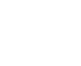 & 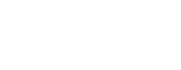 & 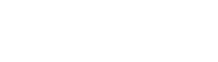 & ….do...... & Ice feetory.... & $\begin{array}{l}152 \\
169\end{array}$ & \begin{tabular}{l|l}
3 \\
6
\end{tabular} & $\begin{array}{c}40 \\
\ldots .\end{array}$ & $b_{125}$ & & $(+)$ & & 121 & sulphur................... & 162 & $\begin{aligned} 75 \\
\text { Several. }\end{aligned}$ & \\
\hline $\begin{array}{l}\text { Do............. } \\
\text { Do............ } \\
\text { Do........... }\end{array}$ & 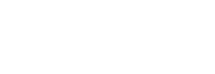 & 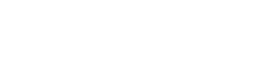 & 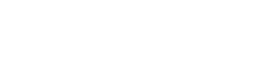 & $\begin{array}{l}1905 \\
1905\end{array}$ & ...do.............. & …do (q) & (n...do..... & 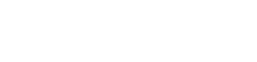 & $\begin{array}{l}150 \\
150\end{array}$ & $\frac{4}{3}$ & $\begin{array}{l}60 \\
70\end{array}$ & & $\begin{array}{l}-17 \\
-17\end{array}$ & $(-)$ & $\ldots \ldots$. & $\begin{array}{l}145 \\
145\end{array}$ & 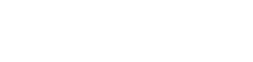 & $\begin{array}{l}25+ \\
25+\end{array}$ & $\begin{array}{l}\text { Many. } \\
\text { Many. }\end{array}$ & \\
\hline Do........ & & $\begin{array}{l}\text { Prarrie Peble Phos- } \\
\text { phate Co. } \\
\text { p..do.......................... }\end{array}$ & Hughes.............. Specialty & $\begin{array}{l}1908 \\
1908\end{array}$ & ‥do........ & 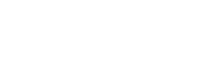 & 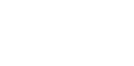 & Phosphate mining .. & $\begin{array}{l}550 \\
800\end{array}$ & $\begin{array}{r}8 \\
14,10\end{array}$ & & & & -40 & & & $\begin{array}{l}\text { Sulphur................. } \\
\text { ….do............... }\end{array}$ & & & Do. \\
\hline $\begin{array}{l}\text { Do... } \\
\text { Niahols.: } \\
\text { Do... }\end{array}$ & & Phosphato Mining co. & well Drimeng co. & 1908 & 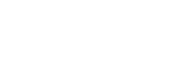 & 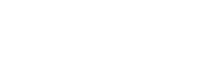 & (....do..... & & $\begin{array}{l}800 \\
233\end{array}$ & $\begin{array}{l}10 \\
10\end{array}$ & 74 & & $(-)$ & 74 & & & 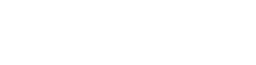 & & & Do. \\
\hline & & 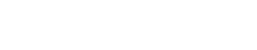 & & & (a.do.: & 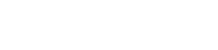 & 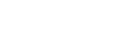 & & $\begin{aligned} 3500+262 \\
250-20\end{aligned}$ & $\begin{array}{l}10 \\
10\end{array}$ & …: & & & & & & & & & $\begin{array}{l}\text { No. } 1 \text { mine; } \\
\text { No. } 2 \text { mine; } 4 \text { wells, } 1 \text { flowing. }\end{array}$ \\
\hline Pebbledaie..... & & Peblodale Phosphate & 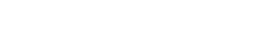 & ï & a.do.: & a.do... & (a...do..... & 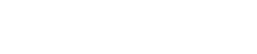 & $\begin{array}{l}320 \\
700\end{array}$ & $\begin{array}{l}10 \\
10\end{array}$ & 150 & $\mid \begin{array}{ll}b & b 10 \\
b & 145\end{array}$ & & $\begin{array}{l}-30 \\
-40\end{array}$ & ... & $700-1$ & $\mid \begin{array}{l}\text { Sulphur... } \\
\text {......do.... }\end{array}$ & $600 \pm$ & $600^{\circ}$ & \\
\hline 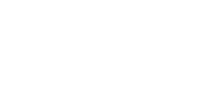 & ....... +2 & Prairie Pobbie Phos- & 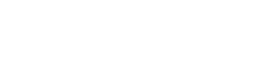 & 1908 & (...do... & 的.do.: & ( & 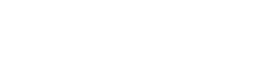 & $\begin{array}{l}730 \\
697\end{array}$ & $\begin{array}{l}12,10 \\
10\end{array}$ & 225 & & & $\begin{array}{l}-40 \\
-20\end{array}$ & & $700-$ & …do........ & 600 & $\begin{array}{l}1,000 \\
175 \pm\end{array}$ & \\
\hline 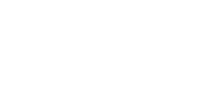 & & 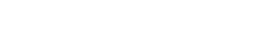 & & & $\ldots$....... & …do. & …do.... & & 750 & ..... & & & & & & & & & & \\
\hline $\begin{array}{r}\text { Tiger Bay........... } \\
\text { Do............ }\end{array}$ & 5 miles north. & Palmetto Phosphate & $\begin{array}{l}\text { Hughes spociaity } \\
\text { Well Drilfing Co. }\end{array}$ & ....... & ando. & a.do.... & - …do.:. & Phosphate mining..... & 596 & 10 & 285 & & & $\because 35$ & $\begin{array}{c}800 \\
\ldots . . .\end{array}$ & $\begin{array}{l}800 \\
165\end{array}$ & Hiard... & $45^{\circ}$ & 650-700 & \\
\hline & …do.......: & 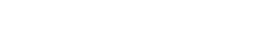 & …do & & 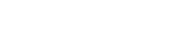 & 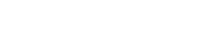 & ,...do...... & 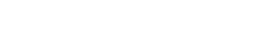 & $\frac{185}{350}$ & $\frac{8}{10}$ & $\begin{array}{r}80 \\
.0 .\end{array}$ & & & $\begin{array}{l}-35 \\
-25\end{array}$ & & 年5 & ......do..... & 45 & & \\
\hline 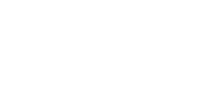 & ii miles west.: & J. Allwood $\ldots$ & C. K. Keod.... & & ;...do................ & Viokisburgianime & , a.do...... & …do................. & $\frac{160 \pm}{200}$ & & & & & & & 165 & & 25 & Many. & \\
\hline 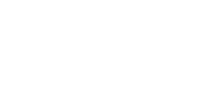 & 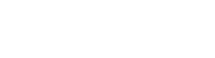 & Ferguson \& Long ..... & 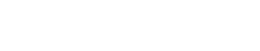 & 1908 & …do............... & & ...do...... & Domostio and stock ... & $\frac{167}{162}$ & 3 & $\infty$ & & & & & & Hard.: & $\cdots .$. & $\begin{array}{l}\text { Many. } \\
\text { Many. }\end{array}$ & \\
\hline & 11) miles west. & Capt. F. A. Whitehead & & & …do. $\quad$ > & $\begin{array}{l}\text { Vicksburgian lime- } \\
\text { stone. }\end{array}$ & ….do...... & Domestio and stock... & 200 & 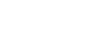 & 200 & & ....... & -20 & & 200 & & $20+1$ & & . \\
\hline
\end{tabular}





\section{PUTNAM COUNTY.}

By G. C. Matson.

\section{GENERAL FEATURES.}

Putnam County occupies an area in the northern part of the peninsula, stretching from St. Johns River westward into the lake region. The lowland near the river forms a terrace that rises 20 to 25 feet above the stream and is bordered on the west by an abrupt scarp. Above this low plain is a second terrace several miles wide and 40 to 60 feet in altitude. Between the second terrace and the upland is a third, with an altitude 70 to 100 feet above sea level and a breadth, in its widest part, of several miles: The upland is a portion of the lake region and is characterized by broad depressions occupied by lakes. Locally these depressions are numerous and some of them are large. Many of them have no surface outlet, the drainage escaping to underground channels which are apparently numerous and many of which are doubtless large.

\section{GEOLOGY.}

The terraces of Putnam County are covered by thin deposits of gray sand representing the Pleistocene. In the southern part of the county, near St. Johns River, the Pleistocene sands are underlain by shell marls of Pliocene age (Nashua marl), the exact extent of which is not known but which may underlie a large part of the lower terrace. Beneath the gray sands of the upland is a clayey sand and gravel. The clay is separated from the sand by washing and is used for the manufacture of pottery. A portion of the county bordering St. Johns River may be underlain by Miocene shell marls (Choctawhatchee marl), but little is known concerning the existence of this marl in Putnam County.

The Alum Bluff and the Hawthorn formations probably lie near the surface over a large portion of Putnam County. Beneath them are the Vicksburgian limestones, which may possibly reach the surface in some of the depressions near the western part of the county. For the most part, however, the Pleistocene sands effectually conceal all the older formations.

The gray sands of Pleistocene age are generally thin, probably averaging less than 25 feet, though in St. Johns River Valley they may attain a thickness considerably greater. The average thickness of the Pliocene marl is probably less than 25 feet and the Miocene, if present, may not be much thicker than the Pliocene. The Alum Bluff and the Hawthorn formations doubtless cap the high hills of the western portion of the county, though they may be absent in some of the depressions. They thicken toward the eastern edge of the county, where they dip beneath the younger beds. It is doubtful 
if these formations are much more than 225 feet thick in the eastern part of the county and they thin abruptly toward the west. The Vicksburgian limestones should have a thickness of several hundred feet in Putnam County.

Few important well logs could be obtained, and none of the wells were deep.

Log of well drilled in bottom of the cistern at the city waterworks at Palatka.

\begin{tabular}{|c|c|c|}
\hline . & Thickness. & Depth. \\
\hline 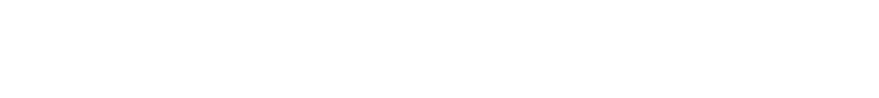 & $\begin{array}{r}\text { Feet. } \\
3 \\
9 \\
15\end{array}$ & $\begin{array}{r}\text { Feet. } \\
3 \\
12 \\
27\end{array}$ \\
\hline
\end{tabular}

Log of Mrs. Mullholland's well at Palatka.

\begin{tabular}{|c|c|c|}
\hline & Thickness. & Depth. \\
\hline 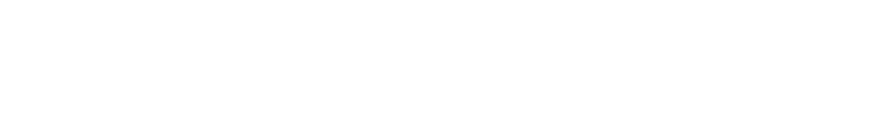 & Feet. $\begin{array}{r}85 \\
5 \\
20 \\
75\end{array}$ & $\begin{array}{r}\text { Feet. } \\
85 \\
90 \\
110 \\
185\end{array}$ \\
\hline
\end{tabular}

Log of well at Interlachen.

\begin{tabular}{|c|c|c|}
\hline & Thickness. & Depth. \\
\hline 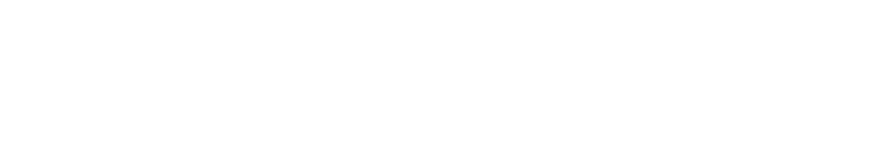 & $\begin{array}{r}\text { Feet. } \\
10 \\
12 \\
40 \\
14 \\
8\end{array}$ & $\begin{array}{r}\text { Feet. } \\
10 \\
22 \\
62 \\
76 \\
84\end{array}$ \\
\hline
\end{tabular}

WATER SUPPLY.

Source.-In Putnam County a large quantity of water is obtained from the Pleistocene and Pliocene deposits. The Hawthorn formation is also an important source of water supply for wells of moderate depth. But the best water-bearing beds are the Vicksburgian limestones, which, owing to their porous character, supply an abundance of water for drilled wells of small diameter and moderate depth. The head is sufficient to give good flowing wells on low ground near St. Johns River.

Quality.-The water of the Pleistocene and Pliocene formations is soft and is satisfactory for ordinary uses. The presence in many localities of a layer of hard rock above the water-bearing sands serves to protect the shallow wells from pollution by impure surface water. Most of the water obtained in the Alum Bluff and the Haw- 
Typical weils of Putnam County.

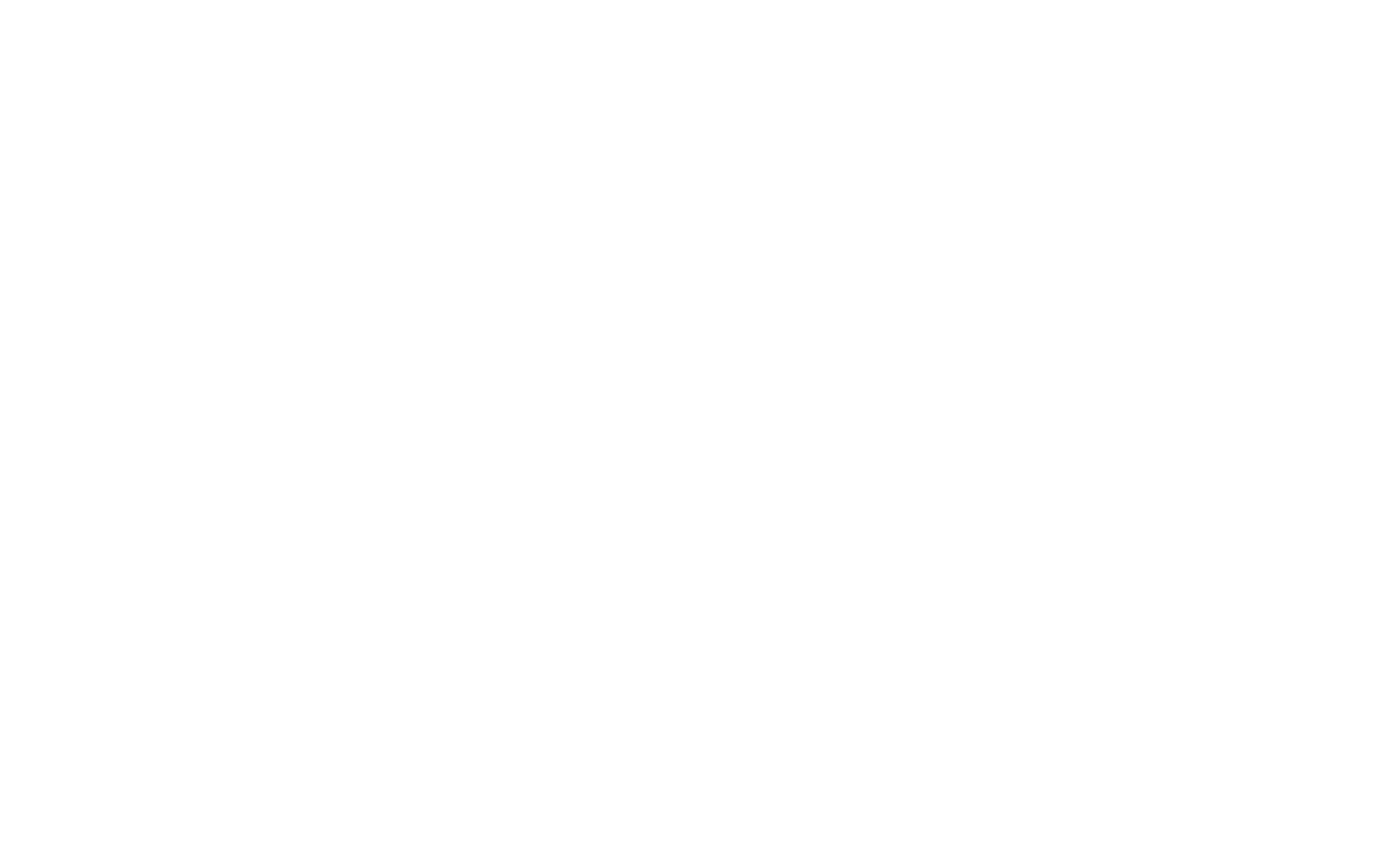



thorn formations is moderately hard. The Vicksburgian limestones supply härd water, and very deep wells in this formation would. doubtless find strong salt water.

Development.-Wells 10 to 30 feet in depth usually obtain good supplies of soft water, but a few wells have been sunk to a depth of 40 to 50 feet. These wells are usually deemed satisfactory for all ordinary purposes, but safer supplies may be obtained at greater depths. In the vicinity of Crescent City a number of flowing wells, which probably obtain water from sands of Pleistocene or Pliocene age, have sufficient head to raise the water about 16 feet above the low ground bordering the river. A deeper supply of artesian water, which heads about 26 feet above the surface, has been obtained by Miller \& Cash at about 300 feet. The supplies from the shallow wells are soft, but the deep well yields hard sulphur water. At Palatka, in the St. Johns Valley, flows are obtained from the Vicksburgian limestones at slightly more than 200 feet. The exact head of this water has not been determined, but it is probably more than 25 feet above the river. In the western part of the county the wells are all shallow. Deep wells would penetrate the Vicksburgian limestones, but flows probably could not be obtained. At Edgar a 65 -foot well, with a head sufficient to raise the water within a few feet of the surface, discharges directly into the pit of the Edgar Plastic Kaolin Co. The exact source of this supply could not be determined, but it is probably some porous layer in the Alum Bluff or the Hawthorn formations.

Small springs are numerous in Putnam County, but none of them are of sufficient size to be important.

Both Crescent City and Palatka have public water supplies. At Crescent City the water is obtained from wells and the supply is regarded as satisfactory. At Palatka the water is taken from springs and wells located near the western edge of the city. Some difficulty has been experienced in obtaining a sufficient quantity and for this reason several test wells have been sunk. These wells appear to have penetrated the Pliocene beds and the supplies obtained were small. A much larger quantity of water, though possibly sulphureted, could doubtless be procured by sinking deeper wells. 
General water resources of Putnam County.

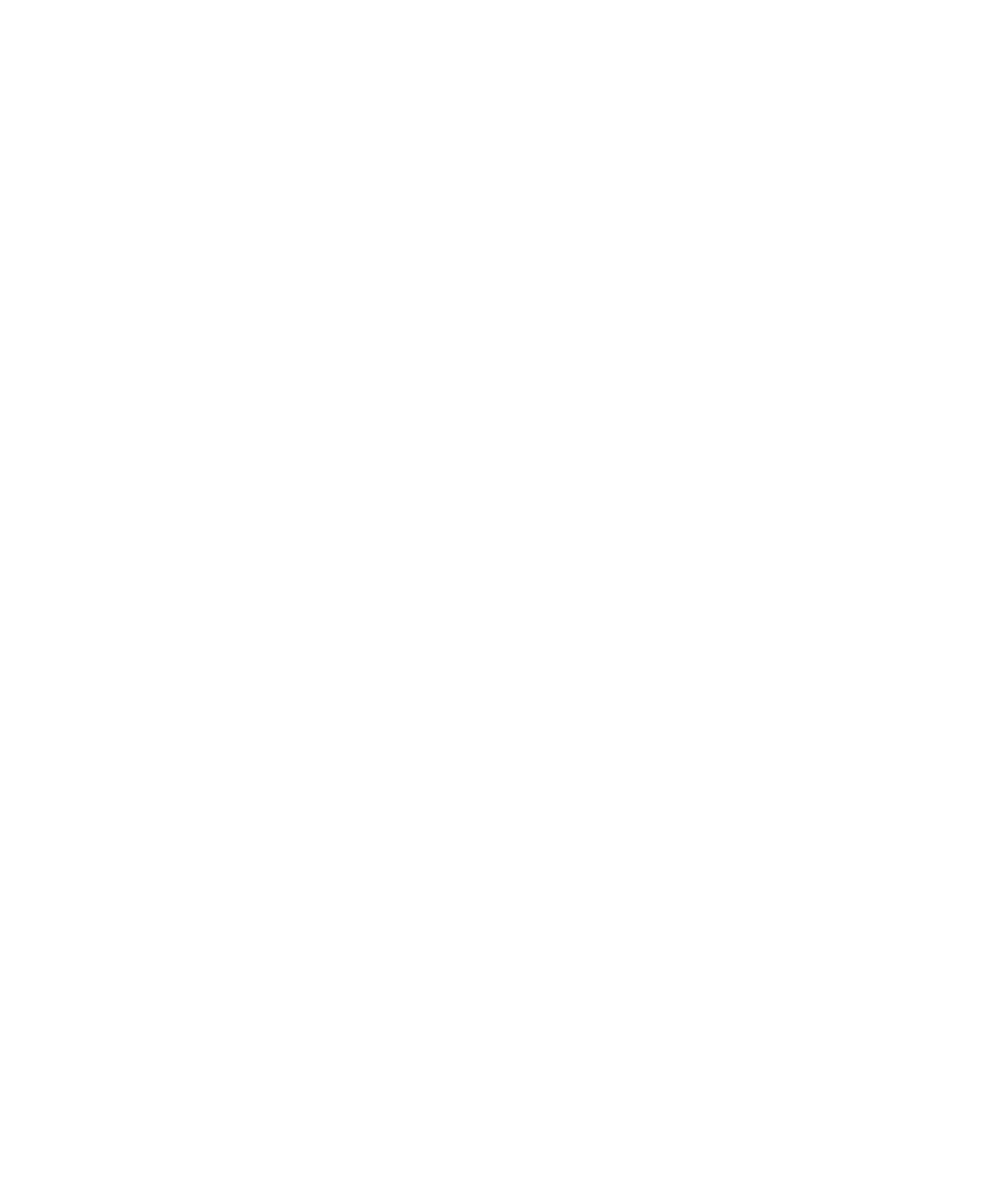

\section{ST. JOHN COUNTY.}

By G. C. Matson.

\section{GENERAL FEATURES.}

St. John County is on the east coast, near the northern end of the State. It comprises a portion of the low coastal belt between the Atlantic Ocean and St. Johns River. The surface is flat and usually rises only a few feet above sea level, though locally it may have an altitude of nearly 50 feet. There are no large streams within the county, but some small creeks, a few miles long, drain the region near the coast. Swamps are numerous, especially during rainy seasons. The coast is bordered by low bars separated from the main- 
land by shallow sounds; the most important, Anastasia Island, is situated opposite St. Augustine. Many of the bars are covered with sand dunes, some of which are of considerable height.

\section{GEOLOGY.}

The entire surface of St. John County is covered by Pleistocene materials consisting largely of white or gray sands. Coquina in small areas occurs near St. Augustine, is well exposed on Anastasia Island, and is also known to underlie the sands in other parts of the county, but exposures are rare. Marls of Pliocene age probably cover a part of the county, but they are known only on St. Johns River near the southwest corner, where the Nashua marl occurs along the banks of the stream. Well records at St. Augustine show that the Jacksonville formation is represented at that locality. The Vicksburgian limestones underlie the entire county, though they are deeply buried beneath younger rocks and their presence has been detected only in samples obtained in drilling wells at St. Augustine and vicinity.

The average thickness of the Pleistocene sands and eoquina in St. John County is probably somewhat more than 50 feet, and the Nashua marl may have an equal thickness, but in the absence of detailed information these estimates are to be regarded as uncertain. The Jacksonville formation is approximately 130 feet thick at St. Augustine, and its maximum thickness toward the northern boundary of the county is probably over 250 feet. No information could be obtained concerning the Apalachicola group in this county. The Vicksburgian limestones were encountered at a depth of about 224 feet at St. Augustine and the samples obtained from the well at the Ponce de Leon Hotel show that it continues to a depth of more than 1,400 feet, thus giving it a minimum thickness of over 1,175 feet.

Log of well at Catholic cemetery, south of St. Augustine.

\begin{tabular}{|c|c|c|}
\hline & Thickness. & Depth. \\
\hline 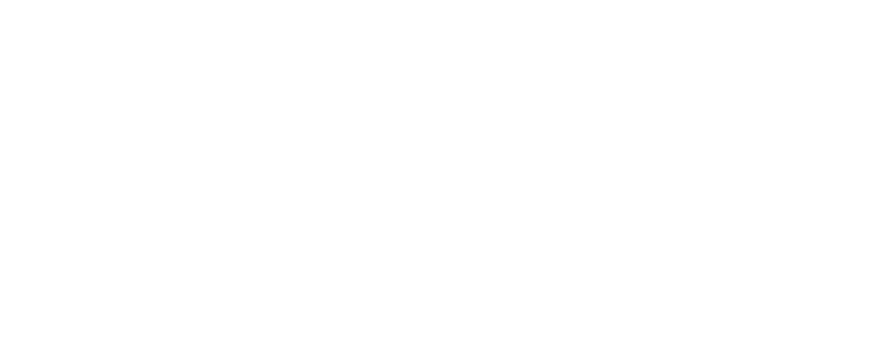 & Feet. $\begin{array}{r}15 \\
10 \\
35 \\
5 \\
12 \\
16 \\
10 \\
1 \\
15 \\
1 \\
50 \\
4 \\
27 \\
17 \\
47\end{array}$ & $\begin{array}{r}\text { Feet. } \\
15 \\
25 \\
60 \\
65 \\
77 \\
93 \\
103 \\
104 \\
119 \\
120 \\
170 \\
174 \\
201 \\
218 \\
265\end{array}$ \\
\hline
\end{tabular}

This well has a good flow of sulphur water, which rises to about 30 feet above the surface. 
The first 93 feet is probably Pleistocene with possibly some Pliocene. The remainder of the material is probably largely Miocene belonging to the Jacksonville formation.

From an incomplete series of samples obtained in drilling a well at the Ponce de Leon Hotel at St. Augustine, Mr. Clapp compiled the following log:

Record of well 1,400 feet deep at Ponce de Leon Hotel, drilled in 1886.

Sand.

Sand with shell (surface water stops here).

Clay, blue

.

Sand...

Clay, indurated, and sand lumps.

Clay, blue...

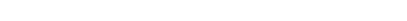

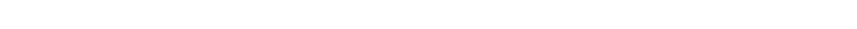
Rock (sulphur water, 350 gallons per minute)

Limestone (1,800 gallons per minute; head +38 feet)

Limestone (flow, $3,000,000$ gallons per day)

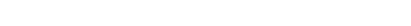

Limestone; dense light brown (sudden increase of water to $7,000,000$ gallons per day;

head +42 feet; temperature, $79^{\circ}$ ).

White chalk, green clay, and porous coral, dark in color.

(Sand pumping resumed at 557 feet, showing the limit of sulphur water is reached. Again in coral full of fossils, early crinoid and pecten shells.)

\section{Limestone.}

Seeps found here

Hard drilling, probably chert

Soft drilling again; sand pump brought up coral as before.

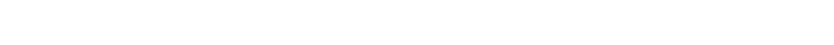

\begin{tabular}{|c|c|}
\hline Thickness. & Depth. \\
\hline $\begin{array}{r}\text { Feet. } \\
35 \\
15 \\
7 \\
8 \\
11 \\
1\end{array}$ & $\begin{array}{r}\text { Feet. } \\
35 \\
50 \\
57 \\
65 \\
76 \\
77\end{array}$ \\
\hline $\begin{array}{r}93 \\
7 \\
173 \\
60 \\
85\end{array}$ & $\begin{array}{l}170 \\
177 \\
350 \\
410 \\
495\end{array}$ \\
\hline $\begin{array}{l}\mathbf{2 5} \\
\mathbf{3 7}\end{array}$ & $\begin{array}{l}520 \\
557\end{array}$ \\
\hline $\begin{array}{l}\ldots \ldots \\
\ldots \ldots \\
\ldots \ldots\end{array}$ & $\begin{array}{l}660 \\
675 \\
685\end{array}$ \\
\hline $\mathbf{8 g}_{0}$ & $\begin{array}{r}520 \\
1,400\end{array}$ \\
\hline
\end{tabular}

The following log shows the nature of the material penetrated in drilling a well 5 miles south of Hastings:

Log of well 5 miles south of Hastings.

\begin{tabular}{|c|c|c|}
\hline & Thickness. & Depth. \\
\hline 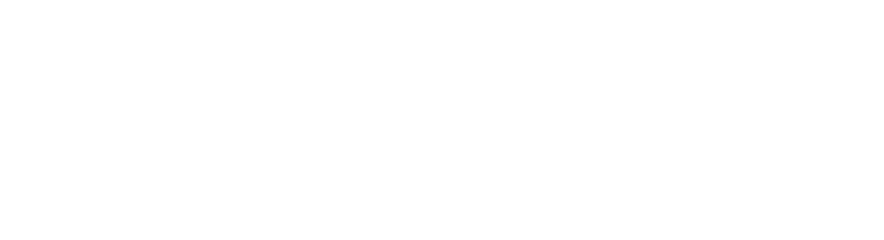 & \begin{tabular}{c|} 
Feet. \\
$\frac{3}{3}$ \\
6 \\
6 \\
18 \\
18 \\
20 \\
20 \\
18 \\
$1 \frac{1}{2}$
\end{tabular} & 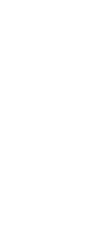 \\
\hline
\end{tabular}

The following general log of materials penetrated at Hastings was supplied by Mr. I. C. Peck, a well driller:

General log at Hastings.

Feet.

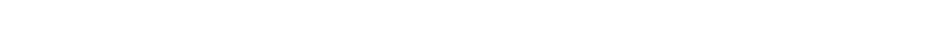

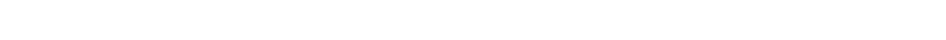

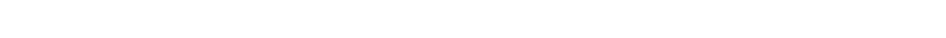

Clay, blue; extends to shell bed..................... 20-30

Shell bed, with first surface water; rock shell bed $\frac{1}{2}$ to 8 feet..... 35-90

Clay, blue, to rock; thickness variable.

Rock, largely limestone with thin beds of chert. Source of water mostly limestone; in some wells white to grayish white....... 
Typical wells of St. John County.

\begin{tabular}{|c|c|c|c|c|c|c|c|c|c|c|c|c|c|c|c|c|c|c|}
\hline $\begin{array}{l}\text { Nearest town or } \\
\text { post office. }\end{array}$ & $\begin{array}{l}\text { Direction and dis- } \\
\text { tanee. }\end{array}$ & Owner. & Driller. & $\begin{array}{l}\text { Date } \\
\text { sunk. }\end{array}$ & Surface formation. & Geologie source. & $\begin{array}{l}\text { Type of } \\
\text { well. }\end{array}$ & Use. & Depth. & $\begin{array}{c}\text { Diam- } \\
\text { eter. }\end{array}$ & Casing. & $\begin{array}{c}\text { Eleva- } \\
\text { tion } \\
\text { above } \\
\text { sea. }\end{array}$ & \begin{tabular}{|c} 
Head \\
abovere \\
or \\
below \\
surface.
\end{tabular} & $\begin{array}{c}\text { Depth } \\
\text { to } \\
\text { rock. }\end{array}$ & $\begin{array}{l}\text { Depth } \\
\text { to prin- } \\
\text { cppal } \\
\text { supply. }\end{array}$ & Quality of water. & $\begin{array}{c}\text { Yield } \\
\text { per } \\
\text { minute. }\end{array}$ & Remarks. \\
\hline Anastasia Island... & 1. mile north of & Betsworth.. & & & Pleistocene.. & $\begin{array}{l}\text { Vicksburgian } \\
\text { stone }\end{array}$ & Drilled... & & $\begin{array}{l}\text { Feet. } \\
250\end{array}$ & $\begin{array}{r}\text { Inches. } \\
6\end{array}$ & Feet. & $\begin{array}{l}\text { Feet. } \\
\text { Few. }\end{array}$ & Feet. & Feet. & Feet. & & Gallons. & \\
\hline $\begin{array}{l}\text { Armstrong......... } \\
\text { Dinner Island.... }\end{array}$ & $\begin{array}{l}\text { lighthouse. } \\
\text { 2miles north....... } \\
\text { Southeast........ }\end{array}$ & $\begin{array}{l}\text { Rev. S. Langlade } a_{\ldots} . . \\
\text { Padmett \& Co }\end{array}$ & Merwin & & 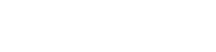 & "viononinom & & & 204 & 6 & & & +12 & 145 & 152 & Hard, sulphur.. & & \\
\hline Elkton $\ldots \ldots$ & 5 miles south...... & 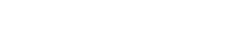 & 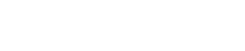 & & ....do..... & 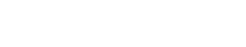 & ...do...... & & 200 & & & & -21 & & & & & \\
\hline $\begin{array}{l}\text { Federal Point. } \\
\text { Do........... }\end{array}$ & 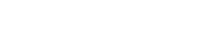 & $\mathrm{J}_{\mathrm{W}} \mathrm{L}_{\mathrm{L}}$ Fonney \& \& Son... & Lloyd Crary................ & 1893 & a.......... & …do......................... & ....do..... & $\begin{array}{l}\text { Domestic and stock... } \\
\text { Irrigation }\end{array}$ & 250 & $\begin{array}{c}4 \\
6\end{array}$ & 175 & $\begin{array}{l}66 \\
15\end{array}$ & $\mid \begin{array}{l}+32^{2} \\
+30\end{array}$ & $\cdots$ & 250 & Sulphur.......... & 500 & Second supply at 200 feet. \\
\hline & …do.................. & $\begin{array}{l}\text { W. A. Evansa } \\
\text { E. A. Hubbard a.......... }\end{array}$ & & & & & & 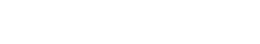 & 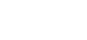 & 6 & & & +45 & 155 & 155 & …do................ & 然00 & \\
\hline & $1 \frac{1}{1}$ miles east. & C. A. Latten a... & Liloy Crary. & (1903 & Pleistocene... & Vieksburgian lime- & Drilied. & Drinking and stock ... & $\begin{array}{l}183 \\
235\end{array}$ & & & 5 & +40 & 160 & & …….......... & 600 & Second supply at 183 feet. \\
\hline Hastings... & 5 miles south... & Frank Bugbee $a \ldots$ & & 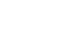 & & $\begin{array}{l}\text { stone. } \\
\ldots \ldots \ldots \ldots\end{array}$ & & Irrigation and drink- & 218 & 4 & ..... & 15 & +20 & 140 & bottom. & ......do................ & Many. & \\
\hline Do..... & & Florida Vegetable Co.. & I. C. Peck............. & 1907 & Pleistocene...... & Vicksburgian & Drilled... & $\begin{array}{l}\text { ing. } \\
\text { Cooling condensers.... }\end{array}$ & 234 & 4 & 178 & $b 20$ & +26 & $\cdots$. & $180+$ & ….do.................. & Many. & Forms scale. \\
\hline Do...... & $1 \frac{1}{2}$ miles south.... & F. S. Bickok $a_{\ldots} . \ldots \ldots$ & & & & & & Irrigation and domestic & 155 & 4 & & 18 & +20 & 139 & 155 & Hard, sulphur, & 120 & \\
\hline $\begin{array}{l}\text { Do.... } \\
\text { Hurds.... }\end{array}$ & $\frac{3}{4}$ mile south.... & 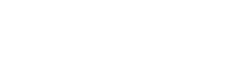 & Owner.... & & $\begin{array}{l}\text { Pleistocene.... } \\
\text {......do.......... }\end{array}$ & vicksburgian lime & $\begin{array}{l}\text { Drilled..... } \\
\text { …do..... }\end{array}$ & Irrigation and farm.... & $\begin{array}{l}148 \\
385\end{array}$ & $\begin{array}{c}4 \\
\ldots\end{array}$ & $\begin{array}{l}130 \\
180\end{array}$ & $\begin{array}{l}b 20 \\
b 38\end{array}$ & \pm 24 & & $130+$ & (n) & Many. & Maximum head at 200 feet. \\
\hline $\begin{array}{l}\text { Do.. } \\
\text { Matanzas }\end{array}$ & & $\begin{array}{l}\text { Hurds Sawmill.. } \\
\text { Cut So Plopil }\end{array}$ & I. C. Peck.. & & do. & $\begin{array}{l}\text { stone. } \\
\ldots \text { do............................... }\end{array}$ & $\cdots$ do.... & & $350 \pm$ & $\cdots$ & & High. & - & & & & & \\
\hline $\begin{array}{l}\text { Matanzas........ } \\
\text { Picolata....... } \\
\text { St. Ancusine }\end{array}$ & 2 miles north. & 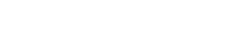 & & 1890 & & l..do & (n.doo... & Irrigation.................. & 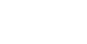 & 6 & & & $\ldots$ & & & Brackish. & Many. & \\
\hline St. Augustine.. & & H. C. Amindoren..... & Owner.. & & .....do.. & ....do.. & ....do... & $\begin{array}{l}\text { Domestle and irriga- } \\
\text { tion. }\end{array}$ & $250+$ & & & & 50-250 & & $250+$ & Sulphur...... & & \\
\hline & i mile north. & 花 & & 1897 & a.do.: & ...do...... & (........... & Pubilic suppiy............. & 年25 & 12 & 100 & 65 & +123 & & $250-500$ & sulphur.. & 1,400 & $\begin{array}{l}\text { Corrodeses metali. } \\
\text { Strong flow about } 500 \text { feet. }\end{array}$ \\
\hline & & $\begin{array}{l}\text { Florida East Coast } \\
\text { Hotel Co. }\end{array}$ & & $\begin{array}{l}1888 \\
1889\end{array}$ & & & a...do...... & $\begin{array}{l}\text { Ponce de Leon Hoteil } \\
\text { Co. }\end{array}$ & 1,350 & $\begin{array}{r}12,9 \\
10\end{array}$ & $\begin{array}{l}145 \\
170\end{array}$ & $\begin{array}{l}05 \\
615\end{array}$ & $t^{+12 \pm}$ & & 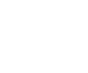 & Salt and sulphur.: & $\begin{array}{c}1,400 \\
5,500 \\
2,-\infty\end{array}$ & $\begin{array}{l}\text { Moo supplies from about } \\
\text { 400 to } 500 \text { feet. Strong } \\
\text { flow at } 520 \text { feet. }\end{array}$ \\
\hline Do... & & 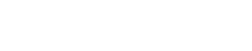 & & & (....do..... & (....do....... & ….do..... & 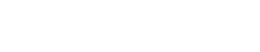 & $\begin{array}{l}520 \pm \\
520+\end{array}$ & & & & $\stackrel{+}{+}$ & & $\begin{array}{l}520 \\
520\end{array}$ & W...do... & 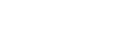 & \\
\hline Do.. & & Florida East Coast $\mathrm{R}$ y. & Partriäge. & & ,...do... & …do.....: & (…do.... & 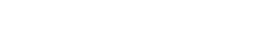 & $\begin{array}{l}523+ \\
375\end{array}$ & .. & & $\ddot{b} 10$ & & $\cdots$ & 520 & ….do............ & Many. & Mouth of well a few feet \\
\hline $\begin{array}{l}\text { Do. } \\
\text { Do. }\end{array}$ & 3 miles north.. & $\begin{array}{l}\text { Gardiner Bros............... } \\
\text { C. F. Hamlin.......... }\end{array}$ & & & …do. & …do. & a.do & $\begin{array}{l}\text { Not used.................. } \\
\text { Power }\end{array}$ & $\begin{array}{l}250 \pm \\
520\end{array}$ & & & & $+15 \pm$ & & & & & $\begin{array}{l}\text { rodes metal. } \\
\text { Locality abandoned. }\end{array}$ \\
\hline & & 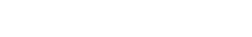 & & & & $\cdots$ & (2...do..... & Domestic and stock.. & $\begin{array}{l}0200 \\
200\end{array}$ & 4,6 & 100 & $\ddot{b} \ddot{2}$ & & 175 & & Sulphur............. & & \\
\hline & 5 miles north..... & $\begin{array}{l}\text { 'North Beach R.R.C.Co. } \\
\text { st. Angustine Water }\end{array}$ & & 1893 & ב...do... & l..do... & …do..... & Not used.................. & $\begin{array}{l}2500 \\
350-450\end{array}$ & & & $\begin{array}{l}+ \\
\text { Few. } \\
+\end{array}$ & +35 & & & lo. & Many. & $\begin{array}{l}\text { Do. } \\
\text { Seven wells. }\end{array}$ \\
\hline $\begin{array}{l}\text { Do.... } \\
\text { Do... }\end{array}$ & & $\begin{array}{l}\text { St. Francis Barracks. } \\
\text { St. }\end{array}$ & & & ...do... & ...do.... & …do.... & & $\begin{array}{l}300 \pm \\
527\end{array}$ & $\begin{array}{r}6 \\
10\end{array}$ & & Few. & t & & & & & Corrodes metal \\
\hline & & $\begin{array}{l}\text { Power Co. } \\
\text { H. Walker............... }\end{array}$ & & & .....do. & ..do. & ....do.. $\quad>$ > & & 250 & 4 & & Few. & +33 & & & & Many. & Do. \\
\hline 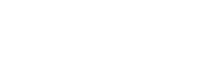 & $\begin{array}{l}\frac{1}{1} \text { miles northeast. } \\
1 \frac{1}{2} \text { miles southwest. }\end{array}$ & $\begin{array}{l}\text { Mo. Armstrong a.... } \\
\text { M. S. Moreman } a . . . . .\end{array}$ & & & ....do. $\quad$ > $>$ & & ....do.. & 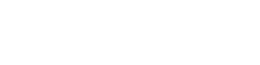 & $\begin{array}{l}265 \\
337 \\
300\end{array}$ & $\begin{array}{l}6 \\
4 \\
2\end{array}$ & & ${ }_{25}^{20}$ & +30 & & $\begin{array}{l}3_{280}^{330} \\
280-1\end{array}$ & $\begin{array}{l}\text { Sofot, sulphur.......... } \\
\text { Soft............... }\end{array}$ & $\begin{array}{l}400 \\
400\end{array}$ & Do. \\
\hline
\end{tabular}



The hard rock which caps the artesian bed is doubtless chert and the water-bearing rock is probably of Oligocene age.

\section{WATER SUPPLY.}

Source.-Good supplies of soft water are obtained from the Pleistocene sands which form the surficial deposits, but the supplies from the older geologic formations are much more extensively utilized. Both the Jacksonville formation and the Vicksburgian limestones yield artesian water. The Vicksburgian limestones afford more water than the younger rocks and they are usually regarded as the best source of supply. In the well at the Ponce de Leon Hotel the first flow is from the Jacksonville formation and the subsequent flows are from Vicksburgian limestones.

Quality.-The Pleistocene sands furnish soft water. The Jacksonville formation and the Vicksburgian limestones yield sulphur water, which becomes more highly mineralized with increasing depth. This fact is well shown by the log of the Ponce de Leon Hotel, where the deep supplies are saline.

Development.-In St. Augustine some old open wells walled with coquina are said to have been dug by the Spaniards. (See Pl. VI, $B$, p. 32.) At present the tendency is to sink deep wells, and these are more desirable than the shallow wells because they are not likely to be polluted by impure surface water. The supplies obtained from drilled wells are large enough to meet all demands and the head is sufficiently great to give good flows along the east coast and in the St. Johns River valley. On some of the high land which forms the divide between St. Johns River and the Atlantic flowing wells can not be obtained, but the water rises nearly to the surface and can be easily pumped. The supplies from all except the very deep wells are satisfactory for all purposes.

There is a general lack of large springs in St. John County, though a large submarine spring is situated off St. Augustine. The water is said to emerge from an orifice about 65 feet in diameter and to rise with sufficient force to make the surface of the ocean immediately above the spring slightly convex. At the spring the sea is reported to be about 50 feet deep and the spring itself about 200 feet.

The St. Augustine public supply is obtained from flowing wells and is reported to be satisfactory. 
General water resources of St. John County.

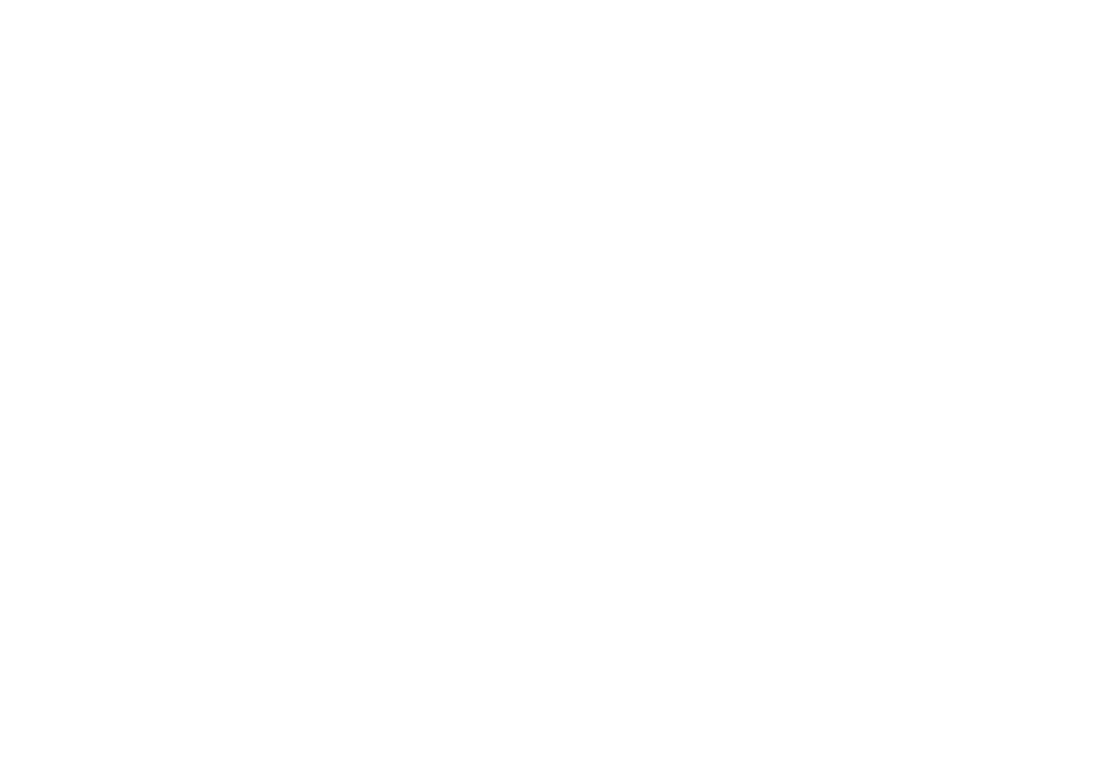

\section{ST. LUCIE COUNTY.}

By G. C. Matson.

\section{GENERAL FeATURES.}

St. Lucie County occupies a tract of land 15 to 30 miles wide, extending from the latitude of the northern end of Lake Okechobee northward to Brevard County. The coast is bordered by a long narrow bar, which is separated from the mainland by a shallow sound known as Indian River and is crossed by Indian River Inlet. This so-called river contains brackish water and has no perceptible current except that caused by winds and tides. On the mainland a short distance from the shore a ridge of nearly pure sand probably represents a beach formed when the sea was farther upon the land than it is at the present time. Westward from this ridge the land is flat and low, rising in few places more than a few feet above sea level and nowhere reaching an altitude of 50 feet. The drainage of this lowland is very defective, the surface being covered with marshes, some of which are large. Locally shallow lakes are numerous, but most of them are small and unimportant.

\section{GEOLOGY.}

Gray sands of Pleistocene age cover the entire surface of St. Lucie County and in places are underlain by marls and coquina which also belong to the Pleistocene. At Fort Pierce the Vicksburgian limestones are buried beneath several hundred feet of younger beds, which 
doubtless include representatives of both the Miocene and Pliocene and the younger Oligocene formations, but their discrimination must await the collection of samples from drillings.

At Ormond, in Volusia County, the Pleistocene sands and marls are at least 68 feet thick, and they are probably somewhat thicker in St. Lucie County. At Fort Pierce the Vicksburgian limestones were encountered at 670 feet. This leaves about 500 feet of strata of undetermined age. It is probably made up in descending order of Pleistocene, Pliocene, Miocene, and upper Oligocene formations.

Log of well of St. Lucie Ice Co., Fort Pierce.

\begin{tabular}{|c|c|c|}
\hline & Thickness. & Depth. \\
\hline 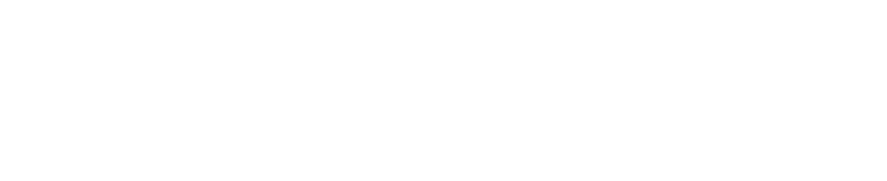 & $\begin{array}{r}\text { Feet. } \\
2 \\
6 \\
4 \\
50 \\
40 \\
570 \\
142\end{array}$ & $\begin{array}{r}\text { Feet. } \\
2 \\
8 \\
10 \\
60 \\
100 \\
670 \\
812\end{array}$ \\
\hline
\end{tabular}

WATER SUPPLY.

Source.-The water supplies of St. Lucie County are obtained from shallow wells in the Pleistocene sands and marls and rarely from the coquina and from deep wells in the Vicksburgian limestones. Water could doubtless be obtained in beds lying stratigraphically between the Pleistocene and Vicksburgian, but no effort has been made to develop these supplies.

Quality.-The Pleistocene sands yield soft water. The water from the Vicksburgian limestone is free from danger of contamination but is highly mineralized and contains sulphur. At several horizons between the Pleistocene and the Vicksburgian limestones it should be possible to obtain water less highly mineralized.

Development.-In St. Lucie County water is readily obtained at depths of less than 30 feet, but it is sometimes of doubtful sanitary quality. Flowing wells could probably be obtained in nearly all parts of the county, but the water is salt. However, artesian water is used at Fort Pierce and could doubtless be used elsewhere.

$76854^{\circ}$-wSP $319-13-26$ 


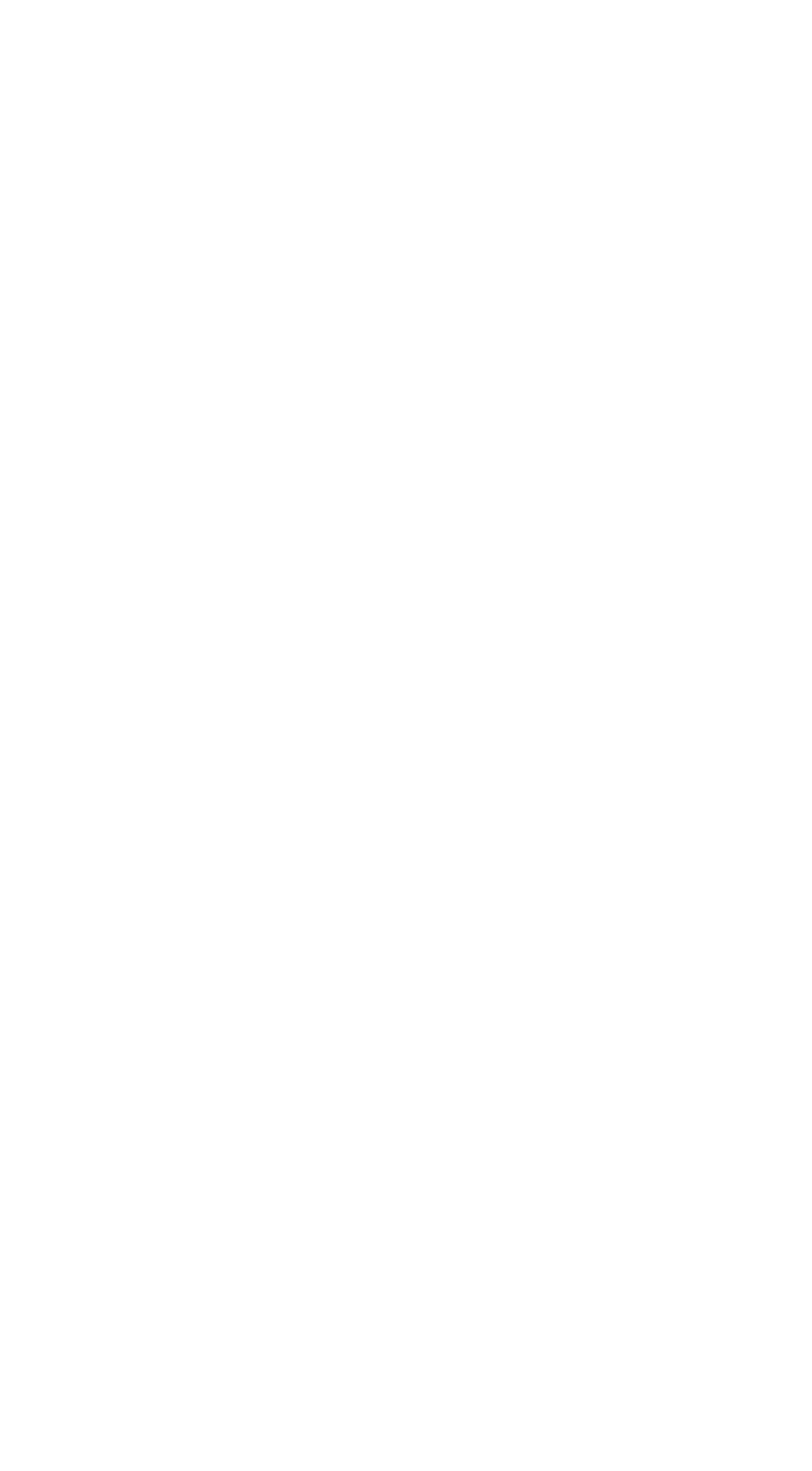




\section{SANTA ROSA COUNTY.}

By G. C. Matson.

GENERAL FEATURES.

Santa Rosa County, near the western end of the State, comprises an area about 40 miles wide extending from the Gulf of Mexico northward to the boundary of the State, a distance of about 30 miles. In the northern part large areas are more than 200 feet in altitude, but near the coast the surface rises only a few feet above sea level. An extensive lowland terrace rising 20 to 30 feet above sea level stretches across the southern end of the county and along the principal streams; it narrows gradually toward the north. Two other terraces, one 40 to 60 feet and the other 70 to 100 feet in altitude, are extensively developed in southern Santa Rosa County and occupy narrow areas along the streams. In the southern part of the county, especially near Yellow River, extensive areas of swamp land lie only a few feet above sea level and after heavy rains are covered by a few inches to 1 or 2 feet of water. The surface of the northern half of the county consists of rolling uplands crossed by the broad valleys of the principal streams and deeply dissected by the narrow channels of the minor streams. This upland evidently represents a former plain greatly modified by erosion.

\section{GEOLOGY.}

The terraces of Santa Rosa County are composed of gray sand of Pleistocene age, which forms a continuous covering over all the lowland portion of the county. On the uplands gray residual sands are underlain by red, yellow, and mottled sands and sandy clays belonging to the Lafayette (?) formation. This formation caps all the remnants of the upland plain and its eroded and redeposited materials are found in the valleys which cut that plain. The Choctawhatchee marl is believed to reach the surface in the vicinity of Milligan and to extend thence in a nearly continuous belt westward to the west boundary of the State. This formation is underlain by sands and marls belonging to the Alum Bluff formation and these in turn are probably underlain by the Chattahoochee formation. The Vicksburgian limestones underlie the entire county but are so deeply buried that it is impossible to obtain information concerning them.

In the lowlands the aggregate thickness of the sands of Pleistocene age may be more than 50 feet. The average thickness of the Lafayette (?) formation is probably less than 30 feet, and its maximum is doubtless less than 50 feet. Practically no information could be obtained concerning the thickness of the Choctawhatchee marl and in- 
formation concerning the underlying formations is very meager. The marls and sands of the Alum Bluff formation doubtless attain a thickness of more than 50 feet and the Chattahoochee possibly of more than 100 feet.

\section{WATER SUPPLY.}

Source.-In the lowlands the gray sands furnish the greater portion of the supplies for the shallow wells, and throughout the upland portions of the county the Lafayette (?) formation is the principal source of supply for wells of moderate depth. Each of the older formations should contain an abundance of water, but as yet practically no reliable information is obtainable concerning their water-bearing capacity within the county. In other counties the Choctawhatchee marl and the marls and sands of the Alum Bluff formation are good water bearers, and satisfactory supplies may be expected from them in Santa Rosa. Both the Chattahoochee formation and the Vicksburgian limestones are known to be good water-bearing rocks and large supplies of water could doubtless be obtained from them in this county.

Quality.- Soft water is obtained from the gray sand of Pleistocene age and generally from the shallow wells which penetrate the Lafayette (?) formation. Moderately hard water may be expected from some of the deeper wells in the sands and marls of the Choctawhatchee and Alum Bluff formations. All the water from the Chattahoochee formation and the Vicksburgian limestones would probably be hard and some of it might be saline.

Development.-Most of the shallow wells in Santa Rosa County go down 15 to 35 feet, at which depth they procure large quantities of water suitable for both domestic and industrial uses. The water level is near the surface and the supplies may be easily pumped. No deep wells have been drilled, but several wells 75 to 100 feet deep have been sunk in the vicinity of Milton and Bagdad. All these wells obtain large quantities of excellent water, though some of it is reported to be moderately hard. There are three flowing wells in the swamps near Bagdad, but the yield is small and the head is sufficient to raise the water only a few feet above the surface. A similar flowing well with a very small yield has been drilled on the shore of Escambia Bay at Robinson Point. Doubtless other similar wells might be obtained on very low ground either in swamps or along the coast. It is probable that deeper wells on the lowland might obtain flows similar to those at Freeport, but as yet no wells have been drilled to sufficient depth to test the matter. 
SANTA ROSA COUNTY.

Typioal wells of Santa Rosa County.

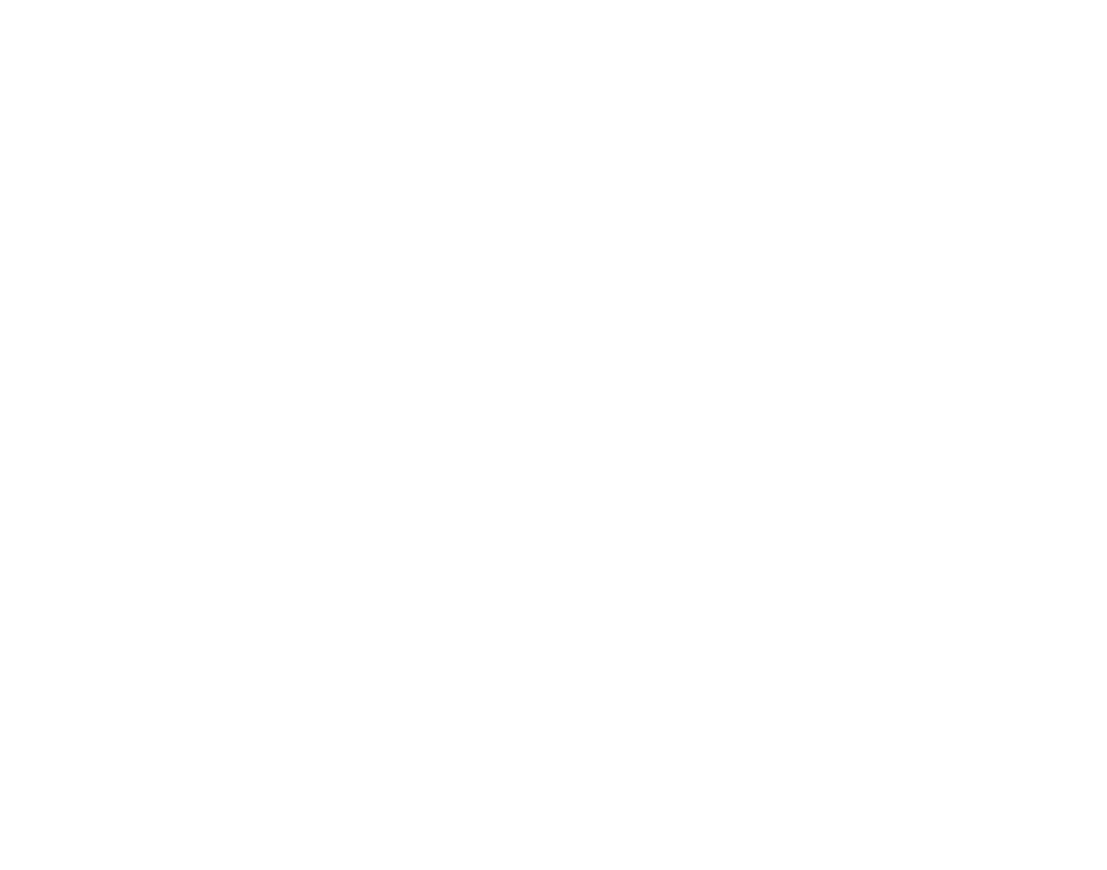

a Tathimated.

General water resources of Santa Rosa County.

\begin{tabular}{|c|c|c|c|c|c|c|c|c|c|c|}
\hline \multirow{2}{*}{ Town. } & \multirow{2}{*}{$\begin{array}{c}\text { Topo- } \\
\text { graphic } \\
\text { loca- } \\
\text { tion. }\end{array}$} & \multirow{2}{*}{\multicolumn{4}{|c|}{ Source of water. }} & \multirow{2}{*}{\multicolumn{2}{|c|}{$\begin{array}{l}\text { Surface forma- } \\
\text { tion. }\end{array}$}} & \multicolumn{3}{|c|}{ Shallow wells. } \\
\hline & & & & & & & & Depth. & $\begin{array}{l}\text { Water } \\
\text { supply. }\end{array}$ & 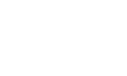 \\
\hline $\begin{array}{l}\text { Bagdad ........ } \\
\text { Chumnckia.... } \\
\text { Milton......... }\end{array}$ & $\begin{array}{l}\text { Plain. } \\
\ldots . \text { do... } \\
\ldots . \text { do... }\end{array}$ & $\begin{array}{c}\mathrm{Du} \\
\mathbf{D u} \\
\cdots\end{array}$ & $\begin{array}{l}\text { g, driven, } \\
\text { gand dril } \\
\text { do........ }\end{array}$ & $\begin{array}{l}\text { ad drilled we } \\
\text { wedts.......................... }\end{array}$ & $\begin{array}{l}\text { lls.... } \\
\ldots . . . . \\
\ldots . . .\end{array}$ & 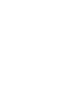 & ocene.... & $\begin{array}{l}\text { Feet. } \\
15-75 \\
20-60 \\
30-55\end{array}$ & $\begin{array}{l}\text { Large... } \\
\text { Ample. } \\
\text { Good... }\end{array}$ & Hard. \\
\hline \multirow{2}{*}{ Town. } & \multicolumn{4}{|c|}{ Deep welts. } & \multirow{2}{*}{\multicolumn{2}{|c|}{$\begin{array}{l}\text { Average } \\
\text { thickness } \\
\text { of sand. }\end{array}$}} & \multirow{2}{*}{$\begin{array}{l}\text { Depth to } \\
\text { water. }\end{array}$} & \multirow{2}{*}{\multicolumn{2}{|c|}{$\begin{array}{c}\text { Inorease or } \\
\text { decrease of } \\
\text { supply. }\end{array}$}} & \multirow{2}{*}{$\begin{array}{l}\text { Sewerage } \\
\text { system. }\end{array}$} \\
\hline & \multicolumn{2}{|c|}{ Bopth. } & $\begin{array}{l}\text { Water } \\
\text { supply. }\end{array}$ & $\begin{array}{l}\text { Quality of } \\
\text { water. }\end{array}$ & & & & & & \\
\hline $\begin{array}{l}\text { Bagdad } \\
\text { Chumuakia....... } \\
\text { Milton.......... }\end{array}$ & \multicolumn{2}{|c|}{$\begin{array}{r}\text { Feet. } \\
78 \\
80 \\
55-85\end{array}$} & $\begin{array}{l}\text { Large... } \\
\text { Large.... }\end{array}$ & $\begin{array}{c}\text { Hard...... } \\
\text { Hard........ }\end{array}$ & $\ldots$ & aet. & $\begin{array}{r}\text { Feet. } \\
20 \\
\begin{array}{r}80 \\
25\end{array}\end{array}$ & \multicolumn{2}{|c|}{$\begin{array}{l}\text { Slight........ } \\
\text { None....... } \\
\text { Slight....... }\end{array}$} & $\begin{array}{c}\text { None. } \\
\text { Do. } \\
\text { Do. }\end{array}$ \\
\hline
\end{tabular}




\section{SUMTER COUNTY.}

By G. C. Matson.

\section{GENERAL FEATURES.}

Sumter County is in the central part of the peninsula on the western slope. A small area in the eastern part of the county rises more than 100 feet above sea level and a large tract near the northwest corner has an altitude of less than 50 feet.

A great deal of the county is very poorly drained and large shallow ponds are common. The southern and western boundaries are formed by Withlacoochee River, near which the land is low and swampy. Lakes are common, the largest being Lake Panasoffkee, which drains to Withlacoochee River.

\section{GEOLOGY.}

Gray sands of Pleistocene age cover the entire surface of the lowlands and more or less effectually conceal the older formations. Beneath the gray sand is another sand of pale-yellow color which appears to be the result of weathering of the older geologic formations. This sand was doubtless derived from the upper Tertiary formations and owes its color to the presence of the hydrated iron oxide, which locally binds the material into a semi-indurated sandstone and renders much of it plastic. In many places a deposit of sandy kaolin underlies the hills, and similar materials are found in some of the depressions.

The southeastern part of the county is underlain by the Apalachicola group, the rocks beirg referred to the Hawthorn formation, though they might with equal propriety be referred to the Alum Bluff or Tampa formation. The Hawthorn formation doubtless caps many of the higher hills, but its detailed distribution has not yet been determined. A large portion of the county is underlain by limestones of Vicksburgian age. These limestones rise to the surface in the western half of the county and dip gradually to the south and east, where they pass beneath the Hawthorn formation.

The Pleistocene gray sands are comparatively thin, in few places amounting to more than 10 to 20 feet and probably averaging less than 5 feet. Toward the southern end of the county they are believed to be thicker than farther north and they may be underlain by sands and marls belonging to the Pliocene and Miocene. The yellow sands in few places attain a thickness greater than 10 to 20 feet. The Hawthorn formation has been subjected to extensive erosion and hence varies greatly in thickness, in many localities comprising only a few feet of chert or clay resting on the Vicksburgian limestones. Probably its maximum thickness is less than 100 feet, though this is very uncertain, because the formation doubtless thickens toward the southeast corner of the county, where there are 
no well records. The Vicksburgian limestones are several hundred feet thick in Sumter County, but no reliable information is extant concerning the character of the older formations, because the base of the Vicksburg group does not appear to have been reached in the deepest wells.

The most satisfactory well logs obtained in Sumter County are those constructed from samples collected while the wells were being drilled. Two of the logs are given below:

Log of well of John E. Charles, at Oxford.

[From samples of drillings in possession of-the U. S. Geological Survey.]

\begin{tabular}{|c|c|c|}
\hline & Thickness. & Depth. \\
\hline 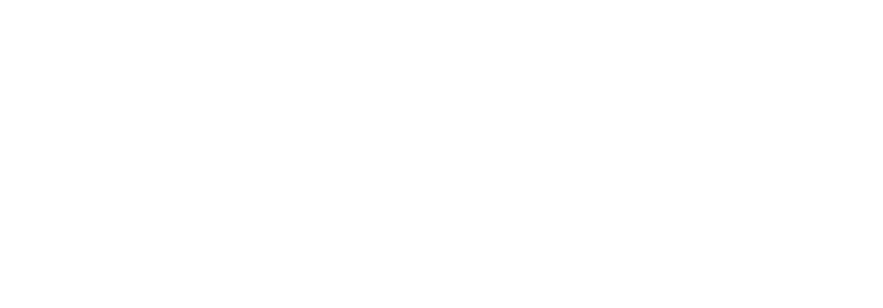 & Feet. \begin{tabular}{r|}
5 \\
5 \\
6 \\
4 \\
5 \\
5 \\
3 \\
1 \\
10 \\
5 \\
20 \\
5 \\
5
\end{tabular} & $\begin{array}{r}\text { Feet. } \\
5 \\
10 \\
16 \\
20 \\
25 \\
30 \\
33 \\
34 \\
45 \\
50 \\
70 \\
75 \\
80\end{array}$ \\
\hline
\end{tabular}

Water was obtained at 60 feet, but the principal supply was encountered at 80 feet. From 5 to 34 feet the material probably belongs to the Hawthorn formation and below 34 feet to the Vicksburg.

Partial log of well of H. O. Collier at Oxford.

[From samples in possession of the U. S. Geological Survey.]

Feet. 10-12

Sand, light yellow 20-23

Clay, green; with some sand

Clay, dark yellow (weathered green clay) .................. 24-25

Clay, light yellow, sandy......................... 28-29

Sand, light yellow, with some clay................... 29-30

Limestone, gray, weathered......................... 35-36

Limestone, soft, white............................. 46-47

Limestone, gray; shell fragments..................... 65

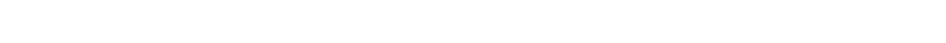

Limestone, light gray to white; shell fragments............ 85

Water was encountered at 56 feet, but the principal supply was obtained at 85 feet. The material represented between 10 and 30 feet is thought to represent the Hawthorn formation. At 75 feet Vicksburg fossils were obtained and it is thought that the Vicksburgian limestones began at 35 feet. 
WATER SUPPLY.

Source.-Well records indicate that the Vicksburgian limestones are the principal source of water in Sumter County. Locally shallow wells may obtain water from the surficial sands or from the sandy beds in the Alum Bluff or Hawthorn formation. From conditions in the adjoining portions of Polk and Osceola counties, Pleistocene or late Tertiary beds may be important aquifers in the southeastern part of the county, but the possibility lacks confirmation because of the absence of wells in that region.

Quality.--Some of the shallow wells in Sumter County obtain soft water from sand, but all the deeper ones get hard water, and even the shallow wells obtain hard water if they enter the Vicksburgian limestones. In general the Vicksburgian limestones furnish hard water and the younger formations soft water. At Sumterville a deep well found sulphur water at 1,400 feet, and all very deep wells will probably do the same.

Development.-Driven or drilled wells 50 to 100 feet deep generally obtain an abundant supply of hard water and some wells obtain good supplies at a depth of less than 50 feet. In a few localities soft water may be procured by wells 15 to 20 feet deep, but it is sometimes of doubtful sanitary quality.

The springs of Sumter County are not extensively utilized. Near Sumterville, water from Branch Mill Spring, owned by D. S. Belton, supplies power for a mill. The yield is reported to be 21,759 gallons per minute and the power is developed by constructing a dam across the stream. The water, which boils up, is hard, coming from the Ocala limestone. Its flow varies appreciably. 
Typical wells of Sumter County.

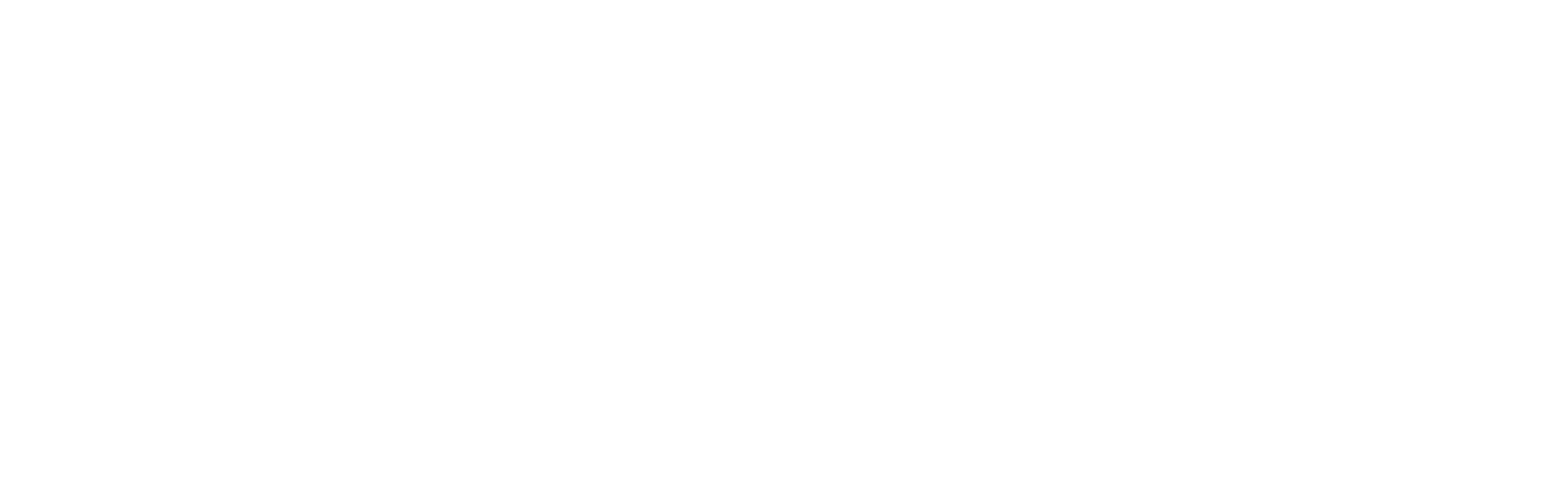

$76854^{\circ}-$ WsP 319-13. (To face page 406.) 
SUMTER COUNTY.

General water resources of Sumter County.

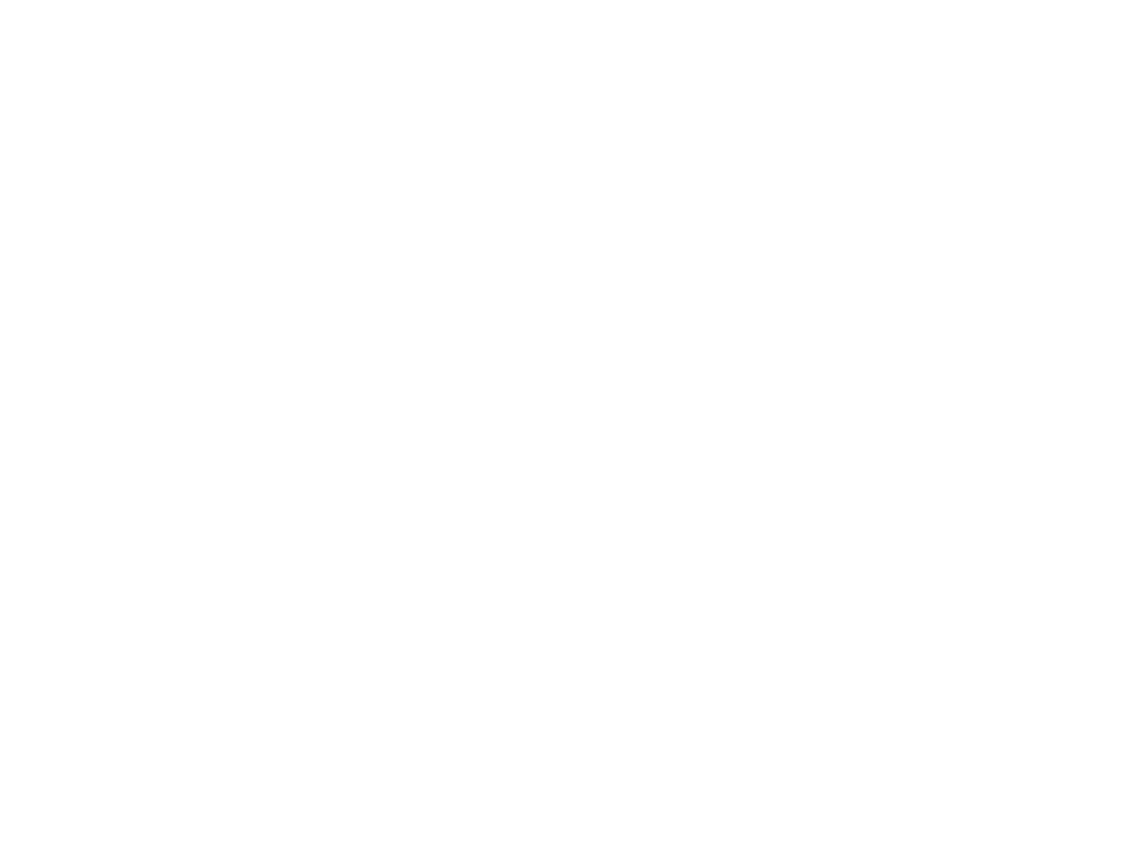




\section{SUWANNEE COUNTY.}

By G. C. Matson.

\section{GENERAL FEATURES.}

Suwannee County is at the northern end of the peninsula near the Georgia line. Its surface is generally rolling and well drained, though in some parts sink holes, small lakes, and ponds are common. The areas bordering Suwannee and Santa $\mathrm{Fe}$ rivers and their principal tributaries are less than 50 feet above sea level, but the upland has an elevation of over 100 feet and a large tract in the northeastern part of the county of over 150 feet.

\section{GEOLOGY.}

Below the 100-foot contour the surface of Suwannee County is covered by gray sand belonging to the Pleistocene. The uplands are covered by a thin mantle of residual sand, underlain by red, yellow, and mottled sands and sandy clays of the Lafayette (?) formation, resting on light-colored sands and clays belonging to the Alum Bluff formation. These deposits overlie limestones belonging to the Hawthorn formation. Near Luraville and in the southeast corner of the county the Vicksburgian limestones appear at the surface, but elsewhere they are for the most part buried beneath the younger formations.

Little is known concerning the thickness of the geologic formations in Suwannee County. The thickness of the Pleistocene sand ranges from a few to about 20 feet, averaging probably not more than 15 feet. The Lafayette (?) formation has a thickness amounting to 30 feet or less and the Alum Bluff formation is somewhat thicker. The thickness of the Hawthorn formation varies greatly, the maximum being not far from 100 feet. The Vicksburgian limestones are doubtless several hundred feet thick, but owing to the absence of good well logs it is impossible to obtain local information concerning them.

\section{WATER SUPPLY.}

Source.-The sands of the Lafayette (?) and Alum Bluff formations will furnish abundant water for shallow wells; and it is probably these sands that are penetrated by many driven wells. The limestone of the Hawthorn formation is also a good water-bearing bed, but the best source of underground water in Suwannee County is the Vicksburgian limestones.

Quality.-Some of the water from the Lafayette (?) and Alum Bluff formations is soft, but a part of it is hard, as is the water from all the older formations. In addition, much of the water from the 
older rocks is sulphureted, a condition especially true of that from the Vicksburgian limestones.

Development.-For domestic and farm uses shallow wells obtain ample supplies of water at depths of 10 to 30 feet. Driven wells 50 to 100 feet deep yield larger supplies, but their water is usually hard and some of it contains sulphur. At Lake City a well sunk to a depth of 1,080 feet yields highly mineralized water, which, however, is reported satisfactory for use as a city supply.

Springs are numerous in Suwannee County, especially along the rivers which border the county. The one best known is the Suwannee Sulphur Springs, a mile northeast of Suwannee. This spring emerges from Oligocene limestone and discharges hard sulphur water at a rate estimated at 52,000 gallons per minute. There is a hotel near the spring and the locality is used as a pleasure resort. The Newland Spring near Falmouth emerges from Oligocene limestone and has a flow of hard water estimated at 100,000 gallons per minute; no use is made of this spring.

Flowing wells can not be obtained in Suwannee County, but the supply of water available for wells which enter the Vicksburgian limestones is practically unlimited. These limestones should be reached by wells varying from a few feet at Luraville to over 200 feet deep in the central and northern parts of the county. 


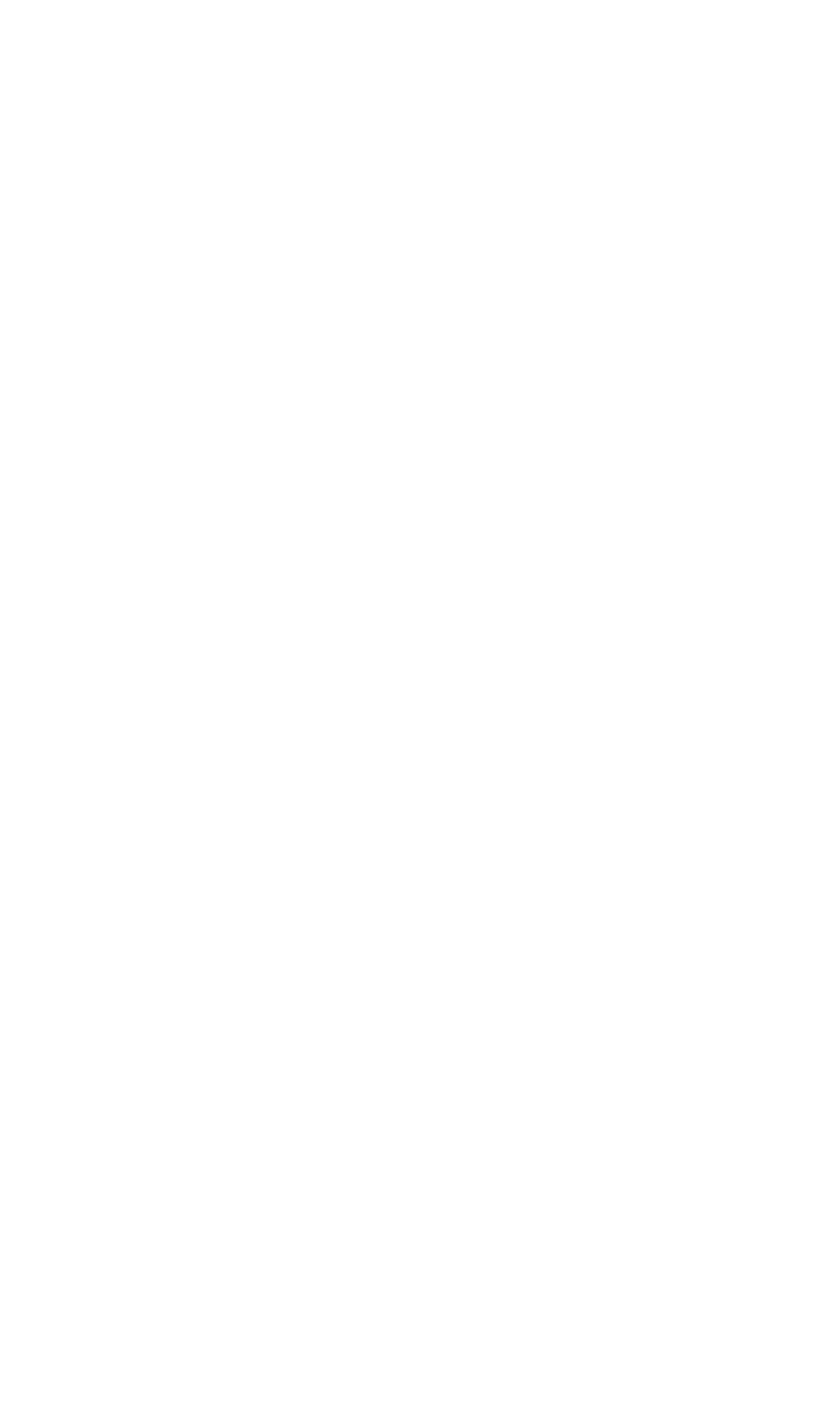




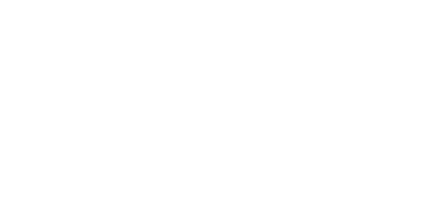

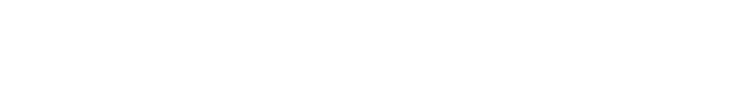

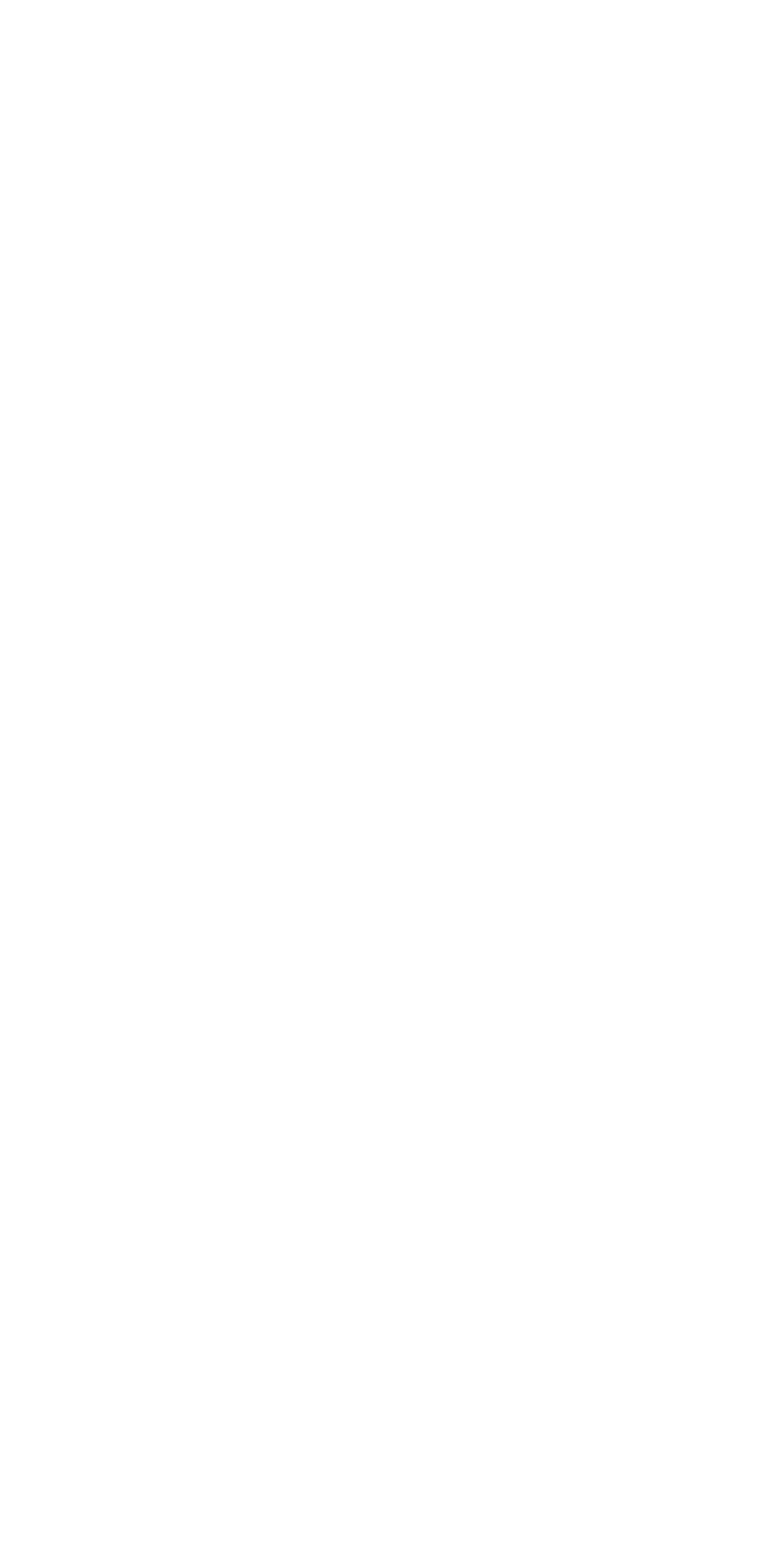




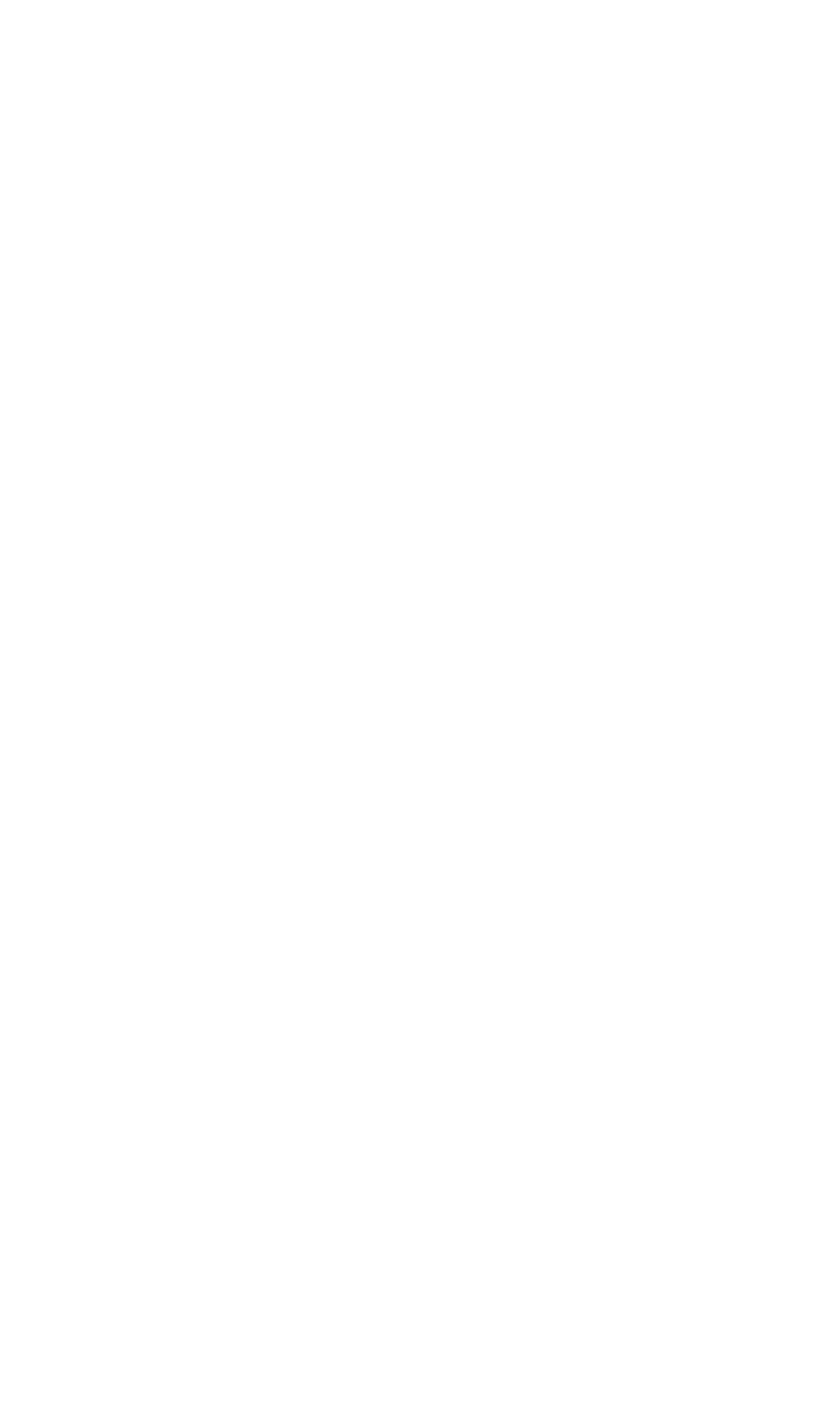




\section{TAYLOR COUNTY.}

By G. C. Matson.

\section{GENERAL FEATURES.}

Taylor County borders the Gulf at the northern end of the peninsula of Florida. A broad terrace 20 to 25 feet above sea level extends back several miles from the coast, another rises to a height of 40 to 60 feet, and a third has an altitude of 70 to 100 feet; each occupies a large area in the southern portion of the county. The eastern boundary is formed by Steinhatchee River and the western boundary by Aucilla River. In addition to these streams, the county is crossed by Fenholloway and Econfina rivers. Though the streams are sufficiently numerous to insure good drainage, there are large areas of swamp land near the coast and near the northern boundary of the county. South of Perry there are many lakes of moderate size.

GEOLOGY.

Gray Pleistocene sand forms the surface over much of the county, and, though thin, it is so uniformly distributed as to obscure the underlying beds. The Alum Bluff and Hawthorn formations are believed to underlie a large portion of the county, though definite information could be obtained at a few localities only. The Vicksburgian limestones are exposed in the phosphate pits at Fenholloway, where they are covered by a few feet of limestones belonging to the Hawthorn formation.

Little is definitely known concerning the thickness of the several geologic formations in Taylor County. The average thickness of the surficial sands is probably several feet, and the sands may be underlain by several feet of older sands and marls. The Hawthorn formation is believed to be comparatively thin, and the Vicksburgian limestones doubtless are several hundred feet thick.

WATER SUPPLY.

Source.-The surficial sands are an important source of water supply, though the underlying sands and limestones also yield abundantly. In many wells it is difficult to determine just what formations supply the water, though probably most wells depend on the limestones of the Hawthorn formation. The Vicksburgian limestones are doubtless the best water-bearing beds of Taylor County, and they should be more extensively utilized.

Quality.-The surficial sands supply an abundance of soft water. The limestones of the Hawthorn formation and the sands of the Alum Bluff formation supply hard water, some of which may contain sulphur. The Vicksburgian limestones supply hard sulphur water, 
which may locally contain some salt, especially where the wells are deep.

Development.-The shallow wells of Taylor County range in depth from about 15 to 30 feet, and the water level is near enough to the surface to permit easy pumping. Most of the wells are less than 100 feet deep, though at Perry two wells exceed 200 feet. These deeper wells are regarded as the most satisfactory, because when properly cased they are not likely to become polluted. Flowing wells may possibly be obtained on low ground near the coast, but as yet no attempt has been made to drill any such. The beds which supply the strong flows in Franklin County probably underlie Taylor County at a depth of less than 500 feet, and if flows are procured the water beds should be encountered between 300 and 500 feet. The town of Perry has a public supply obtained from a drilled well. The quantity is ample to meet all the needs of the town, and the water, though hard, is satisfactory.

Taylor County has a number of small springs which are being utilized for bathing and drinking, the most important being at Perry, Fenholloway, and Hampton Springs.

Typical wells of Taylor County.

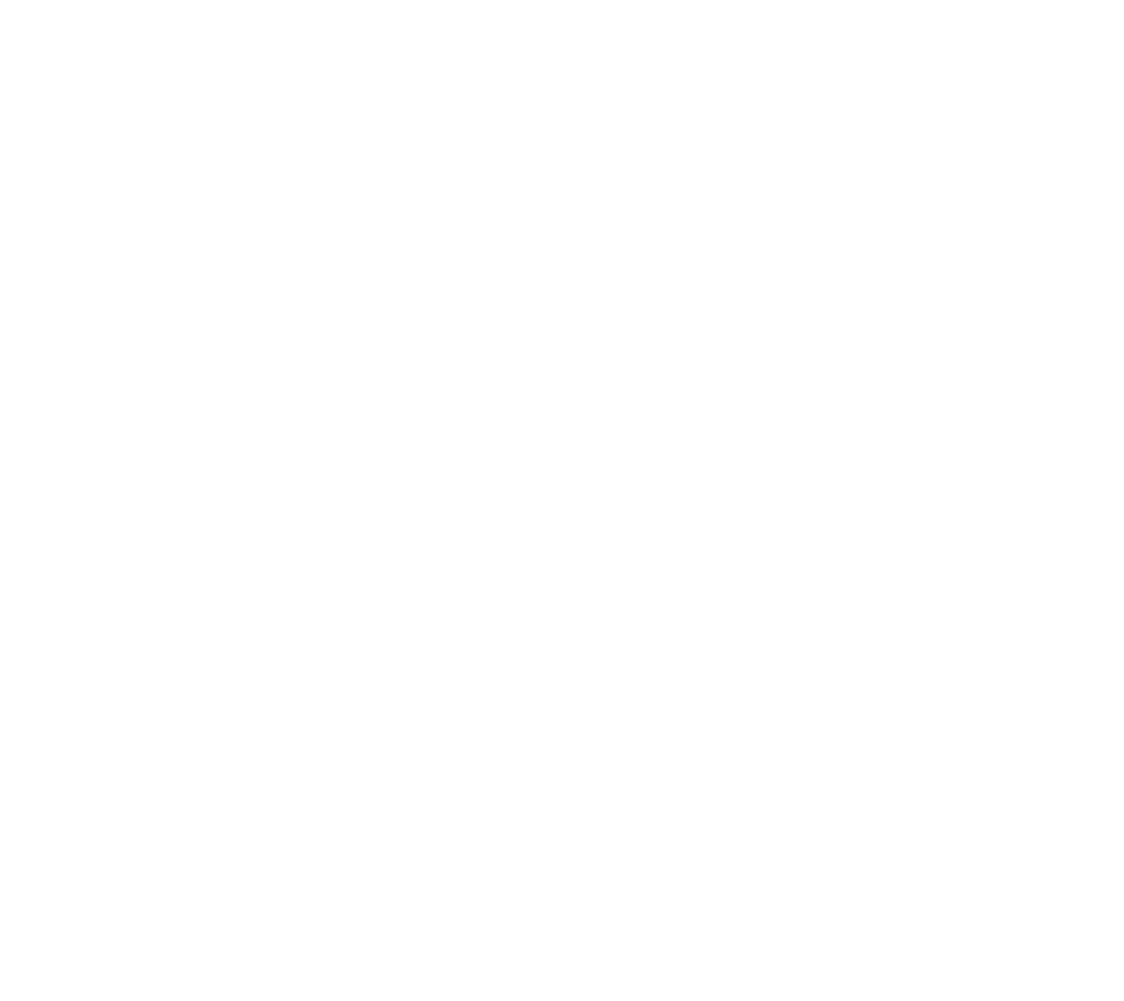


TAYLOR COUNTY.
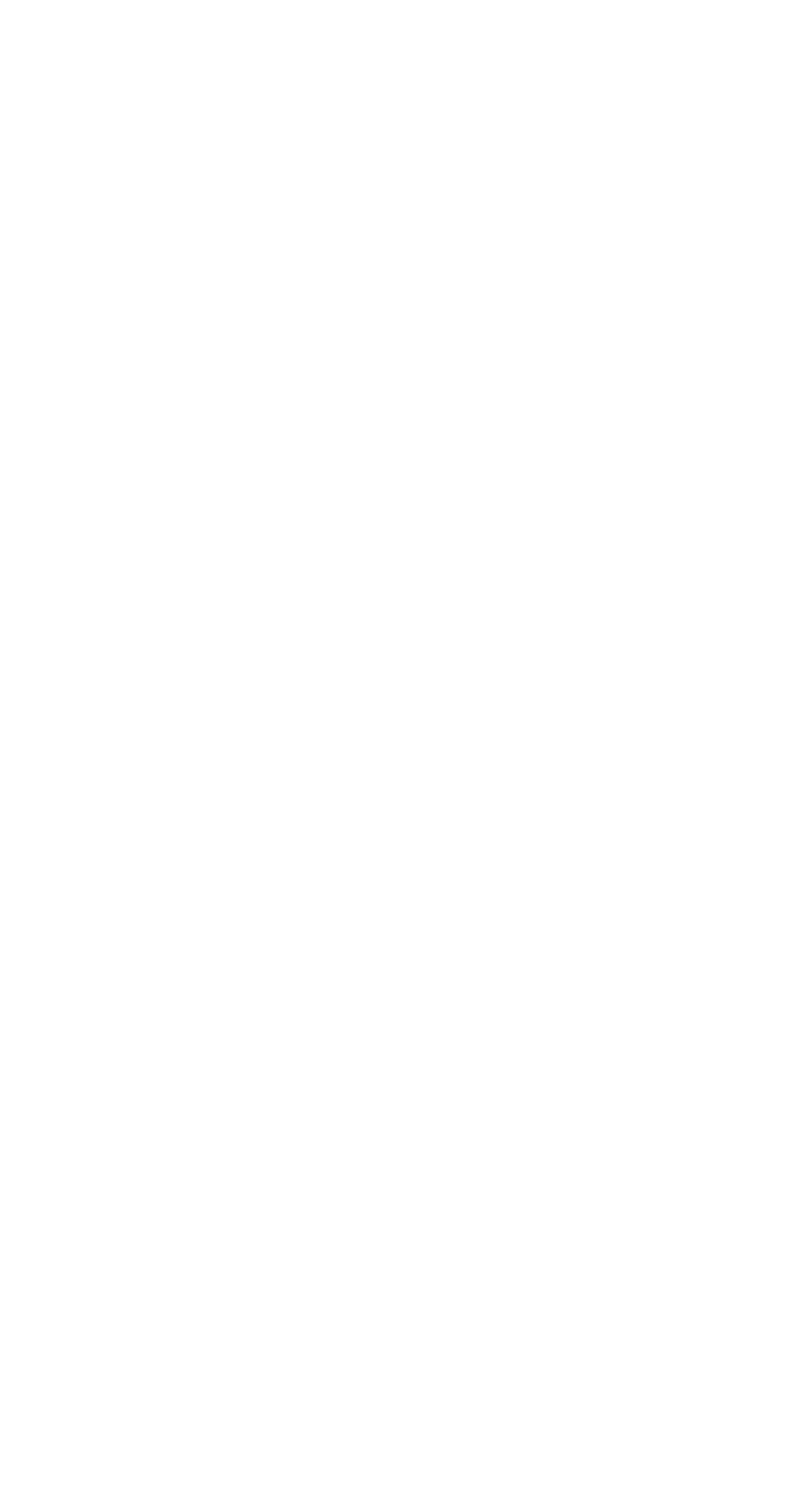


\section{VOLUSIA COUNTY.}

By G. C. Matson.

\section{GENERAL FEATURES.}

Volusia County comprises a large area between St. Johns River and the east coast. Near the coast the surface rises only a few feet above sea level, but farther west a sand ridge extends from Osteen to the northern boundary of the county between Lake George and Dunns Lake. The islands and bars of the coast are covered by dune sands, but they have a smooth, hard beach, which is unexcelled for carriages and automobiles. The mainland is bordered by an ancient beach ridge, which rises about 25 feet above sea level and extends for several miles parallel to the coast. Back of this ridge is a broad tract of low land, which is partly covered by water during wet seasons and contains many extensive areas of swampyland. Along St. Johns River is a low terrace which corresponds to the ridge bordering the east coast. Both ridge and terrace were formed during the late Pleistocene, when some of the present land was beneath the sea.

\section{GEOLOGY.}

The surficial formation of Volusia County consists of gray Pleistocene sand, which is locally underlain by coquina and shell marl of Pleistocene age. Beneath the Pleistocene sands and coquina are sands and shell marls of Pliocene age (Nashua marl), and these are in turn underlain by marls and perhaps by limestones of Miocene age (Choctawhatchee marl). Both the Miocene and Pliocene are exposed in the St. Johns Valley and both are known from well samples at De Land. From a shell marl at Daytona and in well samples from Ormond Vaughan identified fossils which he believed to be Pliocene. The upper Oligocene formations may be represented in Volusia County, but they have not been detected in any of the well samples, and it appears probable that locally the Miocene (Choctawhatchee marl) rests directly on the Vicksburgian limestones. This would mean that the upper Oligocene rocks had been removed by erosion before the deposition of the Choctawhatchee marl.

In Volusia County the thickness of the younger formations is difficult to determine, because they can not be readily discriminated. The Pleistocene sands are at least 68 feet thick at Ormond, but they pass downward into shell marl which can not be easily distinguished from the underlying Pliocene, and the Pliocene marls are so much like those of the Miocene that they can not be differentiated in well logs. The thickness of the entire series of beds from the top of the Pleistocene to the base of the Miocene is apparently less than 150 feet. 
Beneath the Miocene the Vicksburgian limestones are doubtless several hundred feet thick.

A general log of materials penetrated at Daytona is given below. This information is of exceptional value because it was furnished by Bellew and Milton, who have drilled many wells at that locality.

$$
\text { General well log at Daytona. }
$$

Feat.

Sand, or sand and shells............................. $35-56$

Clay, very light blue; no sand ........................ 14-30

Sand and shells.................................. $5-18$

Limestones, soft; with layers of hard chert $1 \frac{1}{2}$ to 2 feet thick indefinitely below.

The first three members of this log probably include the Pleistocene, Pliocene, and Miocene. The limestone is believed to belong to the Vicksburg group.

Log of well of Florida East Coast Hotel Co., at Ormond.

[Prepared from well samples.]

\begin{tabular}{|c|c|c|}
\hline & Thickness. & Depth. \\
\hline 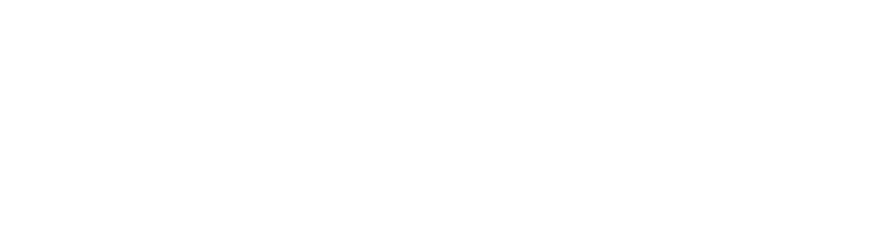 & $\begin{array}{r}\text { Feet. } \\
56 \\
10 \\
24 \\
2 \\
\cdots \\
4 \\
40 \\
50 \\
75\end{array}$ & $\begin{array}{r}\text { Feet. } \\
56 \\
66 \\
90 \\
92 \\
106 \\
110 \\
150 \\
200 \\
275\end{array}$ \\
\hline
\end{tabular}

Vaughan identified shells from 56 to 66 feet that indicate that the material to a depth of 66 feet is Pleistocene. From 66 to 90 feet the material may be either Pleistocene or Pliocene. From 90 to 150 feet the material is of uncertain age. Below 150 feet the limestones are probably of Vicksburg age.

Log of the city well at De Land.

[Prepared from well samples.]

\begin{tabular}{|c|c|c|}
\hline & Thickness. & Depth. \\
\hline 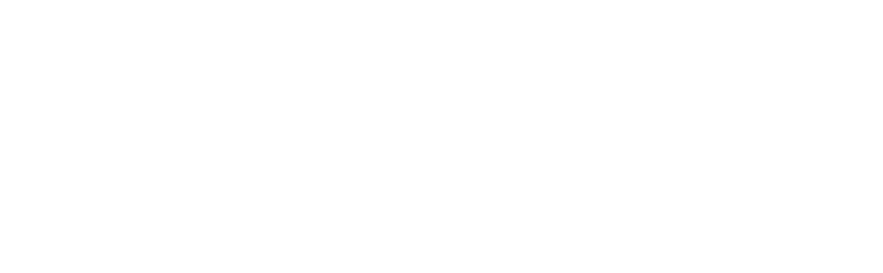 & $\begin{aligned} & \text { Feet. } \\
& 12 \\
& 10 \\
& 14 \\
& 18 \\
& 36 \\
& 20 \\
& 60 \\
& 39 \\
& 21 \\
& 20 \\
& 14\end{aligned}$ & $\begin{array}{r}\text { Eeet. } \\
12 \\
22 \\
36 \\
54 \\
90 \\
110 \\
170 \\
209 \\
230 \\
250 \\
264\end{array}$ \\
\hline
\end{tabular}


Water was encountered between 80 and 135 feet and at 160 feet. It rose to within 29 feet of the surface. Another supply at 207 feet rose to within 27 feet of the surface.

From the samples obtained between 22 and 54 feet Vaughan identified Pliocene fossils. In the sample obtained between 54 and 70 feet he identified Miocene shells. This indicates that both the Nashua and Choctawhatchee marls are present at De Land and gives some idea of their minimum thickness at that locality.

WATER SUPPLY.

Source.-Many shallow wells in Volusia County obtain water from the gray sands of Pleistocene age. Deeper wells reach supplies in the Nashua and Choctawhatchee marls. The deep wells penetrate limestones which are in part of Vicksburgian age, though some of them doubtless obtain water from younger rocks. Unfortunately, in many wells it is impossible to determine the exact age of some of the limestones.

Quality.-The water from the Pleistocene sand is soft, but that from the Nashua and Choctawhatchee marls is hard and locally contains sulphur. The limestone waters are hard, and in most localities they contain sulphur. Salt is common in some of the deep waters that penetrate the Vicksburgian limestones, and it occurs sporadically in the water from other formations.

Development.-Volusia County contains a large number of deep wells, many of which yield excellent flows. The depth of the flowing wells varies greatly, being as low as 20 to 45 feet in localities like Enterprise and Ponce Park. On the east coast good flows are usually obtained at 80 to 150 feet, though larger yields are procured with increasing depth, and some wells are several hundred feet deep.

The head of the flowing wells varies from place to place. At Daytona it was formerly about 17 feet above the sea, but it has gradually declined until at the present time it is rarely more than $14 \frac{1}{2}$ feet. The loss of head appears to be due to the withdrawal of large quantities of water. There are said to be about 1,000 wells in and near the town, and there must be at least several hundred, most of which are allowed to flow uninterruptedly, wasting a large quantity of water.

At Hollyhill, just north of Daytona, and at Ormond and Port Orange the conditions are very similar to those in Daytona. At New Smyrna the conditions are like those at Daytona, except that the head is probably slightly greater and there is no marked evidence of decline. (See PI. XVI, $B$, p. 230.) At Seabreeze, on the island opposite Daytona, the head of the water is lower and the flows are smaller than at Daytona.

At Oak Hill the artesian wells are about 130 feet in depth and the head is sufficient to give good flows. The water is said to contain 
Typied wells of Volusin Contty.

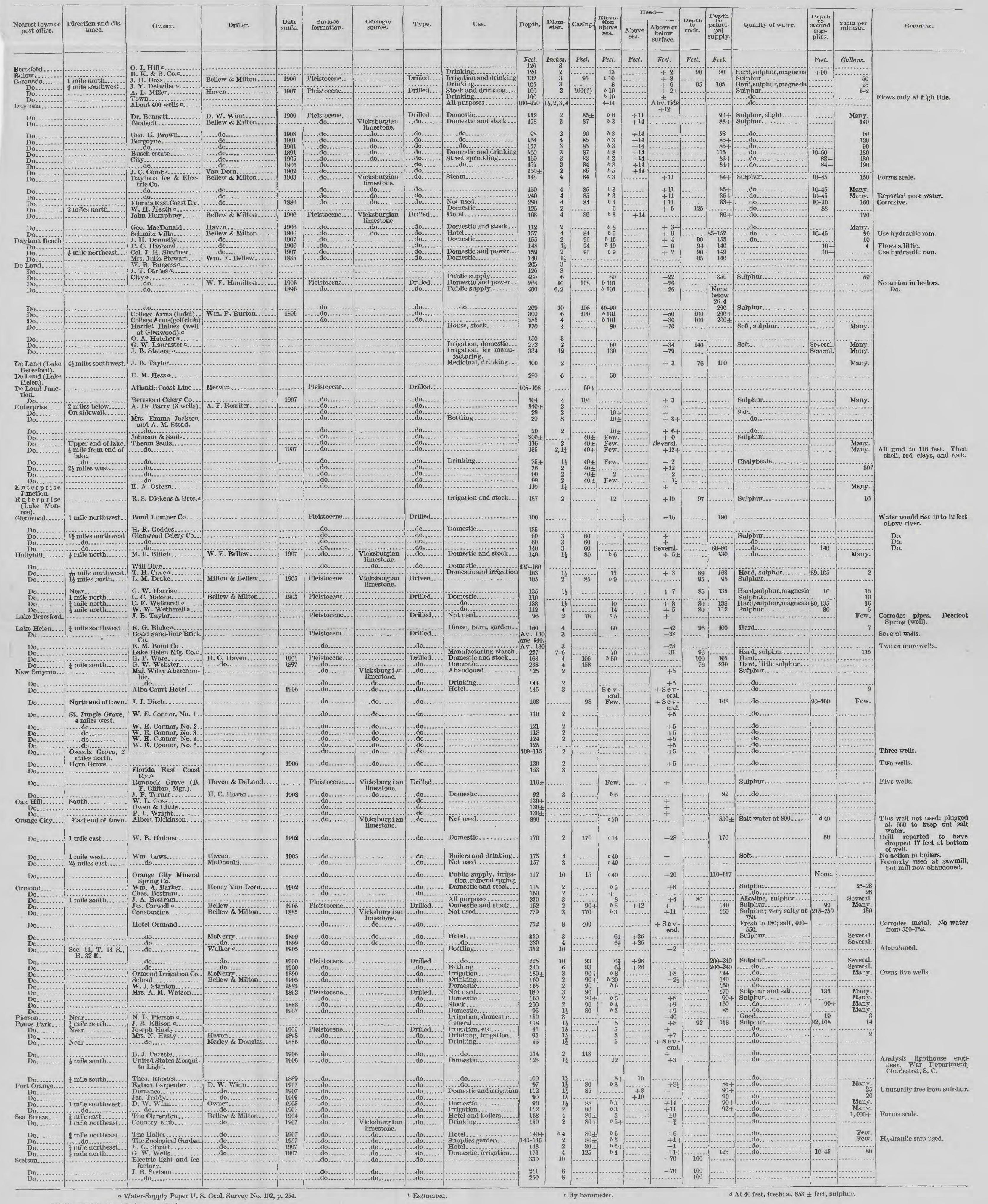


some salt. The locality is apparently near the northern border of the area of saline water. (See p. 226.) At Coronado some good flows are obtained at about 100 feet. The depth required to give good flows at Ponce Park ranges from 45 to over 100 feet, and at Enterprise the range is still greater. The shallow wells at Enterprise and Enterprise Junction probably obtain their supplies from the Pleistocene sands or from the Pliocene and Miocene sands and marls.

In the vicinity of De Land wells do not yield flows except near the river. The water level in the deep wells is usually several feet below the surface at De Land, Stetson, Lake Helen, and Orange City, this being due to the fact that these towns are situated upon high ground.

The present development is sufficient to indicate the possibilities of obtaining good supplies of water. There is little incentive to deep drilling, because the deeper waters are highly mineralized and are locally saline. The best opportunity for improvement is to prevent excessive waste of water, and this could be done by closing wells when they are not in use. Many owners hesitate to check the flow of water because they fear that the wells will become clogged, though there is little or no danger of this if the wells are properly cased.

Volusia County contains some good springs and some deep wells which supply mineral water. De Leon Springs, a mile northwest of the town of the same name, supplies sulphur water, which is extensively used. A bathhouse and a swimming pool have been constructed at the spring, and the water, having a uniform temperature of $76^{\circ}$, is very satisfactory for bathing. A 100 -foot well near De Land Junction, known as Deerfoot Spring, yields water highly charged with sulphur and believed to have medicinal properties. The well is located in the woods a mile south of Beresford and is not used.

Near Enterprise a flowing well 20 feet in depth, supplying excellent salt-sulphur water, is known as the Benson salt spring.

The Orange City Mineral Spring water is obtained from a well 117 feet deep. The quantity is large enough to supply the town, but the water level is about 20 feet below the surface and hence it is necessary to use a pump.

A public supply at De Land is obtained from deep wells. The water is pumped to a standpipe and is distributed by gravity. The supplies at both Orange City and De Land are satisfactory. Seville formerly had a public supply, but it has been abandoned on account of decrease in population. 
Springs of Volusia County.

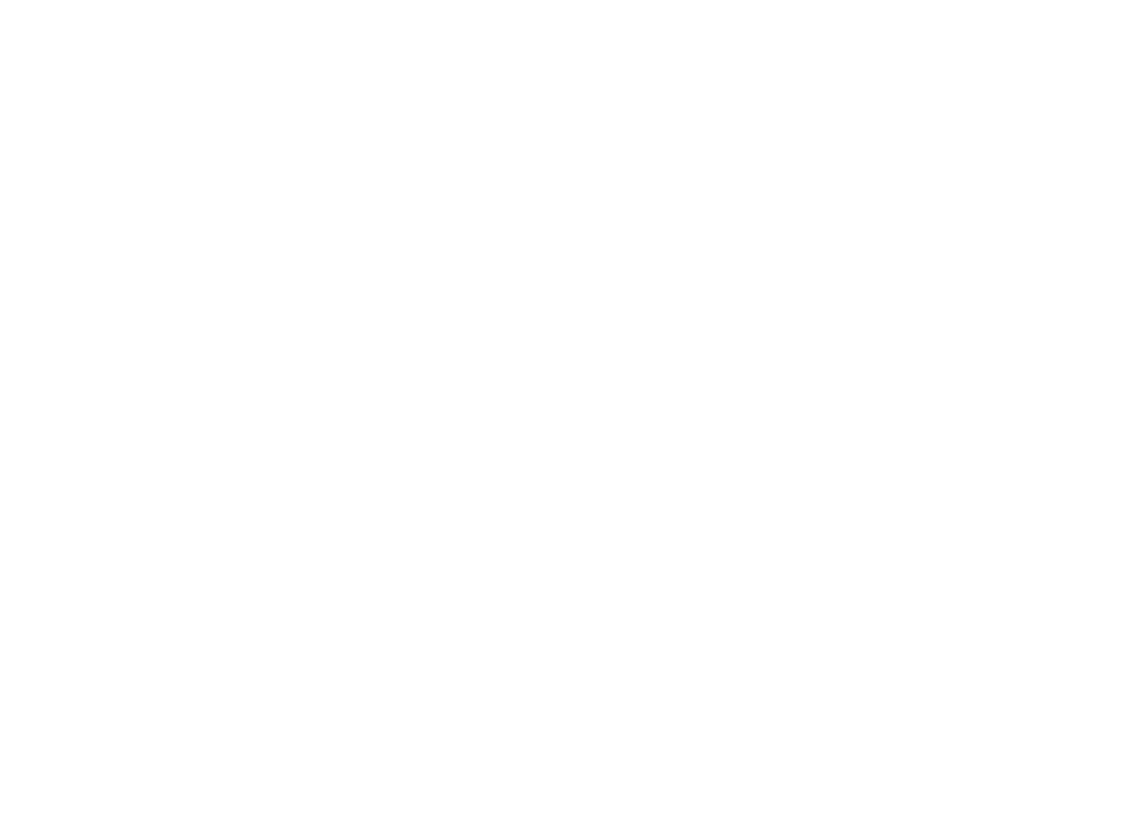

WAKULTA COUNTY.

By G. C. Matson.

\section{GENERAL FEATURES.}

Wakulla County, on the Gulf coast, extends from Ochlockonee River eastward to beyond St. Marks River. Its coastal portion comprises broad swamps rising only a fow feet above sea level. Inward the surface remains flat for many miles and then gradually becomes more diversified with rolling sand ridges and hills. The broad flat which borders the coast is a terrace formed during Pleistocene times when the land was submerged. Toward the northern corner of the county the land rises to over 50 feet above sea level, and another broad terrace represents a still more extensive submergence of the land.

\section{GEOLOGY.}

Gray Pleistocene sand covers the surface of Wakulla County. Toward the northern end the gray sand is underlain by yellow and red sands and sandy clays which rest upon limestones. The "Sopchoppy limestone" is extensively developed along the river of the same name. The Chattahoochee formation is well exposed along the railroad south of Tallahassee and probably underlies at no great depth the entire surface of the county. The Vicksburgian limestones 
also underlie Wakulla County, but they are not known to reach the surface.

The average thickness of the Pleistocene sands is less than 5 or 6 feet, but locally the thickness attained may exceed 40 to 50 feet. The red and yellow sands which underlie the sands of Pleistocene age near the northern end of the county do not attain any great thickness. The combined thickness of the "Sopchoppy limestone" and the Chattahoochee formation is probably more than 200 feet and may amount to over 300 feet. Beneath these limestones are the Vicksburgian limestones with a thickness which has not been determined, but which probably amounts to several hundred feet.

\section{WATER SUPPLY.}

Source.-The surficial sands are the source of an abundant supply of water in all parts of Wakulla County, and the "Sopchoppy limestone" and Chattahoochee formation are also good water-bearing formations. The Vicksburgian limestones will furnish more water than any of the other formations, and the supplies should be satisfactory unless obtained at too great depths.

Quality.-The surficial sands supply soft water. The deeper supplies obtained in Wakulla County will undoubtedly be hard and many of them will contain hydrogen sulphide.

Development.-Nearly all the wells in Wakulla County are shallow. This is largely due to the fact that an abundance of water may be obtained within a few feet of the surface, and hence it is not considered necessary to drill deep wells. The only deep well reported from the county, that of the Coast Cypress \& Railroad Co., 1 has a diameter of 6 inches and a depth of more than 252 feet (to rock) and contains water that is said to be both salt and sulphur. Its curb is 4 feet above sea level and its head is 5 feet below the curb. Flowing wells can probably be obtained on low ground near the coast. The exact depth necessary to obtain flows is somewhat uncertain, though judging from the conditions in Franklin County it should be possible to procure flows at 325 to 400 feet. On the high ground flows could not be obtained, but the same supplies which are obtained from flowing wells should rise near enough to the surface to permit them to be pumped without great expense.

General water resources of Wakulla County.

\begin{tabular}{|c|c|c|c|c|c|c|c|}
\hline \multirow{2}{*}{ Town. } & \multirow{2}{*}{$\begin{array}{c}\text { Topo- } \\
\text { graphic } \\
\text { location. }\end{array}$} & \multirow{2}{*}{ Source of water. } & \multirow{2}{*}{$\begin{array}{c}\text { Surface } \\
\text { formation. }\end{array}$} & \multirow{2}{*}{$\begin{array}{c}\text { Water } \\
\text { beds } \\
\text { in shallow } \\
\text { wells. }\end{array}$} & \multicolumn{2}{|c|}{ Deep wells. } & \multirow{2}{*}{$\begin{array}{l}\text { Sewerage } \\
\text { system. }\end{array}$} \\
\hline & & & & & Supply. & $\begin{array}{l}\text { Quality } \\
\text { of water. }\end{array}$ & \\
\hline St. Marks. & Flat... & Cisterns and springs.... & Limestone & Limestone & Abundant & Hard.... & None. \\
\hline
\end{tabular}

1 Water-Supply Paper U. S. Geol. Survey No. 102, p. 254. 
Springs of Wakulla County.

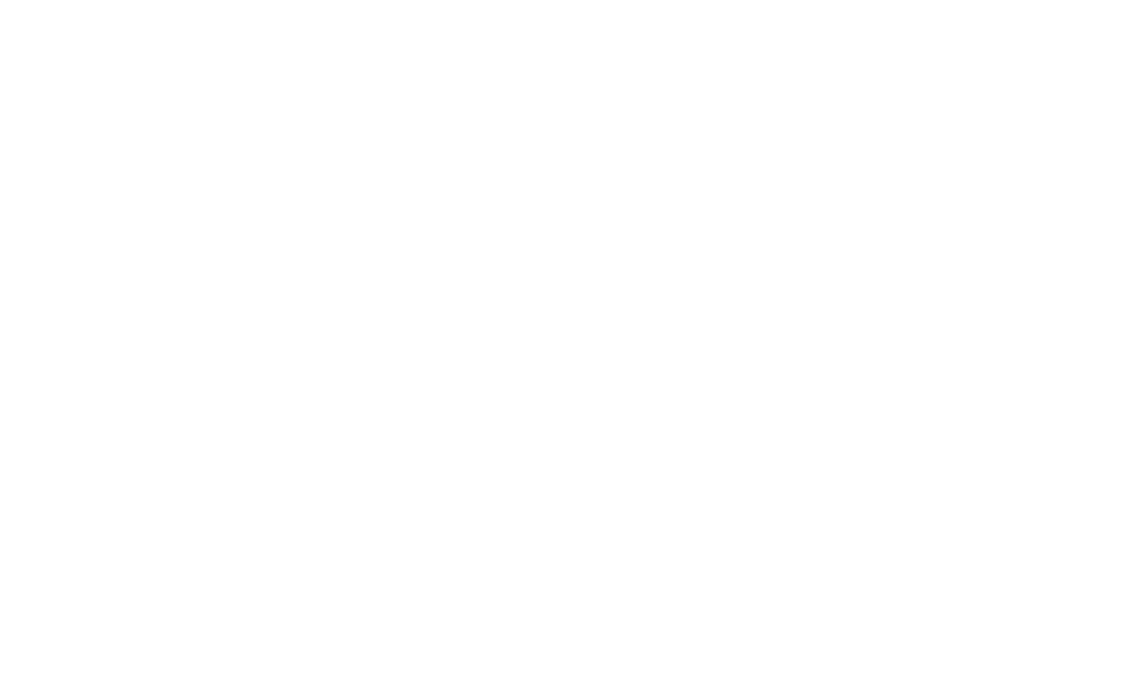

\section{WALTON COUNTY.}

By G. C. Matson.

\section{GENERAL FEATURES.}

Walton County extends from the Gulf of Mexico to the northern boundary of the State and is bordered on the east by Holmes and Washington counties and on the west by Santa Rosa County. Its surface ranges in altitude from about sea level near the coast to nearly 300 feet above the sea near the northern boundary. The southern portion of the county consists of broad flat terraces formed when the sea stood farther inland than at present. There are three of these terraces, having altitudes of 20 to 25 feet, 40 to 60 feet, and 70 to 100 feet. Terraces also occur along the large streams of the county, merging with those just mentioned. A ridge of high land extends from near Deerland eastward beyond De Funiak Springs. Other level tracts are numerous, especially in the northern part of the county, where they form more or less extensive table-lands, rising in places from 200 to over 250 feet above sea level. Near the coast the land is low and swampy and contains a few shallow lakes. There are also a few small lakes in the northern part of the county, and swamps are not uncommon along the larger streams. At Natural Bridge a small stream flows through a channel in the limestone. In the southern part of the county a large arm of the sea is known as Choctawhatchee Bay. 
GEOLOGY.

The terraces in Walton County are mantled gray sand of Pleistocene age. On the uplands residual sand is underlain by red, yellow, and gray sands and sandy clays referred to the Lafayette (?) formation, which is extensively developed north and for several miles south of the Louisville \& Nashville Railroad. In the southern half of the county a broad belt is underlain by the Choctawhatchee marl, which doubtless dips southward beneath the younger formations but which is seldom recognized, because it is deeply buried and it is not easily identifiable in well drillings. The Choctawhatchee marl is underlain by marls, sands, and clays belonging to the Alum Bluff formation, and these materials outcrop at intervals north of the exposures of the Choctawhatchee marl. The Chattahoochee formation underlies the surficial formations in the northern part of the county and dips southward beneath the Alum Bluff formation. At Natural Bridge the Vicksburgian limestones are exposed. These rocks underlie the Chattahoochee formation throughout the county.

The average thickness of the Pleistocene gray sand is probably about 25 feet on the upland and it thickens abruptly toward the south. Near the southern margin of the county there is no information concerning the exact thickness, and it is thought it may locally extend to a depth of over 50 feet. The Lafayette (?) formation is well developed; it probably attains a maximum thickness exceeding 50 feet and it averages at least 30 feet. The thickness of the Choctawhatchee marl is probably more than 50 feet and the marls of the Alum Bluff formation may attain a thickness of over 100 feet, though they seldom exceed 50 feet. Data are lacking to determine the thickness of the Chattahoochee formation and the Vicksburgian limestones, but it should amount to several hundred feet.

Log of the well at the De Funiak Springs waterworks.

\begin{tabular}{|c|c|c|}
\hline & Thickness. & Depth. \\
\hline 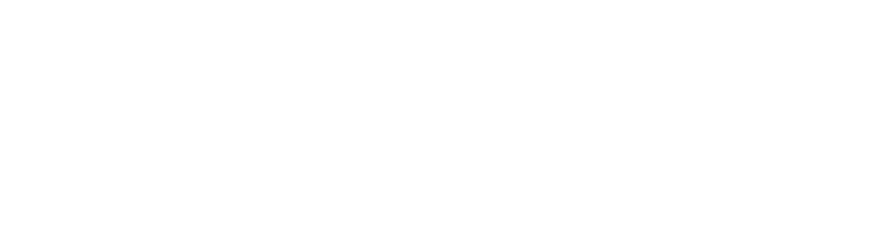 & $\begin{array}{r}\text { Feet. } \\
7 \\
21 \\
75 \\
114 \\
191 \\
12 \pm \\
100 \\
48 \\
6 \\
46\end{array}$ & $\begin{array}{r}\text { Feet. } \\
7 \\
28 \\
103 \\
217 \\
408 \\
420 \\
520 \\
561 \\
574 \\
620\end{array}$ \\
\hline
\end{tabular}

The water in this well rises to within about 150 feet of the surface and is very soft. The well will yield over 110 gallons per minute. 


\section{WATER SUPPLY.}

Source.-The Pleistocene gray sands are comparatively unimportant on the uplands, but on the lowlands they yield abundant water within a few feet of the surface. The sands and sandy clays of the Lafayette (?) formation are usually water bearing and yield excellent supplies. The Choctawhatchee marl is probably a good aquifer, but the number of wells drawing from it is small. The marls and sands of the Alum Bluff formation yield good supplies, which are utilized for farm and domestic purposes. Both the Chattahoochee formation and the Vicksburgian limestones are excellent sources of water, though in Walton County only a few wells have been drilled into these rocks.

Quality.-Both the Pleistocene and the Lafayette (?) formation supply soft water. The water from the Choctawhatchee marl and the marls and sands of the Alum Bluff formation is probably soft, though locally moderately hard water might be encountered in these formations. Both the Chattahoochee formation and the Vicksburgian limestones should yield moderately hard water; but apparently the limestones are partly replaced by sands and sandstones, and the water from these is reported to be soft.

Development.-Throughout the lowland portion of Walton County shallow wells obtain abundant supplies of water within a few feet of the surface, but on some portions of the upland such wells may need to be sunk to a depth of over 60 feet. In general, however, good supplies can be obtained at moderate depths and the presence of more or less clay above the water beds, especially in the upland portions of the county, protects the water from contamination by impure surface drainage.

Very few deep wells have been drilled in Walton County, except in the vicinity of Freeport, where some good flowing wells range in depth from 180 to 188 feet. The well of A. F. Murray at De Funiak Springs is 210 feet deep, but the water supply used is obtained within 60 feet of the surface. The total depth of the well at the city waterworks in De Funiak Springs is 610 feet. Reference to the log previously given will show that several water beds were encountered and that the best one is near the bottom of the well. At Lakewood, near the northern end of the county, the Britton Lumber Co. has a well 604 feet in depth. This is the only deep well reported in that portion of the county, but the yield is sufficiently large to indicate thai good supplies may be obtained by drilling such wells. The exact aquifers penetrated by the flowing wells at Freeport and Whitfield could not be determined; the wells yield moderately hard sulphur water suitable for all purposes.

The city supply at De Funiak Springs was established after the close of the field work for this report, and accurate information concerning 
it is wanting. At Freeport a large number of houses are supplied with water from flowing wells, which have a maximum head of about 20 to 22 feet, sufficient to carry the supply through the mains to near-by dwellings. Similar flowing wells could probably be obtained along the entire southern border of the county.

The large spring at De Funiak Springs is really a small lake. The water is remarkably free from inorganic materials and the quantity is very large. Fluctuations in the level of this lake are governed by the relative amounts of evaporation and rainfall and the surface of the ground water in that vicinity doubtless changes in sympathy with the level of the lake. Water from a smaller spring, located near the western edge of the town and owned by the Beach-Rogers Lumber Co., is used at the sawmill and in the principal hotels of the town. The spring discharges more than 2 gallons a minute of moderately hard water, boiling up from sand. It is improved by a pumping plant and spring house. The water is not muddy after rain. No source of pollution is near.

Typical wells of Walton County.

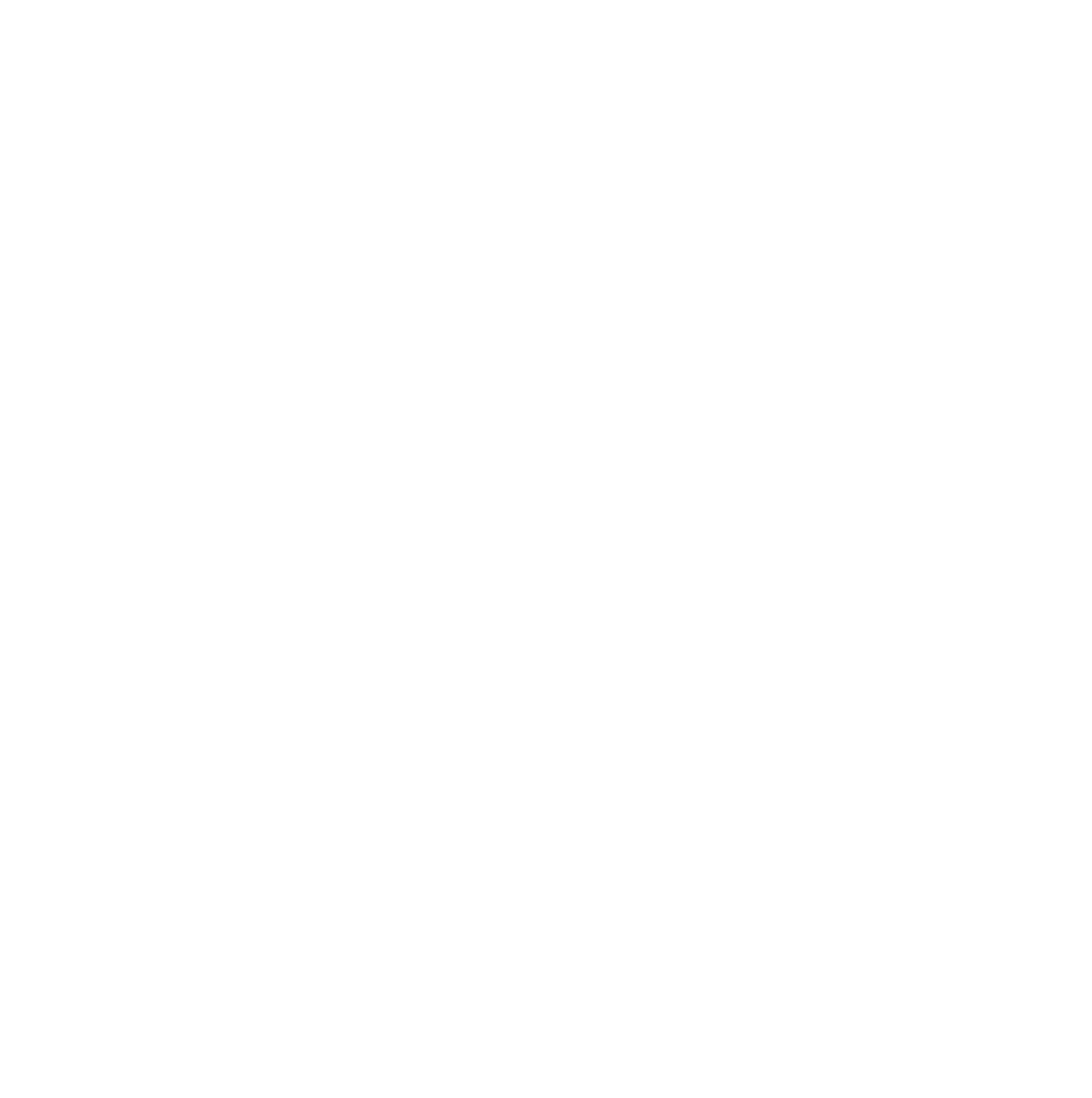


General water resources of Walton County.

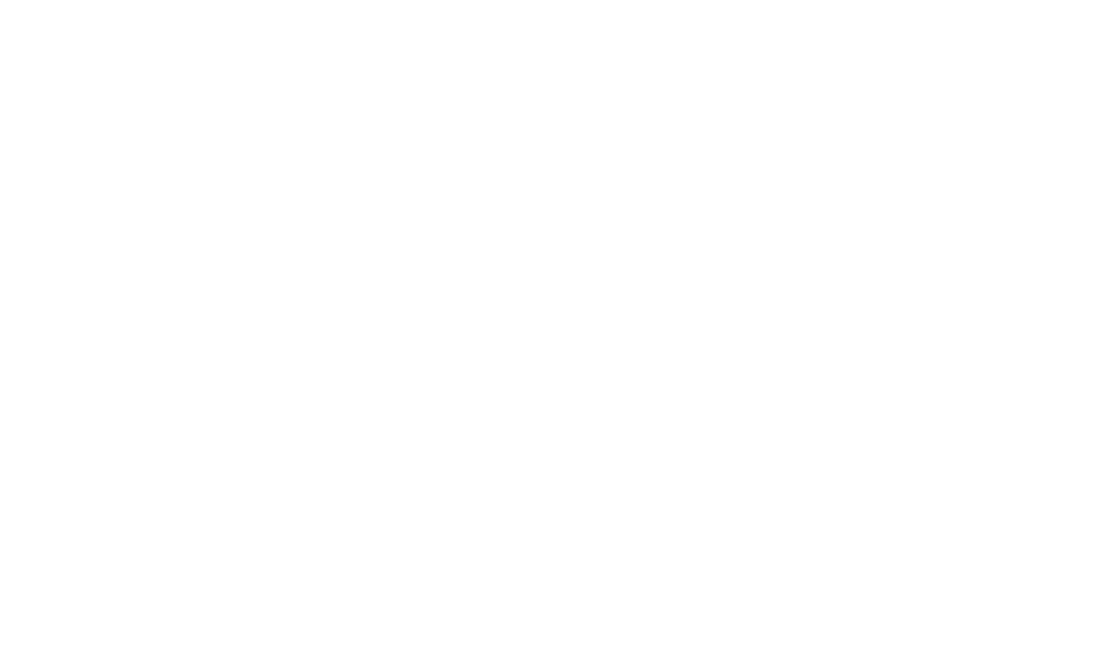

WASHINGTON COUNTY.

By G. C. Matson.

\section{GENERAL FEATURES.}

Washington County occupies a large area bordering on the Gulf coast in west Florida. Its topography is greatly diversified, ranging from low, flat lands near the coast to high, rolling uplands farther northward. The southern part of the county consists of a broad, nearly level terrace rising 20 to 30 feet above sea level. North of this terrace there is a second terrace at an altitude of 40 to 60 feet, and still farther inland a third terrace rises 70 to 100 feet above sea level. Along the principal streams broad flats correspond in a general way with the terraces near the coast. At Caryville a terrace along Choctawhatchee River is 72 feet in altitude, and at Vernon a terrace on Holmes Creek rises to about 50 feet. Similar though less extensive terraces exist along the smaller streams of the county. The uplands represent the edge of an extensive plain which extends northward into Alabama, and which near its southern edge has been eroded into rounded hills separated by deep valleys.

\section{GEOLOGY.}

The terraces of Washington County are composed of gray sand of Pleistocene age. This sand covers all the older geologic formations except on the uplands, where there is a thin mantle of residual sand, underlain by red and yellow sands, sandy clays, and sandstones 
referred to the Lafayette (?) formation. The Choctawhatchee marl is the surface formation in a belt several miles wide, extending nearly east and west across the central portion of the county. Marls, sands, and clays belonging to the Alum Bluff formation underlie the Choctawhatchee marl. North of the area of Choctawhatchee marl a large part of the county is underlain by the Chattahoochee formation, though in the vicinity of Duncan, Wausau, and Chipley this formation has been removed, exposing the Vicksburgian limestones, which underlie the other formations throughout the county but are not known to be exposed except at the localities mentioned.

On the uplands the surficial sands are comparatively thin, but toward the southern end of the county the sands of Pleistocene age may reach a maximum of several feet. The average thickness of the red and yellow sands and sandy clays of the Lafayette (?) formation is probably more than 30 feet and the maximum is believed to exceed 50 feet. Some uncertainty exists about the thickness of the Choctawhatchee marl, but, including the marl which may belong to the Alum Bluff formation, it probably exceeds 50 feet. The thickness of the Chattahoochee formation is variable, the average probably being less than 100 feet and the maximum over 200 feet. The Vicksburgian limestones doubtless have a maximum thickness of several hundred feet.

Log of the well of the Wood Lumber Co. at Caryville.

\begin{tabular}{|c|c|c|}
\hline & Thickness. & Depth. \\
\hline & Feet. & Feet. \\
\hline Rock, pinkish, flinty... & $\begin{array}{r}25 \\
8\end{array}$ & $\begin{array}{l}25 \\
33\end{array}$ \\
\hline Limestone.............. & 18 & 51 \\
\hline 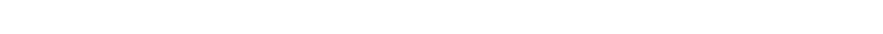 & 18 & 69 \\
\hline Limestone, becoming rotten at bottom.... & 39 & 108 \\
\hline 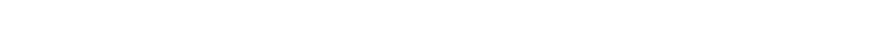 & $\begin{array}{r}30 \\
4\end{array}$ & $\begin{array}{l}138 \\
142\end{array}$ \\
\hline 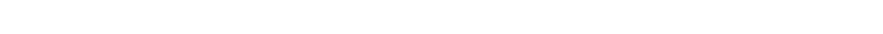 & 80 & 222 \\
\hline 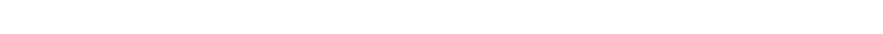 & 10 & 232 \\
\hline $\begin{array}{l}\text { Marl } \\
\text { Sand, greenish }\end{array}$ & $\begin{array}{l}60 \\
20\end{array}$ & $\begin{array}{l}292 \\
312\end{array}$ \\
\hline 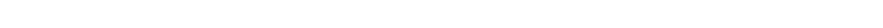 & 140 & 452 \\
\hline Limestone and marl............ & 80 & 532 \\
\hline Sand, gray; present water supply.. & 23 & 555 \\
\hline 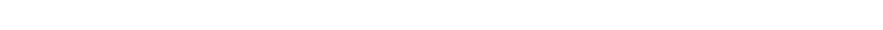 & 7 & 562 \\
\hline 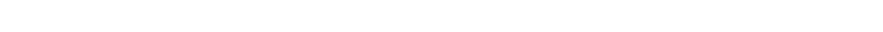 & 110 & 672 \\
\hline 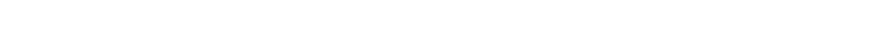 & 8 & $\begin{array}{l}680 \\
697\end{array}$ \\
\hline (1, & 18 & 715 \\
\hline (1) & 32 & 747 \\
\hline Sand $\ldots{ }_{\text {Sandrok }}$ & 17 & $\begin{array}{l}764 \\
796\end{array}$ \\
\hline & & \\
\hline
\end{tabular}

In this well the Pleistocene sand appears to have a thickness of 25 feet and to be underlain by 26 feet of limestone belonging to the Chattahoochee formation. Beneath this last are the rocks of Vicksburg age, and it is thought that the well may pass through these into older geologic formations. 
WATER SUPPLY.

Source.-The gray sands are not important aquifers on the uplands, but on the lowlands they contain abundant supplies within a few feet of the surface. The sands of the Lafayette (?) formation are a very important source throughout the upland portion of the county. The Choctawhatchee marl furnishes an abundance of water, which, however, is little utilized. Large quantities of hard water may be obtained from the Chattahoochee formation, but deep wells are usually sunk to the Vicksburgian limestones and these rocks are regarded as the best water-bearing beds of the county.

Quality.-The sands of the Pleistocene and Lafayette (?) formation supply soft water. Little is known concerning the quality of the water from the Choctawhatchee marl and the Alum Bluff formation, but it is probably moderately hard. Both the Chattahoochee formation and the Vicksburgian limestones furnish hard water. Near the southern end of the county deep wells may encounter salt water, but in general the supplies contain only a maderate quantity of mineral matter and are satisfactory.

Development.-In Washington County mast shallow wells obtain abundance of water within 30 feet of the surface. Many of the wells do not exceed 10 feet, but in a few places it is necessary to sink moderately deep wells and probably the maximum depth of the shallow wells is not far from 50 feet. A few deep wells have been drilled in Washington County and they have been uniformly successful. They range in depth from 160 to 757 feet, but good supplies may usually be obtained at less than 300 feet. The only flowing well reported is at Millville; it is 206 feet deep and its head is said to be 10 feet above the surface. It is probable that flowing wells could be obtained on the low ground near the coast and that the water would usually be satisfactory. 


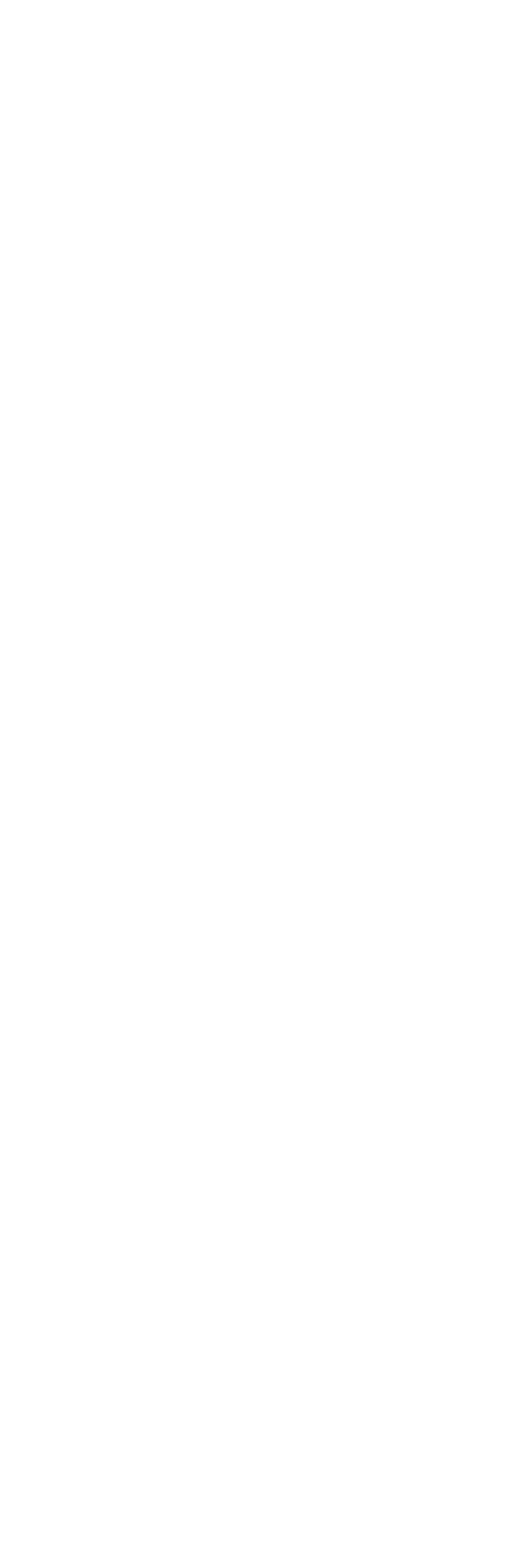




\begin{tabular}{|c|c|c|c|c|c|c|}
\hline & 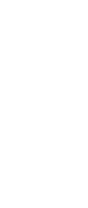 & 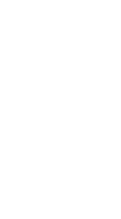 & 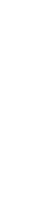 & & 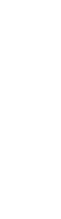 & \\
\hline & 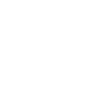 & 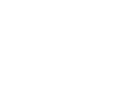 & $\begin{array}{c}\vdots \\
\vdots \\
\vdots \\
\vdots\end{array}$ & ఏ & $\begin{array}{c}\vdots \\
\vdots \\
\vdots \\
\vdots\end{array}$ & לִ \\
\hline & 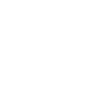 & 迹占 & 离 & 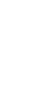 & & 悹 \\
\hline \multicolumn{2}{|c|}{ 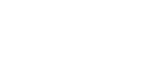 } & 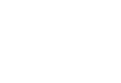 & & & $\stackrel{H}{\stackrel{H}{\ominus}}$ & \\
\hline \multirow{4}{*}{ 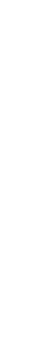 } & 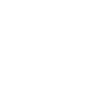 & 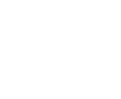 & : & ؛̊ & $\begin{array}{c}\vdots \\
\vdots \\
\vdots \\
\vdots \\
\vdots\end{array}$ & \\
\hline & 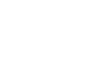 & 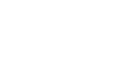 & $\stackrel{ }{+}$ & $\vec{i}$ & $\vec{i}$ & \\
\hline & 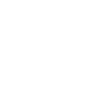 & 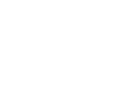 & 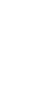 & : & $\begin{array}{c}\vdots \\
\vdots \\
\vdots \\
\vdots\end{array}$ & \\
\hline & $\begin{array}{l}\text { 范 } \\
\text { ă } \\
\text { ă }\end{array}$ & 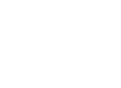 & \& & 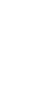 & \& & \\
\hline \multirow{4}{*}{ 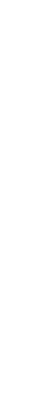 } & 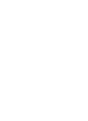 & 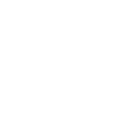 & & & & \\
\hline & 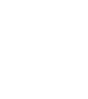 & 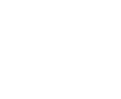 & $\begin{array}{c}\vdots \\
\vdots \\
\vdots \\
\vdots\end{array}$ & 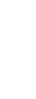 & $\begin{array}{c}\vdots \\
\vdots \\
\vdots \\
\vdots \\
\vdots\end{array}$ & $\begin{array}{c}\vdots \\
\vdots \\
0\end{array}$ \\
\hline & 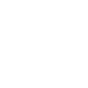 & 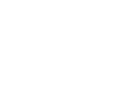 & $\vdots$ & : & 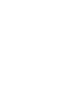 & לִ \\
\hline & 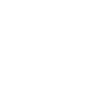 & 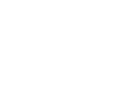 & 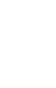 & 㝰 & 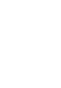 & 足 \\
\hline & 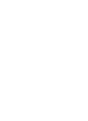 & 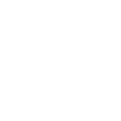 & : & $\begin{array}{c}\vdots \\
\vdots \\
8\end{array}$ & & 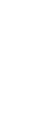 \\
\hline \multicolumn{2}{|r|}{ 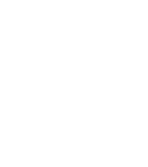 } & \multicolumn{5}{|c|}{ 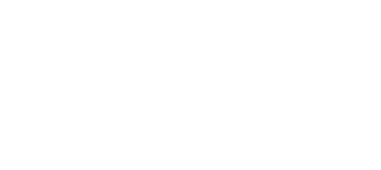 } \\
\hline & 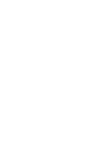 & 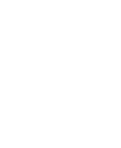 & : & לò & 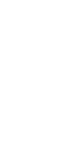 & 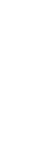 \\
\hline & 追 & 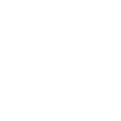 & 总 & 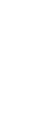 & 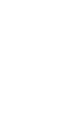 & 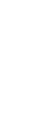 \\
\hline
\end{tabular}




\section{INDEX.}

A.

Abes Spring, section at.

Acknowledgments to those aiding

Adams Spring.

Agassiz, A., cited.

Agassiz, L., cited

Alachua, rock at.

wells at, data on record of.

Alachua clay, character of

distribution of.

fossils of

soil from

stratigraphic position of

structure of.

water in

See also particular counties.

Alachua County, description of

geology of............................ 263-265

public water supply in .............. 254

sinks in ............................ 263 view of $\ldots \ldots \ldots \ldots \ldots \ldots \ldots \ldots \ldots .26$

springs in ..................... 266, 267

water supply of................... 265-267

wells in, data on.................. 254, 266

records of....................... 264

Alachua sink, description of ................ $\quad 27$

location of....................... 263

Alafia River, rocks on.................. 146

Albion, wells at and near.............. 355, 356

Allay, E. C., cited ..................... 207

Allen, J. H., cited ..................... 102

Alliance, wells at..................... 329-330

Alluvial deposits, distribution and character

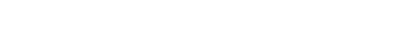

Altamont Springs, spring at............. 378

Altha, wells at........................ $\quad 279$

Altitudes, distribution of ....... 21-23,45,54-55,61

Alton, wells near.................... $\quad 337$

Altoona, wells at...................... 343

Alum Bluff, rocks at and near........... 108, 132

section at and near................ 109-110

Alum Bluff formation, character of......... 67,

$69,109-111,246,250$

deposition of. 203

distribution of

111-117

fossils in

111

members of

description of................... 117-121

stratigraphic position of............. 108-109

structure in ........................ 111

water in.................. 246,248, 250-251

See also particular counties.

Aluminous clay, correlation of........ 127, 129, 131

Alva, well at.......................... 348

Anastasia Island, coquina on............. 192

coquina on, views of............... 80,148

wells near.

396
Anthony, wells at and near............. 367, 368

Antioch, well at...................... $\quad 322$

A palachicola, depression near............. 213

public water supply at............... 254

wells at.......................... 305-308

record of........................ 306

water in, head of ................ $\quad 237$

Apalachicola group, deposition of......... 202-203

formations of............... 66-67, 69-70,246 description of............ 87-121,202,246

nomenclature of .................... 85-87

springs from........................ 229

water in.................... 246, 248-250

See also particular counties.

A palachicola River, rocks at and near.... 108,132 sections at and near................ 19-110

Apopka, springs near.................... $\quad 378$

wells at.......................... 378-379

Arcadia, public water supply at........... 254

rocks near........................ 134, 138

wells at and near................... 294-296

record of......................... 389

Arcadia marl, correlation of.............. 69,134

Archer, rocks near..................... 91

wells at............................. 266

Area of southern Florida................. 42

Argyle, section near.................... 121

wells at........................... 326-327

Armstrong, well near................... 396

Arno, wells at.......................... $\quad 266$

Arredonda, wells at..................... $\quad 266$

Artesia, wells at....................... 276

Ártesian water, areas of, distribution of..... 236-

Artas

conditions for

234-235

figure showing................... 234

fallacies cóncerning :................ 241-242

head of, chapges in ................. 237-241

changes in, figure showing......... 240

controlling factors in............. 234-235

height of, in Florida............. 236-237

relation of, to depth of well....... 241-242

See also Flowing wells.

Aspalaga Landing, rocks at and near....... $\quad 99$

sections at and near. . .................. 98-99

Astor, well at and near................ 342,343

Astor Park, well at and near .............. $\quad 342$

Auburndale, wells at.................. $\quad \mathbf{3 9 0}$

Aucilla, wells near....................... 333

Avoca, well at....................... $\quad \mathbf{3 1 5}$

Avon Park, wells at.................... 296

Aycock, public water supply at............ 254

well at............................ $\quad 328$

B.

Bagdad, wells at and near.............. 402-403

Bahia Honda, nature of ................. 62

rocks on .......................... 188

$76854^{\circ}-$ WSP $319-13-28$ 
Page.

Bailey, J. W., cited.

75,102

Baker County, description of. geology of. 267-268 water supply of.

268-269

Baldwin, wells at and near . ......... 299,300,301

Ballast Point, rocks at.................. 105

Banyan, wells at.................... 276

Bars, occurrence and character of.......... 37

Bartow, public water supply at......... 254,390 rocks near........................ 74,388 wells at and near.................... $\quad 390$

Bass, rocks at....................... 92 wells at........................... $\quad 287$

Bayard, wells at..................... 300,301

Bay City, wells near................... 318

Bay Port, springs near . .............. 317,319

Beach deposits, character of ............. 160 view of .............................. 62

Bed rock. See Rock.

Belleair, public water supply at . ........ 254,323 well near.

Belleview, wells at and near........... 367,368

Benson Salt Springs, occurrence and character

of........................... $\quad 420$

Beresford, well at.................... 418-420

Bessey, Dr., cited ....................... 256

Bibliography of region................. 17-19

Big Blue Spring, occurrence and character of. $\quad 334$

Big Cypress Swamp, location and extent of... 58

Big Pine Key, location and character of...... 61 rocks near.................... 182,188 springs on ......................... 371 wells on ....................... 170,372

water of, assays of ............... 260

Biscayne Bay, pineland near ............ 52,53 rocks near.......................... 51 springs near....................... 256

Black Creek, rocks on.................. 126 section on ...................... 126-127

Blackwelder, E., cited . . . . . . . . . . . . . . ... 183

Blair, wells near........................ 271

Blountstown, wells at.................. $\quad 279$

Blue Spring, occurrence and character of... 356

Bluffisprings, wells at................... 304

Boardman, wells at.................... $\quad 368$

Bone Valley, wells at.................... . 390

Bone Valley gravel, character of. $66,69,145-146,206$ deposition of . . . . . . . . . . . . . . distribution of...................... 146

fossils of $\ldots \ldots \ldots \ldots \ldots \ldots \ldots \ldots \ldots \ldots, 146$ nomenclature of ................... 144-145 stratigraphic position of............. 145 structure of ........................ 146 water in ........................ 245,253

Bonifay, wells at................. 326,329-330

Bored wells, use of . . . . . . . . . . . . . . . 231-232

Bostwick, wells at................... 392,394

Boulware Spring, occurrence and character of. $\quad 267$

Bowling Green, wells near............ 294-296,390

Boyd, wells at....................... 415

Bradentown, public water supply at..... 254,364 soils near ......................... 40 wells at and near.................. 364

water of, head of ................ 237

Bradford County, description of ............ 269 geology of . . . . . . . . . . . . . . . . 269,270 public water supply in. ............. 254
Page.

Bradford County, springs of ........... 270,272 water supply of................... 270-272

Branford, wells at and near............. 410,412

Brevard County, description of ............ 273 geology of. ......................... 273, 275

springs of.......................... 276 water supply of.................. 275-277 wells in, records of................ 274, 275

Brewer Sulphur Spring.................. $\quad 422$ Bridges, natural, occurrence and character of. 28-29 Bristol, wells at. . ..................... 358 Bronson, spring near................ 355,356

Brooksville, rocks near . . . . . . . . . . . . . . . 316-317 wells near....................... 318-319

Brown, wells at...................... 287

Brownville, well at ..................... 294

Bryceville, wells at.................... 375

Buckingham, wells near................ $\quad \mathbf{3 4 8}$

Buck Key, rocks on ..................... 195

well on ..................... 172-173,348 record of $\ldots \ldots \ldots \ldots \ldots \ldots \ldots \ldots \ldots, 172$ water of, assay of ................. 260

Buena Vista, wells at.................... 293

Bulow, well at....................... $\quad 418$

Burnside, well at, record of............... $\quad 299$

\section{C.}

Calhoun County, description of.......... 277-278 geology of . . ..................... 111, 278 water supply of.................. 278-279

Callahan, public water supply at........ 254-374 wells at......................... 374-376

Caloosahatchie marl, character of ....... $66,69,135$ distribution of................... 136-138 fossils of .......................... 185 nomenclature of ..................... 134 stratigraphic position of. . . . . . . . . 134-135 structure of....................... 135-136 water in.......................... 245

Caloosahatchie River, rocks on......... 136, 175 sand dunes near...................... 48-49 sections on ....................... 136, 137

Calvary, wells at..................... 368 Campbell, wells at and near.............. $\quad 380$

Campbellton, wells at. . . . . . . . . . . . . . . . 329-330

Canaveral Lighthouse, wells at........... $\quad 276$ well at, record of...................... 274

Cantonment, rocks near.................. $\quad 130$ well near, record of ................. 303

Cape Canaveral, coast at. ............... 36, 39 See also Canaveral Lighthouse.

Capes, formation and character of.......... 38-39

Cape Sable, ridges at. .................. $\quad 49$ wells at and near .................... 371 water in, assay of ................. 260

Cape St. George, formation of............... 39

Cape San Blas, formation of............. 38-39

Captiva, well near...................... 348

Carrabelle, wells at and near............. $305-308$ wells at and near, record of........... 305 water in, head of................ 237

Carraway, wells at........................ 394

Carrs Mill, geology near................... 111

Carters Mill, wells at.................... 389,390

Caryville, rocks near..................... 101

well at............................ 429-430 record of........................ 427 
Page.

Cassidy Spring, location of

Cattle ranges, location of.

Caverns, occurrence and character of:

Caximbas Pass, sand dunes near.

Cedar Key, spring near.

wells at and near.

334

50

26

48

Center Hill, wells at and near............ 406, 407

Century, wells at...................... 304

Cerithium rock, correlation of.......... 70, 102,103

Chaires, well at....................... 352,353

Channels, underground, occurrence and character of..................... 26, 229

Charlotte Harbor, rocks near.............. 137

wells near........................ 294, 295

Chassahowitzka Springs, occurrence and character of................ 281,282

Chattahoochee, wells at and near ........ 310-312

Chattahoochee formation, character of. 70,94-95, 246 correlation of ...................... 86,87 disposition of ...................... 203 distribution of...................... 96-101

fossils of ........................ 95-96

nomenclature of ...................... 93

stratigraphic position of. .............. 93-94

structure of.......................... 96

view of $\ldots \ldots \ldots \ldots \ldots \ldots \ldots \ldots \ldots, 94$

water in .................... 246,248,249

See also particular counties.

Chattahoochee Landing, rock at............. 93 section of....................... 96-97

Chemical deposits, occurrence and character 161-162

Cherry Lake Spring, description of ......... 361

Chimney rock, occurrence and character of... 78

China, oolite from .................... 183

Chipley, public water supply at. .......... 254 rocks near........................ 427 section near. . . . . . . . . . . . . . . . . . 150 wells at......................... 429, 430

Chipola group or stage, correlation of...... 69,86 Chipola marl member, distribution and character of ............. 108,117-119 fossils in.......................... 118

Chipola River, rocks on.......... 101,118, 130-131 natural bridge on.................. 28-29,74 sections on . . ................. 119,130,131

Choctawhatchee marl, character of. . $69,127-129,246$ distribution of. .................66, 130-133 fossils of . . ....................... 199-130 stratigraphic position of . . ........... 127-128 structure of........................ 130 water in.

See also particular counties.

Choctawhatchee River, rocks on............ 101

Chumuckla, wells at .................... 403

Citra, wells at....................... 368

Citrus County, description of ............. 280 geology of ......................... 280 springs of......................... 281,282 water supply of. . . . . . . . . . . . . . . . 281-282

Clapp, F. G., cited . ..................... 84 work of........................... 18,19

Clark, wells at......................... 266

Clarksville, section near ................ 132 wells at.
Clay, distribution and character of........ $\quad 156$ soil from, distribution and character of. . $\quad 41$ water-bearing quality of............. 242-243

Clay County, description of................ 283 geology of . . . . . . . . . . . . . . . . . . . 283-284

public water supply in............... 254

springs of.......................... 284-285

water supply of . . . . . . . . . . . . . . . . . 284-285

Clayland, wells near.................. 410

Clearwater, public water supply at....... 254,323

rocks near....................... 107

section near. ...................... 107

well at. . . . . . . . . . . . . . . . . . . 322, 324

Clyatt, wells at......................... 266

Coast, artesian head on.................. 236-237

features of . . . . . . . . . . . . . . . . $35-42,44,63$

topography of ................. 35, 44,62-63

wells on ........................ 167-175

See also Coastal swamps.

Coastal Plain, nature of . ................. 21

Coastal swamps, distribution and character of. $58-59$

Cocoa, wells at . . ................... 276,277

Cocoanut Grove, springs at ................ $\quad 289$

rocks at. . . . . . . . . . . . . . . .

wells near......................... $\quad 292$

Coleman, wells at and near........... 406, 407

Columbia, wells at....................... 288

Columbia County, description of............. 286

geology of . . . . . . . . . . . . . . . . . . . . 286-287

public water supply in ............. 254,287

springs of.............................. 287

water supply of....................... 287-288

Concord, wells at.................... 311-312

Conrad, T. A., cited.................. 71, 180, 184

Continental border, submerged, occurrence and character of .............. 35-36

Coquina, deposition of.................. 216 distribution and character of......... 155-156,

$157,174,175,192-193$

marl from

views of ......................... 80,148, 154

Coral reefs, occurrence and character of..... 35 , 42, 197-198

view of $\ldots \ldots \ldots \ldots \ldots \ldots \ldots \ldots \ldots \ldots .62$

Coronado, wells at................... 418, 419

Cortez, well at.......................... 364

Courtenay, wells at................... 276,277

Cottondale, rocks near................... 328

wells at and near . . . . . . . . . . . . . . . 329-330

Crawfordsville, spring at................ 422

Crescent City, public water supply at...... 254,393 wells at.......................... 392-394

Crestview, geology near.................. 129

Croom, rock near........................ 79 wells near......................... 318-319

Crowders Crossing, deposits at............. 120

Crystal River, springs near........... 29, 281, 282 wells near...................... 281, 282

Culture, development of ................. 43

Currents, ocean, work of........... 38-39, 63-64, 216

Cypress, wells at . . . . . . . . . . . . . . . . . $329-330$

Cypress swamps, occurrence and character of. $\quad 58$

D.

Dade City, wells near ................. 386-387

Dade County, description of. .............. 288

geology of . . . . . . . . . . . . . . . . . . 288-289

springs in ......................... 289 
Page.

Dade County, water supply of ........... 289-293 wells in ........................... 289-293

flows from $\ldots \ldots \ldots \ldots \ldots \ldots \ldots \ldots .258,292$

records of.................... 289-291

water of, assays of ................ 260

Dall. W. H., fossils determined by........ 97, 151 on Apalachicola group ............. 86-87, 90-92, 96-97, 102-103, 105, 108-110 on geologic history ........... 203, 209, 212-213 on Miocene series......... 125, 127, 128, 130-133 on Pliocene series............. 134-138, 140-144 on Quaternary rocks .. 151, 156, 160, 189, 190, 198 on structure...................... 164-165 on Vicksburg group......... 71,72,74,76,80-82 work of.

Dall,W.H., and Stanley-Brown, J., cited 112-113, 129

Dams, effect of, on head.................. 241

Dana, J. D., cited...................... 186

Dania, geology near................ 178, 183, 195 wells at and near............... 179, 290, 293 record of ....................... 290

Darlings Slide, section at................ 131

Darton, N. H., cited.................... 168

Data, source of ........................ 17

Day, wells near........................ $\quad 337$

Daytona, rocks at..................... 416 submarine spring near................ 236

wells at and near.................... 418

record of...................... 417

water in, head of ............ 236, 239,418

Daytona Beach, wells at and near......... 418

Deerfoot Spring, description of .........419,420

De Funiak Springs, public water supply at. 254,425 rock near......................... 121 section near........................ 149

spring at......................... 425

wells at.......................... 424-425 record of ............................ 423

De Land, public water supply at........ 254,419 rocks near................. 133, 138,416,418 wells at and near.................. 418-420 record of ........................ 417

De Land Junction, wells near........... 418,419

De Leon Springs, rock near............... 88,91 rock near, view of ................. 140 section near........................ 140 spring near....................... 419,420

Delesse, A., on ground water............ 221

Delray, rocks near............... 177, 180, 192, 195 wells at and near............ 167, 174,384-385 record of........................ 384

De Soto County, description of ............. 294 geology of....................... 294-295 public water supply in . ............... 254 water supply of..................... 295-296

Development, cultural, progress of......... $\quad 43$

Devils Mill Hopper, location of............. 263 rock at............................ 90

Diatomaceous earth, occurrence of......... 159

Dinner Island, well near.................. 396

Double Sink, well near.................. 355

Dowling Park, wells at and near......... 410,412

Drainage, description of.......... 23-25, 43, 54-55

Drainage, underground, description of.... 25-29, 52

Drew, G. A., cited................ 161, 162, 200-201

Drilled wells, use of ................... 232-233
Page.

Driven wells, use of..................... 232

Dug wells, use of $. . . \ldots \ldots \ldots \ldots \ldots \ldots \ldots \ldots . \quad 231$

Duncan, rocks near.................... 78,427

Dunedin, wells at and near ............. 322,324

Dunes. See Sand dunes.

Dunnellon, public water supply at . . ..... 254,367 wells at and near ................... 367,368

Dutton, wells at...................... 266

Duval County, description of ........... 296-297 geology of . . . . . . . . . . . . . . . . . . 297-299 public water supplies in ............. 254,300 springs of ......................... 300 water supply of .................... 299-301 wells in, records of................ 298, 299

\section{E.}

Eagle Lake, wells at.................... $\quad 390$

Early Bird, wells at.................... 368

East Eau Gallie, well at................. $\quad 276$

East Mayport, wells at................ $\quad 300$

Eau Gallie, rocks near................ 153,273

wells at........................ 276,277

records of.................... 274, 275

water of, head of............. 236, 275

Ecphora beds, correlation of........... 69,127

Eden, wells at and near ............... 400

Edgar, wells at........................ 392, 393

Ehren, wells near .................. 386-387

Eldred, wells at....................... 399

Eldridge, G. H., cited............... 27, 155, 171

work of.......................... 17

Eleanor, wells at................... 326-327

Elevations, distribution of...... 21-23,45, 54-55, 61

Ellabee, wells near................... 271

Ellaville, rocks near................... 359 springs near...................... $\quad 360$ wells at......................... 360-361

Ellenton, rocks near.............. 108, 116, 362 sections near ..................... 116,117 soil near........................... 41 wells near......................... 364

Elzey, wells at and near. .............. 355, 356

Emerson, wells at and near............. 410

Enterprise, salt water at.................. 227 wells near...................418, 419, 420

Enterprise Junction, well at.............. 418 Eolian deposits, occurrence and character of. 160-161 Erosion, features of ................ 30,51-52

Escambia County, description of .......... 301-302 geology of . . . . . . . . . . public water supplies in ............... 254 soils of . .......................... 40-41 water supply of ................... 304 wells in, records of................... 303

Espiritu Santo Spring................ 323,324

Estero, wells at and near................. 348 wells at and near, record of ............ 346

Estiffanulga, wells at.................. $\quad 358$ Etna, wells near....................... 281

Eureka, wells at......................... 368

Eustis, diatomaceous earth near........... 159 wells at......................... 342,343 records of.................... 339-340

Everglade, geology at................. 174, 190 well at, record of . . . . . . . . . . . . . . . . . . . 346

Everglades, bedrock in . . . . . . . . . . . 51,55-57 character and extent of ............ 53-54,159 drainage of .................. 41,54-55, 255 
Page.

Everglades, elevation of

54,255

explorations in ...................... 43 origin of ....................... 57-58, 216 section near, figure showing.......... 58 soils of ............................ 41 water of $\ldots \ldots \ldots \ldots \ldots \ldots \ldots \ldots \ldots \ldots, \quad 255$

Everglades limestone, correlation of........ 68 Evinston, wells at....................... $\quad 266$

\section{F.}

Falmouth, spring near.

wells at and near................. 410,412

- Federal Point, wells at and near......... 396,398

Felicia, wells near.................... 281

Fenholloway, springs at............... 414,415 wells near........................ 414

Fernandina, public water supply at...... 254,374 wells at......................... 374,376 record of....................... 374

Fertilizers, use of .................... 41,42 Fivay, wells near..................... 386-387

Flamingo, wells at................... 371

Flatlands, distribution and character of.... 50

Florahome, wells at................. 392,394

Floral Bluff, wells near................. $\quad 300$

Floral City, wells near................ 281,282

Florida, cooperation of ................... 18

Florida, central and northern, geography of.. 21-42 geology of........... 65-211, 212-214, 216-218

Florida, southern, geography of............ 42-64 geology of................ 167-212, 214-218 waters of 255-262

Florida reef, description of............... 61,182 geology of . . . . . . . . . . . 187-188, 197-198 growth of.......................... 185 wells on......................... 371

Floridian group, correlation of.......... 69,134

Flowing wells, effect of pumping on........ 239 occurrence of ....................... $\quad 233$ See also Artesian water.

Foerste, A. F., cited...................... 74

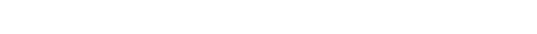

Fort De Soto, well at, record of .......... 321

Fort George, wells at................. $\quad 300$

Fort Lauderdale, dunes near.............. 48 rock near............... 57, 177, 178-179, 180 submarine springs near............... 289 wells at and near, data on........ 178, 179,293 records of...................... 289,290

Fort McCoy, wells at................... 368 Fort Meade, wells at. . . . . . . . . . . . . 296, 390

Fort Myers, rocks near.................. $\quad 51$ section at.......................... $\quad 348$ wells at and near.................. 345,348 records of...................... 349 water in, assays of............... 260 head of ................ 237,345,348 quality of .............. 260,348,349

Fort Ogden, wells at and near........... 294-296

Fort Pierce, rocks at. . . . . . . . . . . . . . . . 398-399 well at .......................... $399-400$ record of . . . . . . .

Fort Reed, wells at.................. 378-379

Fort Thompson, well at................. 348

Fort White, section near................ 84 springs at......................... 287 wolls at and near.
Fossils, occurrence of. See particular formations.

Francis, wells at....................... 394

Franklin County, description of.......... 305 geology of . . . . . . . . . . . . . . . . . . 305-306 public water supply in . . ............ 254,306 water supply of .................. 306-308 wells in, records of................. 305,306

Freeport, public water supplies at.......... 254 wells at........................424,425 water in, head of ................. 237

Fruitland Park, well near............... $\quad 342$ Fruitville, wells near.................... 364

Fuller's earth, deposition of .............. 202 occurrence and character of.... 108,110,112-115

G.

Gadsden County, description of........... $\quad 308$ geology of...................... 308-310 public water supplies in ............... $\quad 254$ water supply of ................... 310-312 wells in, records of................ 309-310 type of, view of.................. 230

Gainesville, public water supply at........ $\quad 254$ rock near................. $74,75,92,143-144$ section near...................... 144 soil near........................... 40 springs at....................... 266-267 wells at and near.................... $\quad 266$ water of ........................ 226

Geography, description of .............. 21-64 Geologic history, account of. . . . . . . . . 66, 199-218 Geologic map of Florida.............. In pocket. Geology, record of. ...................... 65 rocks of, description of.............. 71 succession of .................... $65-70$ table of ....................... 68-70 See also particular counties.

Georgiana, wells at................... 276

Gidley, J. W., on Peace Creek bone beds... 142-143

Glen, well near....................... 294

Glenwood, wells at and near............. 418

Goldsboro, wells at..................... 378-379

Gomez, geology near.................. 381

wells near..................... 382, 384-385

Gorrie, Dr., cited ..................... 213

Goulding, wells at...................... 304

Graceville, wells at.................... 329-330

Grandin, wells at..................... 394

Grand Island, wells at................ 342, 343

wells at, records of ................. 340-341

Grand Ridge, wells at and near......... 329-330

Grant, wells at....................... $\quad 276$

Gravel, water-bearing quality of.......... 242

Gray sand, distribution and character of... 154-155

Green Bay, wells at.................... 390

Green Cove Springs, public water supply at.. $\quad 254$ springs at....................... 29, 284-285 wells near......................... 284

Green Spring, data on .............. 323,324-325

Greenville, wells near.................. 360,361

Greenwood, wells at................. 329-330

Griffins Creek, rock at .................... 94

Griswold, L. S., work of .............. 43, 178, 180

Ground water. See Water, underground.

Gulf Hammock, spring at................. $\quad 356$

Gulf Stream, shore modifications by........ $63-64$

Gulliver, F. P., cited ................... 38,39 
Page.

Gypsum, occurrence of

\section{H.}

Hague, wells at

Haile, wells at ..................... 266

Hamilton County, description of . . . ...... 312 geology of . . ..................... 312-313 springs of ....................... 314 water supply of. ................ 313-315

Hammock lands, fertility of, source of ..... 40

Hampton Springs, springs at........... 414,415 wells near .................. 271, 272,414

Hanson, wells at.................... 312

Hastings, wells at and near............ 396, 398 records of .......................... 396

Havana, public water supply at.......... 254 wells at. ...................... 310-312

Hawthorn, rock near ................. 89 springs at. . . . . . . . . . . . . . . . 266,267 wells at. ..................... 266

Hawthorn formation, character of . ...... 70 $87-89,203,246$

deposition of..................... 203

distribution of . . . . . . . . . . . . . . . . 90-93 fossils of . . . . . . . . . . . . . . . . . . . $89-90$ stratigraphic position of. . . . . . . . . . . $88-89$ structure of....................... 90 water in.................. 246, 249-250 See also particular counties.

Heilbron Springs. 270,272

Heilprin, A., cited ................ 79,80 $82,85,102,108,116-117,126,134,160$

Hernando, rock near. . . . . . . . . . . . . . 85 wells near . ..................... 281, 282

Hernando County, description of........ 316 geology of . . . . . . . . . . . . . . . . . 316-317 springs of..................... 317, 319 water supply of................... 317-319

Herndon, well near. . . . . . . . . . . . . . . . 386-387

Hickman, well at................... 294, 295

Highland, wells at..................... 285

High springs, rock near . . . . . . . . . . . . . . . . . 84 springs at . . . . . . . $\ldots \ldots \ldots \ldots \ldots \ldots . .266,267$ wells at........................ 266

Hill, R. T., cited ................... 207

Hillsboro County, description of . . . . . . . 319 geology of . . . . . . . . . . . . . . . . . 320 321 public water supplies in........... 254,323 springs of ......................... 323 water supply of.................... $322-323$ wells in, records of. . . . . . . . . . . . . . . . . . 320-321

Hillsboro Inlet, geology at and near . . . 192, 196-197 History, geologic, account of. . . . . . . . 66, 199-218

Hobe Sound, wells at. . . . . . . . . . . . . 382, 384-385 wells at, water of, quality of.......... 260

Holder, wells near. . . . . . . . . . . . . . . 281, 282

Holland, rocks near . . . . . . . . . . . . 115, 132, 133

Hollyhill, wells at.................... 418

Holmes County, description of. ......... 325 geology of........................... 325 water supply of. . . . . . . . . . . . . . . . . . $326-327$

Homestead, wells at. . . . . . . . . . . . . . . 292

Homosassa, springs near... . . . . . . . . . . . 281, 282

Hovey, E. O., on well records . . . . . . . 170-173, 181

Hudson, wells at. . . . . . . . . . . . . . . . . 387

Hull, wells at.......................... 294-296
Page.

Human remains, occurrence of. . . . . . . 162-163, 215 Hunt, E. B., cited. . . . . . . . . . 180 183, 185, 187, 197 Hunter, wells at. . . . . . . . . . . . . . . . 392 Huntington, wells near. . . . . . . . . . . . . . . 392 Hurds, wells at. . . . . . . . . . . . . . . . . . . 396

Hypoluxo, rocks near . . . . . . . . . . . . . . 176 wells near . . . . . . . . . . . . . . . . . . . . . . . . 384-385 record of...................... 383

I.

Indian Key, rocks of..................... 187 Indian Key Channel, rocks at. . . . . . . . 187, 195 well at. ........................ 168, 372 record of...................... 169 Indianola, wells at. ................ 276, 277 Inlets, occurrence and character of. ........ 38 Interlachen, wells at and near. . . . . . . . . . 392, 394 wells at and near, record of . .......... 392 Inverness, wells near . . . . . . . . . . . . . . 281, 282 Irrigation, practice of. .................. 41 Island Grove, wells at. . . . . . . . . . . . . . . 266 Istachatta, wells near. .................. 318-319

$\mathrm{J}$.

Jackson County, description of . .......... 327 geology of .......................... $327-328$ public water supplies in ............ 254, 329 water supply of..................... $328-330$

Jacksons Bluff, rocks near. .................133 section of......................... 128

Jacksonville, public water supply at. . ....... 254 rock near....................... 125, 297 section near. . . . . . . . . . . . . . . . . . . 124-125 wells at and near. . . . . . . . . . . . . . $300-301$ records of..................... 298, 299 water of, head of................ 236 Jacksonville formation, character of......... 66 , $69,123-125,246$ distribution of . . . . . . . fossils of ............................ 125-126 stratigraphic position of .............. 123 structure of.......................... 126 water in...................... 246,251,375 See also particular counties.

Jane Jay, wells at and near............... 390

Jasper, wells at and near.............. 313,315

Jefferson County, description of.......... $\quad 330$ geology of . . . . . . . . . . . . . public water supply in.............. $\quad 254$ springs of ........................ 332,334 water supply of ................... 331-334 Jensen, wells at....................... 400 Johnson, wells at........................ 394 Johnson, I. C., cited. . . ............ 80,81, 163-164 Josephi Island, well on, record of ........... 348 Judson, wells at and near................ . 355,356 Juliette, spring near. . ................. 367, 369 wells at and near................. 367,368 Jupiter, well at, water of, assay of........... 260 Jupiter Inlet, geology at. . . . . . . . . . . . . . 192,197

K.

Kendrick, well at.................... 367

Kerr, W. C., and Mitchell, E., cited......... 102

Keuka, wells at........................ 394 
Key Largo, location and character of....... 61

Key Largo limestone, character of..... 68, 186-187 distribution of . . . . . . . . . . . . . . . . . . 188-189 fossils of ............................ 188 stratigraphic position of ............. 186 synonymy of ...................... 184-186 view of...

Keys, altitude of ....................... 61 area of .............................. 42 character of............... 44,59-61,187-188 springs on ......................... 257 wells on ......................... 169-173 records of ................ 169,171-173 See also Florida reef.

Keys (p. - ) , wells at. 292

Key Vaca, mangroves on, view of. rocks on $187,189,195$ wells on $169-170,174$ record of

169

Key West, location and character of ........ 61 rocks on. $181,183,187,188$ springs on ...................... 371 wells on. $170-172,174,371-372$ records of.................... 171,172

Key West oolite, analysis of .............. $18^{4}$ character of................ 68,181-182,184 fossils of........................... 182 mud cracks in, view of ............... 184 origin of. ......................... 182-184 stratigraphic position of ............ 180-181 synonymy of....................... 180 view of........................... 184

King, F. H., cited....................... $\quad 222$

Kingsford, wells at..................... 390

King Spring, occurrence and character of.... 356

Kissimmee, rocks near........ 141, 152, 153,158, 380 salt water near..................... 227 wells at and near............ 254,377, 380-381 water in, head of ............ 237,380, 381

Knights Key, beach of, view of ............ 62 well on ......................... 170,372

Knoxhill, rock near.............. 101,111,121 section near........................ 121

Krome, W. J., cited ..................... 55

Kynesville, rocks near................. 79,328

L.

Labelle, sections near. ............... 136,137

Lacoochee, wells at..................... 387

Lacustrine deposits, distribution and character of....................... 159

Ladylake, well near.................... 342

Lafayette County, description of............ 335 geology of . ........................ 335 water supply of.................. 335-337

Lafayette formation, character of . ... $66,69,147-148$ correlation of . ..................... 146-147 distribution of. ..................... 148-150 fossils of ............................ 148 soils from......................... 39-40 springs from...................... 228-229 stratigraphic position of .............. 147 structure of......................... 148 view of ............................ 148 water in ......................... 245, 253 quality of ..................... 253

See also particular counties.
Lake Beresford, wells at and near......... 418

Lake Bird, wells near.................. $\quad 414$

Lake Charm, well at................... 378

Lake City, public water supply at........ 254,287

rock near............................ 92 sections at and near. ............... 91,92 wells at and near............... 287, 288,409

Lake County, description of .............. 338 geology of........................... 338 public water supply in.............. 254 springs of........................... 342,343 water supply of.................... 341-343 wells in, records of................. 339-341 Lake Helen, wells at.. . . . . . . . . . . . . . . 418, 419

Lake Kerr, well near.................... $\quad 367$

Lakeland, geology near................. 158 public water supply at. ............. 254,390 wells at. .......................... 390

Lake Mary, wells near.................. 377-379 Lake Ogden, wells at and near........... 287 Lake Park, Ga., sink near, views of......... $\quad 27$ Lake region. See Upland region.

Lakes, nature of.................... 24-25, 30

Lakeview, wells at...................... $\quad 426$

Lakewood, wells at.................... 424,425

Lake Worth, rock near. ................. 74

Lamont, springs near................... $\quad 334$ wells at............................ 331-333

Land-pebble phosphate. See Bone Valley gravel.

Langdon, D., cited .................... 71,86,87

Lanier, well near........................ 380

Lantana, dunes near................... 48

Lapenotieres Spring, section near.......... 107

Laurel Hill, wells at and near.......... 425,426

Lawtey, wells at...................... $\quad 272$

Lebanon, spring near.................... $\quad 356$

wells near........................... 355

Lecanto, wells near..................... 281,282

Lee, wells at and near.................. 360,361

Lee County, description of............... 344 geology of......................... 344 springs in......................... 345 water supply of................... 344-350 wells in.......................... 345-350 flows from.............. 258, 259,345,350 records of. ..................... 346-349 water of, assays of ................ 260 quality of................... 260

Leesburg, public water supply at. ........ 254,342 wells at........................... 342,343

Leon County, description of ............. $\quad 350$ geology of . . . . . . . . . . . . . . . . . . . $350-351$ public water supply in. ............ 254,352 water supply of................... $351-353$

Leroy, wells near...................... 367

Levy County, description of .............. 354 geology of ........................... 354 springs of.............................. 356 water supply of..................... 354-356

Levyville, rock near.................... 91 spring near.......................... $\quad 355$ wells near ....................... 355,356 Levyville formation, correlation of......... 70,80

Lewis, E., cited ........................ 214

Liberty County, description of............. $\quad 357$ geology of.......................... $357-358$ water supply of...................... 358 
Page.

Lime, use of, as fertilizer

Limestone, solution and transportation of. $26,52,161$ water-bearing quality of.............. 243

Linton, rock near....................... $\quad 178$

Literature, list of ..................... 17-19

Live Oak, public water supply at......... 254,409 rock near........................... 91

well near, water of.................. 226

wells at and near................... 410,412

Liverpool, well at...................... $\bullet 94,295$

Lloyd, wells near...................... 333

Loam soils, distribution and character of.... 41

Loess, geologic relations of............... 210-211

Longboat Key, well on .................... 364

Long Key, geology of. ................ 180, 183,197

Longwood, wells at................... 378-379

Lostmans Key, wells on................... 371

Lostmans River, rocks on .............. 190, 191

Lostmans River limestone, character of..... 68,190 distribution of...................... 190-191 origin of .......................... 191 stratigraphic position of............. 189-190 synonymy of ........................ $\quad 189$

Lotus, wells at........................ 276

Loughman, wells at.................... 389, 390

Lower Metacumbe, sands at............... 197

Lowland, description of.................. $30-35$

Luraville, rocks near.................... 408 wells near...................... 409-412

Luther, wells near...................... 414

M.

McAlpin, wells at and near

Maccleny, wells of...................... 268-269

McIntosh, wells near.................... $\quad 367$

Madison, public water supply at............ 254 wells at and near................... 360, 361

Madison County, description of............ 359 geology of ......................... 359 public water supply in................ 254 springs of.......................... 360-361 water supply of.................... 359-361

Magnesia spring, occurrence and character of.. $\quad 267$

Magnesia Springs, rock near............... 91

Magnolia Springs, springs at.............. 285 wells near.......................... 284

Mainland, altitude of ................. 21-23, 45 subdivisions of ..................... 25,45 See also Upland region; Lowland; Coast; Pinelands; Swamps.

Maitland, wells at and near.............. 378-379

Malabar, wells at........................ $\quad 276$

Manatee, wells at and near................ 364 wells at and near, water in, head of..... 237

Manatee County, description of............ 362 geology of .......................... 362-363 public water supply in............. 254,364 water supply of................... 363-364 wells in, records of..................... 363

Mandarin, wells at and near................ $\quad 300$

Mangroves, distribution and character of .... 59,60 view of.

Manhattan Beach, wells at.............. $\quad 300$

Map, geologic and topographic...........In pocket.

Maple, wells near.
Page.

Marathon, welis at............... 169-170,372

wells at, record of ................. 169

water of, assays of ................ $\quad 260$

Marco, rocks near..................... $\quad 190$

wells near.......................... 348

record of ........................ 346

water of, assay of ................. 260

Marianna, public water supply at........ 254, 329 rock at and near................. 72,77-78 sections at and near................. 77 wells at and near. ................. 329-330

Marianna limestone, character of ..... 70, 73-74, 247 correlation of ....................... 73 distribution of..................... $75-79$

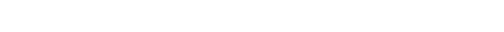

stratigraphic position of .............. 73 structure of........................ 74-75 water in................ 247, 279, 304, 326, 329

Marine deposits, water of, sweetening of..... 207-

$208,225-226$

Marion, well at....................... $\quad 315$

Marion County, description of............ 365

geology of......................... 365-366

public water supplies in ............. 254,367 springs of..................... $366-367,369$

water supply of.................... 366-369

wells in, records of................. 365-366

Marls, distribution and character of ....... 151-154,

$194,196,197,198$

origin of $\ldots \ldots \ldots \ldots \ldots \ldots \ldots \ldots \ldots \ldots .196,216$

soils from

40

See also Planorbis; Chipola; Shoal River; Choctawhatchee; Caloosahatchee; Nashua; and Shell marls.

Martel, wells at and near............. 367, 368 Martin, well near...................... $\quad 367$

Matanzas, well near.................... 396

Matson, G. C., county descriptions by .... 263-288, 294-343, 350-369, 373-381, 385-430

on geography of northern and central Florida....................... 21-42

on geology of northern and central

Florida...................65-166

on underground waters............... 219-254

work of............................ 18,19

Matson, G. C., and Sanford, S., on geologic history.................... 199-218

Maury, C. J., cited ................... 76, 96

Maxville, wells near................... 284, 300

Mayo, public water supply at.............. 254

wells at and near................... $\quad 337$

Mayport, wells at and near.............. 300,301

wells at and near, record of........... 298

Maytown, well at.................... $\quad \mathbf{3 7 8}$

Medulla, wells at...................... $\quad 390$

Melbourne, rocks near.................. $\quad 85$ springs near...................... 277

wells near...................... 276,277

record of.................... 274,275

Melrose, springs at...................... 266,267 wells at........................... 266

Merritts Island, rocks of .................. 273 wells on .......................... 276

Miami, fossils near....................... 179 rock near................ 178, 179, 180, 183 springs near...................... 289 
Page.

Miami, wells at and near................
wells at and near, records of. . . . . $\ldots \ldots \ldots$.

water of, assay of.................. 260

Mismi oolite, character of...... 68, 178-179,216,257 distribution of...................... 180

fossils of .......................... 179-180

springs from...................... 256

stratigraphic position.................. 178

synonymy of................... 177-178

view of ............................ 178

water in............................ 289

Micanopy, well at...................... $\quad 266$ well at, record of ..................... 264

Micco, wells near......................... 276

Middleburg, section near. .............. 126-127 springs near......................... 284 wells near......................... 284

Mikesville, wells at..................... $\quad 287$

Miliolite limestone, correlation of ........... 85

Mill Creek, rocks on. .................... 133

Milligan, rocks near.................... 401

Millview, public water supply at............ 254 wells at........................... 304

Millville, wells at................ 428, 429,430

Milton, wells at and near................ 402-403

Mimms, geology at...................... $\quad 273$ wells at.............................. $\quad 277$

Mineralization of underground water, causes of ............... 225-227, 261, 262 See also Water, underground.

Miocene series, deposition of.............. 204-205 formations of . . . . . . . . . occurrence and character of.......... 123-133, $167,168,170,171,173-174,204-205,246$ nomenclature of . .................. 121-123 water in................... 246, 251-252, 258 See also particular counties.

Miocene time, events in . . . . . . . . . . . . . 203-205

Mitchell, E., and Kerr, W. C., cited....... 102

Mixons, rock near...................... 91

Molino, wells at........................ 304

Monroe, wells near.................... 377, 378

Monroe County, description of............ $\quad 370$ geology of .......................... $\quad 370$ springs of.......................... 371 water supply of.................... 370-372 wells in, water of, assays of ............ $\quad 260$

Montague, wells near.................... $\quad 367$

Monthook, wells at................... 355, 356

Monticello, public water supply at.......... 254 wells at........................... 331-333

Morriston, wells at.................... 355, 356

Mound, ancient, view of................ 154

Mount Dora, wells at and near.......... 342, 343 wells at and near, record of............ $\quad 340$

Muck soils, distribution and character of .... 39 use of .............................. $41-42$

Mulat, wells at....................... 304

Mulberry, public water supply at........... 254 wells at and near. ................. 389,390

Muscogee, wells at and near............. 304

N.

Naranja, wells at

Narcoossee, wells at and near.

380,381

Nashua, rocks near.

133,140

rocks near, view of.
Page.

Nashua marl, character of............ 66, 69, 139 contact of, view of ................... 140 discrimination of ..................... 138 distribution of...................... 140-141 fossils of.......................... 139-140 stratigraphic position of............... 139 structure of........................ 140 water in ......................... 245, 252 See also particular counties.

Nassau County, description of............ $\quad 373$ geology of ....................... 373-374 public water supplies in.............. $\quad 254$ springs of............................ 374 water supply of.................... $374-376$ wells in, records of................... 374 Natural Bridge, rock near.............. 78-79,423 Natural bridges, occurrence and character of. 28-29 Newberry, rock near................... 84 wells at............................. $\quad 266$

Newberry terrace, description of.......... 32-33

Newbridge, view at...................... 94

Newburn, well near..................... 411

Newfound Harbor, rocks at.............. 188 Newland Spring, occurrence and character of. 29 , 409,412

Newnansville, rock near................. 91

Newport, springs near.................. $\quad 422$

New Smyrna, wells at and near........... 418

view of ............................ $\quad 230$

Nichols, wells at. . . . . . . . . . . . . . 324, 389, 390

Nigger Sink, rock at.................... $90-91$

Nocatee, wells at and near............. 294,295

North Indian River, mound in, view of...... 154

Northrop, wells at and near............. $\mathbf{3 0 4}$

Norwalk, springs near................... $\quad 369$

Nummulitic limestone, correlation of ....... 70,80

o.

Oak, wells near....................... $\quad 367$

Oak Grove sand member, distribution and

character of................. 119-120

fossils of .............................. 119

Oak Hill, wells near.................. 418,419

water of, quality of ................... $\quad 276$

Oakland, wells at and near................ 378

$O^{\prime} B r i e n$, wells at and near............411,412

Ocala, fossils from ...................... 143 public water supply at.............. 254,367

quarry near, views in................ 80 rock at and near................. 83,365-366 section at ........................ 83 spring near..................... 366-367,369 wells at and near.................. 367-368

record of ...................... 365-366

Ocala limestone, character of....... 70,81-82,247 distribution of..................... 82-85,286

fossils of ........................... 82 nomenclature of..................... $79-80$ stratigraphic position of.............. 80-81 structure of ........................ 82 views of ............................. 80 water in.......................... 247,406

Ocean currents, work of............. 38-39, 63-64 Ochlockonee River, section on............ 128

Ocheesee beds, correlation of .............. 70,93

Oclakatchee Lake, sink of, view of.......... $\quad 27$

Ocoee, wells at......................... 378-379 
Odessa, well near........................ $\begin{gathered}\text { Page. } \\ 386-387\end{gathered}$

Okahumpka, spring near............... 342,343 wells near........................ 342,343

Okaloacoochee Slough, cypress in........ 58

Okechobee, Lake, drainage of ............ 54-55 soils near........................... $\quad 39$ See also Everglades.

Old Miocene, correlation of ..............69,71

Oligocene series, deposition of........... 199-203 formations of ........66-67,69-70,71,246-247 occurrence and character of ...... 71-121, $167,173,246-247$ soils from......................... 39 water in.................. 246-251, 256, 258 See also particular counties.

Oligocene time, events in............. 199-203

Olustee, wells of......................... 269

Oneco, wells near....................... 364

Oolite, analysis of. ................... 184 formation of . ............... 162, 180, 181-184

Orange City, public water supply at...... 254,419 section at.......................... 158 wells at..................... 418,419,420

Orange County, deseription of ............. 376 geology of . . . . . . . . . . . . . . . . . . 376-377 public-water supplies in .............. $\quad 254$ springs of........................ 378 water supply of ................. 377-379

Orange Park, wells near ............. 284,285

Orange Springs, springs near.......... 367,369 wells at.............................. 368

Orchid, wells near ...................... 276

Organic life, land buildmg by .......... 216-217

Orient, section at....................... 153

Orlando, public water supply at........... 254 sink near........................... 376 wells at and near................ 376,378-379

Ormond, geology near. . . . . . . . . . . . . . 153, 399,416 wells near.......................... 418 record of...................... 417,418

Orthaulax bed, correlation of . . ........... 70, 102

Osborne, Lake, depth of.................. 49 sand dunes near..................... 48

Osceola, wells at......................... $\quad 266$

Osceola County, description of.............. 379 geology of . . ...................... $379-380$ water supply of..................... 380-381

Osprey, human remains near ........... 162-163 sections near......................... 163 well near............................ 364

Otter Creek, spring near................ 355,356 wells at and near.................. 355, 356

Oviedo, wells at...................... 378-379

Oxford, wells at and near.............. 406-407 wells at and near, records of............ 40

Oyster reefs, occurrence and character of... 160, 198

\section{P.}

Pablo Beach, public water supply at..... 254,300 wells at............................. 300,301

Padget, well at....................... 392

Palatka, public water supply at.......... 254,393 wells at............................ 392-394 records of....................... 392

Palm Beach, geology near ............... 154, $175,176,192,195,196-197$
Palm Beach, sand dunes near .............. Page. wells at and near............ 168,382,384-385 records of ...................... 168, 383

Palm Beach County, description of......... 381 geology of........................ 381-382 sprimgs in.......................... 382 water supply of ..................... $382-385$

wells im, flows from................ 258, 384 records of...................... 382-384 water of, assays of ................ 260

Palm Beach limestone, character of. ......68, 176 distribution of . . . . . . . . . . . . . . . . 177

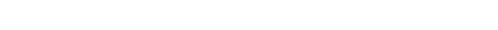
stratigraphic position of . ............. 176 structure of......................... 177 synonomy of . . ..................... 175-176

Palmer, wells at.......................... 266

Palmetto, wells at and near............... 364

Panacea, spring near.................. $\quad 422$

Panasoffkee, wells at..................... $\quad 407$

Panther Key, wells on.................... 371

Parish, wells at and near................. 364

Park, well at........................... 378

Pasadena, well near.................... 386-387

Pasco, well near ............................ 386-387

Pasco County, description of................ 385 geology of . . . . . . . . . . . . . . . . . . . . 385-386 water supply of ....................... 386-387

Pavilion Key, wells on .................. 371

Peace Creek, rocks on.................. 146 sections on ......................... 138

Peace Creek bone bed, correlation of. $69,138,141-143$ fossils of......................... 142-143

Peat, distribution and character of. 195-196, 198-199 relations of ...................... 58 soils from, distribution and character of.. $\quad 39$ use of..........................41-42

Pebbledale, wells at................... $\quad 390$ Pebble phosphates. See Bone Valley gravel.

Peck Mineral Springs, occurrence and character of....................... 285

Peniel, wells at......................... 392,394

Peninsular limestone, character of . ... 70,73-74,247 distribution of. . .................... $75-79$

fossils of ........................... 73

stratigraphic position of.............. 73

structure of....................... 74-75

water in .......................... 247, $269,272,277,296,301,324,364,378,381,390$

Pensacola, public water supply at.......... 254 rocks at. ............................. 75

wells at and near.................... 304

record of........................ 303

Pensacola terrace, description of ............ 34-35

Perched water table, figure showing........ 225 nature of........................... 225

Perrine, wells at......................... 292

Perry, springs at. . .................. 414, 415

wells at and near...................414,415

public water supply at............. 254, 414

Phosphate rock, investigation of........... 18 occurrence of. . . .................... 76,90-91

Phosphoria, wells at.................... $\quad 390$

Picolata, well near....................... 396

Pierce, wells at......................... $\quad 390$

Pierce, James, on coquina. . . ........... 155-156 
Page.

e Barren, wells at

ne Island, sand dunes on................ 48

inelands, area and distribution of. . . . . . . . 45-46 character of......................... 46-52 See also Sand dunes; Sand plains; Flatlands; Ridges.

inella County, organization of. ........... 387 See also Hillsboro County.

inemount, wells at and near..........411,412

inetta, springs near..................... 360

wells at and near................. 360,361

lanorbis marl, distribution and character

of ........................ 155,175

lant City, public water supply at ........ 254 wells at and near. .................... 322, 324

record of . ...................... 320-321

water of ................... 226, 323, 324

lants, evaporation through.............. 223

lantation Key, rocks of. ................ 189

Pleistocene series, expression of ........... 158

formations of ............ $68,151,174-175,245$ correlation of .................. 191-192 description of................... 175-191

fossils of....................... 151-154,158

lithology of ....................... 192-195

marls of. ..................... 151-154, 194 soil from........................ 40

sand of ..................... 154-157, 193 oontact of, view of............... 140 soil from....................... 39 stratigraphic position of . . .......... 156-157 structure of......................... 158 thickness of . ............... 157-158, 194-195 water in .................. 245, 253-254, 258 See also particular counties.

Pleistocene terraces, formation of. ........ 210-211 location of, map showing........... In pocket. occurrence and character of............. 31-35 Pleistocene time, events in . . . . . . . . . . . 207-212 liocene series, deposition of............ 206-207 formations of.............. $66,69,13,147,245$ occurrence and character of...... 134-150, $167,171,173-174$ soils from water in .................... 245, 252-253, 258 See also particular counties.

Pliocene time, events in ............... 205-207

Plummer, wells at....................... 300

Poe Spring, occurrence and character of..... 29,267

Polk County, description of. . . . ............ 388 geology of . . . . . . . . . . . . . . . . . . public water supplies in ................ 254 water supply of..................... $389-390$ wells in, records of.................... 389 Ponce de Leon, wells at................ 326-327 Ponce Park, wells at and near . . . . ........ . 418,419 Ponds, occurrence and character of......... See also Lakes.

Port Orange, wells at and near. ........... 418

Port Riohey, well near . . . . . . . . . . . . . . . . 386-387

Port Tampa, wells at.................. 324

Potable water, depth to ................ 225-227

thickness of sediments containing....... 222

Potholes, formation of .................. 187
Profile section across Florida, figure showing. $\quad 225$ Providence, wells near................. 270,271 Public water supplies, table of.............. 254

Pumpelly, R., cited..................... 93-94 Pumping, effect of, on artesian head...... 239, 241 water wheel for, view of ............... 234 Punta Gorda, wells at and near.......... 294,296 Punta Rasa, wells at and near............. 348 wells at and near, records of ........... 347 water of, assays of ................ 260

Putnam County, description of........... 391 geology of. ......................... 391-392 public water supplies in ............. 254, 393 springs of ........................... 393 water supply of ...................... $392-394$ wells in, records of................... 392

Putnam Hall, wells at.................... 394

\section{Q.}

Quaternary system, formations of, descriptions of............... 151-163,245 subdivisions of . . . . . . . . . . . . . . . . . water in....................... 245, 254

Quincy, fuller's earth near............. 113-114 public water supply at................ 254 rock at.................... section near......................... 113 wells at and near................... 310-312 record of...................... 309-310 view of ......................... 230 water of ........................ 226

R.

Rabbit Key, rock on ................... 198 Rainfall, disposition of................ 220,255 effect of, on artesian head............. 238-239 records of ......................... 219-220

Rams, hydraulic, use of .................. 233 Recent series, formations of..... $68,158,195,216,245$ formations of, description of... 159-163, 195-199 water in......................... 245, 254

Recent time, events in ................. 212-218 Redbay, rocks near.................... 129, 130 Reddick, wells at...................... $\quad 368$ Red Oak, wells near.................... $\quad 360$ Reefs, coral, occurrence and character of..... 35 , $42,61-62,160,197-198$ view of ......................... 62 Reefs, oyster, occurrence and character of.... $\quad 160$ Relief, character of . ................ 21-23, 43-44 map showing.................. In pocket. description of................... 21-22

Rice Creek, wells at..................... $\quad 392$

Richland, well near...................... 386-387

Ridges, rock, erosion of .................. 51-52 occurrence and character of....... 31,51-52,165

River Junction, fossils near............... 101 rocks at and near.................. 100 sections at and near.......... 100-101,112,150 wells at............................ 312 Rivers. See Streams.

Riverside, public water supply at........ 254,300

Robinson Point, wells on................ 403

Rochelle, wells at...................... 266 
Page.

Rock, outcrops of underground solution of. See Drainage, underground.

Rock Bluff, rocks near............. 110,112-113 section at.......................... 113

Rock Hill, rocks on, view of ............. 148

Rockledge, wells near.................... $\quad 276$

Rock Springs, rock near................. 127 wells at and near.................. 367,368

Rodman, wells at...................... 392

Rose, R. E., cited..................... $\quad 57$

Roseland, wells near................... 276

Rossburg, well at...................... 411

Run-off, proportions of................. 220

Runways, tidal, occurrence and character of. $\quad 38$

Rural, well at........................... 318

Russell, wells near...................... 284

s.

Safety Harbor, rocks near.............. 106 section near....................... 106 sprimgs near........................ 324-325

St. Augustine, public water supplies at..... 254 rocks at. . . . . . . . . . . . . . . . . . $74,127,395$ submarine spring near........ 207-208, 213, 236 wells at and near.................... $\quad 396$

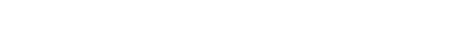
view of ......................... 32 water in, head of ................ 236

St. Francis, well near.................... 342

St. James, wells at.................... $\quad 348$ wells at, water of, assays of............ $\quad 260$

St. John County, description of........... 394-395 geology of ....................... 395 public water supplies in .............. $\quad 254$ springs of........................... 397 water supply of. . . . . . . . . . . . . $396 \ldots \ldots .398$ wells in, records of .................. 395-396

St. Johns River, rocks on......... 138-141, 152, 159

St. Leo, well near...................... 386-387

St. Lucie County, description of ............ 398 geology of. . ......................... 398-399 water supply of. . . . . . . . . . . . . . . 399-400 wells in, records of.................... $\quad 399$

St. Marks, rock near................... 101 uplift near......................... 214

St. Marys River, terrace on, view of......... 32

St. Nicholas, wells at............... 300,301,421

St. Petersburg, publio water supply at..... 254, 323 wells at..................... 322, 323,324 water in, head of. . . ......... 236,323, 324

Salt water, underground, comparison of sea water and .................... 262

distribution of .............. 226-227, 259, 260 relation of, to fresh water......... 261-262 to uplift................... 226, 262 drainage of, from rocks . . . . 207-208, 225-226, 262

San Antonio, wells near . . . . . . . . . . . . . . . 386-387

Sand, color of . . . . . . . . ......... 46-47,50, 193 distribution and character of. . 193, 196-197, 198 water-bearing quality of............... 242

Sand dunes, distribution of.............. 47-49 occurrenceand character of. $30,31,46-47,160-161$ quiescence of...

Sanderson, wells of.

47
269

Sand Key, rocks of.
Sand plains, distribution and character of... $49-50$ Sanford, public water supply at.......... 254,378 wells at ........................... 377-379 water in, head of ................ 237

Sanford, Samuel, cited................... 24 county descriptions by ............. 288-293,

$344-350,370-372,381-385$

work of ......................... 19 on geography of southern Florida....... 42-64 on geology of southern Florida........ 167-199 on waters of southern Florida........ 255-262 Sanford, S., and Matson, G. C., on geologic history ................... 199-218

Sanibel Island, wells on .................. 348 wells on, record of .................. 347 water of, assay of.................. 260 San Mateo, wells at and near............. 392,394 Santa Fe River, natural bridge on.......... 28 sink of, view of..................... 27

Santa Rosa County, description of......... 401 geology of ................ 77,401-402 water supply of................... 402-403 Sarasota, wells near....................... 364 Sarasota Key, rock on .................... 192 rock on, view of .................. 154 Seabreeze, wells at.................... 418 wells at, water in, head of .......... 236,418 Sea water, comparison of, to underground salt water...................... 262

Seepage, recovery of water by ............ 228 water from, quality of ................ 228 Sellards, E. H., cited.............. 26, 85, 89,376 work of..................... 18,224,249 Seminole Spring, occurrence and character of......................... 342,343

Senterfit Creek, deposits on . ............. 120 Seville, public water supply at......... 254,419 wells at and near.................... 392 Shaler, U. S., cited. .......... 164, 177-178, 207-208 Shark River, rock on .................. 190,196 Shark River Archipelago, character of...... 59 Sharpes, wells at and near................ 276 wells at and near, water of, quality of.... 276 Shattuck, G. B., cited................... 211 Shell Bluff, section at................... 120 Shell marl, water-bearing quality of........ 243 Shoal River marl member, distribution and character of................. 120-121 fossils of ........................ 120-121 Shore line. See Coast.

Silex bed, correlation of............... 70,102-104 deposition of...................... 203 See also Tampa formation.

Silver Spring, spring near............... 29,369 wells at and near.................. 367,368

Sinks, absorption of rain by .............. 220 location of, in Williston quadrangle, map showing...................... 26 occurrence and character of. .... 26-28,30,52,56 views of $\ldots \ldots \ldots \ldots \ldots \ldots \ldots \ldots \ldots \ldots, 26,27$ See also particular counties.

Sirmans, wells at and near.............. 360,361 Smith, B., cited...................... 177 Smith, E. A., cited...................... $75-76$ Sneads, wells at and near.............. 329-330 
Page.

3oils, distribution and character of... 39-40, 198-199 evaporation from................... 222-223 origin of ............................ $39-40$ types of ........................... $40-42$ Solution, underground, progress of......... 26,52 Yombrero Key, sands at................. 198 3opchoppy limestone, character of......... 118 correlation of ..................... 69,108 water in .......................... 306 3orrento, spring near.................... 342,343 wells near....................... 342,343 Sounds, occurrence and character of........ $\quad 37$ ship passage through ................. 37 Southwest Cape, formation of.............. 39 Jouth Jacksonville, public water supply at. 254,300 wells at and near.................... 300,301 Southport, wells at..................... $\quad 429$ sparr, wells at and near............... 367,368 spears Grove, wells at. .................... $378-379$ Spouting Rocks, geology at............... 192,193 Spring Park, wells near................... 368 Springs, occurrence and character of......... 29, relation of, to water table............ 224-225 figures showing................. 224,225 water of, quality of ................. 229 Springs, submarine, occurrence and character of............ 207-208,213, 236, 256-257 Stanley-Brown, J., and Dall, W. H., cited.................... 112-113, 129 Starke, springs at and near........... 270,272,285 wells at and near................. 270,271 State Reform School,public water supply at. 254,329 Stetson, wells at...................... 418, 419 streams, character of . ............. 23-25,30,31 sinks of

27

Structure of northern and central Florida.. 163-166 of southern Florida................. 199

Stuarts Bridge, rock near................. 116

submergence, effect of possible............. 44 occurrence of ..................... 202,

$204,205,209-210,211,212-213,215$

Subtropical Miocene, correlation of........ 69,71 Sulphur, deposition of.................. 161 Sumter County, description of............. 404 geology of ......................... 404-405 springs of ........................... 406 water supply of.................... 406-407 Sumterville, springs near................. 406 wells at and near...............208,406, 407 Suwannee, spring near. ............. 29,409,412 wells at.......................... 412 Suwannee County, description of........... 408 geology of ......................... 408 public water supply in . . . .......... 254,409 springs of ........................ 409, 412 water supply of.................... 408-412

Swamps, controlling conditions of....... 45, 52-53 distribution and character of . ......... 25, 52 See also Everglades; Coastal swamps; $\mathrm{Cy-}$ press swamps.

Switzerland, wells near..

$$
\mathrm{T} \text {. }
$$

Tallahassee, fuller's earth near. public water supply at. wells at and near

352,353
Page.

Tampa, public water supply at.......... 254,323 rocks at and near...... 75,76,95-96, 102, 105-107 sections at........................ 105, 106 springs at.................... 323, 324-325 wells at and near.............. 322, 323, 324 water in, head of ......... 237, 238, 323, 324

Tampa formation, character of...... 70, 102-104,246 distribution of................... 105-107 fossils of ........................... 104-105 nomenclature of................... 102-103 soil from......................... 40 stratigraphic position of .............. 103 structure of ......................... 105 view of ............................ 94 water in.......................... 246, 250 See also particular counties.

Tarpon Springs, public water supply at..... 254, 323 rock near........................... 84 spring at......................... 29 wells at........................ 322,323

Tavares, wells at and near............. 342,343

Taylor County, description of............ 413 geology ............................ $\quad 413$ public water supply in.............. 254 springs of ......................... 414,415 water supply of..................... 413-415

Ten Thousand Islands, character of ......... 59,60 rocks of ........................ 189, 196

Terra Ceia Island, wells on............... 364 record of ........................ 363

Terraces, character of .................... 31-35 occurrence of ....................... 31-35 map showing................. In pocket.

Terrell, well near....................... 318

Tertiary system, description of.... 71-150, 245-247 functions of.......................69-70 water in .......................... 245,254

Thomas City, spring near.............. 332,334 Thonotosassa, well near.............. 323,324 Tibbals, wells at....................... 400 Tides, effect of, on artesian head...... 237-238, 256 land building by .................. 217 runways for, occurrence and character of. $\quad 38$

Tiger Bay, wells near.................... • 390 Tildenville, wells at..................... 378

Titusville, rocks near................... 153,273 wells at and near................. 276, 277 water of.................. 227,276-277

Topographic provinces, features of......... 25 See also Upland; Lowland; Coast.

Topography, character of............ 21-23,43-44 relation of, to water table ........... 224-225 figure showing................... 224

See also Mainland; Keys; Coast; Drainage; Relief.

Traders Hill, Ga., terrace near, view of..... 32

Traxler, springs at................... 266,267

wells at............................ 266

Trilby, well near..................... 386-387

Tropic, wells near...................... 276

Tsala A popka terrace, description of........ 33-34

Tuomey, M., cited............... 94, 177, 180, 185

Turtle Mound, view of . .................. 154

Tyler, wells at.......................... 266

U.

Umatilla, wells at..................... 343

Underground water. See Water, underground. 
Page.

urrence and character of... 415 Upland region, position of ................. 22-23 springs of........................... 29 surface features of................... $28-30$ underground drainage of................ 25-28

Uplift, estimates of ................... 207-209 oceurrence of .................... 201-

$202,203-204,207-209,211,212,214-215$

Useppa Island, wells near.............. 348

$$
\mathrm{V} \text {. }
$$

Valkaria, wells near.................... 276

Vaughan, T. W., eited................. 19,

$78,149,161-162,168,181,183$

fossils determined by ............... 95-96 $126,130,132,133,153-154,179-180,182,416,418$ on deposition of rocks................ 200-201 on Alum Bluff formation...... 111-116,119-121 on Chattahoochie formation........... 95-98 on geologic history.................. 200, $203,205,206-207,209-210,214$ on human remains.................. 162-163 on Miocene........... 126, 127, 128, 130, 132, 133 on ocean currents..................... 63-64 work of............................ 17, 19

Vermetus rock, distribution and charac-

ter of ..................... 156, 160

Vernon, publie water supply at............ 254 rocks near........................ 130 sink near, viow of . ................... 26 wells at.......................... 429, 430

Vicksburg, Miss., rocks at................ 73

Vicksburg group, deposition of ........... 199-201 formations of .............. 67, 70, 72-73, 247 description of................ $73-85,247$ nomenclature of ................... $71-73$ soil from........................... 40 springs from..................... 29, 229 water in...... 67,234, 235, 247-249, 250-251, 258 quality of....................... 260 See also particular counties.

Volusia County, description of............. 416 geology of....................... 416-418 public water supplies in............. 254,419 springs of......................... 419,420 water supply of................... 418-420 wells in, records of............. 417

\section{W.}

Wacahoota, wells at. 266

Wacissa, spring near. . . . . . . . . . . . . . . 332, 334

Wades, wells at......................... 266

Wakulla County, description of........... 420 geology of......................... 420-421 springs of......................... 422 water supply of.................... $421-422$

Wakulla Spring, occurrence and character of. $\quad 422$ Waldo, wells at.......................... 266 Waldo formation, correlation of............ 70

Waldo Spring, occurrence and character of... 415 Walker Spring, occurrence and character of. 332, 334 Walkill, wells near..................... 284

Walton County, description of............. $\quad 422$ geology of .................. $77,78,101,423$ public water supplies in ............. 254 springs of........................... 425 water stupply of.................... $424-426$ wells in, record of.
Washington County, deseription of......... Page geology of ....................... $426-42$ public water supplies in............. 25 sink in, view of.................... water supply of.................... $428-43$ weils in, records of.................. 42

Water, underground, amount of . . . . . . . . 221-22 assays of........................... 260 circulation of . .............. 227-228, 261-26 depth to.................. 224-227, 255-25 evaporation of . . . . . . . . . . . . . . . . 222-22 mimeralization of ........... 225-227, 261-262 oceurrence of, in rocks.............. 242-25 pollution of, danger of ........... 229-231, 25 potable supplies of, depth to. ..... 225-227, 26 quality of .... 225-227, 243, 244, 249-254, 259-26 recovery of ...................... 228-234 source of ........................ 219-220,25: See also Water table; Artesian water; Water bearing materials; Springs; Wells; Sal water; particular counties.

Water-bearing materials, character of ..... 242-24: formations of, conditions governing.... 243-24?

description of............... 248-254, 258

Water supplies, public, table of............ 254 Water table, depth to..................... 25 a nature of .......................... 224-22 relation of, to springs and surface contour ..................... 224-22 figures showing................ 224,22: Watertown, wells at................... 28 Water way, through sounds, plan for....... Waterwheel, view of.................... 234 Wauchula, wells at and near............ 294-296 Waukeenah, wolls near.................. 335 Wausau, rocks at and near............427,430 Webster, wells at and near................ 406, 40 Weekewachee Spring, occurrence and character of. ............... 29,317,319 Weirsdale, well near.................... 367 Wekiva Spring, description of........ 29,355, 350 view at........................... 234 Welaka, wells at........................ 392, 394 Welborn, wells at and near............ 411,412 Wells, depth of, considerations governing.. 229-230 making of . . . . . . . . . . . . multiplication of, effect of, on head .... 239-241 placing of............................ 230 figures showing................... 230 pumping from.................... 233-234 types of .......................... 229-230 views of ....................... 32, 230 water of, assays of .................. 260 source of......................... 255 See also particular places; Flowing wells; Dug wells; Bored wells; etc.

West Jupiter, wells near.................. 384-385 records of............................ 382

West Palm Beach, dunes near............. $\quad 48$ See also Palm Beach.

West Sopchoppy, deposits at and near...... 115 West Tampa, public water supply at..... 254,323 wells at........................ $322,323,324$

West Tocoi, wells near.................. 284 Westville, wells at..................... 326-327 White City, wells near............... 276,400 White City Junction, wells near.......... $\quad 400$ 
Whitehouse, wells near.

Page.

White Springs, rock at.

section at.

springs at

wells at and near.

Whitewater Bay, character of.

Whitfield, wells at.

Whitney, well near.

Whitney, Milton, on Florida soils

Wilcox, wells at.

Wildwood, wells at.

Wileys Landing, section of

Willcox, J., cited..

Willeford, wells at.

Williams Crossing, well at

Willis, Bailey, cited

Williston, wells at

Williston quadrangle, sink holes in, map showing..

Willoughby, H. L., cited.

Windleys Island, rocks on.
300

$91-92,116,118$

$91,93,115-116$

314

315

59,60

426

342

40

268

407

98

80,82

266

284

189,191

355,356

26

55
189

Page.

Winfield, wells at and near.

Winter Garden, wells at and near......... 378-379

Winter Haven, wells at and near. ......... 390

Winter Park, wells at . . . . . . . . . . . . 378-379

Woodburn, wells at and near............ 392,394

Worm rock, distribution and character of.... 198

Worthington, public water supply at....... 254

springs at.................... 270,272

Y.

Ybor City, wells at and near............ $\quad 322$

Yellow clay, distribution and character of... 156

Yellow River, deposits on .............. 119-120 section at.......................... $\quad 119$

Yon, well near....................... $\quad 328$

York, well near...................... $\quad 367$

\section{7.}

Zolfo, wells at...................... 294-296

Zuber, well near.................... 367 
